$$
\begin{aligned}
& \text { Pro, } \\
& \text { SEP } 35990
\end{aligned}
$$

NUREG/CR-4624

BMI-2139

Vol. 6

\title{
Radionuclide Release Calculations for Selected Severe Accident Scenarios
}

Supplemental Calculations

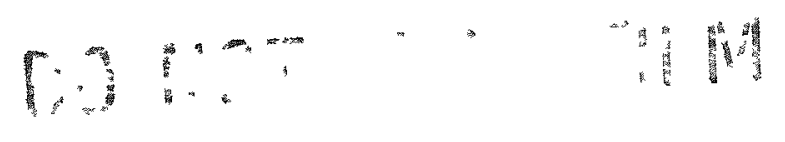

Prepared by $\mathbb{R}$. S. Denning, M. I. Leonard, P. Cybulskis, K. W. Lee,

R. I. Kelly, H. Jordan, P. M. Schumacher, L. A. Curtis

\section{Battelle Columbus Division}

Prepared for

U.S. Nuclear Regulatory Commission 


\section{AVALABILITY NOTICE}

Avallability of Reference Materials Cited in NRC Publications

Most documents cited in NRC publications will be avallable from one of the following sources:

1. The NRC Public Document Room, $2120 \mathrm{~L}$ Street, NW, Lower Level, Washington, DC 20555

2. The Superintendent of Documents, U.S. Govermment Printing Office, P.O. Box 37082, Washington. DC 20013-7082

3. The Natlonal Technlcal Information Service, Springieid, VA 22161

Although the listing that follows represents the majority of documents cited in NRC publications, it is not intended to be exhaustive.

Referenced documents avallable for inspection and copying for a fee from the NRC Public Document Room Include NRC correspondence and internal NRC memoranda; NRC Office of Inspectlon and Enforcement bulletins, circulars, intormation notices, Inspection and investlgation notices: Licensee Event Reports; vendor reports and correspondence; Commisston papers; and applicant and licensee documents and correspondence.

The following documents in the NUREG serles are avallable for purchase from the GPO Sales Program: tormal NRC staff and contractor reports, NRC-\$ponsored conference proceedings, and NRC booklets and brochures. Also avallable are Regulatory Guldes, NRC regulations in the Code of Federal Regulations, and Nuclear Regulatory Commission Issuances.

Doouments avallable from the National Tochnical Information Service include NUPEG serles reports and technical reports prepared by other federal agencles and reports prepared by the Atomic Energy Commission, forerunner agency to the Nuclear Regulatory Commisslon.

Documents avallable from public and special technical libraries Include all open literature Items, such as books. Joumal and periodical articles, and transactlons. Federal Register notices, fedoral and state legisiation, and congressional reports can usually be obtalned from these librarles.

Documents such as theses, dissertatlons, forelon reports and translations, and non-NRC conferance proceedings are avallable for purchase from the organization sponsoring the publlcation clted.

Single coples of NRC draft reponts are avallable free, to the extent of supply, upon mritten request to the Office of information Resources Management. Distribution Section, U.S. Nuolear Regulatory Commission. Washington, DC 20555.

Coples of industry codes and standards used in a substantive manner in the NRC regulatory process are maintained at the NRC LBbrary, 7920 Norfolk Avenue, Bethesda, Maryland, and are avallable there for Peference use by the publlo. Codes and standards are usually copyrighted and may be purchased trom the originating organization or, if they are American Natlonal Standards, Irom the American National Standards Institute, 1430 Broadway, New York, NY 10018.

\section{DISCLAIMER NOTICE}

This report was prepared as an account of work sponsored by an agency of the United States Government. Neither the United States Government nor any agency thereof, or any of their employees, makes any warranty, expresed or implied, or assumes any legal liability of responsibility for any third party's use, or the results of such use, of any information, apparatus, product or process disclosed in this report, or represents that its use by such third party would not infringe privately owned rights. 


\section{DISCLAIMER}

This report was prepared as an account of work sponsored by an agency of the United States Government. Neither the United States Government nor any agency Thereof, nor any of their employees, makes any warranty, express or implied, or assumes any legal liability or responsibility for the accuracy, completeness, or usefulness of any information, apparatus, product, or process disclosed, or represents that its use would not infringe privately owned rights. Reference herein to any specific commercial product, process, or service by trade name, trademark, manufacturer, or otherwise does not necessarily constitute or imply its endorsement, recommendation, or favoring by the United States Government or any agency thereof. The views and opinions of authors expressed herein do not necessarily state or reflect those of the United States Government or any agency thereof. 


\section{DISCLAIMER}

Portions of this document may be illegible in electronic image products. Images are produced from the best available original document. 


\title{
Radionuclide Release Calculations for Selected Severe Accident Scenarios
}

\author{
Supplemental Calculations
}

Manuscript Completed: August 1990

Date Published: August 1990

Prepared by

R. S. Denning, M. T. Leonard, P. Cybulskis, K. W. Lee,

R. F. Kelly, H. Jordan, P. M. Schumacher, L. A. Curtis

Battelle Columbus Division

505 King Avenue

Columbus, OH 43201-2693

\section{Prepared for}

Division of Systems Research

Office of Nuclear Regulatory Research

U.S. Nuclear Regulatory Commission

Washington, DC 20555

NRC FIN D1595

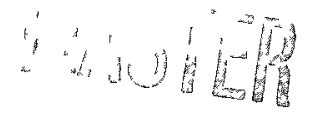





\section{ABSTRACT}

This report provides the results of source term calculations that were performed in support of the NUREG-1150 study, "Severe Accident Risks: An Assessment for Five U. S. Nuclear Power Plants." This is the sixth volume of a series of reports. It supplements results presented in the earlier volumes. Analyses were performed for three of the NUREG-1150 plants: Peach Bottom, a Mark I, boiling water reactor; Surry, a subatmospheric containment, pressurized water reactor; and Sequoyah, an ice condenser containment, pressurized water reactor.

Complete source term results are presented for the following sequences:

- short term station blackout with failure of the ADS system in the Peach Bottom plant

- station blackout with a pump seal LOCA for the Surry plant

- station blackout with a pump seal LOCA in the Sequoyah plant

- a very small break with loss of ECC and spray recirculation in the Sequoyah plant.

In addition, some partial analyses were performed which did not require running all of the modules of the Source Term Code Package. A series of MARCH3 analyses were performed for the Surry and Sequoyah plants to evaluate the effects of alternative emergency operating procedures involving primary and secondary depressurization on the progress of the accident. Only thermalhydraulic results are provided for these analyses. In addition, three accident sequences were analyzed for the surry plant for accident-induced failure of steam generator tubes. In these analyses, only the transport of radionuclides within the primary system and failed steam generator were examined. The release of radionuclides to the environment is presented for the phase of the accident preceding vessel meltthrough. 
TABLE OF CONTENTS

Page

1. INTRODUCTION..................................... 1

2. GENERAL APPROACH............................. 2

2.1 Source Term Code Package......................... 2

2.2 Radionuclide Groups............................. 5

3. DESCRIPTION OF PLANTS AND ACCIDENT SCENARIOS.............. 7

3.1 BWR, Mark I Containment Design.................. 7

3.1.1 Accident Scenarios Considered................ 7

3.1 .2 Primary System Flowpaths...................... 7

3.1.3 Containment Flowpaths....................... 10

3.1.4 Containment Failure Mode and Pressure Level...... 10

3.2 PWR, Subatmospheric Containment Design.............. 12

3.2.1 Accident Scenarios Considered............... 12

3.2.2 Primary System Flowpaths.................... 15

3.2.3 Containment Flowpaths...................... 15

3.2.4 Containment Failure Mode.................. 18

3.3 PWR, Ice Condenser Containment Design.............. 18

3.3.1 Accident Scenarios Considered................ 18

3.3.2 Primary System Flowpaths...................... 23

3.3.3 Containment Flowpaths and Failure Modes.......... 23

4. CALCULATION RESULTS............................ 30

4.1 BWR, Mark I Containment Design................... 30

4.1.1 Phenomenological Modeling Assumptions........... 30

4.1.2 Results of Thermal-hydraulic Analyses........... 33

4.1.3 Radionuclide Sources......................... 52

4.1.4 Radionuclide Release and Transport............. 57

4.2 PWR, Subatmospheric Containment Design.............. 70

4.2.1 Phenomenological Modeling Assumptions............ 70

4.2.2 Results of Thermal-hydraulic Analyses........... 81

4.2.3 Radionuclide Sources........................ 174

4.2.4 Radionuclide Release and Transport............. 174 
TABLE OF CONTENTS (continued)

Page

4.3 PWR, Ice Condenser Containment Design.............. 233

4.3.1 Phenomenological Modeling Assumptions........... 233

4.3.2 Results of Thermal-hydraulic Analyses............ 234

4.3.3 Radionuclide Sources..................... 312

4.3.4 Radionuclide Release and Transport............ 330

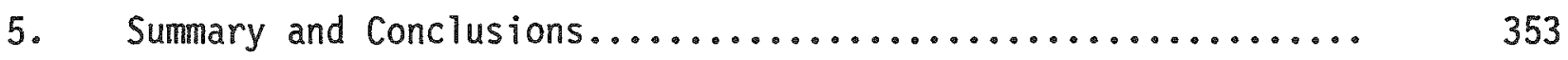

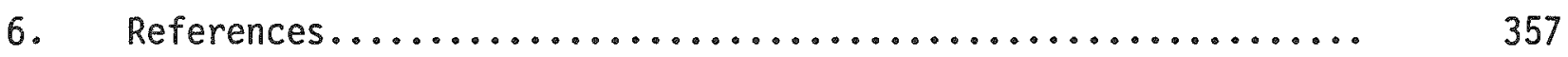




\section{LIST OF FIGURES}

Page

Figure 2.1.1. Source term code package...................

Figure 3.1.1. Flowpaths for fission product transport

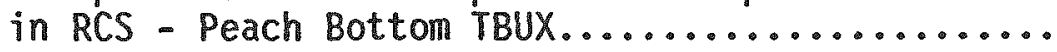

Figure 3.1.2. Schematic of primary system control volumes for the Peach Bottom TBUX sequence..............

Figure 3.1.3. Containment flowpaths for Peach Bottom TBUX sequence with late containment failure...........

Figure 3.2.1.

Primary system flowpaths for the Surry seal

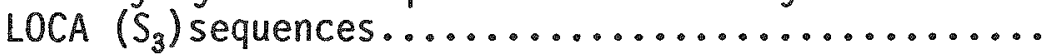

Figure 3.2.2. Schematic of primary system control volumes for the Surry seal LOCA $\left(S_{3}\right)$ sequences..........

Figure 3.3.1. Primary system flowpaths for the Sequoyah seal LOCA $\left(S_{3}\right)$ sequences..........................

Figure 3.3.2 Schematic of primary system control volumes for the Sequoyah seal LOCA $\left(S_{3}\right)$ sequences.........

Figure 3.3.3. Containment fission product flowpaths for

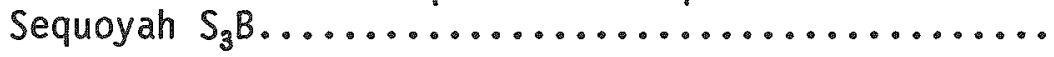

Figure 3.3.4. Containment fission product flowpaths for

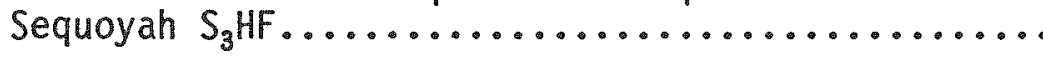

Figure 4.1.1. Primary system water inventory -

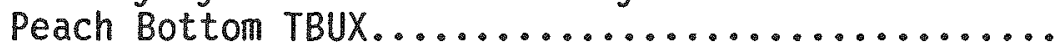

Figure 4.1.2. Steam flow rate through the safety/relief valve Peach Bottom TBUX...........................

Figure 4.1.3. Hydrogen flow rate through the safety/relief valve - Peach Bottom TBUX......................

Figure 4.1.4. Maximum and average core temperatures Peach Bottom TBUX............................

Figure 4.1.5. Temperatures of gases at core exit and leaving the primary system - Peach Bottom TBUX..........

Figure 4.1.6. Fractions of cladding reacted and core melted Peach Bottom TBUX............................. 


\section{$\frac{\text { LIST OF FIGURES }}{\text { continued }}$}

Page

Figure 4.1.7. Primary containment pressure response -

Peach Bottom TBUX........................... 45

Figure 4.1.8. Primary containment temperature response -

Peach Bottom TBUX...........................

Figure 4.1.9. Secondary containment pressure response -

Peach Bottom TBUX..........................

Figure 4.1.10. Secondary containment atmosphere temperature

response - Peach Bottom TBUX...................

Figure 4.1.11. Selected containment structure temperatures -

Peach Bottom TBUX.........................

Figure 4.1.12. Suppression pool water inventory -

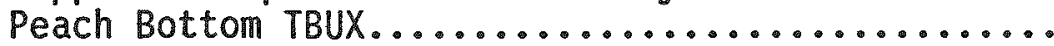

Figure 4.1.13. Suppression pool water temperature -

Peach Bottom TBUX............................

Figure 4.1.14. Progression of concrete attack -

Peach Bottom TBUX.............................

Figure 4.1.15. Total volume of gases leaked from containment -

Peach Bottom TBUX.........................

Figure 4.1.16. Mass of CSI released from indicated RCS components as a function of time -

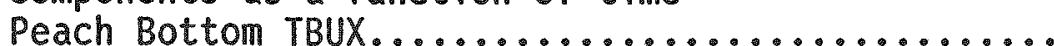

Figure 4.1.17. Mass of $\mathrm{CsOH}$ released from indicated RCS components as a function of time -

Peach Bottom TBUX..........................

Figure 4.1.18. Mass of Te released from indicated RCS components as a function of time - Peach Bottom TBUX.........

Figure 4.1.19. Mass of aerosol released from indicated RCS components as a function of time -

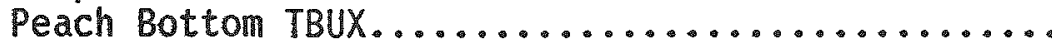

Figure 4.2.1. Primary system pressure response - Surry $S_{3} B \ldots \ldots$

Figure 4.2.2. Steam generator secondary side water inventory -

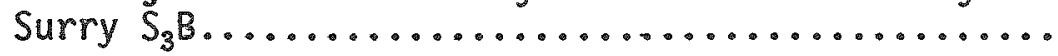




\section{$\frac{\text { LIST OF FIGURES }}{\text { continued }}$}

Page

Figure 4.2.3. Primary system water inventory - Surry $S_{3} B \ldots \ldots$

Figure 4.2.4. Primary system total water and steam leak rate - Surry $S_{3} B \ldots \ldots \ldots \ldots \ldots \ldots \ldots$

Figure 4.2.5. Primary system hydrogen leak rate - Surry $S_{3} B \ldots$

Figure 4.2.6. Maximum and average core temperatures -

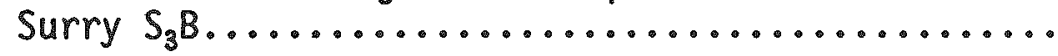

Figure 4.2.7. Temperatures of gases at core exit and leaving the primary system - Surry $S_{3} B \ldots \ldots \ldots$

Figure 4.2.8. Fractions of cladding reacted and core melted - Surry $S_{3} B$

Figure 4.2.9. Containment pressure response - Surry $S_{3} B \ldots \ldots$

Figure 4.2.10. Containment temperature response - Surry $S_{3} B \ldots \ldots$

Figure 4.2.11. Selected containment structure temperatures -

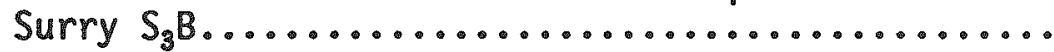

Figure 4.2.12. Progression of concrete attack - Surry $S_{3} B \ldots \ldots$

Figure 4.2.13. Total volume of gases leaked from containment Surry $S_{3} B \ldots \ldots \ldots \ldots \ldots \ldots \ldots \ldots \ldots \ldots \ldots \ldots \ldots \ldots$

Figure 4.2.14. Primary system pressure history - long term station blackout..........................

Figure 4.2.15. Primary system leakage - long term station blackout.

Figure 4.2.16. Maximum and average core temperatures long term station blackout....................

Figure 4.2.17. Fractions of cladding reacted and core melted long term station blackout....................

Figure 4.2.18. Temperatures of gases leaving the core and exiting the primary system - long term station blackout..............................

Figure 4.2.19. Containment pressure history - long term

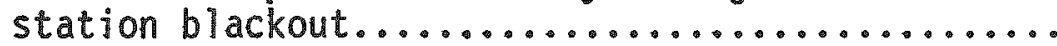




\section{LIST OF FIGURES \\ continued}

$\underline{\text { Page }}$

Figure 4.2.20 Containment temperature history - long term

station blackout...........................

Figure 4.2.21. Hydrogen in the containment - long term station blackout............................

Figure 4.2.22. Containment atmosphere composition - long term station blackout..........................

Figure 4.2.23. Primary system pressure history - station blackout with pump seal failure................

Figure 4.2.24. Primary system leakage - long term blackout with pump seal failure......................

Figure 4.2.25. Maximum and average core temperatures station blackout with pump seal failure......... 126

Figure 4.2.26. Fractions of cladding reacted and core melted station blackout with pump seal failure..........

Figure 4.2.27. Temperatures of gases leaving the core and exiting the primary system - station blackout with pump seal failure.....................

Figure 4.2.28. Containment pressure history - station blackout with pump seal failure......................

Figure 4.2.29. Containment temperature history - station blackout with pump seal failure................

Figure 4.2.30. Hydrogen in the containment - station blackout with pump seal failure.......................

Figure 4.2.31. Containment atmosphere composition - station blackout with pump seal failure................

Figure 4.2.32. Primary system pressure history - very small break with ECCS failure and AFW on..............

Figure 4.2.33. Primary system leakage - very small break with ECCS failure and AFW on.................

Figure 4.2.34. Maximum and average core temperatures - very small break with ECCS failure and AFW on......... 


\section{$\frac{\text { LIST OF FIGURES }}{\text { continued }}$}

Page

Figure 4.2.35. Fractions of cladding reacted and core melted very small break with ECCS failure and AFW on.....

Figure 4.2.36. Temperatures of gases leaving the core and exiting the primary system - very small break

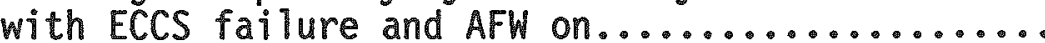

Figure 4.2.37. Containment pressure history - very small break

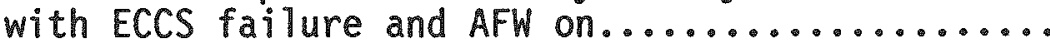

Figure 4.2.38. Containment temperature history - very small break with ECCS failure and AFW on.............

Figure 4.2.39. Hydrogen in the containment - very small

break with ECCS failure and AFW on.............. 146

Figure 4.2.40. Containment atmosphere composition - very small break with ECCS failure and AFW on..............

Figure 4.2.41. Primary system pressure history - very small break with ECCS failure, AFW on, and PORVS open...

Figure 4.2.42. Primary system leakage - very small break with ECCS failure, AFW on, and PORVs open........

Figure 4.2.43. Maximum and average core temperatures - very small break with ECCS failure, AFW on, and PORVS Open...

Figure 4.2.44. Fractions of cladding reacted and core melted very small break with ECCS failure, AFW on, and

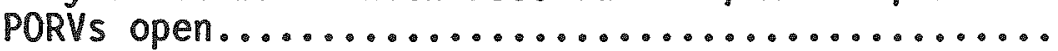

Figure 4.2.45. Temperatures of gases leaving the core and exiting the primary system - very small break with ECCS

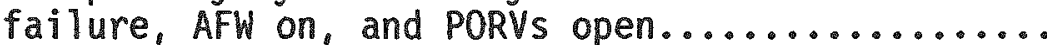

Figure 4.2.46. Containment pressure history - very small break with ECCS failure, AFW on, and PORVs open........

Figure 4.2.47. Containment temperature history - very small break with ECCS failure, AFW on, and PORVs open........

Figure 4.2.48. Hydrogen in the containment - very small break with ECCS failure, AFW on, and PORVS open........

Figure 4.2.49. Containment atmosphere composition - very small break with ECCS failure, AFW on, and PORVS open... 


\section{LIST OF FIGURES \\ continued}

Page

Figure 4.2.50. Primary system pressure history - very small

break with ECCS failure, AFW on, and PORVs open...

Figure 4.2.51. Primary system leakage - small break with ECCS

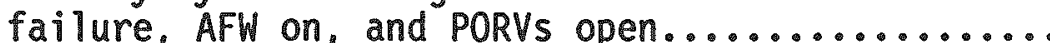

Figure 4.2.52. Maximum and average core temperatures - small break with ECCS failure, AFW on, and PORVS open...

Figure 4.2.53. Fractions of cladding reacted and core melted small break with ECCS failure, AFW on, and PORVs open...................................

Figure 4.2.54. Temperatures of gases leaving the core and exiting the primary system - small break with ECCS

failure, AFW on, and PORVs open.................

Figure 4.2.55. Containment pressure history - small break with ECCS failure, AFW on, and PORVs open.............

Figure 4.2.56. Containment temperature history - small break with ECCS failure, AFW on, and PORVS open.............

Figure 4.2.57. Hydrogen in the containment - small break with ECCS failure, AFW on, and PORVS open.............

Figure 4.2.58. Containment atmosphere composition - small break with ECCS failure, AFW on, and PORVs open........

Figure 4.2.59. Mass of CSI released from indicated RCS components as a function of time - Surry $S_{3} B \ldots \ldots \ldots \ldots . . . .$.

Figure 4.2.60. Mass of $\mathrm{CsOH}$ released from indicated RCS components as a function of time - Surry $S_{3} B \ldots \ldots \ldots \ldots \ldots$

Figure 4.2.61. Mass of Te released from indicated RCS components as a function of time - Surry $S_{3} B \ldots \ldots \ldots \ldots \ldots$

Figure 4.2.62. Mass of aerosol released from indicated RCS

components as a function of time - Surry $S_{3} B \ldots \ldots$

Figure 4.2.63. Mass of CSI released from indicated RCS components as a function of time - Surry HINY-NXY, primary...

Figure 4.2.64. Mass of $\mathrm{CSOH}$ released from indicated RCS components as a function of time - Surry HINY-NXY, primary... 


\section{LIST OF FIGURES \\ continued}

Page

Figure 4.2.65. Mass of Te released from indicated RCS components as a function of time - Surry HINY-NXY, primary...

Figure 4.2.66. Mass of aerosol released from indicated RCS components as a function of time - Surry HINY-NXY,

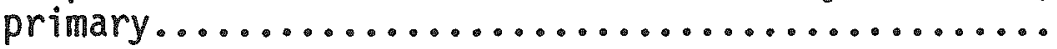

Figure 4.2.67. Mass of CSI released from indicated RCS components as a function of time - Surry HINY-NXY, secondary.

Figure 4.2.68. Mass of $\mathrm{CsOH}$ released from indicated RCS components as a function of time - Surry HINY - NXY, secondary.

Figure 4.2.69. Mass of Te released from indicated RCS components as a function of time - Surry HINY-NXY, secondary.

Figure 4.2.70. Mass of aerosol released from indicated RCS components as a function of time - Surry HINY-NXY,

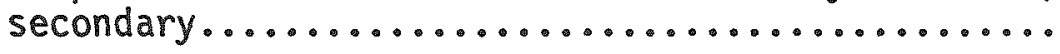

Figure 4.2.71. Mass of CSI released from indicated RCS component as a function of time - Surry GLYY-YXY, primary...

Figure 4.2.72. Mass of CSOH released from indicated RCS component as a function of time - Surry GLYY-YXY, primary...

Figure 4.2.73. Mass of Te released from indicated RCS components as a function of time - Surry GLYY-YXY, primary...

Figure 4.2.74. Mass of aerosol released from indicated RCS component as a function of time - Surry GLYY-YXY,

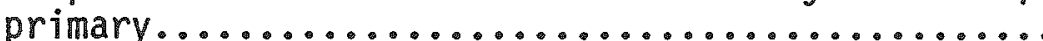

Figure 4.2.75. Mass of CSI released from indicated RCS components as a function of time - Surry GLYY-YXY, secondary.

Figure 4.2.76. Mass of $\mathrm{CsOH}$ released from indicated RCS components as a function of time - Surry GLYY-YXY, secondary.

Figure 4.2.77. Mass of Te released from indicated RCS components as a function of time - Surry GLYY-YXY, secondary.

Figure 4.2.78. Mass of aerosol released from indicated RCS components as a function of time - Surry GLYY - YXY,

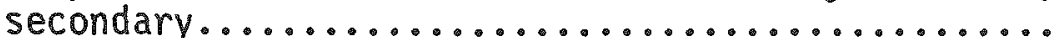

Figure 4.2.79. Mass of CSI released from indicated RCS components as a function of time - Surry HINY-YXY, primary... 


\section{LIST OF FIGURES \\ continued}

Page

Figure 4.2.80. Mass of $\mathrm{CSOH}$ released from indicated RCS components as a function of time - Surry HINY-YXY, primary...

Figure 4.2.81. Mass of Te released from indicated RCS component as a function of time - Surry HINY-YXY, primary...

Figure 4.2.82. Mass of aerosol released from indicated RCS component as a function of time - Surry HINY-YXY,

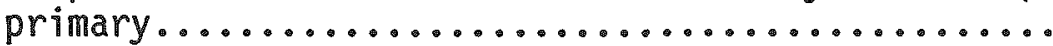

Figure 4.2.83. Mass of CSI released from indicated RCS component as a function of time - Surry HINY-YXY, secondary.

222

Figure 4.2.84. Mass of $\mathrm{CSOH}$ released from indicated RCS component as a function of time - Surry HINY-YXY, secondary.

Figure 4.2.85. Mass of Te released from indicated RCS component as a function of time - Surry HINY-YXY, secondary.

Figure 4.2.86. Mass of aerosol released from indicated RCS component as a function of time - Surry HINY-YXY,

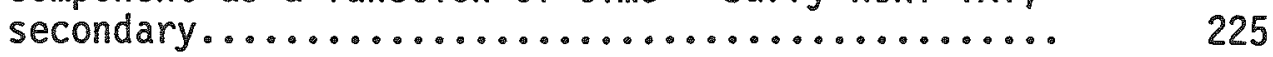

Figure 4.3.1. Primary system pressure response - Sequoyah $S_{3} B \ldots$

Figure 4.3.2. Primary system water inventory - Sequoyah $S_{3} B \ldots$

Figure 4.3.3. Primary system total water and steam leak rate

- Sequoyah $S_{3} B . \ldots . . . . . . . . . . . . . . . . . .$.

Figure 4.3.4. Maximum and average core temperatures Sequoyah $S_{3} B \ldots \ldots \ldots \ldots \ldots \ldots \ldots \ldots \ldots \ldots \ldots \ldots$

Figure 4.3.5. Fractions of cladding reacted and core melted

- Sequoyah $S_{3} B \ldots \ldots . . . . . . . . . . . . . . . .$.

Figure 4.3.6. Primary system hydrogen leak rate - Sequoyah $S_{3} B$. .

Figure 4.3.7. Temperatures of gases at core exit and leaving the primary system - Sequoyah $S_{3} B \ldots \ldots \ldots \ldots \ldots . . . . .$.

Figure 4.3.8. Containment pressure response - Sequoyah $S_{3} B \ldots \ldots 247$

Figure 4.3.9. Containment temperature response - Sequoyah $S_{3} B \ldots$... 248

Figure 4.3.10. Selected containment structure temperatures

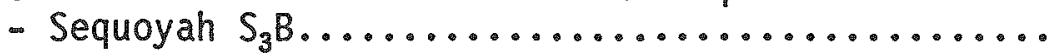




\section{$\frac{\text { LIST OF FIGURES }}{\text { continued }}$}

Page

Figure 4.3.11. Progression of concrete attack - Sequoyah $S_{3} B \ldots \ldots 251$

Figure 4.3.12. Ice inventory - Sequoyah $S_{3} B \ldots \ldots \ldots \ldots \ldots \ldots \ldots \ldots . . \ldots . . \ldots 252$

Figure 4.3.13. Total volume of gases leaked from containment

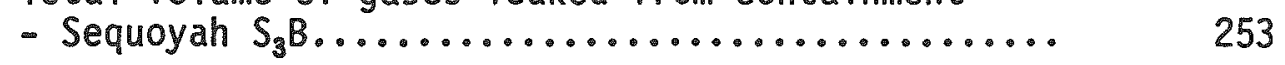

Figure $4.3 .14 \quad$ Noble gas distribution - Sequoyah $S_{3} B \ldots \ldots \ldots \ldots$

Figure 4.3.15. Primary system pressure response - Sequoyah $S_{3} H F . . \quad 257$

Figure 4.3.16. Primary system water inventory - Sequoyah $S_{3} H F \ldots 258$

Figure 4.3.17. Primary system total water and steam leak rate

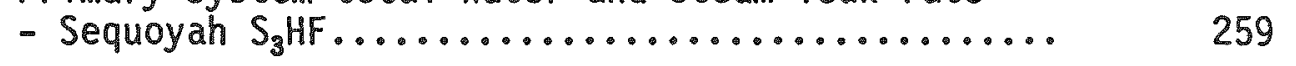

Figure 4.3.18. Maximum and average core temperatures

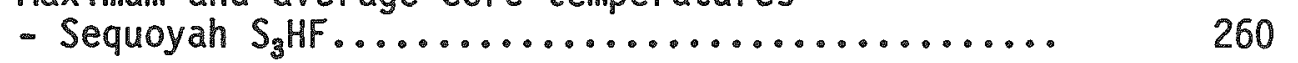

Figure 4.3.19. Fractions of cladding reacted and core melted

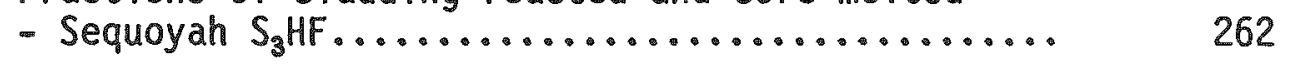

Figure 4.3.20. Primary system hydrogen leak rate - Sequoyah $\mathrm{S}_{3} \mathrm{HF} .263$

Figure 4.3.21. Temperatures of gases at core exit and leaving the primary system - Sequoyah $S_{3} H F \ldots . . . . . . . . . .$.

Figure 4.3.22. Containment pressure response - Sequoyah $S_{3} H F \ldots$

Figure 4.3.23. Containment temperature response - Sequoyah $S_{3} H F$.

268

Figure 4.3.24. Selected containment structure temperatures

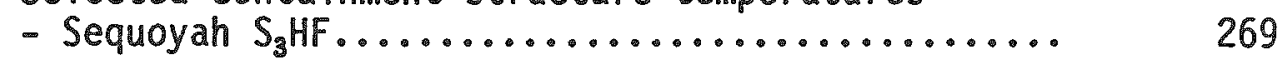

Figure 4.3 .25 . Ice inventory - Sequoyah $S_{g} H F \ldots \ldots \ldots \ldots \ldots \ldots \ldots$

Figure 4.3.26. Progression of concrete attack - Sequoyah $S_{3} H F \ldots 271$

Figure 4.3.27. Total volume of gases leaked from containment

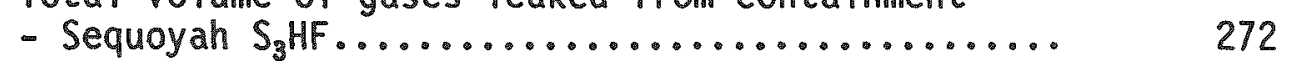

Figure 4.3.28. Containment pressure response - Sequoyah $S_{3} H \ldots \ldots 274$

Figure 4.3.29. Containment temperature response - Sequoyah $\mathrm{S}_{3} \mathrm{H} \ldots \quad 275$

Figure 4.3.30. Progression of concrete attack - Sequoyah $\mathrm{S}_{3} \mathrm{H} \ldots \ldots$ 


\section{$\frac{\text { LIST OF FIGURES }}{\text { continued }}$}

Page

Figure 4.3.31. Ice inventory - Sequoyah $S_{3} H \ldots \ldots \ldots \ldots \ldots \ldots \ldots \ldots \ldots$

Figure 4.3.32. Containment sump and reactor cavity water

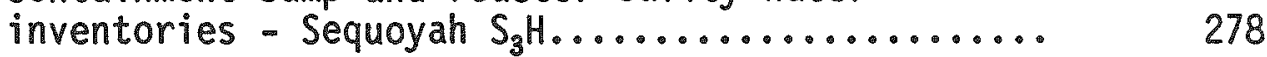

Figure 4.3.33. Containment sump and reactor cavity water temperatures - Sequoyah $S_{3} H \ldots \ldots \ldots . . . . . . . . . .279$

Figure 4.3.34. Primary system pressure history - station blackout

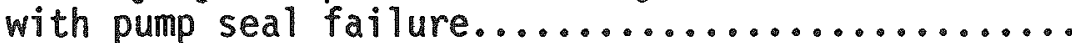

Figure 4.3.35. Primary system leakage - station blackout with

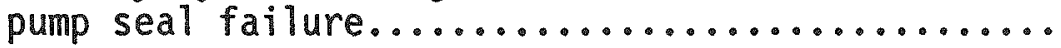

Figure 4.3.36. Maximum and average core temperatures - station blackout with pump seal failure...............

Figure 4.3.37. Fractions of cladding reacted and core melted - station blackout with pump seal failure........

Figure 4.3.38. Temperatures of gases leaving the core and exiting the primary system - station blackout with pump

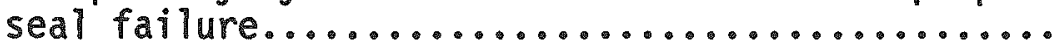

Figure 4.3.39a. Lower compartment pressure history - station

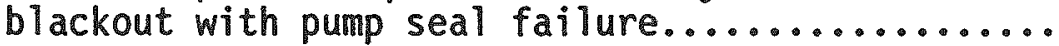

Figure $4.3 .39 \mathrm{~b}$. Upper compartment pressure history - station

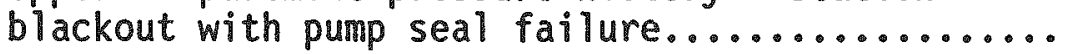

Figure 4.3.40. Containment temperature history - station blackout

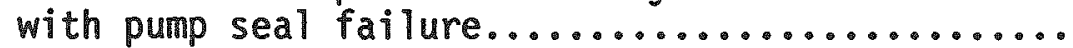

Figure 4.3.41. Ice inventory - station blackout with pump seal

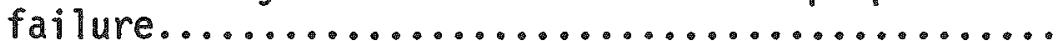

Figure 4.3.42. Hydrogen in the containment - station blackout with

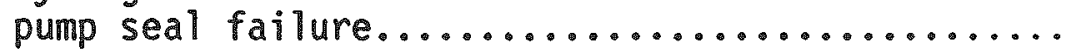

Figure 4.3.43a. Lower containment atmosphere composition - station blackout with pump seal failure................

Figure 4.3.43b. Upper compartment atmosphere composition - station blackout with pump seal failure................

Figure 4.3.44. Primary system pressure history - very small break

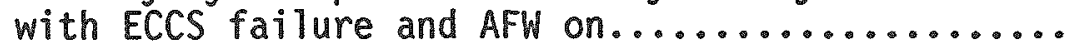




\section{LIST OF FIGURES \\ continued}

Page

Figure 4.3.45. Primary system leakage - very small break with ECCS failure and AFW on..........................

Figure 4.3.46. Hydrogen mass in the primary system - very small break with ECCS fajlure and AFW On.............

Figure 4.3.47. Maximum and average core temperatures - very small

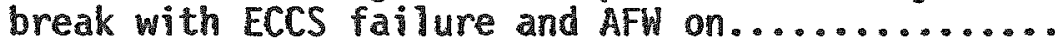

Figure 4.3.48. Fractions of cladding reacted and core melted - very small break with ECCS fajlure and AFW on...

Figure 4.3.49. Temperatures of gases leaving the core and exiting the primary system - very small break with ECCS

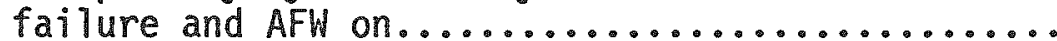

Figure 4.3.50a. Lower compartment pressure history - very small break with ECCS failure and AFW on..............

Figure 4.3.50b. Upper compartment pressure history - very small break with ECCS failure and AFW on.............

Figure 4.3.51. Containment temperature history - very small break with ECCS failure and AFW on..................

Figure 4.3.52. Hydrogen in the containment - very small break with ECCS failure and AFW on...................

Figure 4.3.53. Lower compartment atmosphere composition - very small break with ECCS failure and AFW on..........

Figure 4.3.54. Upper compartment atmosphere composition - very small break with ECCS failure and AFW on.........

Figure 4.3.55. Containment sump and reactor cavity water inventories - very smal1 break with ECCS failure

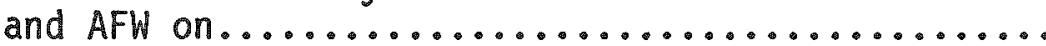

Figure 4.3.56. Containment sump and reactor cavity water temperatures - very small break with ECCS failure

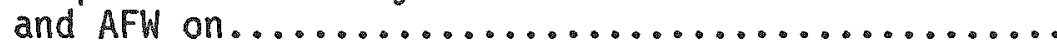

Figure 4.3.57. Ice inventory - very small break with ECCS failure

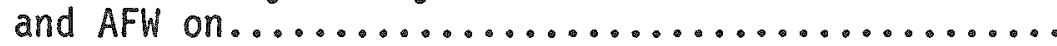

Figure 4.3.58. Mass of CSI released from indicated RCS components as a function of time - Sequoyah $S_{3} B \ldots \ldots . . . .$. 


\section{LIST OF FIGURES \\ continued}

Page

Figure 4.3.59. Mass of CSOH released from indicated RCS components as a function of time - Sequoyah $S_{3} B \ldots \ldots . . . .$.

Figure 4.3.60. Mass of Te released from indicated RCS components as a function of time - Sequoyah $S_{3} B \ldots \ldots . . . . .$.

Figure 4.3.61. Mass of aerosol released from indicated RCS 


\section{LIST OF TABLES}

Page

Table 2.2.1.

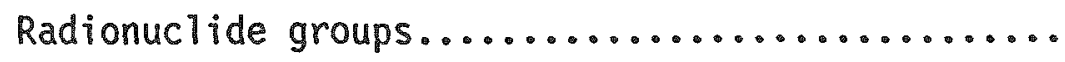

Table 4.1.1.

Timing of key events - Peach Bottom TBUX.........

Table 4.1 .2

Core and primary system response -

Peach Bottom TBUX.......................

Table 4.1.3.

Containment response - Peach Bottom TBUX.

Table 4.1.4.

Containment leak rates - Peach Bottom TBUX........

Table 4.1.5.

Initial inventories of radionuclides and structural materials for Peach Bottom............

Table 4.1.6.

Inventory by group

Table 4.1.7.

Inventory of melt at the time of vessel failure for Peach Bottom TBUX.

Table 4.1.8.

Aerosol release rate during corium-concrete interaction for Peach Bottom TBUX..............

Table 4.1.9.

Masses of dominant species released from fuel and retained on RCS structures as functions of time for the Peach Bottom TBUX sequence..........

Table 4.1.10. Masses of radionuclides released from fuel and retained by RCS (by group) for the Peach Bottom TBUX sequence at the time of reactor vessel

failure.

Table 4.1.11. Fraction of initial core inventory released to the primary containment for Peach Bottom TBUX.....

Table 4.1.12. Size distribution of aerosols in the drywell -

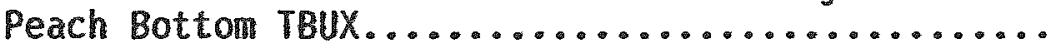

Table 4.1.13. Fraction of core inventory released from the

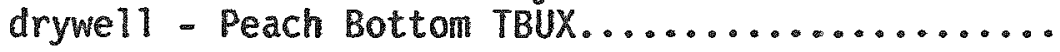

Table 4.1.14. Size distribution of aerosols in the wetwell -

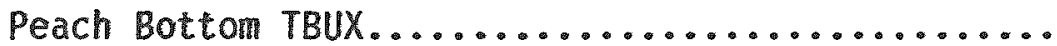

Table 4.1.15. Fraction of core inventory released for the

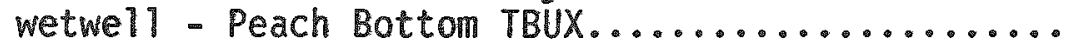

Table 4.1.16. Size distribution of aerosols in the reactor

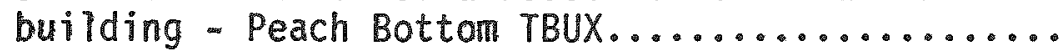




\section{LIST OF TABLES}

Page

Table 4.1.17. Fraction of core inventory released from the reactor building - Peach Bottom TBUX............ 77

Table 4.1.18. Size distribution of aerosols in the refueling bay - Peach Botton TBUX.......................

78

Table 4.1.19. Fraction of core inventory released from the refueling bay - Peach Bottom TBUX................

Table 4.1.20. Final distribution of fission product inventory by group - Peach Bottom rBUX..................

Table 4.2.1.

Timing of key events - Surry $S_{3} B$.

82

Table 4.2.2.

Core and primary system response - Surry $S_{3} B_{0} \ldots \ldots$

Table 4.2 .3

Containment response - Surry $S_{3} B \ldots$

Table 4.2.4.

Containment leak rates - Surry $S_{3} B \ldots \ldots \ldots \ldots \ldots$

94

Table 4.2.5.

Timing of key events - Surry HINY-NXY.

101

Table 4.2.6.

Primary system response - Surry HINY-NXY.

102

Table 4.2.7.

Timing of key events - Surry $G L Y Y-Y X Y \ldots \ldots \ldots \ldots$

104

Table 4.2.8.

Primary system response - Surry GLYY-YXY.

105

Table 4.2.9.

Timing of key events - Surry HINY-YXY.

106

Table 4.2.10.

Primary system response - Surry HINY-YXY.

107

Table 4.2.11.

Timing of key events - Surry TB (with secondary depressurization).

108

Table 4.2.12. Core and primary system response - Surry TB...... 109

Table 4.2 .13

Containment response - Surry TB.................

Table 4.2 .14

Timing of key events - Surry $S_{3} B$.

122

Table 4.2.15. Core and primary system response - Surry $S_{3} B \ldots \ldots$

123

Table 4.2.16.

Containment response - Surry $S_{3} B$

129

Table 4.2 .17

Timing of key events - Surry $S_{3} D X$.

135

Table 4.2.18.

Core and primary system response - Surry $S_{3} D X$. 


\section{LIST OF TABLES}

Page

Table 4.2.19. Containment response - Surry $S_{3} D X \ldots \ldots \ldots \ldots \ldots$

Table 4.2.20. Timing of key events - Surry $S_{3} D Z \ldots \ldots \ldots \ldots \ldots$

Table 4.2.21. Core and primary system response - Surry $S_{3} D Z \ldots$ 149

Table 4.2.22. Containment response - Surry $S_{3} D Z \ldots \ldots \ldots \ldots \ldots$

Table 4.2.23. Timing of key events - Surry $S_{2} D \ldots \ldots \ldots \ldots \ldots 1$

Table 4.2.24. Core and primary system response - Surry $S_{2} D \ldots \ldots 2$

Table 4.2 .25 . Containment response - Surry $S_{2} D \ldots \ldots \ldots \ldots \ldots$

Table 4.2.26. Initial inventories of radionuclides and structural materials for surry............... 175

Table $4.2 .27 . \quad$ Inventory by group.................... 176

Table 4.2.28. Inventory of the melt at the time of vessel

failure for surry $S_{3} B \ldots \ldots \ldots \ldots \ldots \ldots \ldots \ldots \ldots$

Table 4.2.29. Aerosol release rate during corium-concrete interaction for Surry $S_{3} B \ldots \ldots \ldots \ldots \ldots \ldots \ldots$

Table 4.2.30. Masses of dominant species released from fuel and retained on RCS structures as functions of

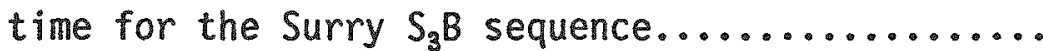

Table 4.2.31. Masses of radionuclide groups released to and retained in RCS at time of vessel failure for

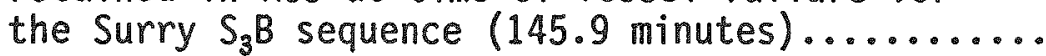

Table 4.2.32. Masses of dominant species released from fuel and retained on RCS structures as functions of time for the Surry HINY-NXY sequence...............

Table 4.2.33. Masses of radionuclide groups released to and retained in RCS at time of vessel failure for the Surry HINY -NXY sequence $(933.7$ minutes) .........

Table 4.2.34. Fraction of initial core inventory released to the

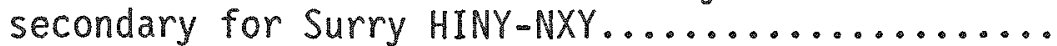

Table 4.2.35. Masses of dominant species released from RCS and retained on secondary structures as functions of time for the Surry HINY-NXY sequence............ 


\section{LIST OF TABLES}

Page

Table 4.2.36. Masses of radionuclide groups released to and retained in secondary at time of vessel failure for the Surry HINY-NXY sequence (933.7 minutes)...

Table 4.2.37. Fraction of initial core inventory released to the environment for Surry HINY-NXY.............

202

Table 4.2.38. Distribution of inventory of principal species,

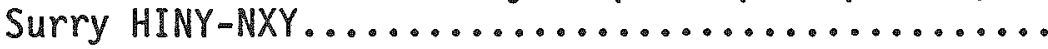

202

Table 4.2.39. Masses of dominant species released from fuel and retained on RCS structures as functions of time for the Surry GLYY-YXY sequence...............

Table 4.2.40. Masses of radionuclide groups release to and retained in RCS at time of vessel failure for the Surry GLYY-YXY sequence (236.4 minutes)........

Table 4.2.41. Fraction of initial core inventory released to the

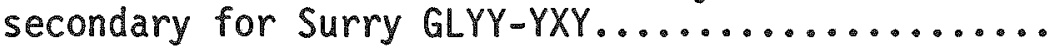

Table 4.2.42. Masses of dominant species released from RCS and retained on secondary structures as functions of time for the Surry GLYY-YXY sequence............

Table 4.2.43. Masses of radionuclide groups released to and retained in secondary at time of vessel failure for the Surry GLYY-YXY sequence (933.7 minutes)...

Table 4.2.44. Fraction of initial core inventory released to the

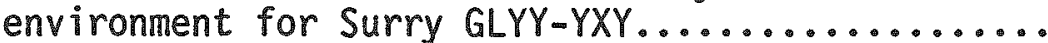

Table 4.2.45. Distribution of inventory of principal species,

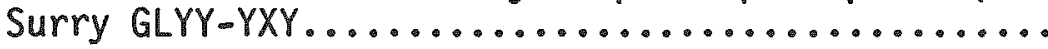

Table 4.2.46. Masses of dominant species released from fuel and retained on RCS structures as functions of time for

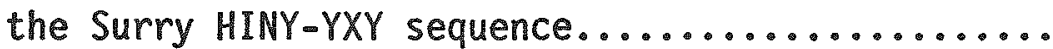

Table 4.2.47. Masses of radionuclide groups released to and retained in RCS at time of vessel failure for the Surry HINY-YXY sequence ( 933.7 minutes).........

Table 4.2.48. Fraction of initial core inventory released to the secondary for Surry HINY-YXY............... 


\section{LIST OF TABLES}

Page

Table 4.2.49. Masses of dominant species released from RCS and retained on secondary structures as functions of

time for the Surry HINY-YXY sequence............

226

Table 4.2.50. Masses of radionuclide groups released to and retained in secondary at time of vessel failure for the Surry HINY-YXY sequence (933.7 minutes).......

Table 4.2.51. Fraction of initial core inventory released to the

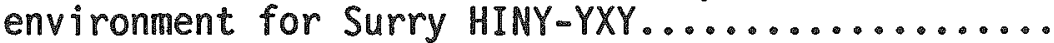

Table 4.2.52. Distribution of inventory of principal species,

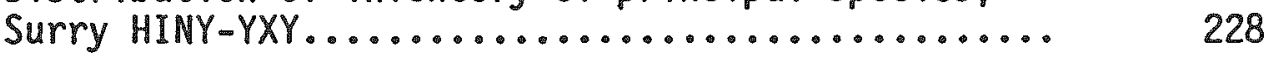

Table 4.2.53. Fraction of initial core inventory released to the containment for Surry $S_{3} B \ldots \ldots \ldots \ldots \ldots \ldots \ldots \ldots . \ldots \ldots$

Table 4.2.54 Fraction of core inventory released from the

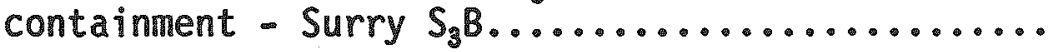

229

Table 4.2.55. Particle size distributions (relative number by diameter) of material released to the containment from the RCS at 26 equi-spaced times throughout the in-vessel period - Surry $S_{3} B \ldots \ldots \ldots \ldots \ldots \ldots$

Table 4.2.56. Size distribution of aerosols in containment

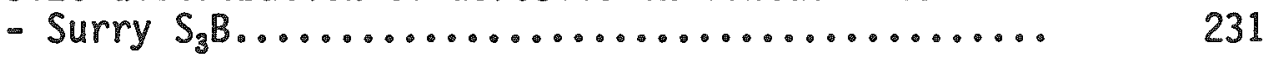

Table 4.2.57. Final distribution of fission product inventory by

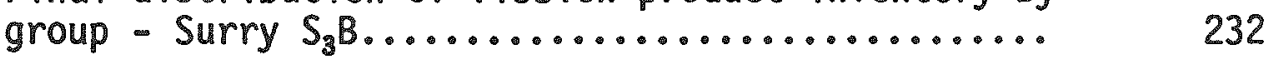

Table 4.3.1. Timing of key events - Sequoyah $S_{3} B \ldots \ldots \ldots \ldots \ldots$

Table 4.3.2. Core and primary system response - Sequoyah $S_{3} B \ldots \quad 236$

Table 4.3.3. Containment response - Sequoyah $S_{3} B \ldots \ldots . . . . . . \quad 245$

Table 4.3.4. Containment leak rates - Sequoyah $S_{3} B \ldots \ldots . . . . .246$

Table 4.3.5. Timing of key events - Sequoyah $S_{g} H F \ldots \ldots \ldots . . . . \quad 255$

Table 4.3.6. Core and primary system response - Sequoyah $S_{3} H F \ldots \quad 256$

Table 4.3.7. Containment response - Sequoyah $S_{3} H F \ldots . . . . . . .265$

Table 4.3.8. Containment leak rates - Sequoyah $S_{3} H F \ldots . . . . .266$

Table 4.3.9. Timing of key events - Sequoyah $S_{3} B \ldots \ldots \ldots \ldots$ 


\section{LIST OF TABLES}

Page

Table 4.3.10. Core and primary system response - Sequoyah $S_{3} B \ldots$

281

Table 4.3.11. Containment response - Sequoyah $S_{3} B \ldots \ldots . . . . .$.

288

Table 4.3.12. Timing of key events - Sequoyah $S_{3} D \ldots \ldots \ldots . . .$.

296

Table 4.3.13. Core and primary response - Sequoyah $S_{3} D \ldots \ldots . .$.

Table 4.3.14. Containment response - Sequoyah $S_{3} D \ldots \ldots . . . .$.

305

Table 4.3.15. Initial inventories of radionuclides and structural materials for Sequoyah..................... 316

Table 4.3.16. Inventory by group......................

Table 4.3.17. Inventory of melt at the time of vessel failure

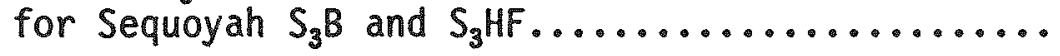

Table 4.3.18. Aerosol release rate during corium-concrete interaction for Sequoyah $S_{3} B \ldots \ldots \ldots \ldots \ldots \ldots$

Table 4.3.19. Aerosol release rate during corium-concrete interaction for Sequoyah $S_{3} H F \ldots \ldots \ldots \ldots \ldots$

Table 4.3.20. Fraction of initial core inventory released from fuel prior to corium-concrete interactions

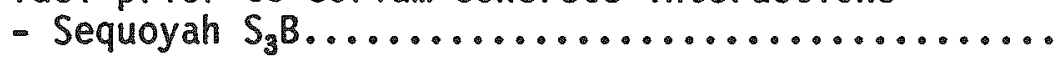

Table 4.3.21. Fraction of initial core inventory released to containment during corium-concrete interactions - Sequoyah $S_{3} B \ldots \ldots \ldots \ldots \ldots \ldots . . . . . . . . . . .$.

Table 4.3.22. Masses of dominant species released from fuel and retained on RCS structures as functions of time for

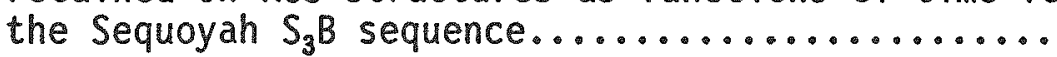

Table 4.3.23. Masses of radionuclides released from fuel and retained by RCS (by group) for the Sequoyah $S_{3} B$ sequence at the time of reactor vessel failure (509.8 minutes)

Table 4.3.24. Particle size distributions (relative number by diameter) of material released to the containment from the RCS at 26 equi-spaced times throughout the in-vessel period - Sequoyah $S_{3} B \ldots \ldots \ldots \ldots$ 


\section{LIST OF TABLES}

Page

Table 4.3.25. Particle size distributions (relative number by diameter) of material released to the containment from the RCS at 26 equi-spaced times throughout the in-vessel period - Sequoyah $S_{3} H F \ldots . . . . . .$.

Table 4.3.26. Fraction of initial core inventory released to containment - Sequoyah $S_{3} B \ldots \ldots . . . . . . . . . .$.

Table 4.3.27. Fraction of core inventory released from the lower compartment to environment - sequoyah $S_{3} B \ldots \ldots$.

Table 4.3.28. Size distribution of aerosols in the lower compartment - Sequoyah $S_{3} B \ldots \ldots \ldots . . . . . . . .$.

Table 4.3.29. Final distribution of fission product inventory

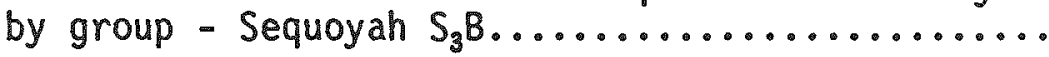

Table 4.3.30. Fraction of initial core inventory released to containment - Sequoyah $S_{3} H F \ldots \ldots . . . . . . . . .$.

Table 4.3.31. Fraction of core inventory released from the lower-to-upper compartment - Sequoyah $S_{3} H F \ldots . . .$.

Table 4.3.32. Size distribution of aerosols in the lower

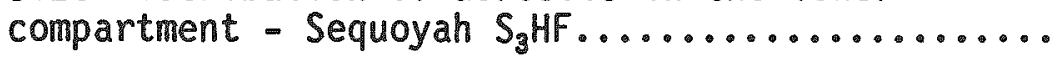

Table 4.3.33. Fraction of core inventory released from the upper compartment to environment - Sequoyah $S_{3} H F$.

Table 4.3.34. Size distribution of aerosols in the upper compartment - Sequoyah $S_{3} H F \ldots \ldots \ldots \ldots \ldots \ldots$

Tabie 4.3.35. Final distribution of fission product inventory by group - Sequoyah $S_{3} H F \ldots \ldots \ldots . . . . . . . . . . . .$. 
REPORT

on

RADIONUCLIDE RELEASE CALCULATIONS

FOR SELECTED SEVERE ACCIDENT SCENARIOS

Supplemental Calculations

\section{INTRODUCTION}

This report presents the results of analyses of the environmental releases of fission products (source terms) for selected accident scenarios in three reactor/containment designs:

- Boiling Water Reactor (BWR) of the Mark I containment design

- Pressurized Water Reactor (PWR) with a subatmospheric containment design

- Pressurized Water Reactor (PWR) with an ice condenser containment design.

These analyses were performed for the U.S. Nuclear Regulatory Commission (NRC) in support of the Severe Accident Risk Reduction/Risk Rebaselining Program (SARRP) ${ }^{(1) *}$, and supplement those performed previously ${ }^{(2)}$ in support of NUREG-1150(3). These calculations provide an extended basis for confirming the adequacy of the parametric source term estimation models used for NUREG-1150(3). Relatively few additional accident scenarios were required for each reference plant design and, thus, the supplemental calculations for all three plant types are documented in this report.

This report also presents results for calculations performed to examine the effect of selected emergency operating procedures on the system response for the Surry and Sequoyah plants. Only the MARCH3 module of the Source Term Code Package (STCP) ${ }^{(4)}$ was run for these sequences. Results are presented that describe the timing of events and thermal-hydraulic behavior for sequences with these emergency procedures but no source term results are provided.

* References are listed in Section 6 of this report. 
2. GENERAL APPROACH

The methods of analysis used to predict fission product release and transport behavior are essentially the same as those presented in NUREG-0956, "Reassessment of the Technical Bases for Estimating Source Terms"(5). These computer codes have since been assembled as the Source Term Code Package ${ }^{(4)}$. The Mod 1 version of the Source Term Code Package ${ }^{(4)}$ (released for public use in 1986) was used for this study.

\subsection{Source Term Code Package ${ }^{(4)}$}

A number of changes have been made in the process of integrating the BMI-2104 ${ }^{(6)}$ source term codes into the Source Term Code Package ${ }^{(4)}$. Many of these changes merely simplify the use of the codes by streamlining and automating the data transfer between codes. Some of the changes, however, involve actual improvements in the physical models or in the coupling between models.

Figure 2.1.1 illustrates the manner in which the codes are grouped in the Source Term Code Package ${ }^{(4)}$. The MARCH2 ${ }^{(7)}$, CORSOR ${ }^{(8)}$, and CORCON-Mod $2^{(9)}$ codes are now coupled. The CORSOR-M version of the CORSOR ${ }^{(8)}$ code, which uses an Arrhenius form for the empirical correlation of fission product release from fuel, has been incorporated into MARCH3. A consistent treatment can now be made of the release of fission products and the transport of sources of decay heat from the fuel. Similarly, CORCON-Mod $2^{(9)}$ is now used in the Code Package ${ }^{(4)}$ to predict the thermal-hydraulic loads on containment due to coreconcrete interactions and as input to the VANESA ${ }^{(16)}$ code to calculate ex-vessel fission product release. In BMI-2104 ${ }^{(6)}$ these processes were treated in a potentially inconsistent manner with two different models, INTER $^{(7)}$ and CORCON-MOd $1^{(11)}$.

Potentially significant changes also resulted from the intimate coupling of the MERGE ${ }^{(12)}$ and TRAP-MELT ${ }^{(13)}$ codes in the Code Package ${ }^{(4)}$. The most important of these are listed below and should be kept in mind when comparing the present results to results presented in BMI-2104(6) for equivalent accident sequences: 


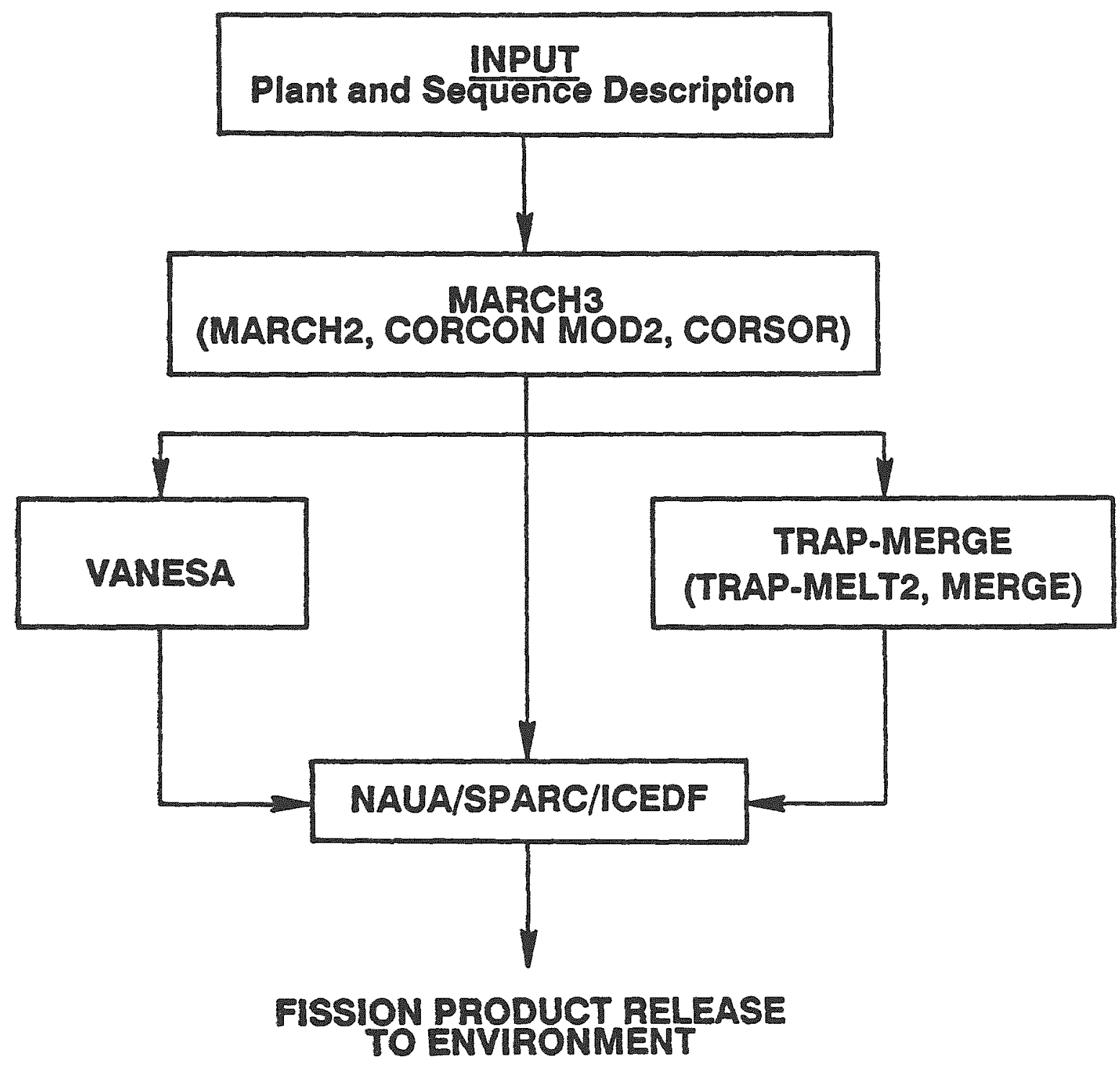

Figure 2.1.1. Source term code package. 
- The decay heat contribution to the thermal-hydraulics of the Reactor Coolant System (RCS) is now considered.

The fission product transport calculations (TRAP) are nodalized congruently with the thermal-hydraulic calculations (MERGE). This includes the use of structures in control volumes that define the boundaries of convective, mixing flow. Previously, distinct structures had to be nodalized as consecutive control volumes.

Gas properties used in TRAP are those calculated by MERGE and now account for the presence of hydrogen.

- Heat transfer coefficients used in TRAP are supplied by MERGE; mass transfer is based on those using the Chilton-Colburn analogy.

- Aerosol particles are allowed to fall back to upstream volumes if orientation and geometry permit.

Aerosol particles settling into the melt are instantaneously revaporized by species constituents with condensed vapors revolatilizing as vapors and particles regenerating as particles with nucleation size.

- The treatment of chemisorption on walls now accounts for gasphase mass transport, which can be limiting for some flows, especially for the highly reactive Te species.

Each of the other codes is run separately in the Code Package ${ }^{(4)}$. In general, the interfaces between the codes have been automated so that an output file from one code is used as the input file for the next.

since earlier work, particularly that related to the TMI-2 accident, had indicated the need for some modeling changes in the thermal coupling between the primary system and the steam generators, the analyses undertaken to 
examine the effect of emergency operating procedures on the course of the accident were performed with a special version of MARCH3. The reference version of MARCH3 is believed to provide adequate treatment of "hands off" accident scenarios of the type normally considered; the improved thermal coupling between the primary and secondary systems becomes more important for the more involved accident scenarios of the type considered here. The model changes utilized here were developed under other efforts.

\subsection{Radionuclide Groups}

Initially in the BMI-2104(8) analyses, four groups of radionuclides were tracked: iodine, cesium, tellurium, and gross aerosols. In order to facilitate ex-plant consequence analyses, the groupings were subsequently changed to the WASH-1400(14) structure: noble gases, iodine, cesium, tellurium, strontium, ruthenium, and lanthanum. In both cases the element named actually represented a group of elements with similar chemical behavior. For the current study, the NRC recommended that two of the WASH-1400(14) groups (strontium and lanthanum) be further subdivided. Table 2.2.1 identifies the radionuclide groups used in this study and the additional elements represented by each group. Additionally, the inert aerosols generated in-vessel and those generated ex-vessel are tracked as separate groups. 
Table 2.2.1. Radionuclide groups.

\begin{tabular}{cl}
\hline \hline Group & \multicolumn{1}{c}{ Elements } \\
\hline 1 & Xe, $\mathrm{Kr}$ \\
2 & $\mathrm{I}, \mathrm{Br}$ \\
3 & $\mathrm{Cs}, \mathrm{Rb}$ \\
4 & $\mathrm{Te}, \mathrm{Sb}, \mathrm{Se}$ \\
5 & $\mathrm{Sr}$ \\
6 & $\mathrm{Ru}, \mathrm{Rh}, \mathrm{Pd}, \mathrm{Mo}, \mathrm{TC}$ \\
7 & $\mathrm{La}, \mathrm{Zr}, \mathrm{Nd}, \mathrm{Pu}, \mathrm{Nb}, \mathrm{Pm}$, \\
8 & $\mathrm{Ce}, \mathrm{Pu}, \mathrm{NP}$ \\
9 & $\mathrm{Ba}, \mathrm{In}$-vessel aerosols \\
10 & Ex-vessel aerosols \\
11 & \\
\hline \hline
\end{tabular}




\section{DESCRIPTION OF PLANTS AND ACCIDENT SCENARIOS}

The STCP modeling of the three plant designs addressed in the present analyses is substantially the same as that developed in BMI-2104(8), and used subsequently in the calculations reported in NUREG/CR-4624(2). The responses of the three plants to severe accidents were analyzed by SARRP(1) for inclusion in NUREG-1150(3).

\subsection{BWR, Mark I Containment Design}

The STCP model for the accident scenario analyzed for the BWR, Mark I containment design utilized the design characteristics specific to the Peach Bottom Atomic Power Station, Unit 2. The accident scenario addressed in this report and a summary of important aspects of the STCP model for Peach Bottom are discussed below.

\subsubsection{Accident Scenarios Considered}

One accident scenario was analyzed for Peach Bottom, a station blackout initiated by a loss of all dc power. This scenario corresponds to the most likely accident progression in the TBUX plant damage state, as evaluated by SARRP(1). The combined failure of $a 11$ ac and $d c$ power buses renders all emergency core coolant systems unavailable at time zero. The operators are assumed to be unable to depressurize the reactor vessel because $d c$ power is unavailable (necessary for safety/relief valve (SRV) operation). The reactor vessel, therefore, remains at the SRV setpoint during the core meltdown period.

\subsubsection{Primary System Flowpaths}

The flowpaths for fission product transport within the reactor coolant system (RCS) for the TBUX sequence are illustrated schematically in Figure 3.1.1. The TRAP-MELT3 control volumes and their connections used to model these flowpaths are illustrated in Figure 3.1.2. After leaving the core region, the fission products pass through the upper core support structure and 


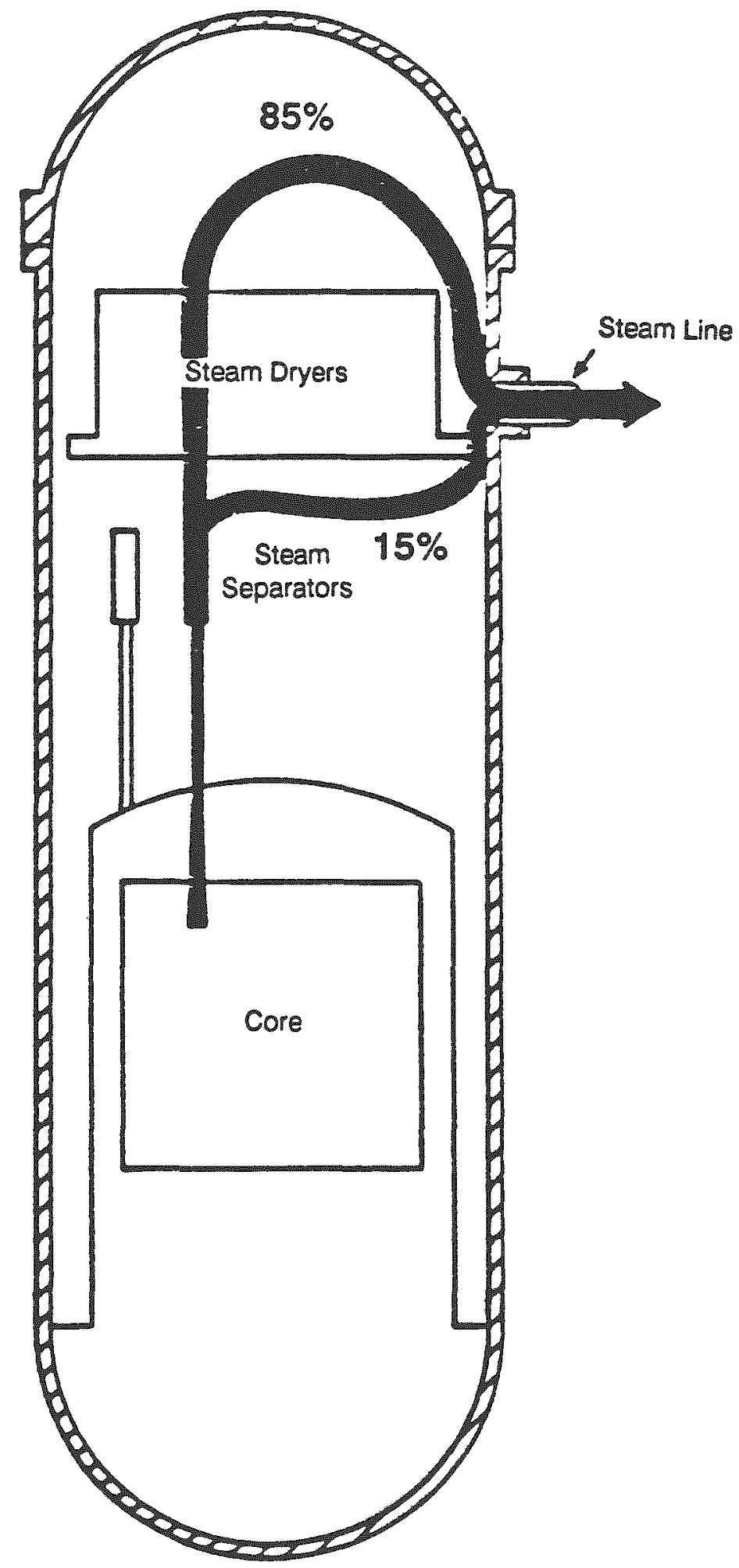

Figure 3.1.1. Flowpaths for fission product transport in RCS - Peach Bottom TBUX. 
9

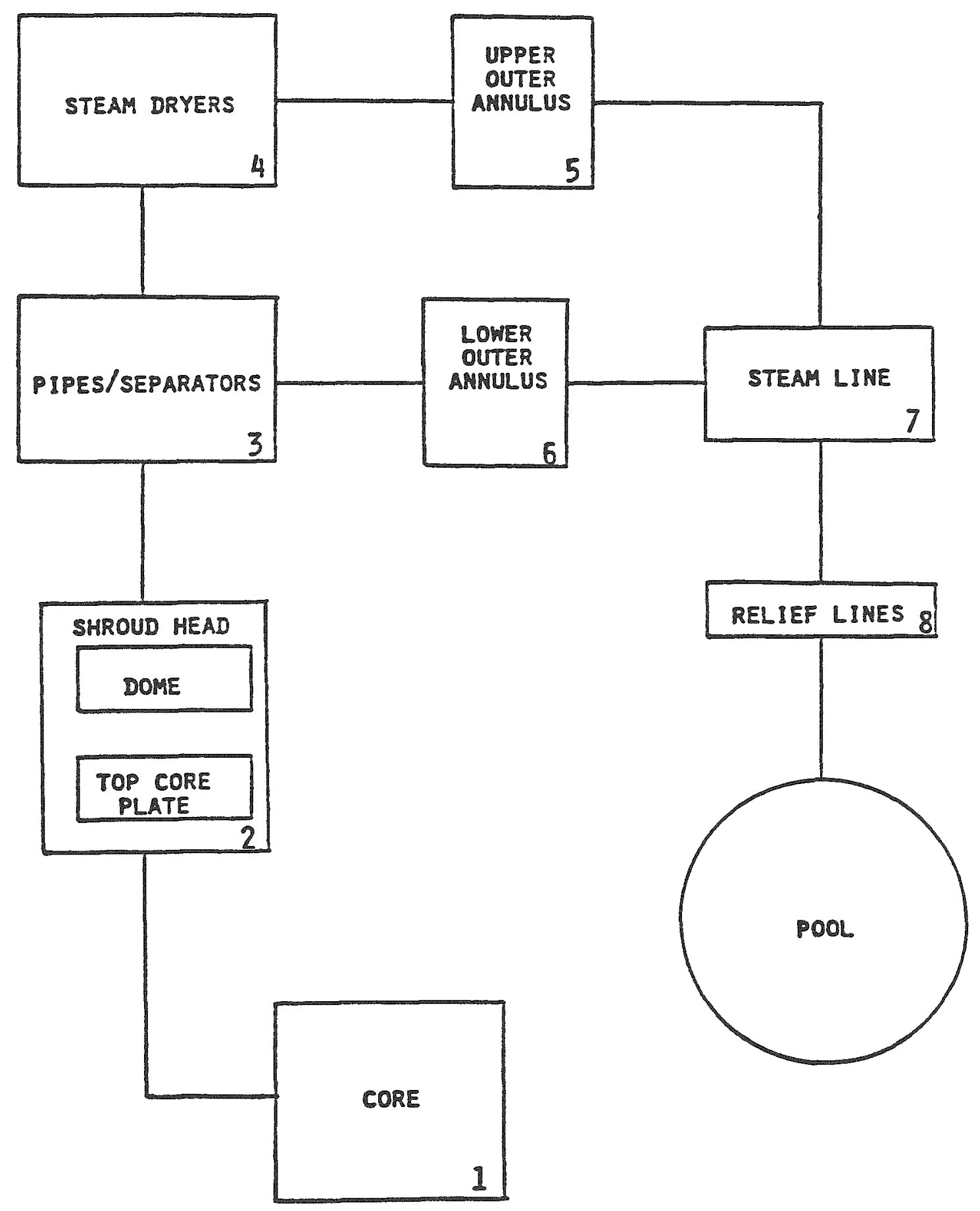

Figure 3.1.2. Schematic of primary system control volumes for the Peach Bottom TBUX sequence. 
flow into the dome region below the shroud head. From there the fission products flow through the standpipes and steam separators. After passing through the steam separators, the flowpath divides, with 85 percent going through the steam dryers and the upper outer annulus, and 15 percent bypassing the steam dryers and going directly to the lower outer annulus. This is the division of flow suggested by General Electric as a result of the BMI-2104 peer review. The two flow streams combine at the stean line and from there flow through the relief lines into the suppression pool.

\subsubsection{Containment Flowpaths}

The containment flowpaths for the Peach Bottom TBUX sequence, which involves containment failure after penetration of the reactor pressure vessel (RPV) by molten core debris, are illustrated in Figure 3.1.3. Only the principal flowpaths are illustrated; normal leakage as well as some possible recirculation flows have been omitted for clarity.

Key points to be noted from this figure are that both the in-vessel melt release as well as the ex-vessel core-concrete interaction release undergo scrubbing by the suppression pool. This is because the location assumed for containment failure is in the wetwell above the suppression pool water level (see next section). The point of entry of gases and released radionuclides into the suppression pool corresponds to the level of submergence of the relief line T-quenchers for in-vessel releases and of the downcomers for ex-vessel releases.

\subsubsection{Containment Failure Mode and Pressure Level}

The primary containment was assumed to fail above the water level in the wetwell at a pressure level of 159 psig. This is a departure from earlier analyses ${ }^{(2,6)}$ in which drywell failures were assumed. The current assumption is based on recent analyses performed by the Chicago Bridge and Iron Co., the designer and builder of the Peach Bottom containment vessel. It is further assumed that when the containment fails, the resulting opening is large (characterized in the MARCH3 analysis with a $7 \mathrm{ft}^{2}$ opening). Although the 
Prior to Vessel Failure

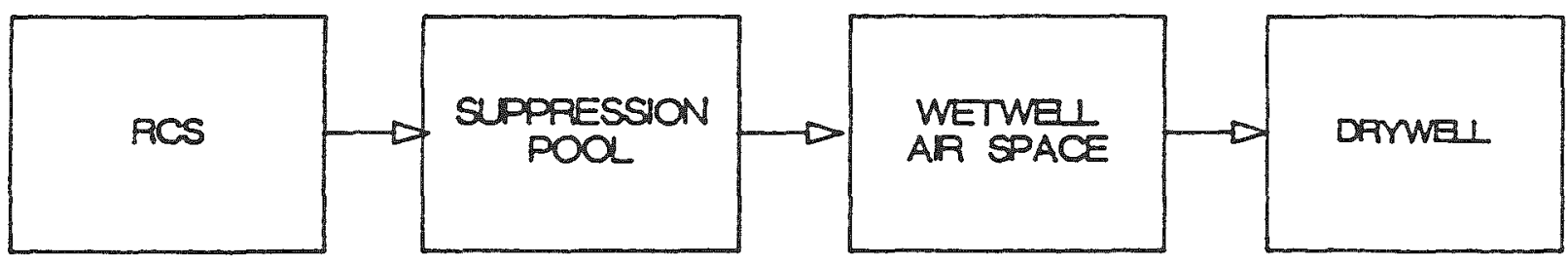

After Vessel Failure

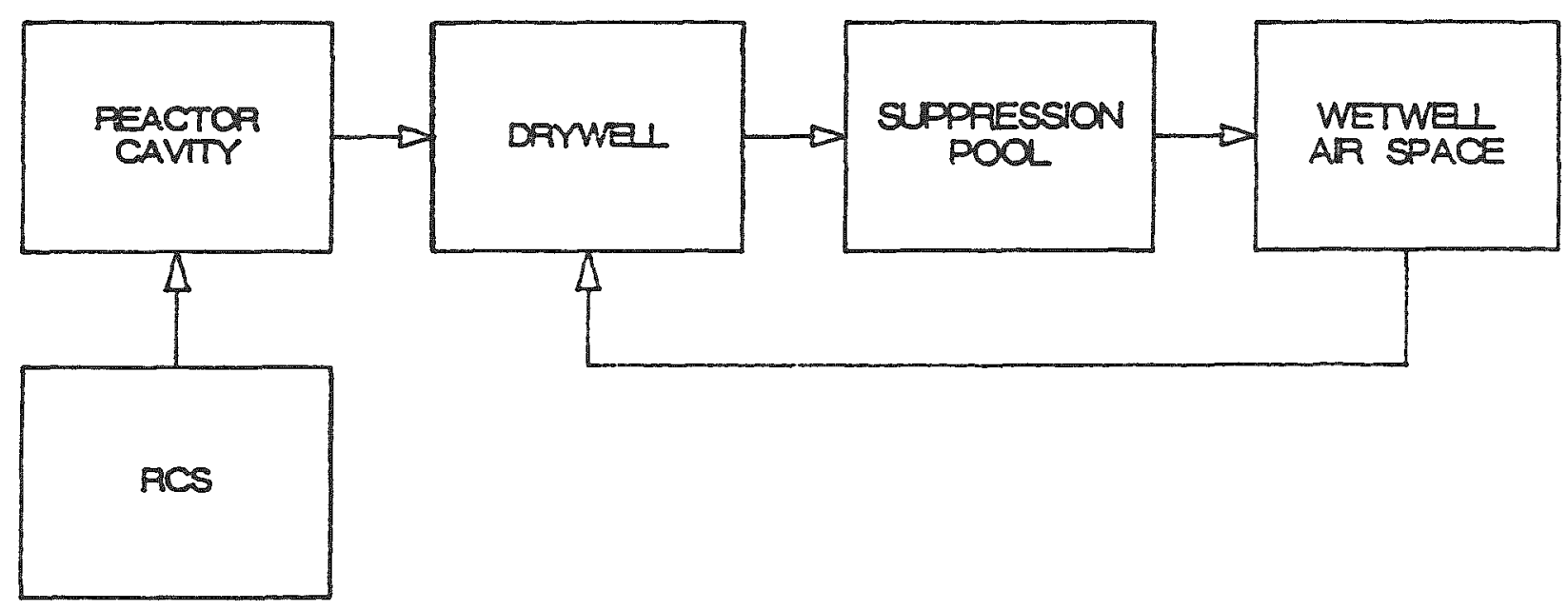

After Vessel and Containment Failure

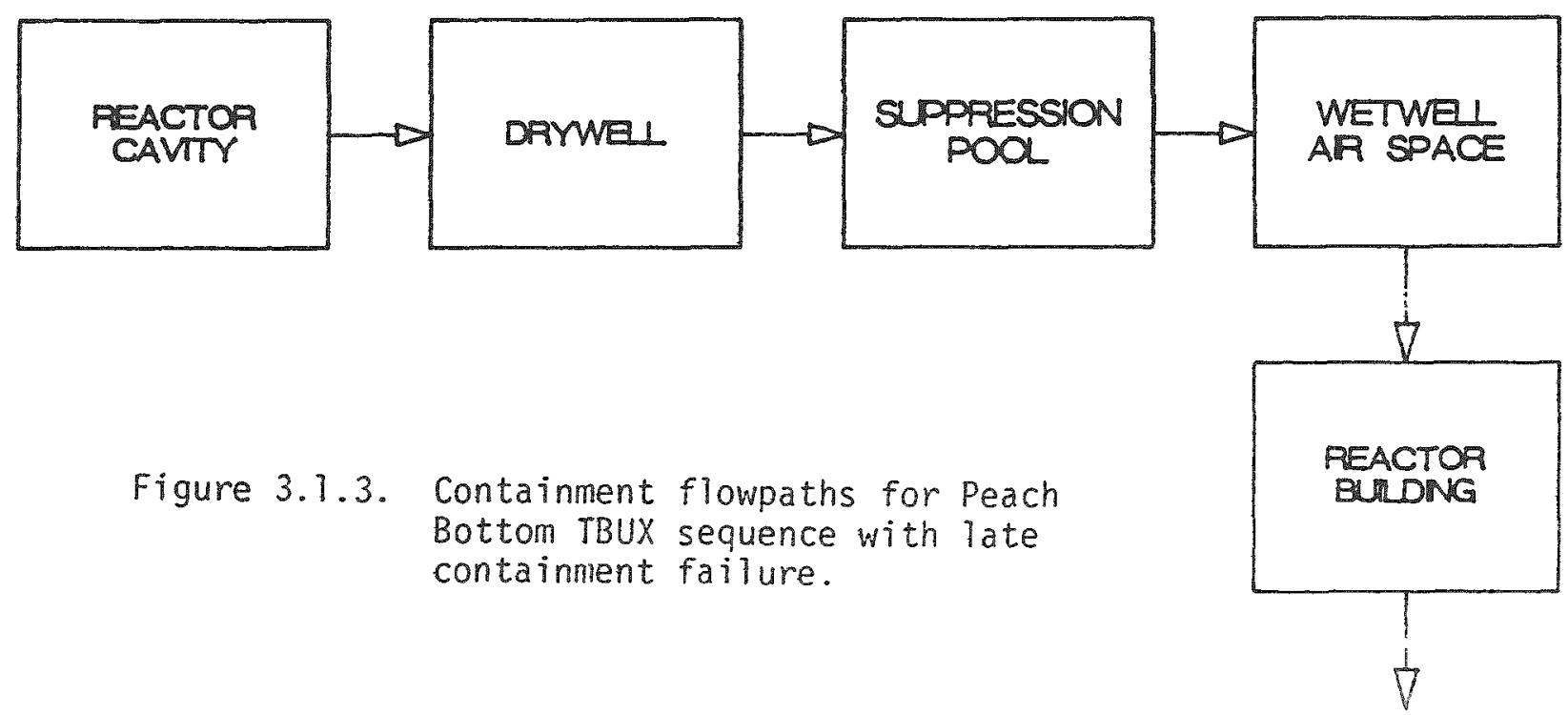


maximum temperatures predicted in the drywell are quite high for the scenarios analyzed, usually these temperatures occur late in the accident and are not assumed to induce any drywell leakage.

In the Peach Bottom Plant design, a reactor building encloses the primary containment. The design pressure of this building is 3 psig. No analyses have been performed to evaluate the expected failure pressure for this building, but there is certainly some margin between design and failure. The reactor building communicates freely (approximately $400 \mathrm{ft}^{2}$ of opening) with an enclosed refueling floor above the reactor building. The same large opening also provides communication between the several levels within the reactor building. Unlike the concrete-walled reactor building, the refueling bay is enclosed with primarily sheet metal structures and has very little strength. There are $240 \mathrm{ft}^{2}$ of blowout panels in the refueling bay which relieve excess building pressure to the atmosphere. Under the conditions imposed on the building in the scenarios analyzed, it is likely that the walls of the refueling bay would be severely damaged and that the effective leakage area would be greater than the area of the blowout panels. In the scenarios analyzed, credit is taken for the retention of radionuclides in the reactor building and the refueling bay. Source terms for containment event tree branches in which the reactor building is bypassed or in which it is assumed to fail early in the accident can be obtained from the source term released from the drywell.

\subsection{PWR, Subatmospheric Containment Design}

The STCP model for the accident scenario analyzed for the PWR, subatmospheric containment design utilized the design characteristics specific to the Surry Nuclear Power Plant, Unit 1. The accident scenario addressed in this report and a summary of the STCP model for Surry are discussed below.

\subsubsection{Accident Scenarios Considered}

Eight accident scenarios were analyzed for Surry. Complete source term calculations were performed for only one sequence, a station blackout with an 
induced reactor coolant pump (RCP) seal loss-of-coolant accident (LOCA) (designated as $S_{3} B$ in the following discussions).

1. $S_{3} B$ : Station blackout with induced $R C P$ seal LOCA. The assumed size of the seal LOCA was such that a leak rate at maximum system pressure is $900 \mathrm{gpm}^{*}$. This corresponds to about a one-inch diameter opening in the MARCH model. With the loss of electric power, none of the active engineered safety systems are available. Containment failure at the time of reactor vessel breach was assumed.

2. HINY-NXY: Steam generator tube rupture initiated accident. The operators fail to depressurize in a timely manner and one SRV on the steam line from the affected steam generator sticks open. The entire contents of the refueling water storage tank (RWST) are pumped through the broken tube before core uncovery begins.

3. GLYY-YXY: Steam generator tube rupture initiated accident which is similar to HINY-NXY except that no SRVs stick open and high pressure injection (HPI) is failed. Operators do not open the pressure-operated relief valves (PORVs) due to operator error. Core uncovery occurs early.

4. HINY-YXY: Steam generator tube rupture initiated accident which is similar to HINY-NXY, except that the PORV also sticks open. Although more inventory escapes the PORV than the SRV, during recirculation enough water is eventually lost from containment that the pumps have inadequate net positive suction head (NPSH).

5. TB (with secondary depressurization): In this scenario the auxiliary feedwater is available for five hours into the accident. The operators

" Leak rate specified as part of accident sequence definition. (Ref: Letter from E. Gorham-Bergeron (SNL) to R. S. Denning (BCD), July 7, 1987.) 
depressurize the secondary side of the steam generators to $175 \mathrm{psig}$, starting at 1.5 hour and completing at 2.5 hours. The PORVs are not opened. Since ac power is not available, the containment safety features are not operable.

6. $S_{3} B$ (with secondary depressurization): The pump seal failure is assumed to take place at 1 hour into the accident with a resulting leak rate at nominal operating conditions of $250 \mathrm{gpm}$ per pump, or $750 \mathrm{gpm}$ total. Auxiliary feedwater is available for 5 hours into the accident. The operators are assumed to depressurize the secondary side of the steam generators to $175 \mathrm{psig}$, starting at 70 minutes and ending at 100 minutes into the accident. The PORVs are not opened. As in the preceding case, containment safety features are not available due to the loss of ac power.

7. $S_{3} D$ (with secondary depressurization): The initiating event is a very small break, assumed to be identical to the pump seal failure of the preceding case, with a total leak rate at normal operating conditions of $750 \mathrm{gpm}$. The auxiliary feedwater system is available indefinitely, but emergency core cooling injection fails. The operators are assumed to depressurize the secondary sides of the steam generators to $175 \mathrm{psig}$, starting at 30 minutes and completing at 60 minutes into the accident. In the base case for this sequence the PORVs are not opened; in the variation of this sequence the PORVS are opened when the average core exit gas temperature reaches $1200^{\circ} \mathrm{F}$.

Since electric power is available in this sequence, the containment safety features would be available. We have assumed that the containment coolers would initially be used to try to control the containment pressure. At a containment pressure of 25 psia the spray injection would be actuated.

With the operation of the containment sprays in this sequence, it is expected that the reactor cavity would receive a continuing inflow of 
water. While it is recognized that significant quantities of water in the cavity could offer the potential for the formation of coolable debris beds, for purposes of the present analyses it has been assumed that the debris would be uncoolable. This assumption permits the analysis of long term generation of combustible gases during the attack of concrete by the core debris.

8. $S_{2} D$ (with secondary depressurization): The initiating event for this sequence is a primary system break 2 inches in diameter. Auxiliary feedwater is available indefinitely, but emergency core cooling system injection fails. The operators are assumed to depressurize the secondary side of the steam generators to 175 psig, starting at 30 minutes and completing at 60 minutes into the accident. The PORVs are assumed to be opened when the average core exit gas temperature reaches $1200^{\circ} \mathrm{F}$.

The containment safety feature actuation assumptions as well as those regarding debris behavior in the reactor cavity are the same as in the previous case.

\subsubsection{Primary System Flowpaths}

The primary system fission product flowpaths for the $S_{3} B$ sequence are illustrated in Figure 3.2.1. Effluent from the reactor vessel passes via a hot leg through steam generator $U$-tubes to the reactor coolant pump and exits via failed RCP seals. The TRAP-MELT3 control volume representation for these flowpaths is illustrated in Figure 3.2.2.

\subsubsection{Containment Flowpaths}

The Surry containment building is treated as a single well mixed volume in these analyses. Thus, any fission products released to the containment atmosphere are assumed to mix instantaneously with the airborne contents of the containment. After containment failure, airborne activity is calculated to leak out of the containment based on orifice flow. After the initial rapid 


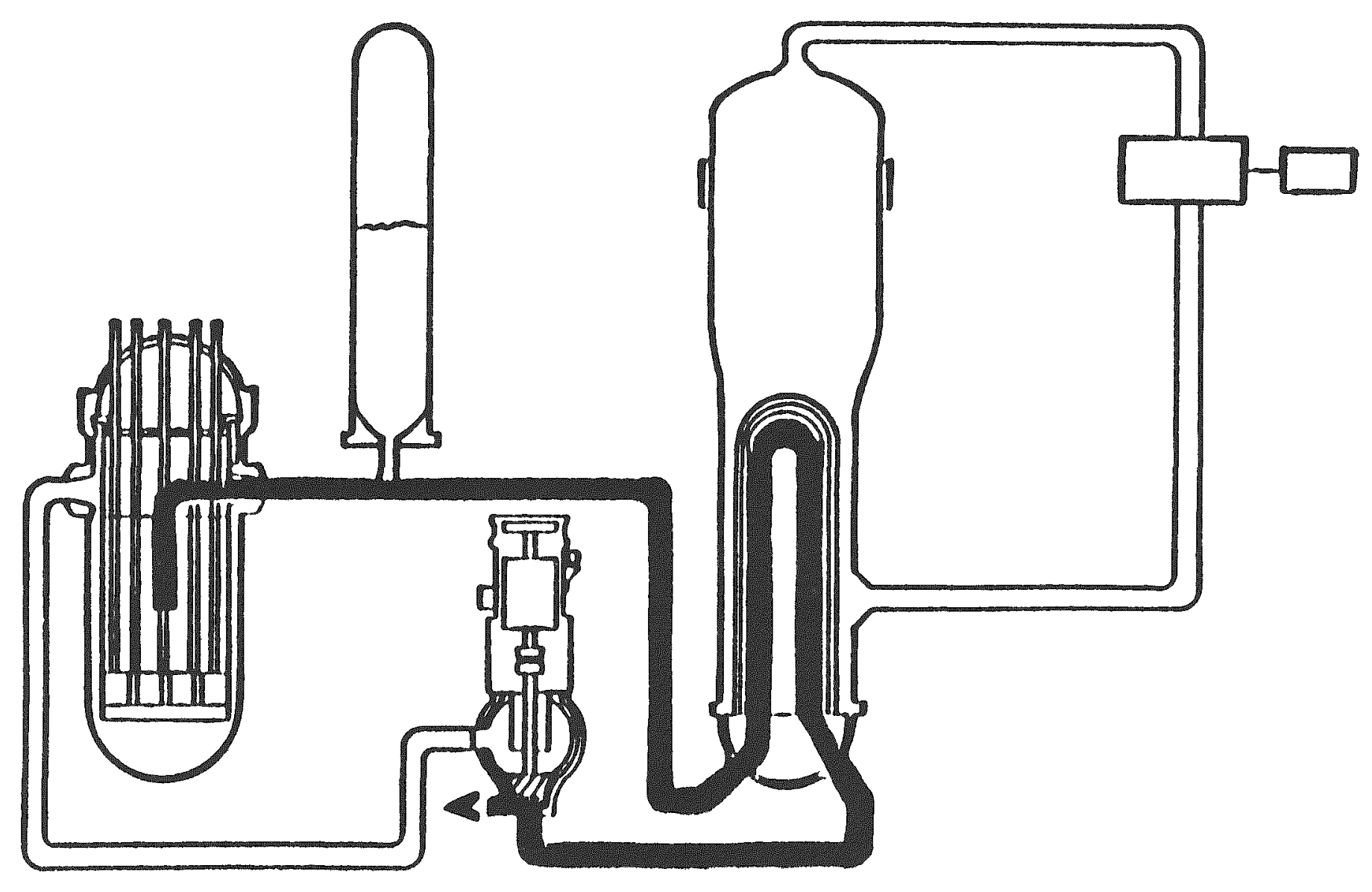

Figure 3.2.1. Primary system flowpaths for the Surry seal LOCA $\left(S_{3}\right)$ sequences. 


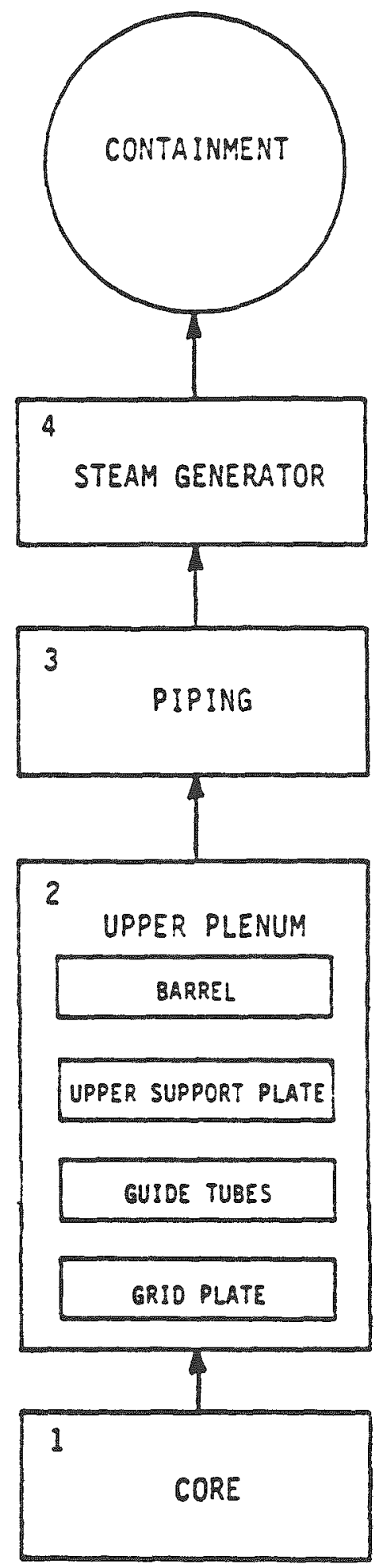

Figure 3.2.2. Schematic of primary system control volumes for the Surry seal LOCA $\left(S_{3}\right)$ sequences. 
depressurization, the leak rate is largely governed by the available driving forces, i.e., gas and vapor generation.

\subsubsection{Containment Failure Mode}

The Surry containment is a steel-lined reinforced concrete structure with a free volume of $1.8 \times 10^{6} \mathrm{ft}^{3}$. It is operated under slightly subatmospheric conditions (a nominal pressure of 10 psia at $100 \mathrm{~F}$ ). As mentioned earlier, containment failure at the time of reactor vessel breach was specified for this scenario (i.e., an energetic event is assumed to occur in the containment immediately following vessel penetration). This event could result from direct containment heating and/or hydrogen combustion.

\subsection{PWR, Ice Condenser Containment Design}

The STCP model for the accident scenario analyzed for the PWR, ice condenser containment design utilized the design characteristics specific to the Sequoyah Nuclear Power Plant, Unit 1. The accident scenarios addressed in this report and a summary of the STCP model for Sequoyah are discussed below.

\subsubsection{Accident Scenarios Considered}

Three accident scenarios were analyzed with the STCP(4) to obtain source terms for Sequoyah. Two sequences were analyzed with only the MARCH3 code to examine the effects of secondary side depressurization.

1. $S_{3} B$ : Station blackout with induced $R C P$ seal $L O C A(s)$. This scenario involves the unavailability of all emergency core cooling systems and the delayed failure of RCP seals in all four pumps three hours into the accident. The size of the seal LOCA(s) is such that a maximum total leak rate of $1200 \mathrm{gpm}^{*}$ would result at full system pressure. Auxiliary feedwater (steam-driven) operates throughout the accident and (according

* Leak rate specified as part of accident sequence definition. (Ref: Personal conversation with D. C. Williams (SNL), September 8, 1987.) 
to plant procedural instructions) the secondary side of the steam generators is depressurized to maintain a reduced primary coolant system pressure. Containment safety systems requiring ac electrical power to operate (sprays, air return fans, and hydrogen igniters) are assumed to be unavailable.

STCP analysis of this scenario involved a number of special considerations, as discussed below.

In response to the initiating event, reactor operators are assumed to partially depressurize the secondary side of the steam generators so as to bring down and maintain the primary system pressure somewhat above the accumulator discharge pressure. The availability of steam-driven auxiliary feedwater permits the pressure reduction and holding at that level. RCP pump seal failures are postulated to occur three hours into the accident. Leakage from the primary system leads to eventual core uncovering, melting, and relocating.

In order to approximate the desired depressurization history*, some modifications to the standard (NUREG-0956(5)) MARCH3 modeling were required. These changes included the provision of a user-specified level to which the secondary side of the steam generators can be depressurized (in lieu of the previously fixed value of 150 psia), as well as some changes in the heat transfer coupling between the primary and secondary sides of the steam generator. Thus, a special version of MARCH3 was utilized for the evaluation of this particular accident scenario.

"The following primary coolant system pressure history was desired by the SARRP analysts:

\begin{tabular}{cc} 
Time after loss of ac power (hr) & Pressure (psia) \\
\hline 0.0 & 2250 \\
1.0 & 1000 \\
2.0 & 600 \\
$2.0+$ & 600
\end{tabular}

This pressure history was to be achieved by controlling steam generator secondary pressure (depressurization). 
The postulated containment failure mode for this sequence is a localized detonation in the ice condenser. It will be recalled, however, that MARCH3 does not explicitly model the ice condenser as a separate containment compartment, but treats it as a heat exchanger in the junction between compartments. Further, all the preceding SARRP Sequoyah analyses ${ }^{(2)}$ have been performed with a two-compartment ice condenser model (an upper and lower compartment, connected by the ice condenser junction). It was desired to maintain consistency with the previous results, yet properly reflect the special aspects of this particular scenario. The approach ultimately adopted for handling this scenario was the result of extensive discussions between Battelle and Sandia and involved several supporting calculations. These are described below.

In order to help answer questions regarding the potential for and timing of detonable hydrogen compositions in the containment, a four-compartment model of the Sequoyah containment was developed and analyzed. The four compartments modeled were: the dead end volumes of the lower containment, the lower compartment volume, the upper plenum of the ice condenser, and the upper compartment. This model is essentially the same as a model developed at Battelle in 1985. MARCH3 analyses of the specified Sequoyah $\mathrm{S}_{3} B$ scenario with this containment model indicated that detonable compositions could be attained in the upper plenum of the ice condenser at about the predicted time of core slumping. It was further observed that such upper plenum compositions were predicted to persist for about 15-20 minutes, with the upper plenum subsequently becoming hydrogen rich. Review of these results with Sandia led to the recommendation that a detonation leading to containment failure be assumed at a time when the upper plenum hydrogen concentration was near stoichiometric. However, since the postulated detonation would be highly localized and involve only a relatively small amount of hydrogen, no explicit burning of hydrogen was desired.

The MARCH3 run used as the basis for the present source term evaluation utilized the two-compartment containment models, used in the NUREG/CR-4624 analyses ${ }^{(2)}$, with containment failure assumed to occur at 
about the time of core slump (the time at which the four-compartment model predicted a near stoichiometric hydrogen concentration in the ice condenser upper plenum). It did not explicitly include modeling of hydrogen combustion. Since the specified accident scenario included the assumption that the postulated detonation fails the ice condenser, the failure was modeled to take place in the lower compartment so as to bypass the remaining ice during the subsequent phases of the accident. Sandia National Laboratories is performing 9-cell CONTAIN ${ }^{(15)}$ calculations to investigate the effects of alternative containment nodalization approaches on the results.

2. S3HF: RCP seal LOCA with failure of emergency core cooling (ECC) and containment spray recirculation. The initiating event is an RCP seal failure (in a single pump) of a size sufficient to yield a maximum leak rate (at full primary system pressure) of $480 \mathrm{gpm} .{ }^{*} \mathrm{ECC}$ and containment spray systems operate in the injection mode but fail upon switchover to the recirculation mode. Auxiliary feedwater to the steam generators is available throughout the sequence, as are containment air return fans and hydrogen igniters.

With the relatively small break in the primary system associated with a single pump seal failure and the availability of the steam generator heat sink, the emergency core cooling system would deplete the refueling water storage tank very slowly. Operation of containment sprays, on the other hand, would rapidly deplete the refueling water storage tank inventory and lead to an early switchover to recirculation. As the primary system inventory becomes depleted the effectiveness of the steam generators decreases and the core uncovers and melting begins.

With the refueling water storage tank inventory transferred to the containment floor (by operation of containment sprays), together with the development of a substantial water inventory from ice melting, the

\footnotetext{
* Leak rate specified as part of accident sequence definition. (Ref: Letter
} from E. Bergeron (SNL) to R. S.Denning (BCD), October 1, 1987. 
reactor cavity is flooded at the time of reactor vessel failure. The core debris is specified to be in a coolable geometry in the reactor cavity; this results in ex-vessel steam generation, continued melting of ice and pressurization of the containment eventually to failure. At the time of containment failure, a large amount of water remains in the reactor cavity which will continue to boil off from core debris decay heating. Eventually, however, the reactor cavity dries out, the core debris heats up and attack of the concrete ensues.

3. $\mathrm{S}_{3} \mathrm{H}$ : RCP seal LOCA with failure of ECC recirculation. This scenario is identical to S3HF with the only exceptions being containment sprays are assumed to operate in both the injection and recirculation modes, and an uncoolable debris bed is formed after reactor vessel failure.

The primary system transient is identical to the preceding case $\left(S_{3} H F\right)$. In contrast to the $\mathrm{S}_{3} \mathrm{HF}$ scenario, containment sprays operate throughout the accident, maintaining a flooded reactor cavity. However, the core debris is specified to be uncoolable; thus, corium-concrete interactions will start shortly after reactor vessel failure and take place under a pool of water.

The major question to be answered by the analysis of this case is the likelihood and timing of containment failure. Earlier (BMI-2104(6)) analyses of sequences with continued spray operation and concrete attack in a flooded reactor cavity had indicated a high likelihood of containment over pressurization due to the buildup of noncondensable gases. The earlier analyses were based on the use of the INTER ${ }^{(7)}$ computer model for describing concrete attack; the latter typically predicted more rapid concrete erosion and greater gas production than those predicted with $\operatorname{CORCON}^{(11)}$.

4. $S_{3} B$ (with secondary depressurization):

This sequence is initiated by a station blackout with steam driven auxiliary feedwater available for five hours. The primary coolant pump 
seals are assumed to fail at one hour into the accident with nominal leakage at normal operating conditions of $250 \mathrm{gpm}$ per pump. The operators are assumed to depressurize the secondary side of the steam generators to 175 psig, starting at 70 minutes and ending at 100 minutes. In the absence of ac power, none of the active containment engineered safety systems would be operable.

5. $S_{3} D$ (with secondary depressurization): The initiating event for this sequence is a very small break, assumed to be identical to the pump seal failures of the preceding case, accompanied by failure of active emergency core cooling injection. Auxiliary feedwater is assumed to operate indefinitely. The operators are assumed to depressurize the secondary sides of the steam generators to 175 psig, starting at 30 minutes and ending at 60 minutes into the accident. With the availability of ac power, the containment sprays, air return fans, and igniters are available in this sequence.

\subsubsection{Primary System Flowpaths}

A11 three accident scenarios have the same primary system fission product flowpaths (illustrated in Figure 3.3.1). Effluent from the reactor vessel flows via hot leg(s), through steam generator U-tubes to the reactor coolant pump(s) and exits via failed RCP seals. The TRAP-MELT3 control volume representation for these flowpaths is illustrated in Figure 3.3.2.

\subsubsection{Containment Flowpaths and Failure Modes}

For the Sequoyah (ice condenser) containment design, and particularly for the specific accident scenarios analyzed, the containment flowpaths for fission product release depend strongly on the assumed mode of containment failure. For this reason, the discussions of containment flowpaths and failure modes are combined below.

For the station blackout $\left(S_{3} B\right)$ scenario, the assumed failure mode was failure in the ice condenser upper plenum region due to a local hydrogen detonation. The size of the breach of containment is assumed to be large 


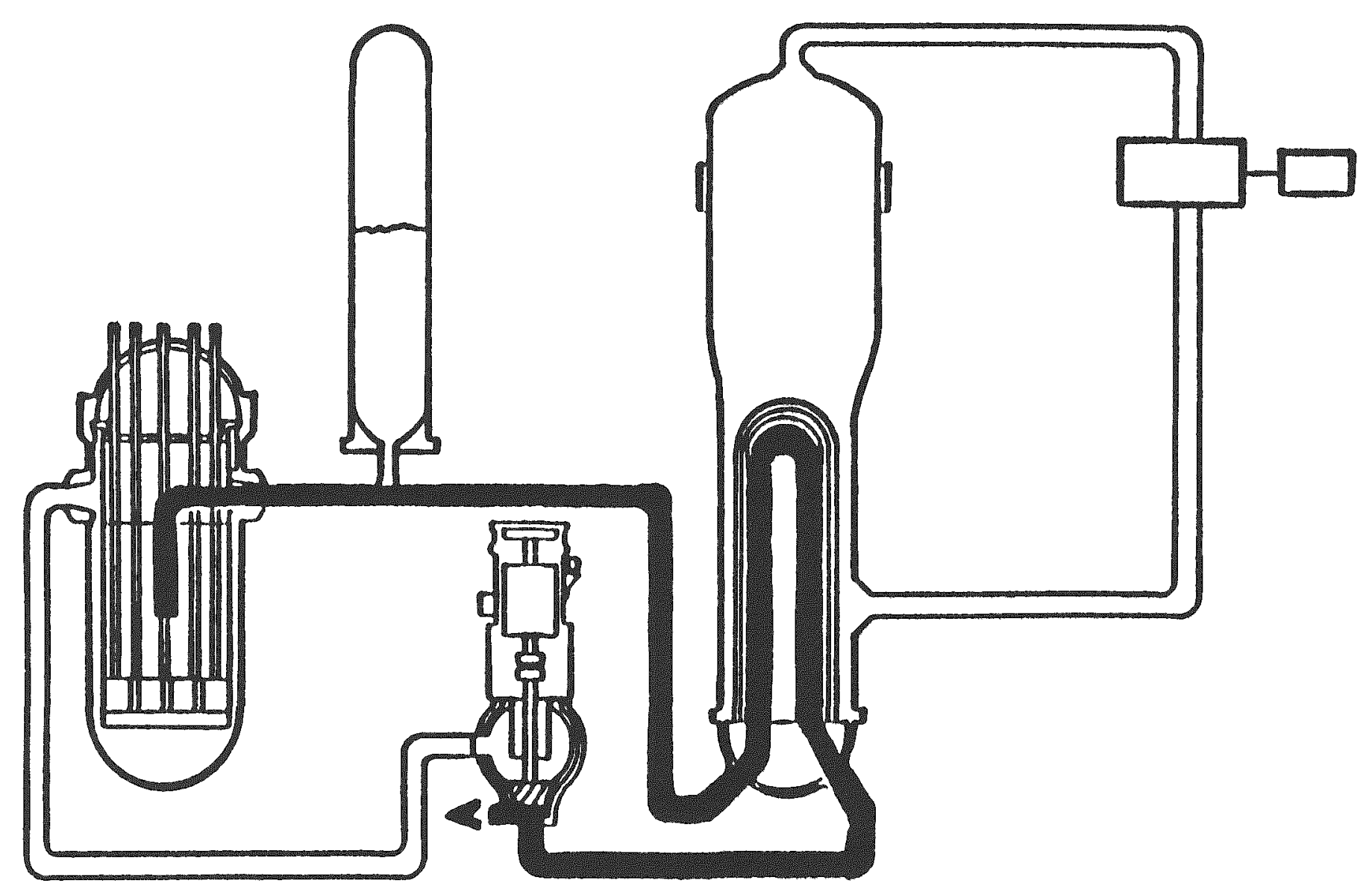

Figure 3.3.1. Primary system flowpaths for the Sequoyah seal LOCA $\left(S_{3}\right)$ sequences. 


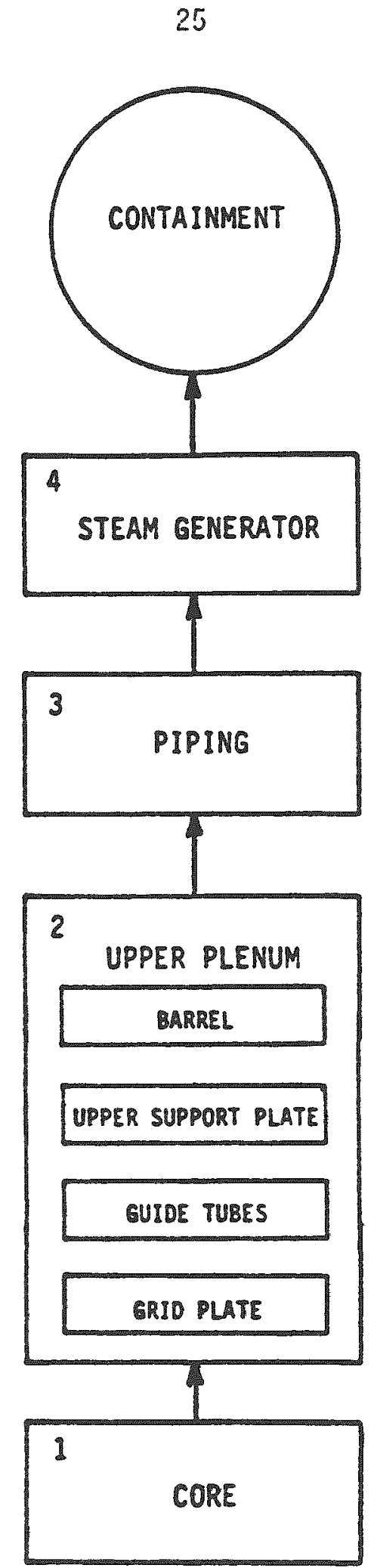

Figure 3.3.2. Schematic of primary system control volumes for the Sequoyah Seal LOCA $\left(S_{3}\right)$ sequences. 
enough to rapidly depressurize the containment ( $7 \mathrm{ft}^{2}$ in the MARCH3 model). The detonation was assumed to cause extensive damage to the ice condenser resulting in complete bypass of the ice condenser after containment failure (i.e., all effluent gases that would normally flow through ice condensers are assumed to flow to the environment without interacting thermally or physically with ice). As described in Section 3.3.1, a detonable mixture is predicted to develop (in this scenario) near the time of core slump (almost one half hour before reactor vessel failure).

Three forms of containment flowpaths were represented in the STCP models to correctly account for changes in radionuclide sources and retention mechanisms over time. The three flowpath forms are illustrated sequentially in Figure 3.3.3. Prior to containment failure, primary system effluent gases flow from the lower compartment to the upper compartment through the ice condenser; ice condenser function is not impaired over this period. Following containment failure, the ice condenser is bypassed and material in the upper and lower compartments passes directly to the environment. After reactor vessel failure, the source of released fission products changes from the reactor coolant system (TRAP-MELT3) to corium-concrete releases (VANESA). Containment sprays do not operate in this scenario, therefore, water is not available to the reactor cavity to scrub corium-concrete releases.

A different failure mode is assumed for the single RCP seal LOCA scenario without containment sprays $\left(S_{3} H F\right)$, and the late containment failure flowpaths are correspondingly different (illustrated in Figure 3.3.4). Prior to reactor vessel breach and containment failure, the flowpaths are similar to those for $S_{3} B$ but the air return fans operate, providing a large recirculation flow through the ice condenser. Due to the early (injection mode) operation of containment sprays, a significant amount of water is available to the reactor cavity resulting in a coolable debris bed. Containment failure is assumed to occur in the upper compartment due to gradual overpressurization from the generation of noncondensable gases and steam (after complete melting of all ice). A failure pressure of 65 psia was assumed, consistent with previous SARRP STCP analyses(2). For the $S_{3} H F$ scenario, this pressure level is predicted to be reached prior to the complete boiloff of reactor cavity water. The long-term (after containment failure and cavity dryout) flowpath (shown at the bottom of Figure 3.3.4) corium-concrete interaction releases effectively 
Pror to Reactor Veasel Fainre and Contahment Falure

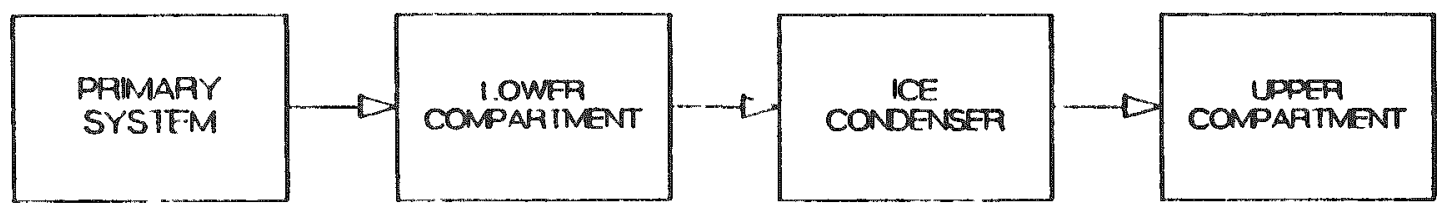

After Contament Failu \& Prior to Peactor Vessed Falhre

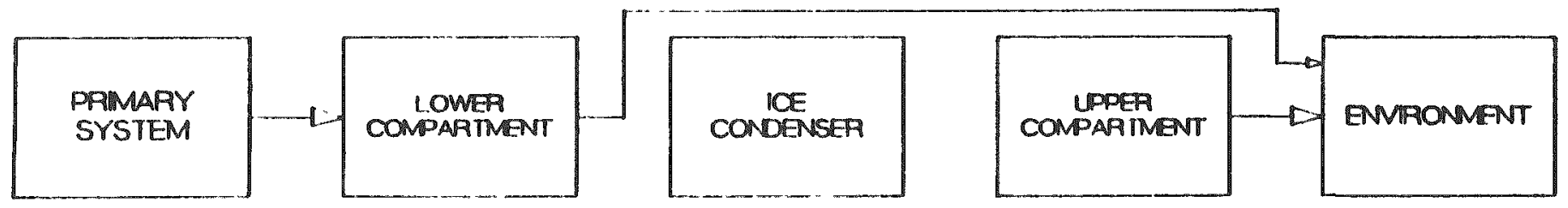

After Pascior Vosod Contabment Finge

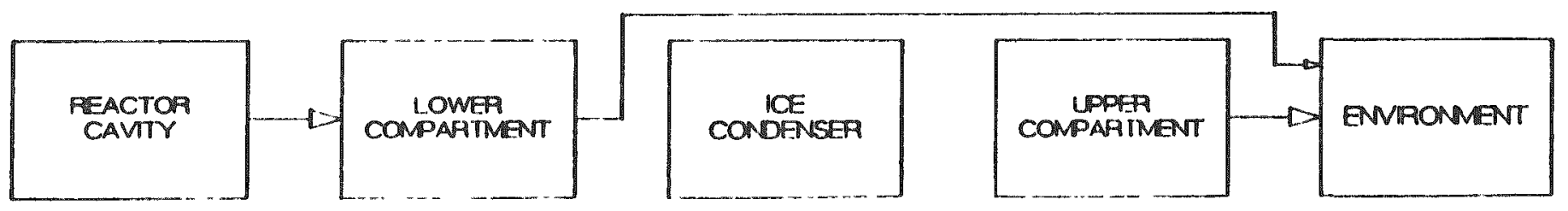

Figure 3.3.3. Containment fission product flowpaths for Sequoyah $S_{3} B$. 
Pror to Reactor Vessel Fallure and Contairment Fallure

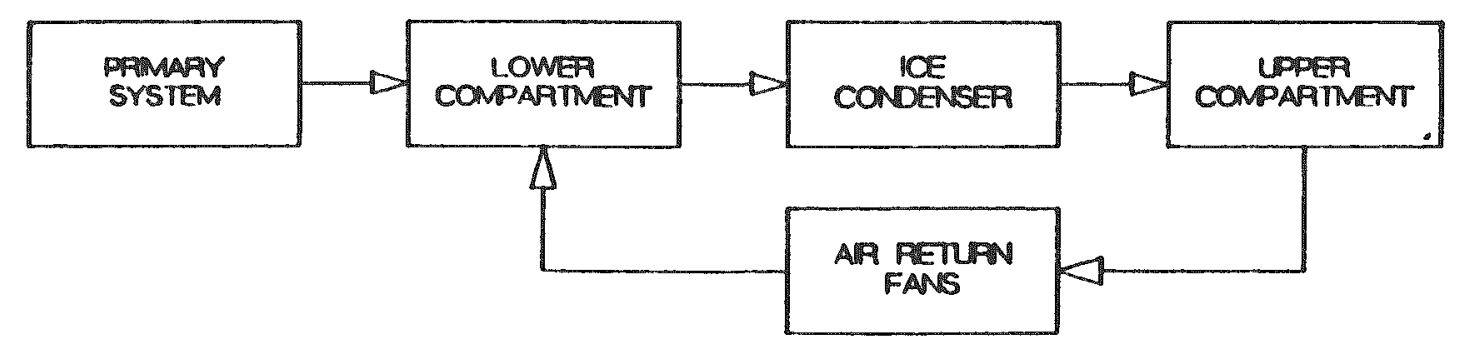

Addutonal Path Arter Contalinment Fain

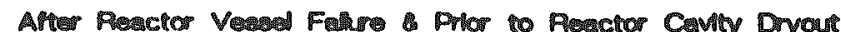
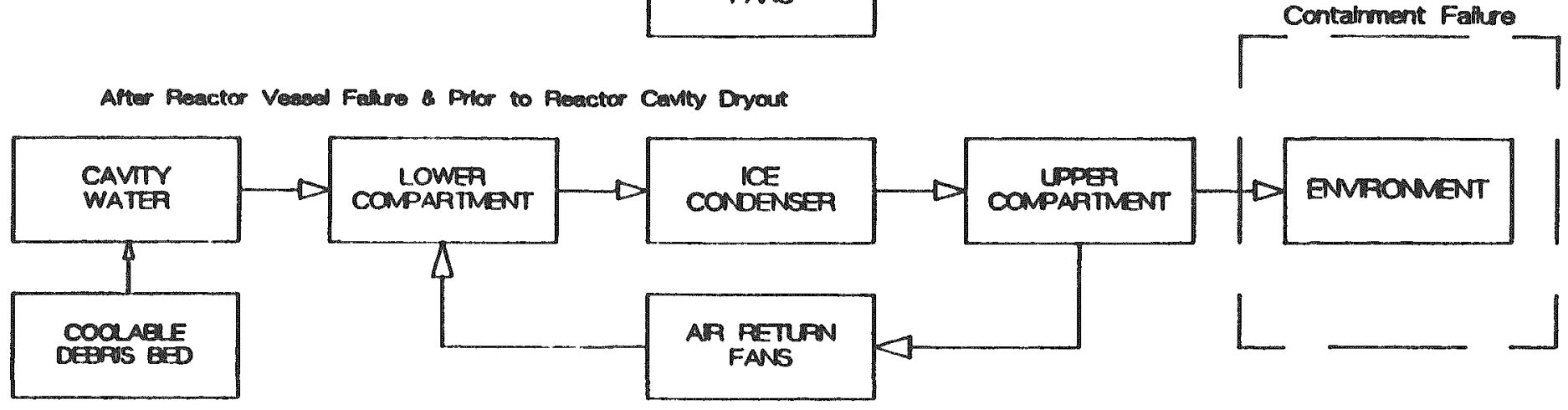

After Contaiment Falne and Reactor Cavity Dyout

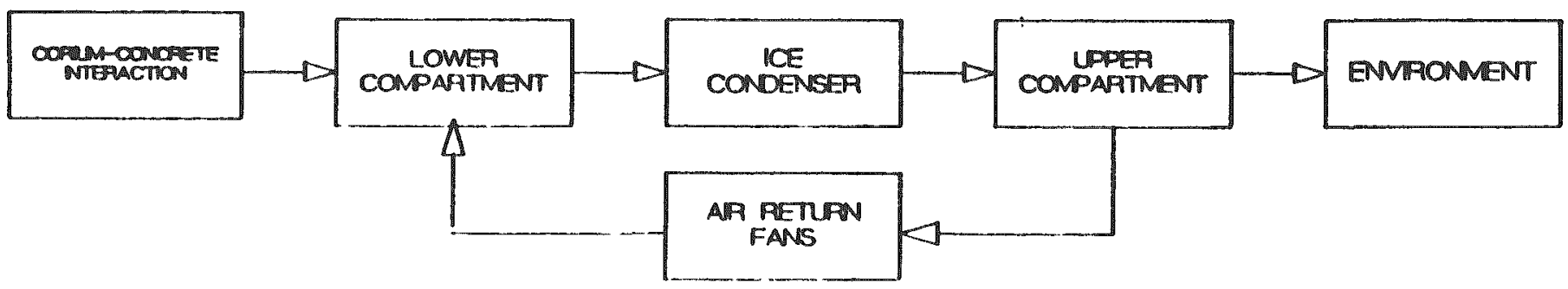

Figure 3.3.4. Containment fission product flowpaths for Sequoyah $S_{3} H F$. 
flow from the lower compartment to the environment through an empty ice condenser since 211 ice melts prior to containment failure.

Containment flowpaths for the $\mathrm{S}_{3} \mathrm{H}$ scenario are not discussed because containment failure was not predicted to occur (refer to Section 4.3.2). 


\section{CALCULATION RESULTS}

The results of analyses of the accident scenarios for each plant are discussed separately. The sub-section numbers for plant analysis results correspond to those shown previously for the plant and scenario descriptions (i.e., Section 4.1 covers the Peach Bottom analyses, 4.2 the Surry analyses, and 4.3 the Sequoyah analyses).

\subsection{BWR, Mark I Containment Design}

The calculated response of the reactor and containment to the postulated accident scenario is dependent on the approach taken to model important severe accident phenomena. A discussion of the important phenomenological modeling assumptions applied in this analysis, therefore, precedes the presentation of calculated results. The results themselves are presented roughly in the order that the calculations are performed with the STCP(4); first the thermal-hydraulic analysis results, followed by a discussion of the modeled radionuclide sources and the results of radionuclide release and transport analyses.

\subsubsection{Phenomenological Modeling Assumptions}

The phenomenological modeling assumptions utilized for the SARRP(1) source term analyses are substantially consistent with the methodology demonstrated in BMI-2104(6); there are, however, several areas in which the earlier approach has been revised. A number of these changes are discussed below.

The current modeling of the Peach Bottom core utilizes the BWR channel box and control blade models as they exist in the reference version of MARCH3; these model options were not fully operational at the time of the BMI-2104 analyses $^{(6)}$ and thus were not utilized at that time.

The core meltdown model utilized is MARCH Model A with gradual, or regionwise, slumping. With this model, and the specific control parameters developed in earlier work, molten fuel is allowed to fall out of the core 
Peach Bottom

when the lowest node in a radial region is fully molten; at that time all the nodes in that radial region that are molten are assumed to fall onto the lower core support structure. When the total core melt fraction reaches 75 percent, the entire core including the unmelted portions is allowed to collapse into the lower plenum of the reactor vessel. Alternatively, the entire core is assumed to fall into the vessel head when the temperature of the lower support structures reaches the melting temperature.

In earlier analyses the metal-water reactions were allowed to continue in the molten nodes both for the PWR as well as BWR designs. The extent of in-vessel hydrogen generation and the most appropriate ways of modeling it continue to be the subject of considerable controversy. Sensitivity studies conducted on a PWR have indicated that the assumption of continued reaction in the melt does not have a major effect on the predicted accident progression and the amount of in-vessel hydrogen generation. Comparable sensitivity studies have not been performed for BWR core designs. Since the arguments in favor of complete steam flow blockage upon core liquifaction are not compelling, and in order to maintain consistency with the earlier analyses, the earlier modeling options were retained for the present analyses. In order to gain insight on the dependence of in-vessel hydrogen generation for BWRs on various modeling assumptions, limited sensitivity studies have been conducted with an early version of the STCP(4) based on the Peach Bottom design; these are described in NUREG/CR-4624, Volume $1^{(2)}$.

Following the onset of fuel slumping, the core debris is assumed to interact with (be held up by) the support structures below the core. In the MARCH modeling of these phenomena, the overheating and failure of the lower structures are required before the onset of reactor vessel attack. The effectiveness of these structures in holding up core debris and thus delaying vessel head heating can be affected by the input values for the effective heat capacity and failure temperature of these structures. The effectiveness of these structures may also depend on assumptions of debris-water interactions in the vessel head; in BMI-2104 ${ }^{(6)}$ and NUREG/CR-4624(2), fragmentation of the debris was assumed. This approach has also been retained in the present analyses.

The amount of lower support structure material actualiy involved in interactions with the core debris depends on specifics of the accident 
scenario. For low-pressure core melt scenarios, there may be little driving force for expulsion of the debris from the primary system and a large fraction of the support structures may overheat and be absorbed into the debris prior to head failure. For high-pressure core melt sequences, on the other hand, collapse of the core debris into the vessel head may lead to early penetration of one or more of the control rod guide tubes and the expulsion under pressure of the core debris out of the primary system before much of the support structures have been overheated. Localized vessel failure was, therefore, assumed to occur in the TBUX analysis, a high-pressure melt scenario.

Following vessel failure, the degree of debris dispersal in the containment needs to be considered. This is, again, a source of considerable uncertainty. In the BMI-2104 analyses ${ }^{(6)}$ the debris was assumed to be confined to the reactor pedestal; other analyses ${ }^{(2)}$ have assumed that the debris would be dispersed over the entire floor of the drywe11. In addition to the primary system pressure as a principal contributor to debris dispersal, the temperature of the debris at the time of vessel head failure should be considered. High-temperature debris would be expected to be dispersed more readily than debris that is only partially molten, for example. Consistent with the NUREG/CR-4624 analyses ${ }^{(2)}$, debris dispersal outside the pedestal region is assumed in the analyses in this report.

As has been previously noted, the SARRP Peach Bottom analyses ${ }^{(2)}$ include modeling of both the primary as well as secondary containments. The primary containment has been represented as a two-compartment system (drywell and wetwel1) with the suppression pool in the junction between them. The secondary containment has been represented as two additional compartments; the reactor building being one compartment, and the refueling bay the other compartment. In the thermal-hydraulic analyses, the primary containment is isolated from the secondary containment until the former fails. While the MARCH pressure equilibration model is used to determine flows between the two compartments of the primary containment and, separately, between the two compartments of the secondary containment, the primary and secondary containments are not required to be at the same pressure. Similary, leakage to the environment from the secondary containment is evaluated on the basis of the orifice flow equation. 
Hydrogen combustion was assumed to occur in the reactor building or refueling bay if the hydrogen concentration in either volume exceeded 8 volume percent. Ignition and continued burning were subject to considerations of oxygen availability and inerting by diluents. Primary containment combustion events were assumed to be impossible because of nitrogen inerting.

\subsubsection{Results of Thermal-hydraulic Analyses}

\section{PRIMARY SYSTEM RESPONSE - PEach Bottom TBUX}

Table 4.1.1 summarizes the timing of accident events as predicted by MARCH3. Core and primary system conditions at key times during the sequence are summarized in Table 4.1.2. Figure 4.1.1 gives the primary system water inventory as a function of time. The primary system pressure is maintained essentially constant by the operation of the safety/relief valves. The safety/relief valve steam and hydrogen flow rates are given in Figures 4.1 .2 and 4.1.3, respectively. Initially all the decay heat goes into boiling off primary coolant and the inventory decreases relatively rapidly. As the core uncovers and heats up, the rate of coolant boiloff decreases to a low level. Core slumping and collapse lead to the rapid boiloff of the water in the vessel head. The final abrupt decrease in the water inventory seen in Figure 4.1.1 is associated with the release of the water trapped in the jet pump region following vessel failure. It is interesting to note in Figure 4.1.3 that essentially all the hydrogen release from the primary system appears to take place following fuel slumping.

Figure 4.1 .4 gives the maximum and average core temperatures for this sequence; core exit gas temperature as well as that leaving the primary system are shown in Figure 4.1.5. The fractions of cladding reacted and core melted are illustrated in Figure 4.1.6. The latter figure indicates that 32 percent of the cladding is predicted to react with steam during this sequence; additionally, about 11 percent of the channel boxes as well as about 9 percent of the stainless steel control blade sheaths are predicted to react. This 
Table 4.1.1. Timing of key events - Peach Bottom TBUX.

\begin{tabular}{lc}
\hline \multicolumn{1}{c}{ Event } & $\begin{array}{c}\text { Time, } \\
\text { Minutes }\end{array}$ \\
\hline Core uncovery & 66.7 \\
Start melt & 134.2 \\
Core slump & 167.7 \\
Core collapse & 168.7 \\
Bottom head dryout & 178.6 \\
Bottom head failure & 201.1 \\
Start concrete attack & 202.2 \\
Corium iayers invert & 339.2 \\
Wetwell failure/secondary containment failure & 349.2 \\
Hydrogen burn & 349.9 \\
End calculation & 802.3 \\
\hline \hline
\end{tabular}


Table 4.1.2. Core and primary system response - Peach Bottom TBUX.

\begin{tabular}{|c|c|c|c|c|c|c|c|}
\hline $\begin{array}{l}\text { Accident } \\
\text { Event }\end{array}$ & $\begin{array}{c}\text { Tires, } \\
\text { inutes }\end{array}$ & $\begin{array}{l}\text { Primary } \\
\text { systei } \\
\text { Pressure, } \\
\text { psia }\end{array}$ & $\begin{array}{l}\text { Primary } \\
\text { Systew } \\
\text { water } \\
\text { Inventory. } \\
16\end{array}$ & $\begin{array}{l}\text { Average Core } \\
\text { Temperature, } \\
\text { of }\end{array}$ & $\begin{array}{l}\text { Peale Core } \\
\text { Temperature, } \\
\text { of }\end{array}$ & $\begin{array}{c}\text { Fraction } \\
\text { Core } \\
\text { Melted }\end{array}$ & $\begin{array}{l}\text { Fraction } \\
\text { Zircaloy } \\
\text { Reacted }\end{array}$ \\
\hline Core uncovery & 66.7 & 1121 & $2.53 \times 105$ & 567 & 571 & 0.0 & 0.0 \\
\hline Start melt & 134.2 & 1122 & $1.68 \times 105$ & 2838 & 4130 & 0.0 & 0.08 \\
\hline Core sluaps & 167.7 & 1123 & $1.85 \times 10^{5}$ & 3547 & 4130 & 0.39 & 0.12 \\
\hline Coro collapse & 166.7 & 1127 & $1.75 \times 105$ & 3752 & $-\infty$ & 0.75 & 0.24 \\
\hline Bottom head dryout & 178.6 & 1143 & $3.58 \times 10^{4}$ & 2614 & $-\infty$ & $-\infty$ & 0.24 \\
\hline Bothor head pilure & 201.1 & 1143 & 0.0 & 2985 & $-\infty$ & $-\infty$ & 0.24 \\
\hline
\end{tabular}

- Vater retsined in jet pupp region. 


\section{PEACH BOTTOM TBUX}

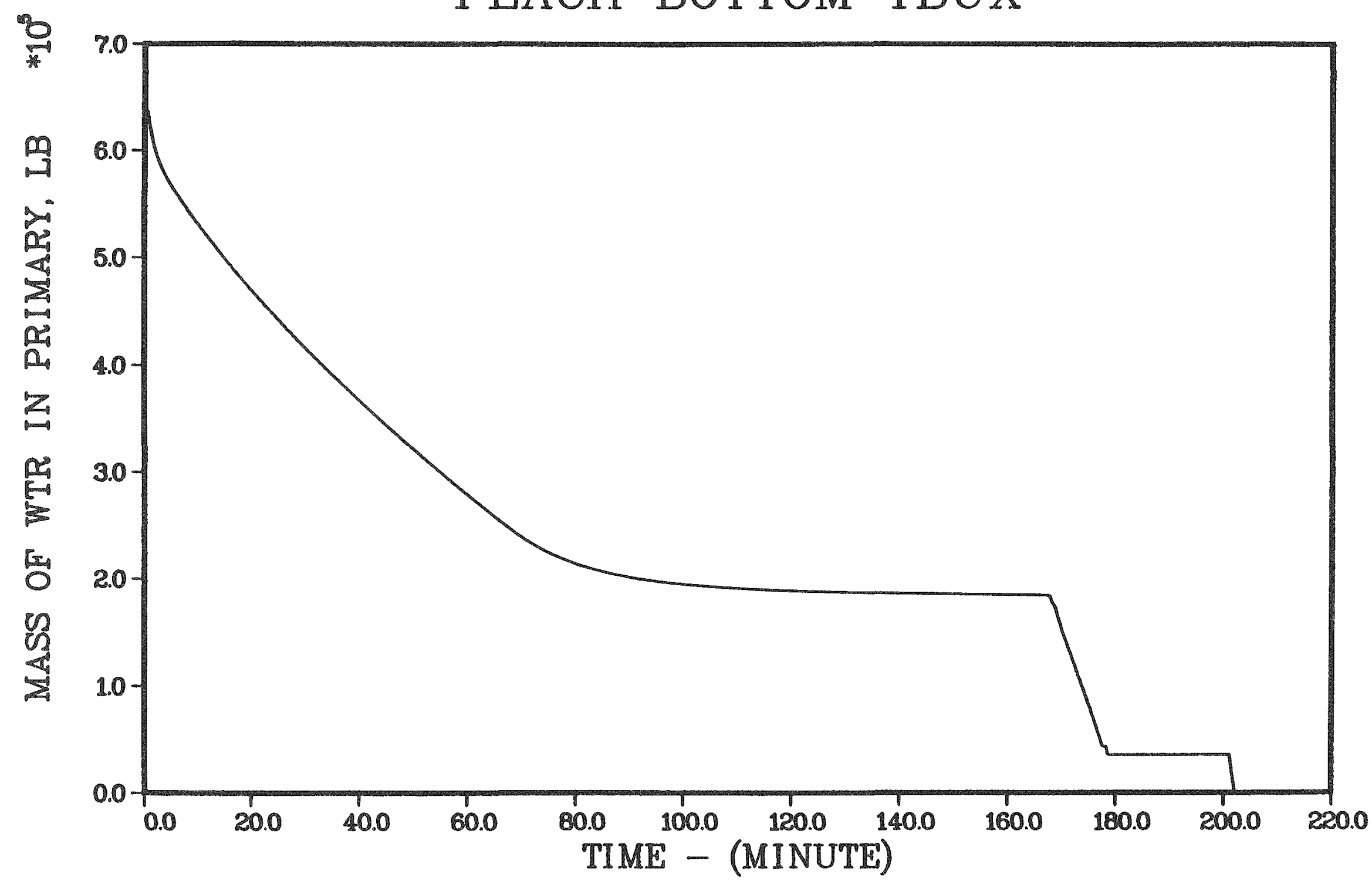

Figure 4.1.1. Primary system water inventory - Peach Bottom TBUX. 


\section{PEACH BOTTOM TBUX}

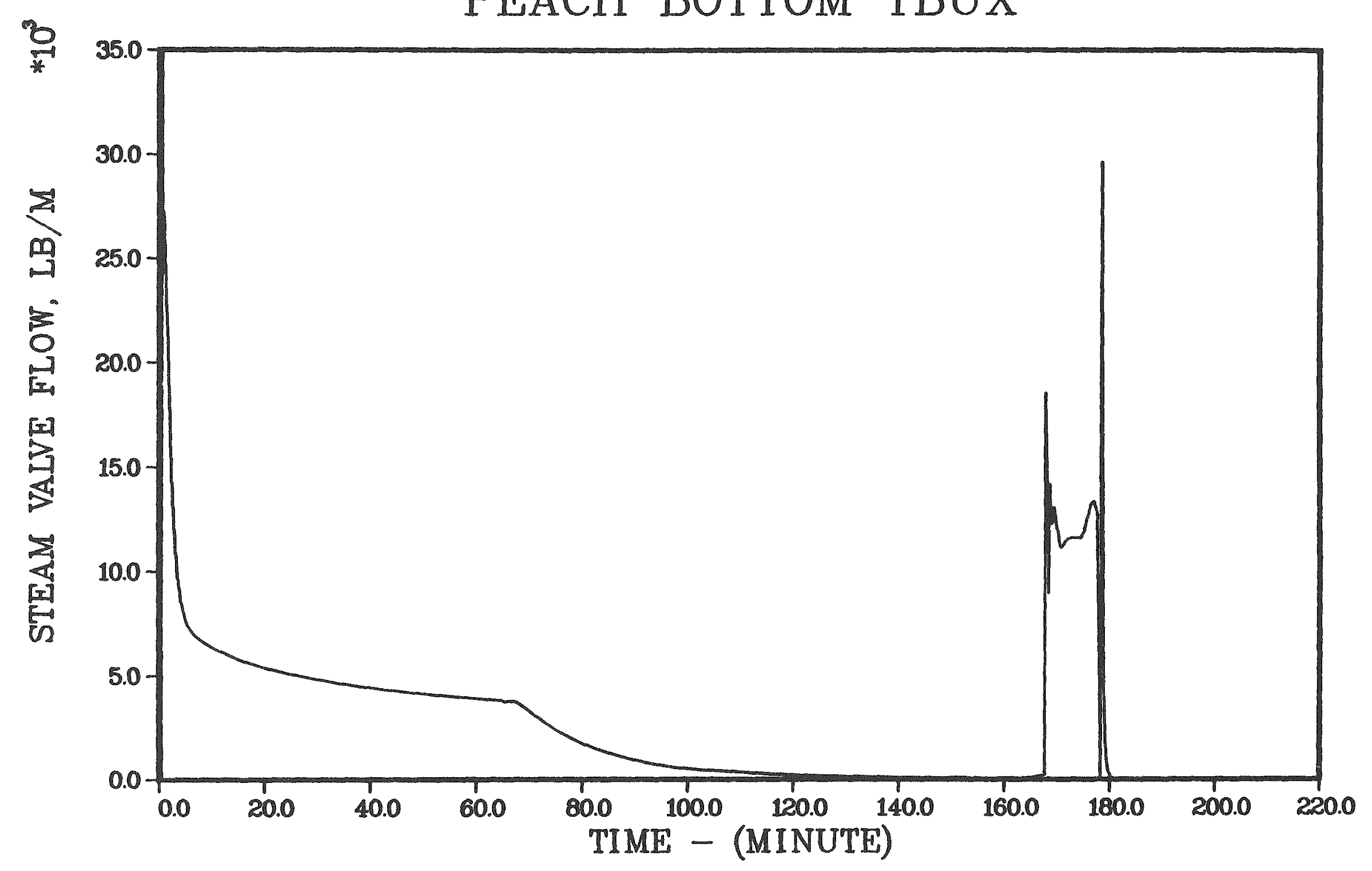

Figure 4.1.2. Steam flow rate through the safety/relief valve - Peach Bottom TBUX. 


\section{PEACH BOTTOM TBUX}

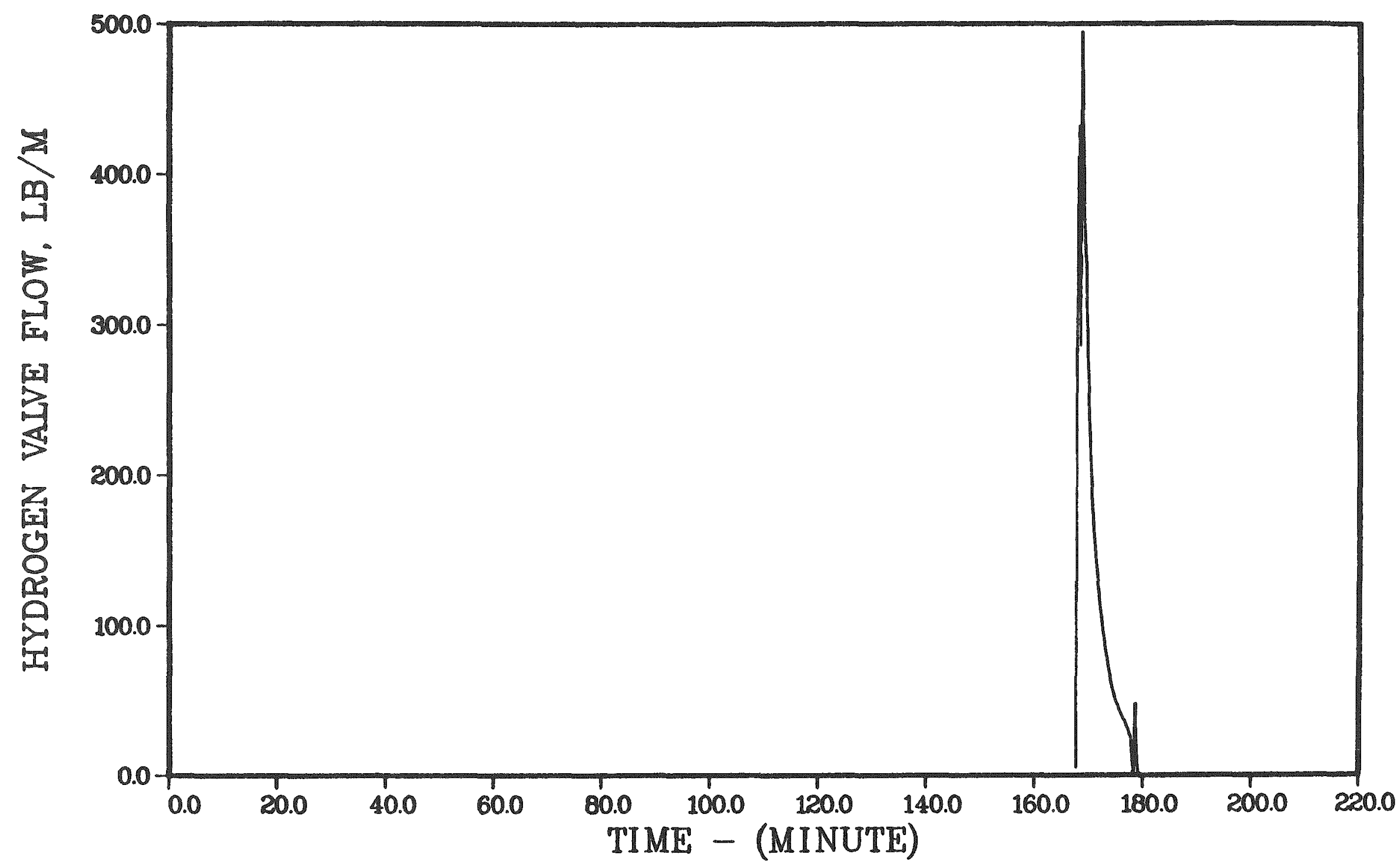

Figure 4.1.3. Hydrogen flow rate through the safety/relief valve - Peach Bottom TBUX. 


\section{PEACH BOTTOM TBUX}

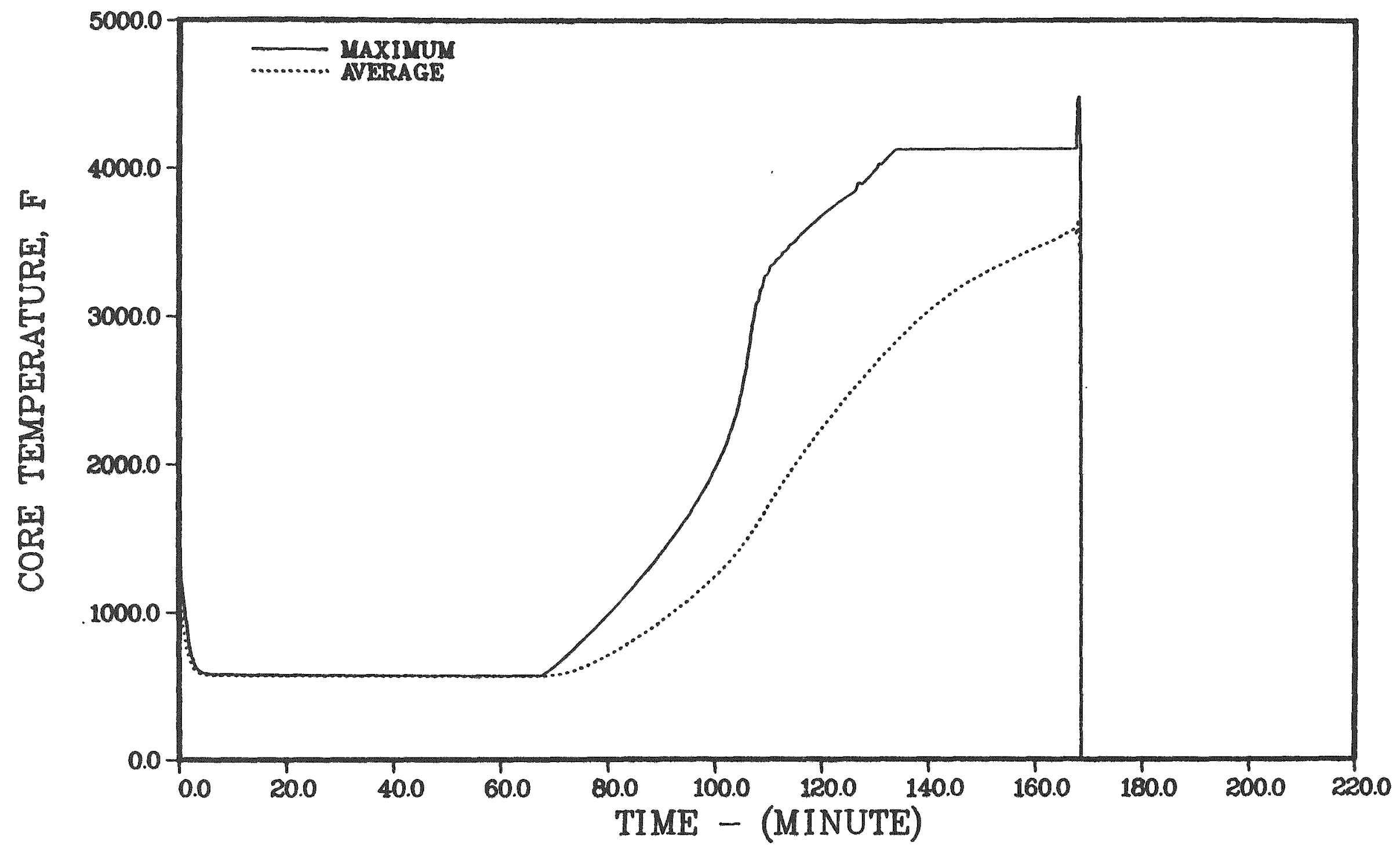

Figure 4.1.4. Maximum and average core temperatures - Peach Bottom TBUX. 


\section{PEACH BOTTOM TBUX}

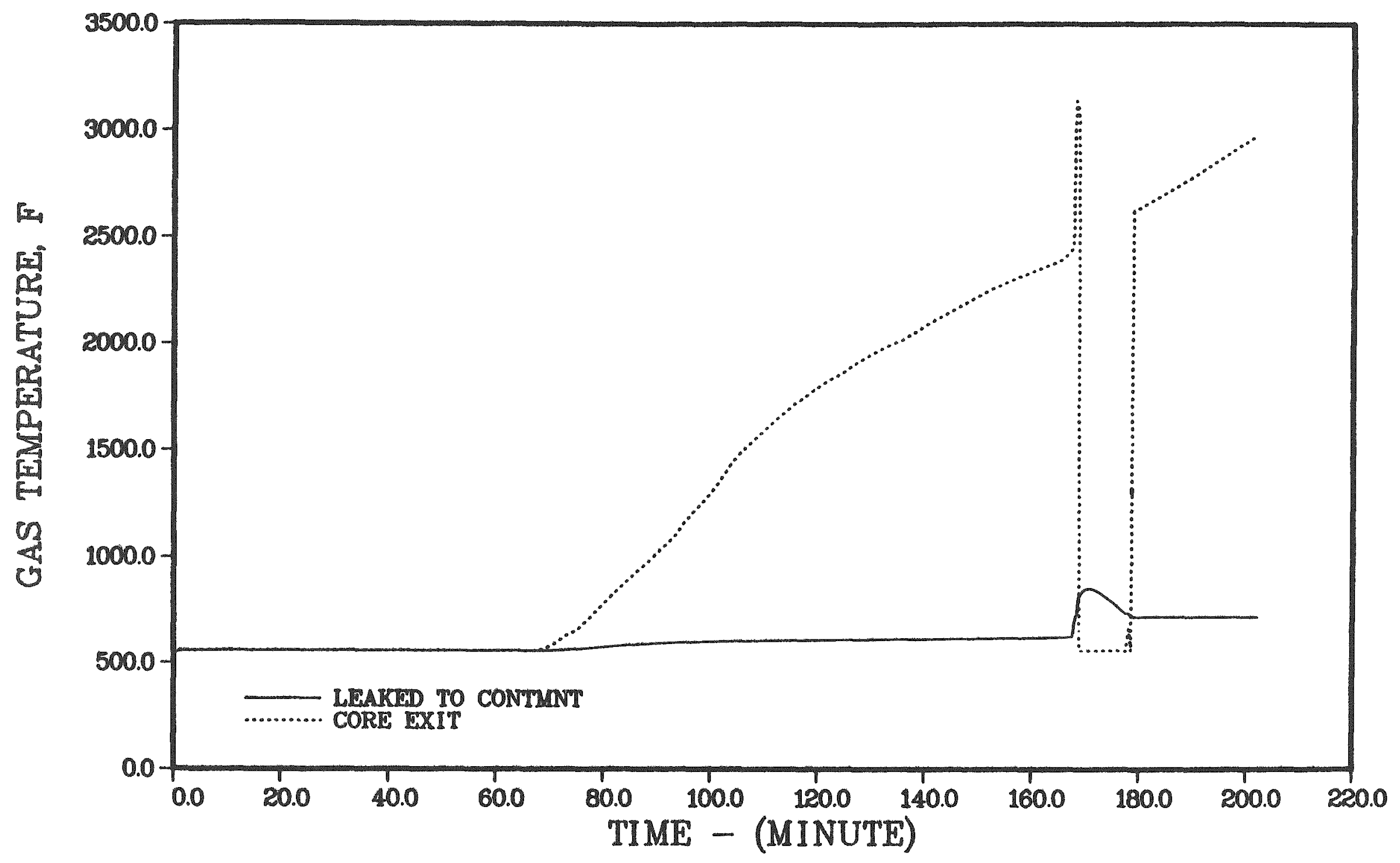

8

Figure 4.1.5. Temperatures of gases at core exit and leaving the primary system - Peach Bottom TBUX. 


\section{PEACH BOTTOM TBUX}

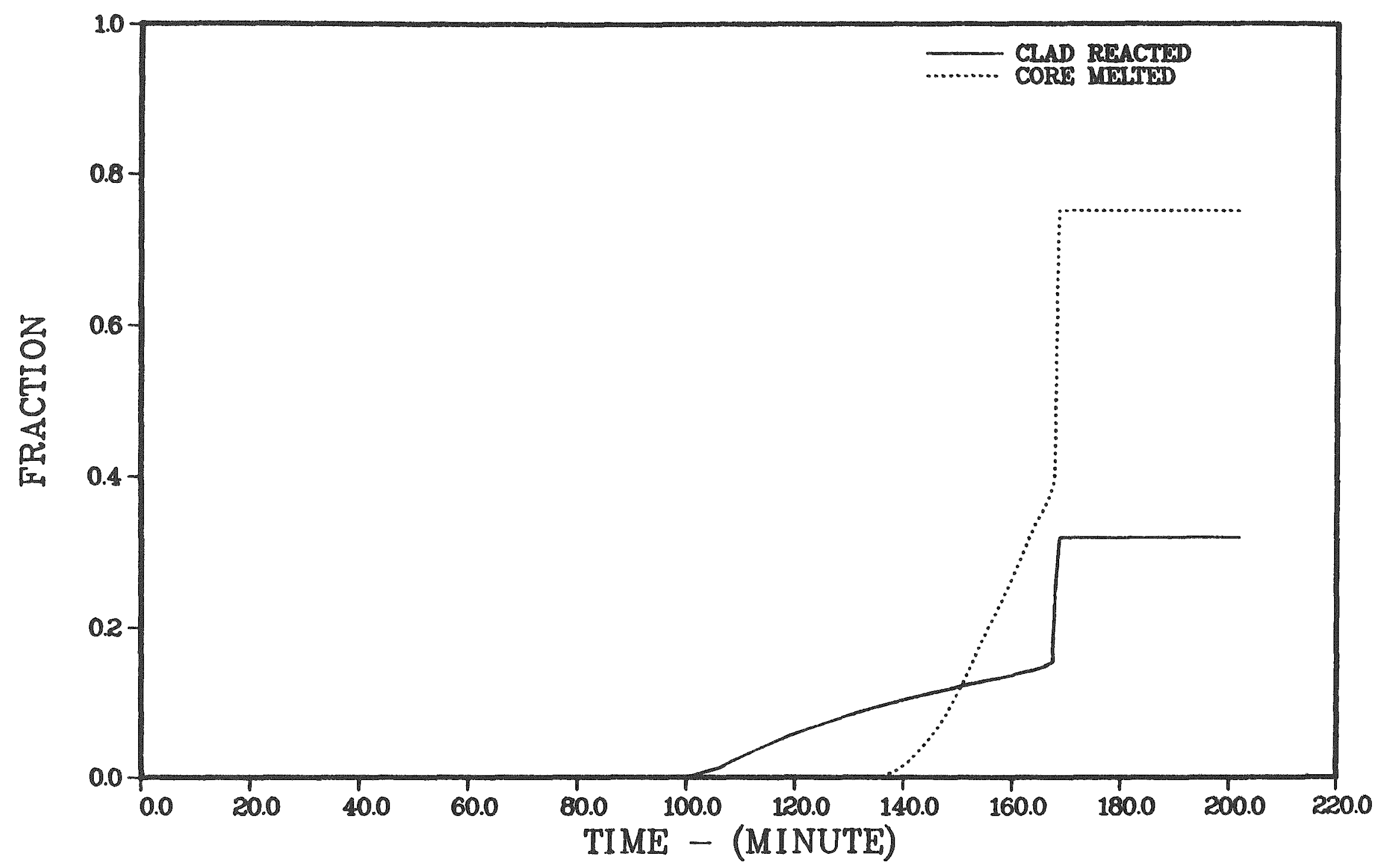

Figure 4.1.6. Fractions of cladding reacted and core melted - Peach Bottom TBUX. 
amount of cladding and channel box oxidation corresponds to about 24 percent of the total Zircaloy in the core.

\section{CONTAINMENT RESPONSE - Peach Bottom TBUX}

Table 4.1.3 summarizes the containment conditions at key times during the accident sequence; the calculated leak rates from the primary containment and reactor building as a function of time are given in Table 4.1.4. The primary containment pressure and temperature histories are given in Figures 4.1.7 and 4.1.8; those for the secondary containment are shown in Figures 4.1.9 and 4.1.10. Selected containment structure temperatures are illustrated in Figure 4.1.11. The suppression pool water inventory and its temperature history are given in Figures 4.1 .12 and 4.1 .13 , respectively. The containment does not experience appreciable pressurization until the time of core slumping and the associated rapid release of steam and hydrogen to the suppression pool. Since the suppression pool is subcooled throughout this sequence, the steam released from the primary system is condensed and the containment pressure during the in-vessel phase of the accident is limited to about 40 psia. The release of high-pressure steam and hydrogen upon vessel failure raises the containment pressure to about 100 psia. The containment pressure declines after that due to steam condensation on structures and thermal equilibration of noncondensables, and then increases slowly due to corium-concrete interactions. The calculated increase in the rate at which the primary containment pressure rises immediately preceding containment failure is a result of corium layer inversion, burnout of the zirconium in the melt, and the subsequent rapid gas generation as predicted by the CORCON module of the STCP(4). A sustained drywell temperature in excess of $1000 \mathrm{~F}$ is predicted after the onset of rapid concrete attack.

The failure of the primary containment releases a large quantity of hydrogen and carbon monoxide to the non-inerted secondary containment. This leads to the prediction of a combustion event initiating in the reactor building and propagating to the refueling bay. The corresponding transient pressures and temperatures shown in Figures 4.1 .9 and 4.1 .10 are the result of the combustion of $1,367 \mathrm{lb}$ of hydrogen and 11,636 lb of carbon monoxide. For 
Table 4.1.3. Containment response - Peach Bottom TBUX.

\begin{tabular}{|c|c|c|c|c|c|c|}
\hline \multirow[b]{3}{*}{$\begin{array}{c}\text { Accident } \\
\text { event }\end{array}$} & \multirow[b]{3}{*}{$\begin{array}{l}\text { Tivere, } \\
\text { minutes }\end{array}$} & \multicolumn{2}{|c|}{ Compartment } & \multirow{3}{*}{$\begin{array}{l}\text { Compartment } \\
\text { wall stean } \\
\text { Condensation。 } \\
\frac{16 / 1}{1 / 2 / 3 / 4}\end{array}$} & \multirow{2}{*}{\multicolumn{2}{|c|}{$\begin{array}{c}\text { Suppression Pool } \\
\text { Water }\end{array}$}} \\
\hline & & \multirow{2}{*}{$\begin{array}{l}\text { Pressure, } \\
\frac{\text { psia }}{1 / 2 / 3 / 4}\end{array}$} & \multirow{2}{*}{$\begin{array}{l}\text { Temperature, } \\
\frac{\text { of }}{1 / 2 / 3 / 4}\end{array}$} & & & \\
\hline & & & & & Mass, & $\begin{array}{l}\text { Temp. } \\
\text { of }\end{array}$ \\
\hline Core uncovery & 66.7 & $17 / 17 / 15 / 15$ & $101 / 145 / 100 / 100$ & $5 / 34 / 0 / 0$ & $8.86 \times 10^{6}$ & 146 \\
\hline Salc aelt & 134.2 & $17 / 17 / 15 / 15$ & $102 / 155 / 100 / 100$ & $2 / 1 / 0 / 0$ & $8.91 \times 10^{\circ}$ & 154 \\
\hline Core slusap & 167.7 & $18 / 18 / 15 / 15$ & $103 / 161 / 100 / 100$ & $3 / 0 / 10 / 0$ & $8.92 \times 10^{8}$ & 154 \\
\hline Cors collapse & 168.7 & $23 / 23 / 15 / 15$ & 129/191/100/100 & $0 / 0 / 0 / 0$ & $8.93 \times 10^{8}$ & 158 \\
\hline $\begin{array}{l}\text { Bottom head } \\
\text { dryout }\end{array}$ & 170.0 & $38 / 38 / 15 / 15$ & $138 / 195 / 108 / 100$ & $27 / 0 / 0 / 0$ & 9.04x10 & 171 \\
\hline Botton head & & & & & & \\
\hline Pailure & 201.1 & $39 / 39 / 15 / 15$ & $128 / 214 / 100 / 100$ & $0 / 0 / 0 / 0$ & 9.05*106 & 173 \\
\hline $\begin{array}{l}\text { Start concreto } \\
\text { attack }\end{array}$ & 202.2 & $94 / 94 / 15 / 15$ & $310 / 313 / 100 / 100$ & $21950 / 1 / 1 \mathrm{M} / \mathrm{A}$ & 9. $m 8 \times 106$ & 178 \\
\hline $\begin{array}{l}\text { Wetwell failure/ } \\
\text { containant } \\
\text { failure }\end{array}$ & 349.2 & $174 / 174 / 15 / 15$ & $1035 / 365 / 105 / 100$ & $0 / 0 / 0 / 0$ & $9.10 \times 10$ & 184 \\
\hline End calculation & 802.3 & $15 / 15 / 15 / 15$ & $1729 / 210 / 157 / 152$ & $0 / 0 / 474 / 0$ & $9.87 \times 10^{8}$ & 194 \\
\hline
\end{tabular}

Legend

1-Drywell 2- Metwell 3-Reactor building 4-Refueling bay 
Table 4.1.4. Containment leak rates - Peach Bottom TBUX.

\begin{tabular}{|c|c|c|c|c|c|c|c|c|c|c|c|c|c|c|c|c|c|c|c|c|c|c|}
\hline \multirow{3}{*}{\multicolumn{2}{|c|}{ 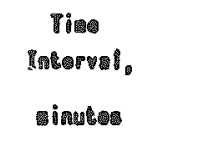 }} & \multicolumn{5}{|c|}{ Druvell Laakmente } & \multicolumn{5}{|c|}{ getwe I Leakease. } & \multicolumn{5}{|c|}{ Moector MUIIIin Luahane } & \multicolumn{5}{|c|}{ Mofurel in Dar Loaken } & \multirow{3}{*}{ menamas } \\
\hline & & \multirow{2}{*}{$\begin{array}{l}\text { Rato(d) } \\
\text { V/mr }\end{array}$} & \multicolumn{2}{|c|}{ Prasure } & \multicolumn{2}{|c|}{ Toneps. } & \multirow{2}{*}{$\begin{array}{l}\text { Attos (b) } \\
\text { Ppp }\end{array}$} & \multicolumn{2}{|c|}{ Pressure } & \multicolumn{2}{|c|}{ Teares } & \multirow{2}{*}{$\begin{array}{l}\text { Mates (c) } \\
\text { v/hr }\end{array}$} & \multicolumn{2}{|c|}{ Presserere } & \multicolumn{2}{|c|}{ Teare } & \multirow{2}{*}{$\begin{array}{l}\text { Rates (d) } \\
\text { uphe }\end{array}$} & \multicolumn{2}{|c|}{ Prossure } & \multicolumn{2}{|c|}{ Teap. } & \\
\hline & & & 啮当 & pain & ${ }_{6}^{6}$ & of & & MP & psia & ${ }^{6} \mathrm{c}$ & $\theta_{F}$ & & MP & paid & ${ }_{c}$ & F & & MPa & paia & ${ }^{0} \mathrm{c}$ & ${ }_{\mathrm{f}}$ & \\
\hline 解. & -128.7 & 1. & . & 10 & 38 & 100 & $\begin{array}{l}0.210 .0 \\
0.1 / 0.0\end{array}$ & $\begin{array}{l}0.11 \\
0.12\end{array}$ & 17 & 72 & $\begin{array}{l}125 \\
158\end{array}$ & 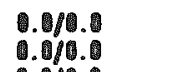 & 0.10 & 15 & 28 & 100 & $\begin{array}{l}\text { 0.010.1 } \\
0.010 .0\end{array}$ & ๑.1. & 18 & צี & 106 & Hots \\
\hline 134.2 & -187.7 & 1. & .12 & 18 & 3ิ & 100 & $0.1 / 0.0$ & 0.12 & 10 & 70 & 167 & 0.010 .10 & & 16 & & 100 & 0.6] & 0.10 & 16 & ate & 100 & co \\
\hline 167.7 & -108.8 & 1. & Q.14 & 26 & 17 & 118 & 14.810 .1 & .11 & 20 & $n$ & 171 & -.9. & 0.10 & II & 3ี่ & 100 & 0.10 .0 & 1.10 & 16 & 觡 & 100 & lut \\
\hline $\begin{array}{l}164.7 \\
170.0\end{array}$ & $\begin{array}{l}-172.8 \\
-201.8 \\
201.1\end{array}$ & ... & $\begin{array}{l}0.23 \\
0.20 \\
0.27\end{array}$ & $\begin{array}{l}34 \\
36 \\
39\end{array}$ & $\begin{array}{l}56 \\
58 \\
58\end{array}$ & $\begin{array}{l}131 \\
122 \\
1190\end{array}$ & 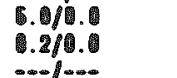 & $\begin{array}{l}1.23 \\
0.20 \\
1.27\end{array}$ & $\begin{array}{l}34 \\
316 \\
30\end{array}$ & 29 & 108 & $\begin{array}{l}0.010 .0 \\
0.0 / 10.0 \\
0.01-\infty\end{array}$ & $\begin{array}{l}0.10 \\
0.10 \\
0.10\end{array}$ & $\begin{array}{l}15 \\
15 \\
18\end{array}$ & $\begin{array}{l}38 \\
38\end{array}$ & 100 & 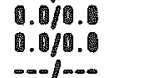 & 0.18 & $\begin{array}{l}16 \\
15 \\
15\end{array}$ & 3ิ & 100 & 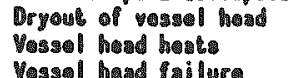 \\
\hline $\begin{array}{l}201.1 \\
201.5\end{array}$ & $\begin{array}{l}281.1 \\
-201.5 \\
-202.1\end{array}$ & 57. & $\begin{array}{l}0.21 \\
0.42 \\
0.02\end{array}$ & ?1: & $\begin{array}{l}\text { 83 } \\
\text { 1168 } \\
\text { 158 }\end{array}$ & $\begin{array}{l}120 \\
240 \\
302\end{array}$ & 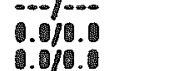 & $\begin{array}{l}. .27 \\
.41 \\
0.50\end{array}$ & 18 & $\begin{array}{l}101 \\
131 \\
151\end{array}$ & $\begin{array}{l}218 \\
204 \\
304\end{array}$ & $\begin{array}{l}0 .-10-0 \\
0.10 .0 \\
0.010 .0\end{array}$ & $\begin{array}{l}0.10 \\
0.10 \\
0.10\end{array}$ & $\begin{array}{l}118 \\
15 \\
15\end{array}$ & 30 & $\begin{array}{l}100 \\
100 \\
100\end{array}$ & $\begin{array}{l}--10-\infty \\
0.010 .0 \\
0.010 .0\end{array}$ & $\begin{array}{l}0.10 \\
0.118 \\
0.10\end{array}$ & $\begin{array}{l}15 \\
15 \\
15\end{array}$ & 34t & $\begin{array}{l}100 \\
100 \\
100\end{array}$ & 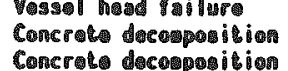 \\
\hline 202.1 & -202.2 & 1. & 0.06 & 4 & IEF & 311 & $1.2 / 0.0$ & 0.05 & 1 & 168 & $\$ 14$ & 0.090. & .10 & is & 30 & 100 & $0.0 / 1.0$ & 0.10 & 18 & 26 & 100 & \\
\hline $\begin{array}{l}208.2 \\
202.3\end{array}$ & $\begin{array}{l}-212.3 \\
-232.2\end{array}$ & 温. & 0.63 & 8 & $\begin{array}{l}152 \\
{ }_{226}\end{array}$ & 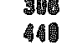 & $\begin{array}{l}15.10 .0 \\
0.210 .0\end{array}$ & $\begin{array}{l}.03 \\
0.68\end{array}$ & 1 & $\begin{array}{l}155 \\
122\end{array}$ & $\begin{array}{l}311 \\
281\end{array}$ & $\begin{array}{r}0.0 / 10.8 \\
0.010 .0\end{array}$ & $\begin{array}{l}.10 \\
0.10\end{array}$ & $\begin{array}{l}15 \\
15\end{array}$ & 2 & $\begin{array}{l}100 \\
100\end{array}$ & 0.010 .0 & $\begin{array}{l}1.18 \\
0.10\end{array}$ & $\begin{array}{l}16 \\
106\end{array}$ & 졸 & $\begin{array}{l}100 \\
100\end{array}$ & $\begin{array}{l}\text { Concrete doceaposition } \\
\text { Conerete docoposition }\end{array}$ \\
\hline 232.2 & -282.8 & .8 & 0.80 & 7 & 277 & 220 & 0.010 .0 & 0.00 & 77 & 132 & 37 & 0.70 .10 & 0.110 & 10 & 30 & 100 & 0.010 .0 & 1.10 & 15 & 9 & Iiv & Concrete decogeromition \\
\hline 208.2 & -340.16 & .0 & 0.70 & I11 & 340 & 043 & พ.011.3. & 0.76 & 100 & 180 & $\$ 21$ & 0.0/6.0xI-4 & 0.10 & 15 & 9 & 100 & 0.010 .0 & 1.10 & 18 & 98 & IN & Conerate decomposition \\
\hline & $\$ 240.16$ & $\infty$ & 1.20 & 184 & 558 & 1030 & $-\infty-\infty=0-\infty$ & 1.20 & 170 & 185 & 366 & $-\infty-\infty-\infty$ & 0.10 & 16 & 36 & 100 & $--1-\cdots$ & 0.10 & 15 & 30 & 100 & 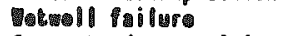 \\
\hline 3 ริง & -340.17 & 08.4 & 1.10 & 172 & E57 & 1034 & 0.01142.1 & 1.17 & 180 & 103 & 361 & 0.0152 .9 & 0.10 & 16 & 81 & 100 & 0.010 .0 & 8.10 & 15 & 3 & 100 & Concrel decomposition \\
\hline & - & & 1.17 & 196 & 556 & 1820 & $-\infty-$ & 1.10 & 106 & 100 & 35: & a & 0.10 & if & 43 & 100 & 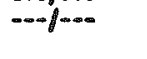 & 0.10 & 15 & 30 & 103 & $\begin{array}{l}\text { secondary conta ingest } \\
\text { fai luse }\end{array}$ \\
\hline 940.17 & -949. 11 &. & 1. & 16 & 552 & 1024 & 111.2 & 1.14 & 160 & 178 & 55 & 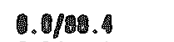 & 0.11 & 16 & 44 & 111 & 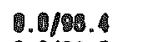 & 0.10 & 18 & 40 & 104 & Conerete decrespilion \\
\hline 320.12 & -3ิA0. & 198.2 & . 64 & 93 & 113 & 980 & 118. & 0.01 & mo & 97 & 208 & a. & 1. 18 & 10 & 67 & 152 & 0.0178 & 0.11 & 10 & 52 & 120 & Concroba deco \\
\hline 240. 2 단 & - 340.0126 & 271.5 & 0.97 & 34 & 520 & 280 & $0.0 / 110.2$ & .97 & 6 & 76 & 160 & $0.0 / 4789$ & 0.12 & 18 & 102 & 323 & $0.0 / 372.2$ & 0.12 & 1 臬 & in & 164 & Mydrogen purm! \\
\hline 34. 200 & & 31.2 & 1. 77 & 84 & 226 & are & 1.9132.1 & 1.97 & 64 & $\pi$ & 170 & 0.010 .10 & 0.87 & 54 & 1366 & 2400 & 76.01046 .4 & .37 & 5. 0 & 071 & 1780 & Hiydrog \\
\hline \$4. 92 & -382.2.2 & 12.7 & .11 & 10 & 576 & 1280 & 1.011. & 7.11 & 10 & 128 & 201 & $0.0 / 1.3$ & 0.10 & 15 & 1 & 177 & $0.0 / 2.8$ & 0.10 & 182 & 207 & 405 & Concret decupposit ion \\
\hline $92 \mathrm{as} .2$ & - & 5. & 0.10 & 18 & 590 & 1101 & $0.01 / 7.1$ & 0.10 & 18 & 120 & 286 & 0.010 .2 & 0.10 & IB & 60 & 140 & & 0.80 & 16 & 26 & 205 & Concrete decoperition \\
\hline & & 7.0 & & If & องด & 1201 & & 0.10 & 18 & III & 232 & & & 15 & 3 & 198 & & 0.10 & 15 & 73 & 164 & \\
\hline 742.2 & -602.8 & 18.8 & 8.18 & 10 & 86 & 1800 & 9118.8 & 1.10 & 15 & ioi & 214 & 1.010. & e.18 & 18 & 7 & 158 & $1.0 / 6.8$ & 0.10 & 18 & 3 & $1 \mathrm{BE}^{6}$ & Concreto decompesition \\
\hline
\end{tabular}

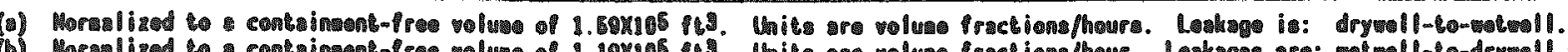

(b) Hor I i

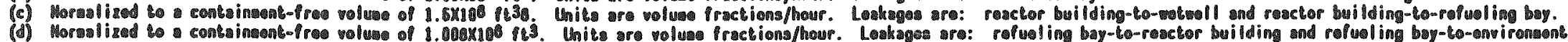

(1) The hydrogen burn orcurs in the paetor building and rofueling bay.

(i) The hydrogen burn occurs in the refuel ing bay. 


\section{PEACH BOTTOM TBUX2}

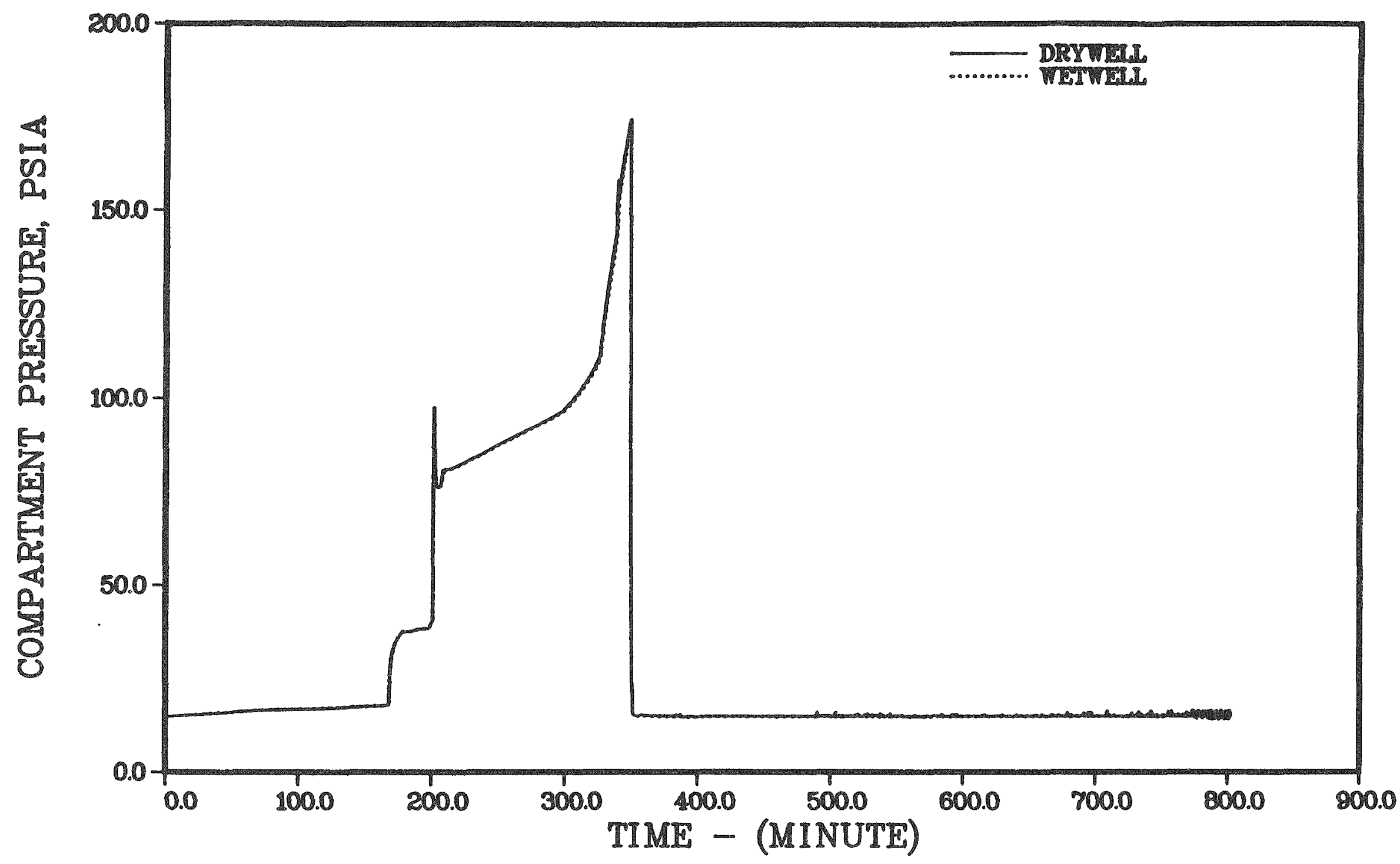

Figure 4.1.7. Primary containment pressure response - Peach Bottom TBUX. 


\section{PEACH BOTTOM TBUX2}

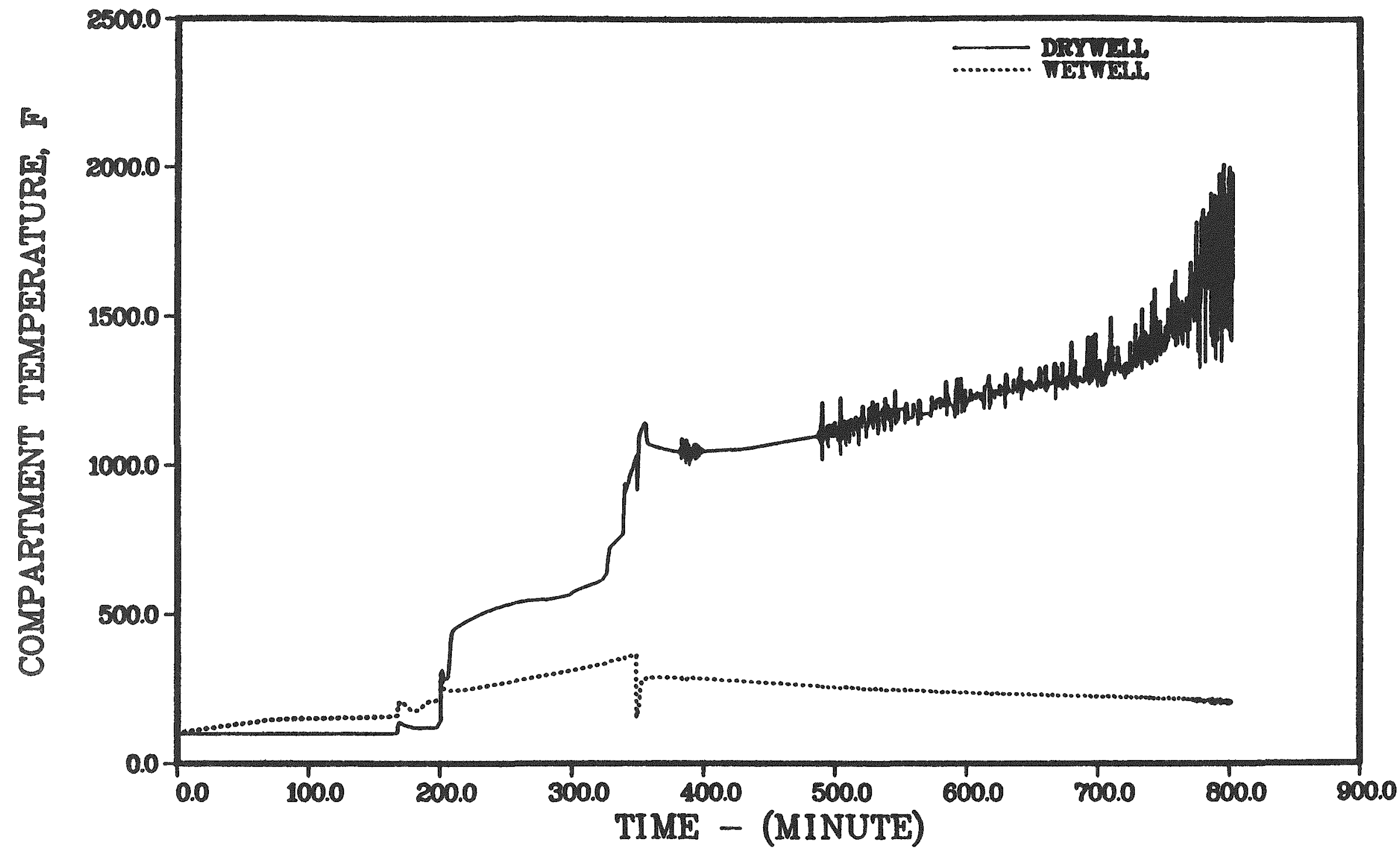

Figure 4.1.8. Primary containment temperature response - Peach Bottom TBUX. 


\section{PEACH BOTTOM TBUX2}

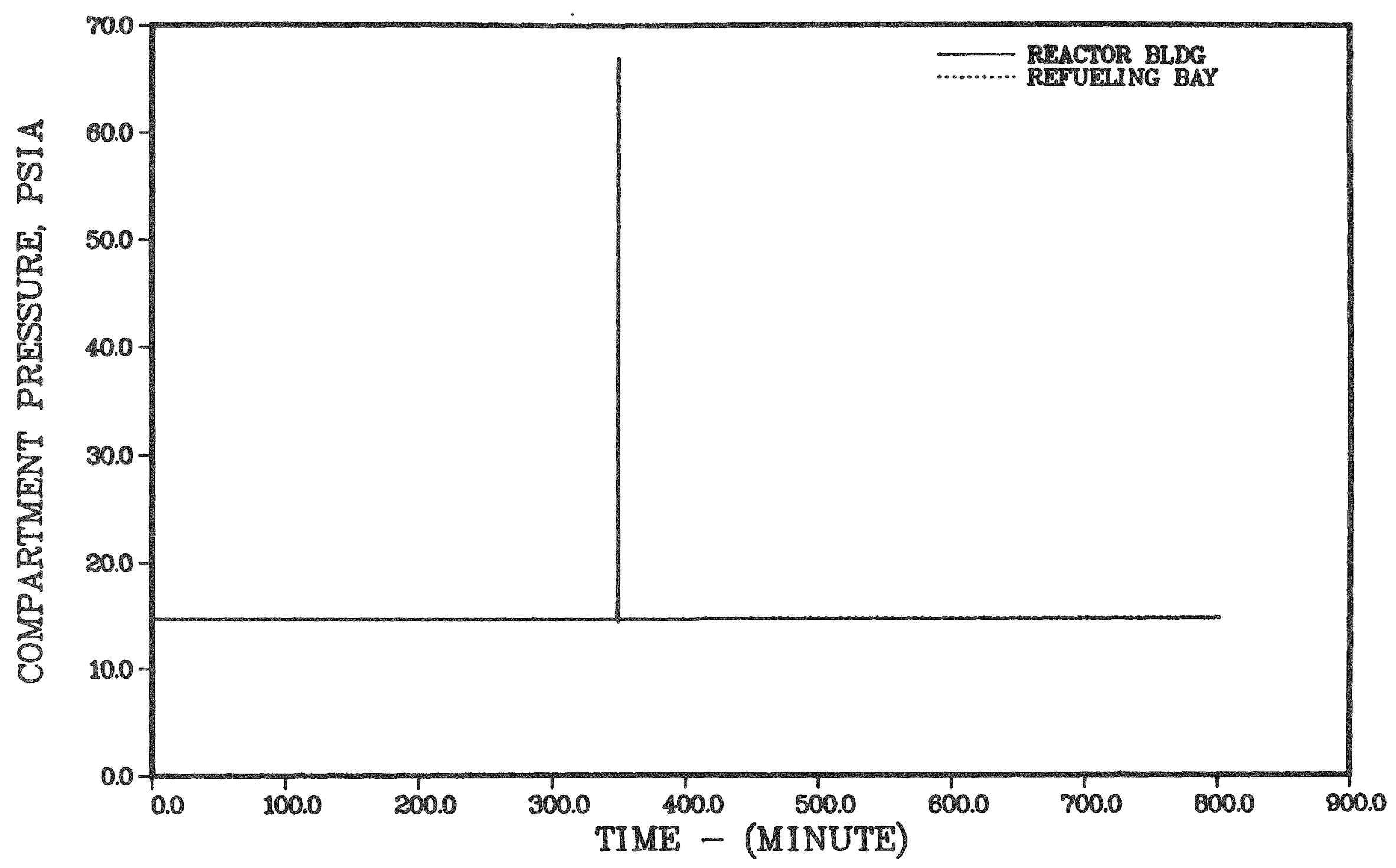

Figure 4.1.9. Secondary containment pressure response - Peach Bottom TBUX. 


\section{PEACH BOTTOM TBUX2}

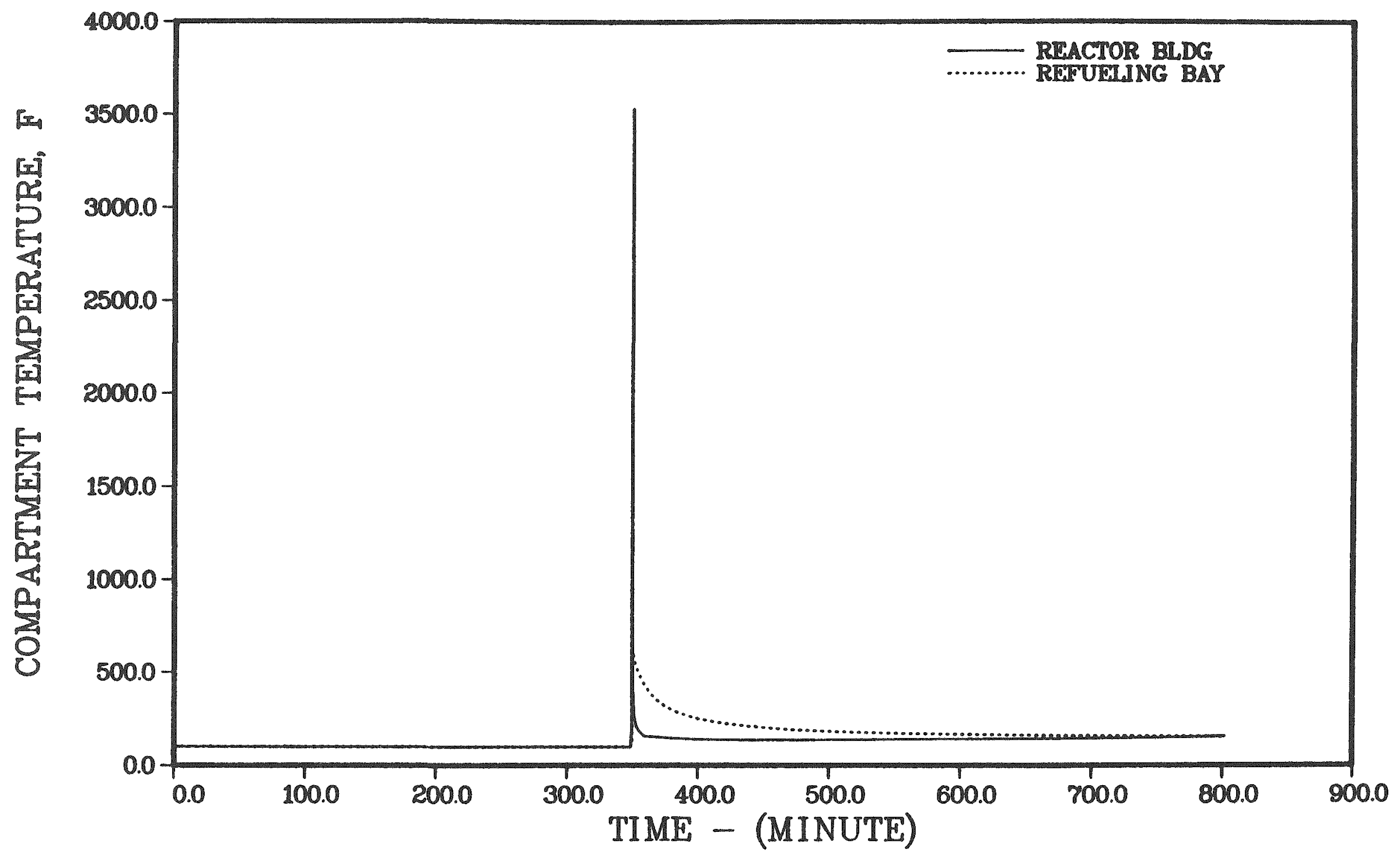

Figure 4.1.10. Secondary containment atmosphere temperature response - Peach Bottom TBUX. 


\section{PEACH BOTTOM TBUX2}

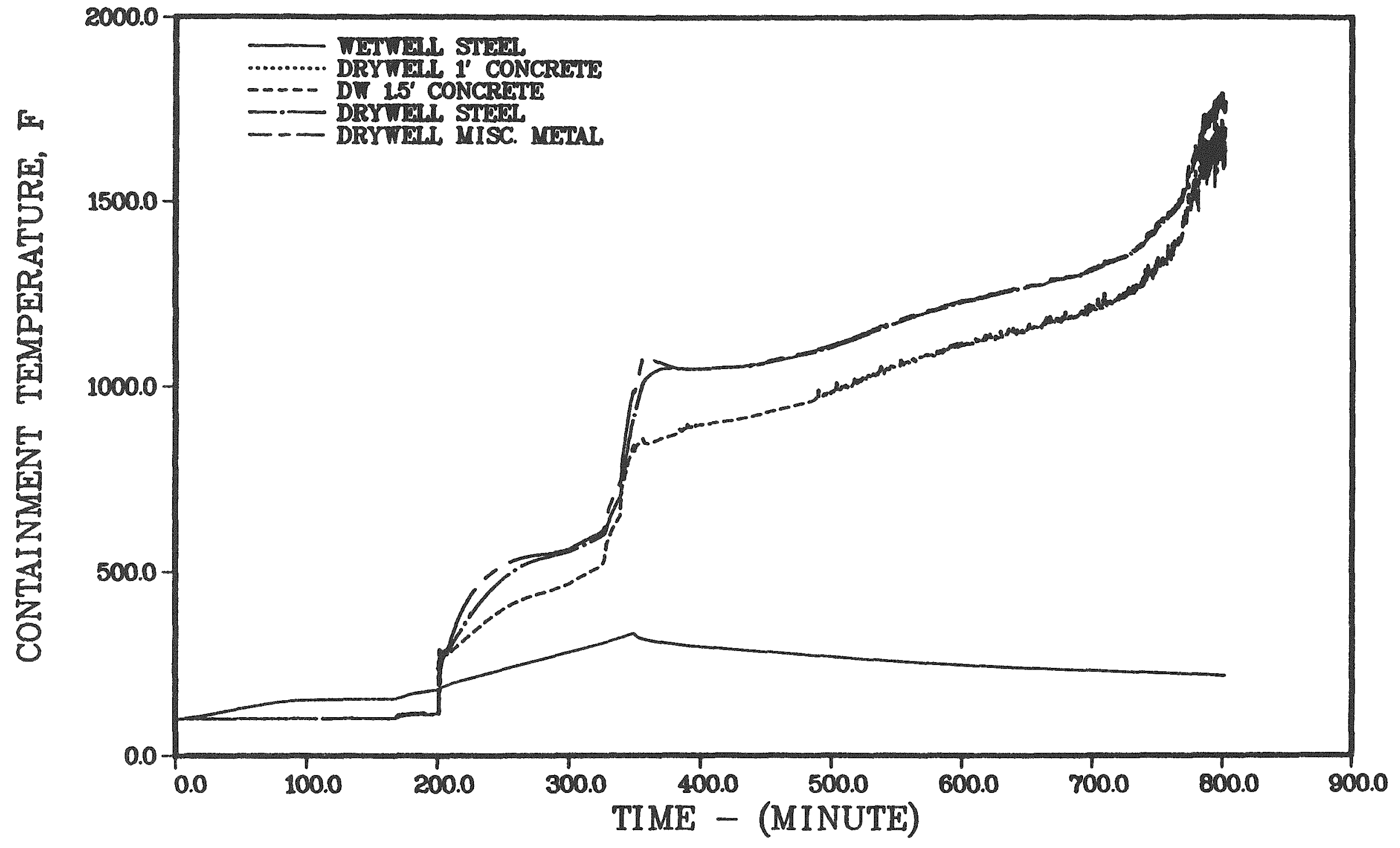

Figure 4.1.11. Selected containment structure temperatures - Peach Bottom TBUX. 


\section{PEACH BOTTOM TBUX2}

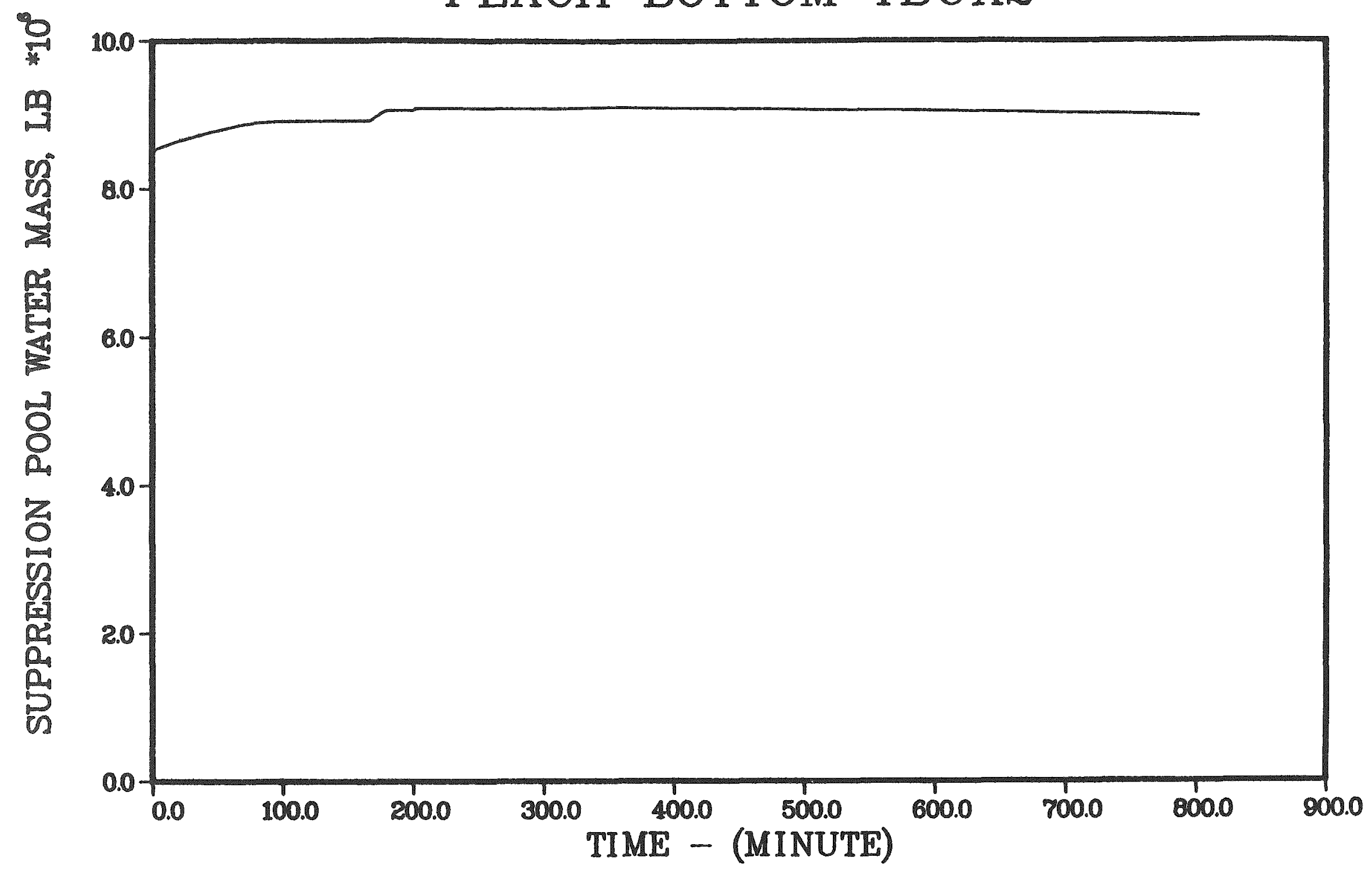

Figure 4.1.12. Suppression pool water inventory - Peach Bottom TBUX. 


\section{PEACH BOTTOM TBUX2}

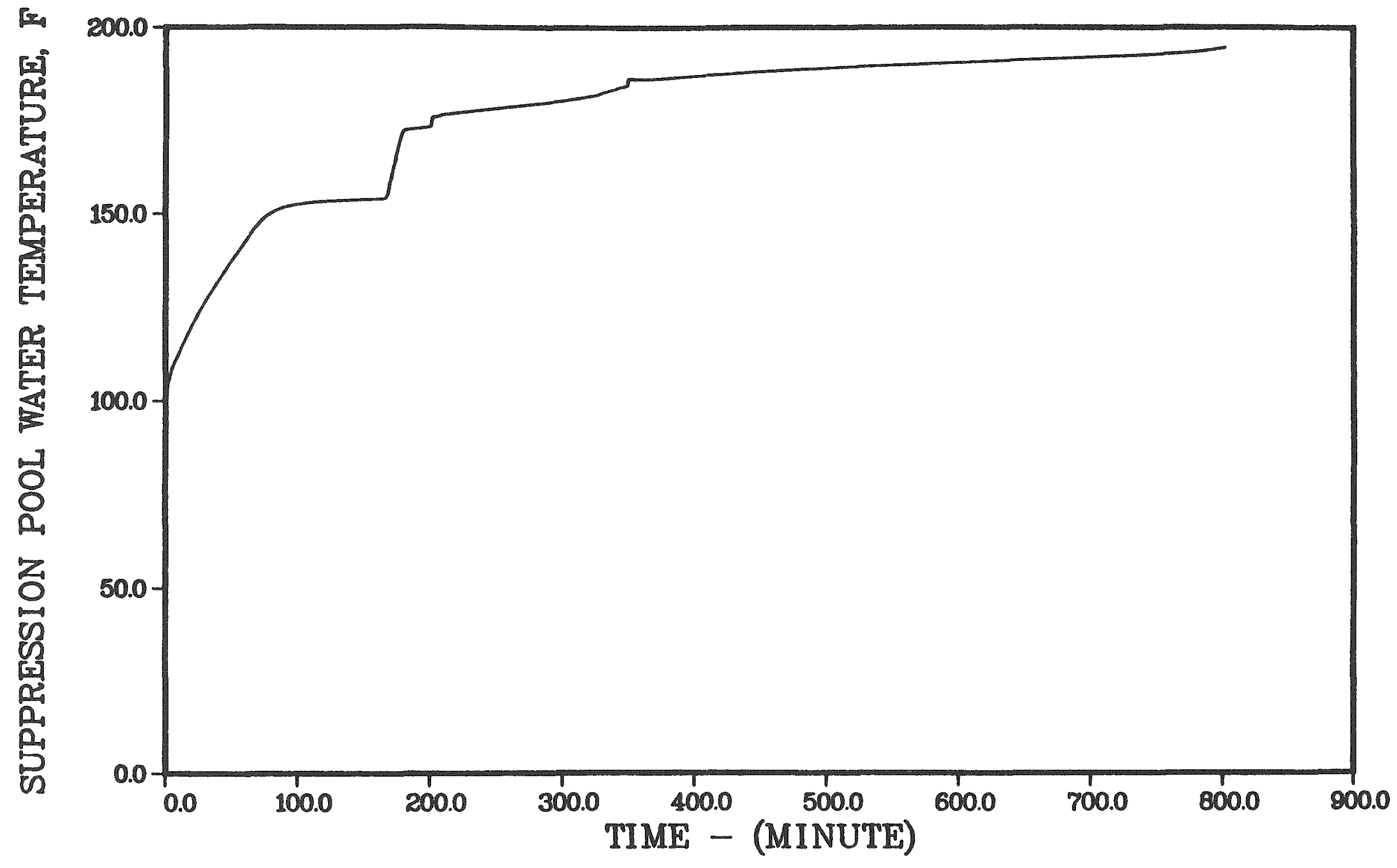

Figure 4.1.13. Suppression pool water temperature - Peach Bottom TBUX. 
the purpose of the present analyses, it has been assumed that the secondary containment will withstand this combustion event.

The predicted progression of concrete attack is shown in Figure 4.1.14. Initially, the denser oxide layer is below the metallic layer and is in contact with the concrete; the predicted concrete erosion is approximately equal in the radial and axial directions. After the metallic and oxide layers invert, the more reactive metal phase comes into contact with the concrete, the radial erosion essentially ceases, and vertical penetration predominates.

The total volume of gases leaked from the containment is illustrated in Figure 4.1.15. The initial rapid leakage is associated with primary containment failure and the large combustion event in the secondary containment. The later gradual increase in leakage is the result of concrete attack by the core debris.

\subsubsection{Radionuclide Sources}

\section{SOURCE WITHIN PRESSURE VESSEL}

The inventory of fission products used for these analyses is the same as that used for the BMI-2104(6) and NUREG/CR-4624(2) analyses. Table 4.1 .5 provides the inventories for each of the key fission products, actinide, and structural elements. These values are based on the results of analyses performed at ORNL for an actual Browns Ferry core ${ }^{(16)}$ using the ORIGEN2 ${ }^{(17)}$ code. In Table 4.1 .6 these elements are collected into the elemental groups used in this study.

\section{SOURCES WITHIN THE CONTAINNENT}

Release into the drywell region can come from the primary circuit, the wetwell, or from corium-concrete interaction. The origin of sources from the wetwell is material transported through the suppression pool either from the RCS through spargers or from the drywell through the downcomers. Changes in the modeled flowpaths among compartments associated with the timing of events which control the flows were discussed in Section 3.1.3. 


\section{PEACH BOTTOM TBUX2}

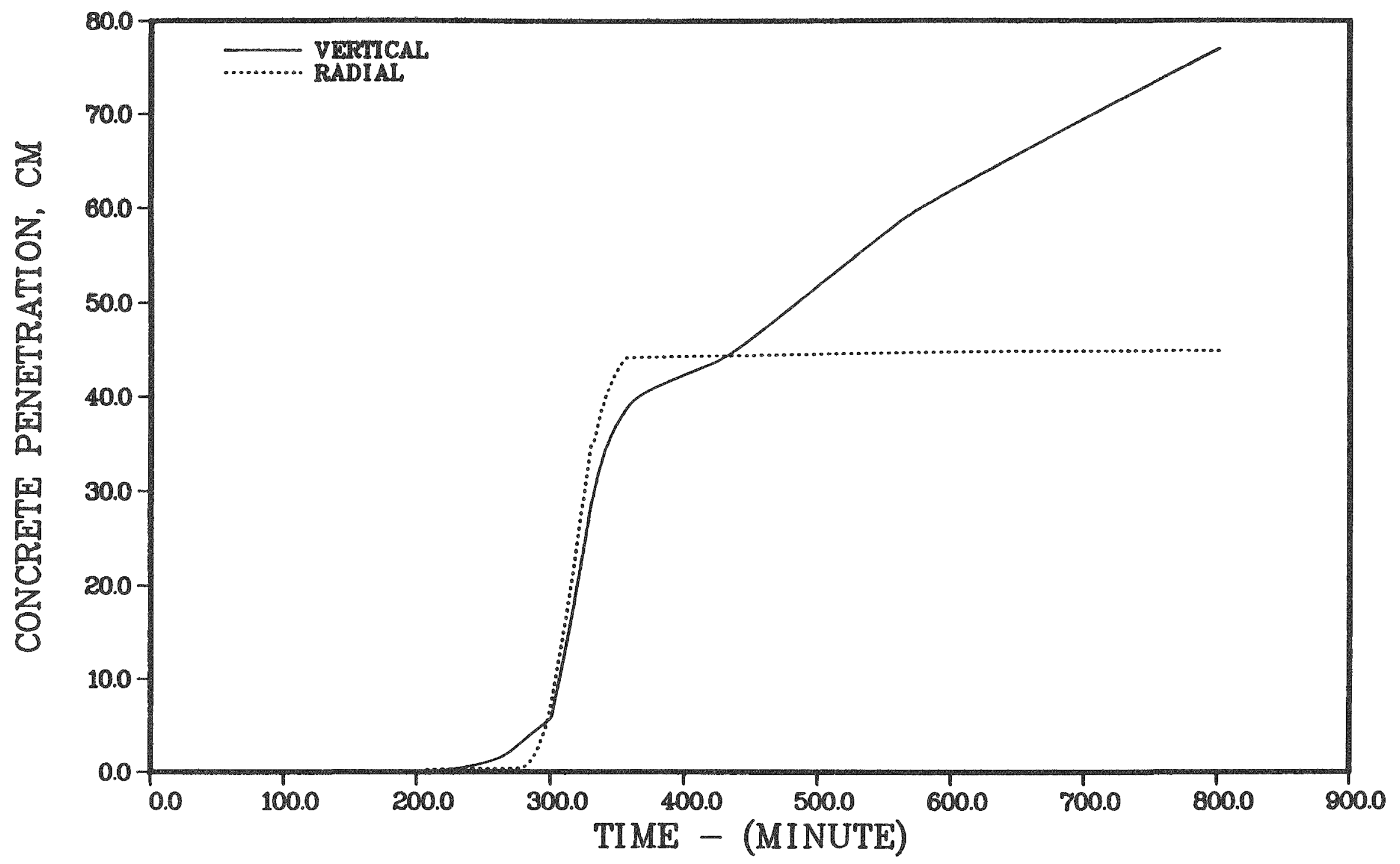

Figure 4.1.14. Progression of concrete attack - Peach Bottom TBUX. 


\section{PEACH BOTTOM TBUX2}

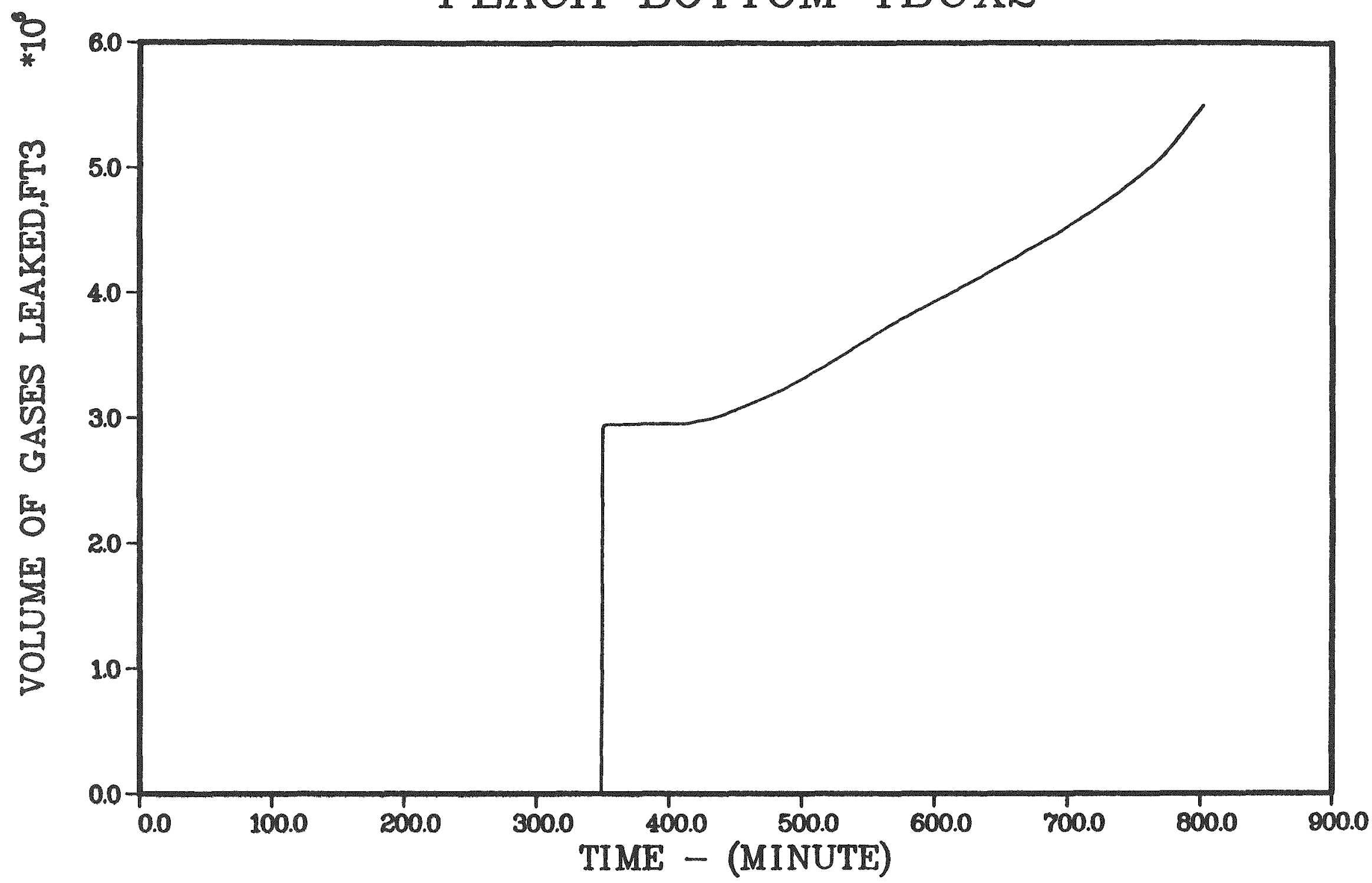

Figure 4.1.15. Total volume of gases leaked from containment - Peach Bottom TBUX. 
Table 4.1.5. Initial inventories of radionuclides and structural materials for Peach Bottom.

\begin{tabular}{|c|c|c|c|}
\hline \multicolumn{2}{|c|}{ Fission Products } & \multicolumn{2}{|c|}{ Actinides/structural } \\
\hline ETement & Mass (hg) & Element & Mass (kg) \\
\hline $\mathrm{Kr}$ & 25.7 & $u$ & 140,500 \\
\hline $\mathrm{Rb}$ & 23.3 & Pu & 743 \\
\hline$s r$ & 62.7 & Np & 41.2 \\
\hline$Y$ & 36.2 & $M n$ & 432 \\
\hline $2 r$ & 267 & $\mathrm{Fe}$ & 5.130 \\
\hline Nb & 4.3 & $\mathrm{Cr}$ & 4.140 \\
\hline TC & 58.8 & Ni & 2,560 \\
\hline Ru & 172 & Ir & 65,500 \\
\hline $\mathrm{Rh}$ & 33.2 & Sn & 1,050 \\
\hline $\mathrm{Pd}$ & 83.2 & Gd & 287 \\
\hline $\mathrm{Te}$ & 34.9 & & \\
\hline I & 16.6 & & \\
\hline $\mathrm{Xe}$ & 387 & & \\
\hline Cs & 207 & & \\
\hline $\mathrm{Ba}$ & 105 & & \\
\hline La & 98.3 & & \\
\hline $\mathrm{Ce}$ & 208 & & \\
\hline $\operatorname{Pr}$ & 80.4 & & \\
\hline Nd & 271 & & \\
\hline Pm & 11.5 & & \\
\hline Sm & 53.8 & & \\
\hline Eu & 14.1 & & \\
\hline
\end{tabular}


Table 4.1.6. Inventory by group.

\begin{tabular}{clc}
\hline \hline Group & \multicolumn{1}{c}{ Elements } & Total Mass $(\mathrm{kg})$ \\
\hline 1 & $\mathrm{Ke}, \mathrm{Kr}$ & 413 \\
2 & I, Br & 16.6 \\
3 & $\mathrm{Cs}, \mathrm{Rb}$ & 230 \\
4 & $\mathrm{Te}, \mathrm{Sb}, \mathrm{Se}$ & 34.9 \\
5 & $\mathrm{Sr}$ & 62.7 \\
6 & $\mathrm{Ru}, \mathrm{Rh}, \mathrm{Pd}, \mathrm{Mo}, \mathrm{Tc}$ & 584 \\
7 & $\mathrm{La}, \mathrm{Zr}, \mathrm{Nd}, \mathrm{Eu}, \mathrm{Nb}, \mathrm{Pm}, \mathrm{Pr}, \mathrm{Sm}, \mathrm{\gamma}$ & 837 \\
8 & $\mathrm{Ce}, \mathrm{Pu}, \mathrm{Np}$ & 992 \\
9 & $\mathrm{Ba}$ & 105 \\
\hline \hline
\end{tabular}


The VANESA code was used to predict aerosol and gas release rates and compositions as functions of time. The fission product inventory of the core materials contacting the concrete was determined with the CORSOR module in MARCH3. The inventory of the debris at the time core-concrete interactions were initiated in the TBUX sequence is given in Table 4.1.7. The concrete was taken to be a high-limestone concrete and the initial temperature of the molten material was as calculated with the MARCH3 module. The total release rates and composition of the release are given in Table 4.1.8.

\subsubsection{Radionuclide Release and Transport}

Transport in and release from the RCS of radionuclide and structural materials was calculated with the TRAP-MELT3 code described in Section 2.1. The release from the RCS defines the aerosol source term to the primary containment of the Peach Bottom plant. The transport through the RCS is of interest because of the high potential for aerosol retention by settling and inertial impaction on wall and internal structure surfaces, the high potential for $\mathrm{Te}$ and $\mathrm{CSOH}$ capture by irreversible chemical reaction with the steel surfaces, and the significant potential for condensation of volatile species on the cooler wall surfaces of the RCS away from the core. Depending on thermal hydraulic and thermodynamic conditions throughout the RCS, volatile fission products may preferentially condense on wall surfaces or on structural material aerosol particles. Clearly their fate in the RCS is a strong function of which one of these processes dominate. These phenomena are discussed in detail in BMI-2104 ${ }^{(B)}$ and will not be treated further here.

Some improvements on the BMI-2104 models were incorporated in the STCP(4) and were used in performing the NUREG/CR-4624 analyses ${ }^{(2)}$. The chemistry and transport models used in NUREG/CR-4624 were also employed in the current analysis and the reader is referred to Volume 1 of that document for further information. 
Table 4.1.7. Inventory of melt at the time of vessel failure for Peach Bottom TBUX.

\begin{tabular}{|c|c|c|c|}
\hline Element & Inventory $(\mathrm{kg})$ & Element & Inventory $(\mathrm{kg})$ \\
\hline cs & 13.4 & $R h$ & 33.2 \\
\hline$I$ & 1.1 & $\mathrm{Pd}$ & 83.2 \\
\hline Xe & 25.6 & Nd & 271. \\
\hline $\mathrm{Kr}$ & 1.7 & Eu & 14.1 \\
\hline Te & 23.7 & Gd & 287. \\
\hline $\mathrm{Ag}(\mathrm{FP})$ & 0. & $N b$ & 4.3 \\
\hline Sb & 0. & $\mathrm{Pm}$ & 11.5 \\
\hline $\mathrm{Ba}$ & 103. & $\operatorname{Pr}$ & 80.4 \\
\hline$S n$ & 960. & $S m$ & 53.8 \\
\hline TC & 58.8 & $Y$ & 36.2 \\
\hline $\mathrm{UO}_{2}$ & 159,000 & $N p$ & 41.2 \\
\hline $\operatorname{Zr}$ (struct) & 49.200 & Pu & 743. \\
\hline $\operatorname{Zr}(F P)$ & 200. & Se & 0. \\
\hline $\mathrm{Fe}$ & 56,800 & Feo & 1250. \\
\hline Mo & 237. & $\mathrm{ZrO}_{2}$ & 21,800 \\
\hline$S r$ & 62.6 & & \\
\hline $\mathrm{Cr}$ & 11,200 & & \\
\hline Ni & 6,240 & & \\
\hline$M n$ & 184. & & \\
\hline La & 98.3 & & \\
\hline $\mathrm{Ag}$ (struct) & D. & & \\
\hline cd & 0. & & \\
\hline In & 0. & & \\
\hline $\mathrm{Ce}$ & 208. & & \\
\hline $\mathrm{Rb}$ & 1.6 & & \\
\hline $\mathrm{Br}$ & 0. & & \\
\hline Ru & 172. & & \\
\hline
\end{tabular}


Table 4.1.8. Aerosol release rate during corium-concrete interaction for Peach Bottom TBUX.

\begin{tabular}{|c|c|c|c|c|c|c|c|c|}
\hline Time (minutes) & 0.1 & 20.0 & 40.0 & 60.0 & 80.0 & 100.0 & 120.0 & 140.0 \\
\hline \multicolumn{9}{|c|}{ Percent of total aerosol source rate } \\
\hline FEO & 31.41 & 17.83 & 11.82 & 8.655 & 14.27 & 16.63 & 14.34 & 25.11 \\
\hline CR203 & .2354 E-19 & $.2393 E-17$ & $.441 E-16$ & $.3239 E_{-}-16$ & $.4881 E-15$ & $.8938 \mathrm{E}-15$ & $.1040 \mathrm{E}-13$ & $.6338 E-15$ \\
\hline MI & $.3995 E-02$ & $.8666 \mathrm{E}-01$ & .4046 & 1.090 & .9858 & .5289 & 1.213 & .1157 \\
\hline MO & $.6835 E-10$ & $.1593 \mathrm{E}-07$ & $.3332 E-06$ & $.1559 E-05$ & $.9514 E-06$ & $.3131 \mathrm{E}-00$ & $.1391 E-05$ & $.2070 E-07$ \\
\hline 咸 & $.5400 \mathrm{E}-09$ & $.1217 E-06$ & .2481E-05 & .1145E-OA & .7037E-05 & $.2338 E-05$ & . 1025E-04 & $.1562 E-06$ \\
\hline SB & 0. & 0. & 0. & 0. & ข. & t. & 1. & 0. \\
\hline TE & .1052 & .3102 & .3878 & .3953 & .5349 & .4790 & .4886 & .2454 \\
\hline AG & 0. & (6. & 0. & 0. & 0. & o. & 0. & t. \\
\hline MN & .2032 & .9868 & 2.193 & 3.017 & 3.487 & 2.572 & 3.573 & .0529 \\
\hline $\mathrm{CAO}$ & 0. & 2.070 & 8.220 & 0.761 & 11.10 & 13.04 & 11. 11 & 19.56 \\
\hline AL203 & 1. & $.6155 E-02$ & 2.003 & 5.314 & 7.845 & 6.743 & 12.90 & .2583 \\
\hline NA20 & 0. & 2.279 & 2.784 & 2.758 & 5.412 & 6.202 & 5.644 & 2.242 \\
\hline SI02 & 0. & 14.90 & 11.40 & 12.66 & 23.03 & 27.79 & 23.95 & 29.08 \\
\hline 002 & .1008 & .1422 & .5904 & 1.425 & 1.172 & .5705 & 1.067 & $.9967 E-01$ \\
\hline ZRO2 & . 134AE-01 & $.9510 E-12$ & .1535E-01 & .3609E-01 & $.2949 E-01$ & $.1721 E-11$ & . .32บE-01 & $.1580 E-01$ \\
\hline $\operatorname{cs} 20$ & 63.42 & 33.85 & 22.38 & 16.15 & $.6827 \mathrm{E}-03$ & 0. & 0. & 0. \\
\hline$B A O$ & 1.468 & 4.636 & 4.181 & 3.537 & 4.945 & 4.512 & 2.754 & 1.314 \\
\hline SAO & 1.933 & 3.712 & 4.959 & 5.124 & ช. 240 & 4.784 & 3.208 & .5729 \\
\hline LA203 & $.2578 \mathrm{E}-12$ & .1040 & .9255 & 2.720 & 2.074 & .8970 & 2.291 & $.8449 E-01$ \\
\hline CEO2 & $.1793 E-14$ & .4498 & 2.680 & 0.291 & 5.222 & 2.485 & 4.284 & .2006 \\
\hline NB205 & $.3793 E-105$ & 3.797 & 10.92 & 13.03 & $.3518 E-03$ & 0. & 0. & 1. \\
\hline CSI & 1.093 & 2.930 & 4.297 & 3.065 & 1.386 & $.4701 E-02$ & .6294E-O5 & ข. \\
\hline $\mathrm{CO}$ & 0. & . & 0. & 0. & 0. & 0. & 0. & 0. \\
\hline SOURCE RATE(GM/S) & 2.882 & 7.364 & 19.14 & 58.99 & 74.19 & 206.2 & 1349. & 293.2 \\
\hline AEROSOL DEMSITY (CM/CM3) & 4.417 & 3..391 & 3.479 & 3.591 & 3.216 & 3. 011 & 3.136 & 2.807 \\
\hline AEROSOL SIZE(MICRON) & .7347 & .9731 & 1.103 & 1.212 & 1.063 & 1.030 & 1.071 & .9127 \\
\hline OUTOE MELT TEMP(K) & 1848. & 2160. & 2391. & 2538. & 2457. & 2363. & 2493. & 2159. \\
\hline
\end{tabular}


Table 4.1.8. (Continued)

\begin{tabular}{|c|c|c|c|c|c|c|c|c|}
\hline Ti周 (面inutes) & 101.0 & 180.0 & 200.0 & 221.0 & 248.0 & 260.0 & 200. & 301.0 \\
\hline \multicolumn{9}{|c|}{ Percent of total aerosol source rato } \\
\hline FEO & 28.71 & 29.47 & 30.46 & 36.36 & 1.120 & 1.035 & .9580 & .0033 \\
\hline CR2OS & $. \$ 8902-16$ & $.0602 E-16$ & $.1500 E-15$ & $.1254 E-13$ & .6654 & .7494 & .7291 & .6588 \\
\hline MI & $.1629 E-01$ & $.1472 E-01$ & $.1435 E-01$ & $.1722 E-01$ & .5570 & .4903 & .4397 & .4034 \\
\hline แมข & $.7303 E-09$ & $.5950 E-09$ & $.5545 E-09$ & $.3422 E-09$ & $.2235 E-04$ & .2364 E-14 & $.2774 E-04$ & $.3667 E-14$ \\
\hline RU & $.5734 E-18$ & $.46805-03$ & $.4365 E-08$ & $.5056 E-18$ & $.1586 E-06$ & $.1305 E-00$ & $.1091 E-08$ & $.9366 E-177$ \\
\hline SH & .1225 & .1192 & .1198 & .1476 & 9.339 & 3. 837 & 0.870 & 0.841 \\
\hline SE & 0. & i. & 0. & 0. & 0. & 0. & 0. & 0. \\
\hline TE & .1303 & .1282 & .1271 & .1570 & 5.232 & 4.900 & 4.694 & 4.582 \\
\hline AG & 0. & 0. & 0. & 0. & 0. & 0. & 0. & t. \\
\hline MAl & .2786 & .2600 & .2599 & .3184 & 10.54 & 9.660 & 0.056 & 0.667 \\
\hline CAl & 22.43 & 23.02 & 20.87 & 5.975 & 1.199 & 1.149 & 1.135 & 1.154 \\
\hline AL203 & .2042E-11 & $.0224 E-02$ & .3935E-02 & $.6665 E-13$ & .1513E-01 & . 1499E-11 & $.1518 \mathrm{E}-11$ & $.1562 E-01$ \\
\hline MA2O & 1.790 & .7716 & 1.090 & .9574 & 1.610 & 2.020 & 2.242 & 2.349 \\
\hline$\$ 102$ & 24.72 & 24.92 & 25.59 & 28.20 & .5851 & .4843 & .3901 & .3289 \\
\hline U12 & . A912E-11 & $.4600 E-01$ & .4603E-01 & $.5647 E-01$ & 2.795 & 2.609 & 2.510 & 2.480 \\
\hline 2802 & .1973E-01 & $.2164 E-01$ & $.2282 E-01$ & $.2913 E-11$ & .9858 & .9135 & .0837 & .0897 \\
\hline $\operatorname{cs} 20$ & 0. & 0. & 0. & 0. & 0. & 0. & 0. & 0. \\
\hline BAO & .2812 & .1057 & .1098 & $.3098 E-01$ & .5411E-01 & $.50795-01$ & $.4951 E-01$ & .5อ20E-บ1 \\
\hline$\$ 80$ & .1481 & . B891E-01 & $.5940 E-01$ & $.1068 E-01$ & $.1950 E-02$ & $.1762 E-02$ & $.1641 E-02$ & $.1419 E-02$ \\
\hline LA203 & $.5315 E-02$ & $.3635 E-02$ & $.2870 E-02$ & $.177 B E-02$ & .1153E-01 & $.1073 E-01$ & $.1022 E-01$ & $.9935 E-02$ \\
\hline CEO2 & . 1458E-DI & .125E-02 & $.5297 E-02$ & $.1702 E-112$ & $.1170 E-01$ & $.1107 E-01$ & $.1071 E-01$ & . IOSAE-11 \\
\hline M8205 & 0. & 0. & 0. & 0. & 0. & 0. & 0. & 0. \\
\hline CSI & 0. & 0. & 0. & 0. & 0. & 0. & 0. & ช. \\
\hline $\mathrm{CO}$ & 0. & 0. & 0. & . & 0. & 0. & 0. & 1. \\
\hline SOURCE RATE(CM/S) & 328.7 & 130.3 & 101.9 & 68.92 & 1.971 & 2.289 & 2.338 & 2.300 \\
\hline AERDSOL DOASITY(CM/CM3) & 2.942 & 2.970 & 2.973 & 3.039 & 2.610 & 2.563 & 2.535 & 2.523 \\
\hline AEROSOL SIRE(MICRON) & .8671 & .8570 & .0473 & .7789 & .2532 & .2571 & .2584 & .2578 \\
\hline OXIOE MELT TEMP(K) & 1984. & 1951. & 1945. & 1940. & 1936. & 1928. & 1919. & 1911. \\
\hline
\end{tabular}


Table 4.1.8. (Continued)

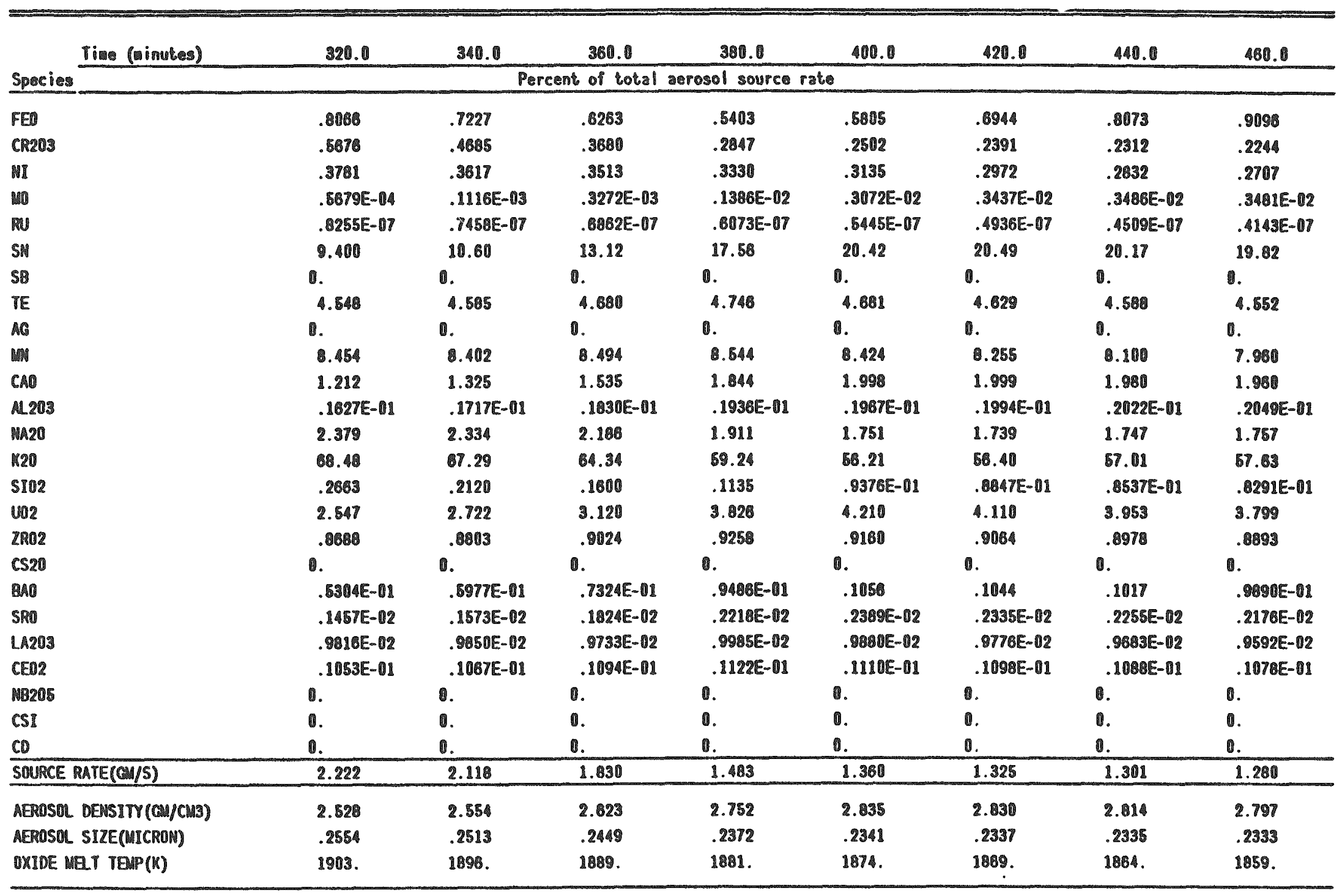


Table 4.1.8. (Continued)

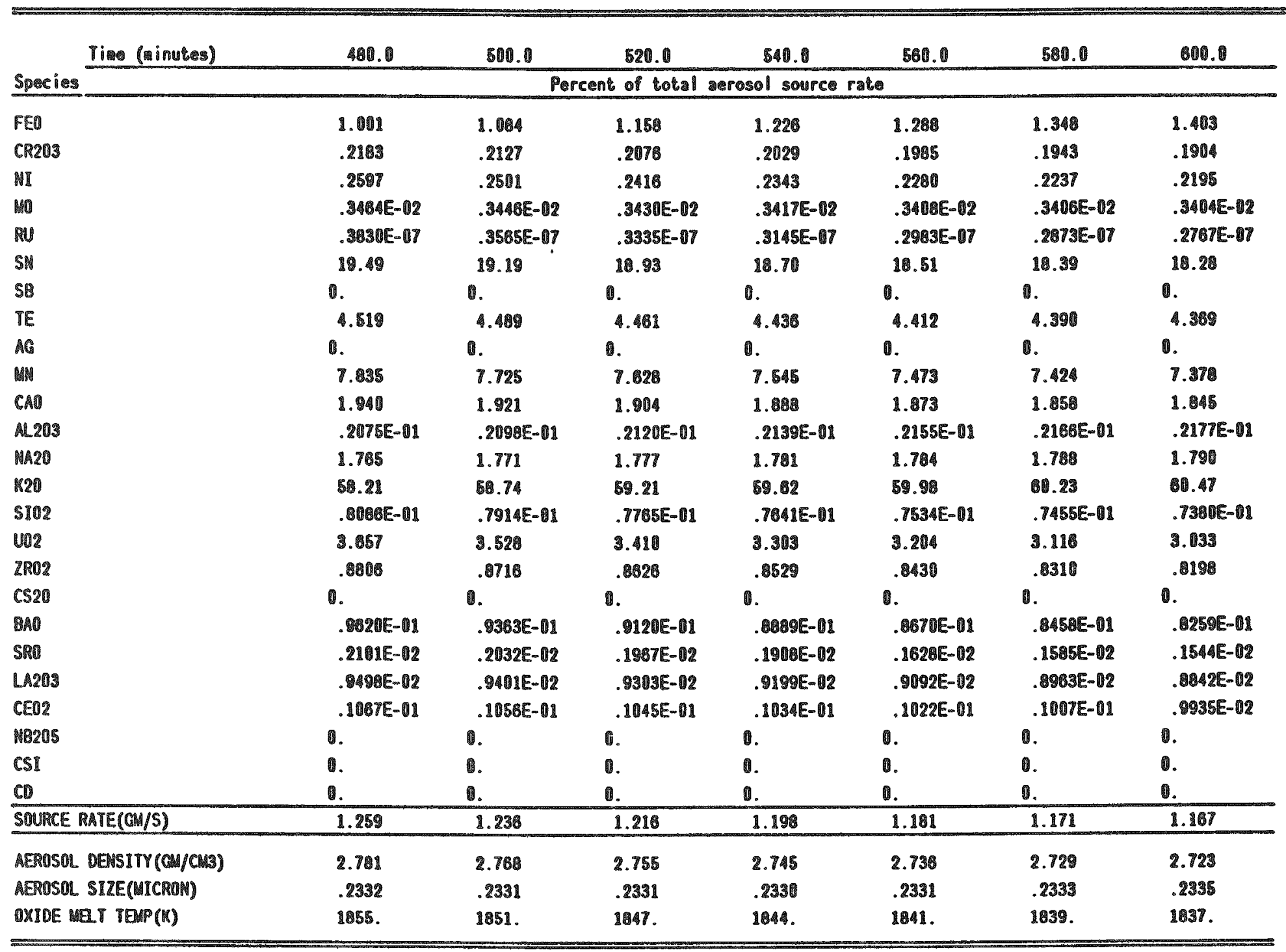




\subsubsection{Results: Transport in the Reactor Coolant System}

Table 4.1 .9 gives an overview of the time-dependent mass transport behavior of the dominant nuclide species in the RCS. The period covered is that from initial fission product release from fuel (after beginning of core uncovery and heatup) to vessel failure. The 20 entries are in roughly 5-minute intervals. Table 4.1 .10 gives cumulative release and retention data for all groups considered, at the time of vessel failure.

In Table 4.1.9, "Ret" refers to material deposited on surfaces of the RCS: "Total" refers to the amount of material released from the fuel. Comparing these two columns at 203.1 minutes into the accident, the time of vessel failure, yields the following retention efficiencies:

CsI: $\quad 26$ percent

$\mathrm{CsOH}: \quad 65$ percent

Te: $\quad 96$ percent

Aerosol: 82 percent.

(Here "aerosol" stands for all structural and control rod material.)

A closer examination of the results shown in Table 4.1 .9 indicates similar retention efficiencies for the volatile radionuclide species up to approximately 151 minutes. Thereafter, the retained CSI material is largely revolatilized and escapes the system. Retention of $\mathrm{CsOH}$ is also observed to decrease, however, not to the extent observed for CSI. Figures 4.1 .16 through 4.1.19 illustrate the time-dependent transport and retention of the volatile species (CSI, CSOH, Te) and released aerosols, respectively.

\subsubsection{Results: Transport in the Containment}

As described in Section 3.1.3, the analysis of fission product transport in the containment includes calculation of radionuclide deposition in the suppression pool, wetwell "airspace", drywell, reactor building and refueling bay. The flowpaths for fission products during various phases of this sequence is shown in Figure 3.1.3. 
Table 4.1.9. Masses of dominant species released from fuel and retained on RCS structures as functions of time for the Peach Bottom TBUX sequence.

(Time $=0.0$ corresponds to start of accident)

\begin{tabular}{|c|c|c|c|c|c|c|c|c|}
\hline \multirow[b]{2}{*}{$\begin{array}{l}\text { Time } \\
(M)\end{array}$} & \multicolumn{2}{|c|}{ CSI } & \multicolumn{2}{|c|}{$\mathrm{CsOH}$} & \multicolumn{2}{|c|}{$\mathrm{Te}$} & \multicolumn{2}{|c|}{ Aerosol } \\
\hline & $\begin{array}{l}\text { Ret } \\
(\mathrm{Kg})\end{array}$ & $\begin{array}{l}\text { Total } \\
(\mathrm{kg})\end{array}$ & $\begin{array}{l}\text { Ret } \\
(\mathrm{Kg})\end{array}$ & $\begin{array}{c}\text { Total } \\
(\mathrm{kg})\end{array}$ & $\begin{array}{l}\overline{\operatorname{Ret}} \\
(\mathrm{Kg})\end{array}$ & $\begin{array}{c}\text { Total } \\
(\mathrm{kg})\end{array}$ & $\begin{array}{l}\text { Ret } \\
(\mathrm{Kg})\end{array}$ & $\begin{array}{c}\text { Total } \\
(\mathrm{kg})\end{array}$ \\
\hline $\begin{array}{l}105.8 \\
110.9 \\
115.9 \\
121.2 \\
126.2 \\
131.2 \\
136.4 \\
141.4 \\
146.4 \\
151.4 \\
156.7 \\
161.7 \\
166.7 \\
171.7 \\
176.8 \\
182.4 \\
187.1 \\
192.1 \\
197.1 \\
203.1\end{array}$ & $\begin{array}{r}.0 \\
.0 \\
.1 \\
1.2 \\
4.2 \\
8.5 \\
13.3 \\
17.4 \\
19.6 \\
19.0 \\
7.4 \\
2.6 \\
2.8 \\
8.3 \\
8.3 \\
8.3 \\
8.3 \\
8.3 \\
8.3 \\
8.3\end{array}$ & $\begin{array}{r}.3 \\
.6 \\
2.1 \\
5.6 \\
10.2 \\
14.9 \\
19.0 \\
21.9 \\
24.0 \\
25.8 \\
26.9 \\
28.0 \\
28.8 \\
31.2 \\
31.4 \\
31.5 \\
31.5 \\
31.5 \\
31.6 \\
31.7\end{array}$ & $\begin{array}{r}.2 \\
.5 \\
1.6 \\
10.3 \\
32.2 \\
63.2 \\
96.7 \\
125.5 \\
144.0 \\
153.5 \\
133.3 \\
91.8 \\
118.9 \\
145.6 \\
145.3 \\
145.3 \\
145.3 \\
145.4 \\
145.5 \\
145.8\end{array}$ & $\begin{array}{r}5.5 \\
8.6 \\
19.3 \\
44.0 \\
75.8 \\
108.3 \\
136.6 \\
156.8 \\
171.0 \\
184.0 \\
191.5 \\
198.8 \\
205.2 \\
221.1 \\
222.7 \\
222.9 \\
223.1 \\
223.4 \\
223.9 \\
224.5\end{array}$ & $\begin{array}{r}.0 \\
.0 \\
.0 \\
.1 \\
.3 \\
.7 \\
1.4 \\
2.4 \\
3.7 \\
5.2 \\
6.7 \\
8.2 \\
9.7 \\
10.7 \\
10.7 \\
10.7 \\
10.7 \\
10.7 \\
10.7 \\
10.8\end{array}$ & $\begin{array}{r}.0 \\
.0 \\
.1 \\
.2 \\
.5 \\
.9 \\
1.8 \\
2.9 \\
4.2 \\
5.7 \\
7.2 \\
8.7 \\
10.1 \\
11.1 \\
11.1 \\
11.1 \\
11.1 \\
11.2 \\
11.2 \\
11.2\end{array}$ & $\begin{array}{r}.0 \\
.0 \\
.2 \\
2.4 \\
10.3 \\
27.0 \\
58.4 \\
108.5 \\
167.8 \\
238.6 \\
320.7 \\
405.7 \\
492.2 \\
537.0 \\
537.2 \\
537.2 \\
537.2 \\
537.2 \\
537.3 \\
537.6\end{array}$ & $\begin{array}{r}.0 \\
.5 \\
3.3 \\
11.3 \\
26.7 \\
53.8 \\
100.5 \\
163.2 \\
235.7 \\
315.3 \\
402.2 \\
486.7 \\
570.2 \\
648.5 \\
652.0 \\
652.4 \\
653.0 \\
653.8 \\
655.0 \\
656.4\end{array}$ \\
\hline
\end{tabular}


Table 4.1.10. Masses of radionuclides released from fuel and retained by RCS (by group) for the Peach Bottom TBUX sequence at the time of reactor vessel failure (203.1 minutes).

\begin{tabular}{lrr}
\hline Group & $\begin{array}{c}\text { Released } \\
(\mathrm{Kg})\end{array}$ & $\begin{array}{c}\text { Reta ined } \\
(\mathrm{Kg})\end{array}$ \\
\hline $\mathrm{I}$ & 15.5 & 4.1 \\
$\mathrm{Cs}$ & 215.4 & 133.5 \\
$\mathrm{Te}$ & 11.2 & 10.8 \\
$\mathrm{Sr}$ & .1 & .0 \\
$\mathrm{Ru}$ & .0 & .0 \\
$\mathrm{La}$ & .0 & .0 \\
$\mathrm{Ng}$ & 385.4 & .0 \\
$\mathrm{Ce}$ & .0 & .0 \\
$\mathrm{Ba}$ & 1.7 & 1.4 \\
\hline
\end{tabular}




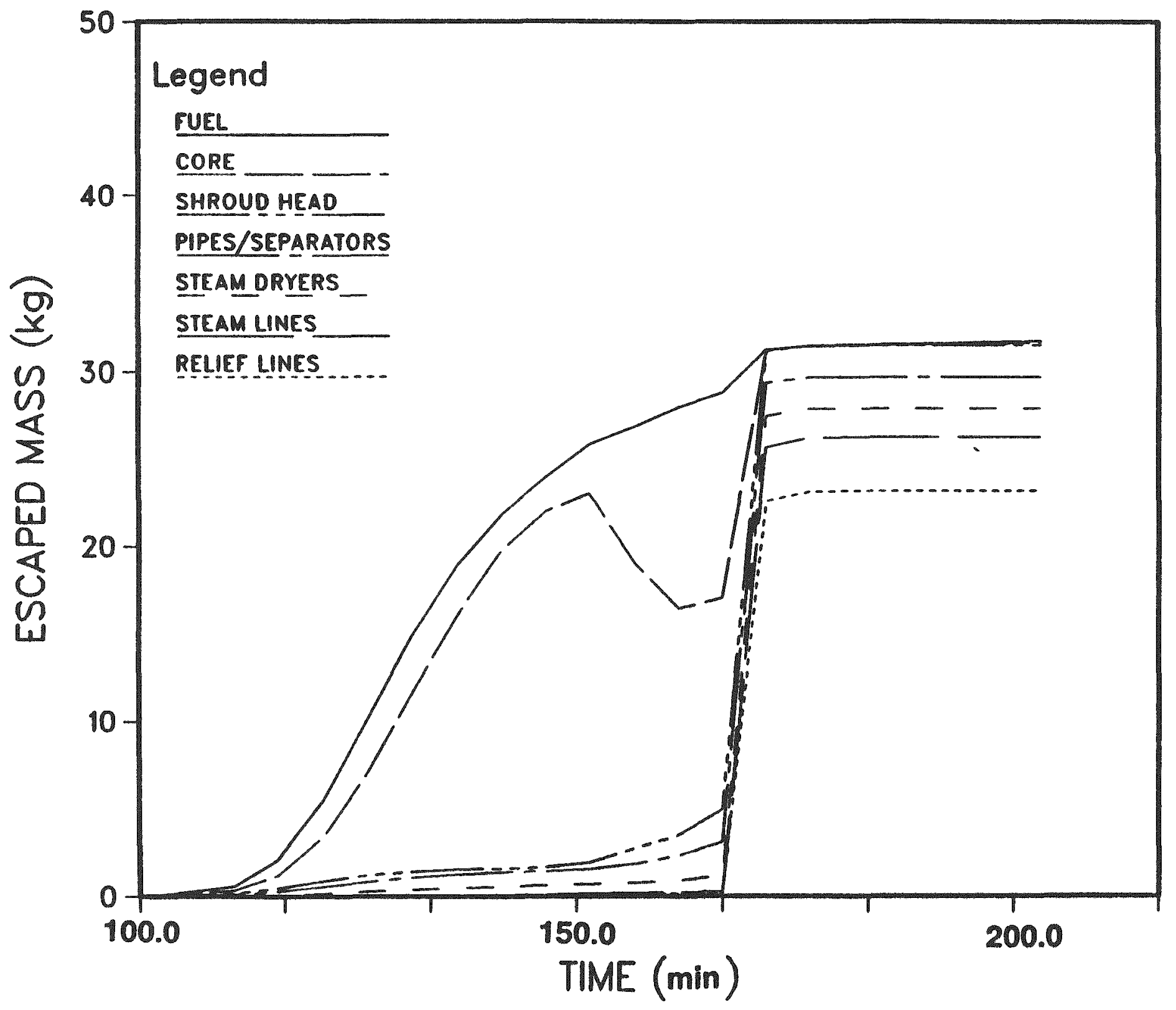

Figure 4.1.16. Mass of CSI released from indicated RCS components as a function of time - Peach Bottom TBUX. 


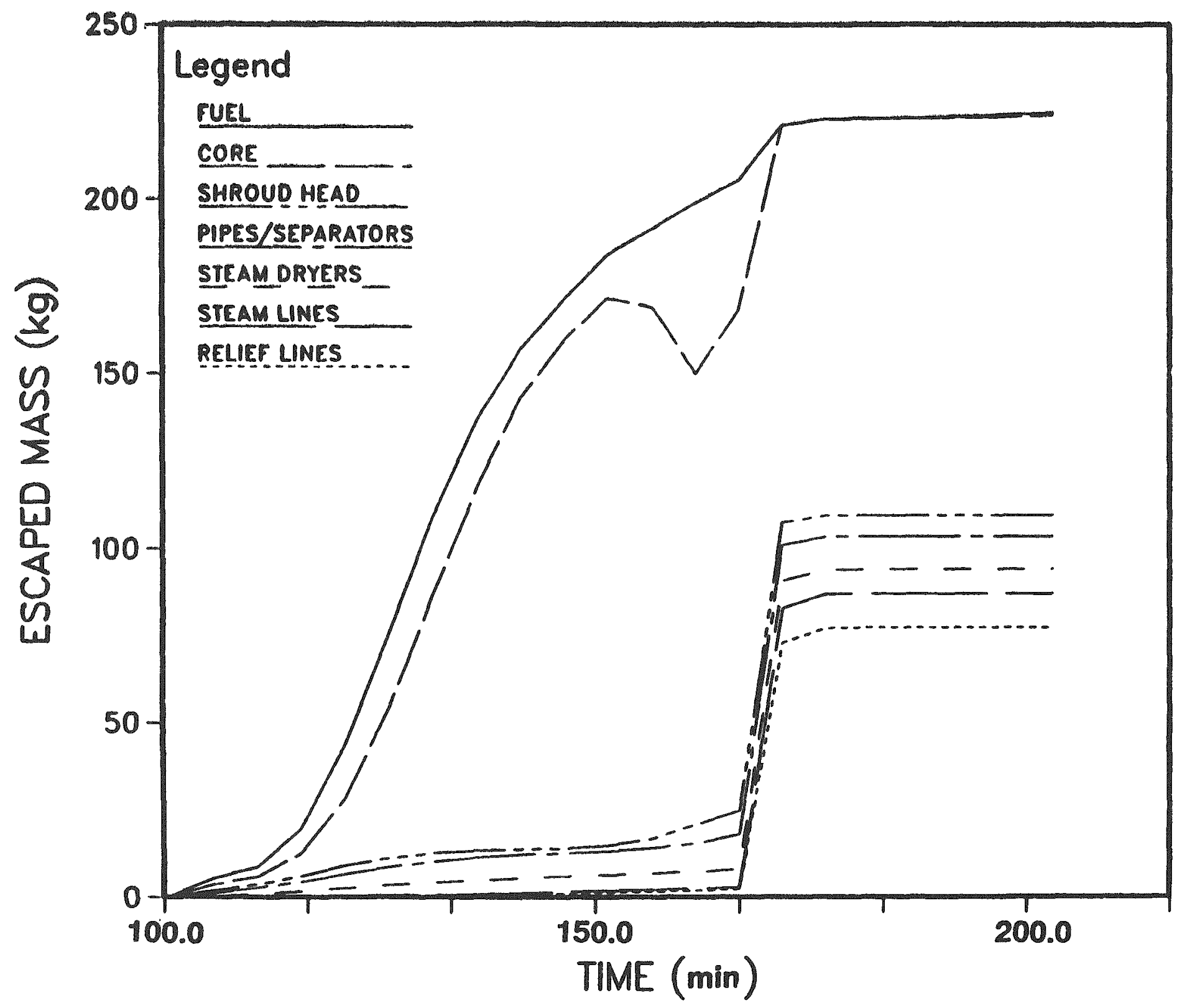

2

Figure 4.1.17. Mass of $\mathrm{CSOH}$ released from indicated RCS components as a function of time - Peach Bottom TBUX. 


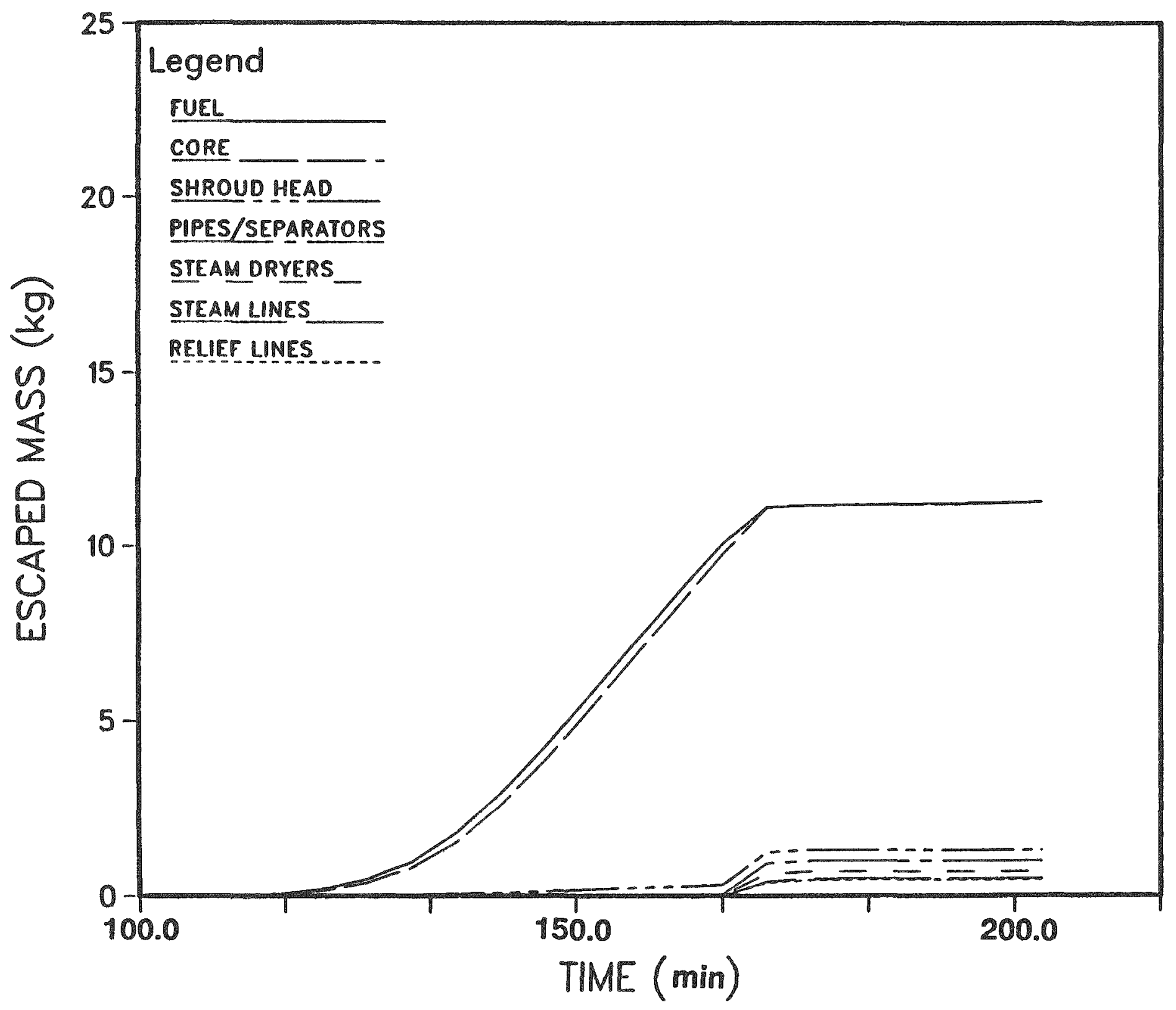

Figure 4.1.18. Mass of Te released from indicated RCS components as a function of time - Peach Bottom TBUX. 


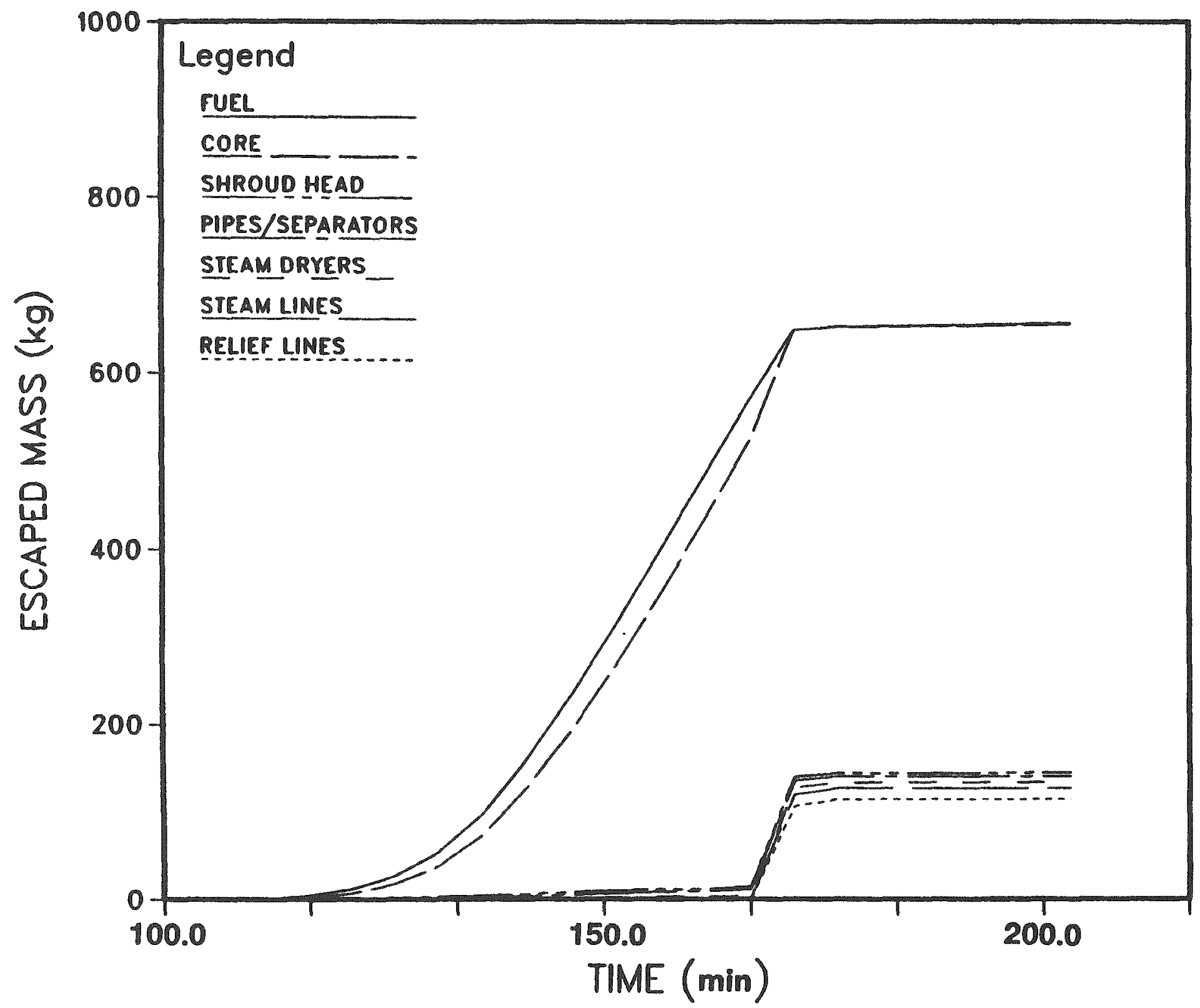

Figure 4.1.19. Mass of aerosol released from indicated RCS components as a function of time - Peach Bottom TBUX. 
Table 4.1.11 summarizes the cumulative fission product source terms to the containment for this sequence. Tables 4.1 .12 and 4.1 .13 show the aerosol size distribution for the fission products suspended in the drywell and the fraction of initial core inventory released from the drywell to the suppression pool, respectively, each as a function of time. Tables 4.1 .14 and 4.1.15, respectively, show the same information for the wetwell airspace; Tables 4.1 .16 and 4.1 .17 , respectively for the reactor building; and Tables 4.1.18 and 4.1.19, respectively, for the refueling bay. Table 4.1.19, therefore, shows the magnitude of the time-dependent release of radionuclides to the environment.

The ultimate fate of radionuclides for each of the nine species is summarized in Table 4.1.20. The environmental source term is relatively small (less than 1 percent of all species are released to the environment) primarily because the release path is assumed to be through the suppression pool throughout the accident.

\subsection{PWR, Subatmospheric Containment Design}

The calculated response of the reactor and containment to the postulated accident scenario is dependent on the approach taken to model important severe accident phenomena. A discussion of important phenomenological modeling assumptions applied in this analysis, therefore, precedes the presentation of calculated results. The results themselves are presented roughly in the order that the calculations are performed with the STCP(4); first the thermalhydraulic analysis results, followed by a discussion of the modeled radionuclide sources and the results of radionuclide release and transport analyses.

\subsubsection{Phenomenological Modeling Assumptions}

The analyzed accident scenario involves a reactor coolant pump seal LOCA which initiates at time zero. The specified leak rate of $900 \mathrm{gpm}$ was represented in the MARCH3 analyses by a hole 0.00501 square feet in area. 
Table 4.1.11. Fraction of initial core inventory released to the primary containment for Peach Bottom TBUX.

\begin{tabular}{|c|c|c|c|}
\hline Group & $\begin{array}{c}\text { During } \\
\text { In-Vessel } \\
\text { Release }\end{array}$ & $\begin{array}{c}\text { During } \\
\text { Puff } \\
\text { Release }\end{array}$ & $\begin{array}{c}\text { During } \\
\text { Core-Concrete } \\
\text { Attack }\end{array}$ \\
\hline I & 0.6812 & $6.9921 E-03$ & $6.7049 E-02$ \\
\hline Cs & 0.3496 & $5.6310 E-03$ & $6.5134 E-02$ \\
\hline Pi & $4.8222 E-04$ & $1.6910 E-05$ & 0.0 \\
\hline Te & $1.2707 E-02$ & $1.7862 E-04$ & 0.4054 \\
\hline $\mathrm{Sr}$ & $1.7398 E-04$ & $1.1704 E-07$ & 0.7542 \\
\hline Ru & $3.7339 E-07$ & $1.7522 E-11$ & $1.3822 E-06$ \\
\hline La & $3.8996 E-08$ & $2.8803 E-14$ & $3.2453 E-02$ \\
\hline $\mathrm{Ng}$ & 0.9261 & $7.6213 E-03$ & 0.0 \\
\hline $\mathrm{Ce}$ & 0.0 & 0.0 & $6.3093 E-02$ \\
\hline $\mathrm{Ba}$ & $3.0788 E=03$ & $7.2779 E-06$ & 0.5261 \\
\hline
\end{tabular}


Table 4.1.12. Size distribution of aerosols in the drywell - Peach Bottom TBUX.

\begin{tabular}{|c|c|c|c|c|c|c|c|c|c|c|}
\hline $\begin{array}{l}\text { Time (Minutes) } \\
\text { Densily (GM/CM33) }\end{array}$ & $\begin{array}{l}204.0 \\
\$ .09 \mathbb{2}\end{array}$ & $\begin{array}{c}234.0 \\
3.30 \% .00\end{array}$ & $\begin{array}{l}264.0 \\
3.501000\end{array}$ & $\begin{array}{l}294.0 \\
3.308+00\end{array}$ & $\begin{array}{c}330.0 \\
3.145 .00\end{array}$ & $\begin{array}{l}390.0 \\
2.020100\end{array}$ & $\begin{array}{c}480.0 \\
2.605\end{array}$ & $\begin{array}{c}6000 \\
2.77 \% \text { 霞 }\end{array}$ & $\begin{array}{l}720.0 \\
2.70 E .00\end{array}$ & $\begin{array}{c}840.1 \\
2.92 E+00\end{array}$ \\
\hline \multicolumn{11}{|l|}{ 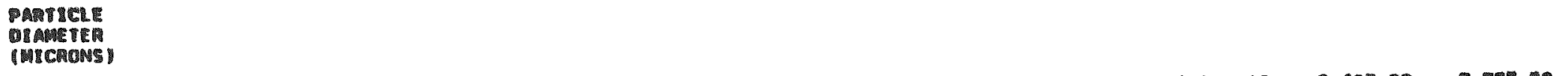 } \\
\hline 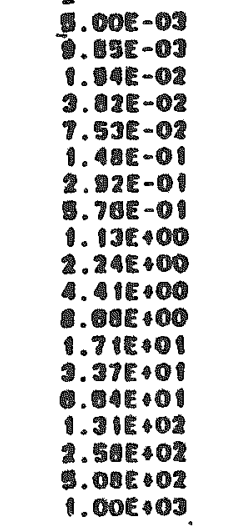 & 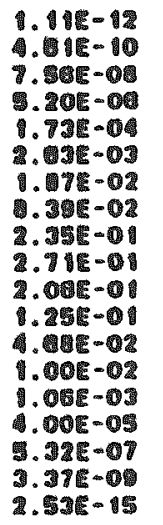 & 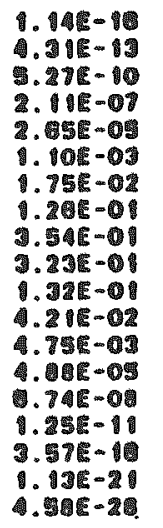 & 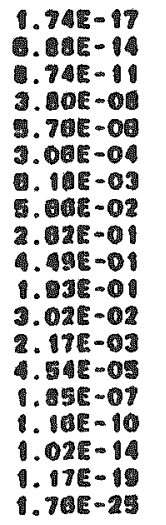 & 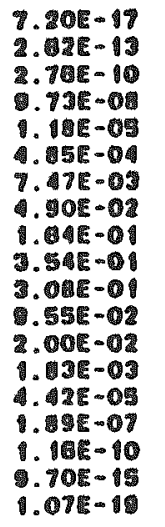 & 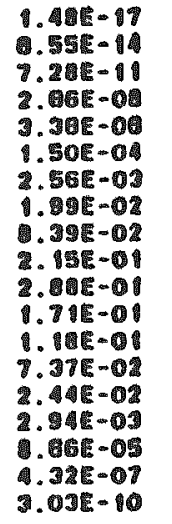 & 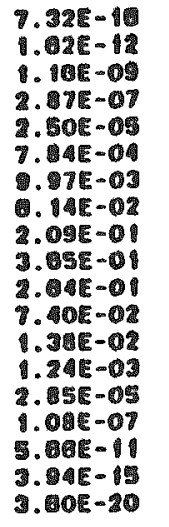 & 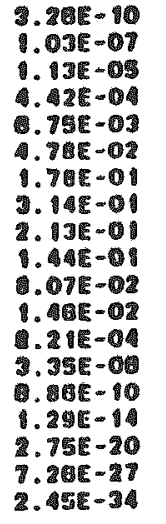 & 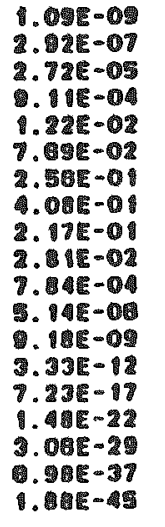 & 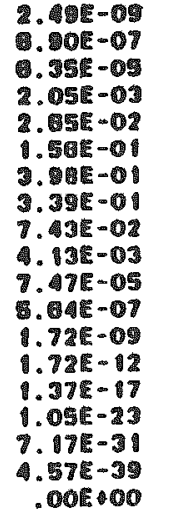 & 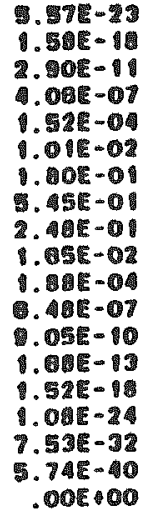 \\
\hline
\end{tabular}


Table 4.1.13. Fraction of core inventory released from the drywell - Peach Bottom TBUX.

\begin{tabular}{|c|c|c|c|c|c|c|c|c|c|c|c|}
\hline Time & \multicolumn{11}{|c|}{ Fission Product Group } \\
\hline (M) & 1 & cs & PI & TE & $\mathbf{S R}$ & RU & 4 & $\mathrm{CE}$ & $B$ & PE & Th \\
\hline 204.0 & $4.45 E-03$ & 2. 10E-03 & $3.46 E-00$ & 1.13E-04 & 1.13E-06 & 2.35E-18 & 2.47E-10 & 1.35E-11 & $1.96 E-45$ & 3.04E-14 & 0.11 \\
\hline 234.0 & $6.25 E-133$ & 4.66E-03 & $0.75 E-180$ & $1.20 E-04$ & $1.72 E-04$ & 2.50E-09 & 5.86E-08 & $8.02 E-87$ & 1.31E-04 & 2.1 & $1.74 E=01$ \\
\hline 284.0 & 8.83E-D3 & 8. $08 E-03$ & 7.78 E-DB & 4. $55 E-04$ & $1.64 E-03$ & $2.72 E-09$ & $1.71 \mathrm{E}-14$ & 5. BOE- 05 & $8.68 E-64$ & 15.8 & $2.28 E-01$ \\
\hline 294.0 & $1.71 E-02$ & 1.67E-02 & $0.14 E-106$ & 2.17E-19 & $1.13 E-02$ & $4.90 E-00$ & 1.03E-03 & 8.41E-0104 & $5.78 E-103$ & 105.2 & 3.00E-11 \\
\hline 330.0 & $2.94 E-02$ & $2.00 E-02$ & 1.00E-MS & $2.96 E-02$ & 1.03E-01 & $3.68 E-08$ & $4.48 E-03$ & 7.18E-03 & B. $82 E-02$ & 19210.0 & 3. OPE-01 \\
\hline 390.0 & $4.08 E-02$ & $3.08 E-02$ & 1.24E-ME & $2.28 E-111$ & 4.33E-01 & 2.35E-07 & 1.93E-02 & 3.77E-02 & $3.21 E-01$ & 22900.0 & $4.72 E-01$ \\
\hline 480.0 & $4.08 E-02$ & $3.06 E-12$ & $1.24 \mathrm{E}-118$ & 2.50E-111 & 4.37E-01 & 2.37E-07 & 1.84E-02 & $3.78 E-02$ & $3.28 \mathrm{E}-01$ & 26400.0 & $4.72 E-01$ \\
\hline 800.0 & 4.08E-02 & 3.86E- 12 & 1.24E-05 & $2.70 E-01$ & 4.37E-01 & $3.12 E-07$ & 1.84E-02 & 3.78E-02 & $3.26 E-01$ & 20500.10 & $4.72 E-01$ \\
\hline 720.0 & 4.08E-02 & 3. 68E-02 & $1.24 E-05$ & 2.83E-111 & 4.37E-01 & $0.71 \mathrm{E}-07$ & 1.84E-02 & $3.78 E-02$ & $3.28 \mathrm{E}-01$ & 26600.0 & $4.72 E-01$ \\
\hline 840.0 & 4.0BE-02 & 3.28E-02 & $1.24 E-15$ & 2.91E-01 & 4.37E-01 & $1.23 E-06$ & 1.04E-02 & $3.78 E-02$ & $3.26 E-11$ & 28700.0 & $4.72 E-01$ \\
\hline
\end{tabular}


Table 4.1.14. Size distribution of aerosols in the wetwell - Peach Bottom TBUX.

\begin{tabular}{|c|c|c|c|c|c|c|c|c|c|c|}
\hline $\begin{array}{l}\text { Time (Minutes) } \\
\text { Densily (GM/CM }\end{array}$ & $\begin{array}{c}351.0 \\
2.05 E+00\end{array}$ & $\begin{array}{c}360.0 \\
2.83 E+00\end{array}$ & $\begin{array}{l}375.0 \\
2.94 E+00\end{array}$ & $\begin{array}{l}405.0 \\
2.90 \%+00\end{array}$ & $\begin{array}{c}450.0 \\
2.99 E+00\end{array}$ & $\begin{array}{l}495.0 \\
2.33 E+00\end{array}$ & $\begin{array}{l}540.0 \\
2.53 E \div 00\end{array}$ & $\begin{array}{c}600.0 \\
2.73 E+00\end{array}$ & $\begin{array}{l}720.0 \\
2.778+00\end{array}$ & $\begin{array}{c}840.1 \\
2.72 \varepsilon+00\end{array}$ \\
\hline \multicolumn{11}{|l|}{$\begin{array}{l}\text { PARTICLE } \\
\text { BInBETER } \\
\text { (MICRONS) }\end{array}$} \\
\hline 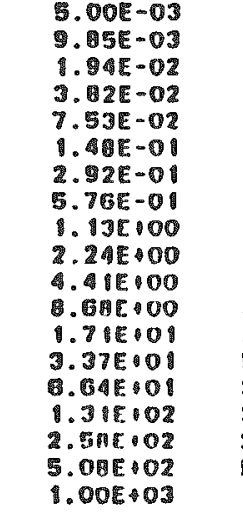 & $\begin{array}{l}2.5 A E-19 \\
.43 E-14 \\
9.77 E-10 \\
1.49 E-00 \\
3.72 E-04 \\
2.07 E-02 \\
2.95 E-01 \\
5.60 E-01 \\
9.00 E-02 \\
2.20 E-02 \\
2.00 E-03 \\
6.50 E-05 \\
2.08 E-05 \\
5.39 E-06 \\
3.75 E-07 \\
3.55 E-09 \\
2.00 E-12 \\
.57 E-17 \\
.00 E+00\end{array}$ & 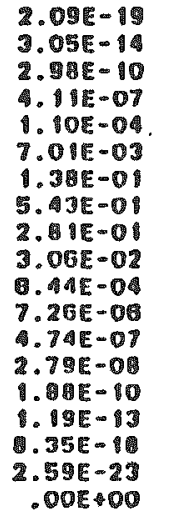 & 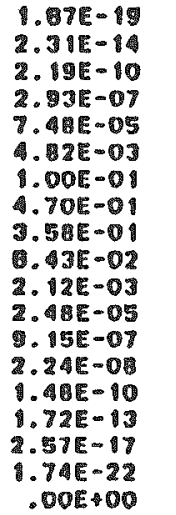 & 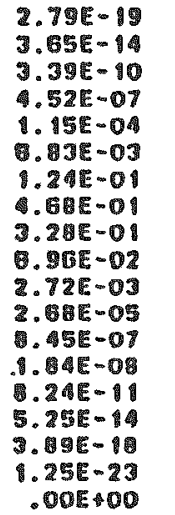 & 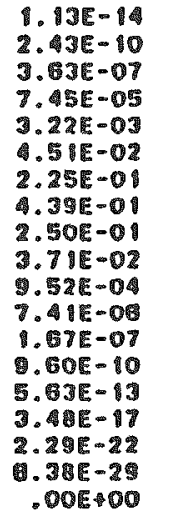 & 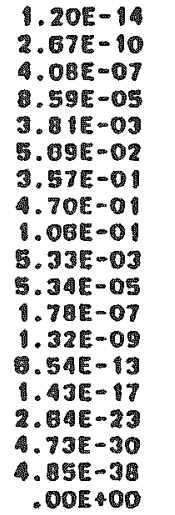 & 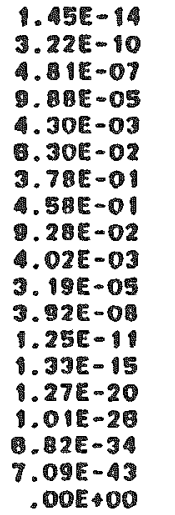 & 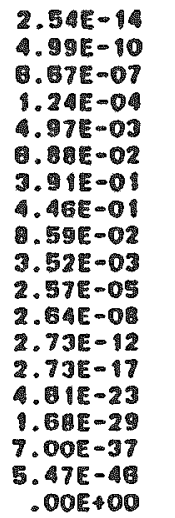 & 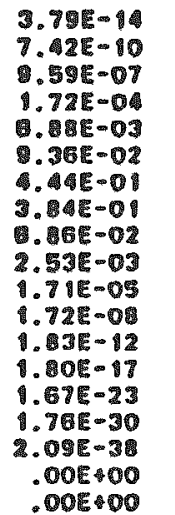 & $\begin{array}{r}.00 E-00 \\
1.22 E-14 \\
.01 E-00 \\
1.035-01 \\
1.14 E-02 \\
1.63 E-01 \\
5.45 E-01 \\
2.60 E-01 \\
1.92 E-02 \\
2.15 E-04 \\
1.70 E-07 \\
2.60 E-13 \\
.00 E+00 \\
.00 E+00 \\
.00 E+00 \\
.00 E 400 \\
.00 E+00 \\
.00 E+00 \\
.004+00\end{array}$ \\
\hline
\end{tabular}


Table 4.1.15. Fraction of core inventory released from the wetwel1 - Peach Bottom TBUX.

\begin{tabular}{|c|c|c|c|c|c|c|c|c|c|c|c|}
\hline \multirow{2}{*}{$\begin{array}{l}\text { Time } \\
\text { (M) }\end{array}$} & \multicolumn{11}{|c|}{ Fission Product Grou } \\
\hline & $\mathbb{I}$ & $c s$ & PI & $T E$ & $S R$ & nu & LA & ce & $a$ & $P E$ & $T$ \\
\hline 361.0 & 4.63E-D3 & 3. TEE-03 & 4. 4ละE-0ิ & 1. $83 E-03$ & 3.4OE-03 & 4.02E-09 & 1. BeE-04 & 3.20E-04 & 2.46E-193 & 135.0 & 6.74E-03 \\
\hline 386.6 & 4.01E-D3 & 3.126-03 & 4. ROE-978 & 3. $00 \mathrm{E}-03$ & F.19E-03 & $5.41 E-09$ & $2.54 E-04$ & $4.98 \mathrm{E}-\mathrm{OH}$ & 3.04E-193 & 250.0 & $6.12 \mathrm{E}-03$ \\
\hline 375.0 & $4.82 \mathrm{E}-119$ & 3. LEE-0 & 4. S9E-16 & 3. $69 \mathrm{E}-03$ & D.76E-03 & C.64E-00 & $2.71 E-04$ & B.3AE-04 & 4.66E-08 & 280.0 & 0.15E-O3 \\
\hline 405.0 & 4.82E- 13 & 3.1อE-03 & 4.59E-08 & 4.20E-013 & 6. BTE-ถి & 5.62E-90 & $2.75 E-04$ & 5.43E-04 & 5.QRE-1S & 460.0 & 6.15E-D3 \\
\hline 450.10 & $4.82 \mathrm{E}-103$ & 3.18E-03 & 4. SOE-DE & $4.53 E-03$ & C.15E-03 & $5.70 E-00$ & $2.76 E-104$ & 5. AME-OA & $5.18 E-03$ & 529.0 & 6.15E-D3 \\
\hline 495.0 & $4.82 \mathrm{E}-128$ & 3. 18E-0? & 4.59E-D & 6.05E-03 & 6.16E-03 & . 10E-09 & $2.78 E-04$ & 5. ASE-OA & 5.10E-DS & 562.0 & 0.15E-D3 \\
\hline 840.0 & 4. 22E-1ำ & 5. 10E-09 & 4. & $.73 E-03$ & 6. 16E-03 & 7.70E-09 & $2.76 E-04$ & 5. 45E-04 & $.20 \mathrm{E}-13$ & 574.0 & 3.15E-ต3 \\
\hline 300.0 & 4.82E-13 & 3. 1อE-อง & 4.59E-16 & 1.22E-02 & 6.17E-03 & 2.60E-08 & $2.76 \mathrm{E}-04$ & 5. $45 E-04$ & 5.22E-13 & 590.0 & 6.15E- \\
\hline 720.0 & 4.02E-13 & $3.18 E-03$ & 4. 59E-DE & 1.05E-02 & . I7E-03 & 2. $29 E-07$ & $2.77 E-B 4$ & 5.46E-04 & 5.26E-13 & 644.0 & 6.15E-03 \\
\hline 340.0 & 4.82E-15 & 3. 1อE-03 & 1. BOE-46 & 2.36C-02 & 8. 17E-03 & 5.26E-07 & $2.77 \mathrm{E}-04$ & $6.46 E-04$ & 5.20E-013 & ององ.1 & 6.15E-13 \\
\hline
\end{tabular}


Table 4.1.16. Size distribution of aerosols in the reactor building - Peach Bottom TBUX.

\begin{tabular}{|c|c|c|c|c|c|c|c|c|c|c|}
\hline $\begin{array}{l}\text { Time (Minutes) } \\
\text { Densily (GM/CM3) }\end{array}$ & $\begin{array}{l}351.0 \\
2.982+00\end{array}$ & $\begin{array}{c}360.0 \\
2.5 E 00\end{array}$ & $\begin{array}{l}375.0 \\
2.045 .00\end{array}$ & $\begin{array}{l}405.0 \\
2.95 E+00\end{array}$ & $\begin{array}{l}450.0 \\
2.906 \cdot 00\end{array}$ & $\begin{array}{l}495.0 \\
2.00 E+00\end{array}$ & $\begin{array}{l}540.0 \\
2.69 E+00\end{array}$ & $\begin{array}{c}600.0 \\
2.04 E+00\end{array}$ & $\begin{array}{l}720.0 \\
2.76 E+00\end{array}$ & $\begin{array}{c}840.0 \\
2.74 E+00\end{array}$ \\
\hline \multicolumn{11}{|l|}{ 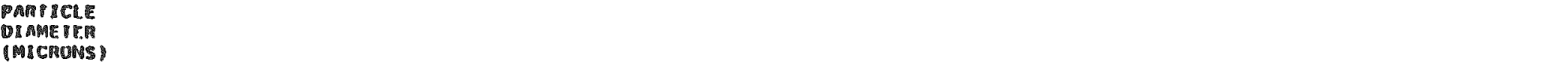 } \\
\hline 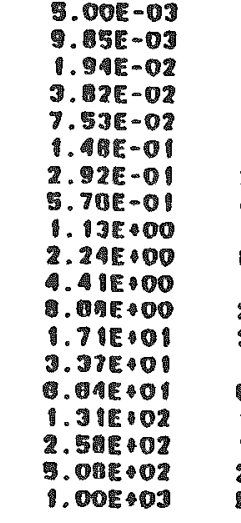 & 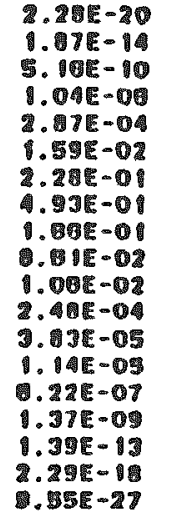 & 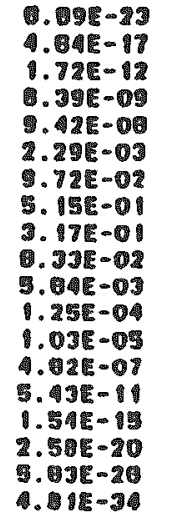 & 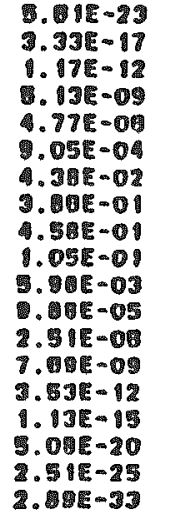 & 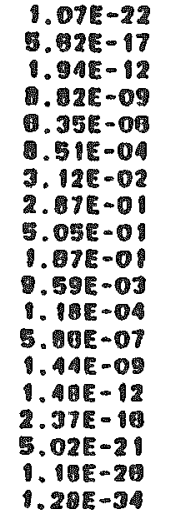 & 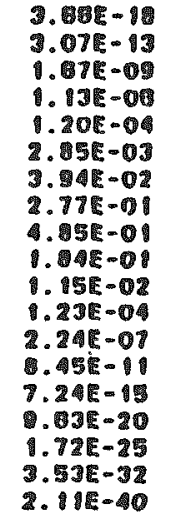 & 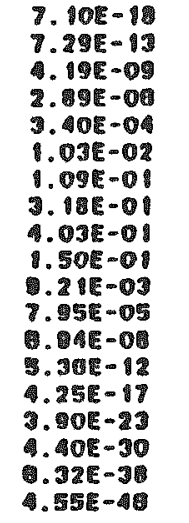 & 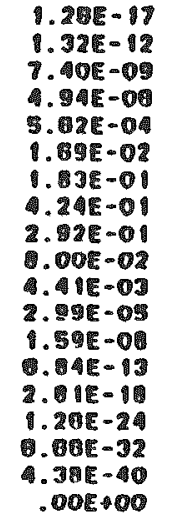 & 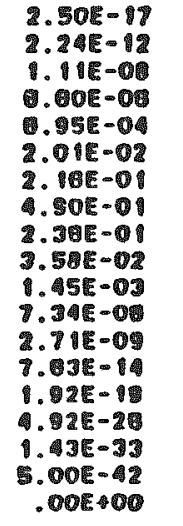 & 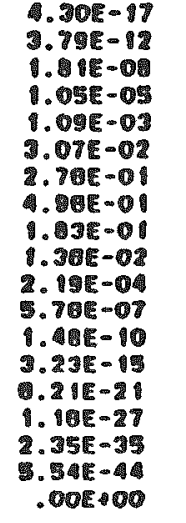 & 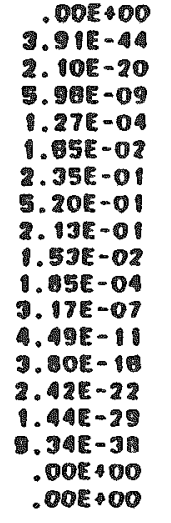 \\
\hline
\end{tabular}


Table 4.1.17. Fraction of core inventory released from the reactor building - Peach Bottom TBUX.

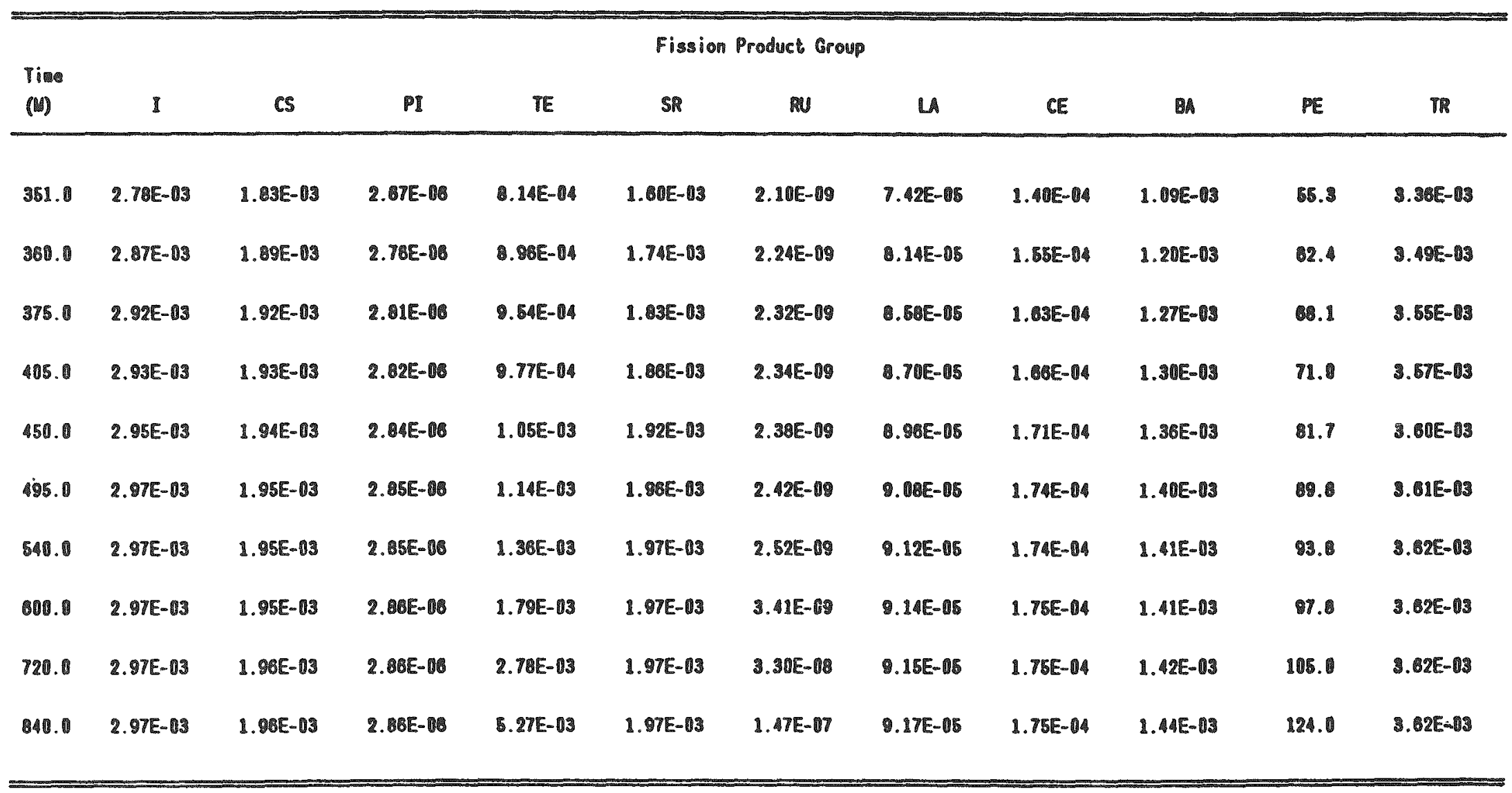


Table 4.1.18. Size distribution of aerosols in the refueling bay - Peach Bottom TBux.

\begin{tabular}{|c|c|c|c|c|c|c|c|c|c|c|}
\hline $\begin{array}{l}\text { Tmo (Minutes) } \\
\text { Densily (GM/CM3) }\end{array}$ & $\begin{array}{l}351.0 \\
9.006+00\end{array}$ & $\begin{array}{l}360.0 \\
2.906 .00\end{array}$ & $\begin{array}{l}375.0 \\
2.02800\end{array}$ & $\begin{array}{l}405.0 \\
.98600\end{array}$ & $\begin{array}{c}450.0 \\
2.97+400\end{array}$ & $\begin{array}{l}495.0 \\
2.97 E=00\end{array}$ & $\begin{array}{l}540.0 \\
2.55 \% 00\end{array}$ & $\begin{array}{c}600.0 \\
2.90 E 400\end{array}$ & $\begin{array}{l}720.0 \\
2.05900\end{array}$ & $\begin{array}{c}940.0 \\
2.78 \%+00\end{array}$ \\
\hline \multicolumn{11}{|l|}{ 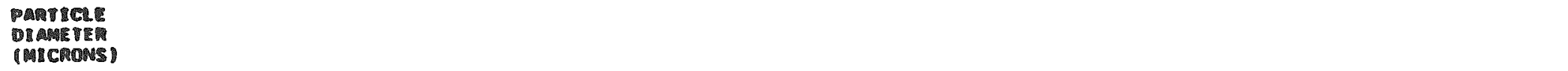 } \\
\hline 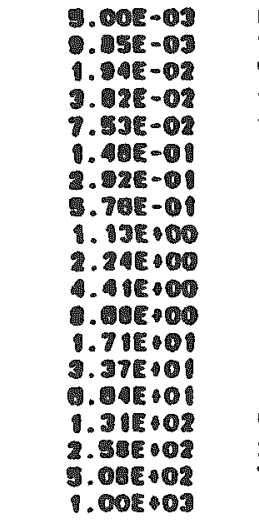 & 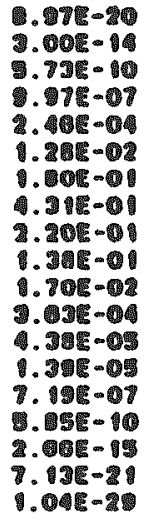 & 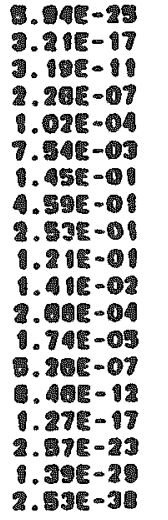 & 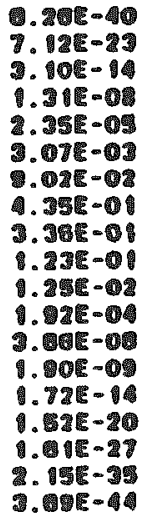 & 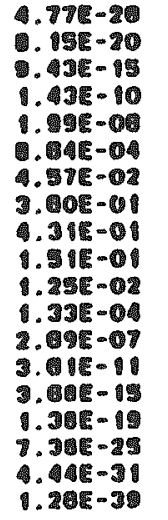 & 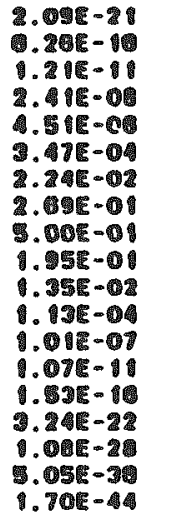 & 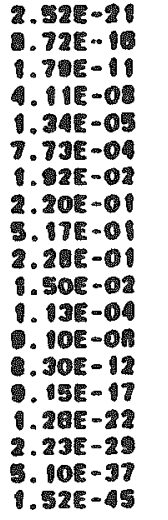 & 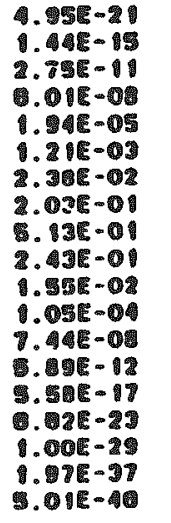 & 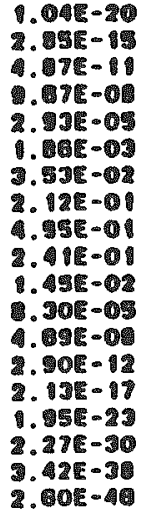 & 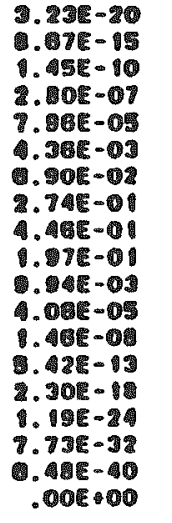 & 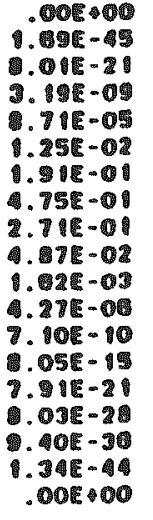 \\
\hline
\end{tabular}


Table 4.1.19. Fraction of core inventory released from the refueling bay - Peach Bottom TBUX.

\begin{tabular}{|c|c|c|c|c|c|c|c|c|c|c|c|}
\hline Time & \multicolumn{11}{|c|}{ Fission Product Group } \\
\hline$(M)$ & $\mathbb{I}$ & cs & PI & TE & $\mathbf{S R}$ & m & La & CE & $B A$ & PE & $T R$ \\
\hline 361.0 & 1. DAE-03 & $1.246-98$ & 1. $12 \varepsilon-08$ & 5.18E-II & 1.02E-03 & 1.\$9E-10 & $4.71 E-16$ & 8.OE-0\% & 2. อนE- & 14.3 & 2.27E-08 \\
\hline 300. & 1. DAE-103 & 1.24E-03 & 1.A2E-Q & R.18E-DI & 1. MaE-1: & 1.MEE-DO & 4.74E-DE & - $.82 E-05$ & $0.04 E-04$ & 24.6 & 2.28E-03 \\
\hline 378.0 & 1.88E-08 & $1.24 E-08$ & 1.02E-06 & 5.10E-14 & 1.03E-03 & 1.90E-18 & $4.74 E-05$ & $0.92 E-05$ & 6.84E-04 & 34.5 & 2.20E-13 \\
\hline 405.1 & $1.85-03$ & 1.24E-18 & 1. $25-06$ & E.18E- & 1. OSE-13 & 1.20E-18 & 4.74E-105 & . .2E-10 & $6.94-04$ & 34.6 & 2.26E-18 \\
\hline 460.0 & 1.07E-08 & 1.30E-03 & 1.DบE- & 5. (63E-14 & 1.10E-DS & 1.47E-68 & $5.00 E-105$ & Q.62E-15 & $7.51 E-04$ & 30.6 & 2.80E-18 \\
\hline 496.8 & 2. IE-OS & 1.3SE-103 & 2. 보트-19 & 6. 4 . & 1.23E-103 & 1.60E-DO & 5.71E-18 & 1. DOE-BA & . BIE-M & 48.8 & 2.65E-08 \\
\hline 640.0 & 2.24E-0B & 1.47E-10 & 2.18E-0 & T.8TE-M & 1. 28E-18 & 1.7RE- & T.30E-15 & $1.20 E-04$ & 1. GIE-O4 & 56. & 2.71E-18 \\
\hline 600.0 & 2.35E-08 & 1.56E-08 & 2. 2ีE-10 & $0.71 E-14$ & 1.40E- 13 & 1. Q8E-DO & C. $.8 E-05$ & 1.30E-D4 & 1. MAE-0I & 64.0 & 2. E- 19 \\
\hline 720.8 & 2.40E- อิ & 1.04E-03 & 2. มพE-טิ & 1.50E- & 1.62E-- & ๑.37E-10 & $7.40 E-106$ & $1.43 E-04$ & 1.15E-08 & 78.7 & 3. อIE- II \\
\hline 940.8 & 2.60E-03 & 1.71E-DS & 2.EDE- & 4.81E- & 1.73E-103 & 1.14E-07 & 6.01E-06 & 1.63E-M4 & $1.25 E-03$ & 108.0 & 3.17E-13 \\
\hline
\end{tabular}


Table 4.1.20. Final distribution of fission product inventory by group - Peach Bottom TBUX.

\begin{tabular}{|c|c|c|c|c|c|c|c|c|}
\hline Spectes & $\operatorname{RCS}$ & Melt & Drywe 11 & $\begin{array}{c}\text { Suppression } \\
\text { Pool }\end{array}$ & Wetwe 11 & $\begin{array}{l}\text { Reactor } \\
\text { Building }\end{array}$ & $\begin{array}{c}\text { Refueling } \\
\text { Bay }\end{array}$ & Environment \\
\hline 1 & $2.4 E-01$ & 0.0 & $5.4 E-02$ & $6.8 \mathrm{E}-01$ & $1.2 E-02$ & 1. $8 E-03$ & $1.2 E-04$ & $2.6 E-03$ \\
\hline $\mathrm{Cs}$ & $5.8 E-01$ & 0.0 & $4.5 E-02$ & $3.6 E-01$ & $7.9 E-03$ & $1.2 E-03$ & $7.6 E-05$ & $1.7 \mathrm{E}-03$ \\
\hline Te & $3.1 E-01$ & $2.7 E-01$ & $1.2 E-01$ & $2.8 E-01$ & $7.8 E-04$ & $1.8 E-02$ & $2.0 E-04$ & $4.3 E-03$ \\
\hline$S r$ & $6.9 E-04$ & $2.4 E-01$ & $3.2 E-01$ & $4.3 E-01$ & $2.8 E-04$ & $4.2 E-03$ & $1.1 E-04$ & $1.7 \mathrm{E}-03$ \\
\hline Ru & $1.2 E-06$ & 1.0 & $1.5 E-07$ & $1.0 E-06$ & $8.0 E-09$ & $3.5 E-07$ & $2.8 E-09$ & $1.1 E-07$ \\
\hline $\mathrm{La}$ & $9.8 E-08$ & $9.7 E-01$ & $1.3 E-02$ & 1. $9 E-02$ & $1.5 E-05$ & $1.8 E-04$ & $5.2 E-06$ & $8.0 E-05$ \\
\hline $\mathrm{Ce}$ & 0.0 & $9.4 E-01$ & $2.5 E-02$ & $3.7 E-02$ & $1.8 E-05$ & $3.7 E-04$ & $1.0 E-05$ & $1.5 E-04$ \\
\hline$B a$ & $1.3 E-02$ & $4.6 E-01$ & $2.0 E-01$ & $3.2 E-01$ & $2.2 E-04$ & $3.8 \mathrm{E}-03$ & $8.4 E-05$ & 1.2E-03 \\
\hline $\operatorname{Tr}$ & 0.0 & 0.0 & $5.3 E-01$ & $4.6 E-01$ & $7.0 E-03$ & $2.5 E-03$ & $1.4 E-05$ & $3.2 E-03$ \\
\hline
\end{tabular}


The phenomenological modeling assumptions utilized in this analysis are consistent with the methodology applied in NUREG/CR-4624, Volume $3^{(2)}$. The reader is referred to that document or Section 4.1 .1 of this report for a description of important parameters.

\subsubsection{Results of Thermal-hydraulic Analyses}

\section{PRIMARY SYSTEM RESPONSE - SUrry $S_{3} B$}

The MARCH3 predicted timing of accident events is given in Table 4.2.1. Core and primary system conditions at key times during the in-vessel phase of the accident are summarized in Table 4.2.2. With the relatively limited leak area associated with pump seal failure the primary system pressure remains at elevated levels during the in-vessel phase of the accident, as illustrated in Figure 4.2.1. It is interesting to note that for this scenario and the input parameters specified, the primary system pressure and temperature remain sufficiently high for the steam generator to be an effective heat sink until its dryout. The steam generator water inventory is shown in Figure 4.2.2. As the effectiveness of the steam generator decreases due to low water leve1, the primary system is seen to repressurize. Primary system water inventory during this scenario is illustrated in Figure 4.2.3. The total water and steam leakage from the primary system is given in Figure 4.2.4. The abrupt drop in leak rate at about 82 minutes corresponds to the uncovery of the break and switchover from water to steam leakage; the subsequent spikes in leak rate correspond to safety valve opening after the system has repressurized. The hydrogen leak rates are illustrated in Figure 4.2 .5 .

The maximum and average core temperatures are illustrated in Figure 4.2.6. The temperatures of the gases leaving the core and those exiting the primary system are shown in Figure 4.2.7. The fractions of cladding reacted and core melted are given in Figure 4.2.8. 
Table 4.2.1. Timing of key events - Surry $S_{3} B$.

\begin{tabular}{lc}
\hline \multicolumn{1}{c}{ Event } & Time, \\
& Minutes \\
\hline Steam generator dryout & 83.9 \\
Core uncovery & 87.6 \\
Start melt & 110.4 \\
Core slump & 131.4 \\
Core collapse & 132.6 \\
Bottom head dryout & 137.8 \\
Bottom head failure & 145.9 \\
Accumulators empty & 146.2 \\
Hydrogen burn & 146.2 \\
Containment failure & 146.3 \\
Start concrete attack & 242.2 \\
Corium layers invert & 283.2 \\
End calculation & 842.2 \\
& \\
\hline \hline
\end{tabular}


Table 4.2.2. Core and primary system response - Surry $S_{3} B$.

\begin{tabular}{|c|c|c|c|c|c|c|c|}
\hline $\begin{array}{c}\text { Accident } \\
\text { Event }\end{array}$ & $\begin{array}{l}\text { Timo. } \\
\text { inubses }\end{array}$ & $\begin{array}{l}\text { Primary } \\
\text { System } \\
\text { Pressuro. } \\
\text { psia }\end{array}$ & $\begin{array}{l}\text { Primary } \\
\text { System } \\
\text { Water } \\
\text { Inventory. } \\
\text { Ib }\end{array}$ & $\begin{array}{l}\text { Average Core } \\
\text { Topporature. } \\
\text { of }\end{array}$ & $\begin{array}{l}\text { Peak Coro } \\
\text { Teaperaturo, } \\
\text { of }\end{array}$ & $\begin{array}{c}\text { Fraction } \\
\text { Core } \\
\text { Helted }\end{array}$ & $\begin{array}{c}\text { Fraction } \\
\text { Clad } \\
\text { Reacted }\end{array}$ \\
\hline Coro uncovery & 7.0 & 2492 & $8.21 \times 10^{4}$ & 679 & 684 & ข. & 1.0 \\
\hline Star & 1110.4 & 2092 & $5.37 \times 104$ & 1994 & 4130 & 0.0 & 1. 16 \\
\hline Coro sluas & 131.4 & 1378 & 6.25x10 & 3621 & 4156 & e.45 & 1.29 \\
\hline Cor collapse & 132.6 & 1734 & $4.84 \times 104$ & 3386 & -- & 0.1 & 0.49 \\
\hline Bottom head dryout & 137. & 2341 & 1.898104 & 3203 & $\cdots$ & $-\infty$ & 0.60 \\
\hline Botlow head failure & 145.0 & 2012 & 0.0 & 3427 & $-\infty$ & $\infty$ & 0.50 \\
\hline
\end{tabular}

- Water retained in low points of priwary system piping. 


\section{SURRY S3B}

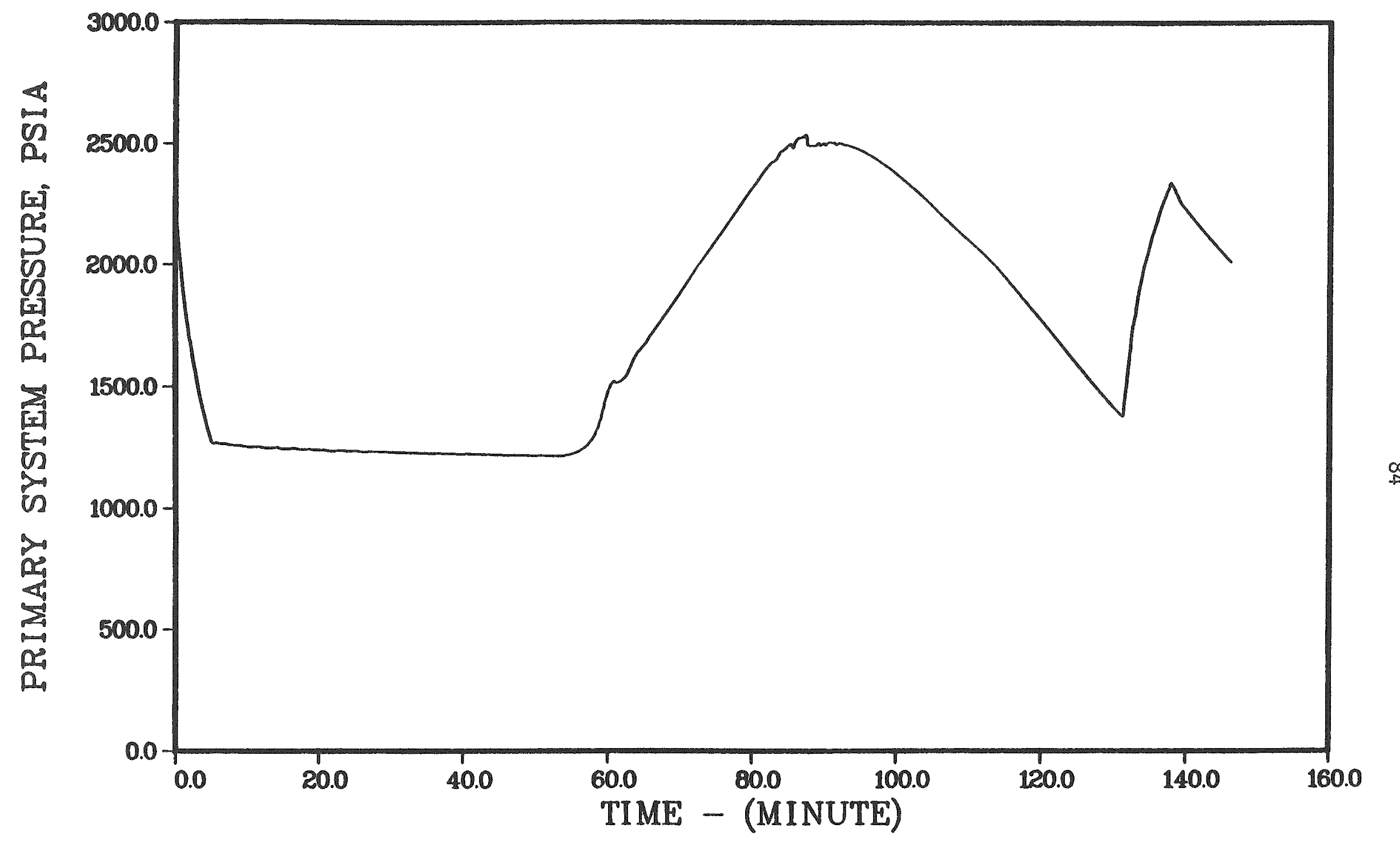

Figure 4.2.1. Primary system pressure response - Surry $S_{3} B$. 


\section{SURRY S3B}

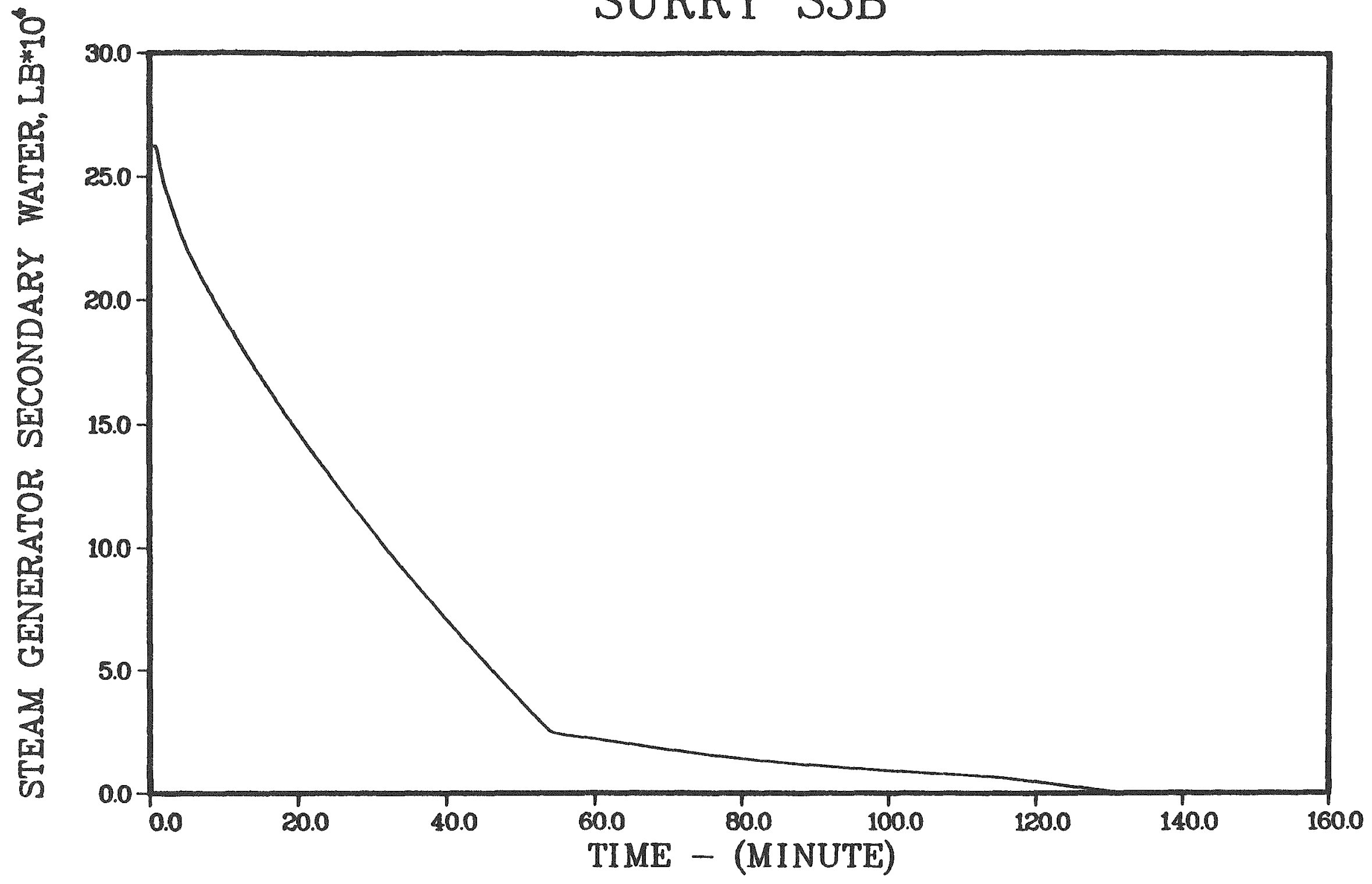

Figure 4.2.2. Steam generator secondary side water inventory - Surry $\mathrm{S}_{3} \mathrm{~B}$. 


\section{SURRY S3B}

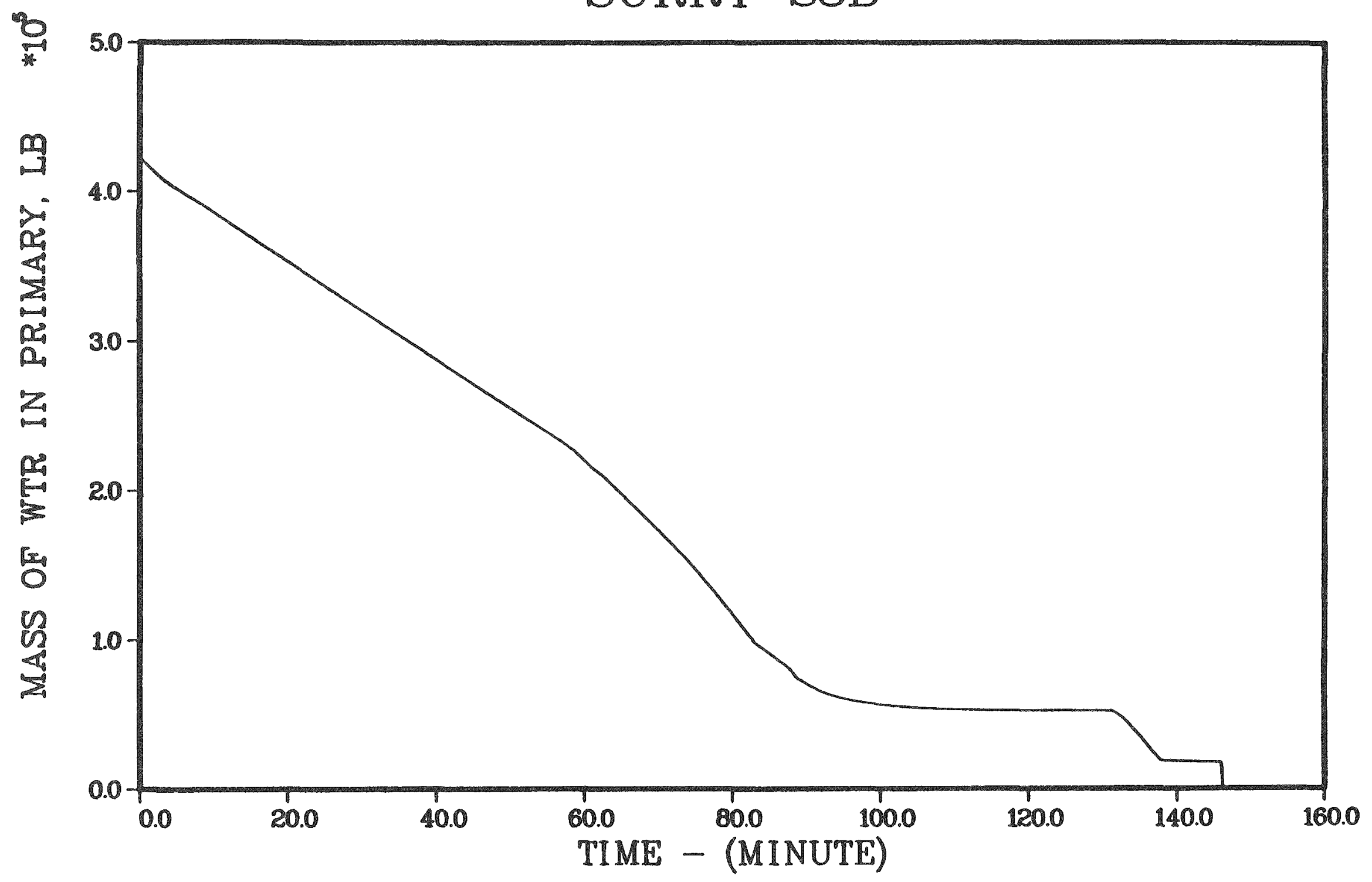

Figure 4.2.3. Primary system water inventory - Surry $S_{3} B$. 


\section{SURRY S3B}

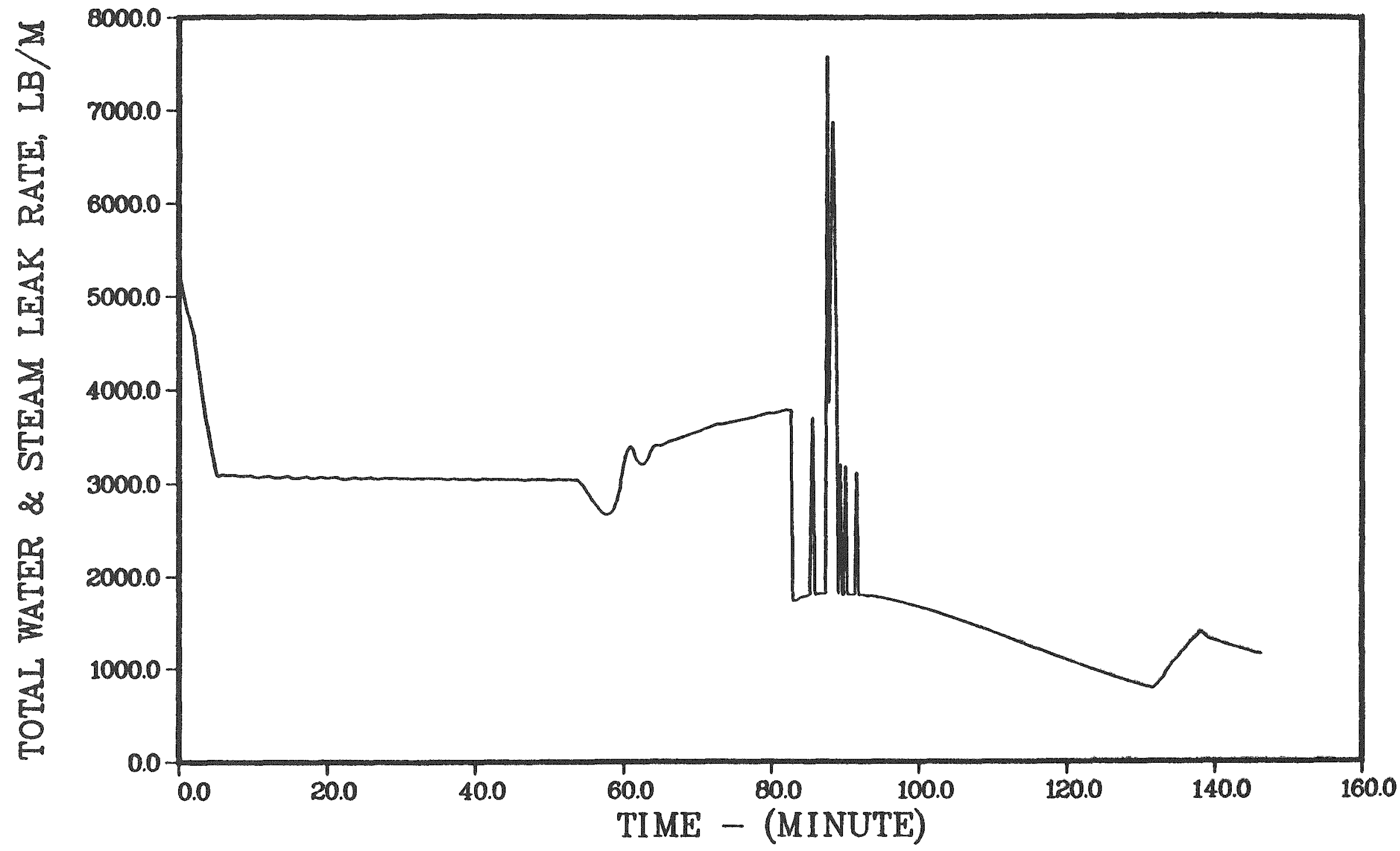

Figure 4.2.4. Primary system total water and steam leak rate - Surry $S_{3} B$. 


\section{SURRY S3B}

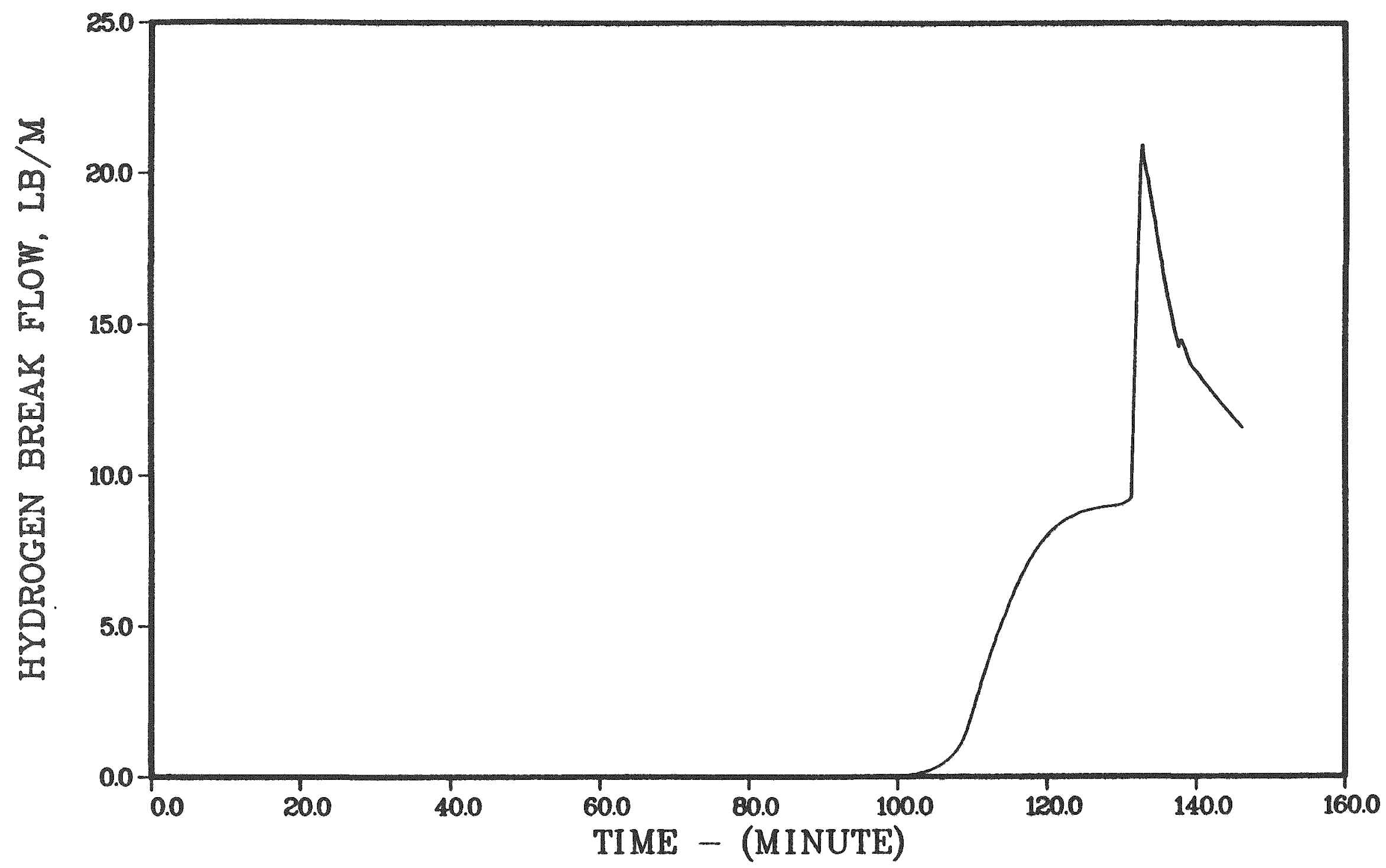

Figure 4.2.5. Primary system hydrogen leak rate - Surry $S_{3} B$. 


\section{SURRY S3B}

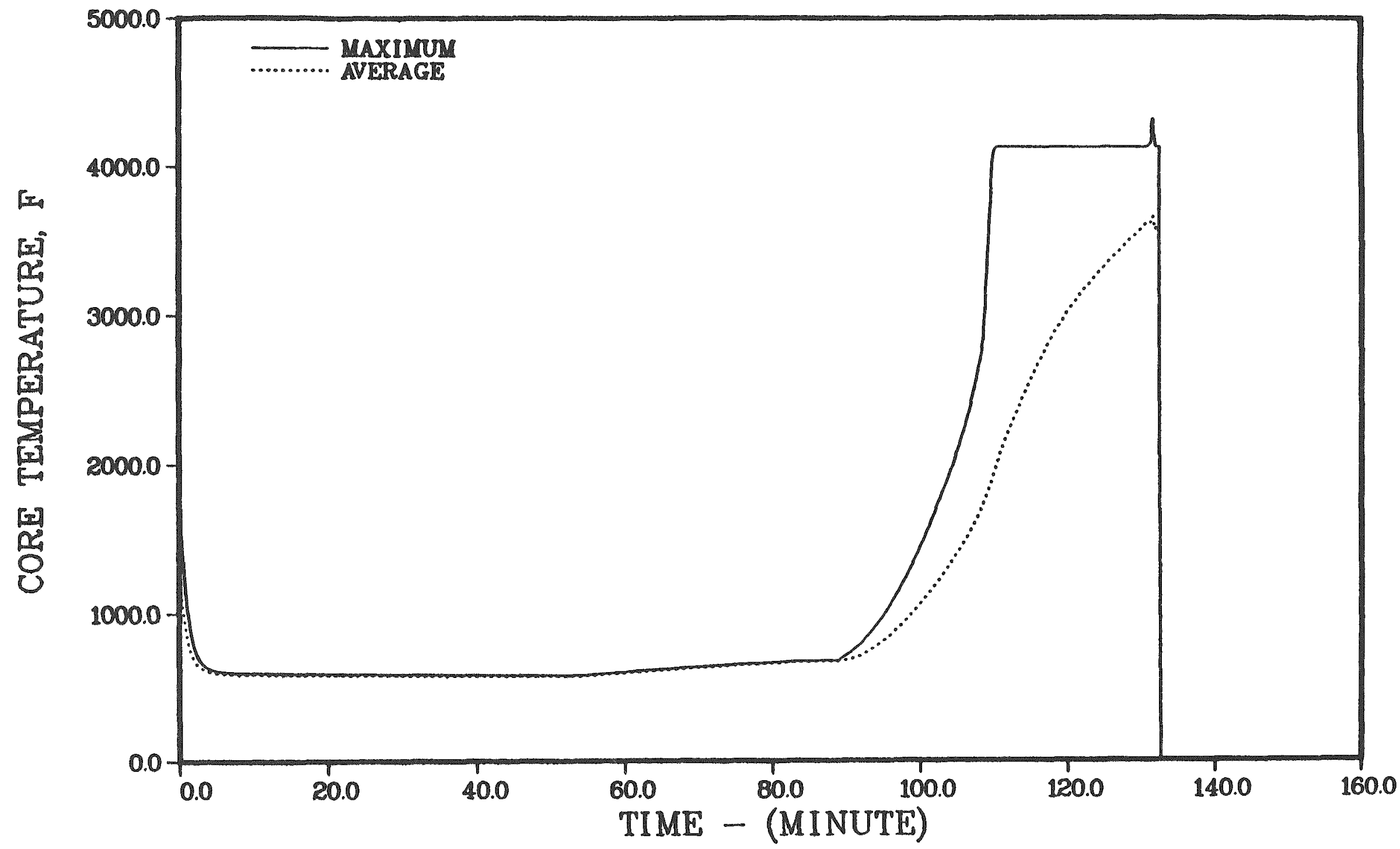

Figure 4.2.6. Maximum and average core temperatures - Surry $S_{3} B$. 


\section{SURRY S3B}

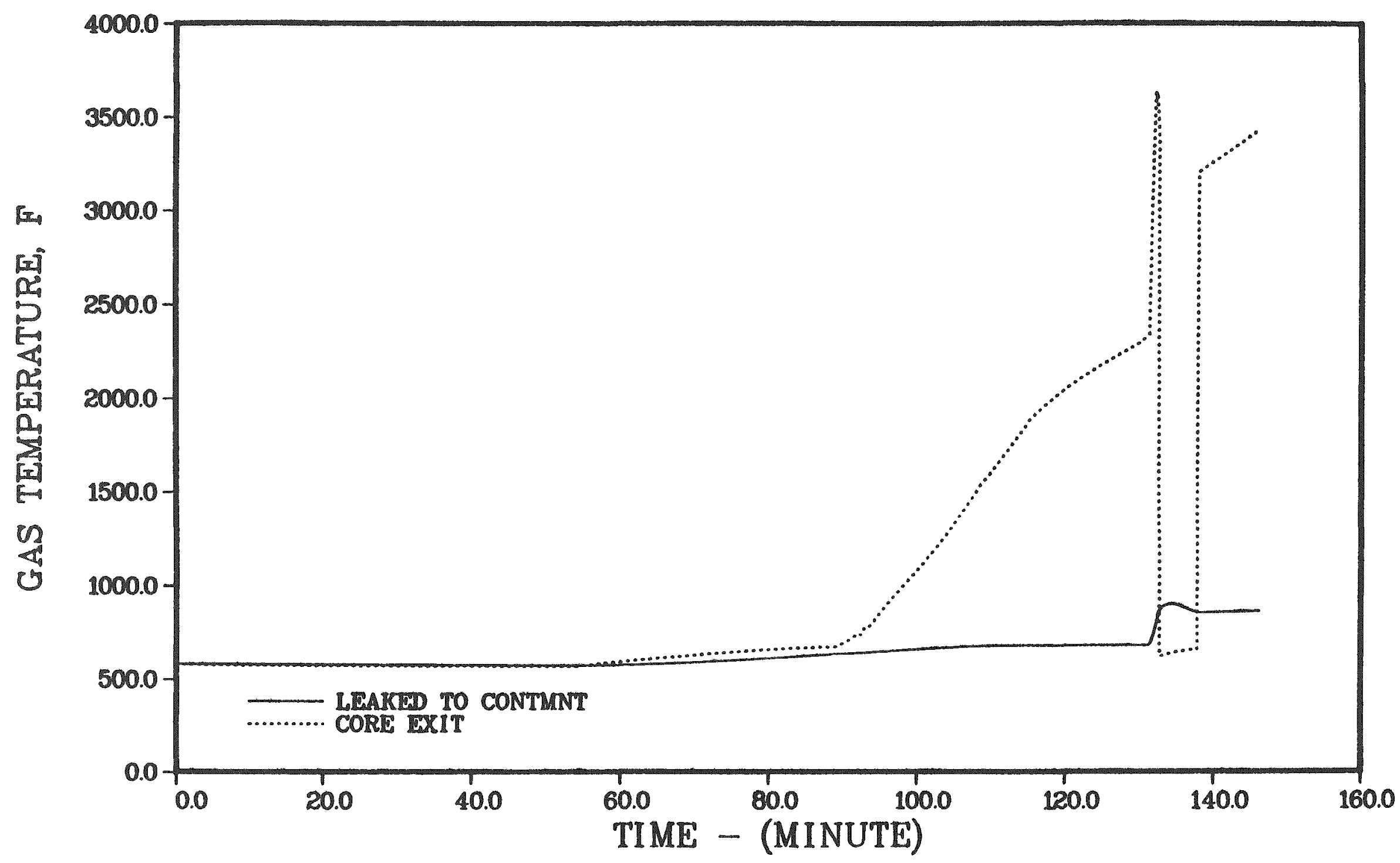

Figure 4.2.7. Temperatures of gases at core exit and leaving the primary system - Surry $S_{3} B$. 


\section{SURRY S3B}

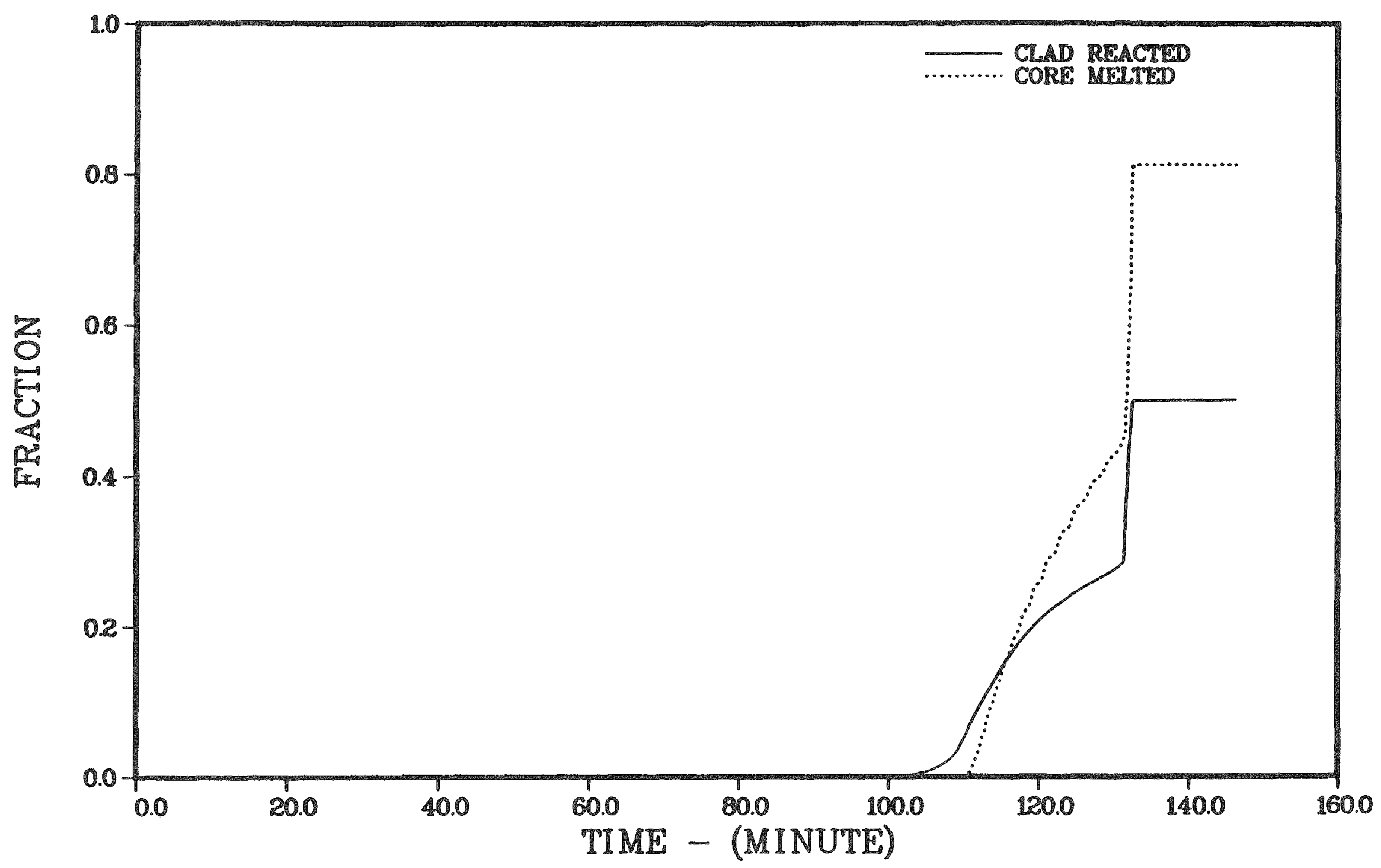

Figure 4.2.8. Fractions of cladding reacted and core melted - Surry $S_{3} B$. 


\section{CONTAINMENT RESPONSE - SUrry $S_{3} B$}

Table 4.2.3 summarizes the containment conditions at key times during the accident sequence and the leak rates from the containment are given in Table 4.2.4. The containment pressure and temperature responses are given in Figures 4.2 .9 and 4.2 .10 ; selected structure temperatures are illustrated in Figure 4.2.11. In this sequence, there is relatively modest containment pressurization up to the time of fuel slumping. As the fuel falls into and interacts with the water in the vessel head, steam generation increases and the containment pressure is raised to about 40 psia; shortly thereafter, the vessel is predicted to fail and the containment pressure rises to the failure level due to the simulated direct heating event. The high-temperature and high-pressure environment associated with direct heating was simulated in MARCH 3 by the combination of a large steam spike from the debris-water interaction and hydrogen combustion. The approach used here was identical to that previously utilized in the STCP analyses for the Zion plant (NUREG/CR-4624, Volume $\left.5^{(2)}\right)$. The predicted progression of concrete attack is shown in figure 4.2.12; the predicted rate of axial and radial concrete erosion are seen to be approximately equal. The total volume of gases leaked from the containment is shown in Figure 4.2.13. The initial large jump in leakage is associated with containment failure; the subsequent rise is due to the evaporation of the water in the reactor cavity. It is interesting to observe that for the basaltic concrete in Surry there is very little additional leakage after the boiloff of the water in the reactor cavity.

\section{PRIMARY SYSTEM RESPONSE - SURRY HINY -NXY}

This scenario is initiated by a double ended rupture of a single steam generator tube and is accompanied by the sticking open of a secondary side atmospheric steam dump valve. The affected steam generator is isolated from the auxiliary feedwater system and the condenser; the other two steam generators continue to receive auxiliary feedwater, but are not depressurized. The emergency core cooling system functions as designed and pumps water from the refueling water storage tank into the primary system; from there the water 
Table 4.2.3. Containment response - Surry $S_{3} B$.

\begin{tabular}{|c|c|c|c|c|c|c|c|c|}
\hline \multirow[b]{2}{*}{$\begin{array}{l}\text { Accident } \\
\text { event }\end{array}$} & \multirow[b]{2}{*}{$\begin{array}{c}\text { Tise. } \\
\text { inutes }\end{array}$} & \multicolumn{2}{|c|}{ Containment } & \multirow{2}{*}{$\begin{array}{l}\text { Containment } \\
\text { wall steam } \\
\text { Condensation. } \\
\text { lb/ }\end{array}$} & \multicolumn{2}{|c|}{ Sume water } & \multicolumn{2}{|c|}{ Reactor Cavily Water } \\
\hline & & $\begin{array}{l}\text { Prossure. } \\
\text { psia }\end{array}$ & $\begin{array}{c}\text { Terperature. } \\
\text { of }\end{array}$ & & ibs & $\begin{array}{l}\text { Teap. } \\
\text { of }\end{array}$ & Mass. & $\begin{array}{c}\text { Tewp. } \\
\text { of }\end{array}$ \\
\hline Care sluap & 131.4 & 23.3 & 205 & 777 & $2.94 \times 10$ & 170 & 1. 1 & $+\infty$ \\
\hline Core collapse & 132.6 & 23.4 & 205 & 767 & $2.95 \times 105$ & 170 & 0.0 & $\infty$ \\
\hline \multicolumn{9}{|l|}{ Botboin head } \\
\hline dryout & 197.0 & 24.2 & 207 & 805 & $2.99 \times 105$ & 178 & 0.0 & $-\infty$ \\
\hline \multicolumn{9}{|l|}{ Bottom ha: } \\
\hline \multicolumn{9}{|l|}{ 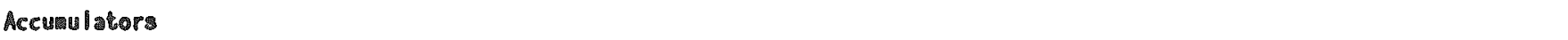 } \\
\hline \multicolumn{9}{|l|}{$\begin{array}{l}\text { Hydrogen burn/ } \\
\text { contai inent }\end{array}$} \\
\hline Pailure & 146.3 & 131.8 & 1290 & 0 & $3.07 \times 105$ & 100 & $6.85 \times 10^{4}$ & 306 \\
\hline \multicolumn{9}{|l|}{ Start concreto } \\
\hline attach & 242.2 & 14.7 & 203 & 92 & 3.13x175 & 180 & $7.79 \times 10^{4}$ & 212 \\
\hline End calculation & 042.2 & 14.8 & 183 & 53 & $3.24 \times 105$ & 176 & $1.92 \times 10^{2}$ & 214 \\
\hline
\end{tabular}


Table 4.2.4. Containment leak rates - Surry $S_{3} B$.

\begin{tabular}{|c|c|c|c|c|c|c|}
\hline \multirow{3}{*}{$\begin{array}{c}\text { Time } \\
\text { Interval, } \\
\text { minutes }\end{array}$} & \multirow{3}{*}{$\begin{array}{l}\text { Leak } \\
\text { Rato (o) } \\
\text { v/hr }\end{array}$} & \multicolumn{4}{|c|}{ Leakage } & \multirow{3}{*}{ ReMarirs } \\
\hline & & \multicolumn{2}{|c|}{ Pressure } & \multicolumn{2}{|c|}{ Temperature } & \\
\hline & & $\mathrm{MPa}$ & psia & oc & of & \\
\hline $0.0-83.8$ & 0.0 & 0.10 & 15 & 68 & 152 & Inital core heatup/dryout of stean generator \\
\hline $83.8-87.6$ & 0.0 & 0.13 & 19 & 84 & 284 & Core heatup \\
\hline $87.8-110.4$ & 0.0 & 0.16 & 22 & 90 & 194 & Core uncovery \\
\hline $110.4-131.4$ & 0.0 & 0.10 & 23 & 95 & 203 & Core melts \\
\hline $131.4-132.6$ & 0.0 & 0.16 & 23 & 98 & 205 & Core sluaps and collapses \\
\hline $132.6-137.8$ & 0.0 & 0.17 & 24 & 97 & 200 & Dryout of vessel head \\
\hline $137.8-145.2$ & 0.0 & 0.17 & 25 & 92 & 210 & Vessi I head hatup \\
\hline 145.9 & $\cdots$ & 0.17 & 25 & 100 & 212 & Vesse I head failure \\
\hline $145.8-146.3$ & 0.0 & 0.73 & 106 & 493 & $\$ 18$ & Accunu lators anpty/hydrogen burns \\
\hline 146.3 & $\cdots$ & 0.91 & 132 & 699 & 1290 & Containaent failure \\
\hline $146.3-146.4$ & 11.1 & 0.85 & 123 & 848 & 1198 & Dryout of pouctor cavity \\
\hline $146.4-147.4$ & 9.2 & 0.54 & 70 & 347 & 857 & Dryout of reactor cavity \\
\hline $197.4-852.5$ & 7.7 & 0.27 & 39 & 157 & 315 & Dryout of reactor cavity \\
\hline $152.5-102.2$ & 1.2 & 0.10 & 15 & 117 & 243 & Dryout of reactor cavity \\
\hline $182.2-242.2$ & 0.8 & 0.10 & 18 & 99 & 211 & Dryout of reactor cavity \\
\hline $242.2-542.2$ & 0.2 & 0.10 & 15 & 96 & 204 & Concrete decomposition \\
\hline $542.2-842.2$ & 0.0 & 0.10 & 16 & 86 & 187 & Concrete decomposition \\
\hline
\end{tabular}

(a) Normalized to a containment-free voluwe of $1.8 \times 10^{6} \mathrm{ft}^{3}$. Units are volued fractions per hours. Leakage is to the environament. 


\section{SURRY S3B}

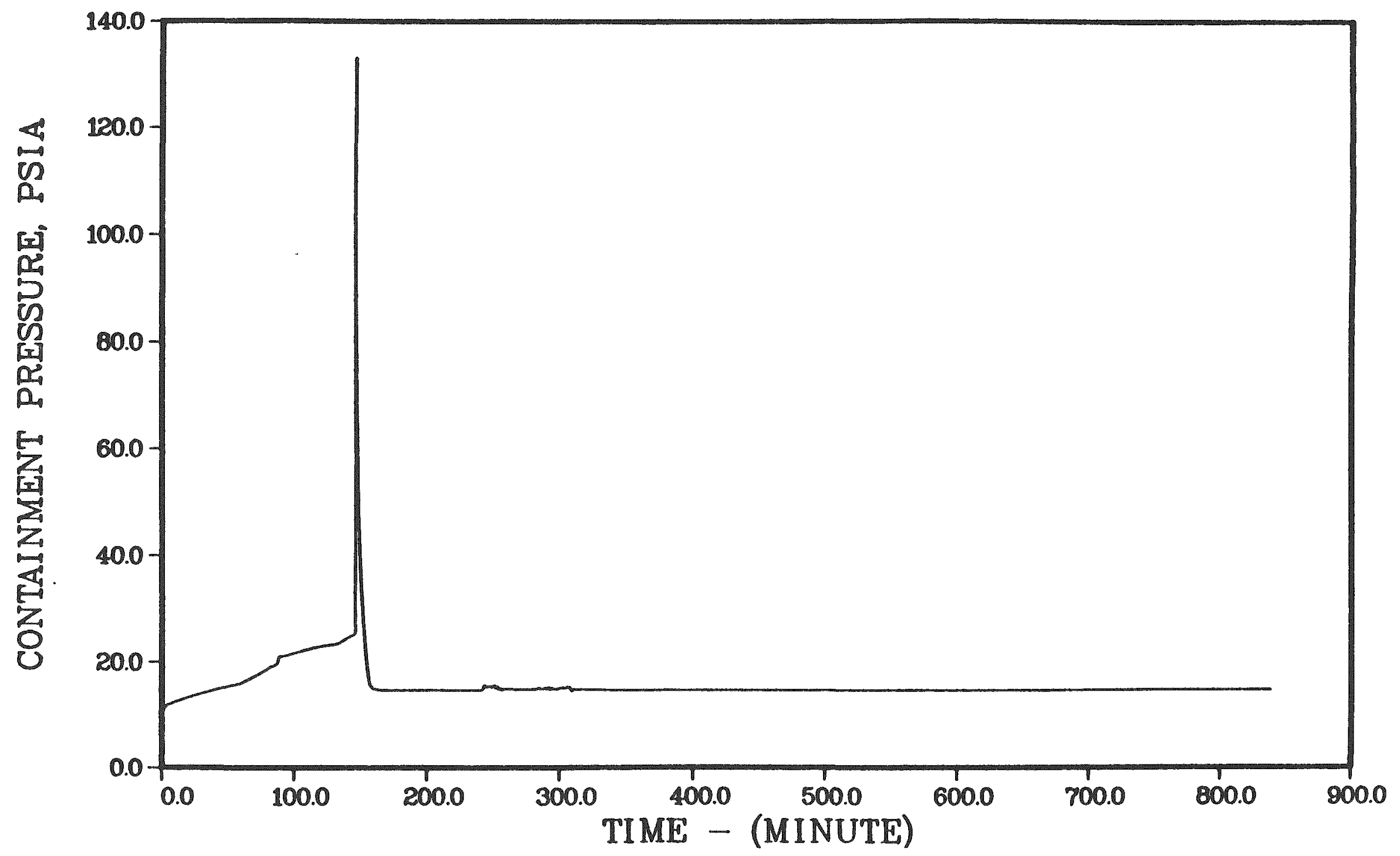

Figure 4.2.9. Containment pressure response - Surry $S_{3} B$. 


\section{SURRY S3B}

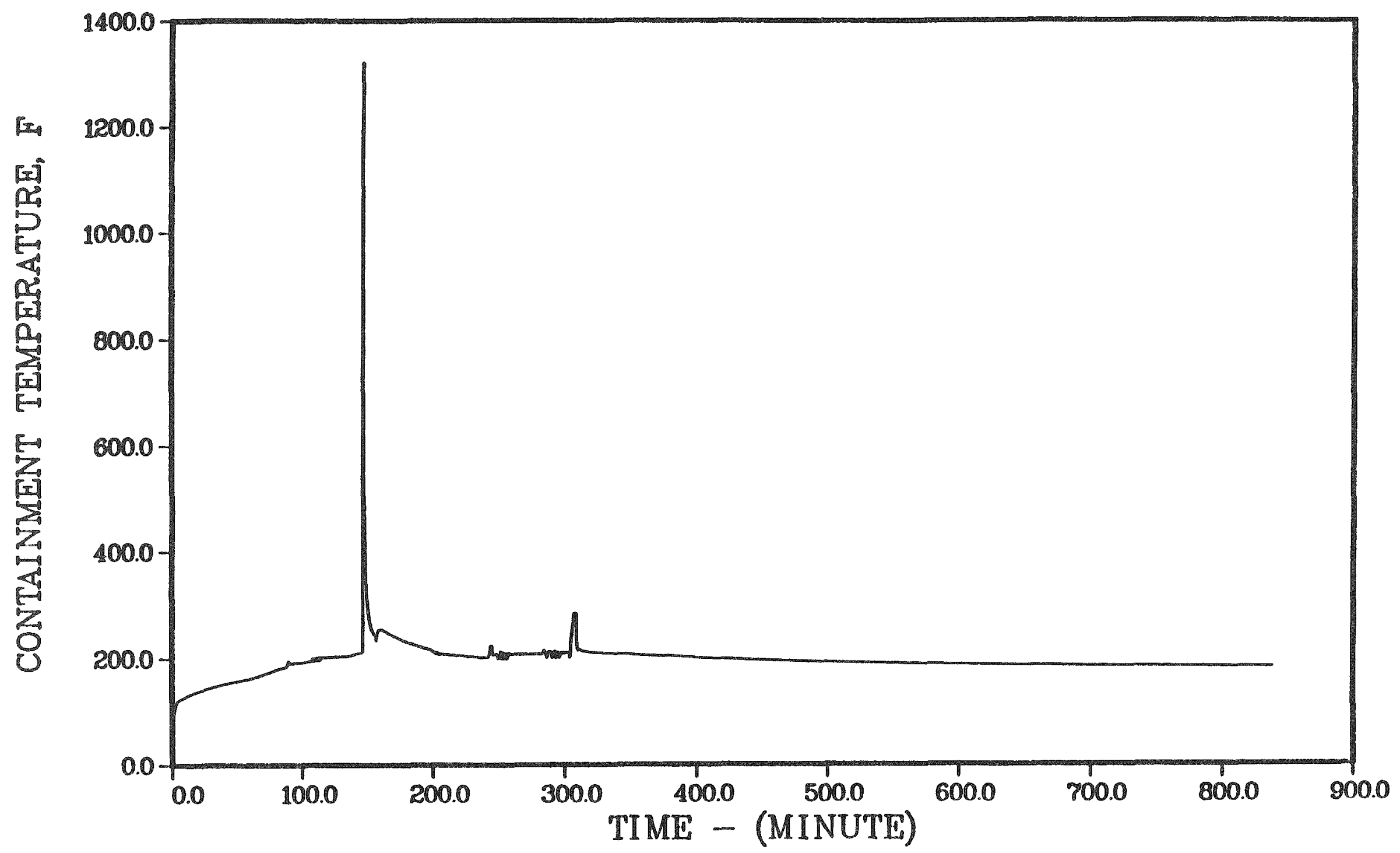

Figure 4.2.10. Containment temperature response - Surry $S_{3} B$. 


\section{SURRY S3B}

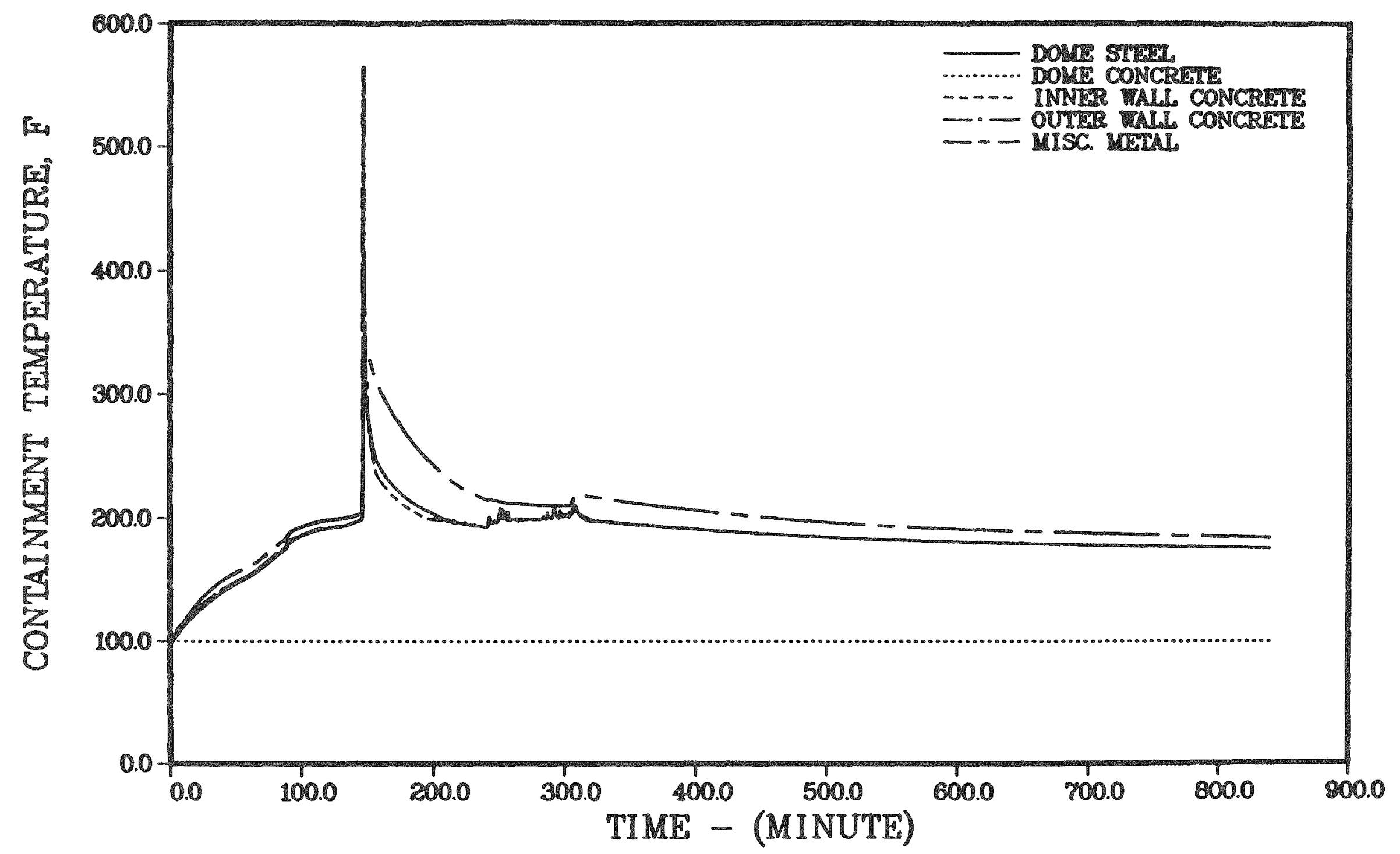

Figure 4.2.11. Selected containment structure temperatures - Surry $S_{3} B$. 


\section{SURRY S3B}

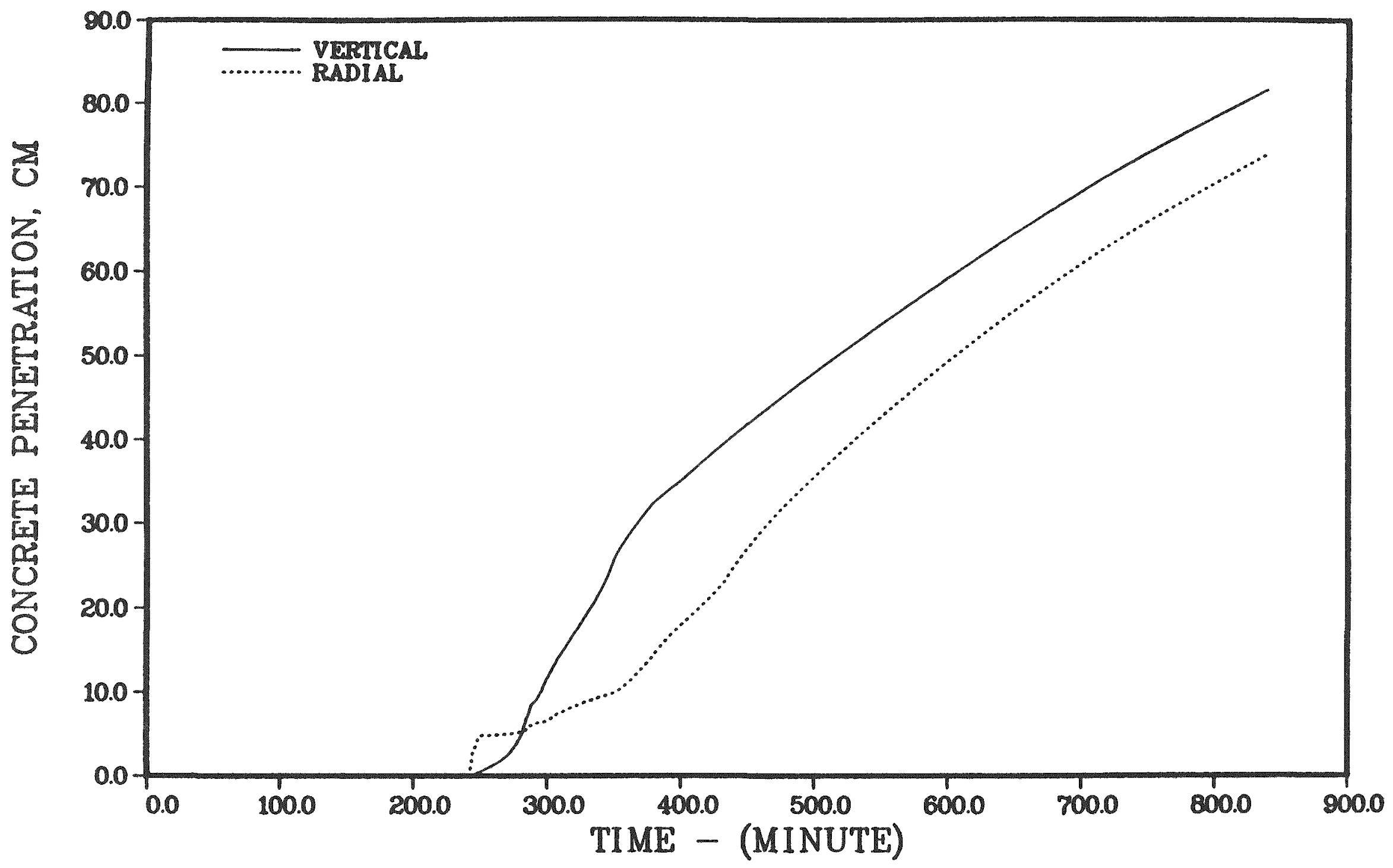

Figure 4.2.12. Progression of concrete attack - Surry $S_{3} B$. 


\section{SURRY S3B}

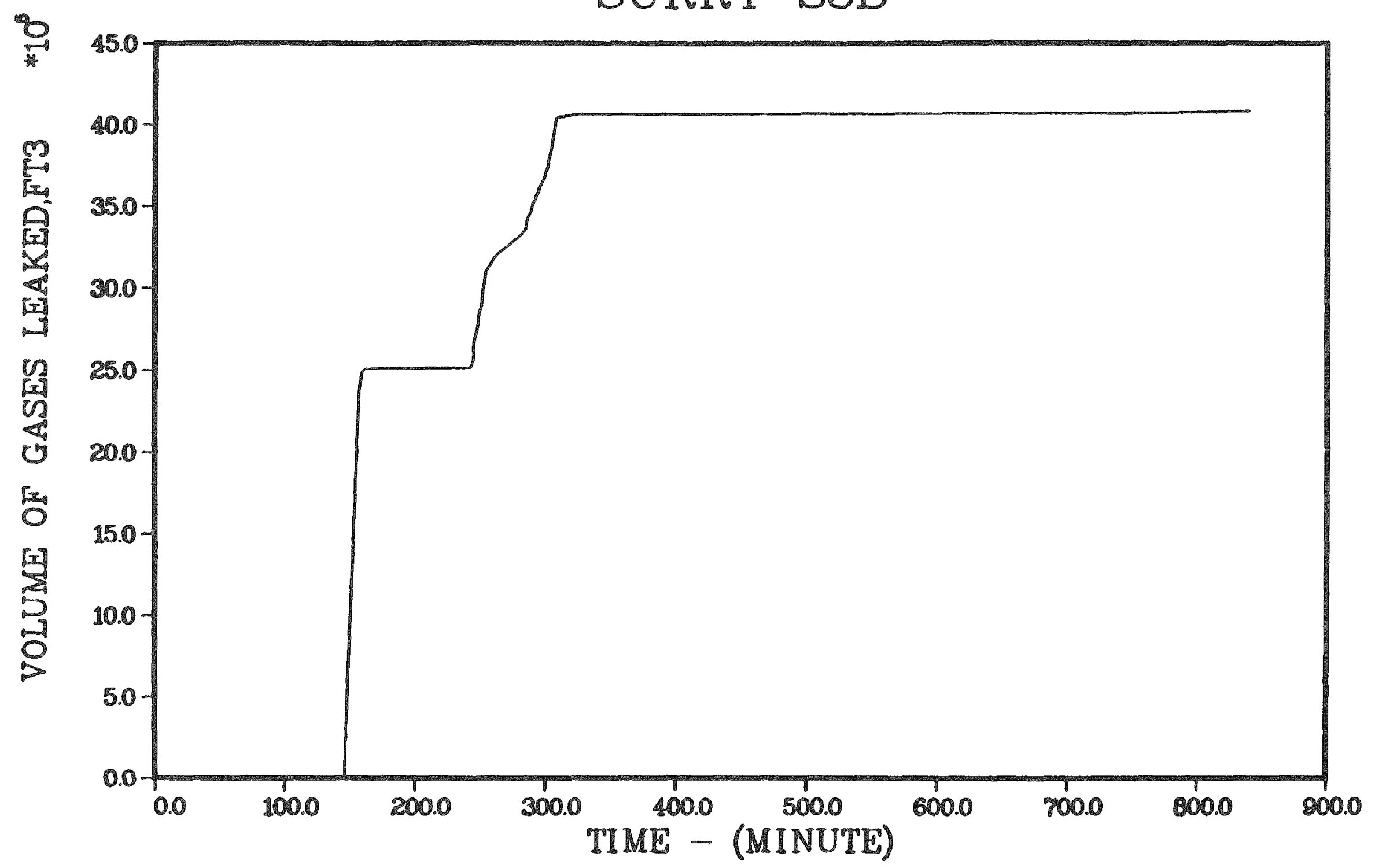

Figure 4.2 .13 . Total volume of gases leaked from containment - Surry $S_{3} B$. 
is lost through the ruptured steam generator tube and the stuck open relief valve. When the refueling water storage tank is emptied, the emergency core cooling system switches to the recirculation mode and fails because the containment sump is dry. It was assumed that the reactor operators would keep the primary coolant pumps operating as long as possible; in the analysis they were turned off at 12 hours into the accident when the liquid level had dropped substantially.

The timing for the HINY-NXY scenario is given in Table 4.2.5. Table 4.2.6 presents information on primary system pressure and flows at selected times during the core heatup and meiting phases of the accident. The distributions of the noble gases are also given. The primary system pressure decreases initially due to the injection of cold emergency core cooling water. Because of the limited leak area and the operating steam generators remaining at pressure, the primary system does not depressurize completely. The flows correspond to primary system residence times of 10-20 minutes (based on the entire primary system volume). The MARCH3 model did not explicitly model the secondary side of the failed steam generator, since it would be at a pressure different from that of the primary system. While the effective flow area of the stuck open steam dump valve would be substantially greater than that of the broken steam generator tube, it is estimated that the secondary side of the failed steam generator would not depressurize completely, but level off at about 120 psia for the given primary system leakages. Under these conditions the secondary side residence time would be of the order of 1 minute.

\section{PRIMARY SYSTEM RESPONSE - SURRY GLYY - YXY}

In this scenario the initiating event is again the double ended rupture of a single steam generator tube, but the secondary side atmospheric dump valves reclose as required. The affected steam generator is isolated from the auxiliary feedwater system and the condenser; the other two steam generators continue to function, but remain at pressure. The high pressure emergency core cooling injection is failed in this case. 
Table 4.2.5. Timing of key events - Surry HINY-NXY

\begin{tabular}{lr}
\hline Event & $\begin{array}{c}\text { Time, } \\
\text { Minutes }\end{array}$ \\
& \\
Reactor coolant pumps off & 594.0 \\
Core uncovery & 796.3 \\
Start melt & 850.5 \\
Core slump & 874.3 \\
Bottom head dryout & 876.5 \\
Bottom head failure & 933.7 \\
Start concrete attack & 1091.5 \\
End calculation & 1691.5 \\
& \\
\hline
\end{tabular}


Table 4.2.6. Primary systeri response - Surry HINY-NXY

\begin{tabular}{|c|c|c|c|c|c|c|c|}
\hline $\begin{array}{l}\text { TIME, } \\
\text { MIN }\end{array}$ & $\begin{array}{l}\text { PRES, } \\
\text { PSIA }\end{array}$ & $\begin{array}{l}\text { WSBRK, } \\
\text { LB/MIN }\end{array}$ & $\begin{array}{l}\text { WHBRK, } \\
\text { LB/MIN }\end{array}$ & $\begin{array}{c}T G L K_{B} \\
{ }_{F}\end{array}$ & XECOR & XEVSL & XEA \\
\hline 796.3 & $\begin{array}{l}\text { Core } \\
\text { uncovery }\end{array}$ & & & & & & \\
\hline 801.3 & 1139 & 957 & $-\infty$ & 581 & 1.6 & $-\infty$ & $-m-$ \\
\hline 853.5 & Start aelt & & & & & & \\
\hline 851.3 & 798 & 572 & 3.8 & 798 & .958 & .038 & .006 \\
\hline 861.3 & 872 & 468 & 14.2 & 850 & .538 & .345 & .117 \\
\hline 971.3 & 551 & 265 & 24.5 & 926 & .181 & .428 & .393 \\
\hline 874.3 & Start slump & & & & & & \\
\hline 874.5 & 518 & 225 & 27.4 & 969 & .113 & .392 & .495 \\
\hline 875.5 & 693 & 245 & 35.5 & 1216 & .097 & .375 & .529 \\
\hline 278.3 & $\begin{array}{l}\text { Core } \\
\text { collapse }\end{array}$ & & & & & & \\
\hline 876.3 & 934 & 274 & 42.9 & 1493 & .05 & .366 &.$\$ 55$ \\
\hline 881.5 & 1568 & 925 & 17.6 & 1063 & .078 & .271 & .651 \\
\hline 898.1 & 1287 & 932 & 9.3 & 839 & .77 & .142 & .781 \\
\hline 097.1 & $\begin{array}{l}\text { Vessel head } \\
\text { dryout }\end{array}$ & & & & & & \\
\hline 915.6 & 799 & 492 & 4.0 & 852 & .077 & .059 & .864 \\
\hline 933.7 & 655 & 428 & 1.6 & 899 & .974 & .26 & .960 \\
\hline 933.7 & Head failure & & & & & & \\
\hline
\end{tabular}

PRES - prisary system pressure, psia

WSERR - steam flow through break, lb/ain

WHBRK - hydrogen flow through break, Ib/ain

TCLK - temperature of gases leaking from vessel. of

XECOR - initial inventory of noble gases still in the fuel

XEVSL - fraction of noble gases in vessel gas space

XEA - fraction of noble gases leaked from the vessel 
Table 4.2.7 provides the timing of key events for this scenario. Table 4.2.8 gives primary system pressure and leak flows at selected times during this sequence. Primary system fission product residence times for this case would be roughly comparable to those of the preceding case. Fission product residence times in the secondary side of the steam generators (at about 10 minutes) would, however, be considerably longer than in the first case; this is a direct consequence of the steam dump valves closing to maintain the secondary side pressure at about 1100 psia.

\section{PRIMARY SYSTEM RESPONSE - SURRY HINY-YXY}

This accident is initiated by a double ended rupture of a single steam generator tube, with the secondary side atmospheric steam dump valve and the PORV sticking open. The PORV sticks open as a consequence of the operator's attempts to depressurize the primary system and is assumed to take place early, at 15 minutes into the accident. The affected steam generator is isolated from the auxiliary feedwater system and the condenser, with the other two steam generators continuing to operate, but remaining at pressure. Emergency core cooling injection functions and empties the refueling water storage tank into the primary system, from where it leaks to the containment as well as to the outside.

Table 4.2 .9 provides the times for key events. Table 4.2 .10 gives the primary system pressure and leak flows from the primary system at selected times during core heatup and melting, as well as the distributions of the noble gases. For these primary system leakages, fission product residence times of the order of five minutes or less are estimated. Fission product residence times in the steam generator secondary are estimated to be on the order of a minute.

\section{PRIMARY SYSTEM RESPONSE - SURRY TB (with secondary depressurization)}

The calculated progression of accident events is summarized in Table 4.2.11. Core and primary system conditions at key times during the accident are summarized in Table 4.2.12. The initial availability of auxiliary 
Table 4.2.7. Timing of key events - Surry GLYY-YXY

\begin{tabular}{ll}
\hline \hline Event & $\begin{array}{c}\text { Time, } \\
\text { Minutes }\end{array}$ \\
\hline & \\
Core uncovery & 127.5 \\
Start melt & 170.0 \\
Core slump & 193.5 \\
Bottom head dryout & 195.6 \\
Bottom head failure & 236.4 \\
Start concrete attack & 354.8 \\
End calculation & 954.8 \\
& \\
\hline
\end{tabular}


Table 4.2.8. Primary system response - Surry GLY-YXY

\begin{tabular}{|c|c|c|c|c|c|c|c|}
\hline $\begin{array}{l}\text { TIME, } \\
\text { MIN }\end{array}$ & $\begin{array}{l}\text { PRES, } \\
\text { PSIA }\end{array}$ & $\begin{array}{l}\text { WSBRK } \\
\text { LB/MIN }\end{array}$ & $\begin{array}{l}\text { WHBRI, } \\
\text { LB/MIM }\end{array}$ & $\begin{array}{c}T G_{0} L K \\
{ }_{F}\end{array}$ & XECOR & XEVSL & XEA \\
\hline 126.4 & 1179 & 992 & -.. & 566 & 1.0 & $-\infty$ & $-\infty$ \\
\hline 127.4 & $\begin{array}{l}\text { Core } \\
\text { uncovery }\end{array}$ & & & & & & \\
\hline 166.4 & 1115 & 577 & .6 & 745 & .988 & .011 & .01 \\
\hline 169.9 & Start nelt & & & & & & \\
\hline 176.4 & 1115 & 398 & 4.3 & 793 & .670 & .303 & .026 \\
\hline 188.4 & 1115 & 165 & 4.2 & 897 & .268 & .631 & .163 \\
\hline 191.4 & 1115 & 657 & 27.6 & 842 & .145 & .668 & .188 \\
\hline 193.4 & Start s luap & & & & & & \\
\hline 195.4 & 1687 & 891 & 45.7 & $12: 4$ & .33 & .669 & .352 \\
\hline 195.6 & $\begin{array}{l}\text { Core } \\
\text { collaps. }\end{array}$ & & & & & & \\
\hline 197.5 & 1829 & 97 & 30.9 & 1125 & . & .546 & .418 \\
\hline 207.3 & 1698 & 1228 & 18. & 878 & .53 & .334 & .632 \\
\hline 217.6 & 1432 & 1663 & 10.6 & 805 & .033 & .215 & .752 \\
\hline 223.6 & $\begin{array}{l}\text { Vessel head } \\
\text { dryout }\end{array}$ & & & & & & \\
\hline 228.5 & 1115 & 336 & 3.1 & 796 & .833 & .147 & .82 \\
\hline 236.4 & 1115 & $-\infty$ & $-\infty$ & 795 & .933 & .146 & .821 \\
\hline 237.4 & Head failure & & & & & & \\
\hline
\end{tabular}

PRES - priary system pressure, psia

WSBRK - stear flow through break, Ib/ain

WHBRK - hydrogen flow through break, $\mathrm{lb} / \mathrm{min}$

TCLK - temperature of gases leaking from vessel, ${ }^{\circ} \mathrm{F}$

XECOR - initial inventory of noble gases still in the fuel

XEVSL - fraction of noble gases in vessel gas space

XEA $\quad$ - fraction of noble gases leaked from the vessel 
Table 4.2.9. Timing of key events - Surry HINY-YXY

\begin{tabular}{lr}
\hline Event & $\begin{array}{c}\text { Time, } \\
\text { Minutes }\end{array}$ \\
& \\
ECC recirculation on & 268.5 \\
ECC off & 580.7 \\
Core uncovery & 692.0 \\
Start melt & 741.8 \\
Core slump & 761.2 \\
Head dryout & 763.6 \\
Head failure & 820.9 \\
Start concrete attack & 978.8 \\
End calculation & 1578.8 \\
& \\
\hline \hline
\end{tabular}


Table 4.2.10 Primary system rasponse - Surry HINY-YXY

\begin{tabular}{|c|c|c|c|c|c|c|c|c|c|c|}
\hline $\begin{array}{l}\text { TIME, } \\
\text { MIM }\end{array}$ & $\begin{array}{l}\text { PRES. } \\
\text { PSIA }\end{array}$ & $\begin{array}{c}\text { WSBRK } \\
\text { LB }\end{array}$ & $\begin{array}{l}\text { WHBRK } \\
\text { MIN }\end{array}$ & $\begin{array}{c}\text { WSRY } \\
\text { LB }\end{array}$ & $\begin{array}{l}\text { WHRV } \\
\text { MTN }\end{array}$ & $\begin{array}{l}\text { ren } \\
\text { of }\end{array}$ & XECOR & XEVSL & XESG & XECON \\
\hline 691.6 & 597 & 568 & $-m-$ & 766 & $-\infty$ & 486 & 1.0 & -- & $-\infty$ & $-\infty$ \\
\hline 692.0 & \multicolumn{10}{|c|}{ Core uncovery } \\
\hline 731. & 341 & 257 & .2 & 387 & .3 & 782 & 1.6 & $-\infty$ & -- & $-\infty$ \\
\hline 741. & 254 & 171 & 2.2 & 258 & 3.4 & 929 & .982 &. & .094 & .005 \\
\hline 741.8 & \multicolumn{10}{|c|}{ Start it } \\
\hline 751.0 & 170 & 64 & 13.2 & 96 & 19. & 1876 & .553 & .185 & .105 & .158 \\
\hline 761.2 & \multicolumn{10}{|c|}{ Start slump } \\
\hline 781.2 & 1118 & 5.4 & 18.2 & 7.6 & 26.9 & 1429 & .134 & .066 & .322 & .477 \\
\hline 763.4 & 257 & 32 & 26.7 & 46 & 40.3 & 2121 & .698 & .043 & .347 & .513 \\
\hline 763.6 & \multicolumn{10}{|c|}{ Core collapse } \\
\hline 764.4 & 353 & 137 & 10.2 & 297 & 15.4 & 1539 & .092 & .935 & .352 & .521 \\
\hline 773.8 & 1234 & 876 & 1.4 & 1320 & 2.1 & 714 & .067 & .012 & .363 & .537 \\
\hline 776.4 & \multicolumn{10}{|c|}{ Vessel head dryout } \\
\hline 778.0 & 954 & 801 & 1.1 & 1277 & 1.6 & 711 & .887 & .98 & .385 & .540 \\
\hline 798.8 & 240 & 170 & .1 & 255 & .2 & 1033 & .086 &. & .368 & .545 \\
\hline 819.0 & 73 & 46 & $-\infty$ & 57 & $-\infty$ & 1246 & .78 & .094 & .371 & .549 \\
\hline 220.9 & \multicolumn{10}{|c|}{ Head failure } \\
\hline $\begin{array}{l}\text { PRES } \\
\text { WSBRK } \\
\text { WHERK } \\
\text { TCLK } \\
\text { XECOR } \\
\text { XEVSL } \\
\text { XEA }\end{array}$ & \multicolumn{10}{|c|}{$\begin{array}{l}\text { - primary system pressure, psia } \\
\text { - steam flow through break, Ib/min } \\
\text { - hydrogen flow through break, Ib/win } \\
\text { - teaperature of gases leaking frow vessel, of } \\
\text { - initial inventory of noble gases still in the fuel } \\
\text { - fraction of noble gases in vessel gas space } \\
\text { - fraction of noble gases leaked from the vessel }\end{array}$} \\
\hline
\end{tabular}


Table 4.2.11. Timing of key events - Surry TB (with secondary depressurization)

\begin{tabular}{lr}
\hline \hline Event & $\begin{array}{c}\text { Time, } \\
\text { Minutes }\end{array}$ \\
& \\
& \\
Start steam generator depressurization & 90.0 \\
End steam generator depressurization & 150.0 \\
Partial accumulator discharge & $250-340$ \\
AFW off & 300.0 \\
Steam generator dryout & 459.6 \\
Core uncovery & 667.9 \\
Start melt & 707.9 \\
Core slump & 745.1 \\
Bottom head dryout & 750.8 \\
Bottom head failure & 757.8 \\
Accumulators empty & 758.8 \\
Start concrete attack & 758.9 \\
Corium layers invert & 841.9 \\
End calculation & 1358.9 \\
& \\
\hline
\end{tabular}


Table 4.2.12. Core and primary system response - Surry TB.

\begin{tabular}{|c|c|c|c|c|c|c|c|}
\hline $\begin{array}{l}\text { Accident } \\
\text { Event }\end{array}$ & $\begin{array}{l}\text { Time, } \\
\text { minutes }\end{array}$ & $\begin{array}{l}\text { Primary } \\
\text { Systeen } \\
\text { Pressure, } \\
\quad \text { psia }\end{array}$ & $\begin{array}{l}\text { Primary } \\
\text { Syster } \\
\text { vater } \\
\text { Inventory. } \\
\text { Ib }\end{array}$ & $\begin{array}{c}\text { Average Core } \\
\text { Temperature, } \\
\text { of }\end{array}$ & $\begin{array}{l}\text { Peak Core } \\
\text { Temperature, } \\
\text { of }\end{array}$ & $\begin{array}{l}\text { Fraction } \\
\text { Core } \\
\text { Melted }\end{array}$ & $\begin{array}{l}\text { Fraction } \\
\text { Clad } \\
\text { Reacted }\end{array}$ \\
\hline AFW off & 300.0 & 536 & $4.30 \times 10^{5}$ & 420 & 424 & -- & $-m$ \\
\hline \multicolumn{8}{|l|}{ Accumulators } \\
\hline discharge & 341.9 & 522 & $4.92 \times 10^{5}$ & 395 & 399 & $\ldots$ & -. \\
\hline \multicolumn{8}{|l|}{ Steam generators } \\
\hline dry & 459.6 & 507 & $4.92 \times 10^{5}$ & 388 & 392 & -- & -- \\
\hline Core uncovery & 667.9 & 2517 & $8.37 \times 10^{4}$ & 674 & 677 & 0.0 & 0.0 \\
\hline Start melt & 707.9 & 2514 & $5.28 \times 10^{4}$ & 2254 & 4130 & 0.0 & 0.09 \\
\hline Core slump & 745.1 & 1376 & $5.03 \times 104$ & 3491 & 4377 & 0.39 & 0.27 \\
\hline Core collapse & 746.7 & 1734 & $4.00 \times 10^{4}$ & 3429 & $-\cdots$ & 0.80 & 0.56 \\
\hline Bottom head dryout & 750.8 & 2519 & $1.88 \times 10^{4}$ & 3240 & $\ldots$ & -.- & 0.59 \\
\hline Bottom head failure & 757.8 & 2518 & $1.83 \times 10^{4 *}$ & 3380 &.-- & --- & 0.59 \\
\hline
\end{tabular}

* Water retained in low points of primary system piping. 
feedwater together with the depressurization of the steam generators provide an effective heat sink to the primary system and lead to substantial depressurization of the latter, as is illustrated in Figure 4.2.14. The depressurization of the steam generators allows the primary system to be cooled below the accumulator pressure. However, since the primary system is essentially ful1, only partial accumulator discharge can take place. After the loss of the auxiliary feedwater system at 5 hours into the accident, the steam generators dry out (at abut 460 minutes) and the primary system repressurizes to the safety valve setting. Primary coolant discharge rates through the safety valves are illustrated in Figure 4.2.15. Thus, the eventual core overheating takes place with the primary system at high pressure. Maximum and average core temperatures for this sequence are illustrated in Figure 4.2.16; fractions cladding reacted and core melted are shown in Figure 4.2.17. The temperatures of the gases leaving the top of the core and exiting the primary system are shown in Figure 4.2.18. The initial availability of auxiliary feedwater together with steam generator depressurization have substantially delayed the time of the onset of core damage.

\section{CONTAIMMENT RESPONSE - SURRY TB (with secondary depressurization)}

The conditions in the containment at key times during the accident progression are summarized in Table 4.2.13. Containment pressure and temperature histories are illustrated in Figures 4.2 .19 and 4.2.20. Immediately after the predicted time of reactor vessel failure, the containment contains $902 \mathrm{lb}$ of hydrogen, with corresponding mole fractions of 0.031 hydrogen, 0.059 oxygen, and 0.675 steam. With the uncoolable debris attacking concrete, it takes approximately 3 hours to evaporate the accumulator water from the cavity. At the end of the calculation, after 10 hours of concrete attack, the containment contains $2310 \mathrm{lb}$ of hydrogen, with corresponding mole fractions of 0.133 hydrogen, 0.072 oxygen, and 0.505 steam. Hydrogen buildup in the containment is illustrated in Figure 4.2 .21 and the mole fractions of the major constituents of the containment atmosphere are shown in Figure 4.2.22. 


\section{S'URRY 'I'B}

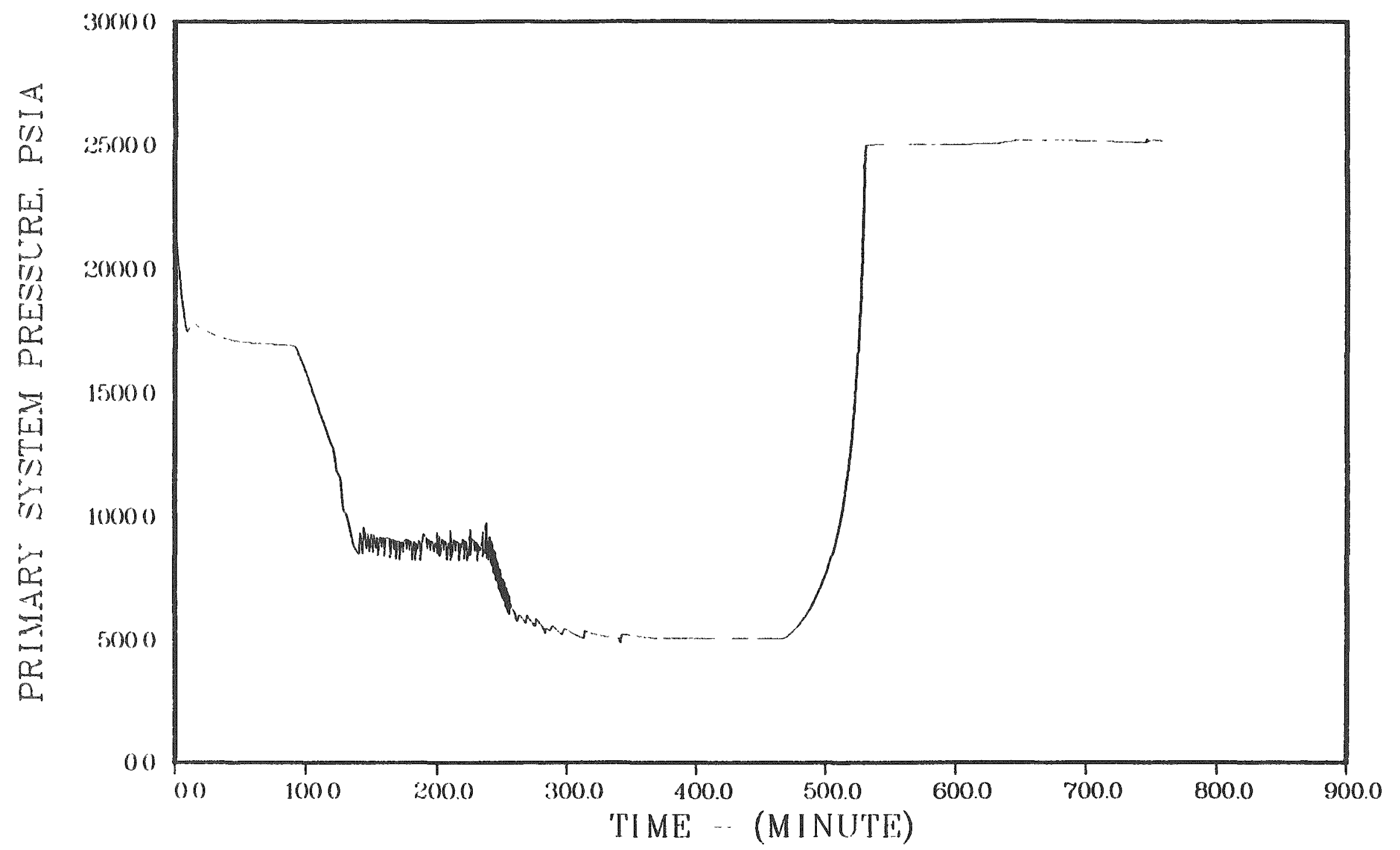

Figure 4.2.14. Primary system pressure history - long term station blackout. 


\section{SURRY 'I'B}

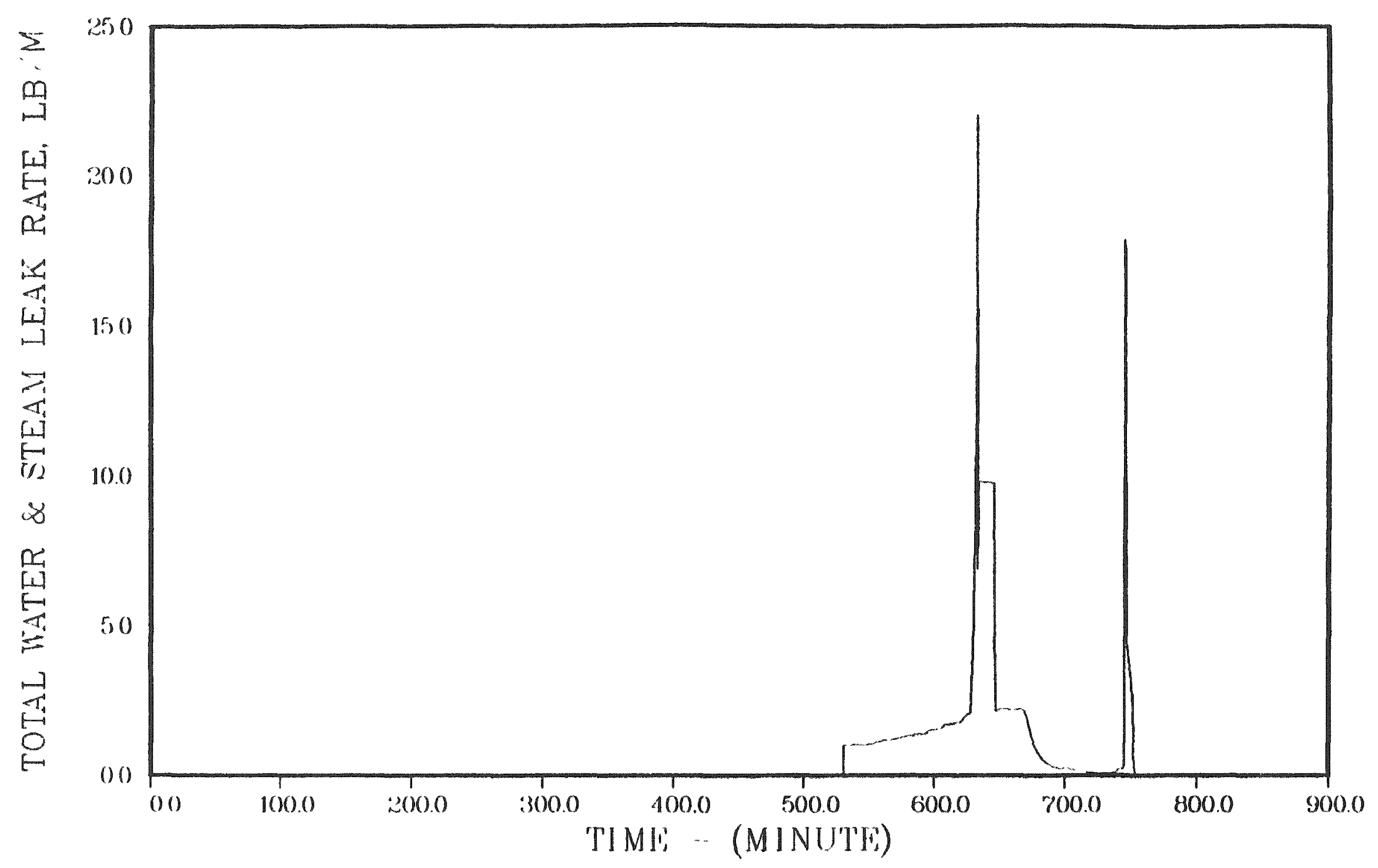

Figure 4.2.15. Primary system leakage - long term station blackout. 


\section{SURRY TB}

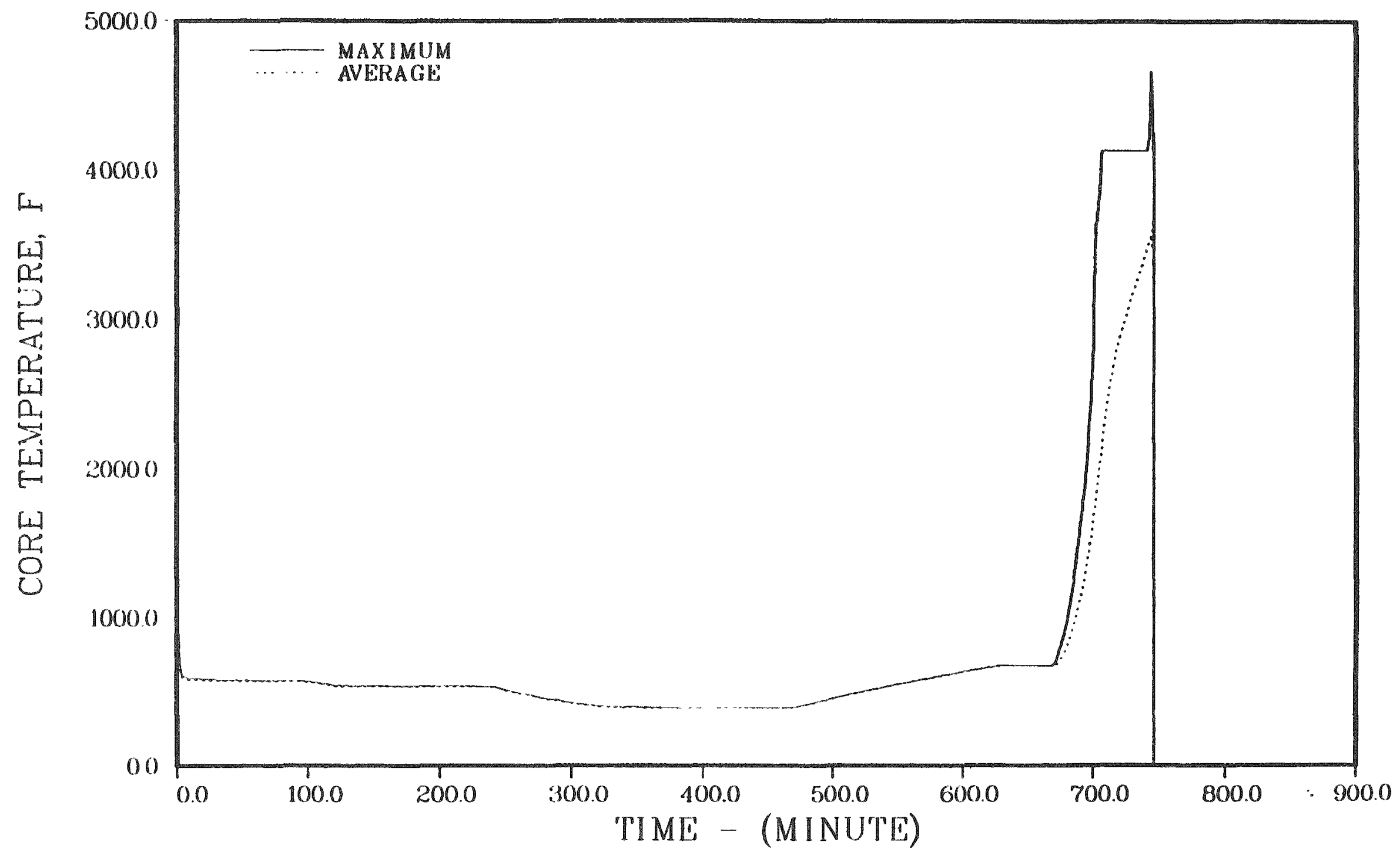

Figure 4.2.16. Maximum and average core temperatures - long term station blackout. 


\section{SURRY 'I'B}

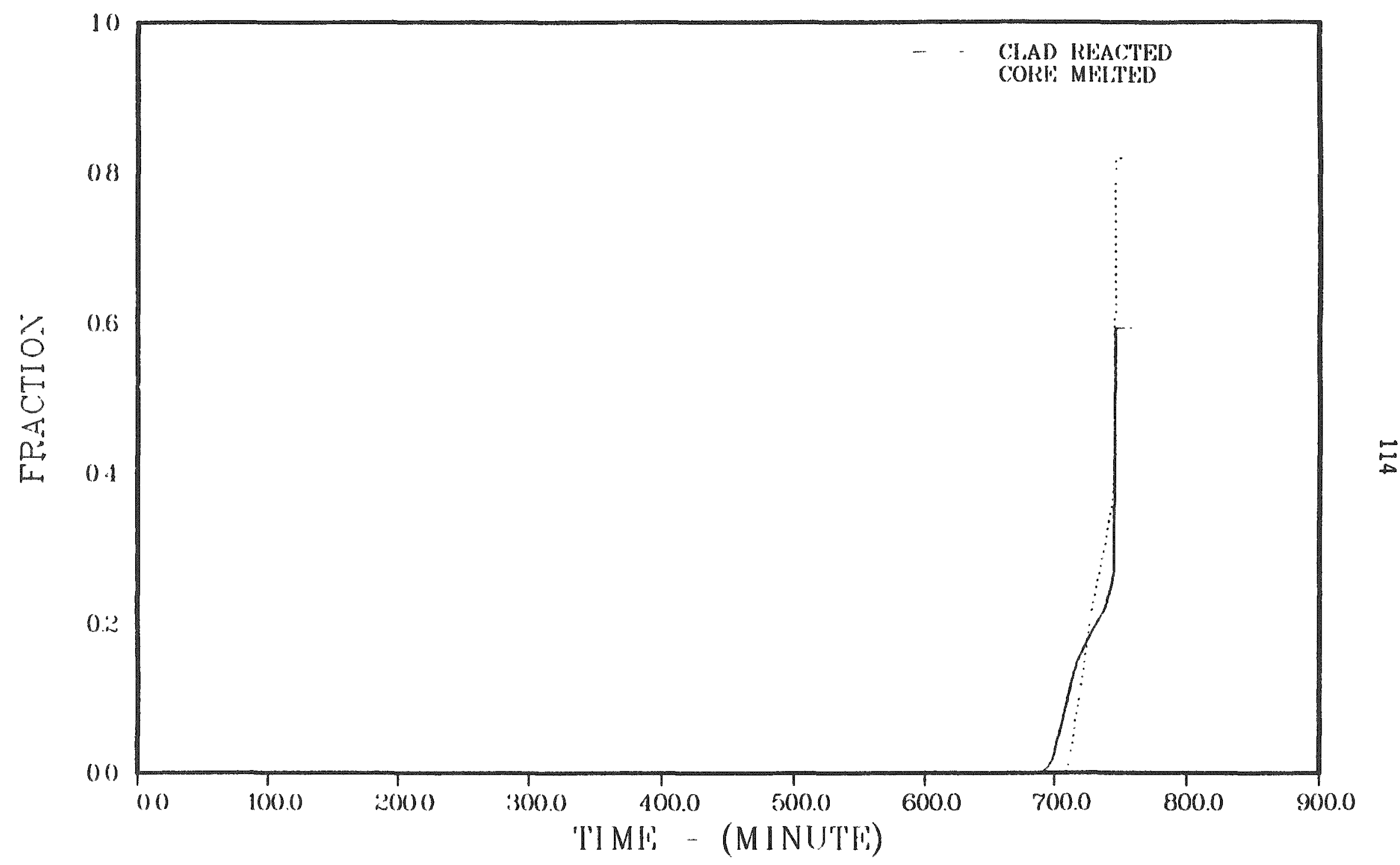

Figure 4.2.17. Fractions of cladding reacted and core melted - long term station blackout. 


\section{SURRY 'I'J}

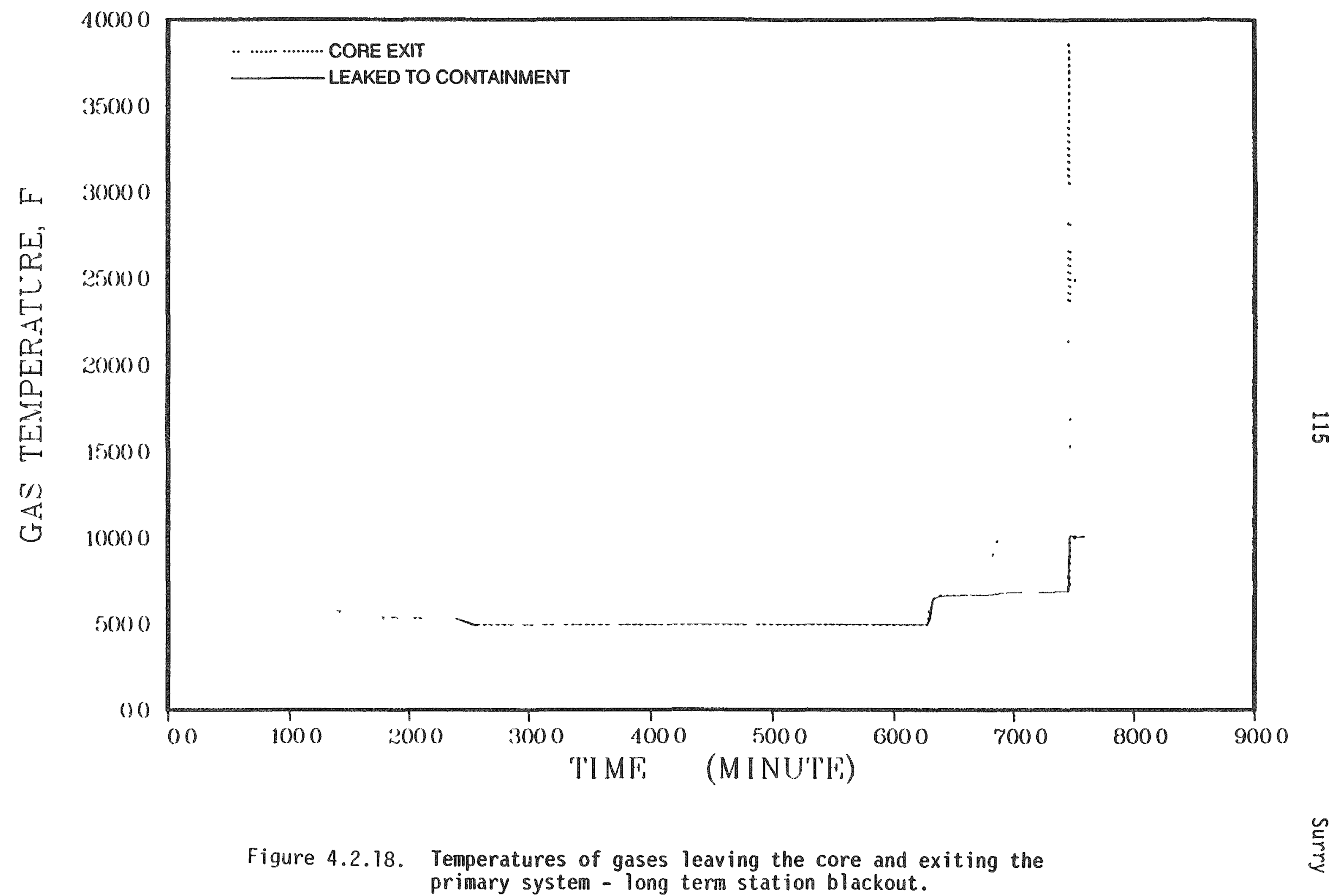


Tabl 4.2.13 Containament Respons - Surry TB

\begin{tabular}{|c|c|c|c|c|c|c|c|c|}
\hline \multirow[b]{2}{*}{$\begin{array}{l}\text { Accident } \\
\text { Event }\end{array}$} & \multirow[b]{2}{*}{$\begin{array}{l}\text { Tine, } \\
\text { minutes }\end{array}$} & \multicolumn{2}{|c|}{ Conta inment } & \multirow{2}{*}{ 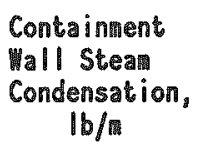 } & \multicolumn{2}{|c|}{ Sump Water } & \multicolumn{2}{|c|}{ Reactor Cavity water } \\
\hline & & $\begin{array}{l}\text { Pressure, } \\
\text { Psia }\end{array}$ & Temperature & & $\begin{array}{l}\text { Mass, } \\
\text { lb }\end{array}$ & Temp., & Mass, & ${ }^{\text {Temp. }}$ \\
\hline Core uncovery & 667.9 & 27.4 & 215 & 1724 & $2.77 \times 10^{5}$ & 187 & 0.0 & --- \\
\hline Start melt & 707.9 & 23.6 & 202 & 576 & $3.29 \times 10^{5}$ & 196 & 0. & $-\infty$ \\
\hline Core slump & 745.1 & 20.8 & 196 & 123 & $3.36 \times 10^{5}$ & 196 & 0. & -- \\
\hline Core collapse & 746.7 & 26.6 & 229 & 0 & $3.37 \times 10^{5}$ & 191 & 1. & $-\infty$ \\
\hline Botton head dryout & 750.6 & 29.2 & 227 & 1676 & $3.44 \times 10^{5}$ & 191 & Ø. & --- \\
\hline Bottor head failure & 757.8 & 27.9 & 219 & 872 & $3.52 \times 10^{5}$ & 192 & 0.0 & -- \\
\hline Accumulators empty & 758.8 & 44.6 & 266 & (6) & $3.56 \times 10^{5}$ & 192 & $1.92 \times 10^{5}$ & 120 \\
\hline Start concrete attack & 758.9 & 44.5 & 258 & 0 & $3.56 \times 10^{5}$ & 192 & $1.62 \times 10^{5}$ & 121 \\
\hline End calculation & 1358.9 & 35.3 & 23. & 50 & $5.54 \times 11^{5}$ & 213 & $1.04 \times 10^{2}$ & 213 \\
\hline
\end{tabular}




\section{SURRY TR}

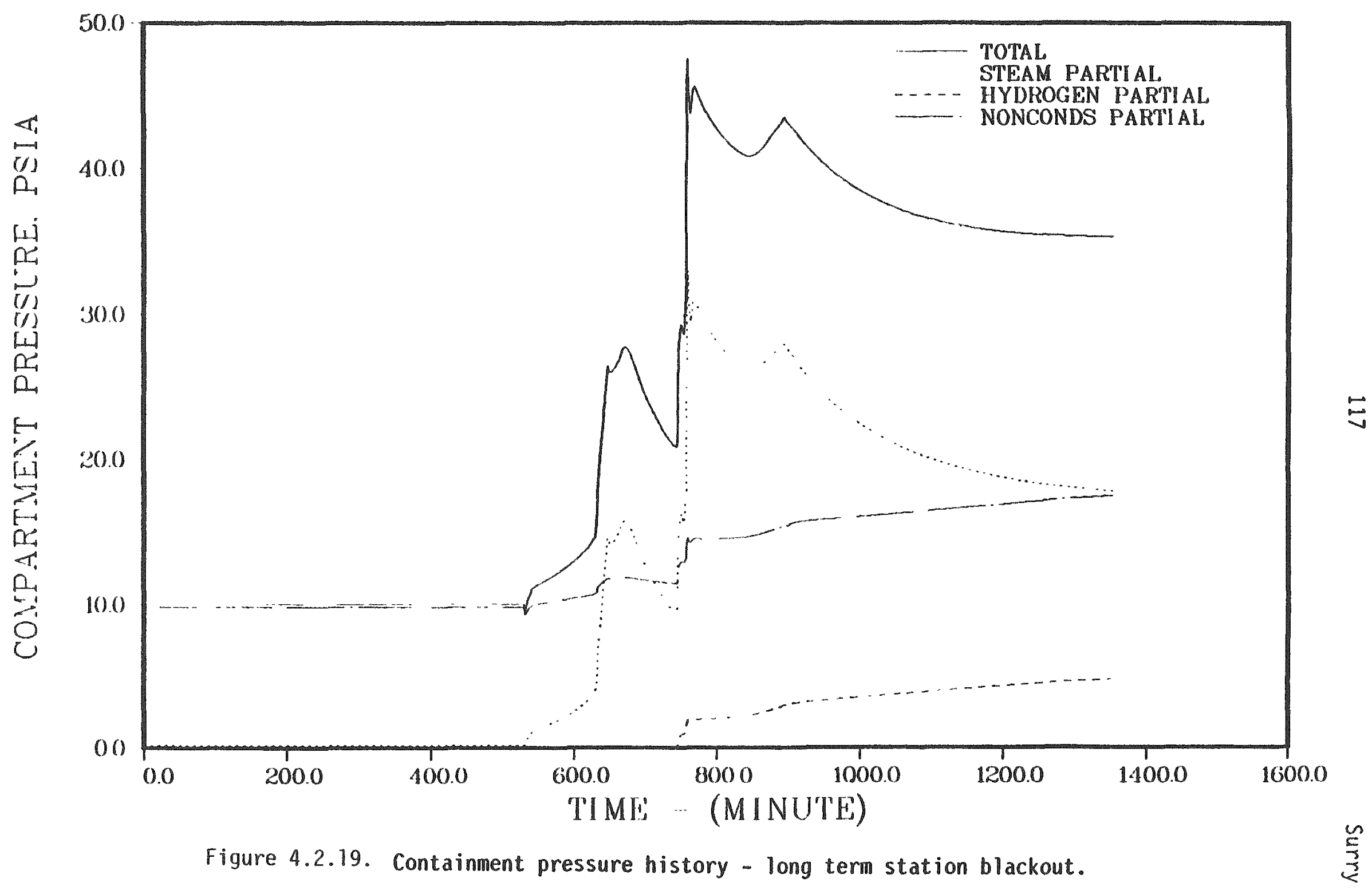




\section{SURRY 'T'B}

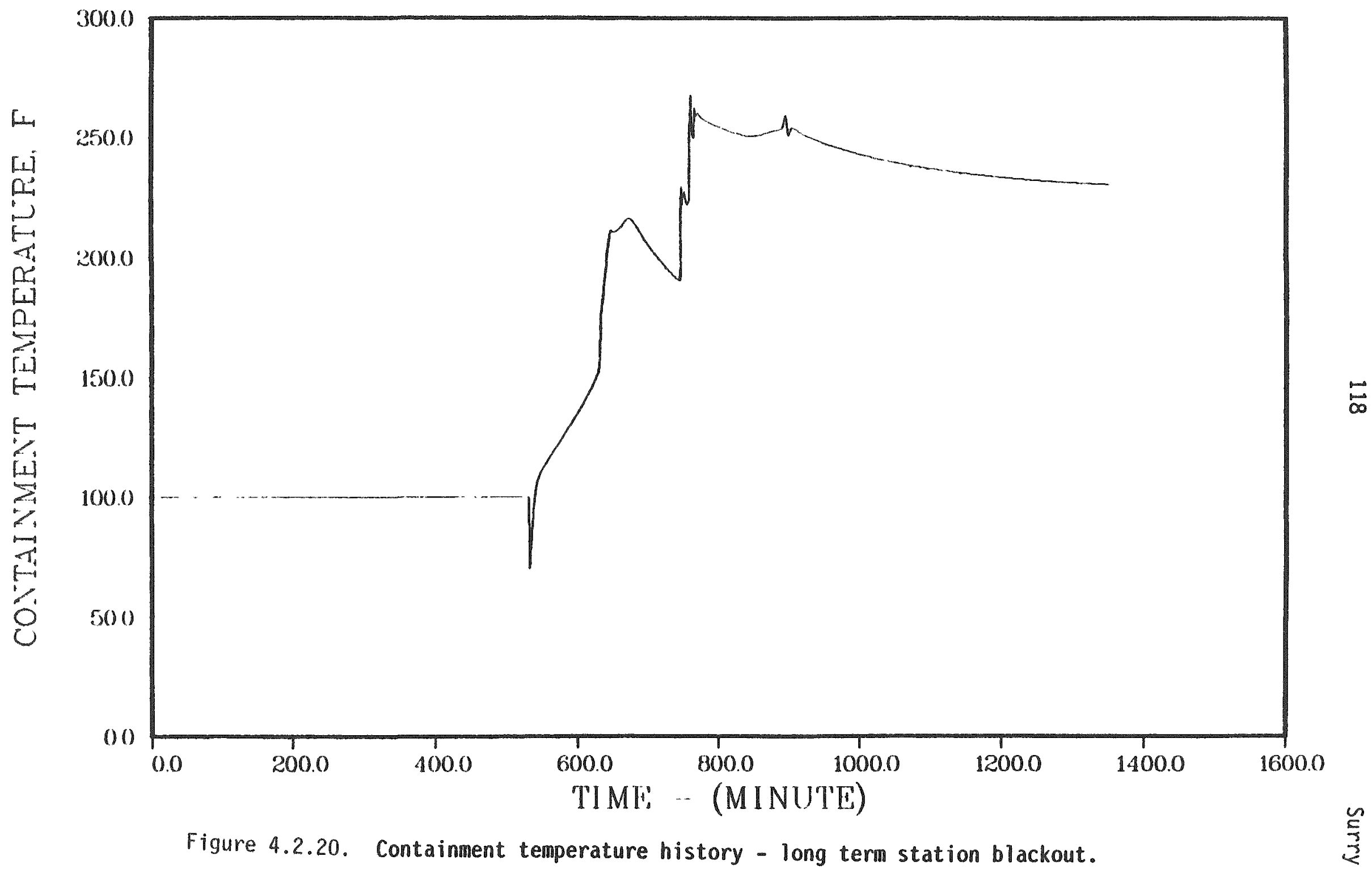




\section{SURRY 'T'B}

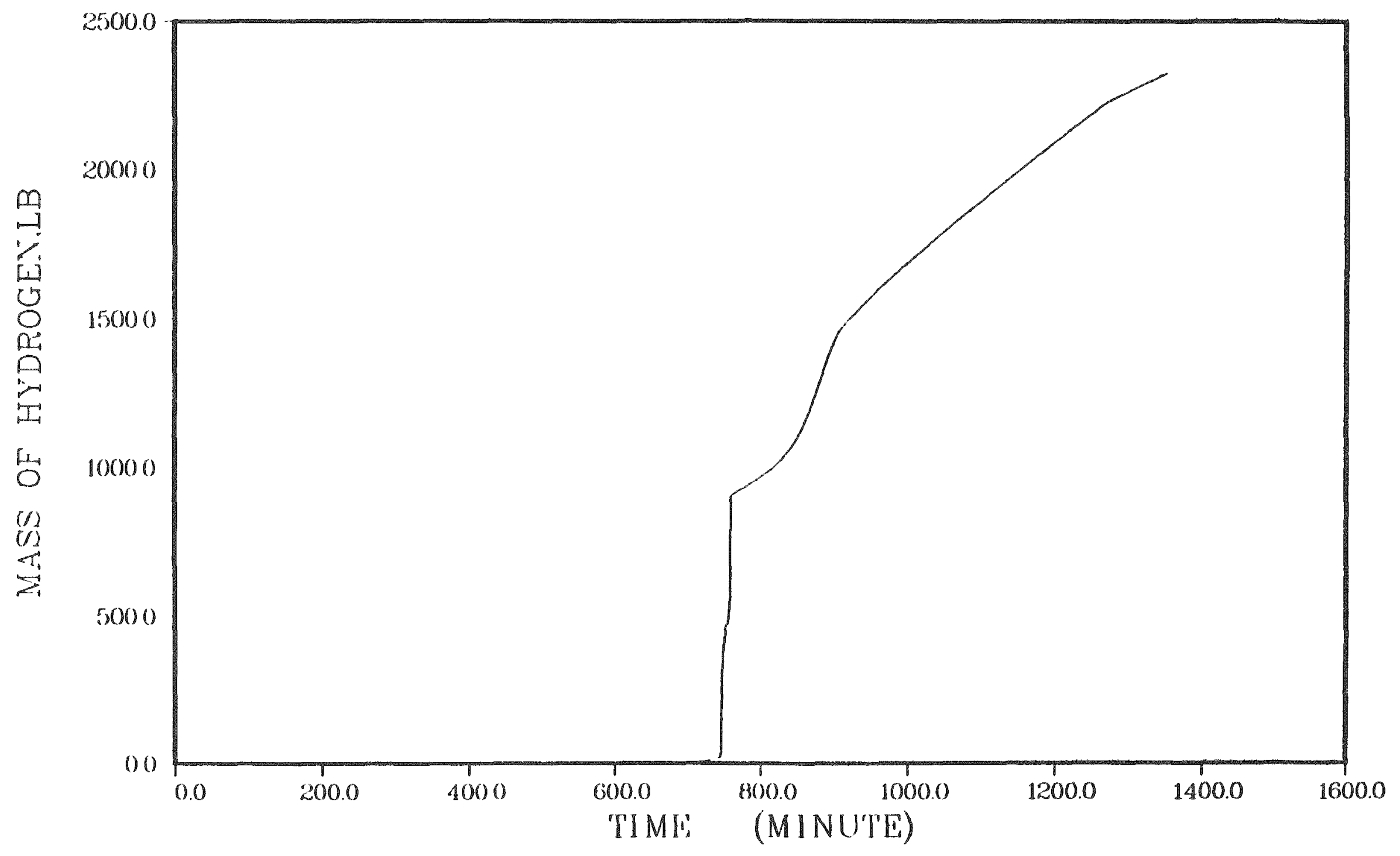

$\rightleftarrows$

Figure 4.2.21. Hydrogen in the containment - long term station blackout. 


\section{SURRY TB}

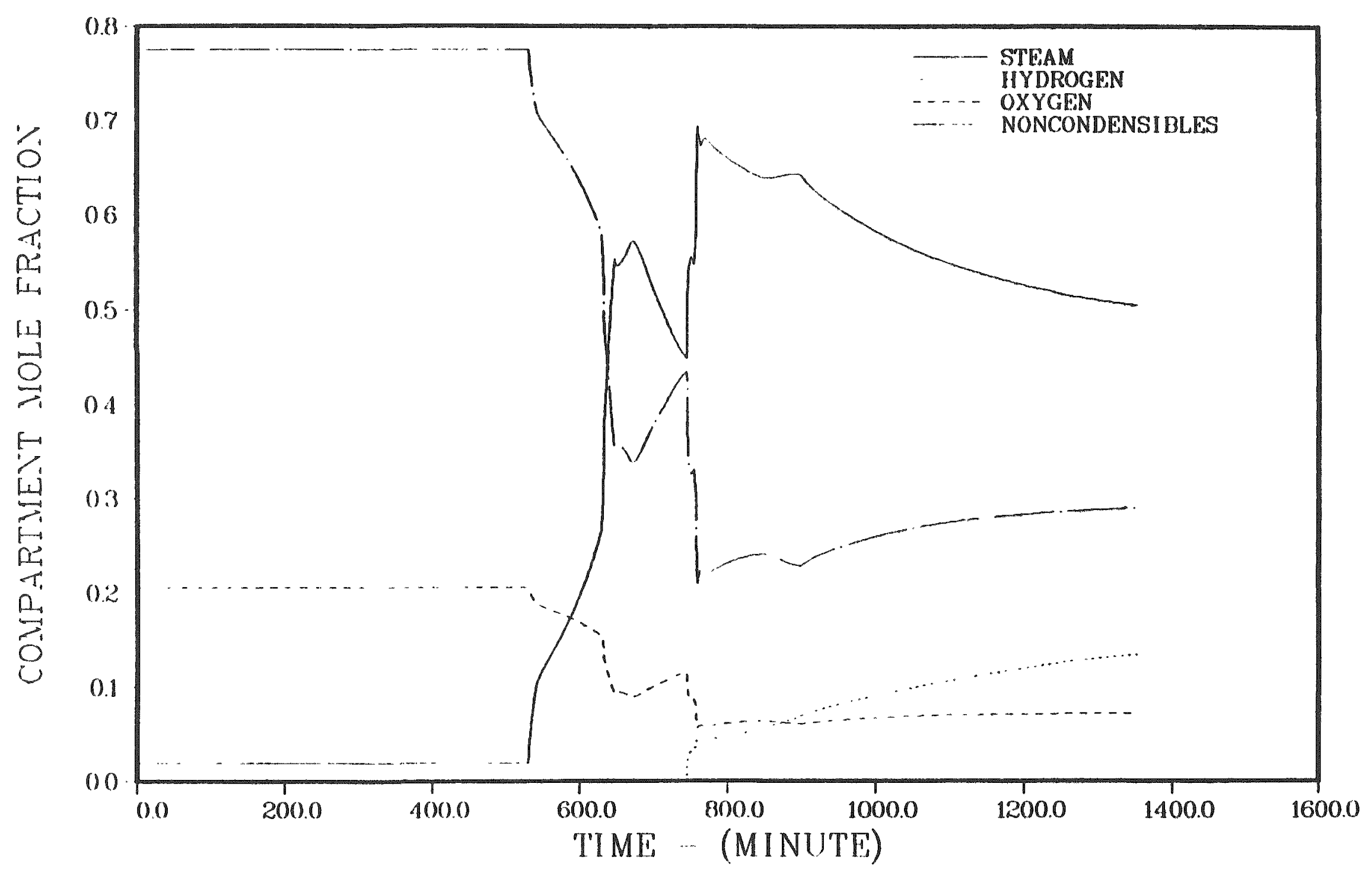

Figure 4.2.22. Containment atmosphere composition - long term station blackout. 


\section{PRIMARY SYSTEM RESPONSE - SURRY $S_{3} B$ (with secondary depressurization)}

The predicted prgression of accident events is summarized in Table 4.2.14. Core and primary system conditions at key times during the accident are summarized in Table 4.2.15. The operation of the auxiliary feedwater system together with depressurization of the steam generators result in most of the decay heat being accommodated by the steam generators, with relatively little mass and energy release to the containment. The primary system pressure is lowered below the accumulator setpoint with complete discharge of the accumulators into the primary system at about two hours into the accident. The primary system pressure history is given in Figure 4.2.23. After the auxiliary feedwater system is lost, the steam generators dry out (about 489 minutes) and the primary system repressurizes. The latter is due to the fact that the small leak rate associated with the pump seal failure cannot relieve a 11 the steam generated. Primary system leakage is shown in Figure 4.2.24. Thus, core overheating and melting take place with the primary system at an elevated pressure. A further pressure increase is associated with the collapse of the core into the vessel head. Maximum and average core temperatures are illustrated in Figure 4.2 .25 ; fractions cladding reacted and core melted are given in Figure 4.2.26. Temperatures of the gases leaving the top of the core and exiting the primary system are shown in Figure 4.2.27. The initial availability of auxiliary feedwater and steam generator depressurization lead to a significant delay in the time of core overheating.

\section{CONTAINMENT RESPONSE - Surry $S_{3} B$ (with secondary depressurization)}

The conditions in the containment at key times during the accident progression are summarized in Table 4.2.16. Containment pressure and temperature histories are given in Figures 4.2 .28 and 4.2.29. Immediately after reactor vessel failure the containment contains $980 \mathrm{lb}$ of hydrogen, with corresponding mole fractions of 0.059 hydrogen, 0.075 oxygen, and 0.586 steam. Since the accumulators have discharged prior to reactor vessel breech, the reactor cavity is dry throughout this sequence. At the end of the calculation, after ten hours of concrete attack, the containment contains 
Table 4.2.14. Timing of key events - Surry $S_{3} B$

Event

Time,

Minutes

RCP seal LOCA initiated

Start steam generator depressurization

End steam generator depressurization

Accumulator discharge

AFW off

Steam generator dryout

Core uncovery

Start melt

Core slump

Core collapse

Bottom head dryout

Bottom head failure

Start concrete attack

Corium layers invert

End calculation

60.0

70.0

100.0

101-141

300.0

488.7

521.4

581.7

607.2

608.6

616.1

628.2

628.6

715.5

1228.6 
Table 4.2.15. Core and primary system response - Surry $S_{3} B$

\begin{tabular}{|c|c|c|c|c|c|c|c|}
\hline $\begin{array}{l}\text { Accident } \\
\text { Event }\end{array}$ & $\begin{array}{c}\text { Tines, } \\
\text { minutes }\end{array}$ & $\begin{array}{l}\text { Primary } \\
\text { System } \\
\text { Pressure, } \\
\text { psia }\end{array}$ & 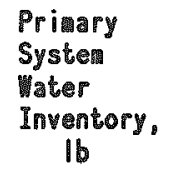 & $\begin{array}{c}\text { Average Core } \\
\text { Temperature, } \\
\text { of }\end{array}$ & $\begin{array}{l}\text { Peak Core } \\
\text { Temperature, } \\
\text { Of }\end{array}$ & $\begin{array}{c}\text { Fraction } \\
\text { Core } \\
\text { Melted }\end{array}$ & $\begin{array}{l}\text { Fraction } \\
\text { Clad } \\
\text { Reacted }\end{array}$ \\
\hline $\begin{array}{l}\text { Accuinulators } \\
\text { empty }\end{array}$ & 1418.9 & 291 & $4.42 \times 10^{5}$ & 426 & 434 & $\cdots$ & -- \\
\hline AFW of & 350. & 287 & $2.59 \times 16^{5}$ & 418 & 422 & -- & $-\infty$ \\
\hline $\begin{array}{l}\text { Strat generators } \\
\text { dry }\end{array}$ & 488.7 & 272 & $1.33 \times 10^{5}$ & 414 & 418 & --- & $-\infty$ \\
\hline Core uncovery & $\$ 21.4$ & 681 & $1.18 \times 10^{5}$ & 505 & 509 & 6.6 & 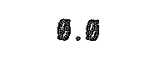 \\
\hline Stapt melt & 581.7 & 1171 & $7.55 \times 10^{4}$ & 1781 & 4134 & 10 & 9.65 \\
\hline Core slump & 667.2 & 904 & $5.91 \times 10^{4}$ & 3597 & 4144 & .52 & 0.48 \\
\hline Core collapse & 608.6 & 1332 & $0.58 \times 10^{4}$ & 3362 & $-\cdots$ & 0.84 & 64 \\
\hline Bottom head dryout & 618.1 & 2266 & $2.78 \times 10^{4} \cdot$ & 2787 & $\ldots$ & $\cdots$ & 65 \\
\hline Bottom head failure & 628.2 & 1896 & $2.54 \times 10$ & $362 \sqrt{20}$ & $-\infty$ & $\infty-\infty$ & .65 \\
\hline
\end{tabular}

* Water retained in low points of primary system piping. 


\section{SURRY S3B}

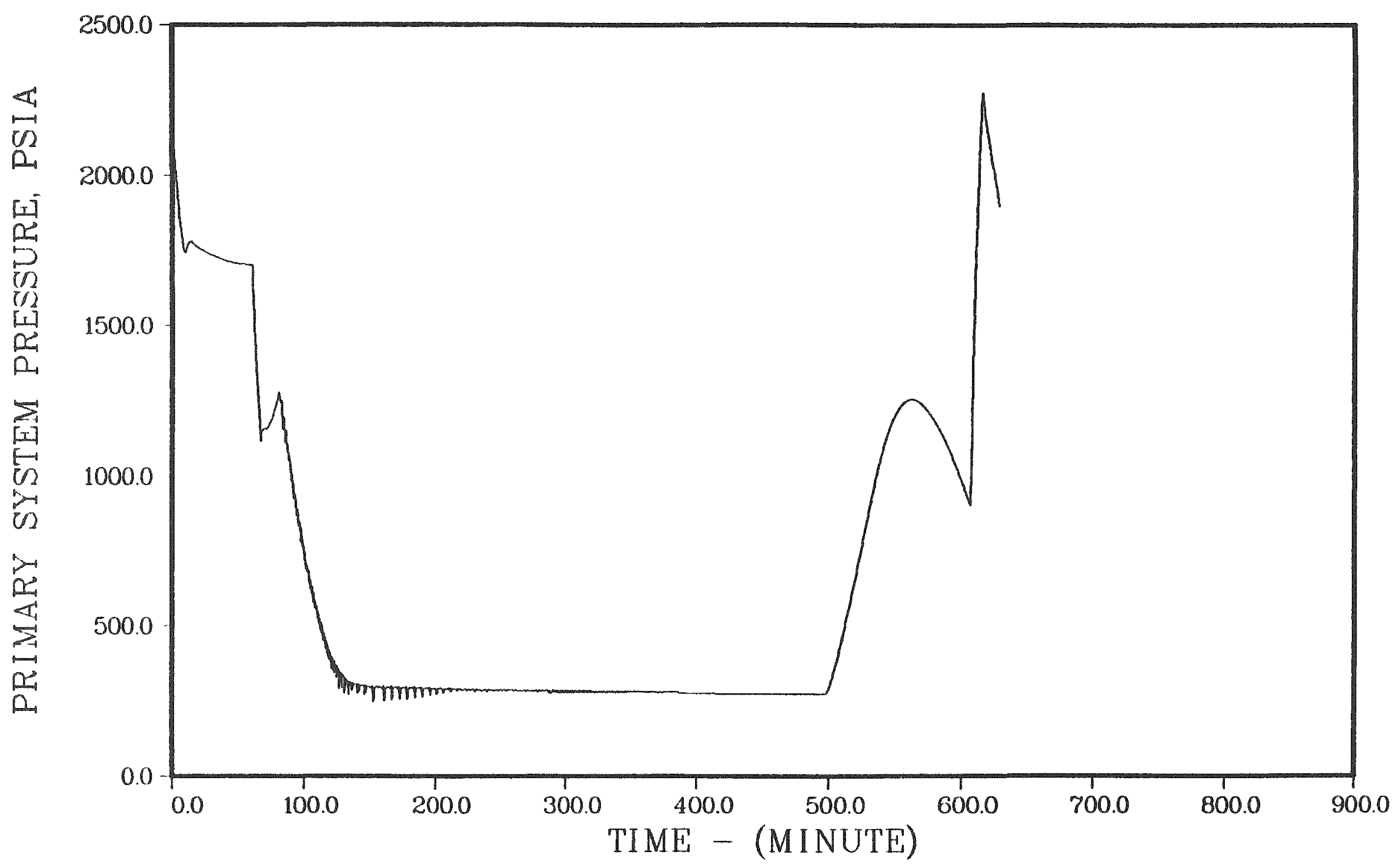

Figure 4.2.23. Primary system pressure history - station blackout with pump seal failure. 


\section{SURRY S3B}

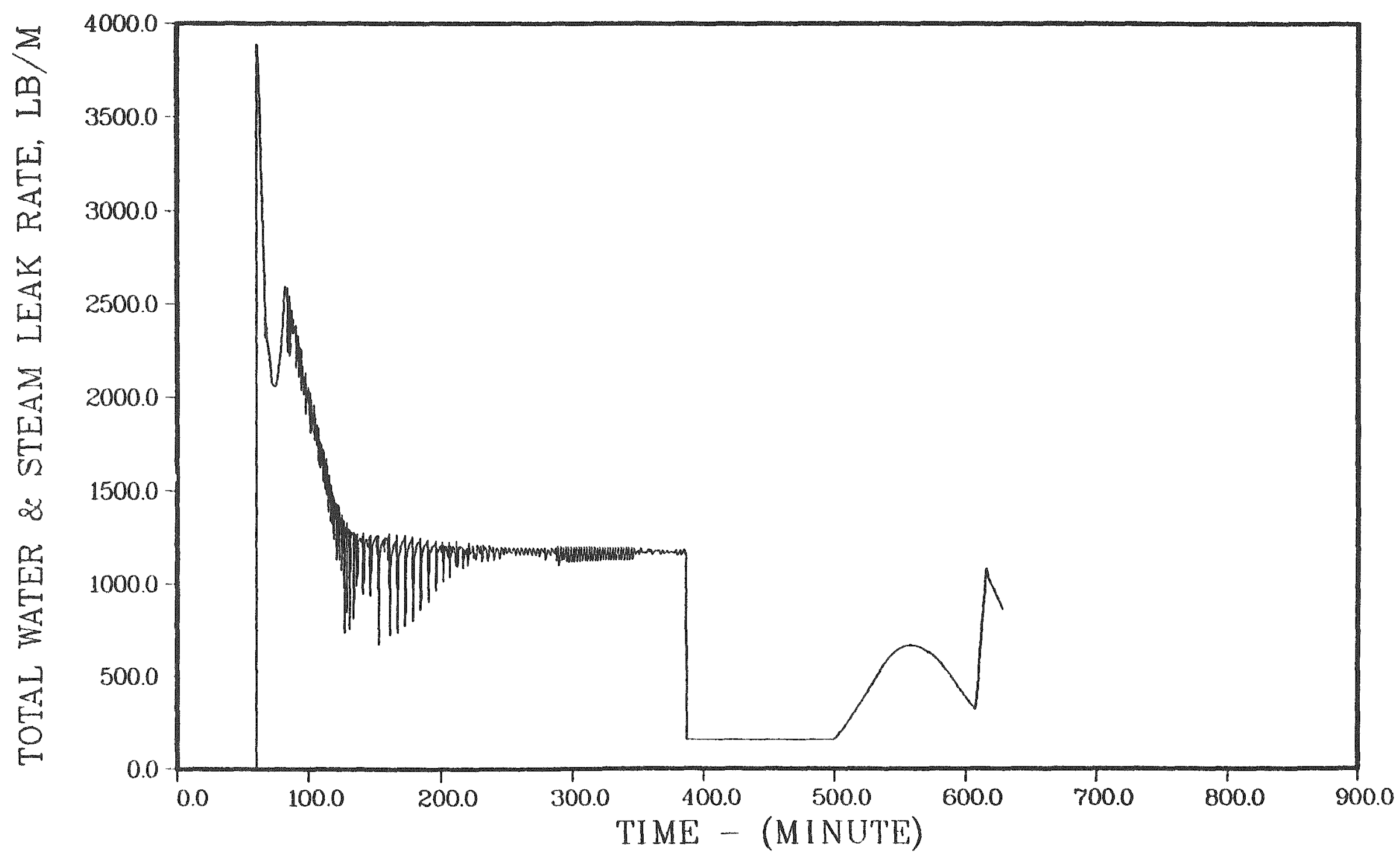

Figure 4.2.24. Primary system leakage - long term blackout with pump seal failure. 


\section{SURRY S3B}

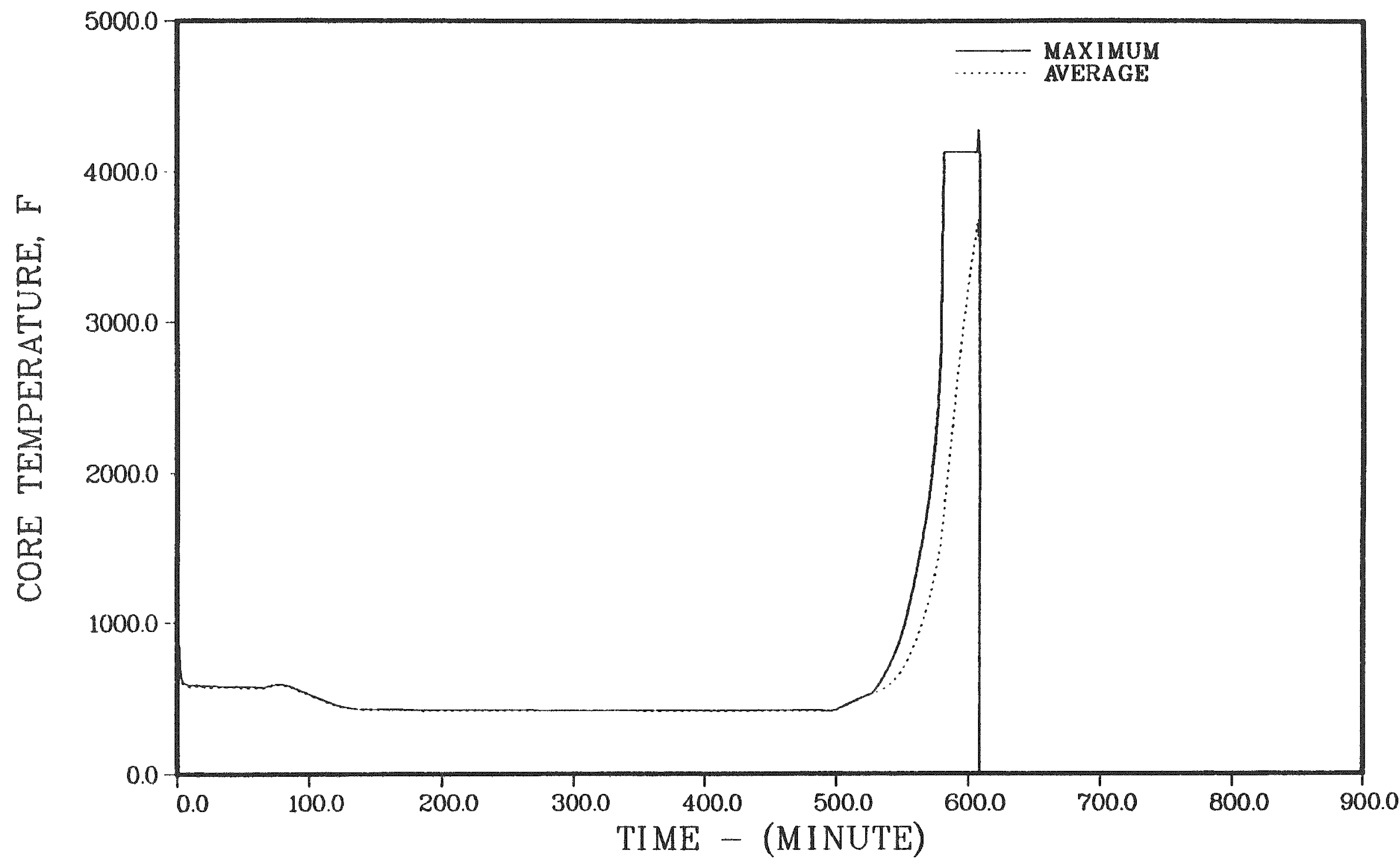

Figure 4.2.25. Maximum and average core temperatures - station blackout with pump seal failure. 


\section{SURRY S3B}

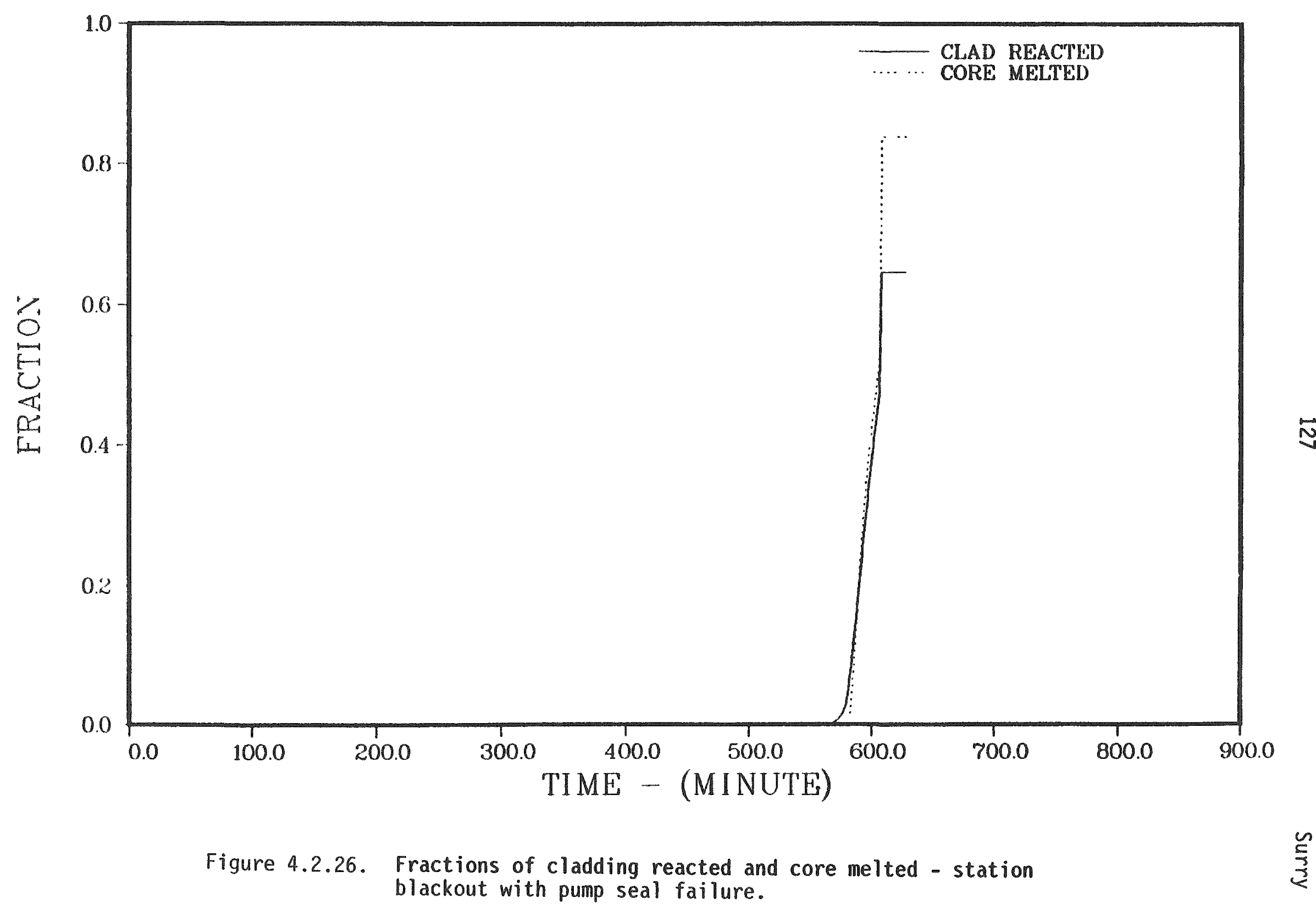




\section{SURRY S3B}

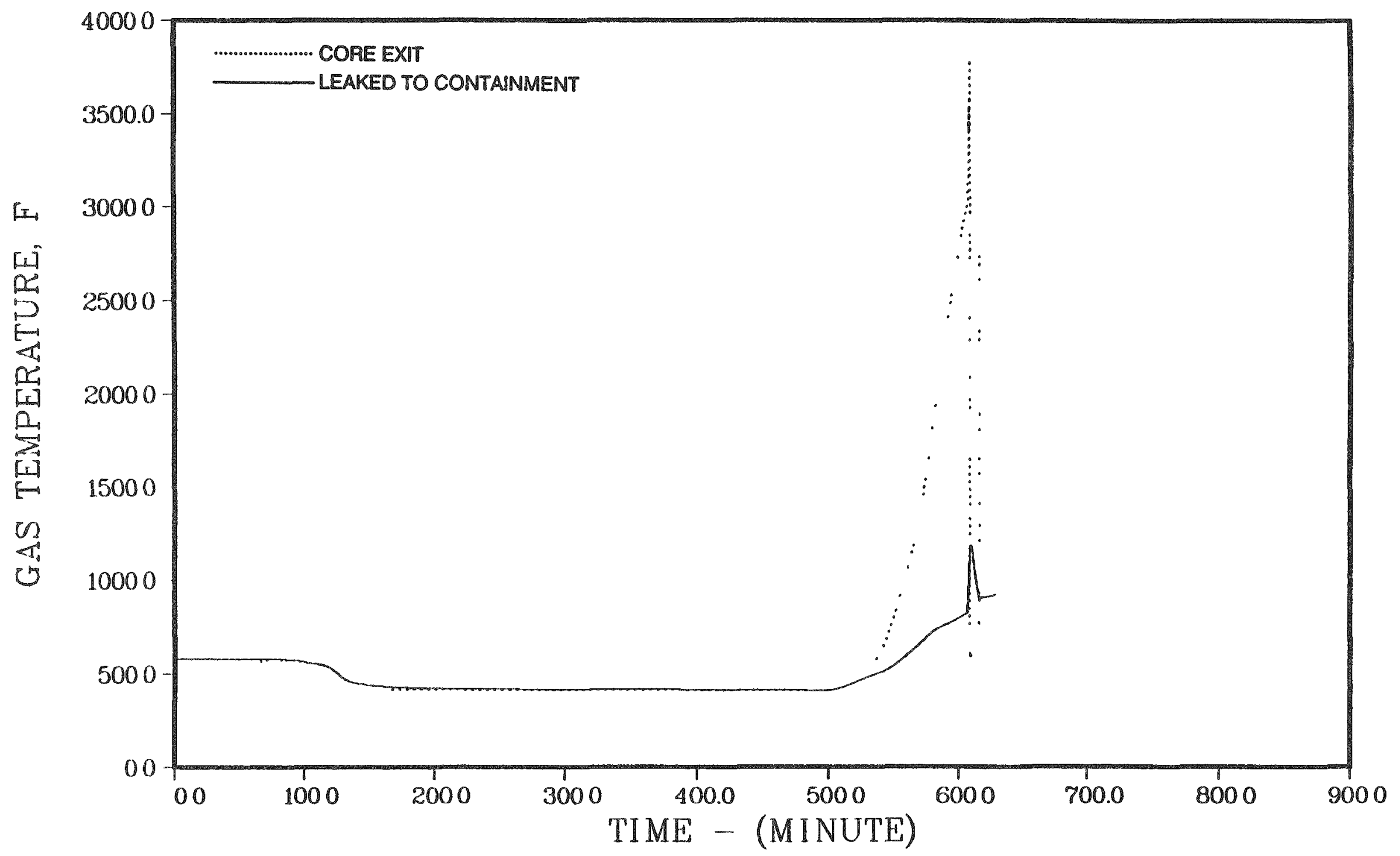

system - station blackout with pump seal failure. 
Table 4.2.16 Containment response - Surry $S_{3} B$

\begin{tabular}{|c|c|c|c|c|c|c|c|c|}
\hline \multirow[b]{2}{*}{$\begin{array}{c}\text { Accident } \\
\text { Event }\end{array}$} & \multirow[b]{2}{*}{$\begin{array}{c}\text { Time, } \\
\text { inutes }\end{array}$} & \multicolumn{2}{|c|}{ Containment } & \multirow{2}{*}{$\begin{array}{c}\text { Contain } \\
\text { yant } \\
\text { Condensation. } \\
\text { Ib/ }\end{array}$} & \multicolumn{2}{|c|}{ Sump Water } & \multicolumn{2}{|c|}{ Reactor Cavity Water } \\
\hline & & $\begin{array}{l}\text { Pressure, } \\
\text { Psia }\end{array}$ & Terperature & & $\begin{array}{l}\text { Ibss, } \\
\text { Ib }\end{array}$ & Temp.: & $\begin{array}{l}\text { Mass. } \\
\mathrm{Ib}\end{array}$ & ${ }_{\mathrm{F}}^{\text {Teip. }}$ \\
\hline Core uncovery & $\$ 21.4$ & 14.4 & 150 & 276 & $4.49 \times 10^{5}$ & 147 & . & $-\infty$ \\
\hline Start & 581.7 & 18.7 & 171 & 482 & $4.78 \times 10^{5}$ & 148 & 0.0 & -- \\
\hline Core slupp & 697.2 & 17.7 & 175 & 273 & $4.85 \times 10^{5}$ & 148 & 1.5 & --- \\
\hline Core collapse & 698.6 & 17.8 & 175 & 146 & $4.86 \times 10^{5}$ & 148 & . & $-\infty$ \\
\hline Botton head dryout & 618.1 & 18.2 & 180 & 518 & $4.88 \times 19^{5}$ & 148 & . & -- \\
\hline Botto head failure & 828.2 & 20.5 & 189 & 529 & $4.84 \times 10^{5}$ & 149 & (1) & -- \\
\hline Start concreto attack & 628.6 & 33.8 & 227 & 11827 & $4.97 \times 16^{5}$ & 149 & 10 & $-\infty$ \\
\hline End calculation & 1228.6 & 28.3 & 297 & 20 & $5.65 \times 10^{5}$ & 157 & 0.0 & -- \\
\hline
\end{tabular}




\section{SURRY S3B}

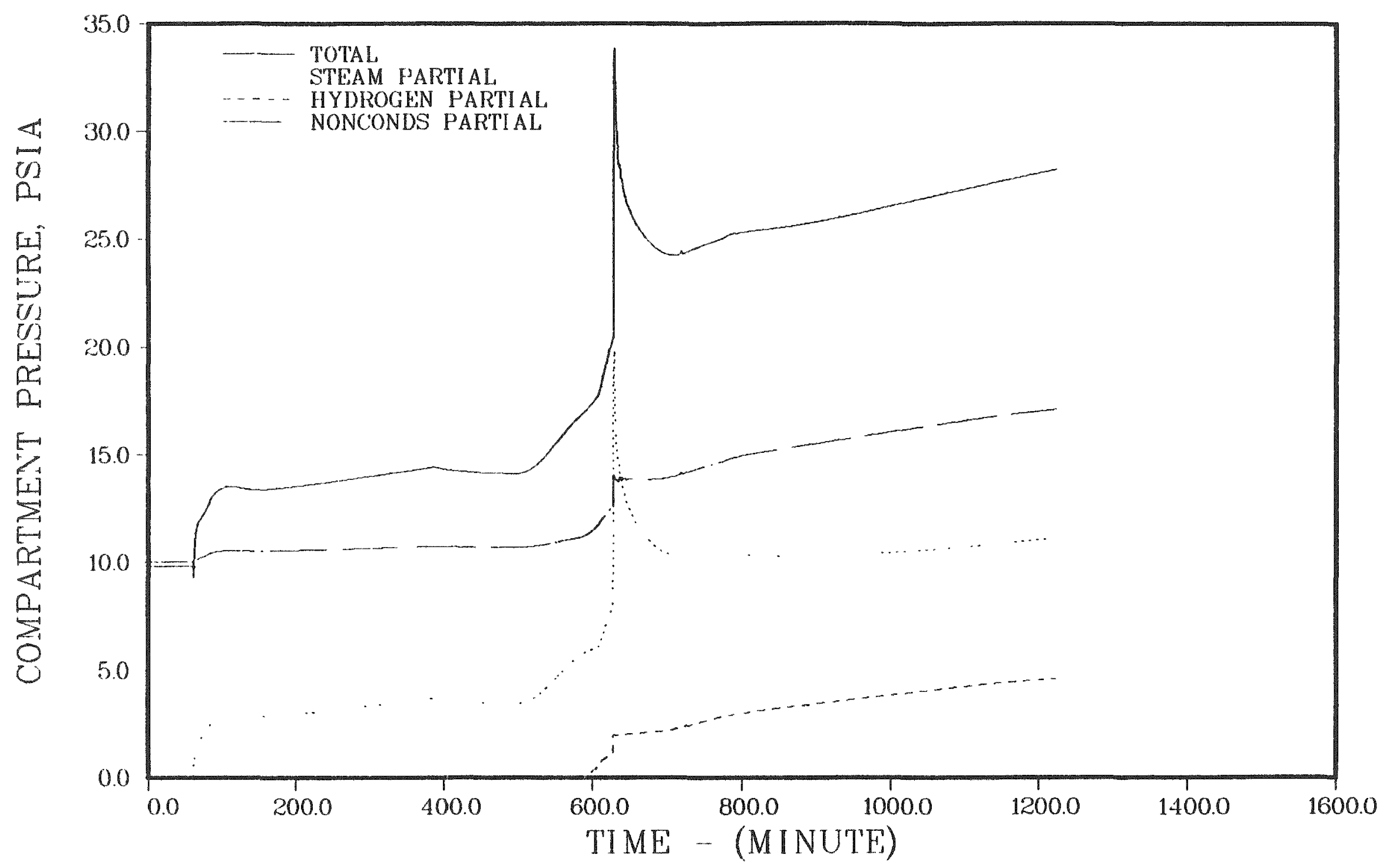

Figure 4.2.28. Containment pressure history - station blackout with pump seal failure. 


\section{SURRY S3B}

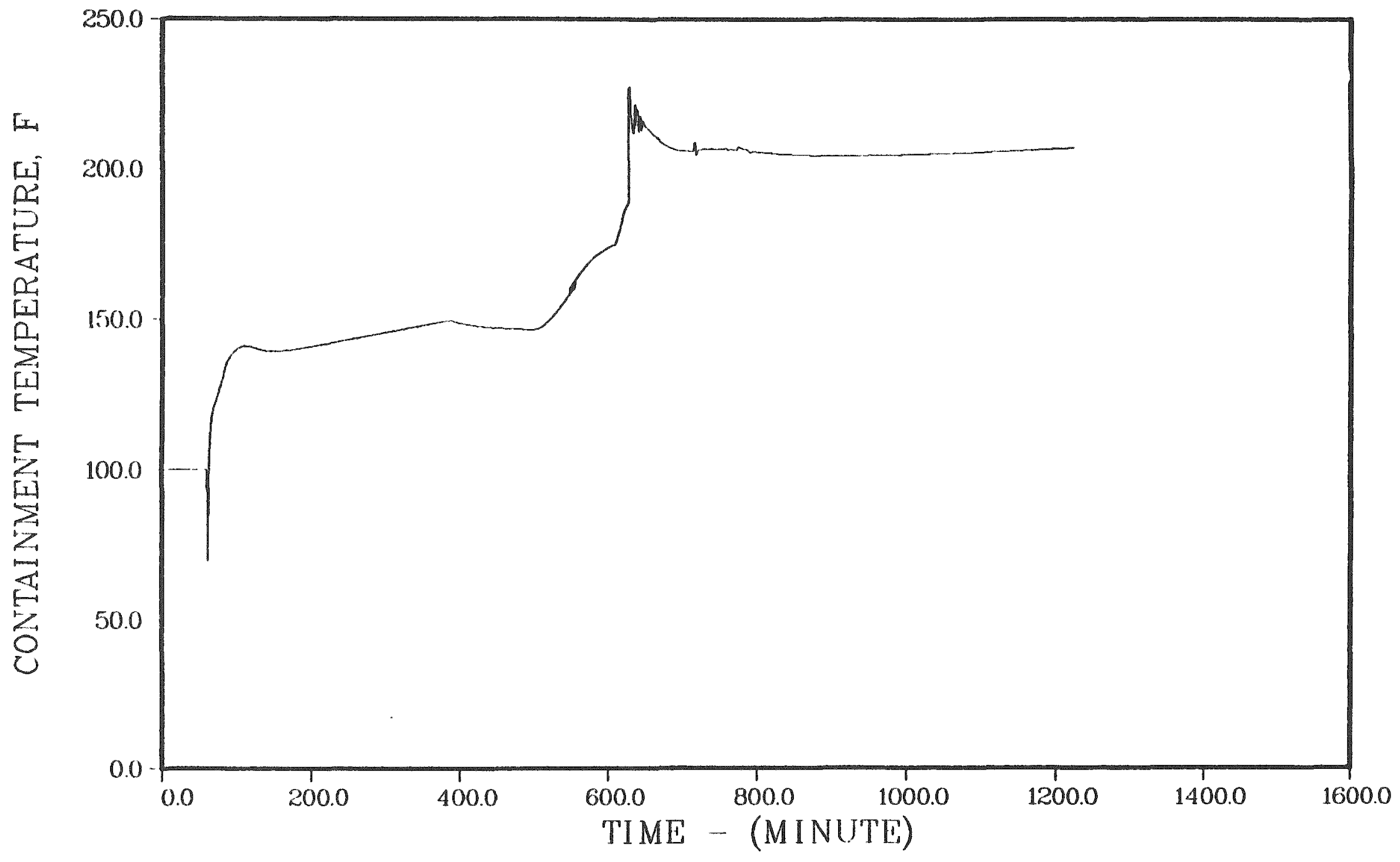

Figure 4.2.29. Containment temperature history - station blackout with pump seal failure. 
2331 ib of hydrogen, with corresponding mole fractions of 0.163 hydrogen, 0.087 oxygen, and 0.394 steam. Hydrogen buildup in the containment is illustrated in Figure 4.2.30. The mole fractions of the principal components of the containment atmosphere are illustrated in Figure 4.2.31.

\section{PRIMARY SYSTEM RESPONSE - SURRY $S_{3} D X$ (with secondary depressurization)}

The calculated timing of the accident events is summarized in Table 4.2.17. Core and primary system conditions at key times during the accident progression are summarized in Table 4.2.18. In this sequence depressurization of the secondary sides of the steam generators was assumed to occur from 30 to 60 minutes after the start of the event. This together with coolant loss through the break led to the rapid primary system depressurization, with accumulator discharge predicted at about an hour into the accident. The primary system pressure history is given in Figure 4.2 .32 ; primary coolant leakage is shown in Figure 4.2.33. Since auxiliary feedwater is available indefinitely, the steam generators do not dry out and continue to remove heat even after core uncovery. Core uncovery and heatup take place due to the loss of coolant through the break in the primary system. The continued refluxing of the steam condensed by the steam generators keeps the lower core nodes cooled and delays core slumping and collapse. The buildup of hydrogen in the primary system decreases the effectiveness of the steam generators; as the hydrogen concentration decreases due to leakage out of the system, the steam generator heat transfer again becomes significant and leads to the arrest of core melting. This can be seen in the plot of maximum and average core temperatures in Figure 4.2.34, and even more dramatically in the fraction of core melted in Figure 4.2.35. The interaction between hydrogen generation and steam generator heat transfer, together with the core slumping model utilized, lead to the prediction of very high in-vessel cladding oxidation. (It may be noted that the core slumping model used here is the same as in previous studies and represents the NUREG-0956(5) methodology.) Given the large fraction of the core molten at that time, it is quite plausible that core collapse could take place at about 720 minutes rather than the later time actually calculated. The temperatures of the gases leaving the top of the 


\section{SURRY S3B}

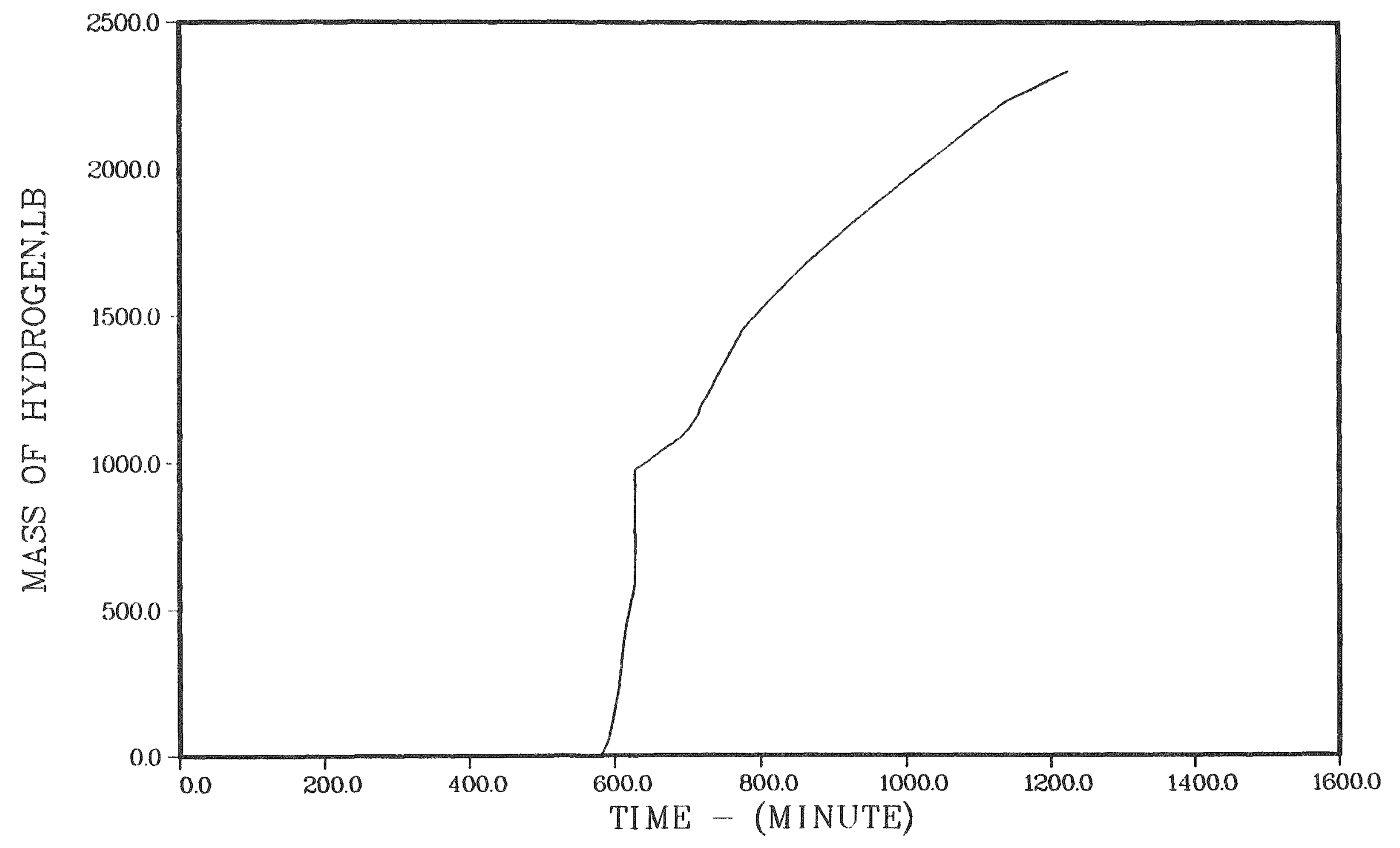

Figure 4.2.30. Hydrogen in the containment - station blackout with pump seal failure. 


\section{SURRY S3B}

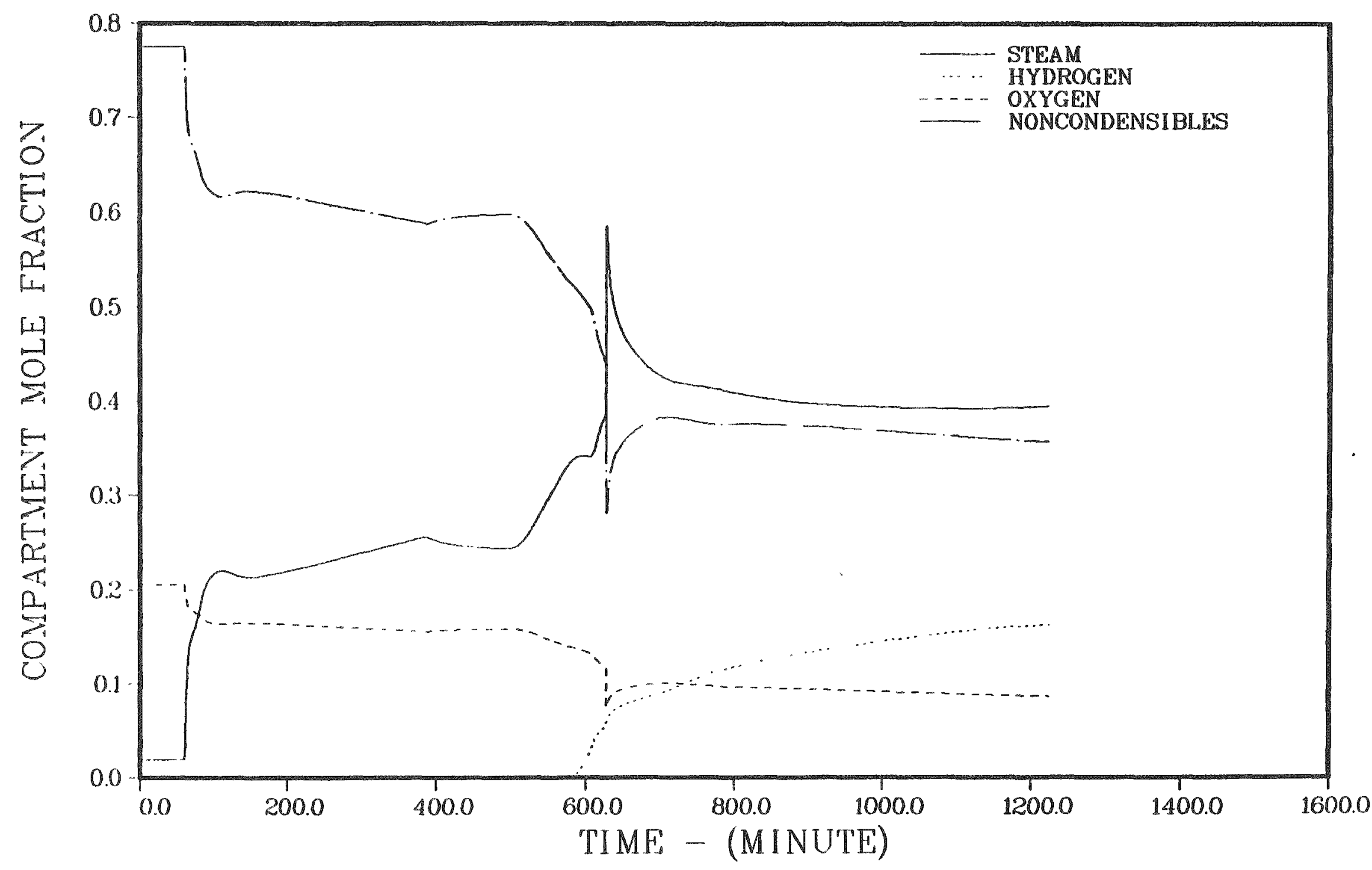

Figure 4.2.31. Containment atmosphere composition - station blackout with pump seal failure. 
Table 4.2.17. Timing of key events - Surry $S_{3} D X$

\begin{tabular}{lr}
\hline \hline Event & $\begin{array}{c}\text { Time, } \\
\text { Minutes }\end{array}$ \\
& \\
RCP seal LOCA initiated & 0.0 \\
Containment coolers on & 1.0 \\
Start steam generator depressurization & 30.0 \\
End steam generator depressurization & 60.0 \\
Accumulator discharge & $40-80$ \\
Core uncovery & 525.4 \\
Start melt & 684.7 \\
Core slump & 813.8 \\
Core collapse & 814.3 \\
Bottom head failure & 835.0 \\
Start concrete attack & 835.4 \\
Containment spray on & 835.7 \\
Containment spray recirculation on & 930.4 \\
Corium layers invert & 956.4 \\
End calculation & 1435.4 \\
& \\
\hline
\end{tabular}


Table 4.2.18. Core and primary system response - Surry $S_{3} D X$

\begin{tabular}{|c|c|c|c|c|c|c|c|}
\hline $\begin{array}{c}\text { Accident } \\
\text { Event }\end{array}$ & $\begin{array}{l}\text { Tines } \\
\text { rinutes }\end{array}$ & $\begin{array}{l}\text { Prinary } \\
\text { System } \\
\text { Pressure, } \\
\text { psia }\end{array}$ & $\begin{array}{l}\text { Primary } \\
\text { Syster } \\
\text { water } \\
\text { Inventory. } \\
\quad \text { Ib }\end{array}$ & $\begin{array}{c}\text { Averag Coro } \\
\text { Tomperature, } \\
\text { of }\end{array}$ & $\begin{array}{l}\text { Peak Coro } \\
\text { Temperature, } \\
\text { of }\end{array}$ & $\begin{array}{c}\text { Fraction } \\
\text { Core } \\
\text { Melted }\end{array}$ & $\begin{array}{c}\text { Fraction } \\
\text { Clad } \\
\text { Reacted }\end{array}$ \\
\hline $\begin{array}{l}\text { Accumulators } \\
\text { empty }\end{array}$ & 80.5 & 319 & $4.22 \times 10^{5}$ & 431 & 436 & $-\infty$ & $-\infty$ \\
\hline Core uncovery & 525.4 & 27 & $1.15 \times 10^{5}$ & 424 & 427 & 10 & 0.6 \\
\hline Start melt & 684.7 & 287 & $9.58 \times 10^{4}$ & 2401 & 4130 & . & 9.65 \\
\hline Core slump & 813.8 & 292 & $7.62 \times 10^{4}$ & 3813 & 4988 & 0.95 & 9.94 \\
\hline Cor collapse & 814.3 & 293 & $7.02 \times 10^{4}$ & 3010 & $\infty$ & 1.95 & 9.94 \\
\hline Bottor hesd failure & 835. 둘 & 1659 & $2.95 \times 10^{4}$ & 1554 & $-\infty$ & $-\infty$ & 0.94 \\
\hline
\end{tabular}




\section{SURRY S3DX}

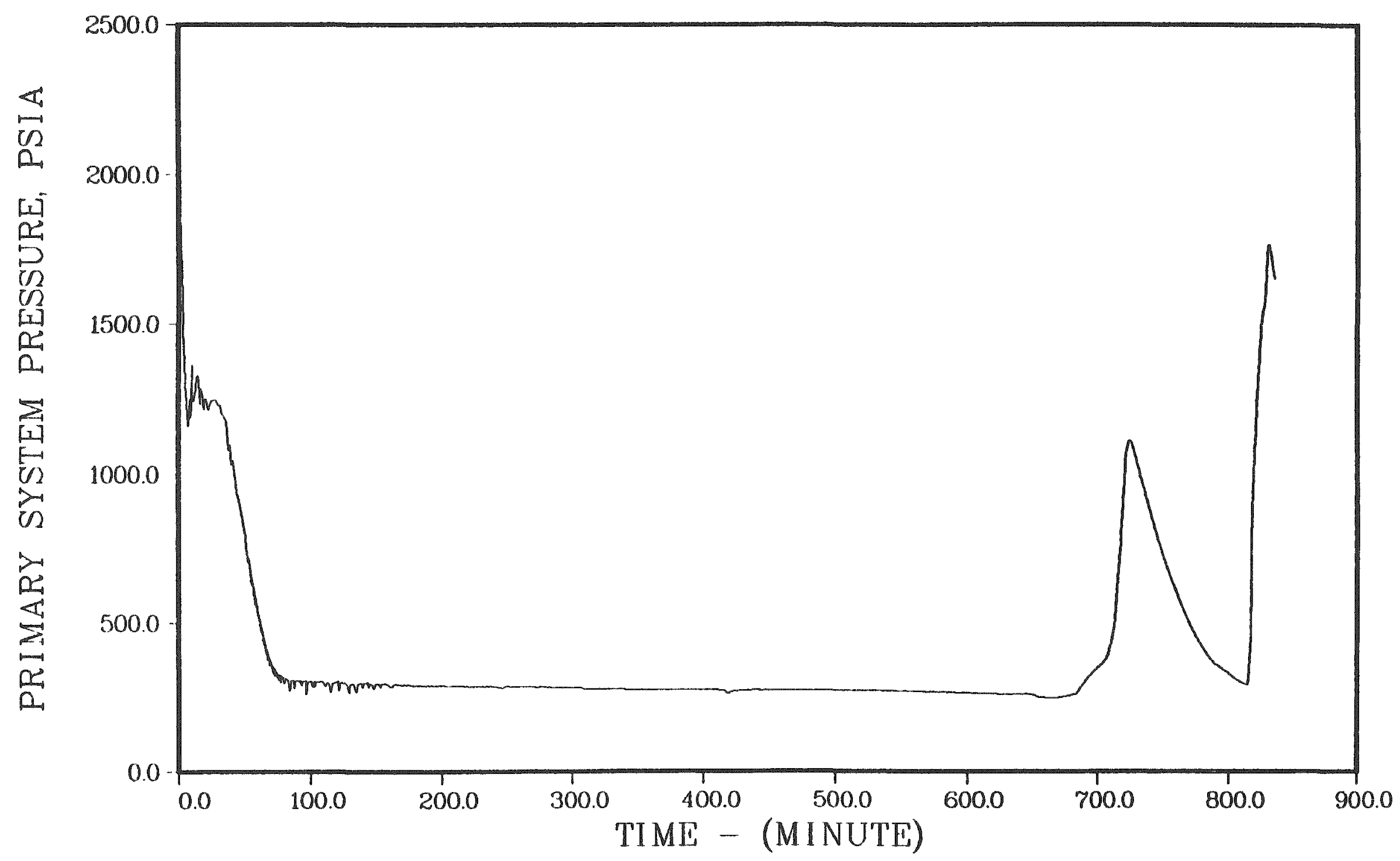

Figure 4.2.32. Primary system pressure history - very small break with ECCS failure and AFW on. 


\section{SURRY S3DX}

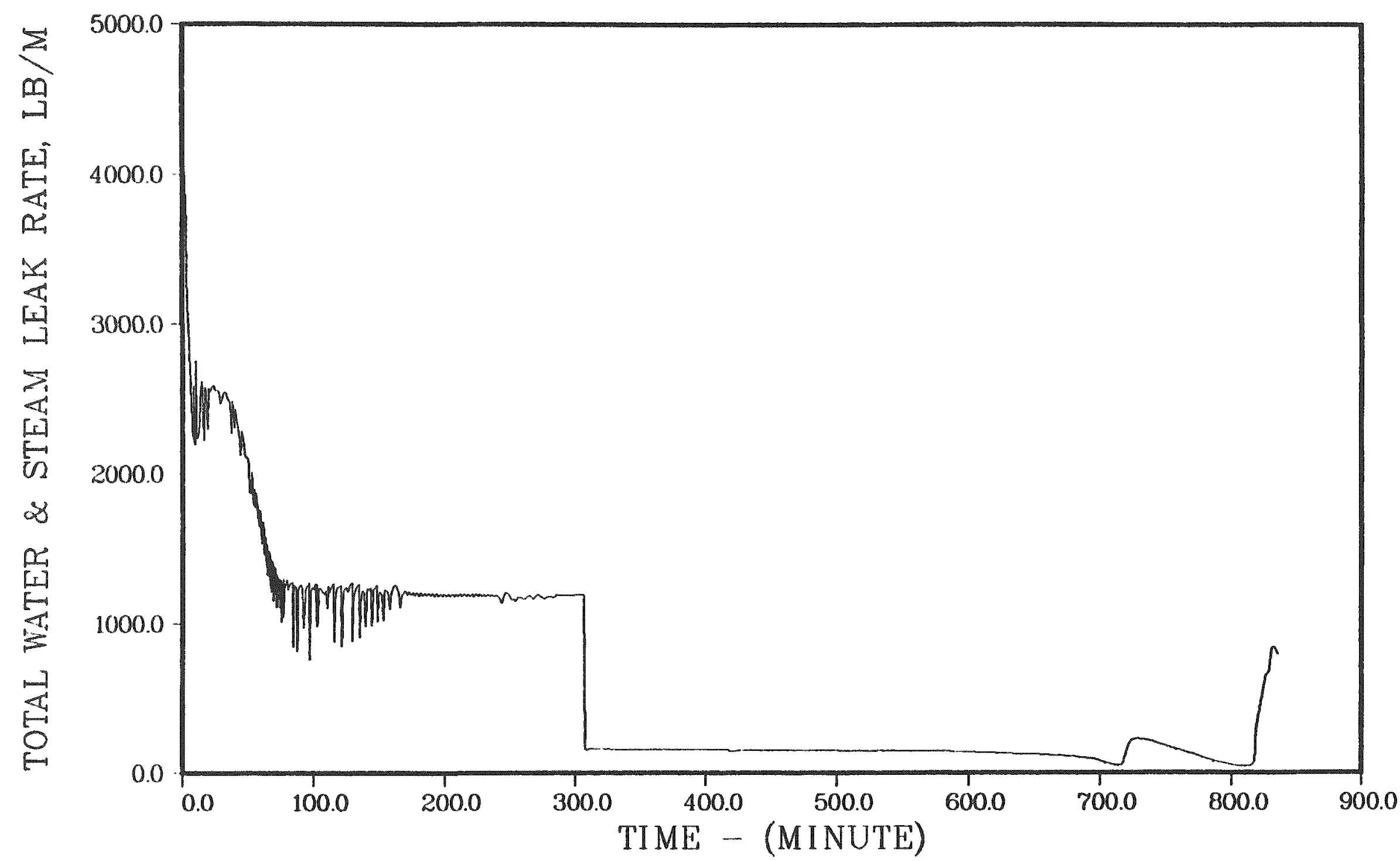

Figure 4.2.33. Primary system leakage - very small break with ECCS failure and AFW on. 


\section{SURRY S3DX}

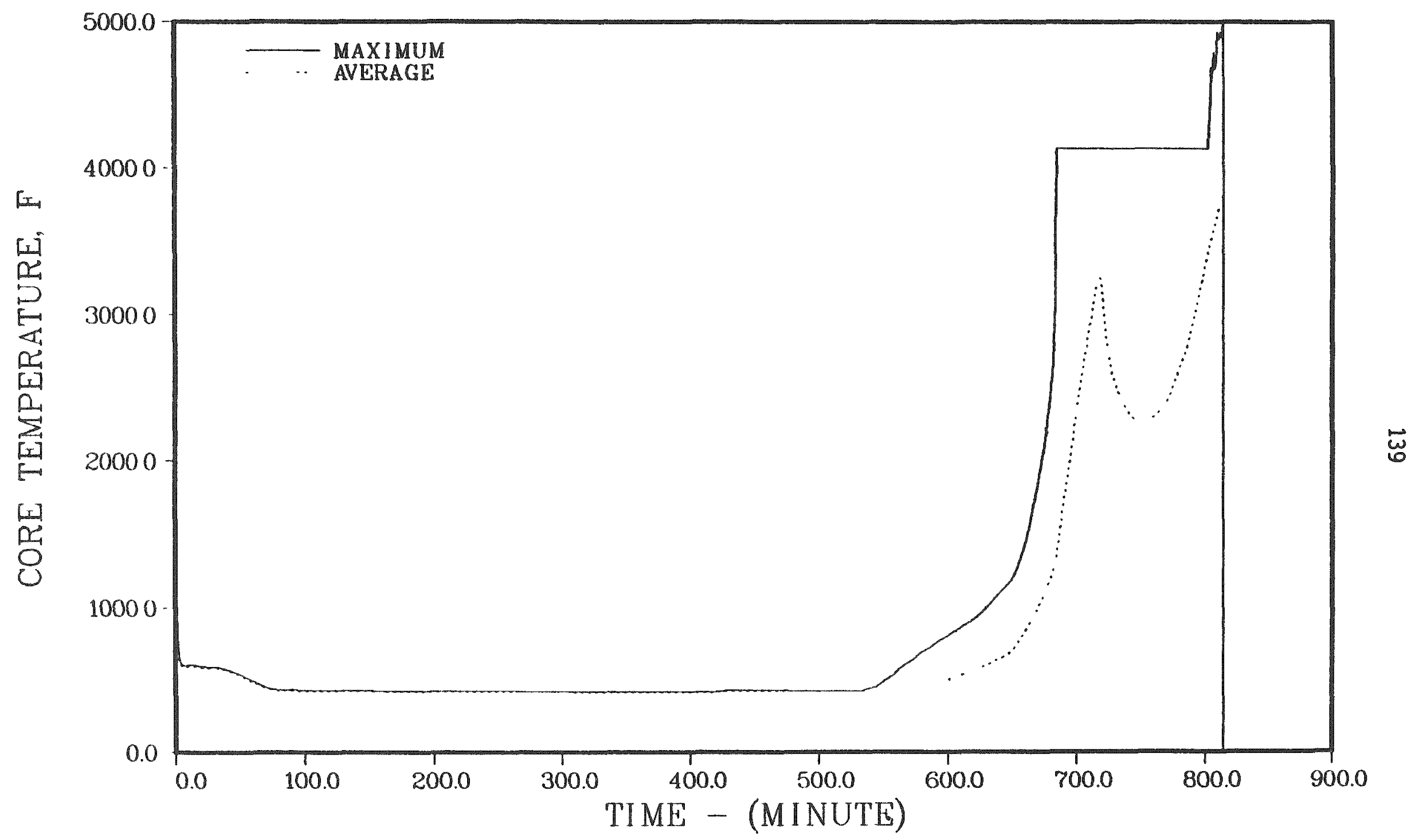

Figure 4.2.34. Maximum and average core temperatures - very small break with ECCS failure and AFW on. 


\section{SURRY S3DX}

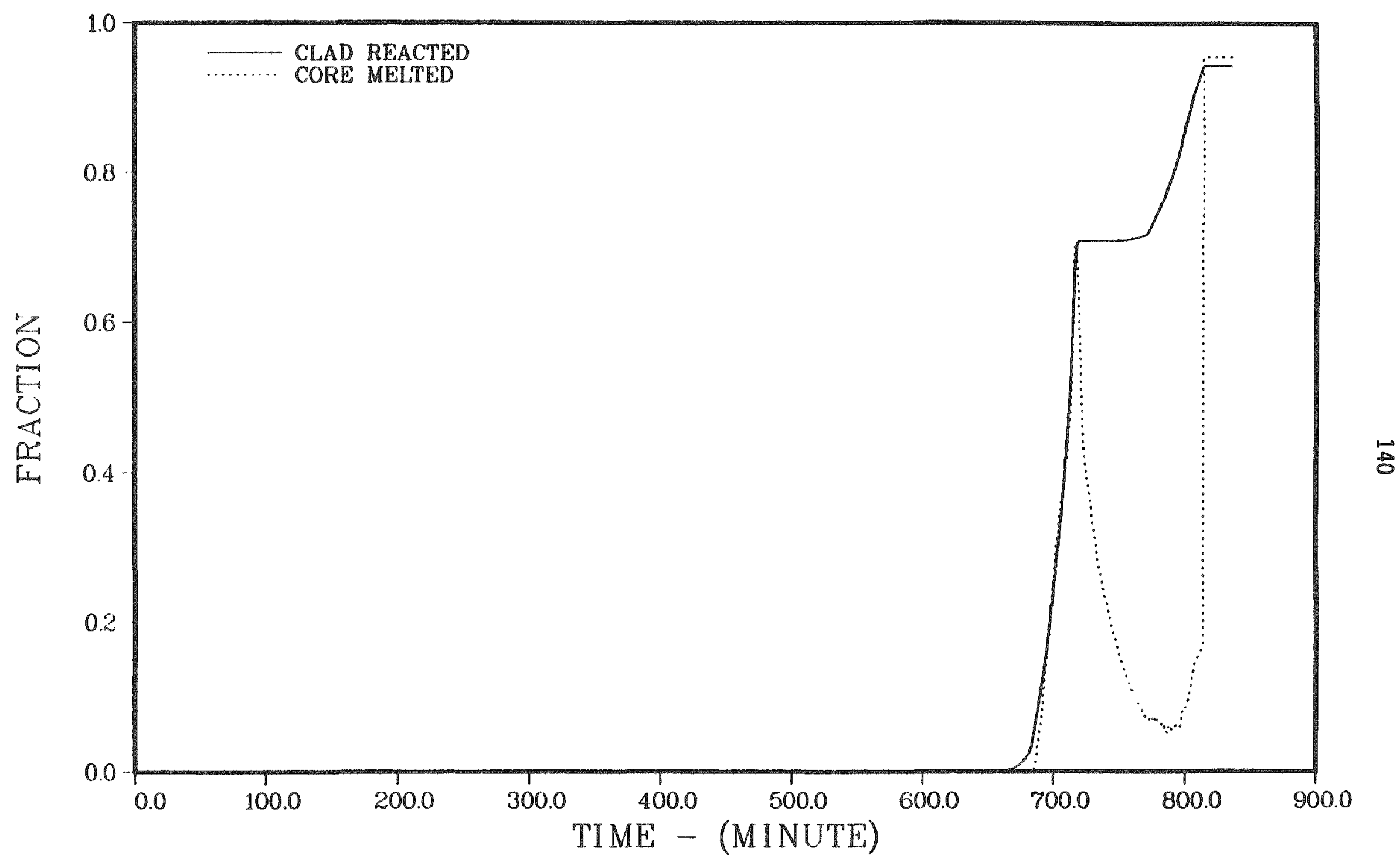

Figure 4.2.35. Fractions of cladding reacted and core melted - very small break with ECCS failure and AFW on. 
core and those exiting the primary system are shown in Figure 4.2.36.

\section{CONTAINMENT RESPONSE - SURRY $S_{3}$ DX (with secondary depressurization)}

The conditions in the containment at key times during the accident progression are summarized in Table 4.2.19. The containment coolers are able to maintain the containment pressure below the spray actuation point until the time of reactor vessel failure, as can be seen in the containment pressure and temperature histories given in Figures 4.2.37 and 4.2.38. The debris are released to an initially dry cavity, but water accumulates over the debris subsequently due to spray operation. Immediately after reactor vessel failure the containment contains $1436 \mathrm{lb}$ of hydrogen, with corresponding mole fractions of 0.090 hydrogen, 0.078 oxygen, and 0.536 steam. At the end of the calculation, after ten hours of concrete attack there are $2379 \mathrm{lb}$ of hydrogen, with corresponding mole fractions of 0.235 hydrogen, 0.123 oxygen and 0.168 steam. The buildup of hydrogen in the containment is shown in Figure 4.2.39. The mole fractions of the principal constituents of the containment atmosphere are illustrated in Figure 4.2.40.

\section{PRIMARY SYSTEM RESPONSE - SURRY $S_{3} D Z$}

(with primary and secondary depressurization)

In a variation of the foregoing scenario the PORVs were assumed to be opened when the average core exit gas temperature reached $1200 \mathrm{~F}$, in accordance with emergency operating procedures. In the foregoing case this exit gas temperature was predicted to be reached at 658 minutes into the accident. With the opening of the PORVs coolant loss from the primary system was somewhat more rapid, leading to earlier core slumping and collapse. Table 4.2.20 provides times for key events. Table 4.2.21 tabulates core and primary system conditions. The primary system pressure history and coolant leakage for this case are illustrated in Figures 4.2.41 and 4.2.42. Under the assumption of a failure of a penetration, head failure was predicted at 804 minutes. However, since the primary system is essentially depressurized, gross head failure may be a more appropriate failure mode. With the latter 


\section{SURRY S3DX}

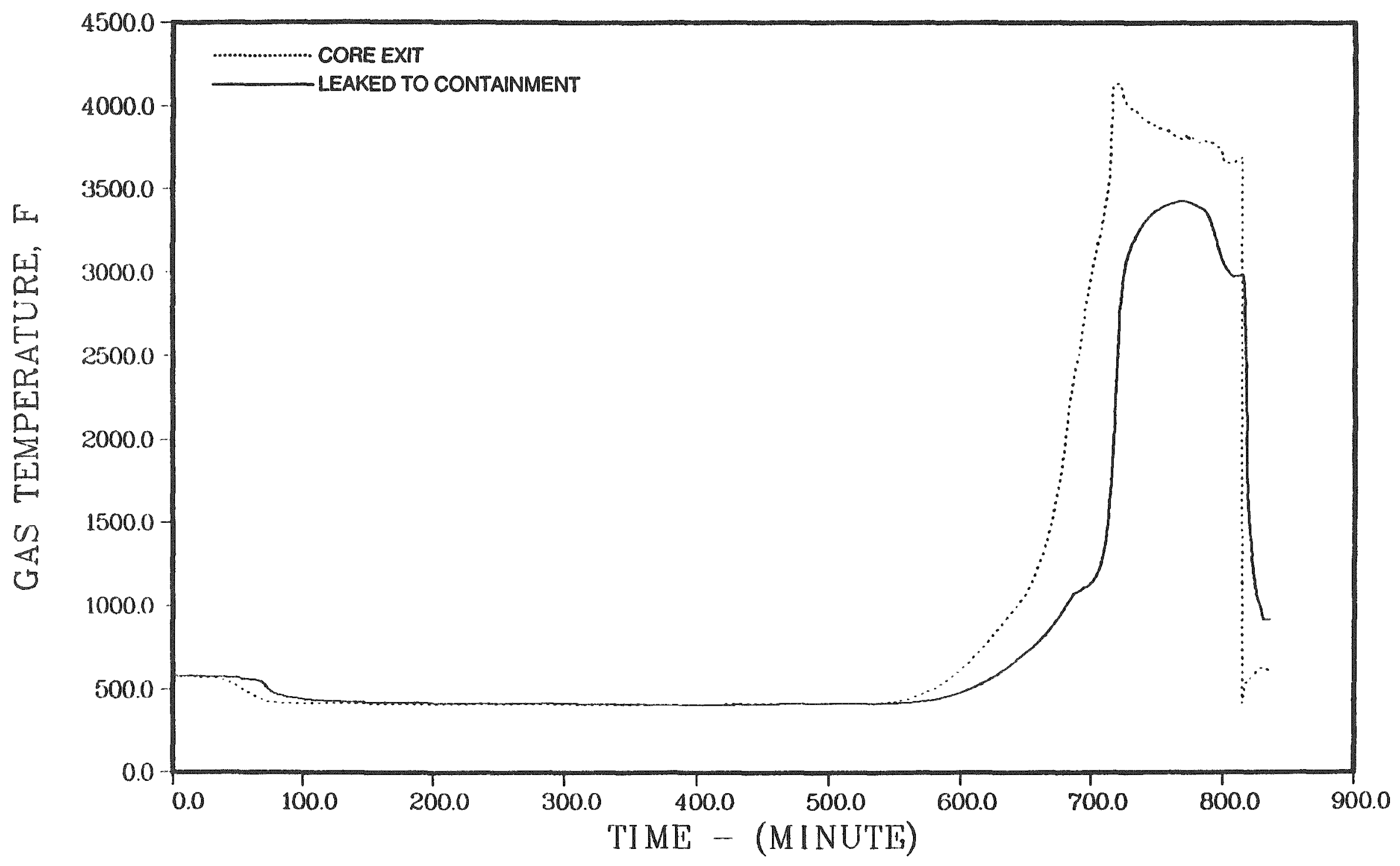

Figure 4.2.36. Temperatures of gases leaving the core and exiting the primary system - very small break with ECCS failure and AFW on. 
Table 4.2.19 Containaent response - Surry $S_{3} D X$

\begin{tabular}{|c|c|c|c|c|c|c|c|c|}
\hline \multirow[b]{2}{*}{$\begin{array}{l}\text { Accident } \\
\text { Event }\end{array}$} & \multirow[b]{2}{*}{$\begin{array}{l}\text { Time, } \\
\text { minutes }\end{array}$} & \multicolumn{2}{|c|}{ Containaent } & \multirow{2}{*}{$\begin{array}{c}\text { Containment } \\
\text { Wail Staam } \\
\text { Condensation, } \\
\text { Ib/ }\end{array}$} & \multicolumn{2}{|c|}{ Sump Water } & \multicolumn{2}{|c|}{ Reactor Cavity Water } \\
\hline & & $\begin{array}{l}\text { Pressure. } \\
\text { Psia }\end{array}$ & Texperature & & $\begin{array}{l}\text { Mass, } \\
\mathrm{Ib}\end{array}$ & Temp.: & $\begin{array}{l}\text { Mass } \\
16\end{array}$ & $\operatorname{Temp}_{\mathrm{F}}$ \\
\hline Coro uncovery & 525.4 & 13.1 & 136 & 85 & $4.65 \times 10^{5}$ & 136 & 0.0 & -- \\
\hline Start melt & 684.7 & 13. & 136 & 104 & $4.87 \times 10^{5}$ & 135 & 0.0 & $-\infty$ \\
\hline Core slump & 813.8 & 17.9 & 162 & 23 & $4.93 \times 16^{5}$ & 135 & 0.0 & -- \\
\hline Core collapse & 814.3 & 17.9 & 162 & 22 & $4.23 \times 10^{5}$ & 135 & T. & -- \\
\hline Bottom head failure & 835.6 & 19.5 & 174 & 382 & $4.98 \times 10^{5}$ & 135 & 0.0 & $-\cdots$ \\
\hline Start concrete attack & 835.4 & 31.8 & 212 & 12010 & 5. $1 \times 10^{5}$ & 136 & 6 & $-\infty$ \\
\hline $\begin{array}{l}\text { Containment spray on } \\
\text { Containsent spray }\end{array}$ & 935.7 & 36.9 & 217 & 9815 & $5.05 \times 10^{5}$ & 137 & 0.0 & $-\infty$ \\
\hline pecirculation on & 939.4 & 12.8 & 85 & 6 & $2.74 \times 10^{6}$ & 95 & $3.75 \times 10^{5}$ & 186 \\
\hline End calculation & 1435.4 & 18.5 & 143 & 120 & $2.43 \times 16^{6}$ & 140 & $8.96 \times 10^{5}$ & 224 \\
\hline
\end{tabular}




\section{SURRY S3DX}

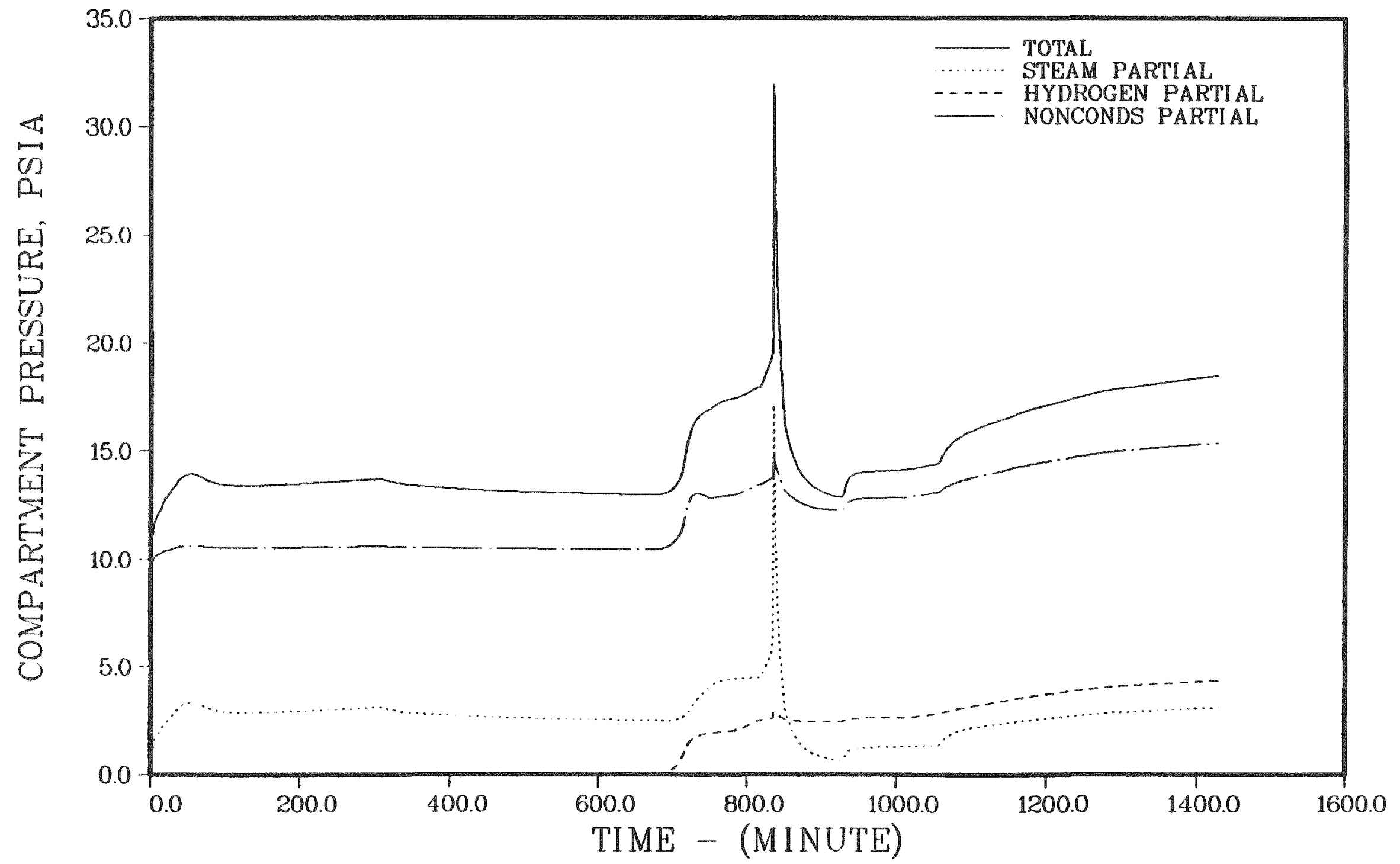

Figure 4.2.37. Containment pressure history - very small break with ECCS failure and AFW on. 


\section{SURRY S3DX}

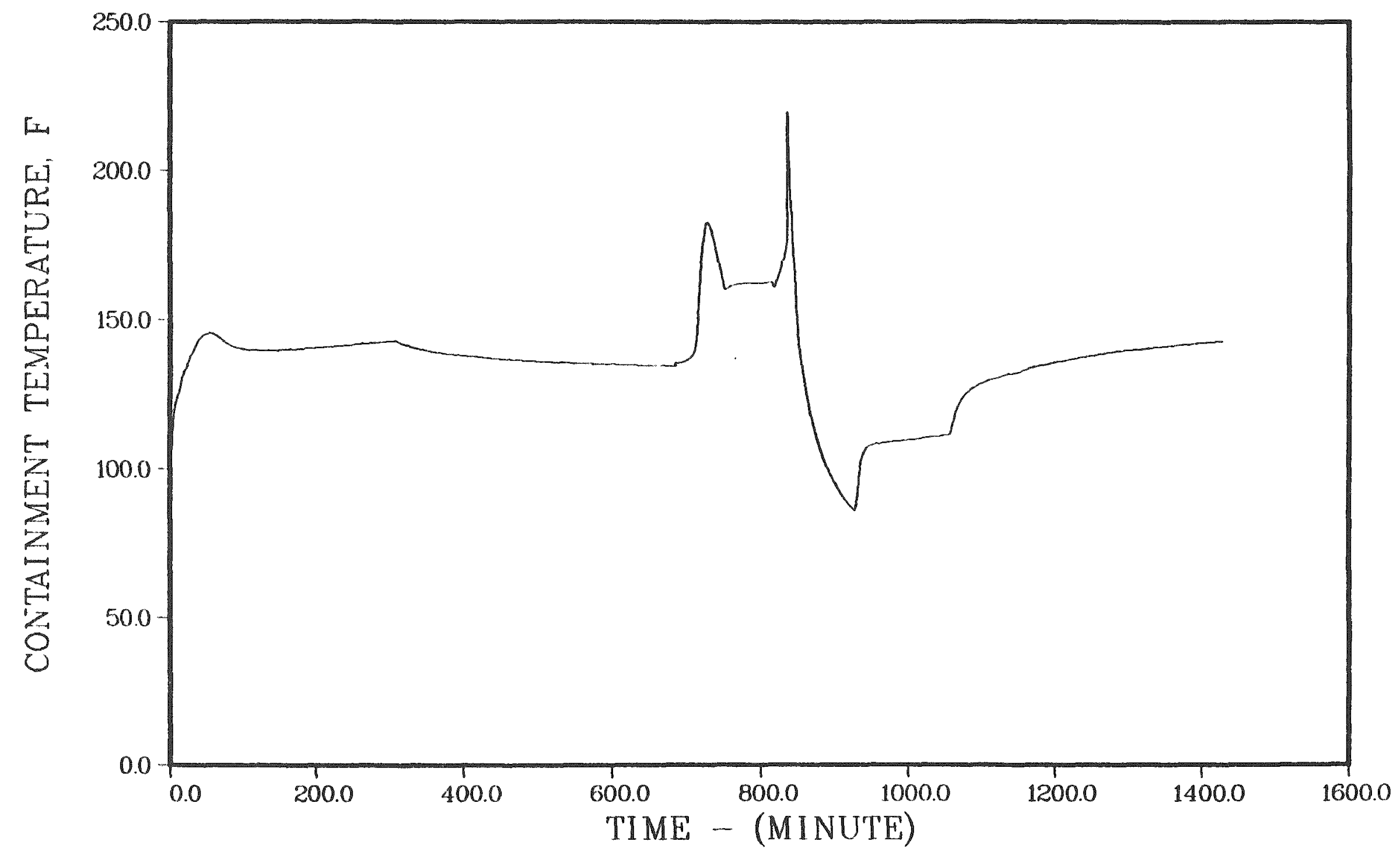

Figure 4.2.38. Containment temperature history - very small break with ECCS failure and AFW on. 


\section{SURRY S3DX}

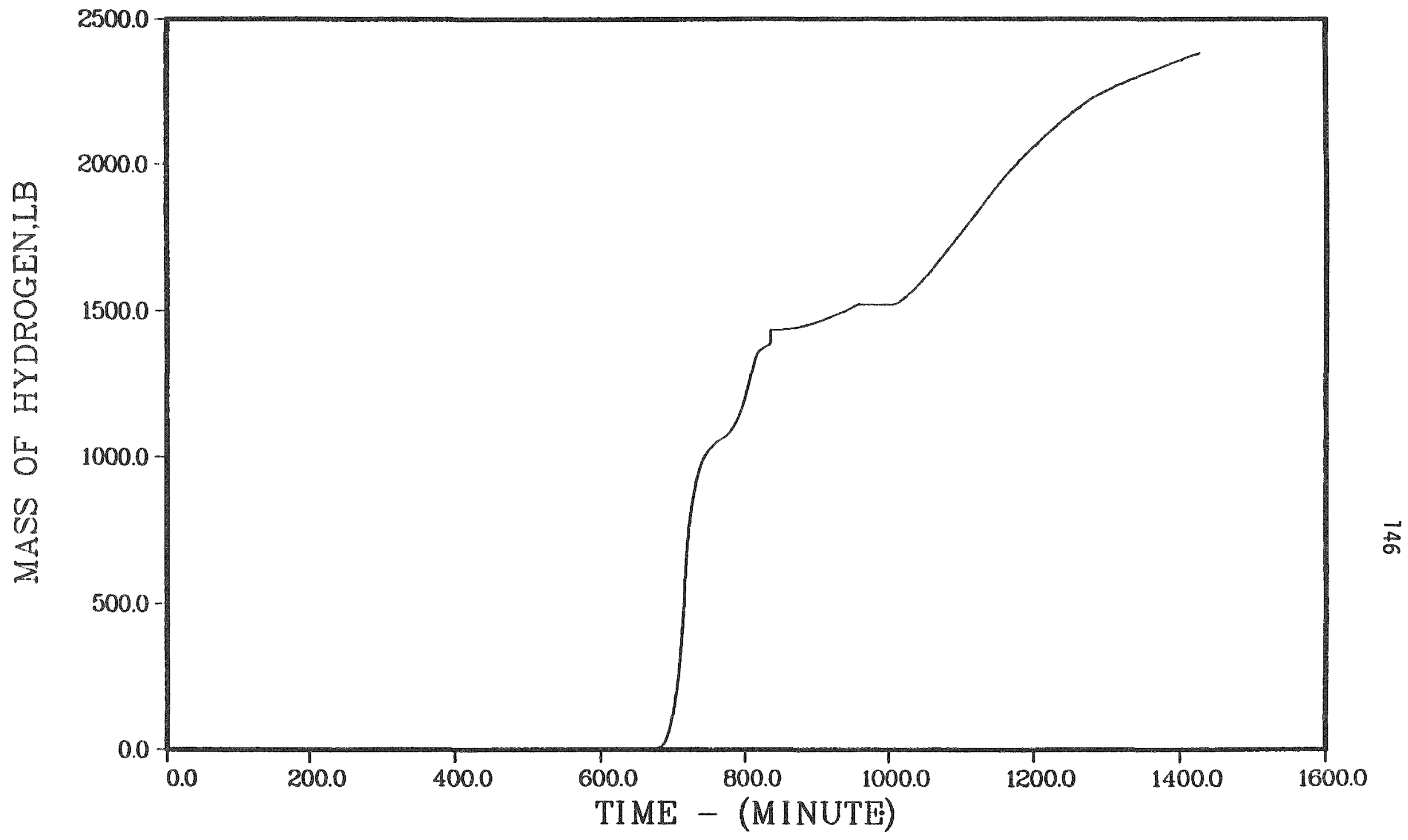

Figure 4.2.39. Hydrogen in the containment - very small break with ECCS failure and AFW on. 


\section{SURRY S3DX}

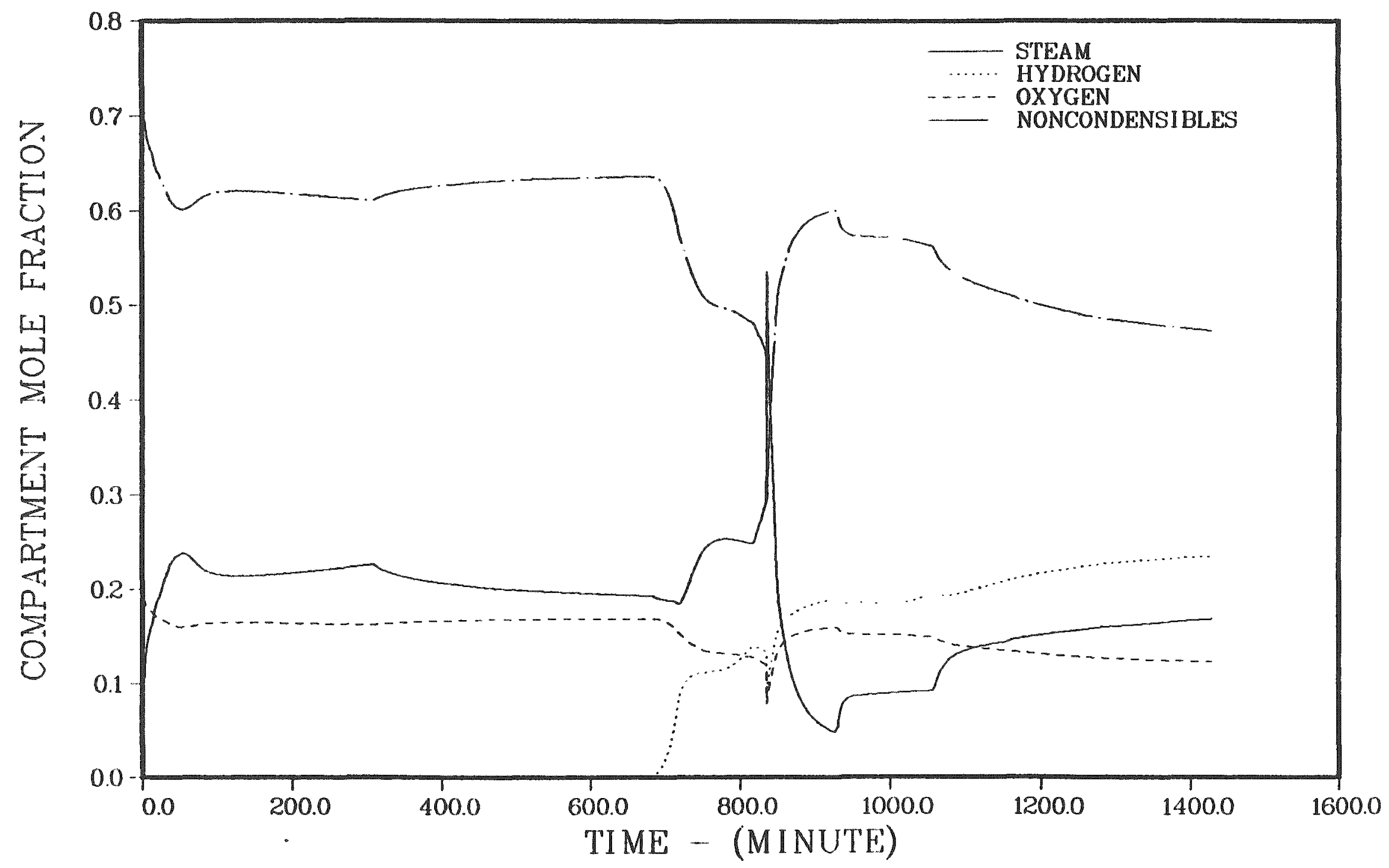

Figure 4.2.40. Containment atmosphere composition - very small break with ECCS failure and AFW on. 
Table 4.2.20. Timing of key events - Surry $S_{3} D Z$

\begin{tabular}{lr}
\hline \hline Event & Time, \\
& Minutes \\
& \\
RCP seal LOCA initiated & 0.0 \\
Containment coolers on & 1.0 \\
Start steam generator depressurization & 30.0 \\
End steam generator depressurization & 60.0 \\
Accumulator discharge & $40-80$ \\
Core uncovery & 525.4 \\
PoRVs open & 658.0 \\
Start melt & 687.3 \\
Core slump & 707.9 \\
Core collapse & 716.7 \\
Bottom head dryout & 740.6 \\
Bottom head failure & 849.1 \\
Start concrete attack & 850.1 \\
Corium layers invert & 921.1 \\
End calculation & 1450.1 \\
& \\
\hline \hline
\end{tabular}


Table 4.2.21. Core and primary systell respense - Surry $S_{3} D Z$

\begin{tabular}{|c|c|c|c|c|c|c|c|}
\hline $\begin{array}{l}\text { Accident } \\
\text { Event }\end{array}$ & $\begin{array}{c}\text { Time, } \\
\text { inutes }\end{array}$ & $\begin{array}{l}\text { Prinary } \\
\text { Syster } \\
\text { Pressure, } \\
\text { psia }\end{array}$ & $\begin{array}{l}\text { Primary } \\
\text { Syster } \\
\text { Water } \\
\text { Inventory, } \\
\quad \text { Ib }\end{array}$ & $\begin{array}{c}\text { Average Core } \\
\text { Temperature, } \\
\text { of }\end{array}$ & $\begin{array}{l}\text { Peak Core } \\
\text { Temperature, } \\
\text { Of }\end{array}$ & $\begin{array}{c}\text { Fraction } \\
\text { Core } \\
\text { Melted }\end{array}$ & $\begin{array}{c}\text { Fraction } \\
\text { Clad } \\
\text { Reacted }\end{array}$ \\
\hline $\begin{array}{l}\text { Accumul ators } \\
\text { empty }\end{array}$ & 80.5 & 319 & $4.22 \times 10^{5}$ & 431 & 438 & -- & --- \\
\hline Core uncovery & 525.4 & 270 & $1.15 \times 18^{5}$ & 424 & 427 & 0.6 & 0 \\
\hline Start malt & 687.3 & 143 & $0.54 \times 17^{4}$ & 1666 & 4130 & 0.0 & 0.06 \\
\hline Core sluap & 797.9 & 53 & $7.76 \times 17$ & 3646 & 4140 & 0.60 & 18.56 \\
\hline Core collapse & 716.7 & 140 & $7.52 \times 10^{4}$ & 2859 & $-\infty$ & 0.88 & 0.7 . \\
\hline Botto head dryout & 7418.8 & 224 & $2.87 \times 1)^{4}$ & 1946 & $\cdots$ & $-\cdots$ & 9.76 \\
\hline Botton head failur & 849.1 & 22 & $2.35 \times 11^{4}$ & 3747 & $\cdots$ & -- & 0.76 \\
\hline
\end{tabular}

* Water rotained in low points of primary system piping. 


\section{SURRY S3DZ}

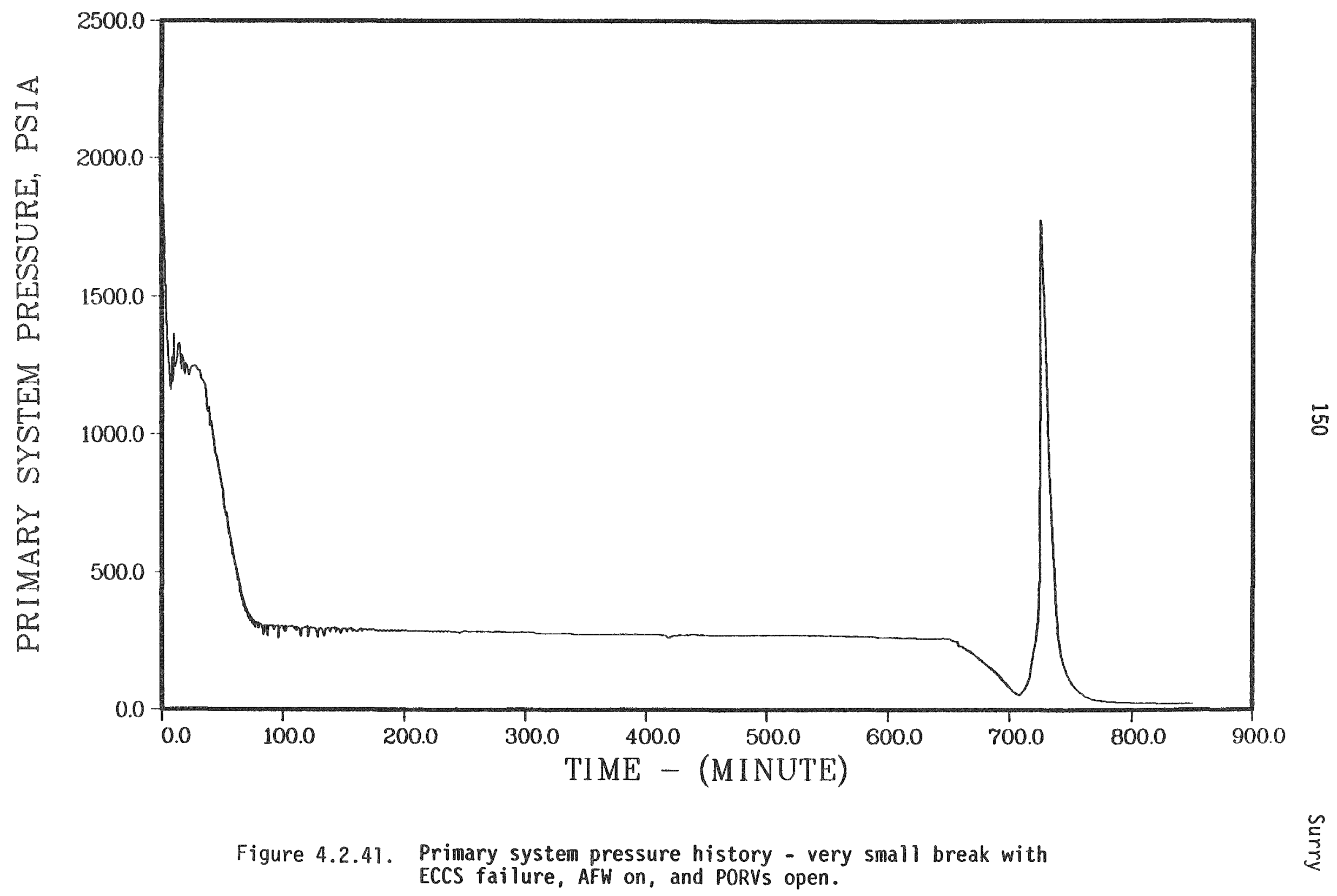




\section{SURRY S3DZ}

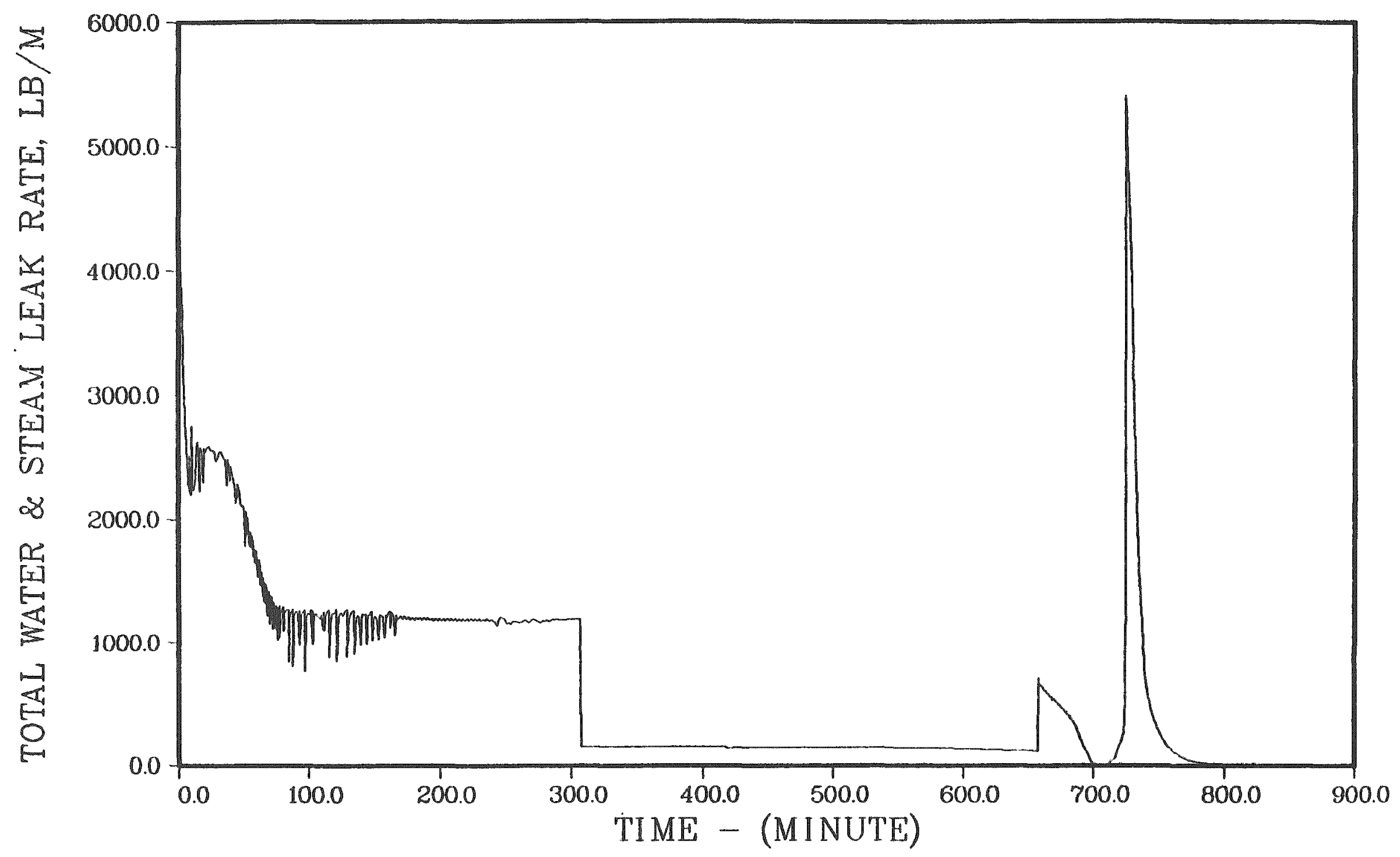

Figure 4.2.42. Primary system leakage - very small break with ECCS failure, AFW on, and PORVs open. 
assumption bottom head failure would be predicted at 849 minutes. The peak and average core temperatures are shown in Figure $4.2 .43 ;$ the fractions cladding reacted and core melted are given in Figure 4.2.44. The temperatures of the gases leaving the top of the core and exiting the primary system are illustrated in Figure 4.2.45. The case with the opening of the PORVs is more typical and does not show the peculiar interaction between the steam generator heat transfer and core slumping of the preceding case.

\section{CONTAINMENT RESPONSE - SURRY $S_{3} D Z$ (with primary and secondary depressurization)}

Containment conditions are provided in Table 4.2.22. Containment pressure and temperature histories for the case with PORV opening and a gross head failure mode are given in Figures 4.2 .46 and 4.2.47. There are $10731 \mathrm{~b}$ of hydrogen in the containment immediately after vessel failure; this corresponds to mole fractions of 0.108 hydrogen, 0.125 oxygen, and 0.299 steam. At the end of the calculation after ten hours of concrete attack, there are $23401 \mathrm{~b}$ of hydrogen, with corresponding mole fraction of 0.201 hydrogen, 0.107 oxygen, and 0.254 steam. Hydrogen buildup in the containment is illustrated in Figure 4.2.48. The mole fractions of the principal constituents of the containment atmosphere are shown in Figure 4.2.49.

\section{PRIMARY SYSTEM RESPONSE - $S_{2} D$ (with primary and secondary depressurization)}

The calculated timing of the principal accident events is summarized in Table 4.2.23. Core and primary system conditions at key times during the accident progression are summarized in Table 4.2.24. Coolant leakage through the break together with heat removal by the steam generator lead to the rapid depressurization of the primary system in this sequence, as can be seen in Figure 4.2.50. The accumulator discharge pressure is reached shortly after initial core uncovery. The accumulator water is discharged and recovers the core; thus, significant core heatup is delayed until after boiloff of the accumulator water. The average core exit gas temperature reaches $1200 \mathrm{~F}$ at 148 minutes; the PORV'S were opened at this time. Coolant leakage from the primary system is illustrated in Figure 4.2.51. Peak and average core 


\section{SURRY S3DZ}

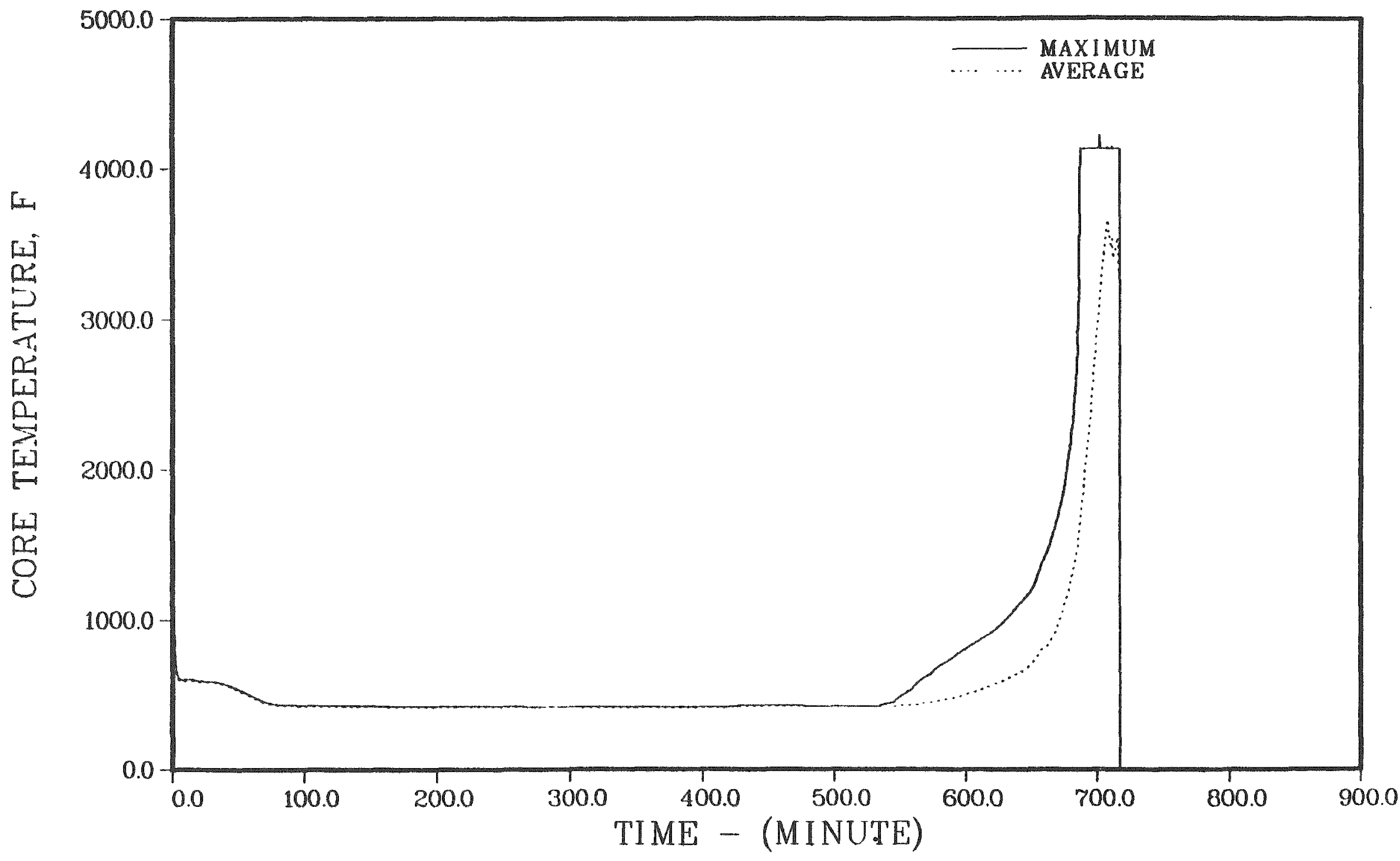

Figure 4.2.43. Maximum and average core temperatures - very small break 


\section{SURRY S3DZ}

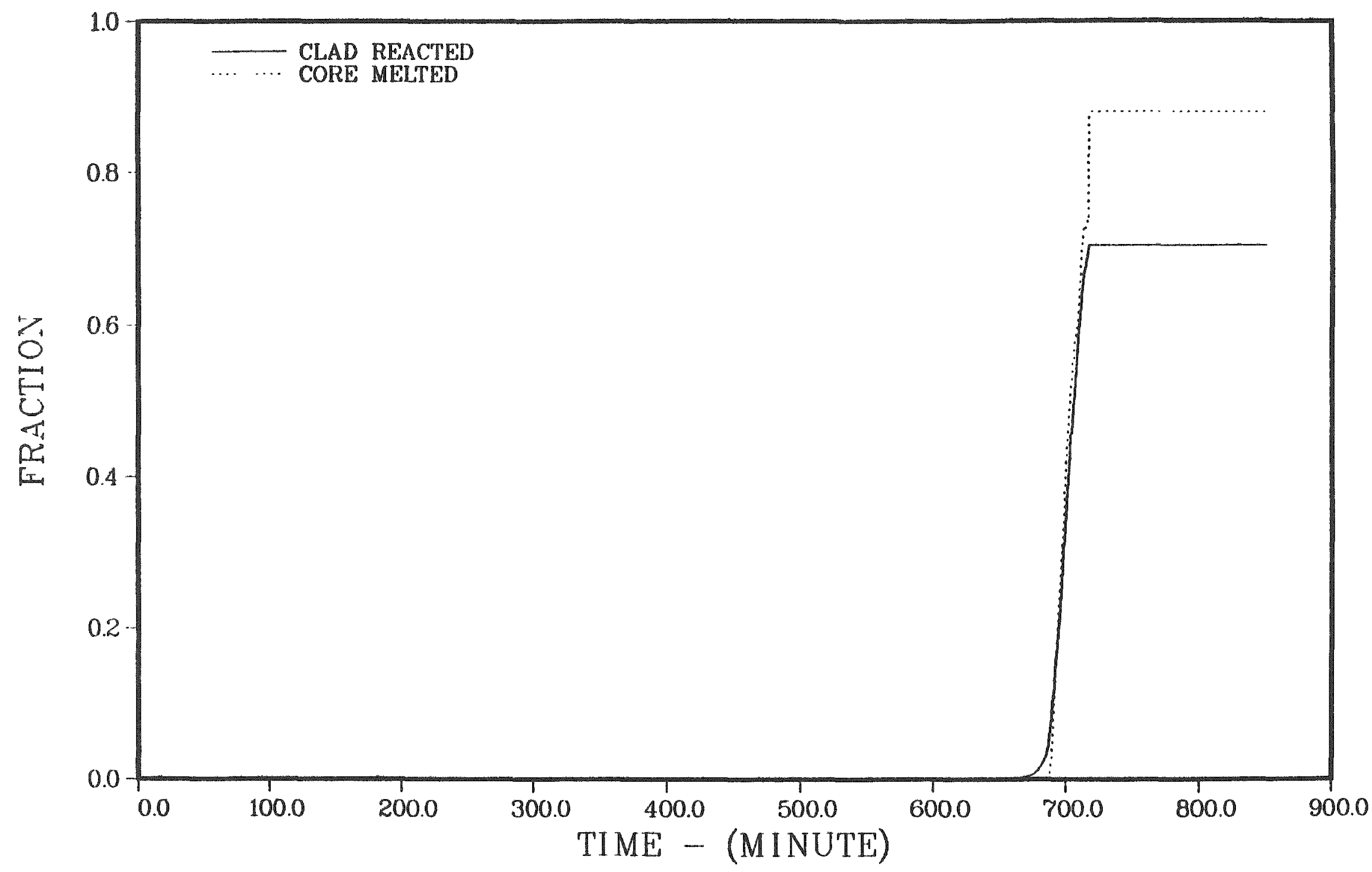

Figure 4.2.44. Fractions of cladding reacted and core melted - very small break with ECCS failure, AFW on, and PORVs open. 


\section{SURRY S3DZ}

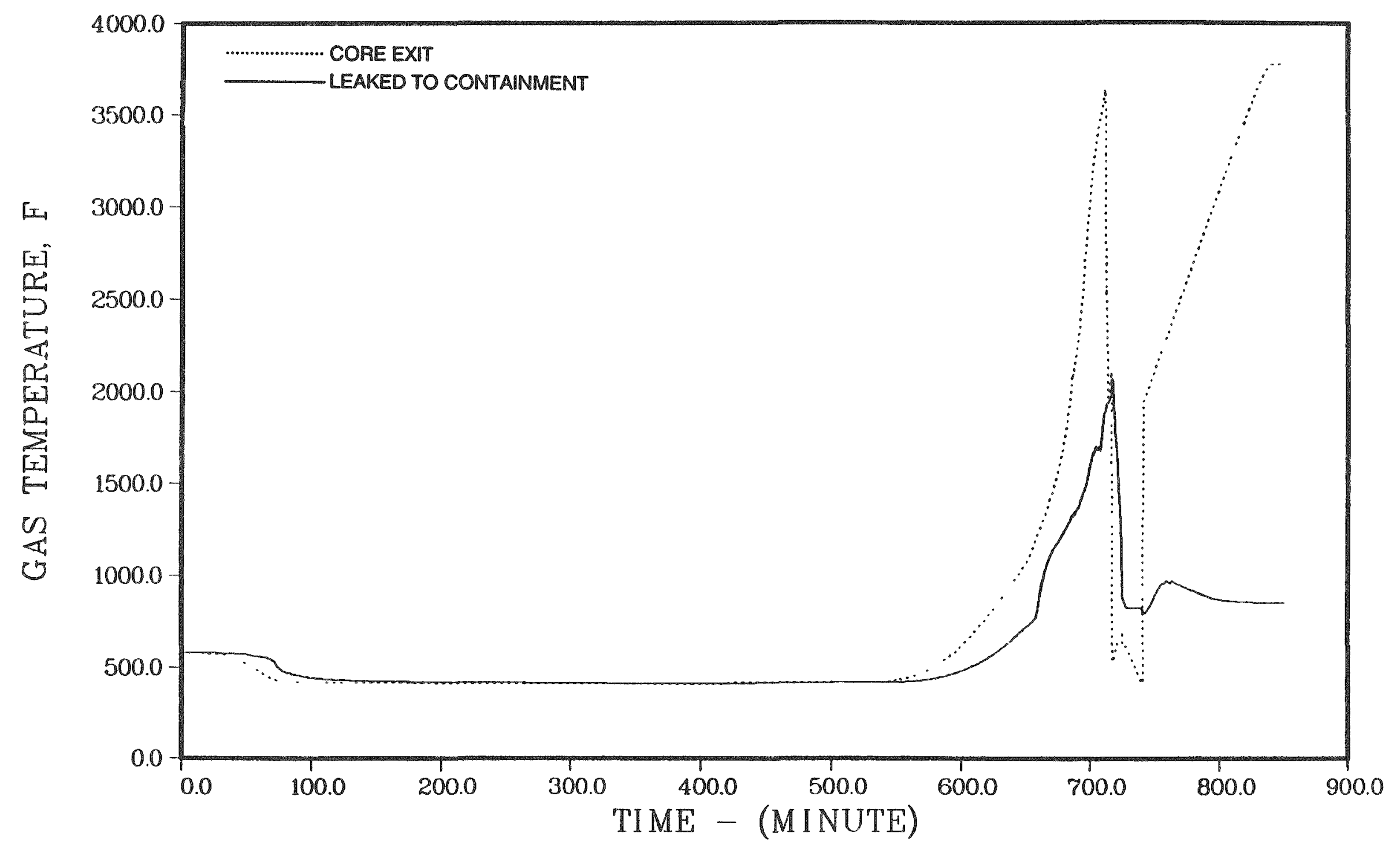

Figure 4.2.45. Temperatures of gases leaving the core and exiting the primary system - very 
Tabl 4.2.22 Containeent respons - Surry $S_{3} D Z$

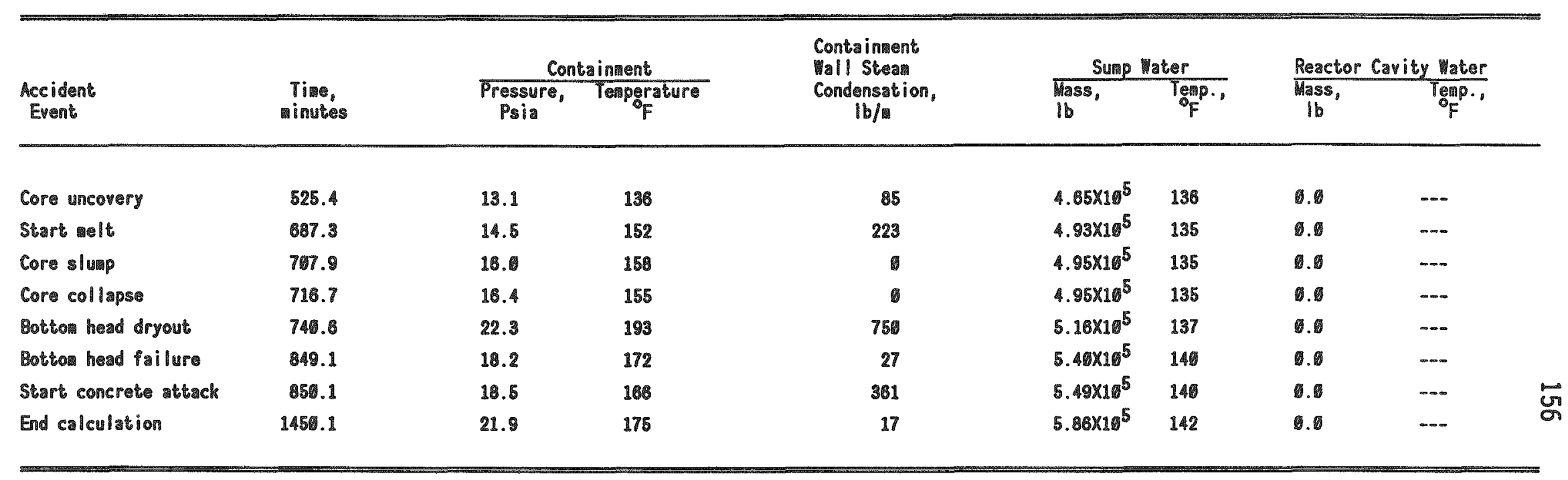




\section{SURRY S3DZ}

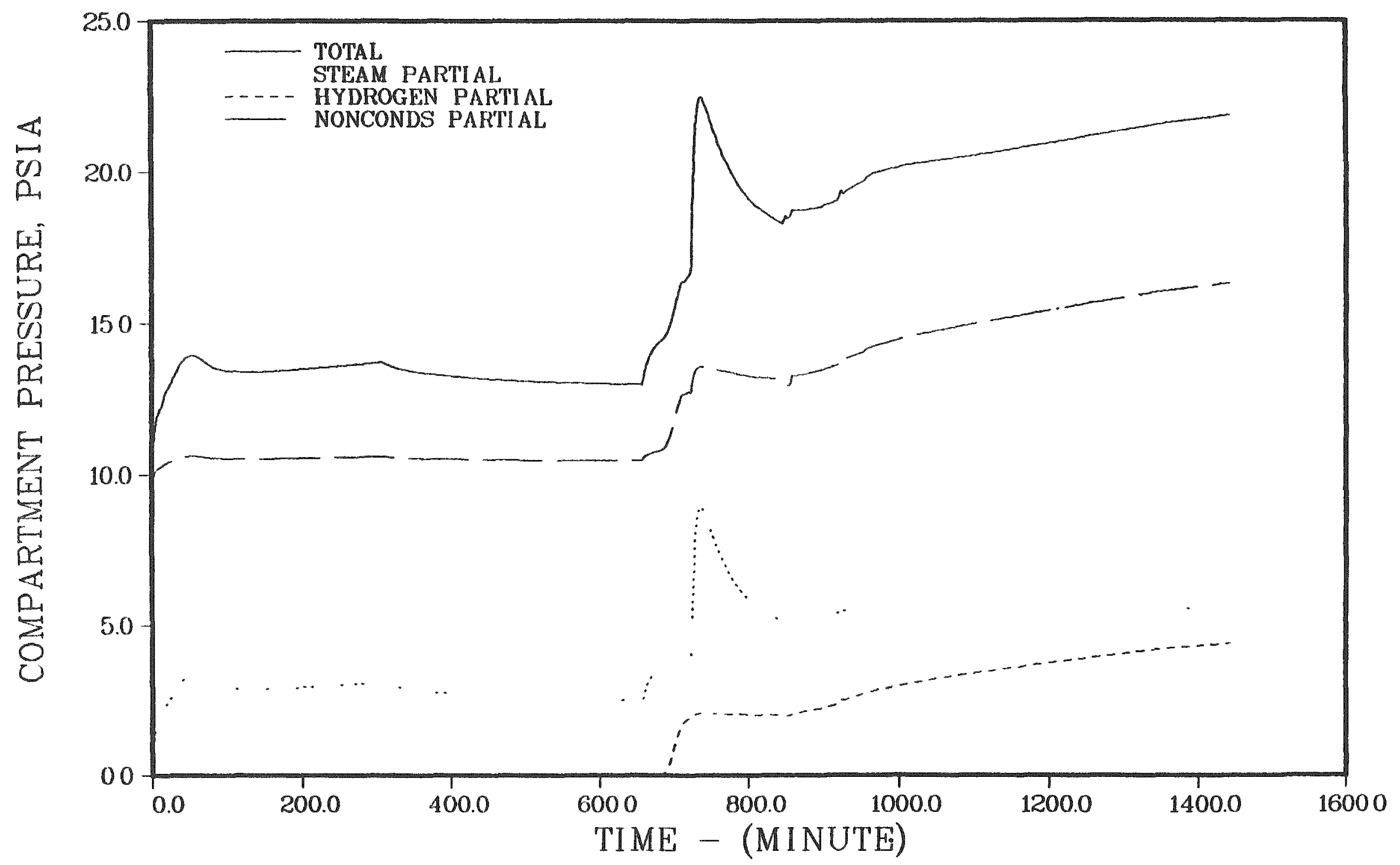

Figure 4.2.46. Containment pressure history - very small break with ECCS failure, AFW on, and PORVs open. 


\section{SURRY S3DZ}

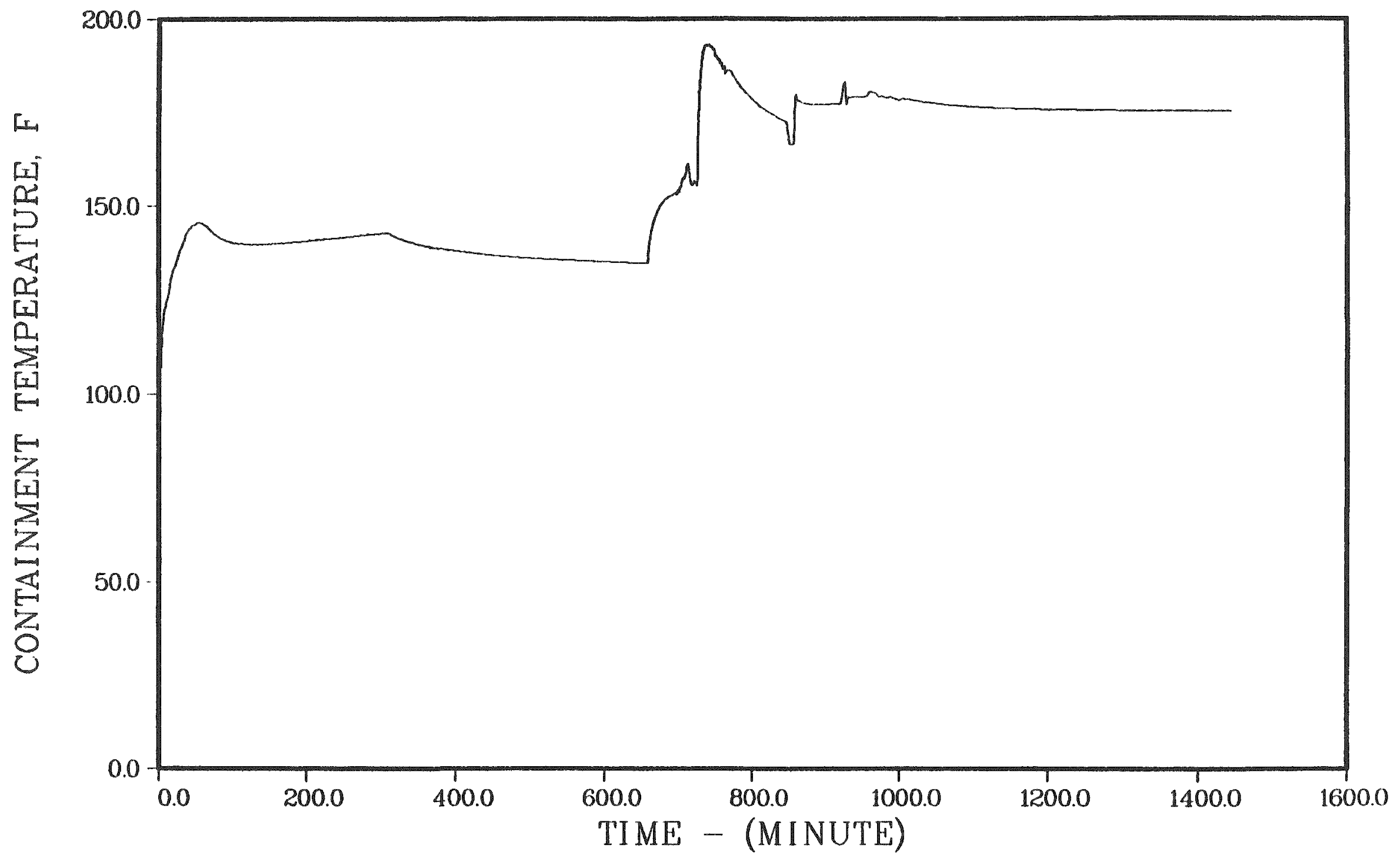

Figure 4.2.47. Containment temperature history - very small break with ECCS failure, AFW on, and PORVs open. 


\section{SURRY S3DZ}

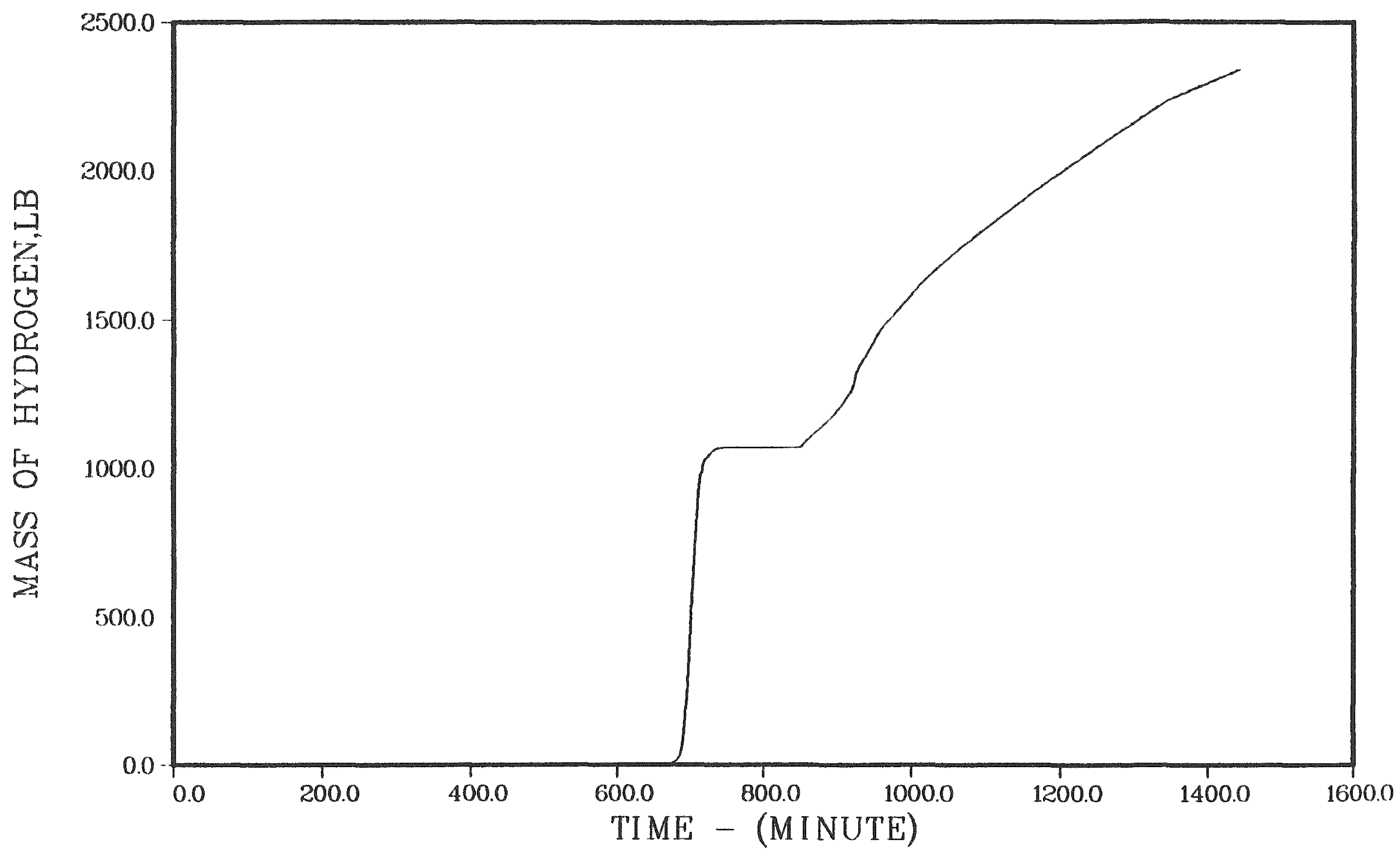

Figure 4.2.48. Hydrogen in the containment - very small break with 


\section{SURRY S3DZ}

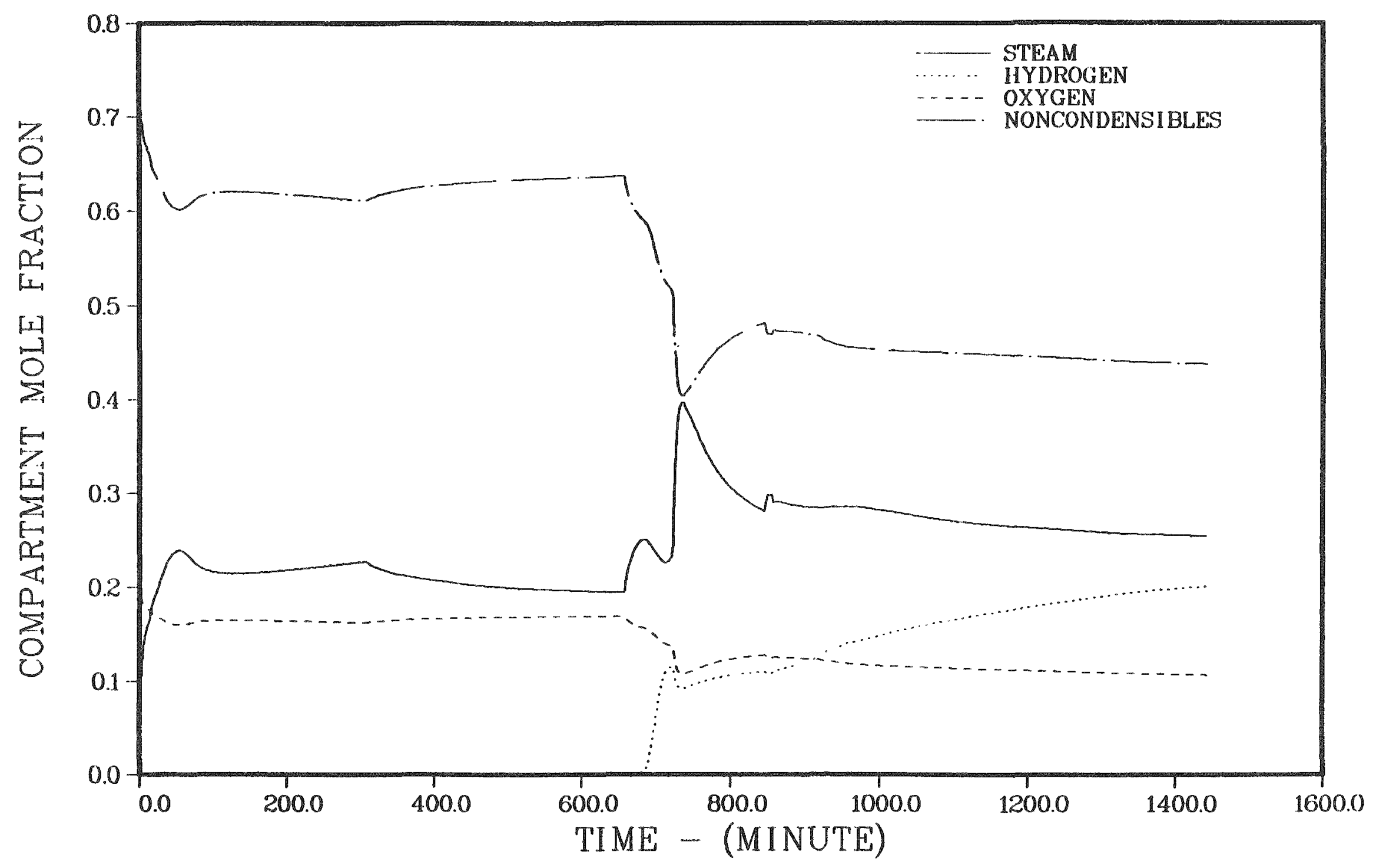

Figure 4.2.49. Containment atmosphere composition - very small break with ECCS failure, AFW on, and PORVs open. 
Table 4.2.23. Timing of key events - Surry $S_{2} D$

Event

Time,

Minutes

Containment coolers on

Start steam generator depressurization

Core uncovery

Accumulators empty

End steam generator depressurization

Core uncovery

PORVS open

Start melt

Core slump

Core collapse

Containment spray on

Bottom head dryout

Containment spray recirculation on

Bottom head failure

Start concrete attack

1.0

$30.0 *$

41.3

44-65

60.0 *

114.7

148.0

161.6

176.8

180.6

188.0

209.2

282.4

314.4

315.5

Corium layers invert

372.5

End calculation

915.5

* From sequence definition 
Table 4.2.24. Core and primary system response - Surry $S_{2} D$

\begin{tabular}{|c|c|c|c|c|c|c|c|}
\hline $\begin{array}{l}\text { Accident } \\
\text { Event }\end{array}$ & $\begin{array}{l}\text { Time, } \\
\text { minutes }\end{array}$ & $\begin{array}{l}\text { Primary } \\
\text { System } \\
\text { Pressure, } \\
\text { psia }\end{array}$ & $\begin{array}{l}\text { Primary } \\
\text { System } \\
\text { Matrer } \\
\text { Imventory. } \\
\quad \text { Ib }\end{array}$ & $\begin{array}{c}\text { Average Core } \\
\text { Temperature, } \\
\text { of }\end{array}$ & $\begin{array}{l}\text { Peak Core } \\
\text { Temperature, } \\
\text { of }\end{array}$ & $\begin{array}{l}\text { Fraction } \\
\text { Core } \\
\text { Melted }\end{array}$ & $\begin{array}{c}\text { Fraction } \\
\text { Clad } \\
\text { Reacted }\end{array}$ \\
\hline Core uncovery & 41.3 & 853 & 1. $2 \times 10^{5}$ & 547 & 554 & 0.0 & 0.0 \\
\hline $\begin{array}{l}\text { Accura lators } \\
\text { ompty }\end{array}$ & 64.6 & 317 & $1.86 \times 16^{5}$ & 434 & 440 & $-\infty$ & $-\infty$ \\
\hline Core uncovery & 114.7 & 278 & $1.13 \times 10^{5}$ & 427 & 432 & -- & --- \\
\hline Start molt & 161.6 & 124 & $.23 \times 10$ & 1758 & 4135 & 0.6 & 2.05 \\
\hline Core slump & 176.8 & 46 & $7.52 \times 10^{4}$ & 3875 & 4152 & 6.63 & 0.51 \\
\hline Core collapso & 189.6 & 77 & $7.35 \times 10^{4}$ & 3262 & $-\infty$ & .82 & .61 \\
\hline Botton head dryout & 290.2 & 391 & $2.84 \times 10^{4}$ & 1244 & -- & $m$ & 0.62 \\
\hline Bottow head failure & 314.4 & 18 & $2.23 \times 10^{4} \cdot$ & 3745 & -- & $-\infty-$ & .62 \\
\hline
\end{tabular}

* Water rotained in low points of primary system piping. 


\section{SURRY SRDY}

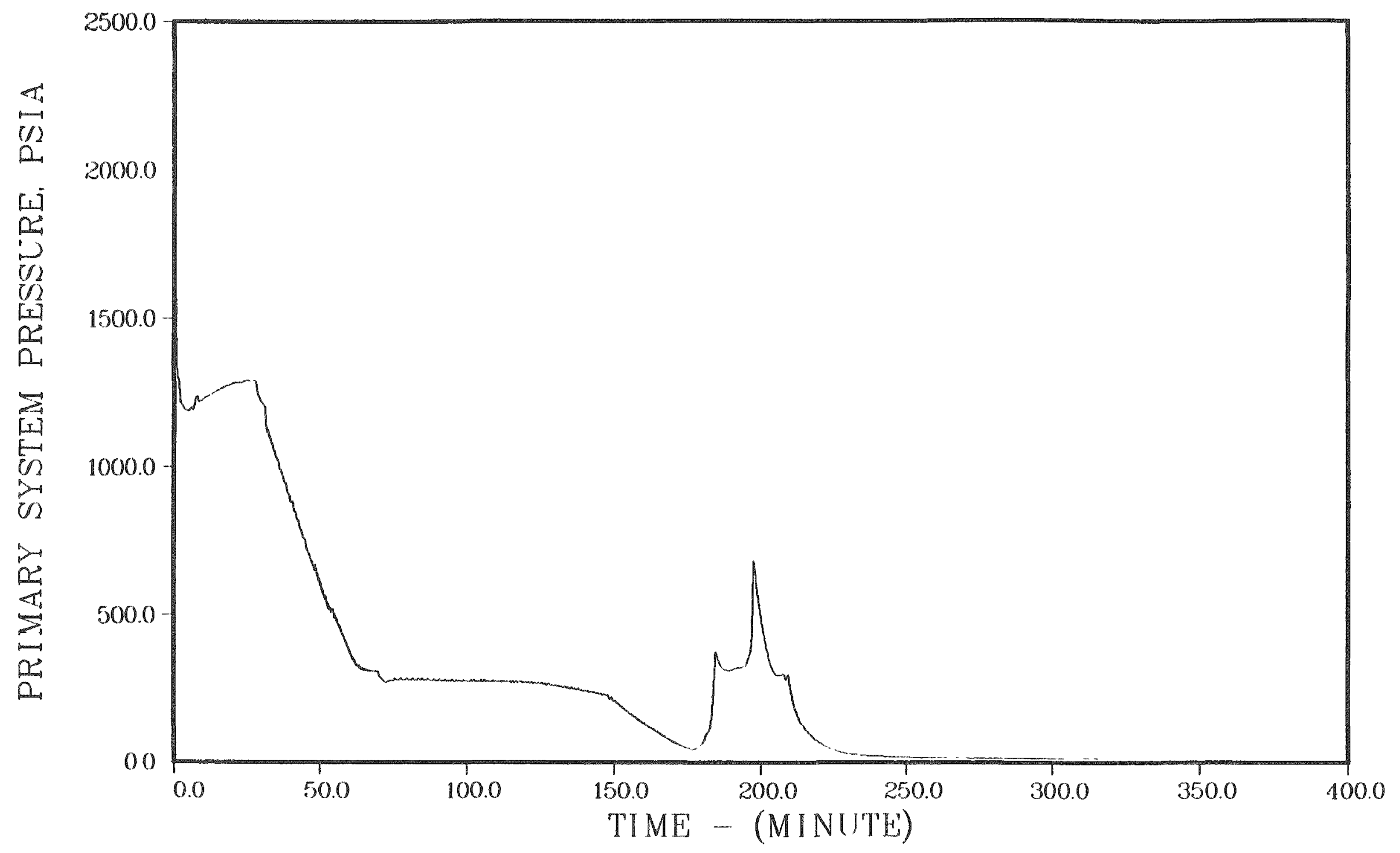

Figure 4.2.50. Primary system pressure history - small break with ECCS failure, AFW on, and PORVs open. 


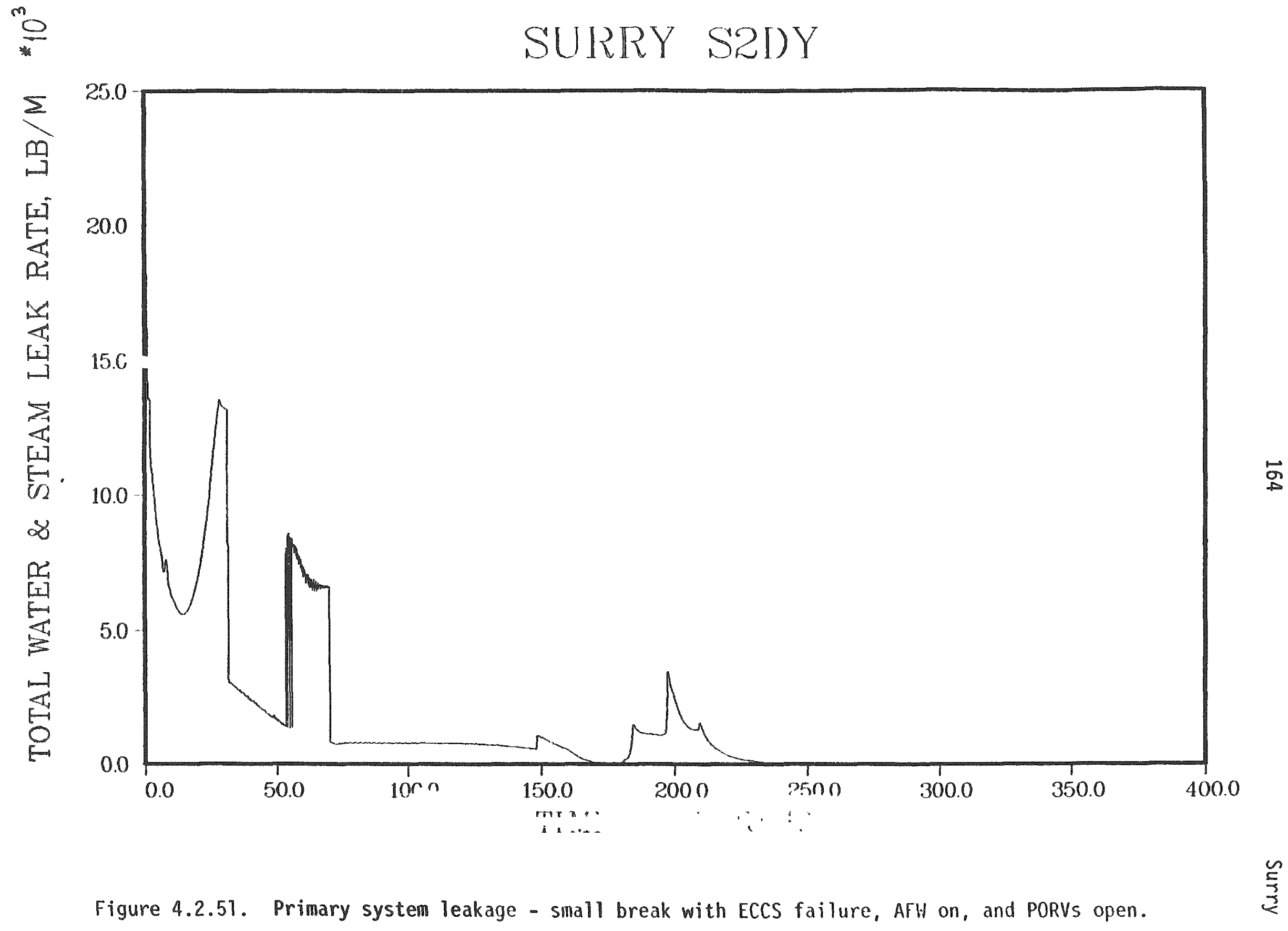


temperatures are illustrated in Figure 4.2 .52 ; fractions cladding reacted and core melted are shown in Figure 4.2.53. The temperatures of the gases leaving the top of the core and those exiting the primary system are given in Figure 4.2.54. The open PORVs together with the initial break in the primary system allow the primary system to depressurize essentially to the containment pressure. Thus, there is little stress on the bottom head and a considerable time is required to reach head failure. In the absence of internal pressure, it was assumed that gross failure would be the governing mode. At the time of failure in this sequence, the head was predicted to be molten to a depth of 1.5 inches.

\section{CONTAINMENT RESPONSE - $S_{2} D$ (with primary and secondary depressurization)}

The conditions in the containment at key times during the accident progression are summarized in Table 4.2.25. Containment pressure and temperature histories are shown in Figures 4.2 .55 and 4.2.56. The containment sprays were actuated at a pressure of $25 \mathrm{psia}$, which was reached after the collapse of the core into the vessel head. It may be noted that the containment pressure almost reached this value at about an hour into the accident. The possible earlier actuation of the containment sprays would not be expected to have an appreciable effect on the calculated accident progression. Immediately after reactor vessel failure the containment contains $942 \mathrm{lb}$ of hydrogen, with corresponding mole fractions of 0.116 hydrogen, 0.152 oxygen, and 0.158 steam. At the end of the calculation, after ten hours of concrete attack, there are are $2194 \mathrm{lb}$ of hydrogen with corresponding mole fractions of 0.203 hydrogen, 0.115 oxygen, and 0.237 steam. Hydrogen buildup in the containment is illustrated in Figure 4.2.57. The mole fractions of the principal constituents of the containment atmosphere are illustrated in Figure 4.2.58. 


\section{SURRY SRDY}

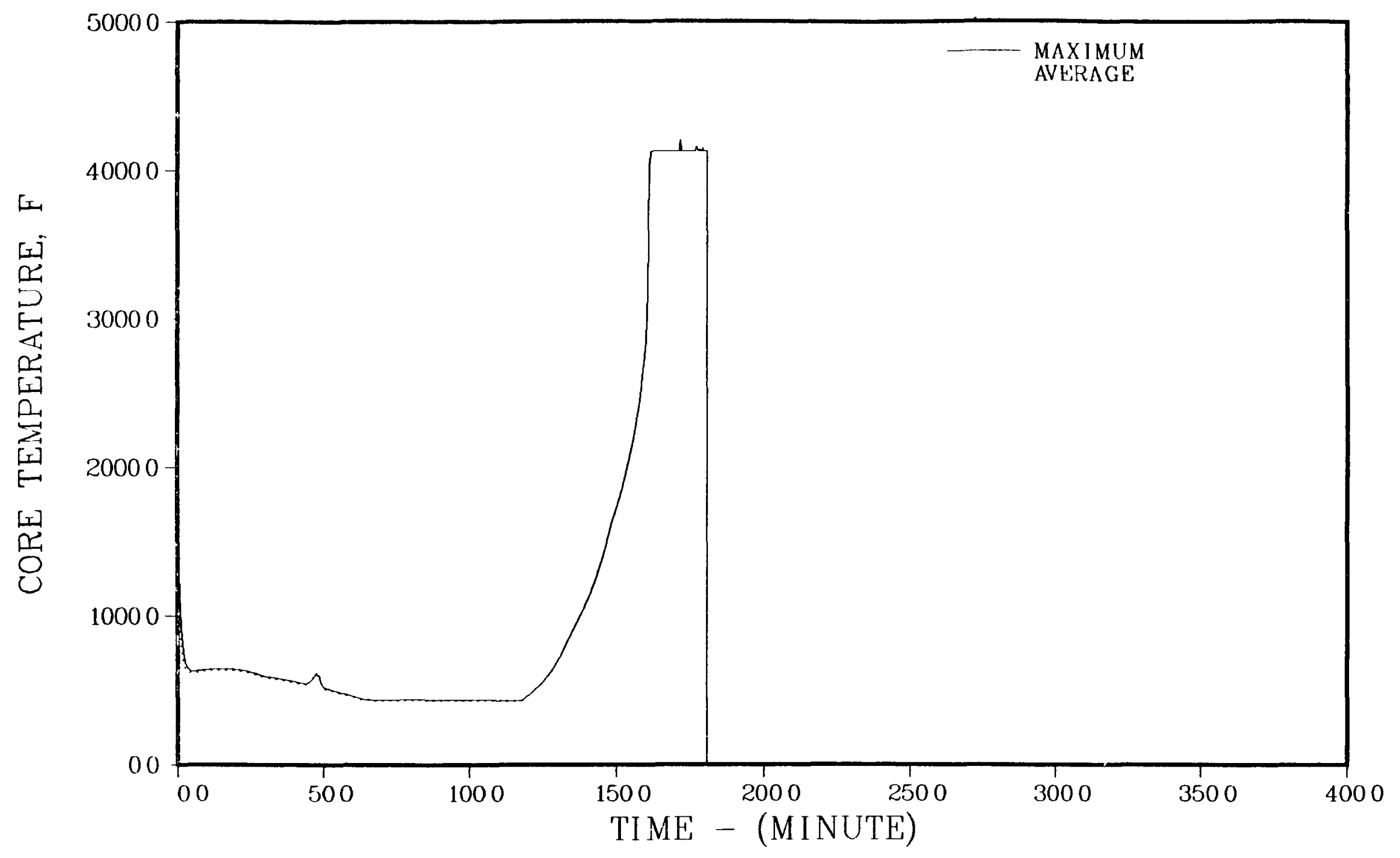

Figure 4.2.52. Maximum and average core temperatures - small break 


\section{SURRY SRDY}

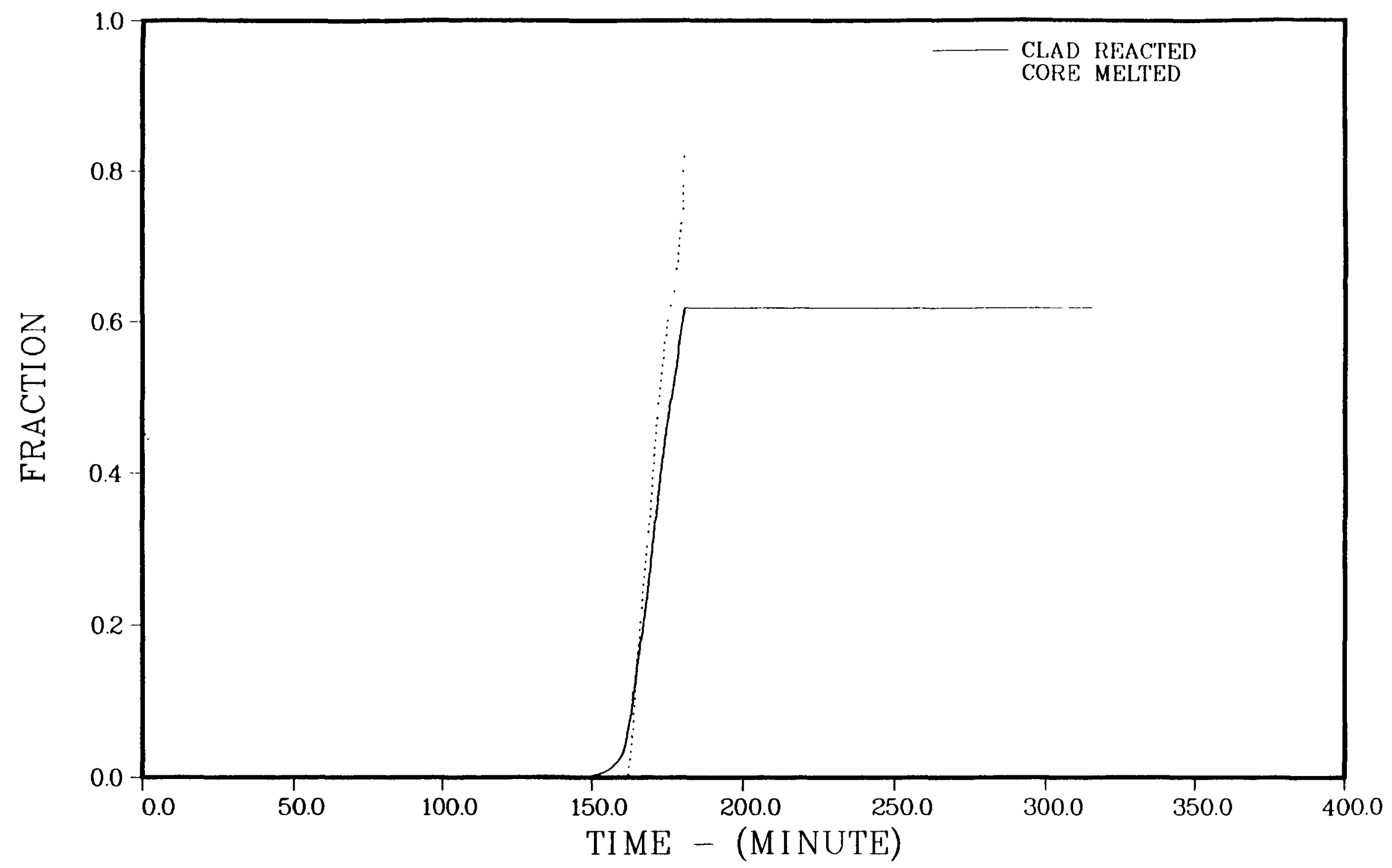

Figure 4.2.53. Fractions of cladding reacted and core melted - small break with ECCS failure, AFW on, and PORVs open. 


\section{SURRY SRDY}

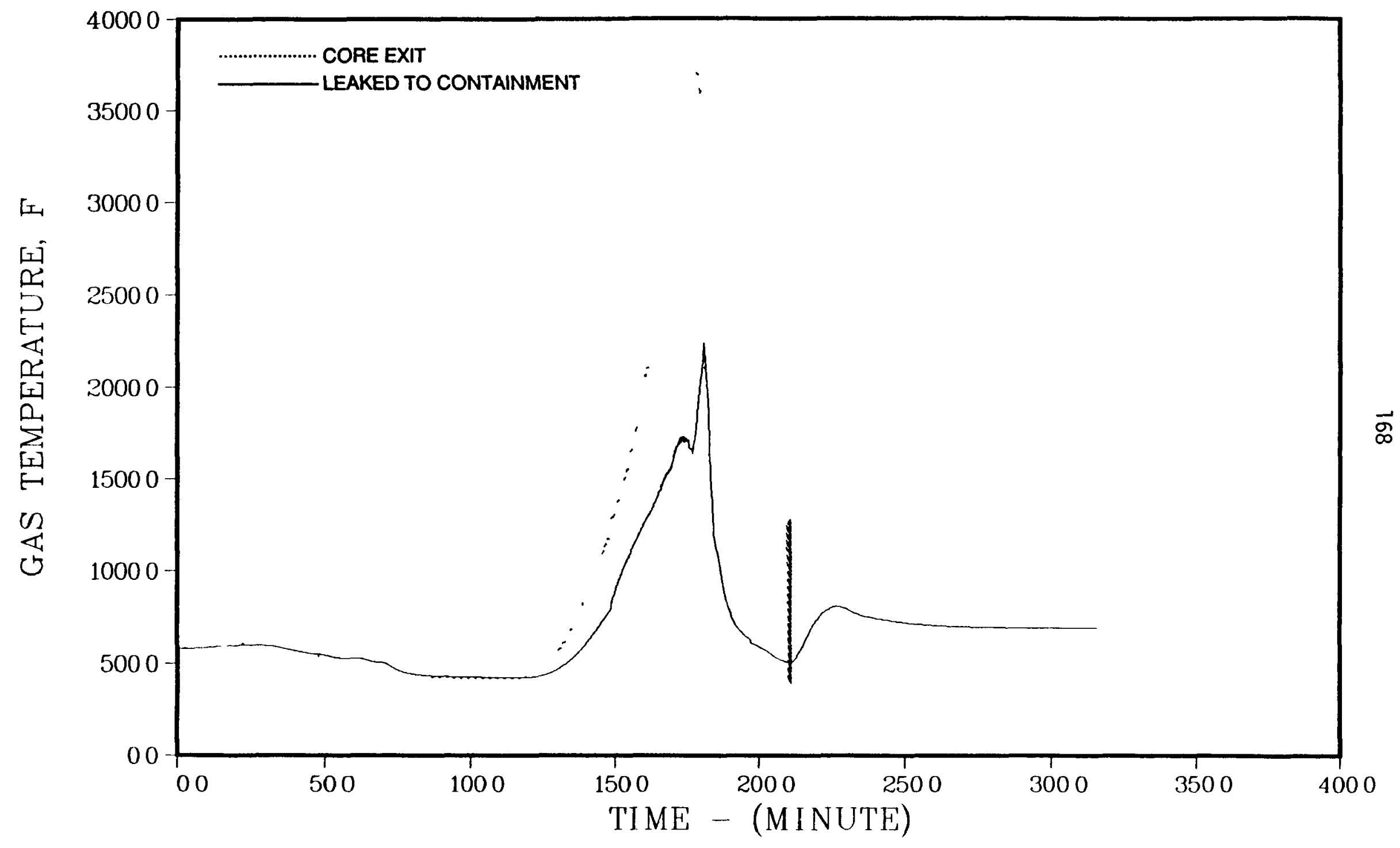

Figure 4.2.54. Temperatures of gases leaving the core and exiting the primary system - small break with ECCS failure, AFW on, and PORVs open. 
Table 4.2.25 Containment respense - Supry $\$_{2} D$

\begin{tabular}{|c|c|c|c|c|c|c|c|c|}
\hline \multirow[b]{2}{*}{$\begin{array}{l}\text { Accident } \\
\text { Event }\end{array}$} & \multirow[b]{2}{*}{$\begin{array}{l}\text { Tires, } \\
\text { inutes }\end{array}$} & \multicolumn{2}{|c|}{ Containment } & \multirow{2}{*}{$\begin{array}{c}\text { Containment } \\
\text { Wall Stean } \\
\text { Condensation, } \\
\text { Ib/a }\end{array}$} & \multicolumn{2}{|c|}{ Sump llater } & Reactor Cavity & \multirow{2}{*}{$\frac{\text { Water }}{\text { Temp. }}$} \\
\hline & & $\begin{array}{l}\text { Pressure, } \\
\text { Psia }\end{array}$ & Temperature & & $\begin{array}{l}\text { Mass, } \\
\text { Ib }\end{array}$ & Temp.: & $\begin{array}{l}\text { Mass, } \\
\text { Ib }\end{array}$ & \\
\hline Core uncovery & 41.3 & 24.1 & 269 & 1781 & $2.51 \times 10^{5}$ & 192 & 0.6 & $-\infty$ \\
\hline Start acle & 161.6 & 22.8 & 294 & 423 & $4.63 \times 18^{5}$ & 198 & 0.0 & -- \\
\hline Core slump & 176.0 & 23.6 & 203 & 173 & $4.68 \times 10^{5}$ & 198 & 9.6 & $-\infty$ \\
\hline Core collapse & 189.6 & 23.8 & 202 & 58 & $4.68 \times 10^{5}$ & 195 & 0.0 & $-\infty$ \\
\hline Containament spray on & 188.0 & 25.2 & 210 & 6 & $4.69 \times 18^{5}$ & 195 & 0.0 & \\
\hline Bottom head dryout & 299.2 & 19.2 & 172 & t & $1.00 \times 10^{6}$ & 175 & $8.51 \times 10^{4}$ & 175 \\
\hline \multicolumn{9}{|l|}{ Containent spray } \\
\hline recirculation on & 282.4 & 13. & 107 & . & $2.71 \times 10^{6}$ & 117 & $3.69 \times 10^{5}$ & 113 \\
\hline Bottom head failure & 314.4 & 14.1 & 125 & . & $2.58 \times 10^{6}$ & 118 & $4.98 \times 10^{5}$ & 116 \\
\hline Start concrete attack & 315.5 & 14.6 & 131 & (3) & $2.59 \times 10^{6}$ & 118 & $4.98 \times 10^{5}$ & 116 \\
\hline End calculation & 915.5 & 26.3 & 181 & 137 & $2.46 \times 10^{6}$ & 159 & $6.94 \times 10^{5}$ & 229 \\
\hline
\end{tabular}




\section{SURRY SRDY}

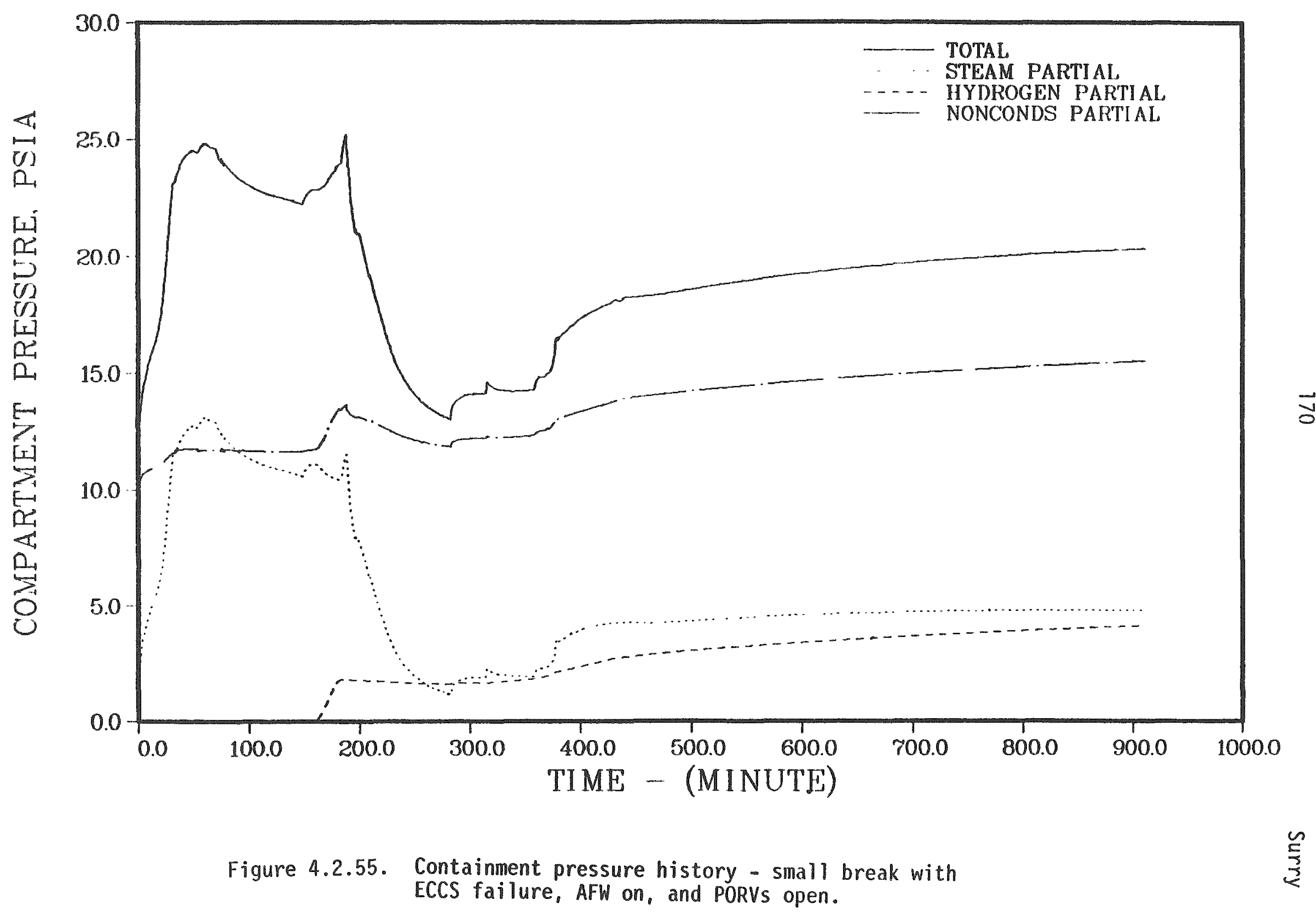




\section{SURRY SRDY}

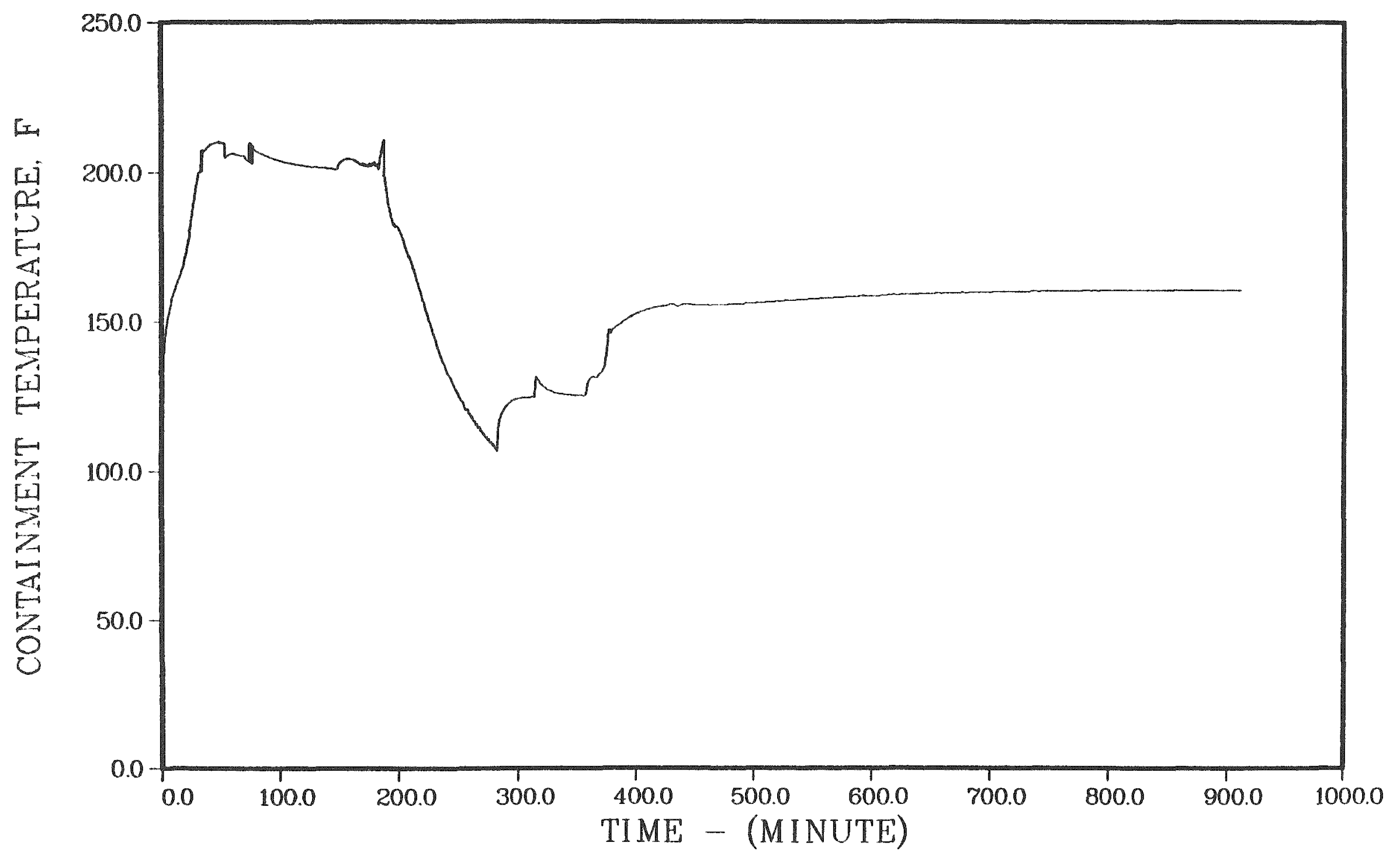

Figure 4.2.56. Containment temperature history - small break with ECCS failure, AFW on, and PORVS open. 


\section{SURRY SRDY}

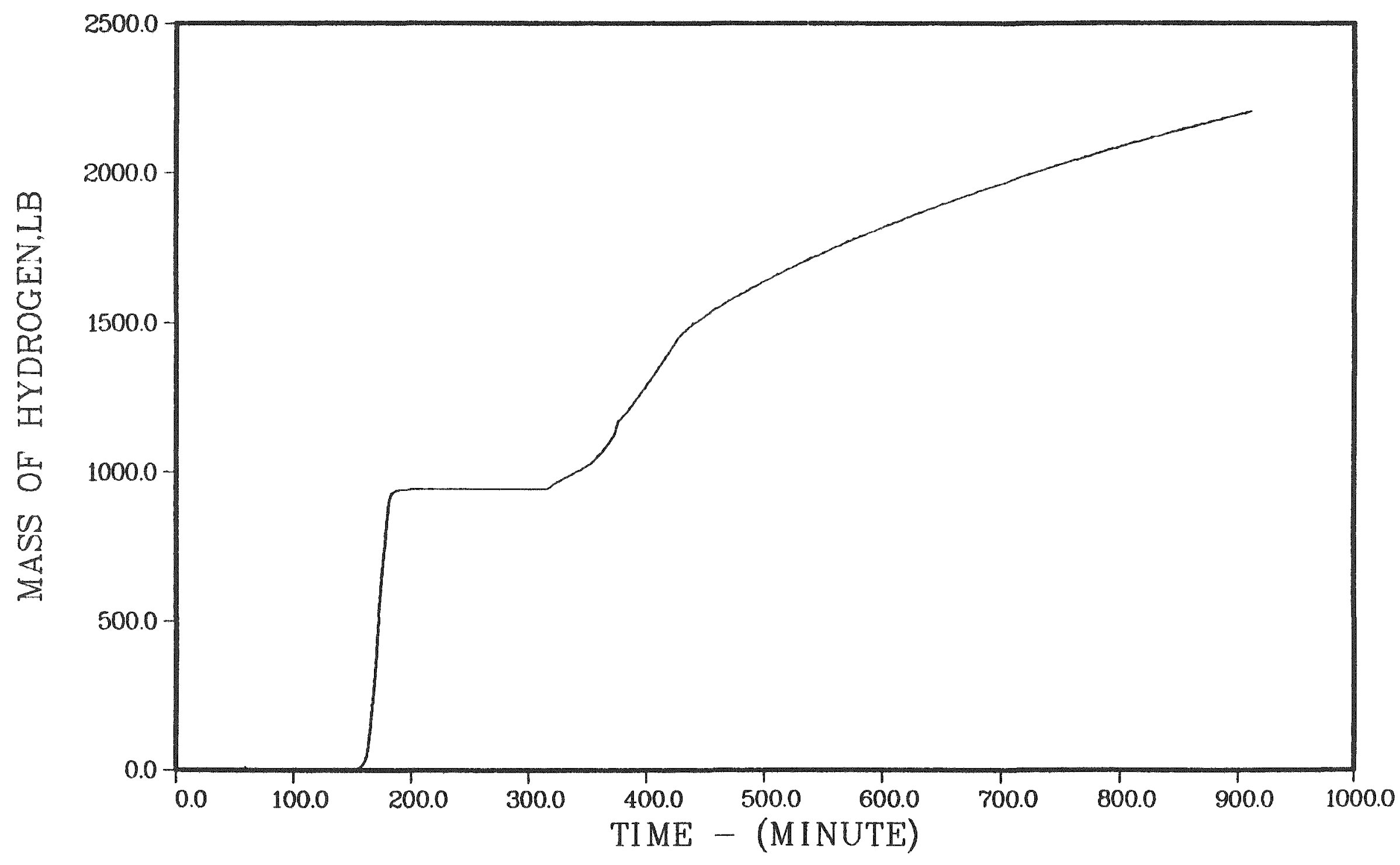

Figure 4.2.57. Hydrogen in the containment - small break with ECCS failure, AFW on, and PORVs open. 


\section{SURRY SRDY}

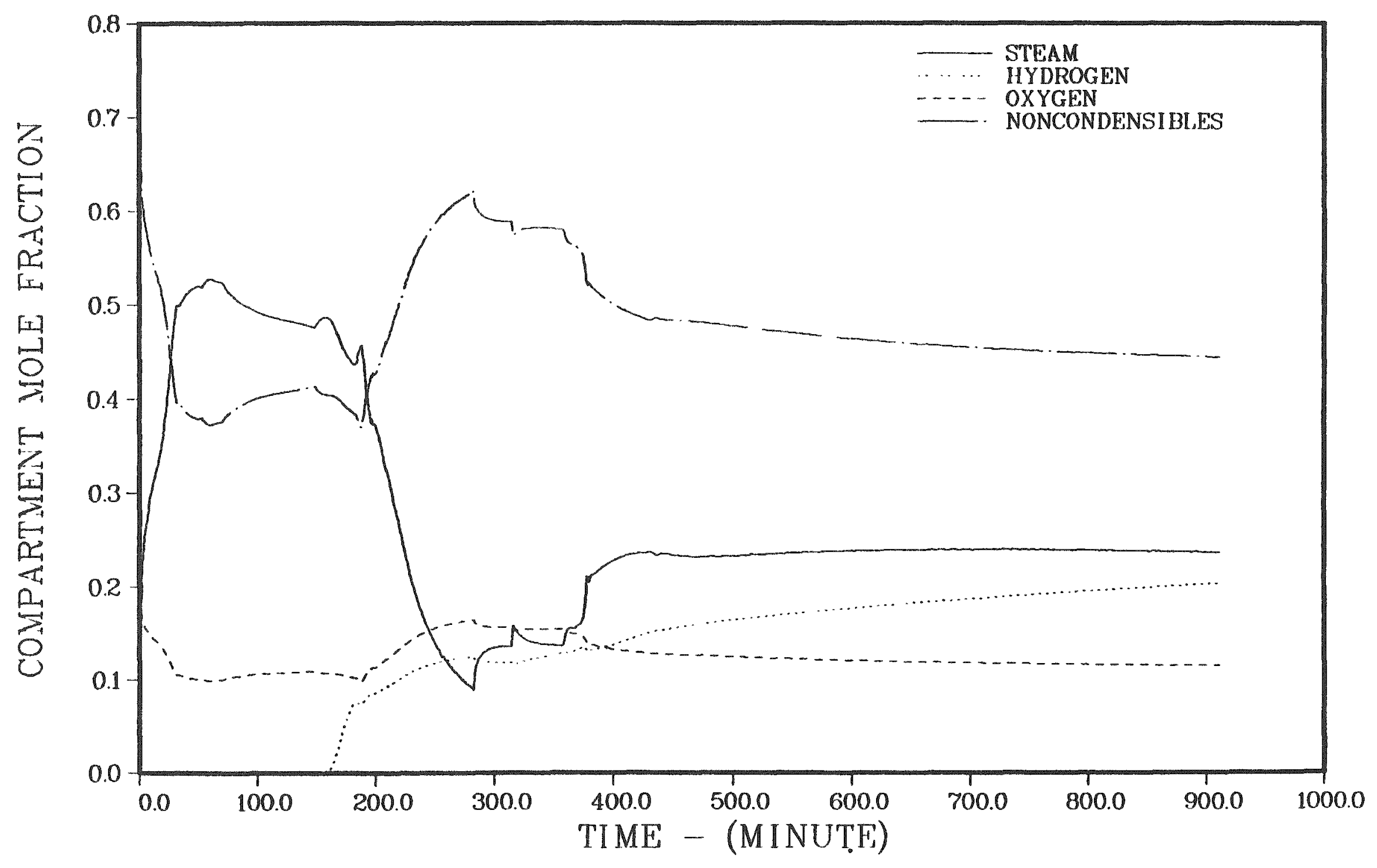

Figure 4.2.58. Containment atmosphere composition - small break with ECCS failure, AFW on, and PORVs open. 


\subsubsection{Radionuclide Sources}

\section{SOURCE WITHIN PRESSURE VESSEL}

The inventory of fission products used in these analyses is the same as that used for the BMI-2104 ${ }^{(6)}$ and NUREG/CR-4624 ${ }^{(2)}$ analyses. Table 4.2 .26 provides the inventories for each of the key fission product, actinide and structural elements. The values for the radionuclides are based on an ORIGEN2 ${ }^{(17)}$ analys is for end-of-cycle conditions in a three-region model with burnups of $11,000 / 22,000 / 33,000 \mathrm{MW}$ days/tonne. The structural masses are based on values provided in the FSAR. In Table 4.2.27 the elements are collapsed into the elemental groups used in this study.

\section{SOURCES WITHIN THE CONTAINMENT}

The VANESA code was used to predict the release of fission products and inert materials to the containment during corium-concrete interaction. The composition of the melt entering the reactor cavity for $S_{3} B$ is presented in Table 4.2.28. The total release rates and composition of released materials are given in Table 4.2.29.

\subsubsection{Radionuclide Release and Transport}

Transport in and release from the RCS of radionuclide and structural materiais was calculated with the TRAP-MELT3 code described in Section 2.1. The release from the RCS (and corium-concrete interactions) define the aerosol source term to the containment.

\subsubsection{Results: Transport in the Reactor Coolant System}

\section{Surry $S_{3} B$}

Tables 4.2 .30 and 4.2 .31 summarize the mass transport behavior of the dominant radionuclide prior to vessel failure in the RCS. Table 4.2 .30 gives the 
Table 4.2.26 Initial inventories of radionuclides and structural materials for Surry

\begin{tabular}{|c|c|c|c|}
\hline \multicolumn{2}{|c|}{ Fission Products } & \multicolumn{2}{|c|}{ Actinides/Structural } \\
\hline Element & $\operatorname{Mass}(\mathrm{kg})$ & Element & Mass (kg) \\
\hline kr & 13.4 & U & 70,210 \\
\hline $\mathrm{Rb}$ & 14.7 & Pu & 469 \\
\hline$S r$ & 47.6 & Np & 26.0 \\
\hline$\gamma$ & 22.9 & $\mathrm{Zr}$ & 16,460 \\
\hline $2 r$ & 179 & Sn & 262 \\
\hline $\mathrm{Nb}$ & 2.7 & Ag & 2.750 \\
\hline TC & 37.1 & In & 505 \\
\hline Ru & 104 & $\mathrm{~cd}$ & 173 \\
\hline $\mathrm{Rh}$ & 20.9 & $\mathrm{Fe}$ & 4.670 \\
\hline $\mathrm{Pd}$ & 52.5 & $\mathrm{Cr}$ & 1,167 \\
\hline Te & 25.4 & $\mathrm{Ni}$ & 649 \\
\hline I & 12.4 & & \\
\hline $\mathrm{Xe}$ & 260 & & \\
\hline Cs & 131 & & \\
\hline $\mathrm{Ba}$ & 61.2 & & \\
\hline La & 62.3 & & \\
\hline $\mathrm{Ce}$ & 131 & & \\
\hline $\operatorname{Pr}$ & 50.7 & & \\
\hline Nd & 171 & & \\
\hline $\mathrm{Pm}$ & 7.2 & & \\
\hline$S m$ & 34.0 & & \\
\hline Eu & 8.9 & & \\
\hline
\end{tabular}


Table 4.2.27 Inventory by group.

\begin{tabular}{clc}
\hline \hline Group & Elements & Total Mass (kg) \\
\hline 1 & Xe, Kr & 273.4 \\
2 & I, Br & 12.4 \\
3 & Cs, Rb & 145.7 \\
4 & Te, Sb, Se & 25.4 \\
5 & Sr & 47.6 \\
6 & Ru, Rh, Pd, Mo, Tc & 369.5 \\
7 & La, Zr, Nd, Eu, Nb, Pm, Pr, Sm, Y & 538.7 \\
8 & Ce, Pu, Np & 626.0 \\
9 & $\mathrm{Ba}$ & 61.2 \\
\hline
\end{tabular}


Table 4.2.28 Inventory of the melt at the time of vessel failure for Surry $S_{3} B$.

\begin{tabular}{llll}
\hline \hline Element & Mass $(\mathrm{kg})$ & Element & Mass $(\mathrm{kg})$ \\
\hline $\mathrm{Cs}$ & 4.6 & $\mathrm{Cd}$ & 75.9 \\
$\mathrm{I}$ & 0.46 & $\mathrm{In}$ & 494. \\
$\mathrm{Xe}$ & 9.4 & $\mathrm{Ce}$ & 131 \\
$\mathrm{Kr}$ & 0.49 & $\mathrm{Rb}$ & 0.55 \\
$\mathrm{Te}$ & 18.0 & $\mathrm{Br}$ & 0. \\
$\mathrm{Ag}$ (Fp) & 0. & $\mathrm{Ru}$ & 104. \\
$\mathrm{Sb}$ & 0. & $\mathrm{Rh}$ & 20.9 \\
$\mathrm{Ba}$ & 60.6 & $\mathrm{Pd}$ & 52.5 \\
$\mathrm{Sn}$ & 249. & $\mathrm{Nd}$ & 171. \\
$\mathrm{TC}$ & 37.1 & $\mathrm{Eu}$ & 8.90 \\
$\mathrm{UO}$ & $\mathrm{Gd}$ & 0. \\
$\mathrm{Zr}$ (Struct) & 79650. & $\mathrm{Nb}$ & 2.70 \\
$\mathrm{Zr}$ (Fp) & 7480. & $\mathrm{Pm}$ & 7.20 \\
$\mathrm{Fe}$ & 81.3 & $\mathrm{Pr}$ & 50.7 \\
$\mathrm{Mo}$ & $23,200$. & $\mathrm{Sm}$ & 34.0 \\
$\mathrm{Sr}$ & 155 & $\mathrm{r}$ & 22.9 \\
$\mathrm{Cr}$ & 47.6 & $\mathrm{~Np}$ & 26.0 \\
$\mathrm{Ni}$ & 6370. & $\mathrm{Pu}$ & 469. \\
$\mathrm{Mn}$ & 3540. & $\mathrm{Se}$ & 0. \\
$\mathrm{La}$ & 0. & $\mathrm{FeO}$ & 12.660. \\
$\mathrm{Ag}$ (Struct) & 62.3 & $\mathrm{ZrO}$ & 12.030. \\
& 2610. & & \\
\hline \hline & & & \\
\hline
\end{tabular}


Table 4.2.29. Aerosol release rate during corium-concrete interaction for Surry $S_{3} B$.

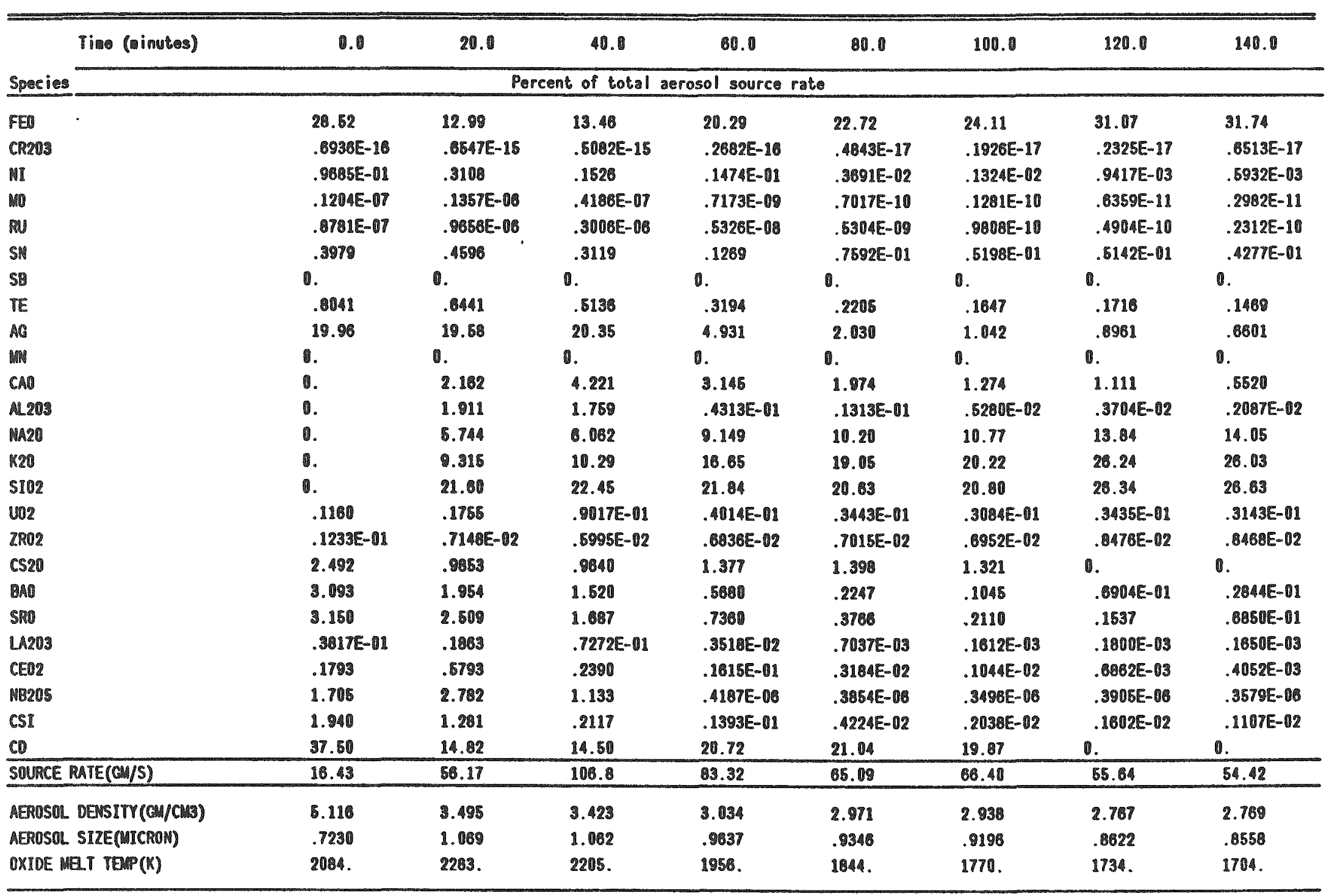


Table 4.2.29. (Continued)

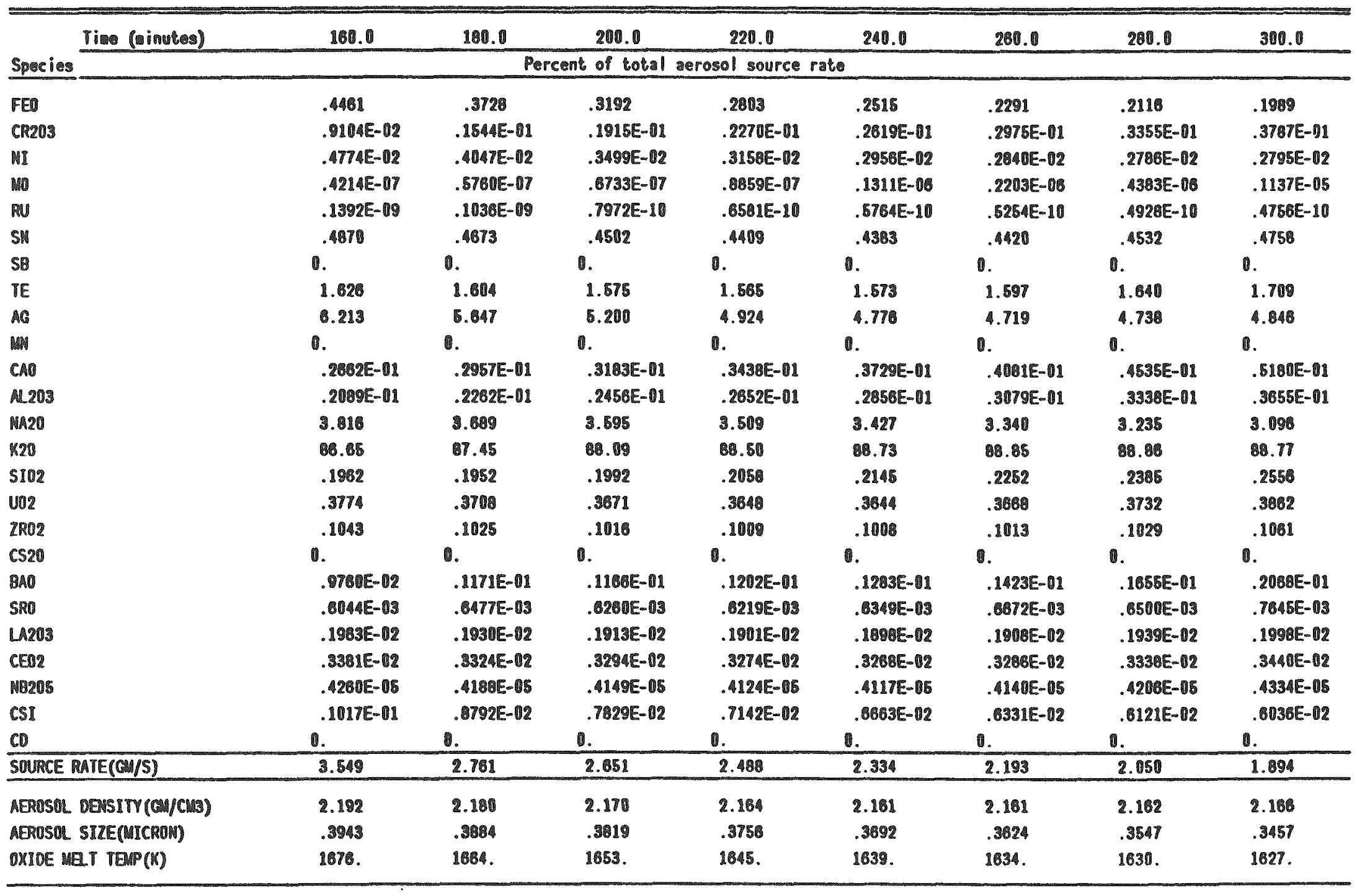


Table 4.2.29. (Continued)

\begin{tabular}{|c|c|c|c|c|c|c|c|c|}
\hline Time (inintes) & 320. & 340.6 & 360.0 & 380.1 & 400.0 & 420.0 & 40.0 & 460.0 \\
\hline \multicolumn{9}{|c|}{ Percent of total aerosol source rato } \\
\hline FED & .1939 & .2138 & .2817 & .2689 & .2710 & .2748 & .2786 & .2021 \\
\hline CR2O3 & $.4302 \mathrm{E}-01$ & $.4938 E-11$ & $.5042 \mathrm{E}-01$ & $.4870 E-01$ & $.4723 E-01$ & $.4577 E-01$ & $.940 E-01$ & $.4293 E-01$ \\
\hline m & $.2084 \mathrm{E}-02$ & $.3093 E-02$ & $.3205 E-02$ & $.3052 \mathrm{E}-02$ & $.2906 E-02$ & $.2773 E-02$ & $.2686 E-02$ & $.2598 E-02$ \\
\hline 10 & $.8060 \mathrm{E}-05$ & $.7750 E-04$ & $.1081 E-02$ & $.1093 E-02$ & $.1068 \mathrm{E}-02$ & $.1042 E-02$ & $.1021 E-12$ & $.9989 E-03$ \\
\hline m & . $4755-11$ & $.4853 E-10$ & $.4670 E-10$ & $.4312 E-10$ & $.3985 E-10$ & $.3700 E-10$ & $.3529 E-10$ & $.3356 E-10$ \\
\hline SW & .5211 & .6368 & .7910 & .7670 & .7415 & .7175 & .0981 & .6789 \\
\hline SE & ข. & 1. & 0. & 0. & 0. & to. & i. & 0. \\
\hline TE & 1.617 & 1.989 & 1.076 & 1.933 & 1.891 & 1.852 & 1.019 & 1.786 \\
\hline AC & 6.073 & B. 439 & 5.421 & 5.228 & 5.045 & 4.877 & 4.758 & 4.638 \\
\hline$M$ & 0. & . & o. & 0. & 0. & 0. & 0. & 0. \\
\hline CAD & .B257E-11 & $.8771 E-01$ & .1124 & .1192 & .1120 & .1198 & .1202 & .1206 \\
\hline 사이 & $.4071 E-11$ & $.4831 E-01$ & $.4876 E-01$ & . $4949 E-11$ & $.5021 \mathrm{E}-01$ & . 508RE-01 & . Б1398-01 & . 8191E-11 \\
\hline กม20 & 2.977 & 2.423 & 1.977 & 1.958 & 1.846 & 1.933 & 1.920 & 1.922 \\
\hline K20 & 08.53 & 88.17 & 80.27 & 00.57 & 08.85 & 89.11 & 89.30 & 82.80 \\
\hline 5102 & .2709 & .3105 & .3237 & .3284 & .3330 & .3373 & .3407 & .3440 \\
\hline 002 & .4105 & .4640 & .5202 & .5098 & .4914 & .4743 & .457 & .4427 \\
\hline ZRO2 & .1116 & .1202 & .1202 & .1163 & .1126 & .1091 & .1056 & .1023 \\
\hline CS20 & 0. & 0. & 0. & 0. & ขึ. & 0. & t. & 0. \\
\hline DAO & .2021E-01 & $.5584 E-01$ & . D219E-01 & $.0872 E-101$ & $.8497 E-01$ & . B140E-01 & $.7833 E-01$ & $.7537 \mathrm{E}-01$ \\
\hline SPO & .1704E-12 & $.1716 \mathrm{E}-02$ & $.26886-12$ & $.2564 E-02$ & $.2434 \mathrm{E}-02$ & $.2324 \mathrm{E}-02$ & $.2220 \mathrm{E}-02$ & .2139E-O2 \\
\hline LA203 & .2101E-22 & $.2264 E-02$ & $.2264 E-02$ & $.2189 E-02$ & $.2119 E-02$ & $.2064 E-02$ & .1980 -02 & $.1927 E-02$ \\
\hline CEO2 & .3619E-02 & .3899E-02 & .3900E-02 & $.3770 E-02$ & $.3850 E-02$ & $.3537 E-02$ & $.3423 E-02$ & . 3318E-02 \\
\hline B215 & . A552E-05 & $.4012 E-05$ & $.4013 E-05$ & $.4749 E-05$ & $.4502 \mathrm{E}-05$ & $.4456 E-05$ & $.4313 E-05$ & $.4180 \mathrm{E}-08$ \\
\hline CSI & . D101E-02 & $.6328 E-02$ & . COPTE-O2 & $.5683 E-02$ & $.5310 E-102$ & $.4977 E-02$ & $.4698 E-02$ & $.1493 E-02$ \\
\hline$C D$ & 0. & 0. & 0. & 0. & 0. & 0. & 0. & D. \\
\hline SOURCE RATE(CU/S) & 1.723 & 1.635 & 1.976 & 1.472 & 1.667 & 1.462 & 1.466 & 1.459 \\
\hline AEROSOL DENSITY(CM/CMS) & 2.173 & 2.186 & 2.191 & 2.126 & 2.182 & 2.177 & 2.174 & 2.171 \\
\hline AEROSUL SIZE (MICROM) & .3947 & .3214 & .3169 & .3167 & .3164 & .3162 & .3162 & .3161 \\
\hline OXIDE MRT TEAP(K) & 1624. & 1821. & 1618. & 1816. & 1613. & 1811. & 1609. & 1600 \\
\hline
\end{tabular}


Table 4.2.29. (Continued)

\begin{tabular}{|c|c|c|c|c|c|c|c|}
\hline Time (minutes) & 480.0 & 500.0 & 520.0 & 540.0 & 560.0 & 580.0 & 600.0 \\
\hline \multicolumn{8}{|c|}{ Percent of total aerosol source rate } \\
\hline FEO & .2645 & .2966 & .2886 & .2905 & .2923 & .2940 & .2958 \\
\hline CR2OS & $.4187 E-01$ & $.9094 E-01$ & $.4002 E-01$ & $.3914 E-01$ & $.3820 E-01$ & $.3738 E-01$ & $.3660 E-01$ \\
\hline MI & $.2448 E-02$ & $.2306 E-02$ & $.2190 E-02$ & $.2089 E-02$ & $.1998 E-12$ & $.1915 E-02$ & $.1840 E-02$ \\
\hline M10 & $.9706 \mathrm{E}-03$ & $.0438 E-015$ & $.9201 E-03$ & $.8981 E-03$ & $.9776 \mathrm{E}-03$ & $.8582 E-03$ & $.0401 E-03$ \\
\hline PU & $.3041 E-10$ & $.2751 E-10$ & $.2526 \mathrm{E}-10$ & $.2337 \mathrm{E}-10$ & $.2174 E-10$ & $.2030 E-10$ & $.1903 E-10$ \\
\hline SN & .6540 & .0318 & .0117 & .5931 & .5758 & .5596 & .5444 \\
\hline Sto & 0. & 10. & 0. & 0. & 0. & 0. & 0. \\
\hline TE & 1.747 & 1.711 & 1.676 & 1.647 & 1.617 & 1.588 & 1.582 \\
\hline$A C$ & 4.451 & 4.270 & 4.119 & 3.903 & 3.858 & 3.743 & 3.638 \\
\hline 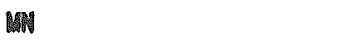 & 0. & 0. & 0. & 1. & I. & 0. & 0. \\
\hline $\mathrm{CAO}$ & .1205 & .1203 & .1203 & .1202 & .1202 & .1202 & .1202 \\
\hline ML203 & $.52656-01$ & . $5330 E-11$ & $.5401 E-11$ & $.5460 \mathrm{E}-11$ & $.5515 E-01$ & $.5568 E-01$ & $.5617 E-01$ \\
\hline Mล20 & 1.903 & 1.883 & 1.887 & 1.852 & 1.838 & 1.826 & 1.915 \\
\hline 1120 & 89.78 & จ0.05 & 90.28 & 90.48 & 90.69 & 90.87 & 91.03 \\
\hline$\$ 102$ & .3480 & .3535 & .3578 & .3614 & .3640 & .3683 & .3715 \\
\hline 002 & .4298 & .9178 & .4067 & .3963 & .3863 & .3769 & .3670 \\
\hline ZRO2 & $.9970 E-01$ & $.9758 E-01$ & $.9541 E-01$ & $.9331 E-01$ & $.9128 E-01$ & $.8933 E-01$ & $.0746 E-01$ \\
\hline $\operatorname{cs} 20$ & 0. & t. & 0. & 0. & to. & 0. & 0. \\
\hline BAO & $.7250 \mathrm{E}-01$ & $.0990 \mathrm{E}-01$ & $.0754 E-01$ & $.6539 \mathrm{E}-01$ & $.6320 E-01$ & $.6135 E-01$ &. S95AE-01 \\
\hline SRO & $.2044 E-02$ & $.1958 E-02$ & $.1802 E-02$ & $.1812 E-12$ & $.1747 \mathrm{E}-12$ & $.1087 E-02$ & $.1631 E-02$ \\
\hline LA203 & $.1879 E-02$ & $.1838 E-92$ & $.1797 E-02$ & $.1757 \mathrm{E}-02$ & $.1710 E-02$ & $.1682 E-02$ & $.1647 \mathrm{E}-02$ \\
\hline CEO2 & $.3236 \mathrm{E}-02$ & $.3164 E-02$ & $.3094 \mathrm{E}-02$ & $.3026 E-12$ & .2960 -02 & $.2897 E-02$ & $.2936 E-02$ \\
\hline MB205 & $.4976 E-05$ & $.3988 E-05$ & $.3898 E-05$ & $.3812 E-05$ & $.3720 E-05$ & $.3850 E-05$ & $.3573 E-05$ \\
\hline $\operatorname{csl}$ & $.4168 E-02$ & $.3926 E-12$ & $.3716 E-02$ & $.352 . \mathrm{E}-02$ & $.3357 E-02$ & $.3200 E-02$ & $.3057 E-02$ \\
\hline $\mathrm{CO}$ & 0. & 0. & 0. & 0. & 0. & 0. & 0. \\
\hline SOURCE RATE(CM/S) & 1.407 & 1.355 & 1.331 & 1.323 & 1.315 & 1.307 & 1.299 \\
\hline AERBSAL DENSITY(CU/CHS) & 2.168 & 2.182 & 2.158 & 2.155 & 2.152 & 2.140 & 2.146 \\
\hline AEROSOL SIRE(MICRAM) & .3155 & .3148 & .3143 & .3130 & .3134 & .3130 & .3127 \\
\hline OXIOE MET TOAP(N) & 1605. & 1601. & 1599. & 1598. & 1594. & 1592. & 1590. \\
\hline
\end{tabular}


Table 4.2.30. Masses of dominant species released from fuel and retained on RCS structures as functions of time for the Surry $S_{3} B$ sequence.

(Time $=0.0$ corresponds to start of accident)

\begin{tabular}{|c|c|c|c|c|c|c|c|c|}
\hline \multirow[b]{2}{*}{$\begin{array}{l}\text { Time } \\
(M)\end{array}$} & \multicolumn{2}{|c|}{ CSI } & \multicolumn{2}{|c|}{$\mathrm{CsOH}$} & \multicolumn{2}{|c|}{ Te } & \multicolumn{2}{|c|}{ Aerosol } \\
\hline & $\begin{array}{l}\text { Ret } \\
(\mathrm{Kg})\end{array}$ & $\begin{array}{c}\text { Total } \\
(\mathrm{Kg})\end{array}$ & $\begin{array}{l}\overline{\operatorname{Ret}} \\
(\mathrm{Kg})\end{array}$ & $\begin{array}{c}\text { Total } \\
(\mathrm{kg})\end{array}$ & $\begin{array}{l}\text { Ret } \\
(\mathrm{Kg})\end{array}$ & $\begin{array}{c}\text { Total } \\
(\mathrm{kg})\end{array}$ & $\begin{array}{l}\overline{\text { Ret }} \\
(\mathrm{Kg})\end{array}$ & $\begin{array}{c}\text { Total } \\
(\mathrm{kg})\end{array}$ \\
\hline $\begin{array}{l}106.9 \\
109.0 \\
111.1 \\
113.1 \\
115.4 \\
117.4 \\
119.4 \\
121.4 \\
123.4 \\
125.6 \\
127.6 \\
129.6 \\
131.6 \\
133.6 \\
135.7 \\
127.7 \\
139.8 \\
141.8 \\
143.9 \\
145.9\end{array}$ & $\begin{array}{r}.0 \\
.0 \\
.1 \\
1.0 \\
3.0 \\
5.2 \\
7.6 \\
10.0 \\
12.2 \\
14.4 \\
16.1 \\
17.5 \\
19.0 \\
18.0 \\
18.0 \\
18.0 \\
18.0 \\
18.0 \\
18.0 \\
18.0\end{array}$ & $\begin{array}{r}.2 \\
.3 \\
1.7 \\
4.9 \\
8.3 \\
11.1 \\
13.6 \\
15.6 \\
17.3 \\
18.9 \\
20.1 \\
21.2 \\
22.1 \\
23.1 \\
23.3 \\
23.5 \\
23.6 \\
23.7 \\
23.9 \\
24.9\end{array}$ & $\begin{array}{r}.0 \\
.1 \\
1.3 \\
7.7 \\
20.1 \\
33.2 \\
47.7 \\
61.9 \\
74.7 \\
87.2 \\
96.6 \\
104.7 \\
112.8 \\
111.5 \\
111.3 \\
111.3 \\
111.0 \\
111.1 \\
111.3 \\
111.5\end{array}$ & $\begin{array}{r}3.5 \\
4.5 \\
12.8 \\
31.1 \\
49.3 \\
66.6 \\
81.8 \\
94.2 \\
104.2 \\
113.4 \\
120.2 \\
125.8 \\
130.8 \\
136.5 \\
137.9 \\
138.7 \\
139.4 \\
140.2 \\
141.3 \\
146.9\end{array}$ & $\begin{array}{l}.0 \\
.0 \\
.0 \\
.1 \\
.2 \\
.4 \\
.7 \\
1.0 \\
1.4 \\
1.9 \\
2.4 \\
2.9 \\
3.7 \\
4.8 \\
5.0 \\
5.1 \\
5.1 \\
5.3 \\
5.5 \\
5.8\end{array}$ & $\begin{array}{l}.0 \\
.0 \\
.0 \\
.2 \\
.5 \\
.9 \\
1.3 \\
1.7 \\
2.2 \\
2.8 \\
3.3 \\
3.8 \\
4.4 \\
5.9 \\
6.2 \\
6.4 \\
6.6 \\
6.8 \\
7.0 \\
7.7\end{array}$ & $\begin{array}{r}.0 \\
.1 \\
7.3 \\
25.2 \\
47.9 \\
68.5 \\
90.7 \\
112.9 \\
134.3 \\
157.5 \\
178.0 \\
198.2 \\
238.8 \\
260.5 \\
261.3 \\
261.3 \\
261.3 \\
261.3 \\
261.3 \\
261.4\end{array}$ & $\begin{array}{r}.0 \\
16.0 \\
45.0 \\
67.1 \\
89.4 \\
115.1 \\
138.0 \\
160.8 \\
181.8 \\
206.2 \\
226.7 \\
250.6 \\
292.0 \\
341.6 \\
342.3 \\
342.8 \\
343.1 \\
343.6 \\
344.3 \\
348.8\end{array}$ \\
\hline
\end{tabular}


Table 4.2.31. Masses of radionuclide groups released to and retained in RCS at time of vessel failure for the Surry $S_{3} B$ sequence ( 145.9 minutes).

\begin{tabular}{lrr}
\hline Group & $\begin{array}{c}\text { Released } \\
(\mathrm{Kg})\end{array}$ & $\begin{array}{c}\text { Retained } \\
(\mathrm{Kg})\end{array}$ \\
\hline $\mathrm{I}$ & 12.1 & 8.8 \\
$\mathrm{Cs}$ & 143.0 & 108.1 \\
$\mathrm{Te}$ & 7.7 & 5.8 \\
$\mathrm{Sr}$ & .0 & .0 \\
$\mathrm{Ru}$ & .0 & .0 \\
$\mathrm{La}$ & .0 & .0 \\
$\mathrm{Ng}$ & 268.2 & .0 \\
$\mathrm{Ce}$ & .0 & .0 \\
$\mathrm{Ba}$ & .6 & .4 \\
\hline
\end{tabular}


the released mass from fuel ("Total") and the mass deposited on structural surfaces of the RCS ("Ret") as a function of time at roughly 2 -minute intervals. The percent of the released mass of the three volatile species (CsI, $\mathrm{CsOH}$, and $\mathrm{Te}$ ) that is retained on RCS surfaces as a function of time is illustrated in Figures 4.2 .59 through 4.2.61, respectively; the time-dependent release of aerosols is illustrated in Figure 4.2 .62 . At the time of vessel failure (145.9 minutes), 77 percent of CsI (released from fuel), 76 percent of CSOH, and 75 percent of both Te and aerosol material are retained on surfaces. The remainder has been transported to the containment.

A more detailed analysis of the TRAPMELT3 code output reveals that 81 percent of the deposited tellurium is, in fact, chemically bound and not available for revolatilization that may occur after vessel failure. Only about 7 percent of $\mathrm{CsOH}$ is so bound however. CsI apparently does not chemisorb to stainless steel. Both $\mathrm{CSI}$ and $\mathrm{CsOH}$ are deposited largely by aerosol mechanisms. Aerosol particle sizes range between approximately 3 and $8 \mu \mathrm{m}$.

\section{Surry HINY - NXY}

In the HINY-NXY sequence which was initiated by a steam generator tube rupture two TRAP-MELT analyses were performed, one to determine the primary system deposition and the second to determine the amount of deposition in the secondary side of the steam generator. Tables 4.2 .32 and 4.2 .33 summarize the results obtained for transport on the primary side. As illustrated in Figures 4.2 .63 and 4.2 .64 , most of the cesium and iodine are released from the fuel in a time period of approximately 30 minutes. Greater than half the released material leaks through the ruptured tube to the secondary side of the steam generator. Most of the $\mathrm{CSI}$ and $\mathrm{CSOH}$ that is retained within the primary system is deposited in the upper plenum. A small fraction is deposited on the hot leg. Figure 4.2.65 indicates that only one third of the tellurium released from the fuel excapes the primary system. Most of the tellurium is deposited in the upper plenum. Figure 4.2 .66 shows the behavior of the aerosols released in vessel. The behavior of the aerosols is similar to that of the iodine and cesium except that a larger fraction settles and remains in 


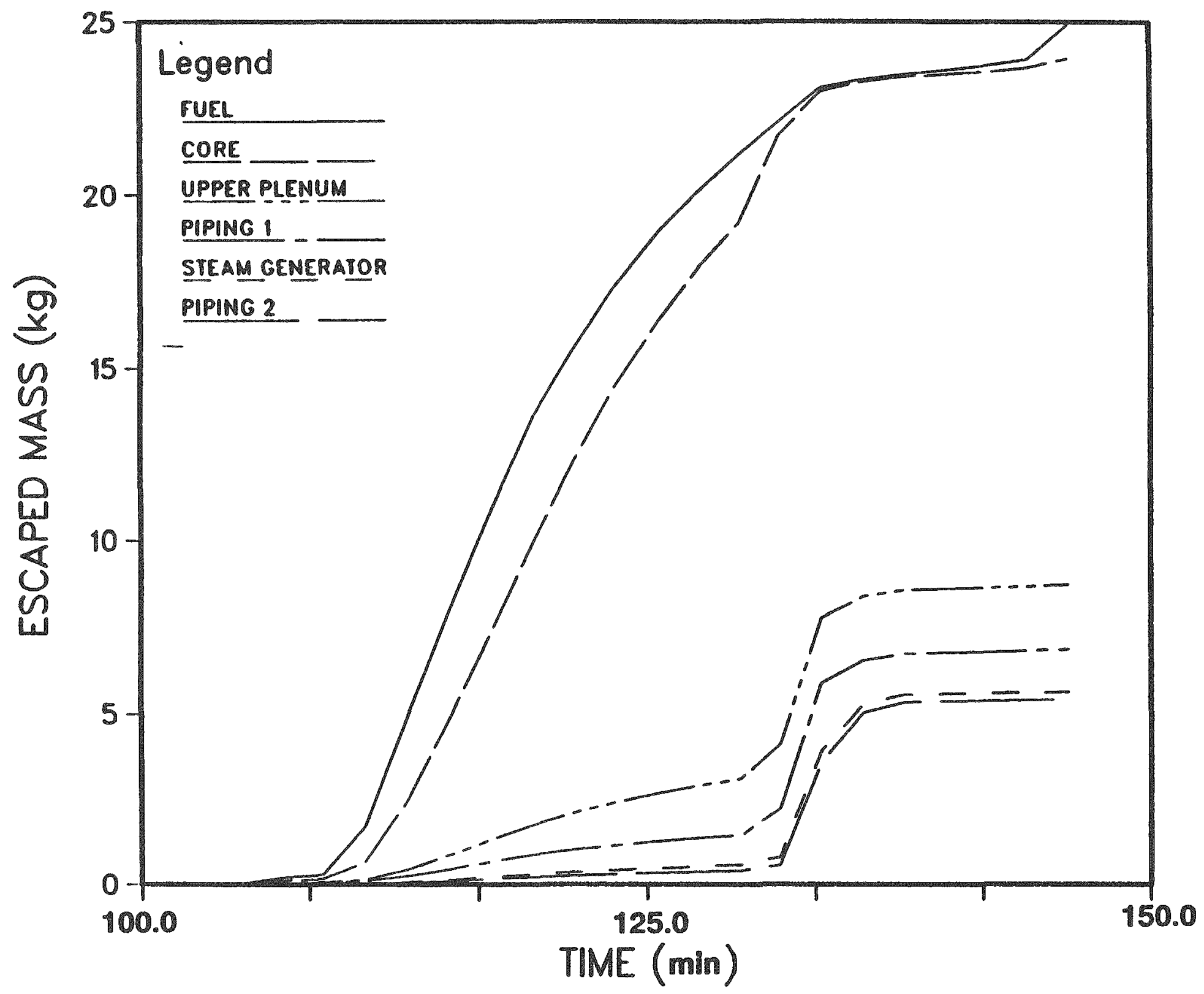

Figure 4.2.59. Mass of CSI released from indicated RCS components as a function of time - Surry $S_{3} B$. 


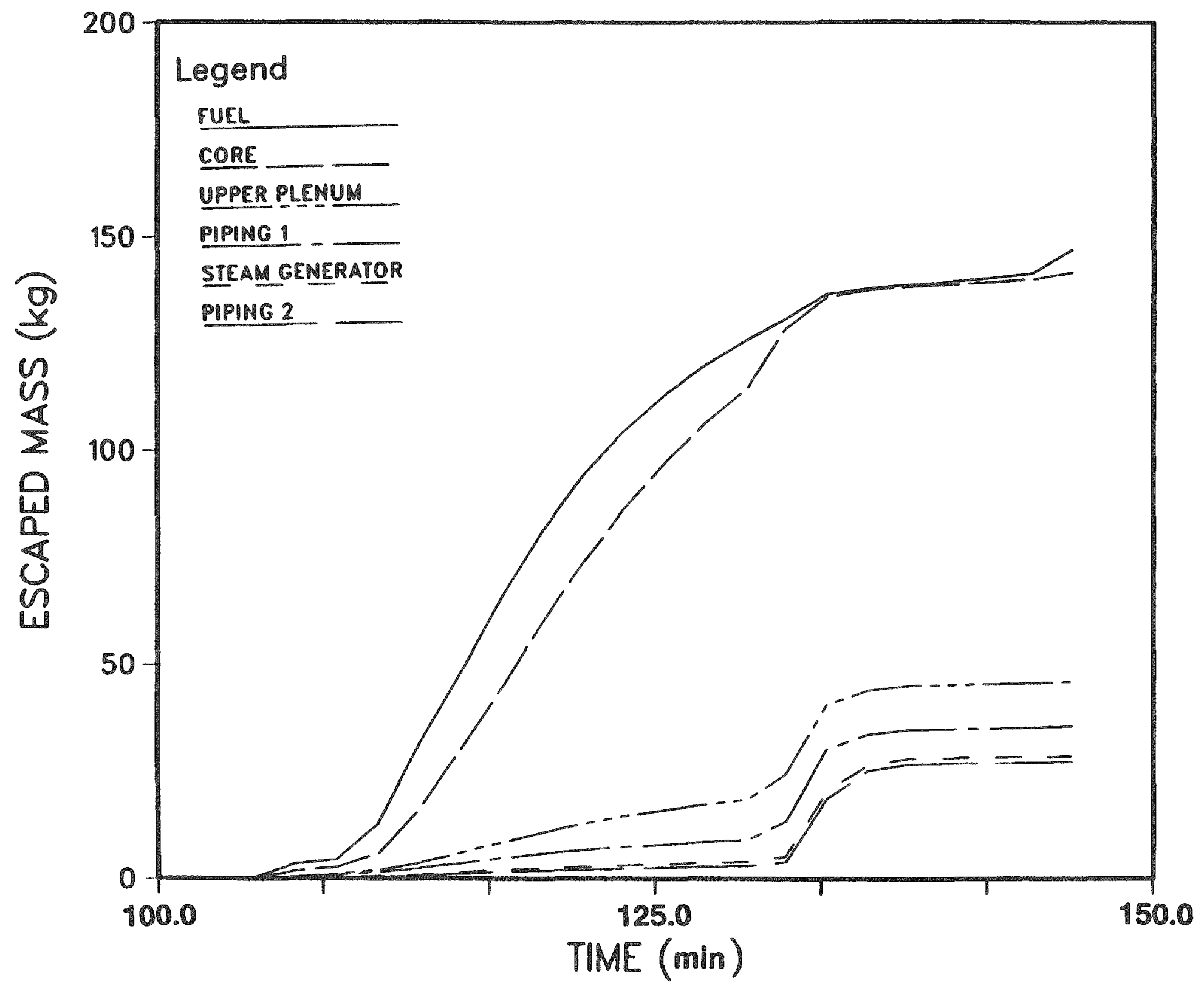

Figure 4.2.60. Mass of $\mathrm{CSOH}$ released from indicated $\mathrm{RCS}$ components as a function of time - Surry $S_{3} B$. 


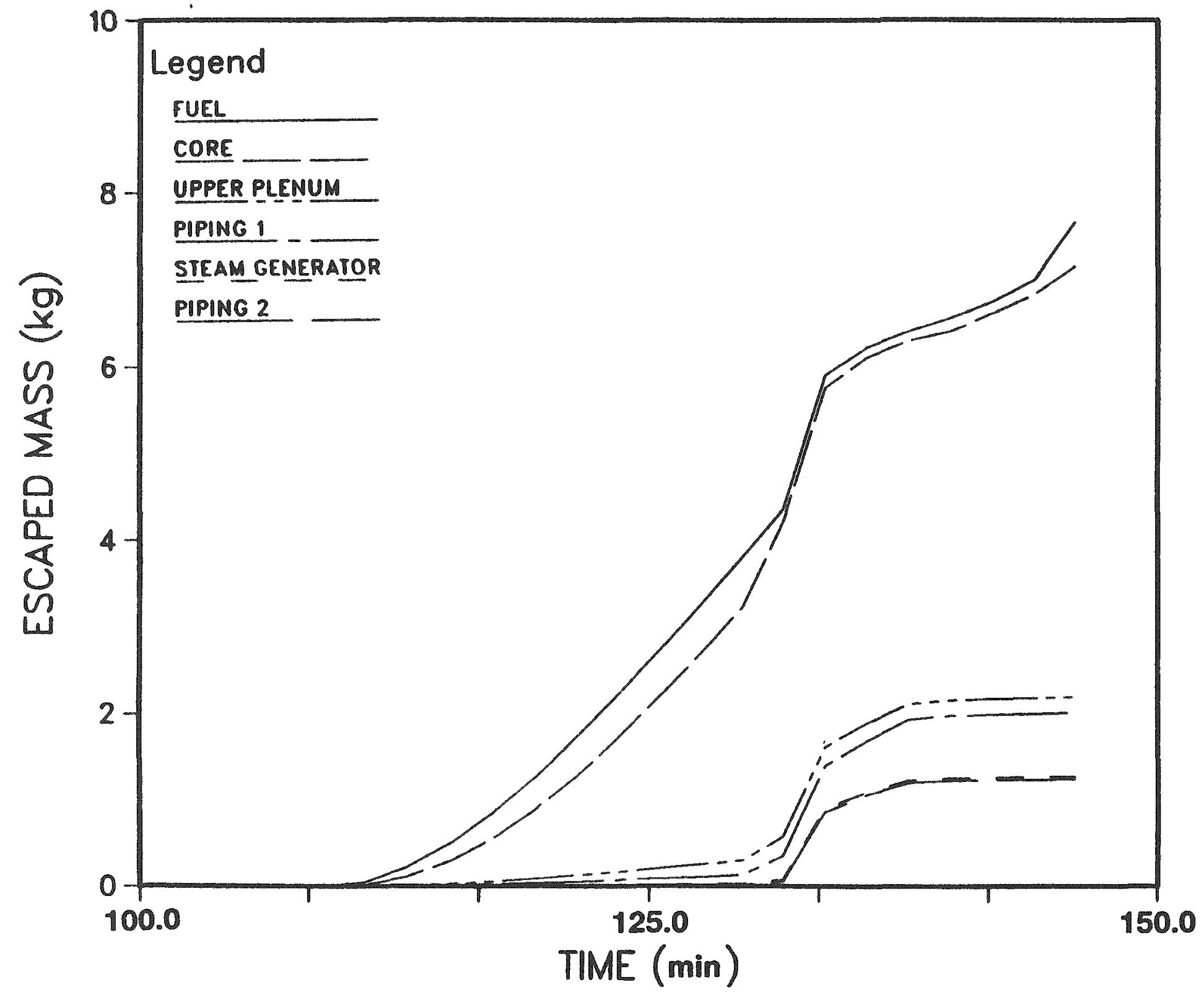

Figure 4.2.61. Mass of Te released from indicated RCS components as a function of time - Surry $S_{3} B$. 


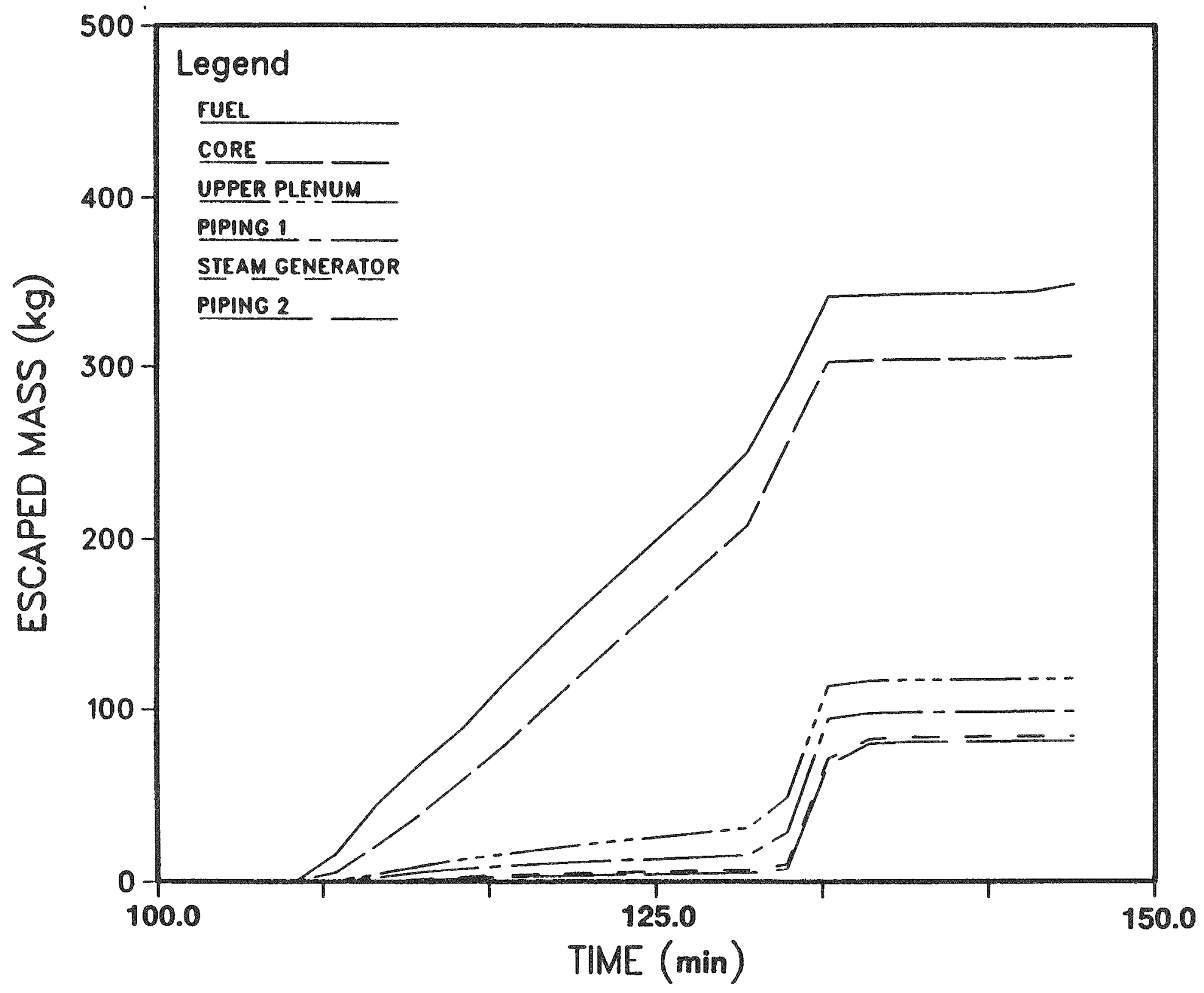

$\vec{\infty}$

Figure 4.2.62. Mass of aerosol released from indicated RCS components as a function of time - Surry $S_{3} B$. 
Table 4.2.32. Masses of dominant species released from fuel and retained on RCS structures as functions of time for the SURRY HINY-NXY sequence

\begin{tabular}{|c|c|c|c|c|c|c|c|c|}
\hline \multicolumn{3}{|c|}{ CSI } & \multicolumn{2}{|c|}{$\mathrm{CSOH}$} & \multicolumn{2}{|c|}{$T E$} & \multicolumn{2}{|c|}{ AEROSOL } \\
\hline $\begin{array}{l}\text { TIME } \\
\text { (M) }\end{array}$ & $\begin{array}{l}\overline{R E T} \\
(K G)\end{array}$ & $\begin{array}{l}\text { TOTAL } \\
\text { (KG) }\end{array}$ & $\begin{array}{l}\overline{\mathrm{RET}} \\
(\mathrm{KG})\end{array}$ & $\begin{array}{l}\text { TOTAL } \\
(\mathrm{KG})\end{array}$ & $\begin{array}{l}\overline{\mathrm{RET}} \\
(\mathrm{KG})\end{array}$ & $\begin{array}{l}\text { TOTAL } \\
(\mathrm{KG})\end{array}$ & $\begin{array}{l}\mathrm{RET} \\
(\mathrm{KG})\end{array}$ & $\begin{array}{l}\text { TOTAL } \\
(\mathrm{KG})\end{array}$ \\
\hline 846.6 & $\begin{array}{r}.0 \\
.0 \\
1.5 \\
4.4 \\
7.3 \\
9.3 \\
10.5 \\
9.3 \\
9.3 \\
9.3 \\
9.3 \\
9.3 \\
9.2 \\
9.2 \\
9.2 \\
9.3 \\
9.3 \\
9.3 \\
9.3 \\
9.3\end{array}$ & $\begin{array}{r}.2 \\
.8 \\
5.3 \\
10.6 \\
15.7 \\
19.6 \\
22.3 \\
23.3 \\
23.4 \\
23.4 \\
23.4 \\
23.4 \\
23.4 \\
23.4 \\
23.4 \\
23.4 \\
23.4 \\
23.4 \\
23.5 \\
23.5\end{array}$ & $\begin{array}{r}.1 \\
.5 \\
9.3 \\
26.1 \\
42.8 \\
54.4 \\
61.6 \\
57.2 \\
57.0 \\
57.0 \\
57.0 \\
57.0 \\
56.9 \\
56.9 \\
56.9 \\
57.0 \\
57.0 \\
57.0 \\
56.9 \\
56.9\end{array}$ & $\begin{array}{r}2.9 \\
7.4 \\
33.4 \\
63.7 \\
93.4 \\
116.2 \\
131.8 \\
138.0 \\
138.3 \\
138.3 \\
138.3 \\
138.3 \\
138.3 \\
138.3 \\
138.4 \\
138.4 \\
138.4 \\
138.5 \\
138.7 \\
138.8\end{array}$ & $\begin{array}{r}.0 \\
.0 \\
.2 \\
.9 \\
2.8 \\
6.6 \\
9.9 \\
10.6 \\
10.6 \\
10.5 \\
10.5 \\
10.5 \\
10.5 \\
10.5 \\
10.5 \\
10.5 \\
10.5 \\
10.5 \\
10.5 \\
10.5\end{array}$ & $\begin{array}{r}.0 \\
.0 \\
.5 \\
1.7 \\
5.1 \\
9.9 \\
13.4 \\
15.4 \\
15.5 \\
15.5 \\
15.5 \\
15.5 \\
15.5 \\
15.5 \\
15.5 \\
15.5 \\
15.5 \\
15.5 \\
15.6 \\
15.6\end{array}$ & $\begin{array}{r}.0 \\
5.0 \\
27.6 \\
56.2 \\
88.8 \\
115.2 \\
138.9 \\
148.7 \\
148.7 \\
148.7 \\
148.7 \\
148.7 \\
148.7 \\
148.7 \\
148.7 \\
148.7 \\
148.7 \\
148.7 \\
148.7 \\
148.7\end{array}$ & $\begin{array}{r}.0 \\
30.9 \\
69.8 \\
123.0 \\
178.4 \\
233.5 \\
290.0 \\
337.3 \\
337.4 \\
337.4 \\
337.4 \\
337.4 \\
337.4 \\
337.4 \\
337.4 \\
337.4 \\
337.4 \\
337.4 \\
337.5 \\
337.5\end{array}$ \\
\hline
\end{tabular}

Table 4.2.33. Masses of radionuclide groups released to and retained in $R C S$ at time of vessel failure for the Surry HINY-NXY sequence (933.7 minutes)

\begin{tabular}{crc}
\hline Group & $\begin{array}{c}\text { Released } \\
(\mathrm{KG})\end{array}$ & $\begin{array}{c}\text { Released } \\
(\mathrm{KG})\end{array}$ \\
I & 11.5 & 4.5 \\
TS & 135.1 & 55.2 \\
TE & 15.6 & 10.5 \\
RU & .0 & .0 \\
LA & .0 & .0 \\
NG & .0 & .0 \\
CE & 253.1 & .0 \\
BA & .0 & .0 \\
\hline
\end{tabular}




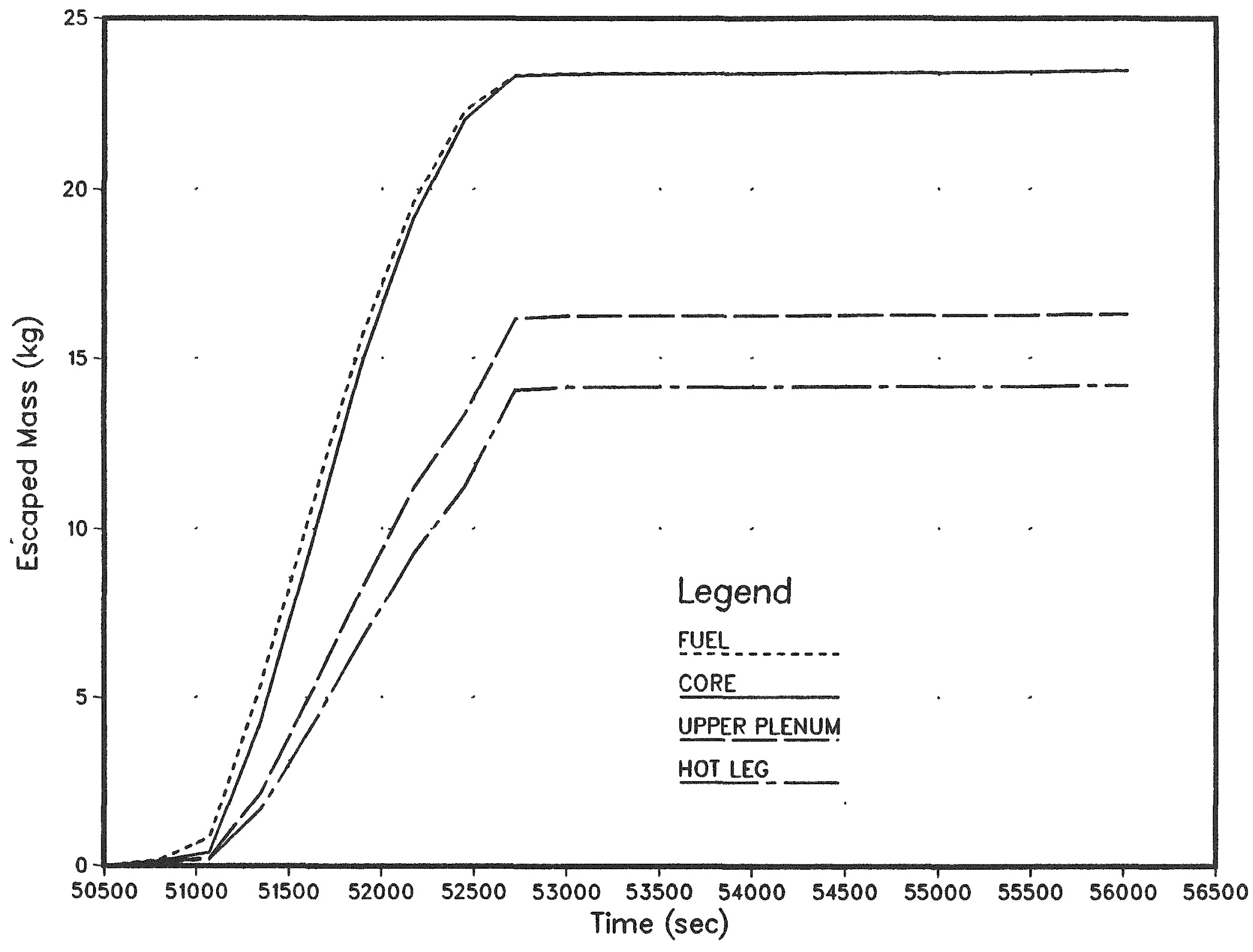

Figure 4.2.63. Mass of CsI released from indicated RCS components as a function of time - Surry HINY-NXY, primary. 


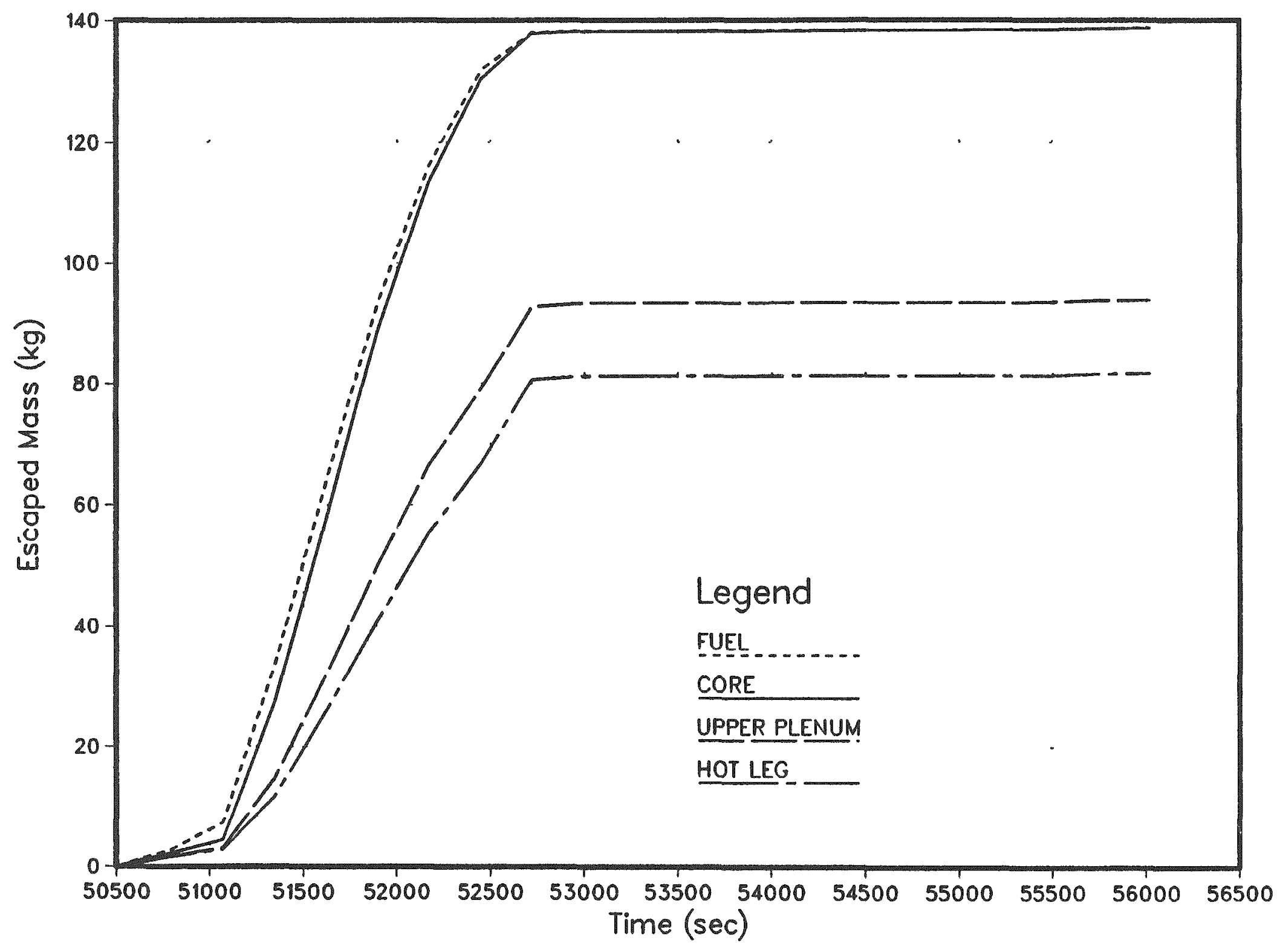

$\omega$

Figure 4.2.64. Mass of CsOH released from indicated RCS components as a function of time - Surry HINY-NXY, primary. 


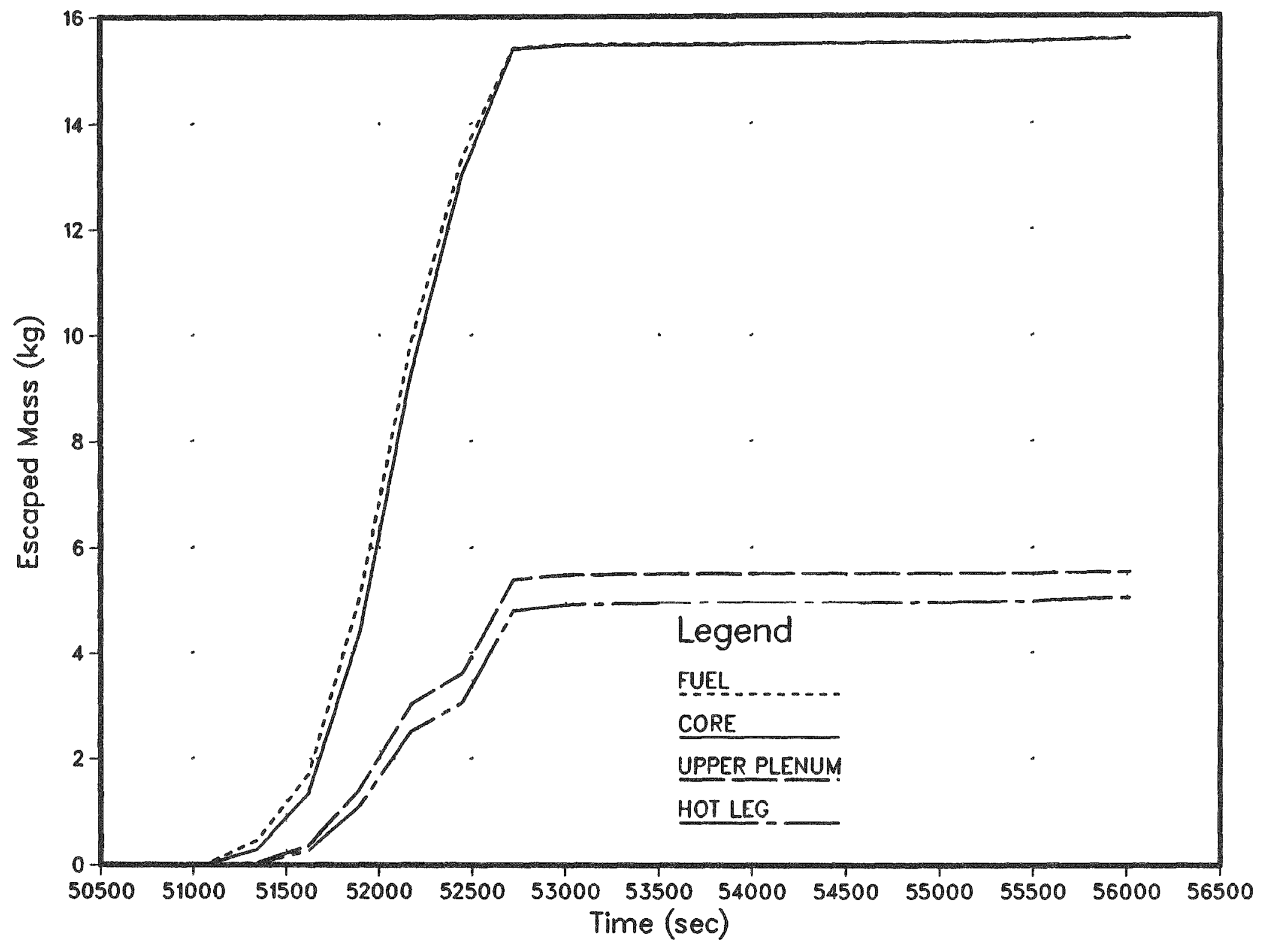

Figure 4.2.65. Mass of Te released from indicated RCS components as a function of time - Surry HINY-NXY, primary. 


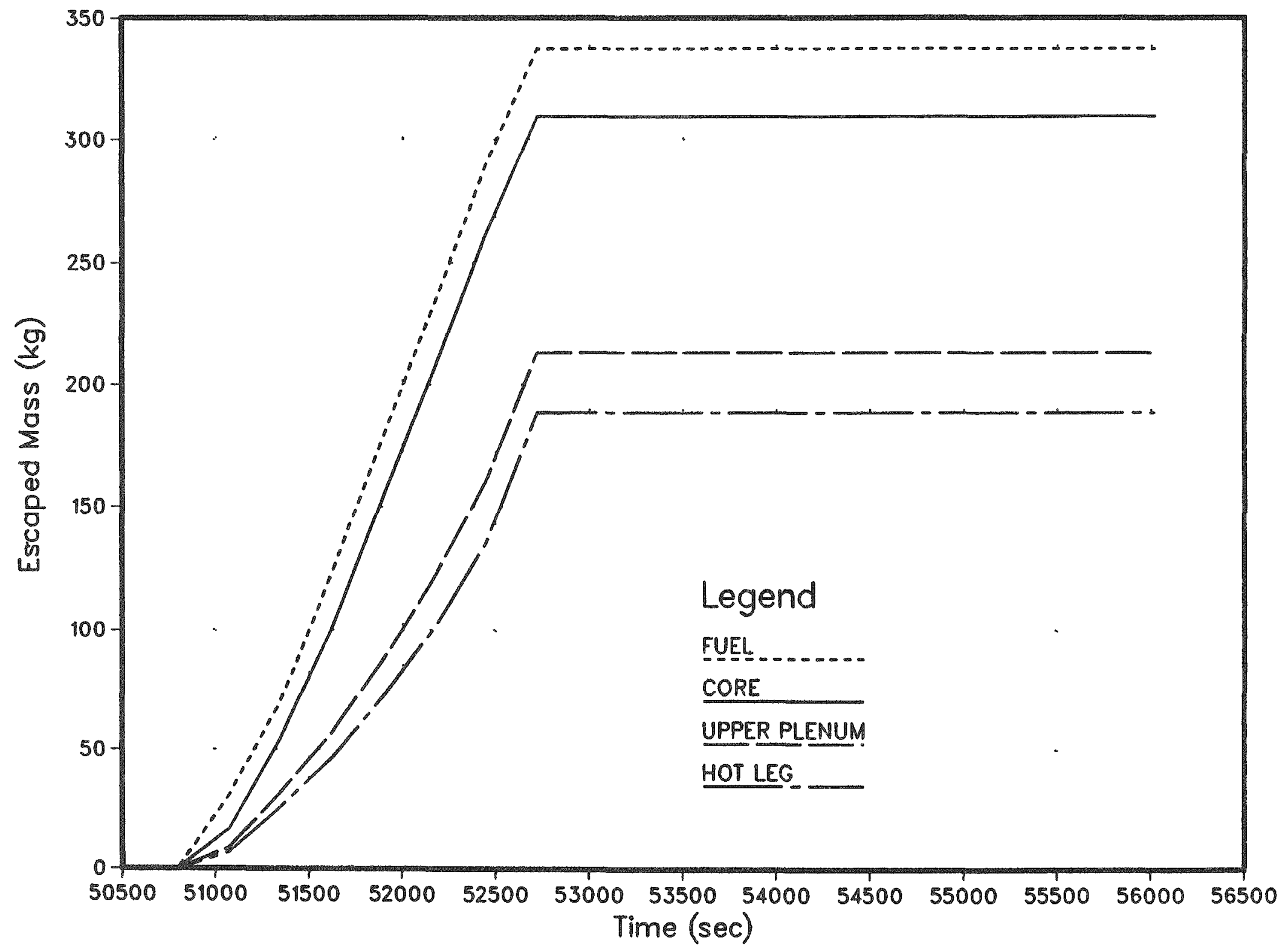

Figure 4.2.66 Mass of aerosol released from indicated RCS components as a function of time - Surry HINY-NXY, primary. 
the core region. Table 4.2.34 summarizes the fractional release from the primary system.

After being released through the failed steam generator tube, the fission products are transported through the secondary side of the steam generator and to the environment through the stuck open relief valve. Tables 4.2 .35 and 4.2.36 summarize this behavior for the dominant species as a function of time and for the elemental groups of radionuclides. As illustrated in Figures 4.2.67 to 4.2.70, most of the radionuclides released to the secondary side escape to the environment. Deposition on the secondary side is small because of the short residence time. Release fractions for the secondary side are summarized in Table 4.2.37. The ultimate location of the principal species at the time of vessel failure is provided in Table 4.2.38.

\section{Radionuclide Transport - Surry GLYY-YXY}

Because the primary system residence time is essentially the same as for HINY-HXY the amount of deposition is very similar. Thus Figures 4.2 .71 to 4.2.74 are similar to Figures 4.2 .63 to 4.2 .66 and Tables 4.2 .39 to 4.2 .41 are similar to Tables 4.2 .32 to 4.2 .34 except that the retention is slightiy higher.

The secondary side characteristics are quite different, however. Whereas, there is almost no retention on the secondary side with the atmospheric dump valves stuck open, approximately sixty percent of the radioactive material entering the secondary side is predicted to be retained on these surfaces. Most of this retention occurs within the tube bundle. This behavior is illustrated in Figures 4.2 .75 to 4.2 .78 and in Tables 4.2 .42 to 4.2 .44 . Table 4.2.45 summarizes the ultimate location of each group of radionuclides.

\section{Radionuclide Transport - Surry HINY-YXY}

The principal difference difference between this case and the previous two cases is that a substantial fraction of the primary system flow is diverted to the containment via the stuck open PORV and thus does not excape through the broken steam generator tube. Primary system behavior is illustrated in 
Table 4.2.34. Fraction of initial core inventory released to the secondary for Surry HINY-NXY

Core Inventory Fraction Released from the Primary System

$\begin{array}{cc}\text { Group } & \text { During In-Vessel Release } \\ \text { I } & .5587 \\ \text { CS } & .5476 \\ \text { PI } & 1.7758 \mathrm{E}-03 \\ \text { TE } & .1986 \\ \text { SR } & 2.9219 \mathrm{E}-04 \\ \text { RU } & 5.2870 \mathrm{E}-07 \\ \text { LA } & 4.6108 \mathrm{E}-08 \\ \text { NG } & .9251 \\ \text { CE } & 0.0 \\ \text { BA } & 5.3862 \mathrm{E}-03\end{array}$




\section{Table 4.2.35. Masses of dominant species released from RCS and retained on secondary structures as functions \\ of time for the Surry HINY-NXY sequence}

\begin{tabular}{|c|c|c|c|c|c|c|c|c|}
\hline \multirow[b]{2}{*}{$\begin{array}{l}\text { TIME } \\
(M)\end{array}$} & \multicolumn{2}{|c|}{ CSI } & \multicolumn{2}{|c|}{$\mathrm{CSOH}$} & \multicolumn{2}{|c|}{ TE } & \multicolumn{2}{|c|}{ AEROSOL } \\
\hline & $\begin{array}{l}\overline{\mathrm{RET}} \\
(\mathrm{KG})\end{array}$ & $\begin{array}{l}\text { TOTAL } \\
(K G)\end{array}$ & $\begin{array}{l}\overline{\mathrm{RET}} \\
(\mathrm{KG})\end{array}$ & $\begin{array}{l}\text { TOTAL } \\
\text { (KG) }\end{array}$ & $\begin{array}{l}\overline{\mathrm{RET}} \\
(\mathrm{KG})\end{array}$ & $\begin{array}{l}\text { TOTAL } \\
\text { (KG) }\end{array}$ & $\begin{array}{l}\text { RET } \\
(K G)\end{array}$ & $\begin{array}{l}\text { TOTAL } \\
(K G)\end{array}$ \\
\hline $\begin{array}{l}846.6 \\
851.2 \\
855.8 \\
860.4 \\
864.9 \\
869.5 \\
874.1 \\
878.7 \\
883.3 \\
887.9 \\
892.4 \\
897.0 \\
901.6 \\
906.2 \\
910.8 \\
915.4 \\
919.9 \\
924.5 \\
929.1 \\
933.7\end{array}$ & $\begin{array}{l}.0 \\
.0 \\
.1 \\
.3 \\
.6 \\
.9 \\
1.1 \\
1.4 \\
1.4 \\
1.4 \\
1.4 \\
1.4 \\
1.4 \\
1.4 \\
1.4 \\
1.4 \\
1.4 \\
1.4 \\
1.4 \\
1.4\end{array}$ & $\begin{array}{r}.1 \\
.2 \\
1.7 \\
4.1 \\
6.7 \\
9.3 \\
11.2 \\
14.1 \\
14.1 \\
14.1 \\
14.1 \\
14.1 \\
14.1 \\
14.2 \\
14.2 \\
14.2 \\
14.2 \\
14.2 \\
14.2 \\
14.2\end{array}$ & $\begin{array}{l}.0 \\
.1 \\
.7 \\
2.1 \\
3.8 \\
5.5 \\
6.9 \\
8.5 \\
8.6 \\
8.6 \\
8.6 \\
8.6 \\
8.6 \\
8.6 \\
8.6 \\
8.6 \\
8.6 \\
8.6 \\
8.6 \\
8.7\end{array}$ & $\begin{array}{r}1.7 \\
2.9 \\
11.7 \\
25.9 \\
40.9 \\
55.5 \\
66.7 \\
80.7 \\
81.3 \\
81.3 \\
81.3 \\
81.3 \\
81.4 \\
81.4 \\
81.4 \\
81.4 \\
81.4 \\
81.4 \\
81.8 \\
81.8\end{array}$ & $\begin{array}{l}.0 \\
.0 \\
.0 \\
.0 \\
.2 \\
.5 \\
.6 \\
1.0 \\
1.0 \\
1.0 \\
1.0 \\
1.0 \\
1.0 \\
1.0 \\
1.0 \\
1.0 \\
1.0 \\
1.0 \\
1.0 \\
1.0\end{array}$ & $\begin{array}{l}.0 \\
.0 \\
.0 \\
.3 \\
1.1 \\
2.5 \\
3.1 \\
4.8 \\
4.9 \\
4.9 \\
4.9 \\
4.9 \\
5.0 \\
5.0 \\
5.0 \\
5.0 \\
5.0 \\
5.0 \\
5.0 \\
5.0\end{array}$ & $\begin{array}{r}.0 \\
.2 \\
1.8 \\
3.8 \\
6.3 \\
9.4 \\
13.3 \\
19.7 \\
19.7 \\
19.7 \\
19.7 \\
19.7 \\
19.7 \\
19.7 \\
19.7 \\
19.7 \\
19.7 \\
19.7 \\
19.7 \\
19.7\end{array}$ & $\begin{array}{r}.0 \\
7.0 \\
26.1 \\
46.4 \\
71.7 \\
101.1 \\
135.3 \\
188.6 \\
188.7 \\
188.7 \\
188.7 \\
188.7 \\
188.7 \\
188.7 \\
188.7 \\
188.7 \\
188.7 \\
188.7 \\
188.8 \\
188.8\end{array}$ \\
\hline
\end{tabular}


Table 4.2.36. Masses of radionculide groups released to and retained in secondary at time of vessel failure for the Surry HINY-NXY sequence (933.7 minutes)

\begin{tabular}{ccc}
\hline Group & $\begin{array}{c}\text { Released } \\
(K G)\end{array}$ & $\begin{array}{c}\text { Released } \\
(K G)\end{array}$ \\
I & 6.9 & .7 \\
TS & 79.8 & 8.4 \\
TE & 5.0 & .0 \\
RU & .0 & .0 \\
LA & .0 & .0 \\
NG & .0 & .0 \\
CE & .0 & .0 \\
BA & .0 & .0 \\
\hline
\end{tabular}




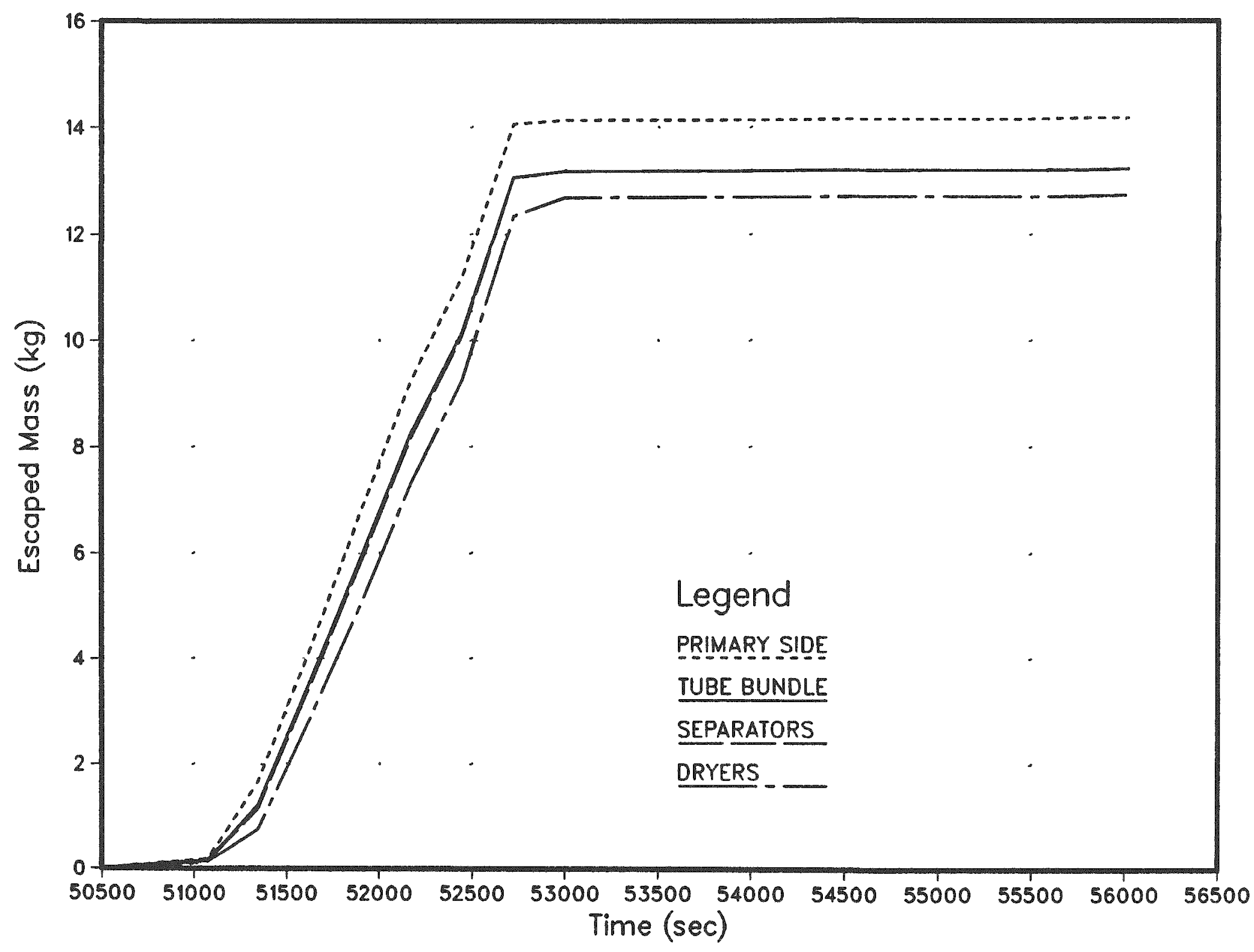

Figure 4.2.67. Mass of CsI released from indicated $\mathrm{R} C S$ components as a function of time - Surry HINX-NXY, secondary. 


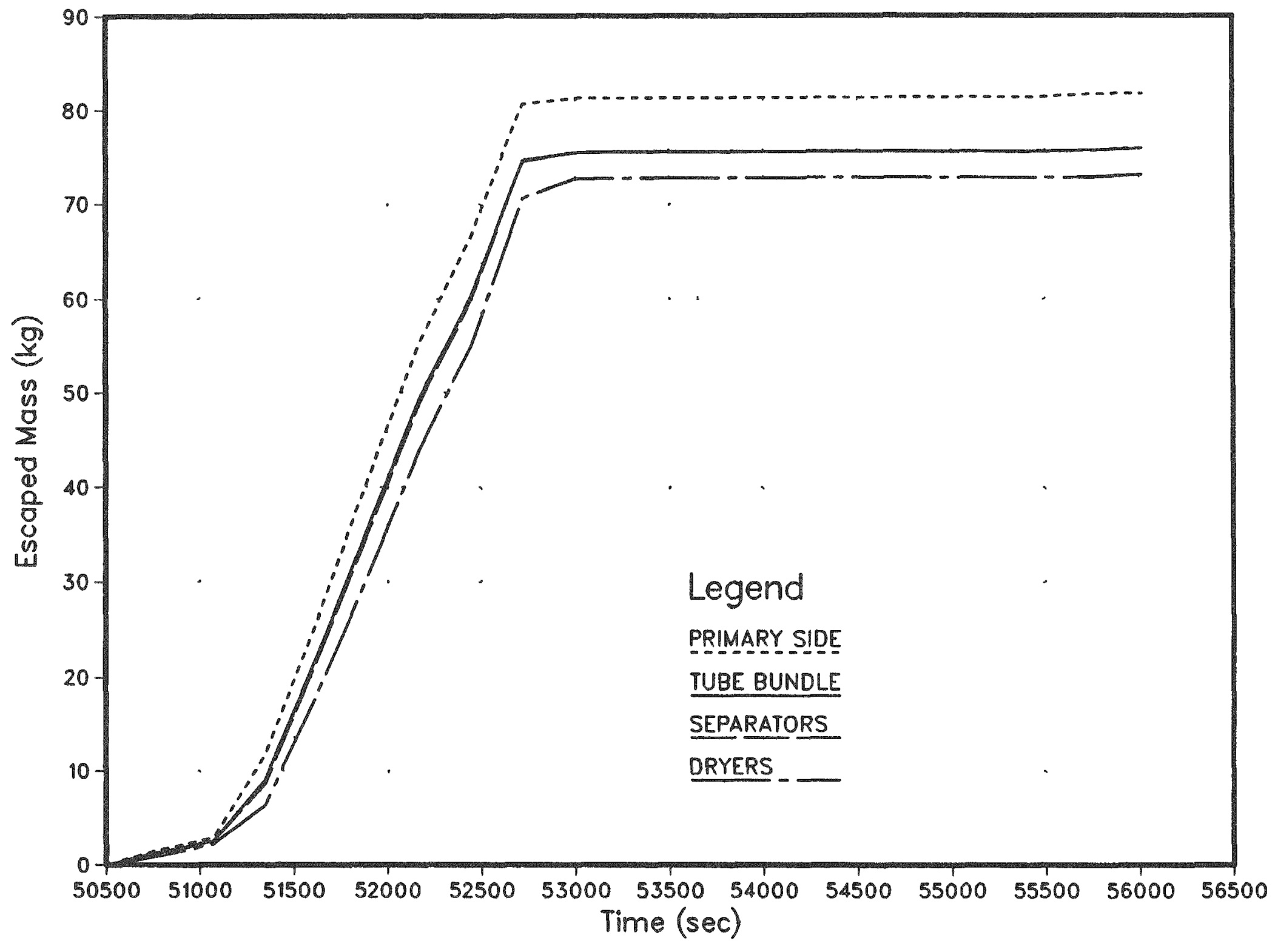

Figure 4.2.68. Mass of $\mathrm{CSOH}$ released from indicated $\mathrm{RCS}$ components as a function of time - Surry HINY $\sim N X Y$, secondary. 


$$
\text { TE-2 }
$$

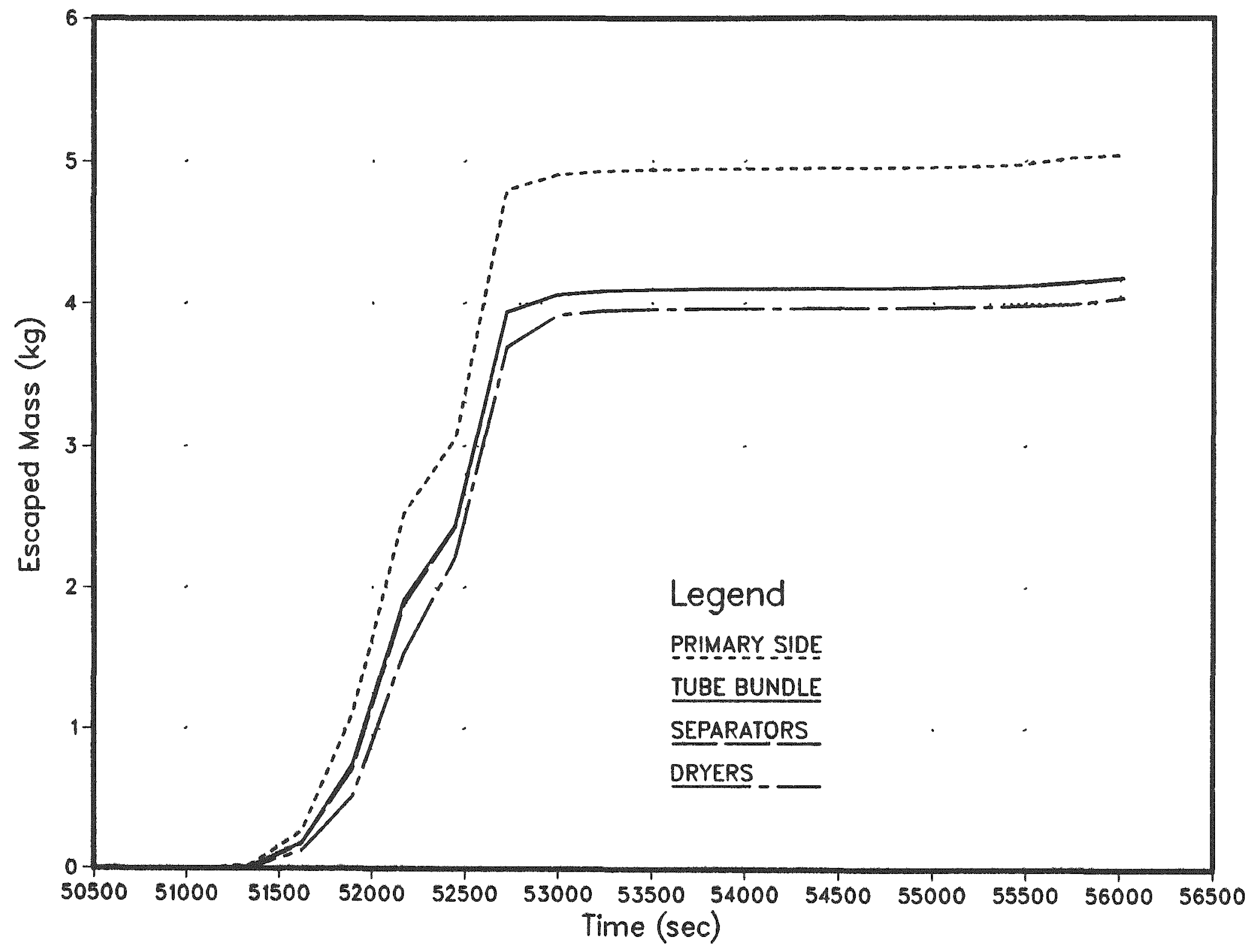

Figure 4.2.69. Mass of Te released from indicated RCS components as a function of time - Surry HINY-NXY, secondary. 


$$
\mathrm{Pl}-2
$$

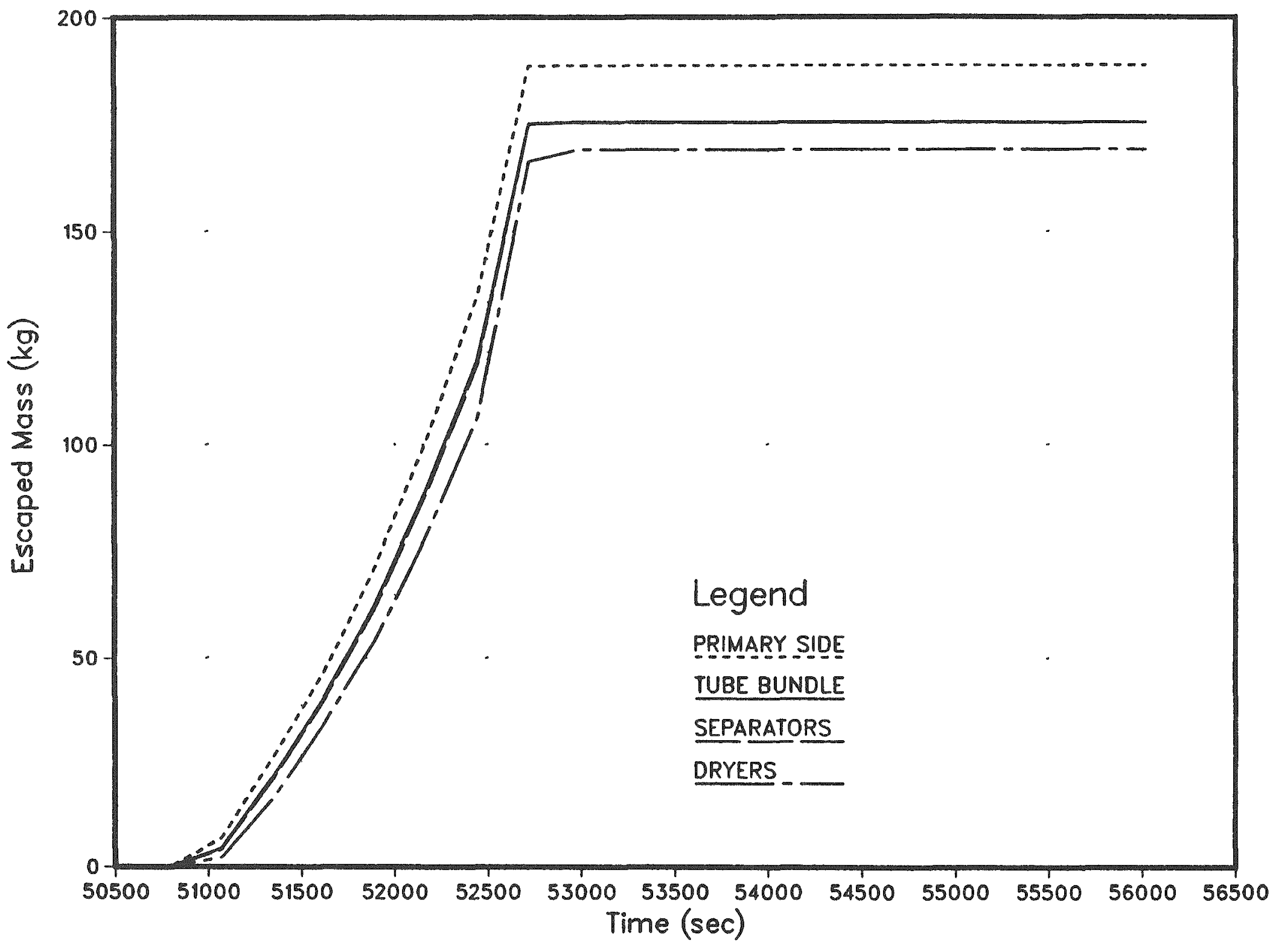

Figure 4.2.70. Mass of aerosol released from indicated RCS components a function of time - Surrv HINY-NXY, secondary. 

Table 4.2.37. Fraction of initial core inventory released
to the environment for Surry HINY-NXY

$\begin{array}{cc}\text { Core Inventory Fraction Released to the Environment } \\ \text { Group } & \text { During In-Vessel Release } \\ \text { I } & .5018 \\ \text { CS } & .4898 \\ \text { PI } & 1.5905 \mathrm{E}-03 \\ \text { TE } & .1590 \\ \text { SR } & 2.5988 \mathrm{E}-04 \\ \text { RU } & 4.7018 \mathrm{E}-07 \\ \text { LA } & 4.1003 \mathrm{E}-08 \\ \text { NG } & 0 . \\ \text { CE } & 0 . \\ \text { BA } & 4.7908 \mathrm{E}-03\end{array}$

Table 4.2.38. Distribution of inventory of principal species, Surry HINY-NXY

\begin{tabular}{ccccc}
\hline \hline \multicolumn{5}{c}{ Location at Vessel Failure (percent) } \\
Species & Fue & RCS & SG Secondary & Environment \\
CSI & 7.5 & 37 & 5.5 & 50 \\
CsOH & 7.2 & 38 & 5.8 & 49 \\
Te & 39 & 41 & 3.9 & 16 \\
\hline \hline
\end{tabular}




\section{$\mathrm{Cl}-1$}

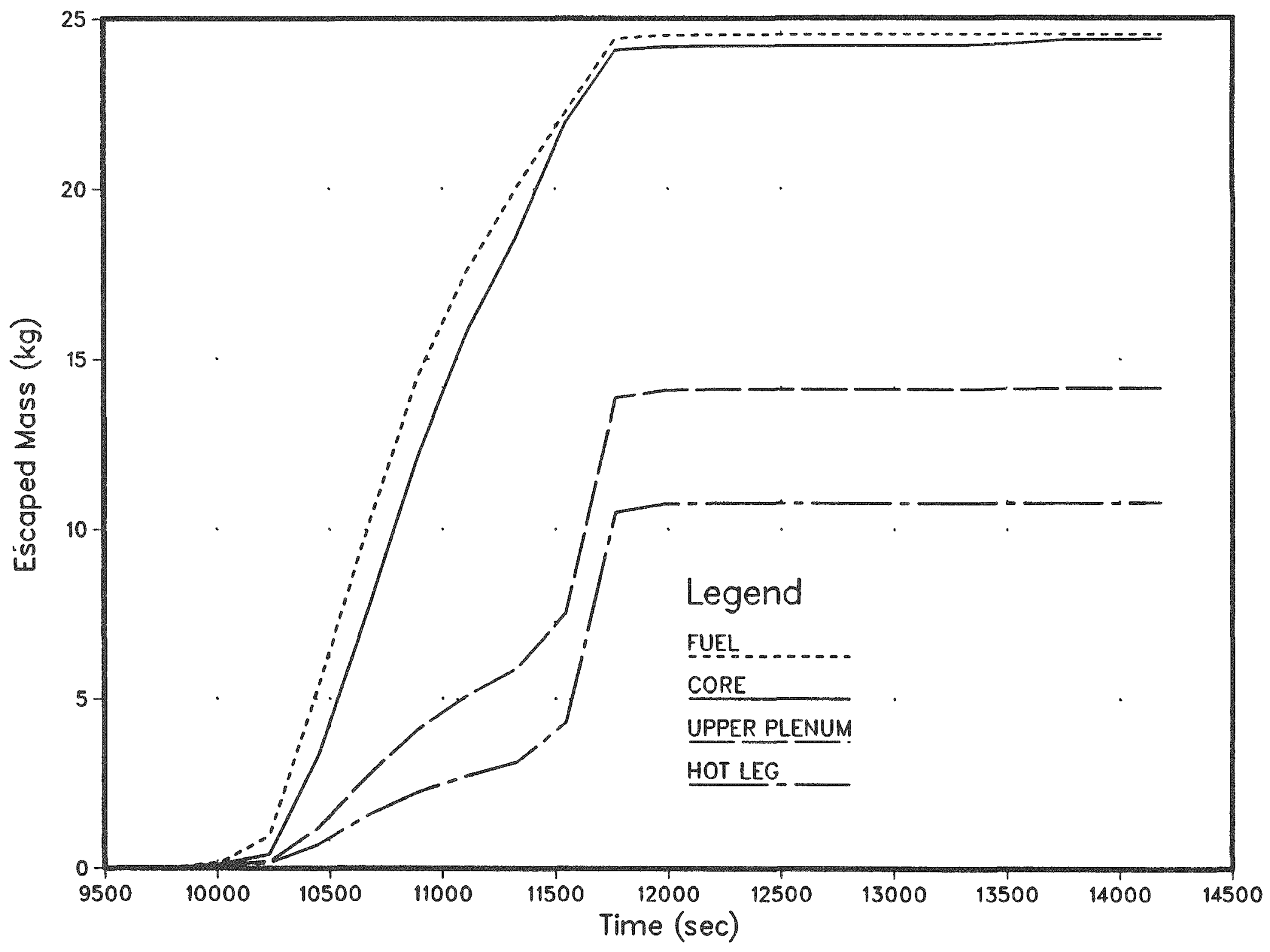

Figure 4.2.71. Mass of CsI released from indicated RCS component as a function of time - Surry GLYY-YXY, primary. 


\section{$\mathrm{CH}-1$}

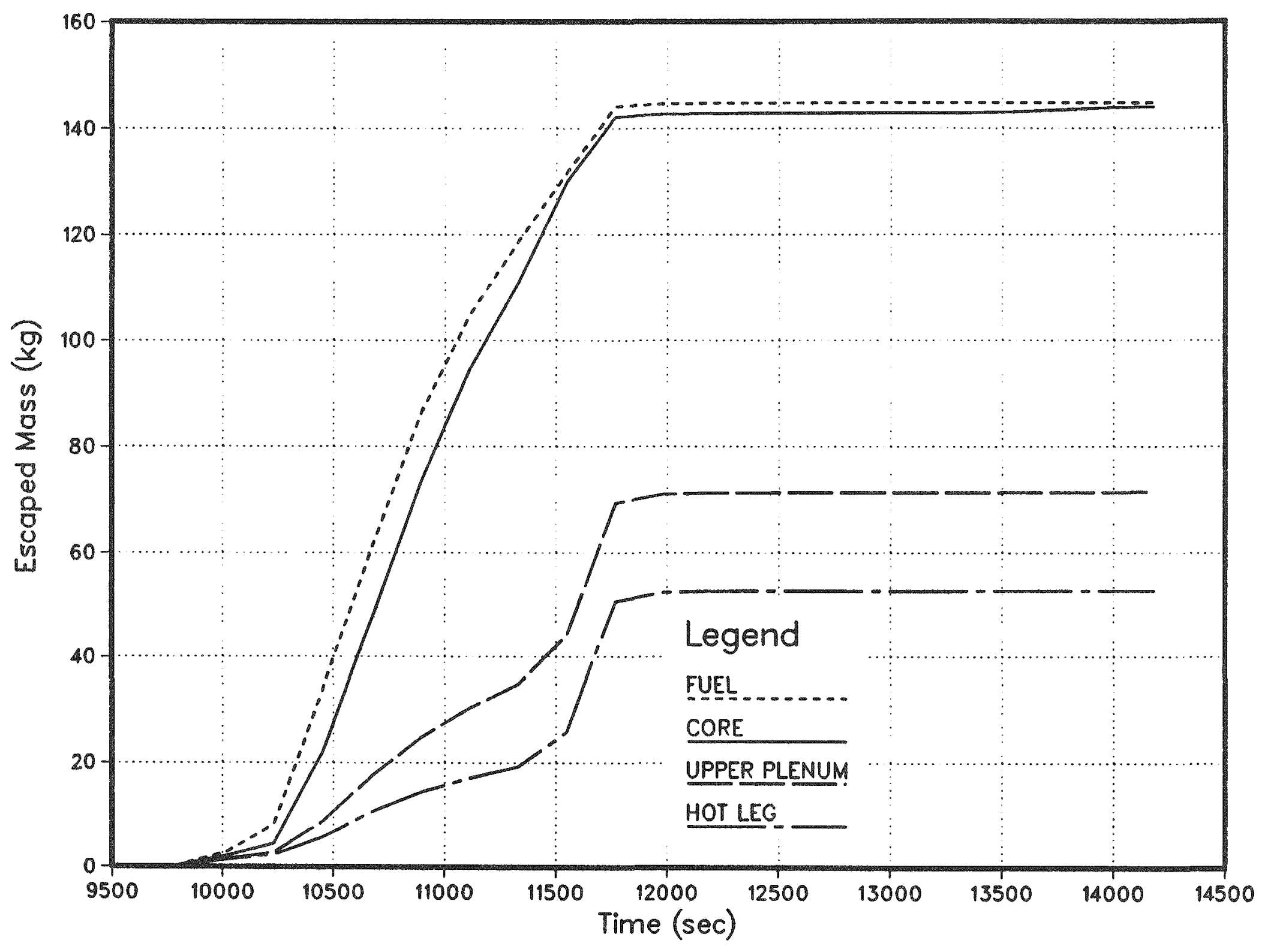

Figure 4.2.72. Mass of $\mathrm{CsOH}$ released from indicated $\mathrm{RCS}$ component as a function of time - Surry GLYY-YXY, primary. 
TE-1

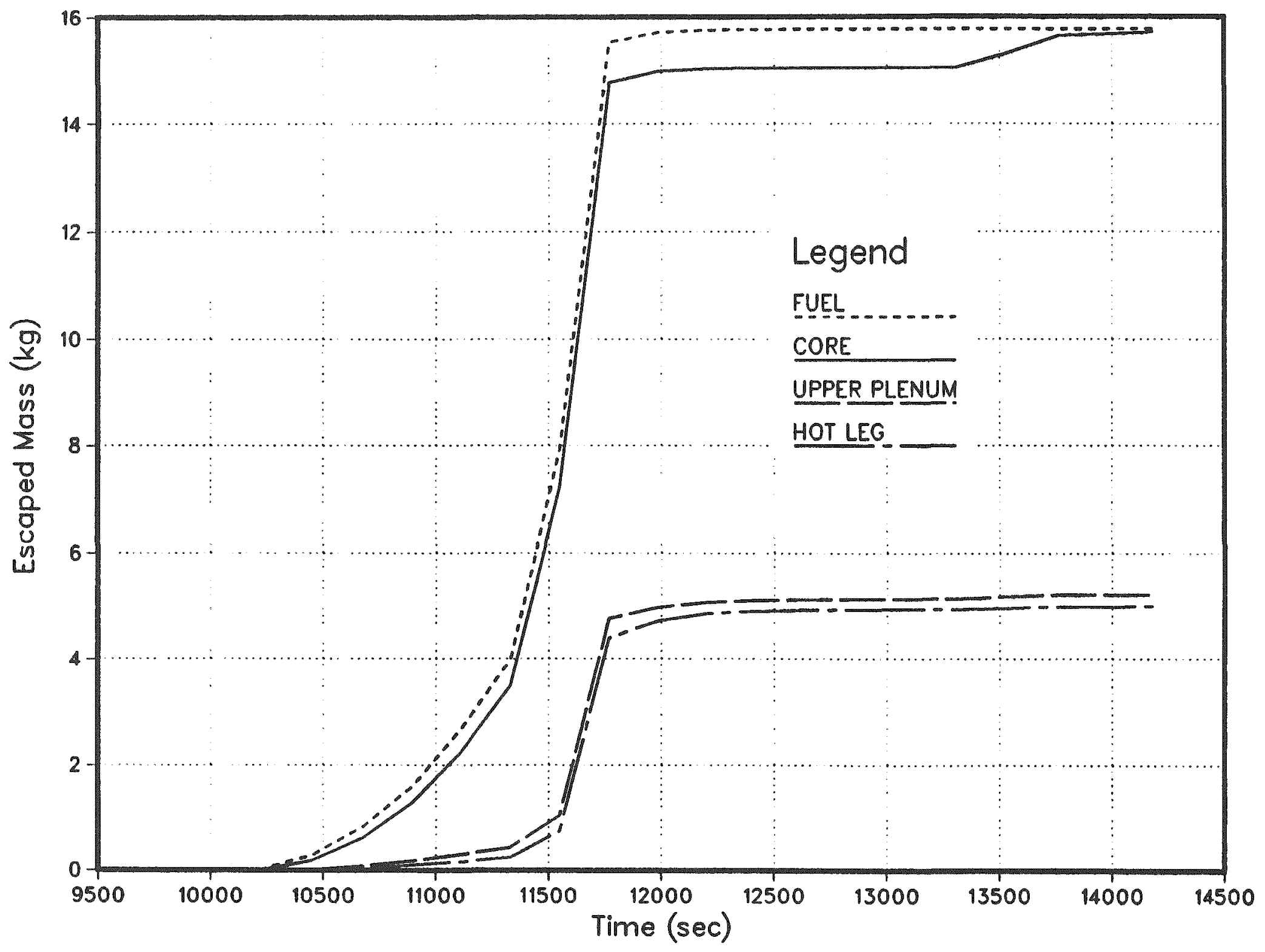

옹

Figure 4.2.73. Mass of Te released from indicated RCS component as a function of time - Surry GLYY-YXY, primary. 


$$
\mathrm{Pl}-1
$$

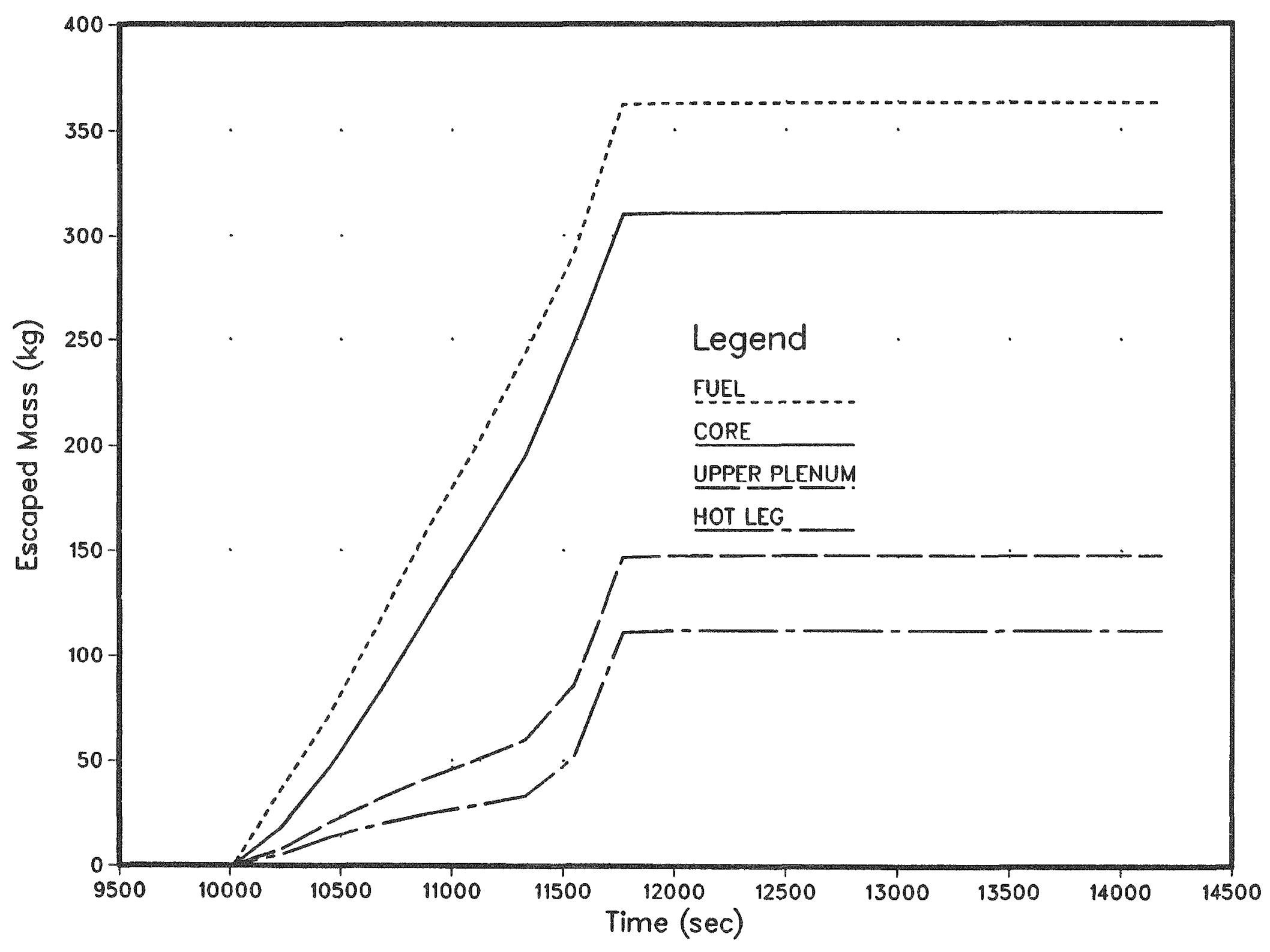

Figure 4.2.74. Mass of aerosol released from indicated RCS component as a function of time - Surry GLYY-YXY, primary. 
Table 4.2.39. Masses of dominant species released from fuel and retained on RCS structures as functions of time for the SURRY GLYY-YXY sequence

\begin{tabular}{|c|c|c|c|c|c|c|c|c|}
\hline \multicolumn{3}{|c|}{ CSI } & \multicolumn{2}{|c|}{$\mathrm{CSOH}$} & \multicolumn{2}{|c|}{ TE } & \multicolumn{2}{|c|}{ AEROSOL } \\
\hline $\begin{array}{l}\text { TIME } \\
(M)\end{array}$ & $\begin{array}{l}\text { RET } \\
(\mathrm{KG})\end{array}$ & $\begin{array}{l}\text { TOTAL } \\
\text { (KG) }\end{array}$ & $\begin{array}{l}\overline{R E T} \\
(K G)\end{array}$ & $\begin{array}{l}\text { TOTAL } \\
\text { (KG) }\end{array}$ & $\begin{array}{l}\text { RET } \\
(K G)\end{array}$ & $\begin{array}{l}\text { TOTAL } \\
\text { (KG) }\end{array}$ & $\begin{array}{l}\text { RET } \\
(\mathrm{KG})\end{array}$ & $\begin{array}{l}\text { TOTAL } \\
\text { (KG) }\end{array}$ \\
\hline $\begin{array}{l}166.9 \\
170.5 \\
174.2 \\
178.0 \\
181.6 \\
185.2 \\
188.9 \\
192.5 \\
196.1 \\
199.8 \\
203.5 \\
207.1 \\
210.8 \\
214.5 \\
218.1 \\
221.8 \\
225.5 \\
229.4 \\
233.4 \\
236.4\end{array}$ & $\begin{array}{r}.0 \\
.1 \\
1.7 \\
5.1 \\
9.0 \\
12.3 \\
14.9 \\
17.2 \\
13.8 \\
13.7 \\
13.7 \\
13.7 \\
13.7 \\
13.7 \\
13.7 \\
13.7 \\
13.6 \\
13.5 \\
13.5 \\
13.5\end{array}$ & $\begin{array}{r}.2 \\
1.0 \\
5.4 \\
10.2 \\
14.5 \\
17.7 \\
20.0 \\
22.3 \\
24.4 \\
24.5 \\
24.5 \\
24.5 \\
24.5 \\
24.5 \\
24.5 \\
24.5 \\
24.5 \\
24.5 \\
24.5 \\
24.5\end{array}$ & $\begin{array}{r}.2 \\
.9 \\
11.1 \\
31.5 \\
53.9 \\
73.4 \\
88.4 \\
101.8 \\
92.9 \\
92.1 \\
92.0 \\
92.0 \\
92.0 \\
92.0 \\
92.0 \\
92.0 \\
91.6 \\
90.9 \\
90.8 \\
90.9\end{array}$ & $\begin{array}{r}2.9 \\
8.2 \\
33.9 \\
61.5 \\
86.4 \\
104.8 \\
118.7 \\
131.7 \\
144.1 \\
144.6 \\
144.7 \\
144.8 \\
144.8 \\
144.8 \\
144.8 \\
144.8 \\
144.8 \\
144.8 \\
144.8 \\
144.8\end{array}$ & $\begin{array}{r}.0 \\
.0 \\
.1 \\
.5 \\
1.1 \\
2.0 \\
3.2 \\
6.2 \\
11.1 \\
11.0 \\
10.9 \\
10.9 \\
10.8 \\
10.8 \\
10.8 \\
10.8 \\
10.4 \\
10.6 \\
10.6 \\
10.7\end{array}$ & $\begin{array}{r}.0 \\
.0 \\
.3 \\
.8 \\
1.6 \\
2.7 \\
4.0 \\
7.9 \\
15.5 \\
15.7 \\
15.8 \\
15.8 \\
15.8 \\
15.8 \\
15.8 \\
15.8 \\
15.8 \\
15.8 \\
15.8 \\
15.8\end{array}$ & $\begin{array}{r}.0 \\
7.7 \\
35.7 \\
70.1 \\
109.0 \\
144.4 \\
181.1 \\
225.5 \\
250.7 \\
250.8 \\
250.8 \\
250.8 \\
250.8 \\
250.8 \\
250.8 \\
250.8 \\
250.8 \\
250.8 \\
250.8 \\
250.8\end{array}$ & $\begin{array}{r}.0 \\
36.3 \\
72.0 \\
117.0 \\
161.2 \\
200.2 \\
243.6 \\
291.8 \\
362.4 \\
362.9 \\
363.0 \\
363.0 \\
363.0 \\
363.0 \\
363.0 \\
363.0 \\
363.0 \\
363.0 \\
363.0 \\
363.0\end{array}$ \\
\hline
\end{tabular}




\begin{tabular}{|c|c|c|}
\hline $\begin{array}{r}\text { Table } 4 \\
\text { and } \\
t\end{array}$ & $\begin{array}{l}\text { radionucli } \\
\text { time of } \\
\text { sequence }\end{array}$ & to \\
\hline Group & $\begin{array}{l}\text { Released } \\
(K G)\end{array}$ & $\begin{array}{l}\text { Released } \\
(K G)\end{array}$ \\
\hline $\begin{array}{l}I \\
C S \\
T E \\
\text { SR } \\
\text { RU } \\
\text { LA } \\
\text { NG } \\
C E \\
\text { BA }\end{array}$ & $\begin{array}{r}12.0 \\
141.0 \\
15.8 \\
.0 \\
.0 \\
.0 \\
264.3 \\
.0 \\
.7\end{array}$ & $\begin{array}{r}6.6 \\
87.6 \\
10.7 \\
.0 \\
.0 \\
.0 \\
.0 \\
.0 \\
.5\end{array}$ \\
\hline
\end{tabular}

Table 4.2.41. Fraction of initial core inventory released to the secondary for Surry GLYY-YXY

Core Inventory Fraction Released from the Primary System

Group

I

CS

PI

TE

SR

RU

LA

$N G$

CE

$B A$
During In-Vessel Release

$$
\begin{aligned}
& .4257 \\
& .3596 \\
& 1.0559 E=03 \\
& .1970 \\
& 1.7935 E-04 \\
& 3.2618 E-07 \\
& 2.8682 E-08 \\
& .9667 \\
& 0 . \\
& 3.2969 E-03
\end{aligned}
$$




\section{$\mathrm{Cl}-2$}

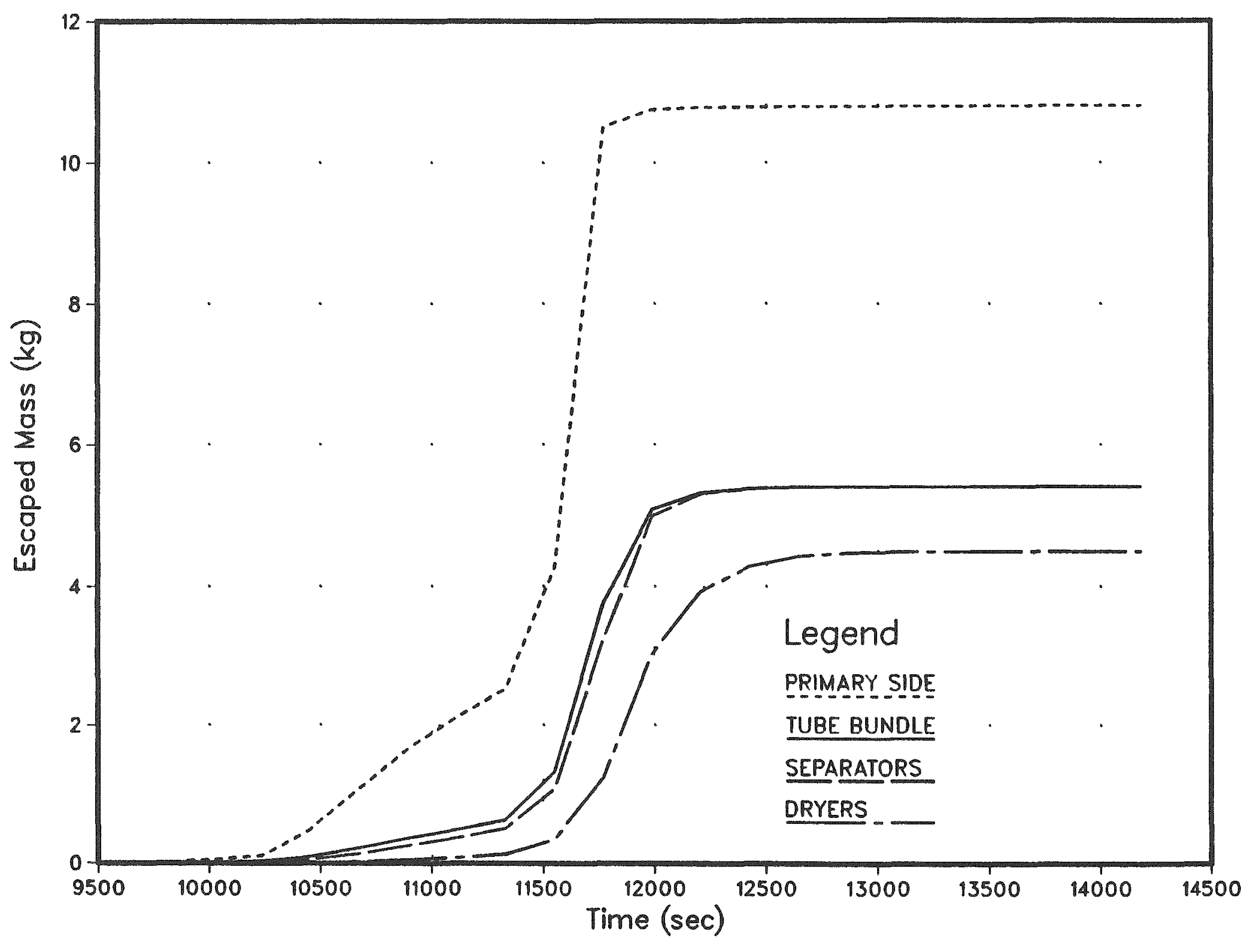

Figure 4.2.75. Mass of Csil released from indicated RCS components as a function of time - Surry GLYY-YXY, secondary. 

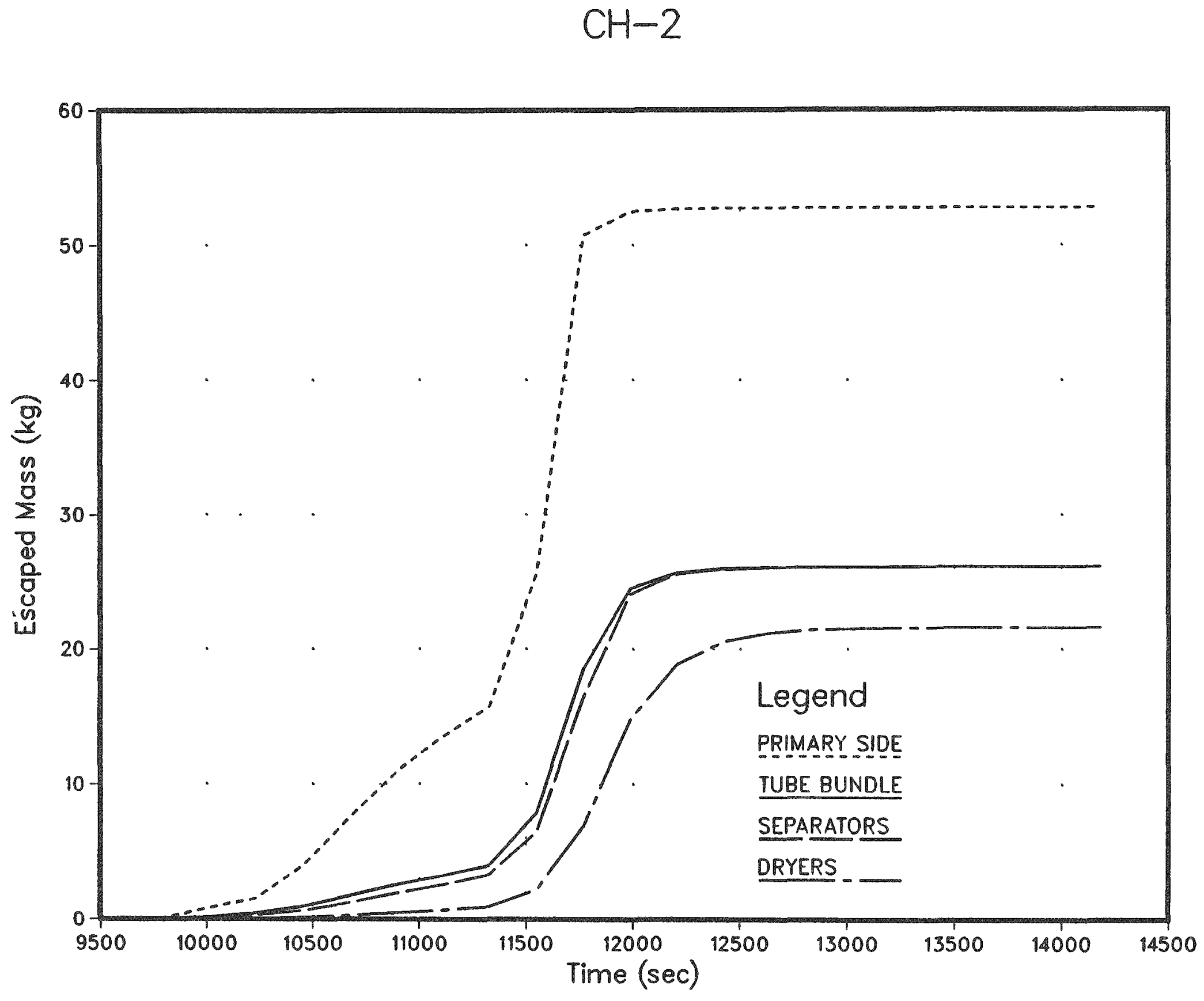

Figure 4.2.76. Mass of $\mathrm{CsOH}$ released from indicated $\mathrm{RCS}$ components as a function of time - Surry GLYY-YXY, secondary. 


\section{TE-2}

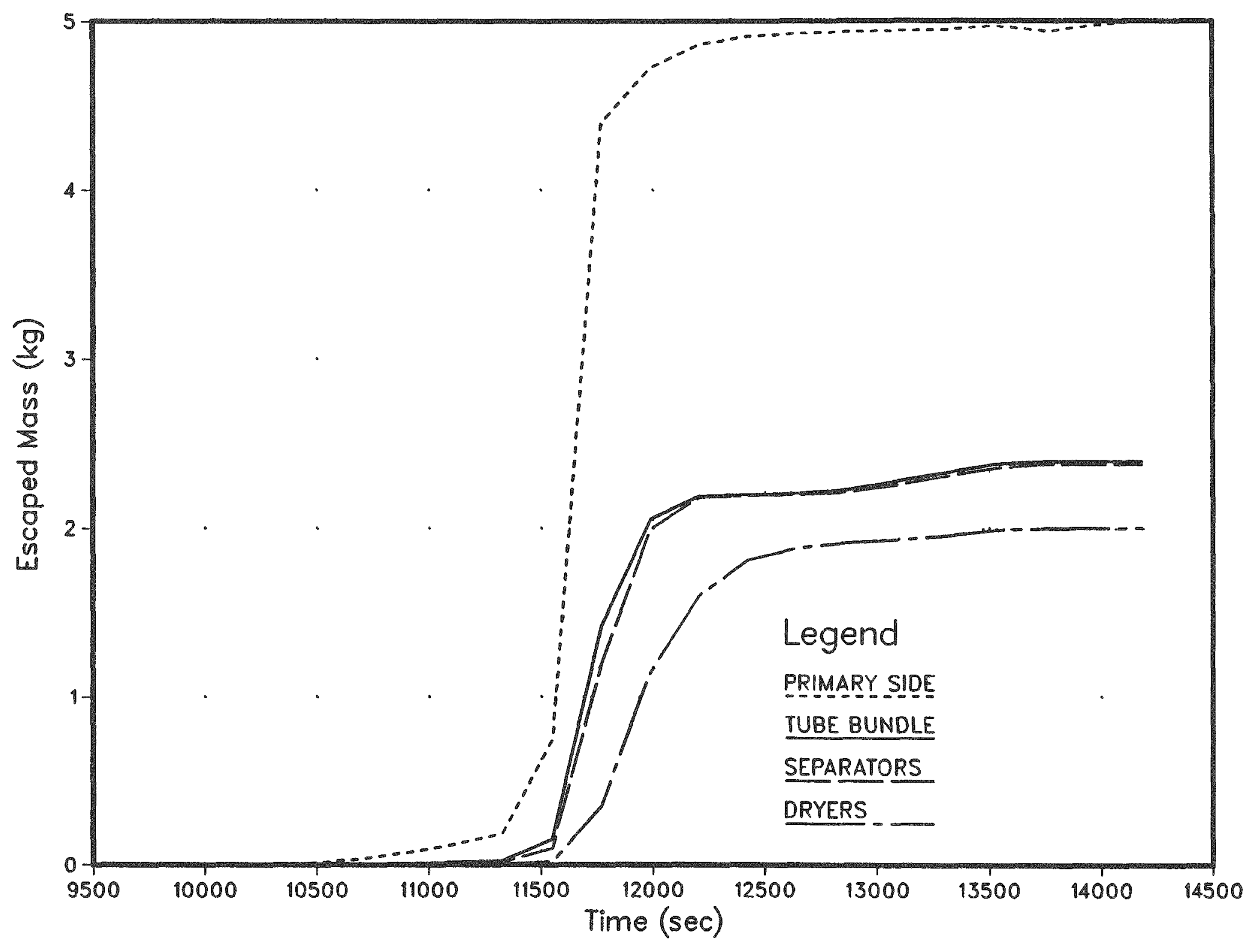

Figure 4.2.77. Mass of Te released from indicated RCS components as a function of time - Surry GLYY-YXY, secondary. 


\section{$\mathrm{PI}-2$}

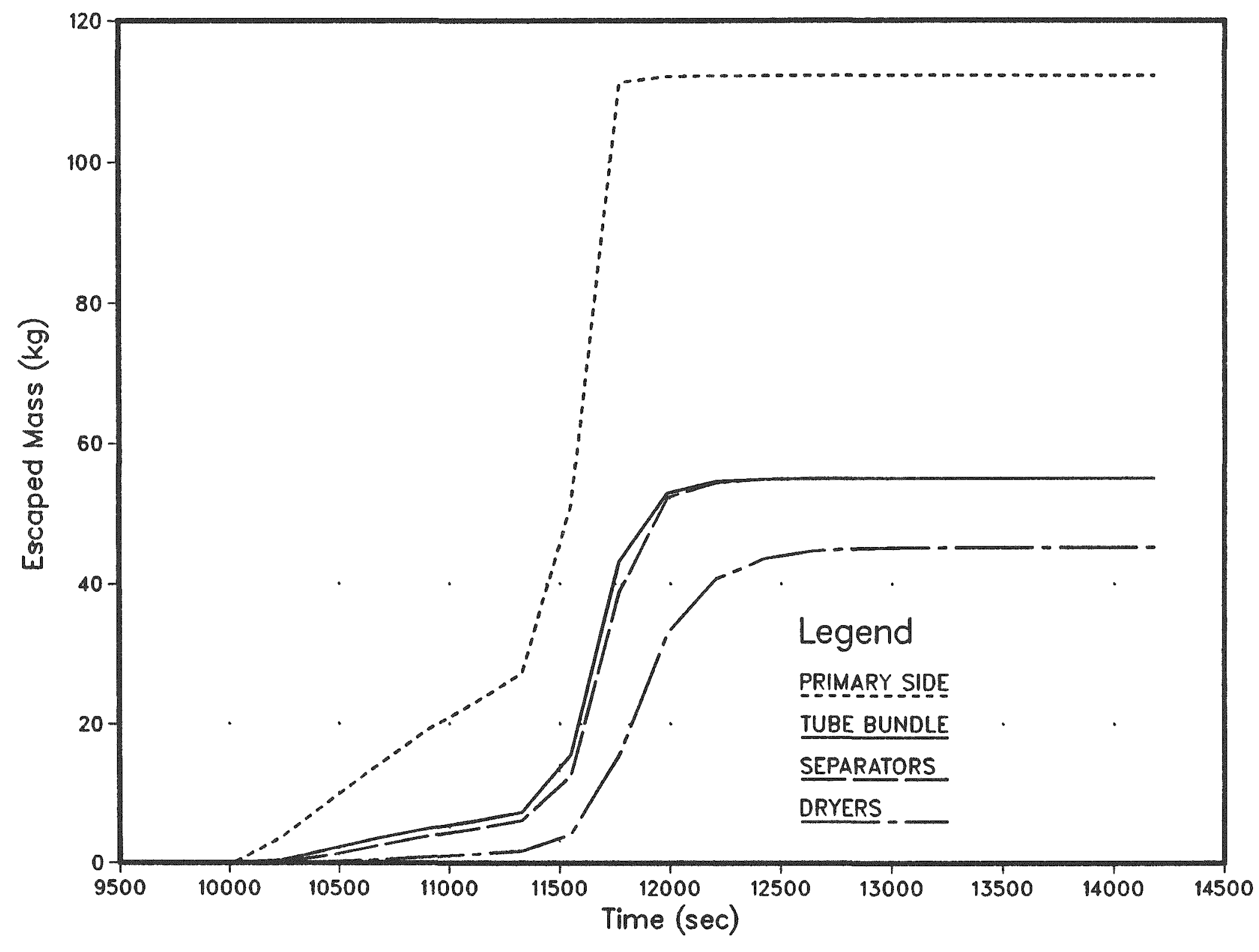

Figure 4.2.78. Mass of aerosol released from indicated RCS components as a function of time - Surry GLYYY-YXY, secondary. 
Table 4.2.42. Masses of dominant species released from RCS and retained on secondary structures as functions of time for the Surry GLYY-YXY sequence

\begin{tabular}{|c|c|c|c|c|c|c|c|c|}
\hline & \multicolumn{2}{|c|}{ CSI } & \multicolumn{2}{|c|}{$\mathrm{CSOH}$} & \multicolumn{2}{|c|}{ TE } & \multicolumn{2}{|c|}{ AEROSOL } \\
\hline $\begin{array}{l}\text { TIME } \\
\text { (M) }\end{array}$ & $\begin{array}{l}\overline{R E T} \\
(K G)\end{array}$ & $\begin{array}{l}\text { TOTAL } \\
(\mathrm{KG})\end{array}$ & $\begin{array}{l}\overline{R E T} \\
(K G)\end{array}$ & $\begin{array}{l}\text { TOTAL } \\
(K G)\end{array}$ & $\begin{array}{l}\overline{R E T} \\
(K G)\end{array}$ & $\begin{array}{l}\text { TOTAL } \\
\text { (KG) }\end{array}$ & $\begin{array}{l}\text { RET } \\
(K G)\end{array}$ & $\begin{array}{l}\text { TOTAL } \\
\text { (KG) }\end{array}$ \\
\hline $\begin{array}{l}166.9 \\
170.5 \\
174.2 \\
178.0 \\
181.6 \\
185.2 \\
188.9 \\
192.5 \\
196.1 \\
199.8 \\
203.5 \\
207.1 \\
210.8 \\
214.5 \\
218.1 \\
221.8 \\
225.5 \\
229.4 \\
233.4 \\
236.4\end{array}$ & $\begin{array}{l}.0 \\
.0 \\
.1 \\
.3 \\
.7 \\
1.0 \\
1.3 \\
1.7 \\
4.9 \\
6.0 \\
6.2 \\
6.3 \\
6.3 \\
6.3 \\
6.3 \\
6.3 \\
6.3 \\
6.3 \\
6.3 \\
6.3\end{array}$ & $\begin{array}{r}.1 \\
.2 \\
.7 \\
1.6 \\
2.3 \\
2.8 \\
3.1 \\
4.3 \\
10.5 \\
10.7 \\
10.8 \\
10.8 \\
10.8 \\
10.8 \\
10.8 \\
10.8 \\
10.8 \\
10.8 \\
10.8 \\
10.8\end{array}$ & $\begin{array}{r}.1 \\
.2 \\
.7 \\
2.6 \\
5.2 \\
7.1 \\
8.8 \\
11.0 \\
25.2 \\
30.1 \\
30.9 \\
31.1 \\
31.2 \\
31.2 \\
31.2 \\
31.2 \\
31.2 \\
31.2 \\
31.1 \\
31.1\end{array}$ & $\begin{array}{r}1.4 \\
5.9 \\
10.7 \\
14.5 \\
17.0 \\
19.2 \\
26.0 \\
50.7 \\
52.5 \\
52.7 \\
52.8 \\
52.8 \\
52.8 \\
52.8 \\
52.8 \\
52.8 \\
52.9 \\
52.9 \\
52.9 \\
52.8\end{array}$ & $\begin{array}{l}.0 \\
.0 \\
.0 \\
.0 \\
.0 \\
.1 \\
.1 \\
.2 \\
2.2 \\
2.7 \\
3.0 \\
2.9 \\
3.0 \\
2.9 \\
2.9 \\
2.9 \\
2.8 \\
2.8 \\
2.9 \\
2.9\end{array}$ & $\begin{array}{l}.0 \\
.0 \\
.0 \\
.1 \\
.2 \\
.2 \\
.8 \\
4.4 \\
4.7 \\
4.9 \\
4.9 \\
4.9 \\
4.9 \\
4.9 \\
4.9 \\
5.0 \\
5.0 \\
5.0 \\
5.0 \\
5.0\end{array}$ & $\begin{array}{r}.0 \\
.2 \\
1.5 \\
4.8 \\
9.0 \\
12.1 \\
14.9 \\
19.2 \\
56.0 \\
65.0 \\
66.4 \\
66.8 \\
66.9 \\
66.9 \\
67.0 \\
67.0 \\
67.0 \\
67.0 \\
67.0 \\
67.0\end{array}$ & $\begin{array}{r}.0 \\
5.6 \\
13.7 \\
19.8 \\
24.9 \\
28.8 \\
33.3 \\
51.7 \\
111.3 \\
112.1 \\
112.2 \\
112.2 \\
112.2 \\
112.2 \\
112.2 \\
112.2 \\
112.3 \\
112.2 \\
112.3 \\
112.2\end{array}$ \\
\hline
\end{tabular}


Table 4.2.43. Masses of radionculide groups released to and retained in secondary at time of vessel failure for the Surry GLYY-YXY sequence (933.7 minutes)

\begin{tabular}{ccc}
\hline Group & $\begin{array}{c}\text { Released } \\
(K G)\end{array}$ & $\begin{array}{c}\text { Released } \\
(K G)\end{array}$ \\
I & 5.3 & 3.1 \\
CS & 52.4 & 30.8 \\
TE & 5.0 & 2.9 \\
SR & .0 & .0 \\
LA & .0 & .0 \\
NG & .0 & .0 \\
CE & .0 & .0 \\
BA & .0 & .0 \\
\hline
\end{tabular}

Table 4.2.44. Fraction of initial core inventory released to the environment for Surry GLYY-YXY

Core Inventory Fraction Released to the Environment

Group During In-Vessel Release

\begin{tabular}{ll} 
I & \multicolumn{1}{c}{.1774} \\
CS & .1474 \\
PI & $4.2587 \mathrm{E}-04$ \\
TE & $7.8793 \mathrm{E}-02$ \\
SR & $7.7083 \mathrm{E}-05$ \\
RU & $1.4005 \mathrm{E}-07$ \\
LA & $1.2321 \mathrm{E}-08$ \\
NG & 0. \\
CE & 0. \\
BA & $1.4206 \mathrm{E}-03$
\end{tabular}


Table 4.2 .45 Distribution of inventory of principal species, Surry GLYY-YXY

\begin{tabular}{ccccc}
\hline & \multicolumn{5}{c}{ Location at Vessel Failure (percent) } \\
Species & Fue & RCS & SG Secondary & Environment \\
CSI & 3.5 & 53 & 25 & 18 \\
CSOH & 3.3 & 61 & 21 & 15 \\
Te & 3.8 & 42 & 11 & 8.3 \\
\hline
\end{tabular}

Figures 4.2 .79 to 4.2 .82 and in Tables 4.2 .46 to 4.2 .48 . The large separation between the first and second segments of the hot leg in these figures represents flow diverted to the containment.

Secondary side retention is intermediate between the first and second cases. The flow rate through the secondary side of the system is reduced somewhat relative to HINY-NXY because of the reduced primary system pressure. Results are presented in Figures 4.2 .83 to 4.2 .86 and in Tables 4.2 .49 to 4.2.51. The final distribution of radionuclides is shown in Table 4.2.52.

\subsubsection{Results: Transport in the Containment}

\section{Surry $S_{3} B$}

In the $S_{3} B$ scenario the containment fails within 1 minute of bottom head failure. The principal driving forces for the release of radionuclides from the containment are the steam produced from boiloff of water from the RCS and the gases produced during core-concrete attack. Table 4.2 .53 summarizes the various sources of radionuclides to the containment. Table 4.2 .54 provides the time-dependent release from containment for each of the fission product groups. Table 4.2 .55 shows the time-dependent size distribution of the aerosols released from the RCS to containment; Table 4.2 .56 shows the aerosol size distribution for material released from the containment. Gravitational settling is the dominant mechanism for retention of aerosols in the containment. The locational distribution of radionuclides at the end of the accident is tabulated in Table 4.2.57. 
$\mathrm{Cl}-1$

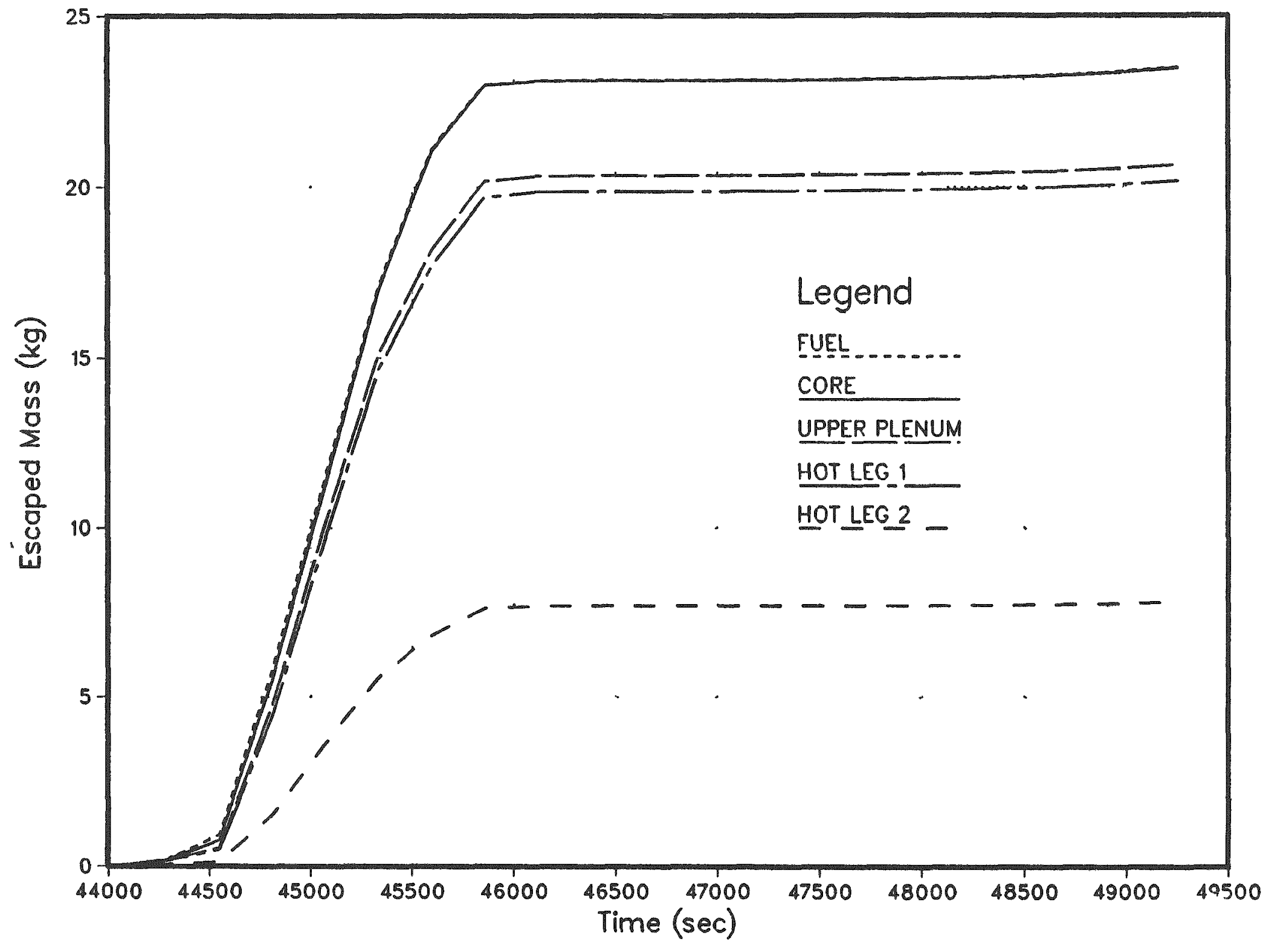

Figure 4.2.79. Mass of CSI released from indicated RCS components as a function of time - Surry HINY-YXY, primary. 


\section{$\mathrm{CH}-1$}

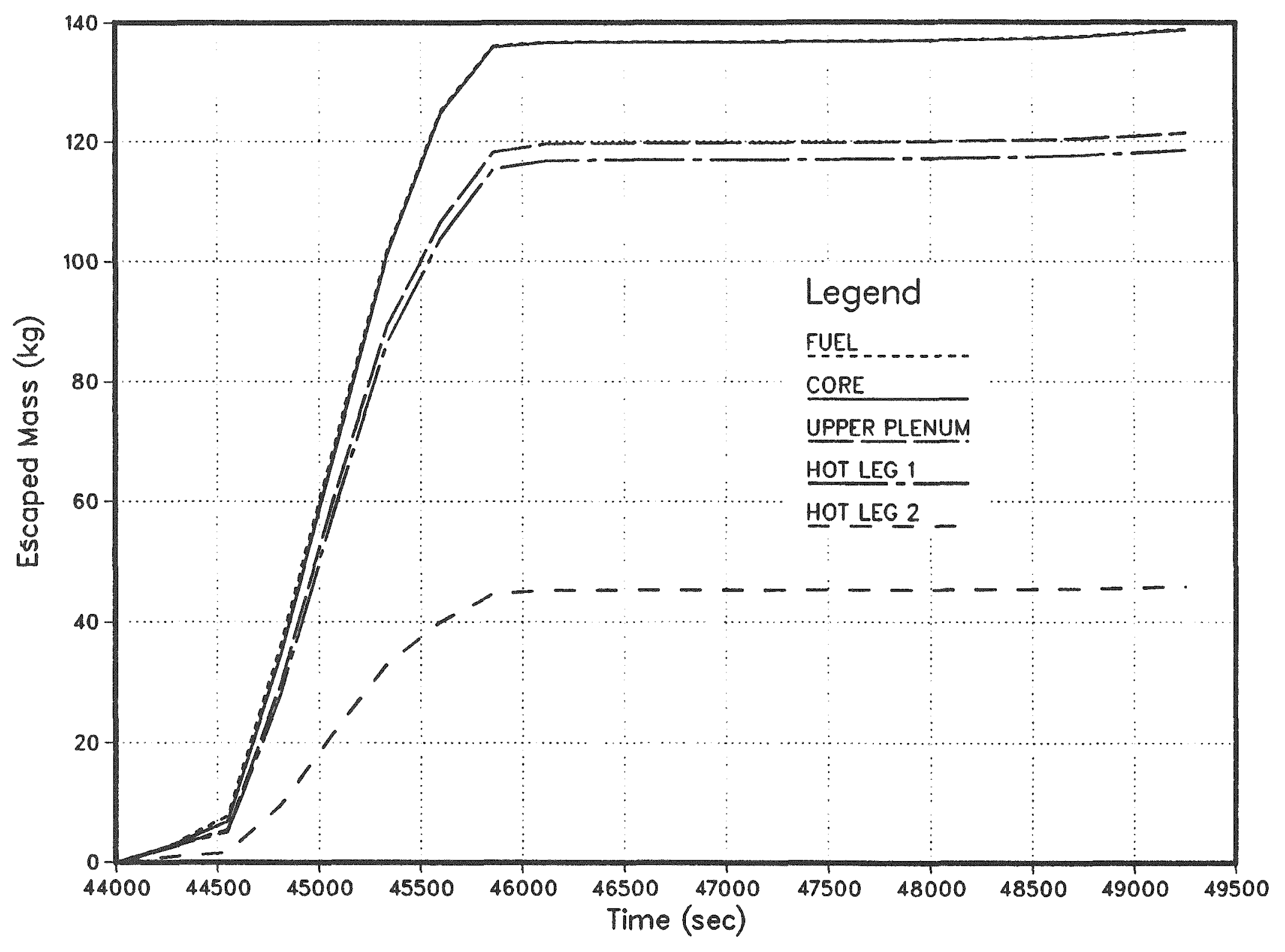

Figure 4.2.80. Mass of $\mathrm{CsOH}$ released from indicated $\mathrm{RCS}$ component as a function of time - Surry HINY-YXY, primary. 
TE-1

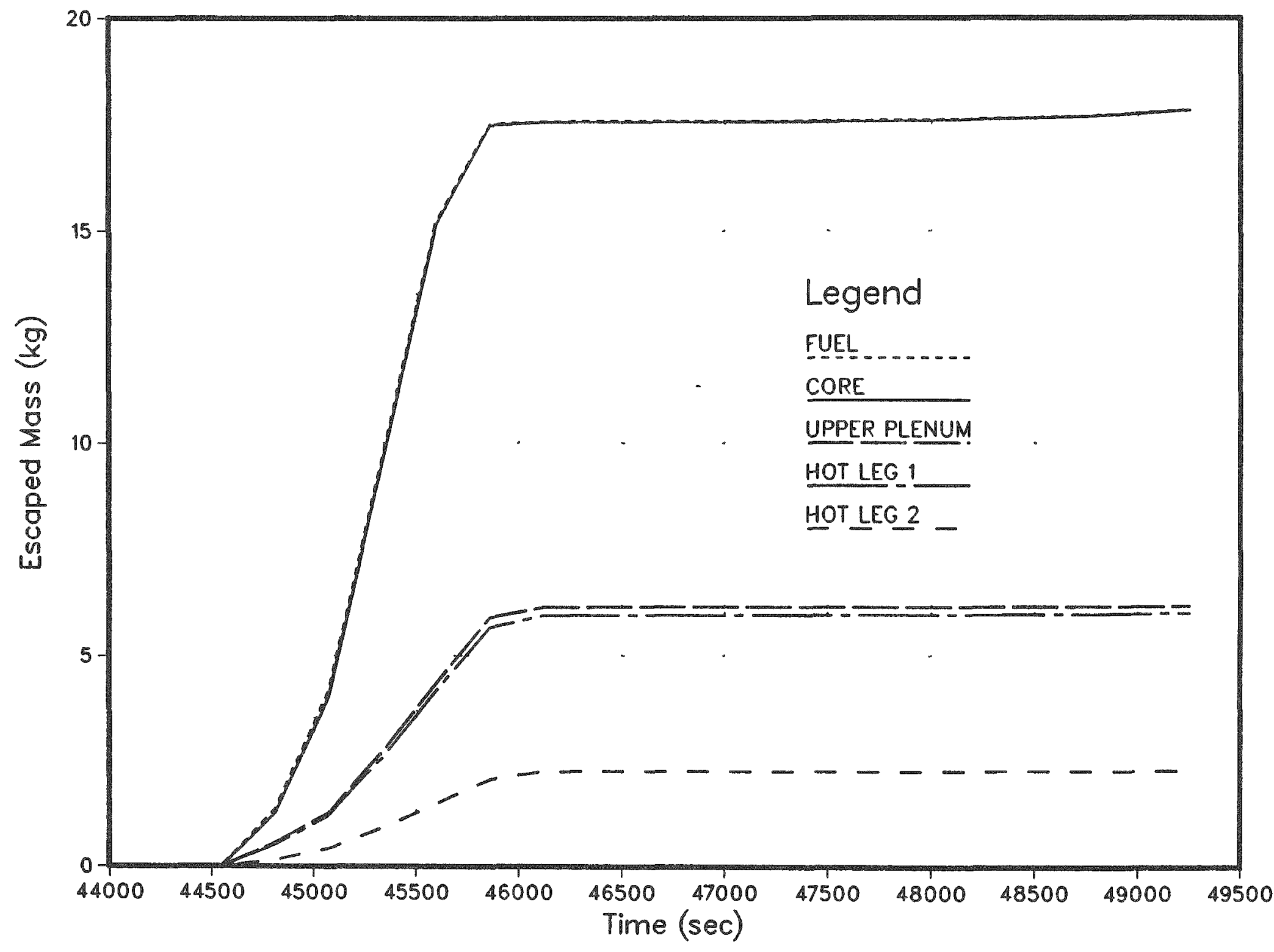

Figure 4.2.81. Mass of Te released from indicated RCS component as a function of time - Surry HINY-YXY, primary. 


\section{$\mathrm{PI}-1$}

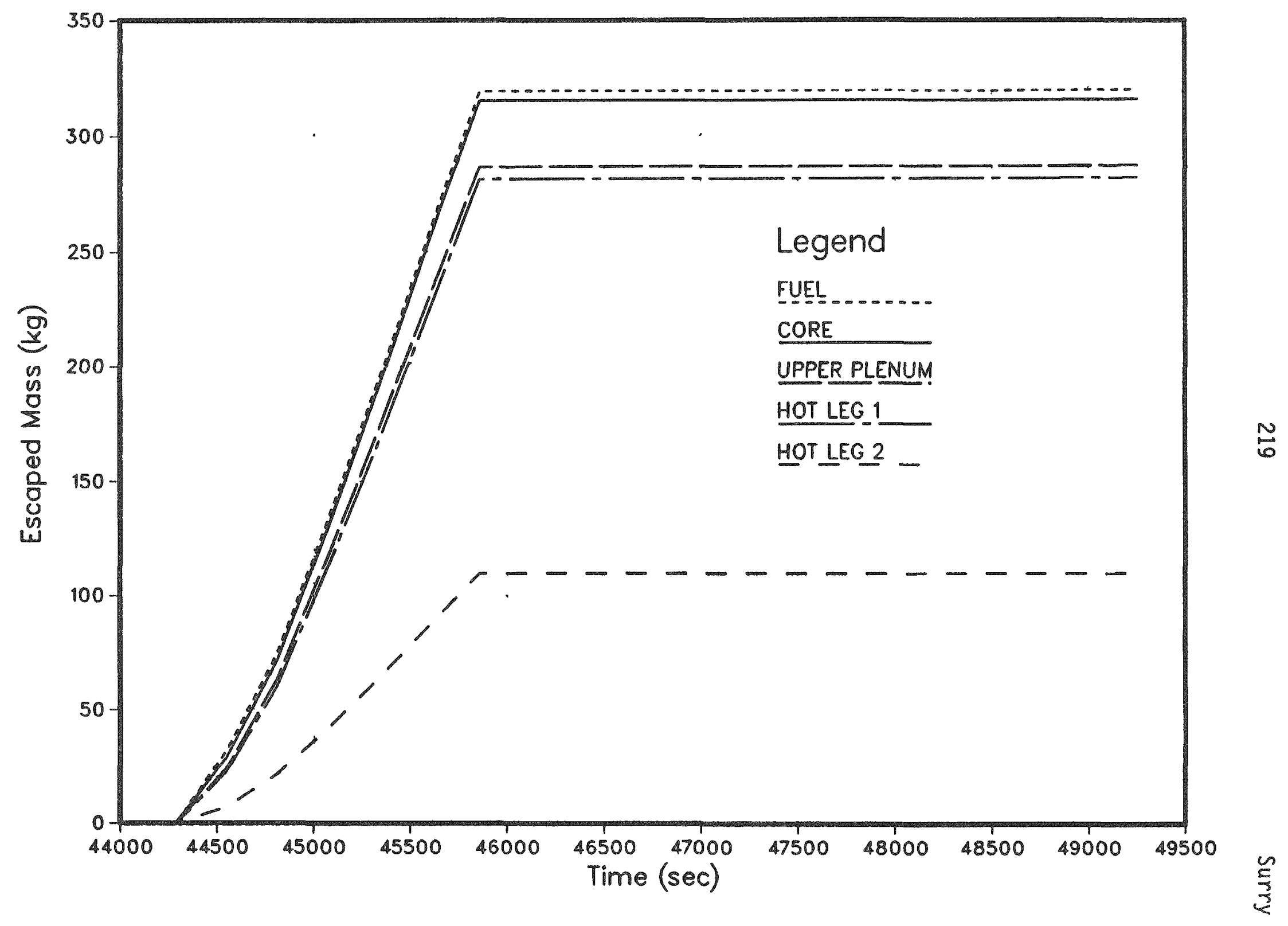

Figure 4.2.82. Mass of aerosol released from indicated RCS component as a function of time - Surry HINY-YXY, primary. 
Table 4.2.46. Masses of dominant species released from fuel and retained on RCS structures as functions of time for the SURRY HINY-YXY sequence

\begin{tabular}{|c|c|c|c|c|c|c|c|c|}
\hline \multicolumn{3}{|c|}{ CSI } & \multicolumn{2}{|c|}{$\mathrm{CSOH}$} & \multicolumn{2}{|c|}{ TE } & \multicolumn{2}{|c|}{ AEROSOL } \\
\hline $\begin{array}{l}\text { TIME } \\
(M)\end{array}$ & $\begin{array}{l}\overline{R E T} \\
(K G)\end{array}$ & $\begin{array}{l}\text { TOTAL } \\
(\mathrm{KG})\end{array}$ & $\begin{array}{l}\overline{R E T} \\
(K G)\end{array}$ & $\begin{array}{l}\text { TOTAL } \\
\text { (KG) }\end{array}$ & $\begin{array}{l}\mathrm{RET} \\
(\mathrm{KG})\end{array}$ & $\begin{array}{l}\text { TOTAL } \\
(\mathrm{KG})\end{array}$ & $\begin{array}{l}\overline{\mathrm{RET}} \\
(\mathrm{KG})\end{array}$ & $\begin{array}{l}\text { TOTAL } \\
(\mathrm{KG})\end{array}$ \\
\hline $\begin{array}{l}738.2 \\
742.5 \\
746.9 \\
751.2 \\
755.6 \\
759.9 \\
764.3 \\
768.7 \\
773.0 \\
777.4 \\
781.7 \\
786.1 \\
790.5 \\
794.8 \\
799.2 \\
803.5 \\
807.9 \\
812.2 \\
816.6 \\
820.9\end{array}$ & $\begin{array}{l}.0 \\
.0 \\
.6 \\
1.4 \\
2.3 \\
3.5 \\
3.5 \\
3.5 \\
3.5 \\
3.5 \\
3.5 \\
3.5 \\
3.5 \\
3.5 \\
3.5 \\
3.5 \\
3.5 \\
3.5 \\
3.5 \\
3.5\end{array}$ & $\begin{array}{l}.2 \\
1.0 \\
5.8 \\
11.5 \\
17.1 \\
21.1 \\
23.0 \\
23.1 \\
23.1 \\
23.1 \\
23.1 \\
23.1 \\
23.2 \\
23.2 \\
23.2 \\
23.2 \\
23.2 \\
23.3 \\
23.4 \\
23.5\end{array}$ & $\begin{array}{r}.1 \\
.4 \\
4.0 \\
8.4 \\
14.3 \\
21.7 \\
21.9 \\
21.2 \\
21.2 \\
21.2 \\
21.2 \\
21.2 \\
21.2 \\
21.2 \\
21.2 \\
21.2 \\
21.2 \\
21.3 \\
21.4 \\
21.5\end{array}$ & $\begin{array}{r}3.2 \\
8.0 \\
36.1 \\
69.0 \\
101.6 \\
125.0 \\
136.1 \\
136.8 \\
136.8 \\
136.8 \\
136.8 \\
136.9 \\
136.9 \\
137.0 \\
137.0 \\
137.2 \\
137.4 \\
137.7 \\
138.3 \\
139.0\end{array}$ & $\begin{array}{r}.0 \\
.0 \\
.6 \\
2.8 \\
7.0 \\
11.1 \\
11.9 \\
11.8 \\
11.7 \\
11.7 \\
11.7 \\
11.7 \\
11.7 \\
11.7 \\
11.8 \\
11.8 \\
11.8 \\
11.8 \\
11.9 \\
11.9\end{array}$ & $\begin{array}{r}.0 \\
.0 \\
1.4 \\
4.2 \\
9.7 \\
15.2 \\
17.5 \\
17.6 \\
17.6 \\
17.6 \\
17.6 \\
17.6 \\
17.6 \\
17.6 \\
17.6 \\
17.6 \\
17.7 \\
17.7 \\
17.8 \\
17.9\end{array}$ & $\begin{array}{r}.0 \\
2.4 \\
8.7 \\
16.3 \\
24.4 \\
32.8 \\
40.6 \\
40.6 \\
40.6 \\
40.6 \\
40.6 \\
40.6 \\
40.6 \\
40.6 \\
40.6 \\
40.6 \\
40.6 \\
40.6 \\
40.6 \\
40.6\end{array}$ & $\begin{array}{r}.0 \\
32.2 \\
74.6 \\
133.1 \\
193.9 \\
258.0 \\
319.4 \\
319.6 \\
319.6 \\
319.6 \\
319.6 \\
319.6 \\
319.6 \\
319.6 \\
319.6 \\
319.7 \\
319.7 \\
319.8 \\
320.0 \\
320.3\end{array}$ \\
\hline
\end{tabular}


Table 4.2.47. Masses of radionuclide groups release to and retained in RCS at time of vessel failure for the Surry HINY-YXY sequence (933.7 minutes)

\begin{tabular}{crc}
\hline Group & $\begin{array}{c}\text { Released } \\
(\mathrm{KG})\end{array}$ & $\begin{array}{c}\text { Released } \\
(\mathrm{KG})\end{array}$ \\
I & 11.5 & 1.7 \\
CS & 135.3 & 20.8 \\
TE & 17.9 & 11.9 \\
SR & .0 & .0 \\
RU & .0 & .0 \\
LA & .0 & .0 \\
NG & 253.5 & .0 \\
CE & .0 & .0 \\
BA & .5 & .1 \\
\hline
\end{tabular}

Table 4.2.48. Fraction of initial core inventory released to the secondary for Surry HINY-YXY

Core Inventory Fraction Released from the Primary System

$\begin{array}{cc}\text { Group } & \text { During In-Vessel Release } \\ \text { I } & .3080 \\ \text { CS } & .3070 \\ \text { PI } & 1.0347 \mathrm{E}-03 \\ \text { TE } & 8.9693 \mathrm{E}-02 \\ \text { SR } & 1.4979 \mathrm{E}-04 \\ \text { RU } & 2.7137 \mathrm{E}-07 \\ \text { LA } & 2.3688 \mathrm{E}-08 \\ \text { NG } & .3690 \\ \text { CE } & 0 . \\ \text { BA } & 2.7634 \mathrm{E}-03\end{array}$




$$
\mathrm{Cl}-2
$$

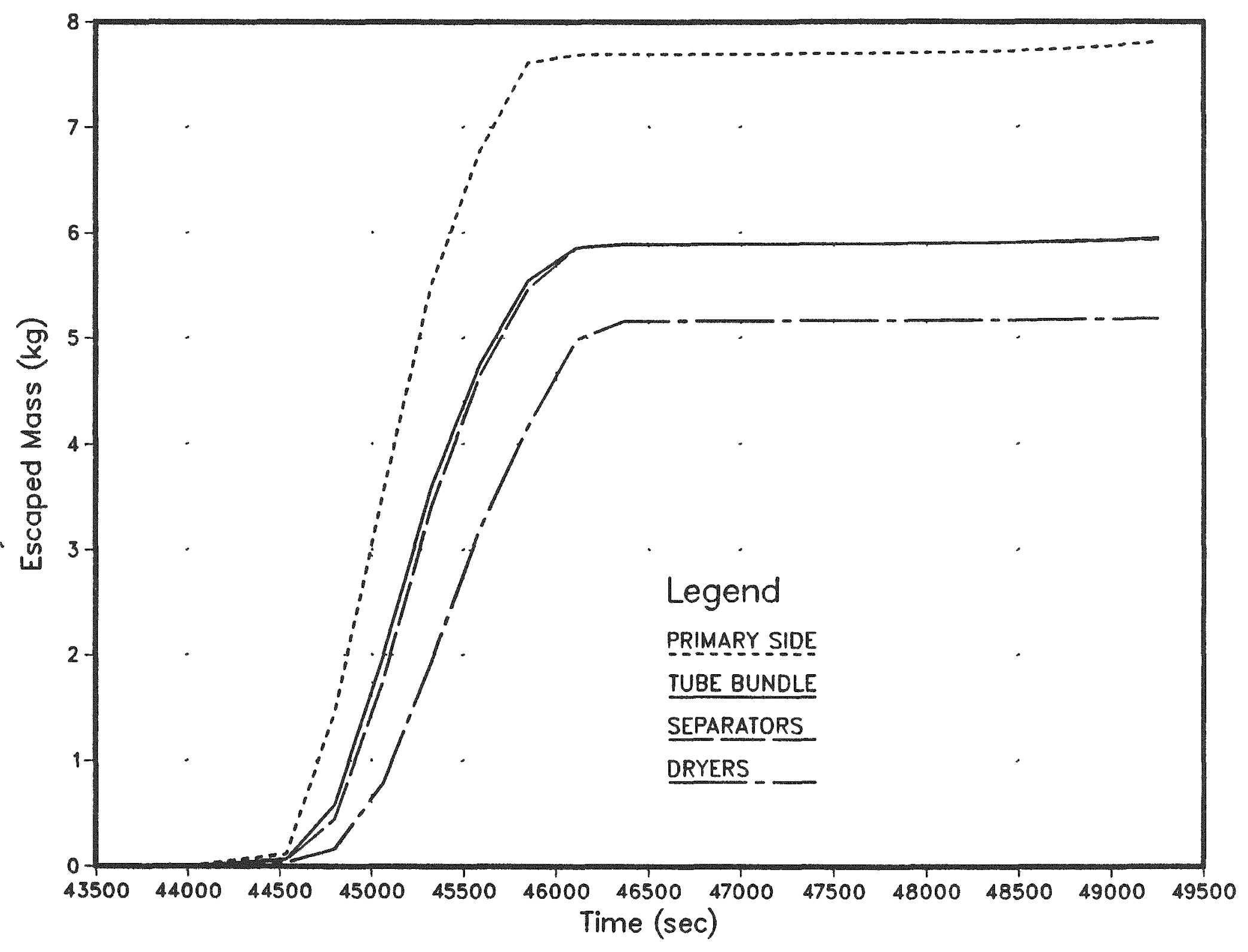

Figure 4.2.83. Mass of CsI released from indicated RCS component as a function of time - Surry HINY-YXY, secondary. 
$\mathrm{CH}-2$

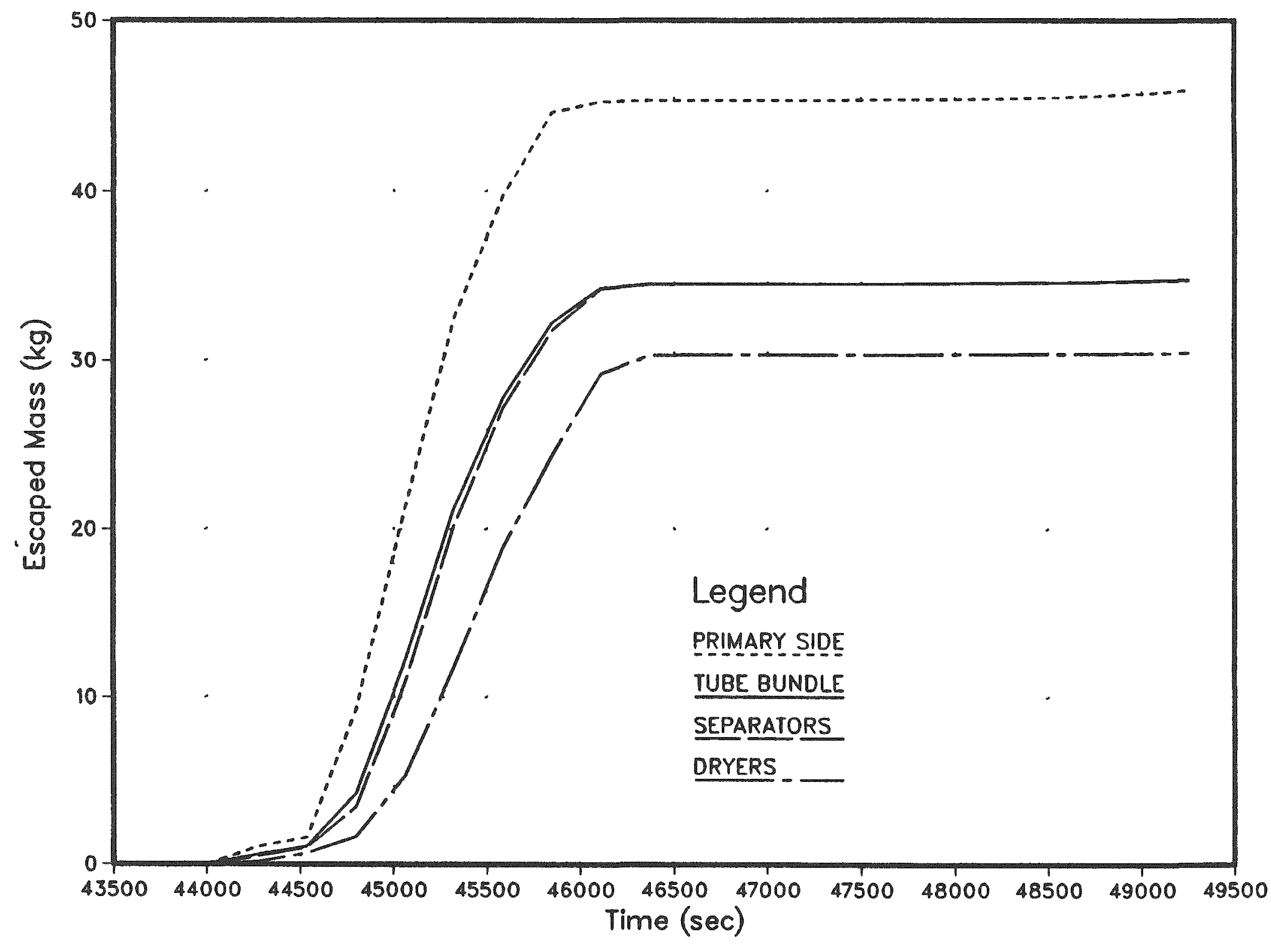

Figure 4.2.84. Mass of $\mathrm{CsOH}$ released from indicated $\mathrm{RCS}$ component as a function of time - Surry HINY-YXY, secondary. 
TE-2

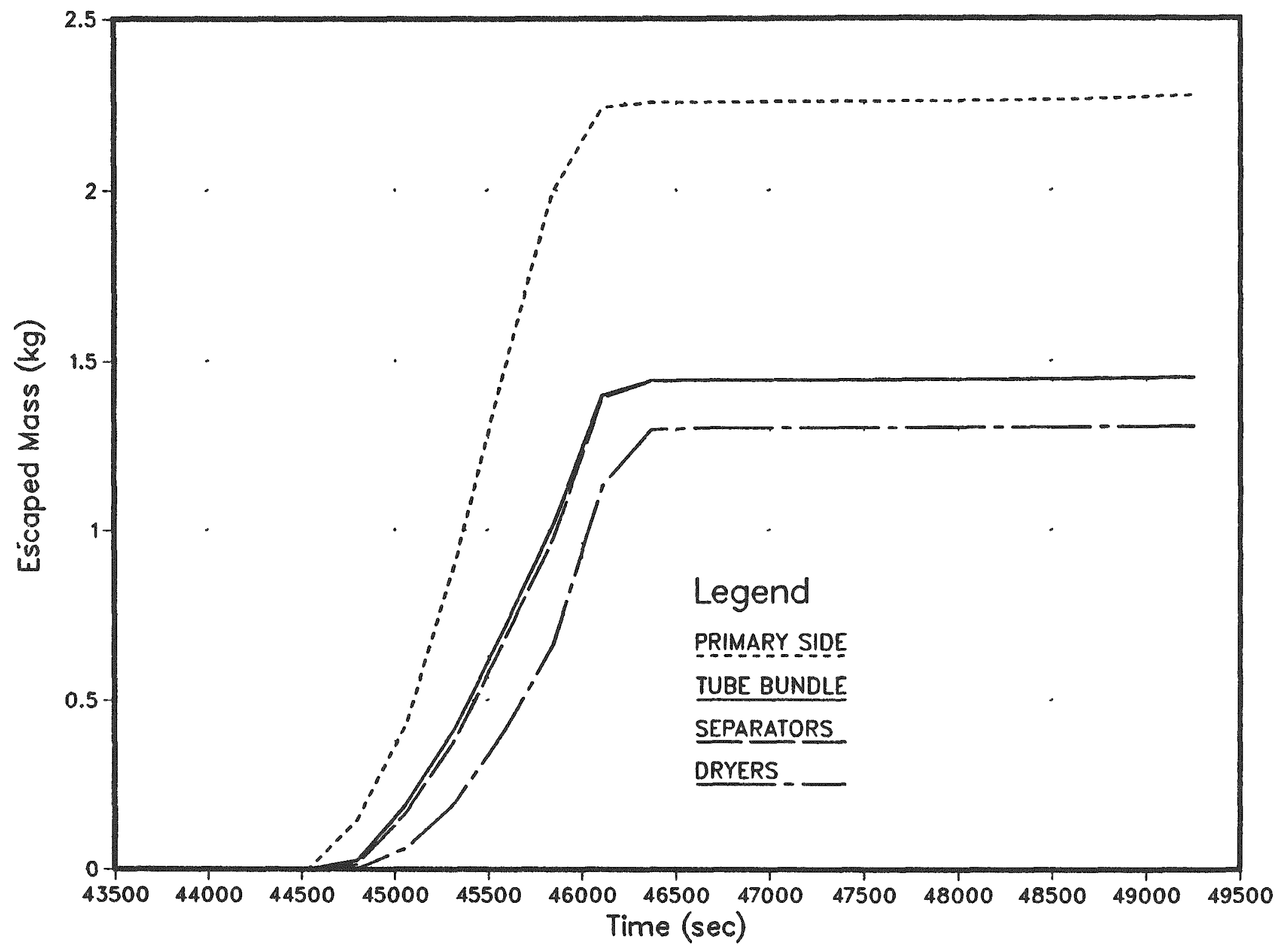

Figure 4.2.85. Mass of Te released from indicated RCS component as a function of time - Surry HINY-YXY, secondary. 
$\mathrm{PI}-2$

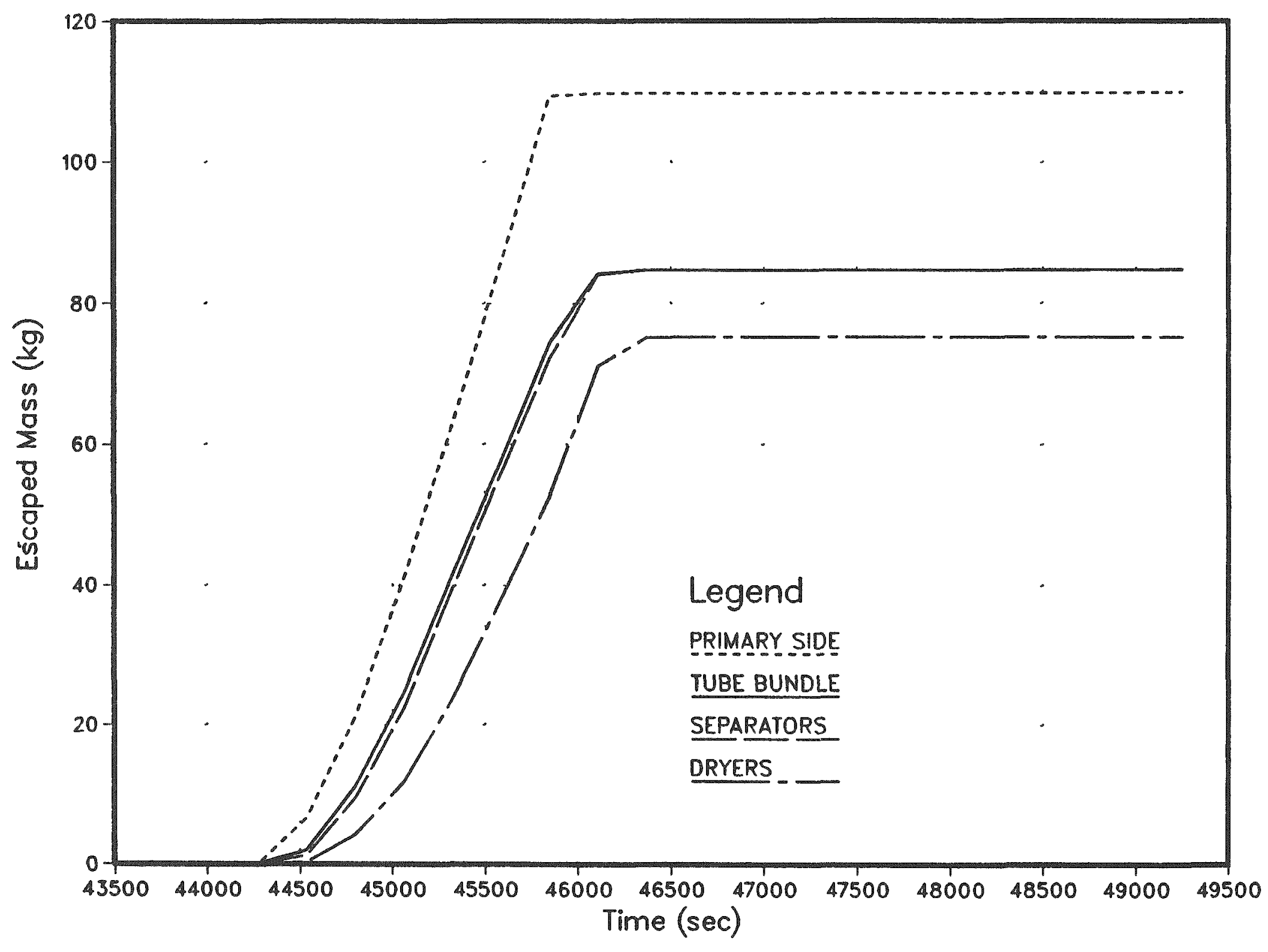

Figure 4.2.86. Mass of aerosol released from indicated RCS component as a function of time - Surry HINY-YXY, seconciary. 
Table 4.2.49. Masses of dominant species released from RCS and retained on secondary structures as functions of time for the Surry HINY-YXY sequence

\begin{tabular}{|c|c|c|c|c|c|c|c|c|}
\hline \multirow[b]{2}{*}{$\begin{array}{l}\text { TIME } \\
\text { (M) }\end{array}$} & \multicolumn{2}{|c|}{ CSI } & \multicolumn{2}{|c|}{$\mathrm{CSOH}$} & \multicolumn{2}{|c|}{$\mathrm{TE}$} & \multicolumn{2}{|c|}{ AEROSOL } \\
\hline & $\begin{array}{l}\text { RET } \\
(K G)\end{array}$ & $\begin{array}{l}\text { TOTAL } \\
\text { (KG) }\end{array}$ & $\begin{array}{l}\text { RET } \\
(K G)\end{array}$ & $\begin{array}{l}\text { TOTAL } \\
\text { (KG) }\end{array}$ & $\begin{array}{l}\text { RET } \\
(K G)\end{array}$ & $\begin{array}{l}\text { TOTAL } \\
(K G)\end{array}$ & $\begin{array}{l}\text { RET } \\
(K G)\end{array}$ & $\begin{array}{l}\text { TOTAL } \\
\text { (KG) }\end{array}$ \\
\hline $\begin{array}{l}738.2 \\
742.5 \\
746.9 \\
751.2 \\
755.6 \\
759.9 \\
764.3 \\
768.7 \\
773.0 \\
777.4 \\
781.7 \\
786.1 \\
790.5 \\
794.8 \\
799.2 \\
803.5 \\
807.9 \\
812.2 \\
816.6 \\
820.9\end{array}$ & $\begin{array}{l}.0 \\
.0 \\
.1 \\
.5 \\
1.3 \\
2.0 \\
2.4 \\
2.5 \\
2.5 \\
2.5 \\
2.5 \\
2.5 \\
2.5 \\
2.5 \\
2.5 \\
2.5 \\
2.5 \\
2.5 \\
2.5 \\
2.5\end{array}$ & $\begin{array}{l}.1 \\
.1 \\
1.4 \\
3.5 \\
5.5 \\
6.8 \\
7.6 \\
7.7 \\
7.7 \\
7.7 \\
7.7 \\
7.7 \\
7.7 \\
7.7 \\
7.7 \\
7.7 \\
7.7 \\
7.7 \\
7.8 \\
7.8\end{array}$ & $\begin{array}{r}.0 \\
.1 \\
.7 \\
3.1 \\
7.7 \\
12.0 \\
14.5 \\
15.0 \\
15.0 \\
15.0 \\
15.0 \\
15.0 \\
15.0 \\
15.0 \\
15.0 \\
15.0 \\
15.0 \\
15.0 \\
15.0 \\
15.0\end{array}$ & $\begin{array}{r}1.1 \\
1.6 \\
9.3 \\
21.3 \\
32.5 \\
39.8 \\
44.6 \\
45.3 \\
45.3 \\
45.3 \\
45.3 \\
45.3 \\
45.3 \\
45.4 \\
45.4 \\
45.4 \\
45.5 \\
45.6 \\
45.7 \\
45.9\end{array}$ & $\begin{array}{l}.0 \\
.0 \\
.0 \\
.1 \\
.3 \\
.6 \\
.9 \\
1.0 \\
1.0 \\
1.0 \\
1.0 \\
1.0 \\
1.0 \\
1.0 \\
1.0 \\
1.0 \\
1.0 \\
1.0 \\
1.0 \\
1.0\end{array}$ & $\begin{array}{l}.0 \\
.0 \\
.1 \\
.4 \\
.9 \\
1.5 \\
2.0 \\
2.0 \\
2.3 \\
2.3 \\
2.3 \\
2.3 \\
2.3 \\
2.3 \\
2.3 \\
2.3 \\
2.3 \\
2.3 \\
2.3 \\
2.3\end{array}$ & $\begin{array}{r}.0 \\
.2 \\
2.0 \\
6.0 \\
14.2 \\
24.2 \\
32.3 \\
34.4 \\
34.5 \\
34.5 \\
34.5 \\
34.5 \\
34.5 \\
34.5 \\
34.5 \\
34.5 \\
34.5 \\
34.5 \\
34.5 \\
34.5\end{array}$ & $\begin{array}{r}.0 \\
6.8 \\
21.2 \\
41.1 \\
62.9 \\
85.8 \\
109.3 \\
109.7 \\
109.7 \\
109.7 \\
109.7 \\
109.7 \\
109.7 \\
109.7 \\
109.7 \\
109.7 \\
109.8 \\
109.8 \\
109.8 \\
109.9\end{array}$ \\
\hline
\end{tabular}


Table 4.2.50. Masses of radionculide groups released to and retained in secondary at time of vessel failure for the Surry HINY-YXY sequence (933.7 minutes)

\begin{tabular}{ccc}
\hline \hline Group & $\begin{array}{c}\text { Released } \\
(K G)\end{array}$ & $\begin{array}{c}\text { Released } \\
(\mathrm{KG})\end{array}$ \\
I & 3.8 & 1.2 \\
CS & 44.8 & 14.6 \\
TE & 2.3 & 1.0 \\
SR & .0 & .0 \\
RU & .0 & .0 \\
LA & .0 & .0 \\
CE & .0 & .0 \\
BA & .0 & .0 \\
\hline
\end{tabular}

Table 4.2.51. Fraction of initial core inventory released to the environment for Surry HINY-NXY

Core Inventory Fraction Released to the Environment

Group During In-Vessel Release

\begin{tabular}{ll} 
I & \multicolumn{1}{c}{.2042} \\
CS & .2035 \\
PI & $7.0829 \mathrm{E}-04$ \\
TE & $5.1411 \mathrm{E}-02$ \\
SR & $9.8897 \mathrm{E}-05$ \\
RU & $1.7914 \mathrm{E}-07$ \\
LA & $1.5638 \mathrm{E}-08$ \\
NG & 0. \\
CE & 0. \\
BA & $1.8223 \mathrm{E}-03$
\end{tabular}




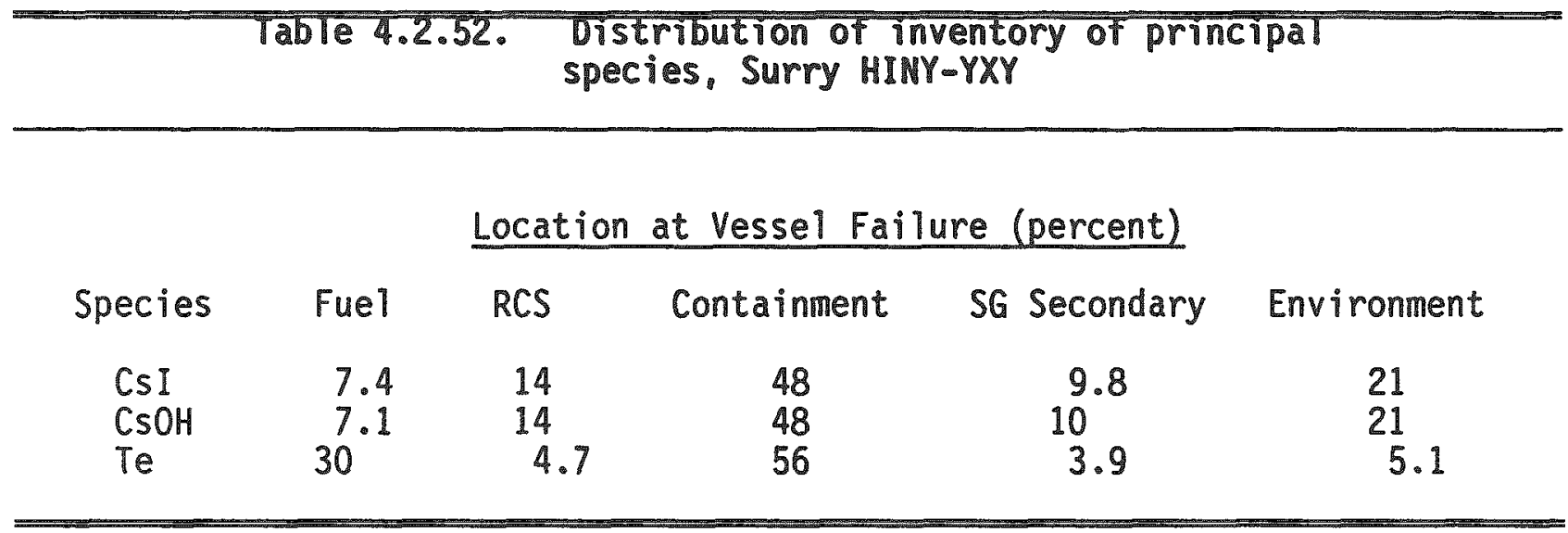

Table 4.2.53. Fraction of initial core inventory released to the containment for Surry $S_{3} B$.

\begin{tabular}{llll}
\hline \hline Group & $\begin{array}{c}\text { During } \\
\text { In-Vessel } \\
\text { Release }\end{array}$ & $\begin{array}{c}\text { During } \\
\text { Puff } \\
\text { Release }\end{array}$ & $\begin{array}{c}\text { During } \\
\text { Core-Concrete } \\
\text { Attack }\end{array}$ \\
\hline I & 0.2133 & $5.9171 E-02$ & $2.3417 E-02$ \\
Cs & 0.1837 & $5.5623 E-02$ & $3.0090 E-02$ \\
Pi & $7.6461 E-04$ & $5.7268 E-05$ & 0.0 \\
Te & $4.8863 E-02$ & $2.4586 E-02$ & $9.8421 E-02$ \\
Sr & $1.0549 E-04$ & $5.6956 E-06$ & $7.0084 E-02$ \\
Ru & $1.9609 E-07$ & $2.2270 E-09$ & $5.7238 E-07$ \\
La & $1.8002 E-08$ & $4.5273 E-11$ & $2.9130 E-03$ \\
Ng & 0.9232 & $5.7648 E-02$ & 0.0 \\
Ce & 0.0 & 0.0 & $6.7445 E-04$ \\
Ba & $1.9445 E-03$ & $2.2130 E-04$ & $4.7305 E-02$ \\
\hline \hline
\end{tabular}


Table 4.2.54. Fraction of core inventory released from the containment - Surry $S_{3} B$.

\begin{tabular}{|c|c|c|c|c|c|c|c|c|c|c|c|}
\hline \multirow{2}{*}{$\begin{array}{l}\text { Time } \\
\text { (M) }\end{array}$} & \multicolumn{11}{|c|}{ Fission Product Group } \\
\hline & I & CS & PI & TE & SR & RU & LA & $C E$ & $B A$ & $P E$ & $T R$ \\
\hline 204.0 & 1.61E-11 & 1. $41 E-01$ & $4.04 E-04$ & $4.52 E-02$ & 6.30E-05 & 1. 11E-07 & 1.01E-08 & D.00E-00 & 1.24E-03 & 0.0 & 7.03E-01 \\
\hline 234.0 & 1. B1E-01 & 1.4IE-01 & 4.04E-04 & $4.52 E-12$ & 6.30E-05 & 1. ME-UT & 1.01E-00 & บ. ข0E-00 & $1.24 E-03$ & 0.0 & 7.03E-01 \\
\hline 264.0 & $1.72 E-11$ & 1.50E-01 & 4.93E-04 & 4.07E-12 & 1.0ISE-03 & 1.1DE-OT & $4.08 E-05$ & $7.45 E-06$ & 2.08E-113 & 22.7 & 7. B2E-01 \\
\hline 294.0 & $1.79 E-11$ & 1. SAE-MI & 5. 03E-04 & $5.30 E-12$ & $8.18 E-03$ & 1.21E-07 & $3.76 E-04$ & $7.63 E-05$ & 5.67E-13 & 158.1 & $7.70 E-01$ \\
\hline 390.0 & 1.83E-D1 & 1. BBE-D1 & 5.00E-04 & $5.78 E-12$ & 1. 19E-02 & 1.22E-07 & 6.8E-04 & 1.44E-04 & 0.75E-03 & 380.1 & $7.78 E-01$ \\
\hline 390.0 & 1.65E-01 & 1.60E-11 & 5.10E-14 & 1. 14E-02 & 1.58E-02 & 1.23E-07 & . 15E-04 & $1.79 E-04$ & 1.24E-92 & 619.0 & 7.22E- 11 \\
\hline 480.11 & 1. S5E-11 & 1.60E-11 & D.10E-DA & 6.14E-02 & 1.58E-02 & 1.23E-07 & . $15 E-04$ & $1.79 \mathrm{E}-04$ & $1.24 E-102$ & 619.1 & $7.02 E-01$ \\
\hline 600.10 & $1.85 E-01$ & 1. COE-01 & 3.10E-04 & 6.14E-02 & 1.58E-02 & 1.23E-07 & $0.15 E-04$ & $1.79 E-04$ & $1.24 E-12$ & 619.0 & $7.82 E-11$ \\
\hline 720.0 & $1.856-01$ & 1.60E-11 & $5.10 E-04$ & $0.14 E-02$ & $1.58 E-12$ & 1.23E-07 & $.15 E-04$ & $1.79 E-0.6$ & $1.24 E-12$ & 619.1 & $7.62 \mathrm{E}-11$ \\
\hline (3) & 1.65E-01 & $1.60 E-01$ & 5.10E-D & Q.1AE-02 & $1.58 E-02$ & 1.24E-BV & - I5E-04 & $1.79 E-04$ & 1.2RE-02 & 820.1 & $7.82 \mathrm{E}-01$ \\
\hline
\end{tabular}


Table 4.2.55. Particle size distributions (relative number by diameter) of material released to the containment from the RCS at 26 equi-spaced times throughout the in-vessel period - Surry $S_{3} B$.

\begin{tabular}{|c|c|c|c|c|c|c|c|c|c|c|c|c|c|}
\hline 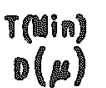 & 120.2. & 117.6 & 10 & 111.0 & 112.7 & 114.2 & 118. & 117. & 111.2 & 120.7 & 122.2 & 123. & 128.8 \\
\hline
\end{tabular}

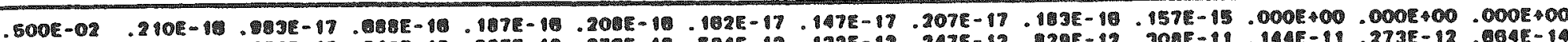

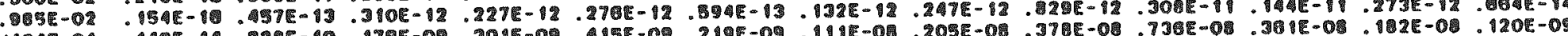
.

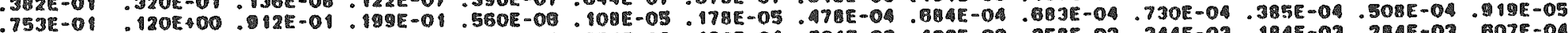

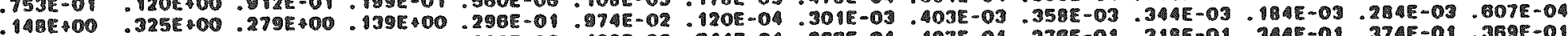

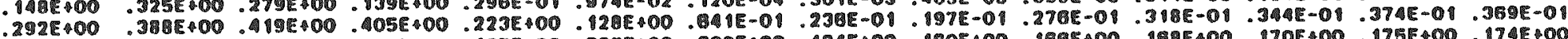

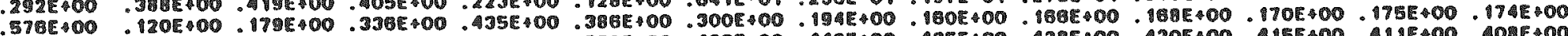

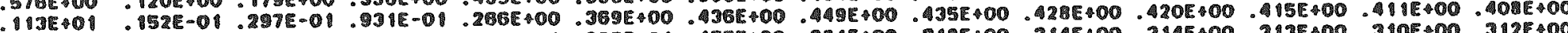

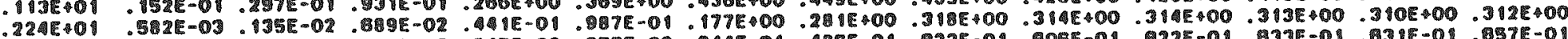

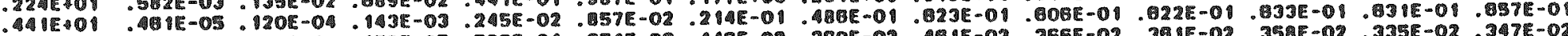

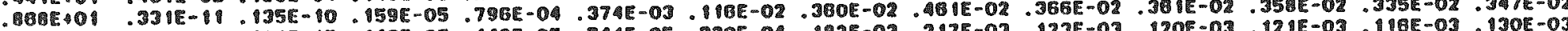

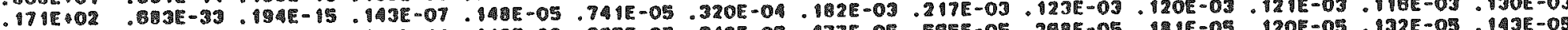
$.337 E-02.000 E+00$. .29E-20.12 .

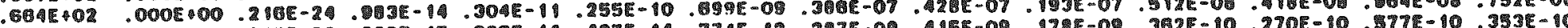

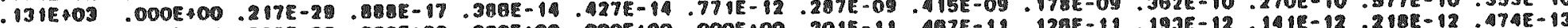

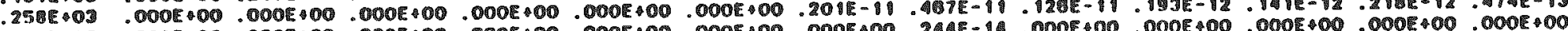

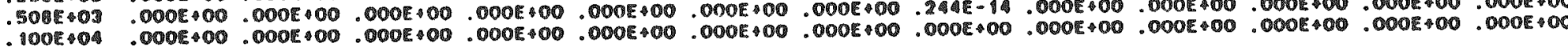

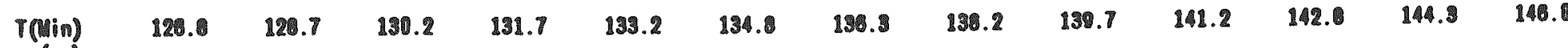

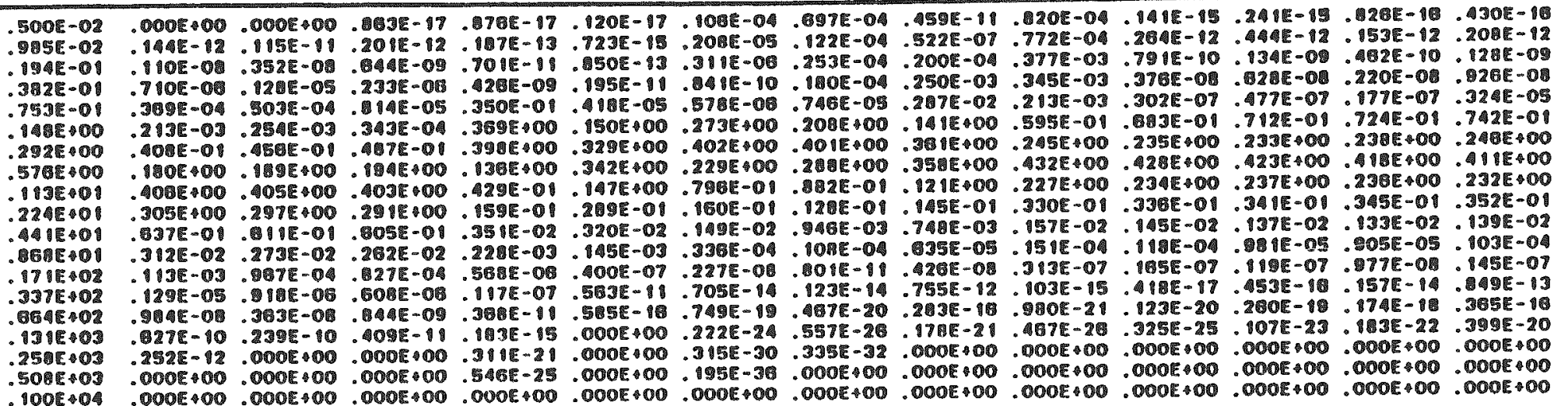


Table 4.2.56. Size distribution of aerosols in containment - Surry $S_{3} B$.

\begin{tabular}{|c|c|c|c|c|c|c|c|c|c|c|}
\hline $\begin{array}{l}\text { Thm fuminetes) } \\
\text { Donsily (GM/CM }\end{array}$ & 3) $\begin{array}{c}2040 \\
3.00800\end{array}$ & $\begin{array}{c}2340 \\
3.00600\end{array}$ & $\begin{array}{c}2640 \\
3.526 .00\end{array}$ & $\begin{array}{l}294.0 \\
\text { 7. . }\end{array}$ & $\begin{array}{c}3300 \\
\text { 3. } 125000\end{array}$ & $\begin{array}{c}9000 \\
2.80000\end{array}$ & $\begin{array}{c}4800 \\
\text { 2. 20:000 }\end{array}$ & $\begin{array}{c}6000 \\
2.720000\end{array}$ & $\begin{array}{c}7200 \\
2.96000\end{array}$ & $\begin{array}{c}9400 \\
2.386000\end{array}$ \\
\hline \multicolumn{11}{|l|}{ 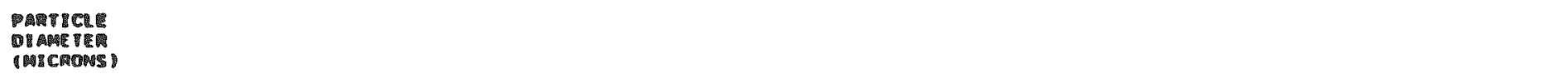 } \\
\hline 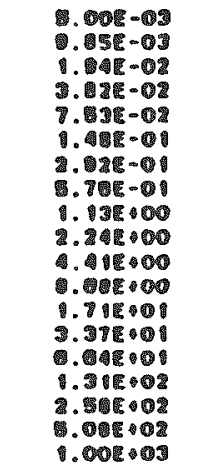 & 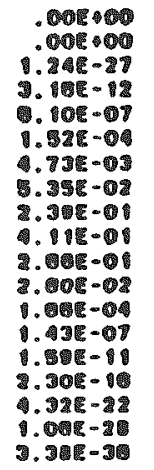 & 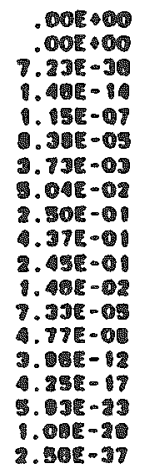 & 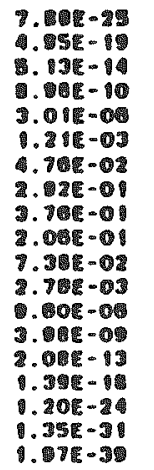 & 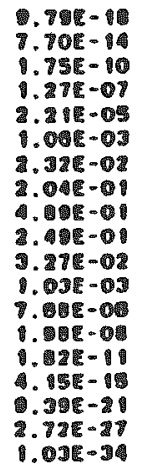 & 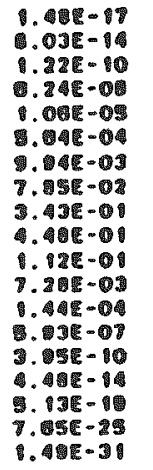 & 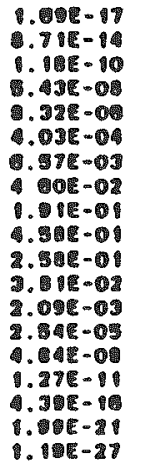 & 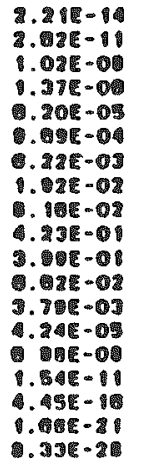 & 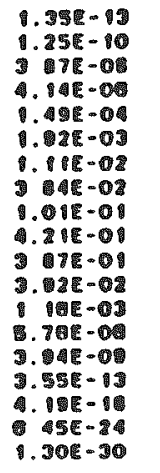 & 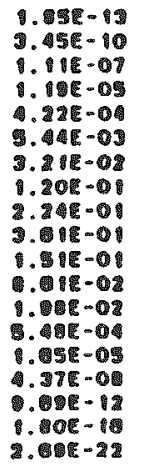 & 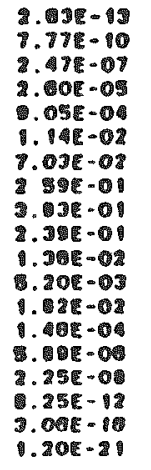 \\
\hline
\end{tabular}


Table 4.2.57. Final distribution of fission product inventory by group - Surry $\mathrm{S}_{3} \mathrm{~B}$.

\begin{tabular}{cccccc}
\hline Species & RCS & Melt & $\begin{array}{c}\text { Cavity } \\
\text { Water }\end{array}$ & Containment & Environment \\
\hline I & $7.08 E-01$ & $2.23 E-04$ & $1.30 E-02$ & $1.10 E-01$ & $1.85 E-01$ \\
Cs & $7.42 E-01$ & $1.90 E-05$ & $5.54 E-03$ & $1.09 E-01$ & $1.60 E-01$ \\
Te & $2.29 E-01$ & $5.96 E-01$ & $1.35 E-02$ & $1.04 E-01$ & $6.14 E-02$ \\
Sr & $3.76 E-04$ & $9.09 E-01$ & $2.09 E-02$ & $5.40 E-02$ & $1.58 E-02$ \\
Ru & $6.77 E-07$ & 1.0 & $8.12 E-10$ & $4.63 E-07$ & $1.24 E-07$ \\
La & $5.88 E-08$ & $9.92 E-01$ & $1.27 E-03$ & $2.08 E-03$ & $8.15 E-04$ \\
Ce & 0.0 & $9.99 E-01$ & $2.66 E-04$ & $4.92 E-04$ & $1.79 E-04$ \\
Ba & $6.97 E-03$ & $9.29 E-01$ & $1.49 E-02$ & $3.67 E-02$ & $1.24 E-02$ \\
$\operatorname{Tr}$ & $-\ldots$ & $\ldots$ & $-\cdots$ & $2.11 E-01$ & $7.82 E-01$ \\
\hline \hline
\end{tabular}




\subsection{PWR, Ice Condenser Containment Design}

The calculated response of the reactor and containment to the postulated accident scenario is dependent on the approach taken to model important severe accident phenomena. A discussion of the important phenomenological modeling assumptions applied in this analysis, therefore, precedes the presentation of calculated results. The results themselves are presented roughly in the order that the calculations are performed with the STCP(4); first the thermal-hydraulic analysis results, followed by a discussion of the modeled radionuclide sources and the results of radionuclide release and transport analyses.

\subsubsection{Phenomenological Modeling Assumptions}

The phenomenological modeling assumptions utilized for the present analyses of the ice condenser PWR design are substantially the same as those applied in the NUREG/CR-4624 analyses ${ }^{(2)}$. Areas in which the present analyses differ or require special attention are noted below.

In contrast to the $S_{3} H F$ sequence, described in NUREG/CR-4624, Volume $2{ }^{2}{ }^{(2)}$ the present source term analyses assumed the formation of coolable debris beds after reactor vessel failure. This is equivalent to assuming substantial fragmentation and resultant quenching of the core debris upon contact with cavity water. This results in a substantial delay in time for the initiation of corium-concrete interactions.

Another (although a much less important) difference between the NUREG/CR-4624 analysis ${ }^{(2)}$ of $S_{3} H F$ and the present analysis includes the operation of containment air return fans; they were assumed to fail at containment failure in the former and remain operating in the latter.

Hydrogen generation, transport, and combustion have important impact on the $S_{3} B$ scenario. The hydrogen generation (and in-vessel core-melt progression) models utilized in the present analysis are the same as those used for NUREG/CR-4624(2) and are entirely consistent with NUREG-0956 methodology. In the assessment of plausible times at which detonable concentrations of hydrogen might develop in the ice condenser, a detonable concentration was considered to be one in excess of $15 \mathrm{v} / \mathrm{O}$, subject to 
considerations of oxygen availability and inerting by diluents. In addition to these phenomenological modeling assumptions, a different approach was taken to represent the compartmentalization of the ice condenser containment for investigating hydrogen distributions. This is described in Section 3.3.1.

In each of the Sequoyah calculations, hydrogen deflagrations were assumed to occur if the hydrogen concentration exceeded $8 \mathrm{v} / 0$, subject to oxygen availability and inerting by diluents.

\subsubsection{Results of Thermal-hydraulic Analyses}

\section{PRIMARY SYSTEM RESPONSE - Sequoyah $\mathrm{S}_{3} B$}

The predicted timing of important events during this scenario is summarized in Table 4.3.1. Note that the time at which RCP seal failures occur was specified as part of the accident sequence definition. Core and primary system conditions at key times during the accident progression are summarized in Table 4.3.2.

Figure 4.3 .1 illustrates the calculated primary system pressure response. Shortly after the start of the event, the primary system pressure decreases in response to the imposed depressurization of the secondary side of the steam generators. The steam generators were assumed to be depressurized to 600 psia; the primary side pressure is observed to correspondingly level off at about $1000 \mathrm{psia}$. The implied difference in temperatures is required to provide the driving force for heat transfer. During the depressurization of the primary system, the setpoint of the upper head injecton (UHI) accumulator was reached and a partial injection of UHI accumulator inventory was predicted; this can be observed in Figure 4.3 .2 as the primary system water inventory is shown to increase at approximately 30 minutes. Since the primary system is essentially full at this time, however, the amount of accumulator injection was limited.

With the initiation of the RCP seal LOCA at 180 minutes, the primary system experienced further depressurization and a corresponding loss of inventory; the latter can be clearly observed in Figure 4.3.2. The leak rate from the primary system is illustrated in Figure $4.3 .3 ;$ at about 300 
Table 4.3.1. Timing of key events - Sequoyah $S_{3} B$.

\begin{tabular}{lr}
\hline \multicolumn{1}{c}{ Event } & $\begin{array}{c}\text { Time, } \\
\text { Minutes }\end{array}$ \\
\hline Loss of all ac power & 0.0 \\
RCP seal LOCAs initiated & 180.0 \\
Core uncovery & 362.0 \\
Start melt & 434.3 \\
Core slump & 461.3 \\
Lower compartment failure & 462.0 \\
Core collapse & 463.3 \\
Bottom head dryout & 471.1 \\
Bottom head failure & 509.3 \\
Accumulators empty & 509.8 \\
Start concrete attack & 673.0 \\
Corium layers invert & 849.0 \\
End calculation & 1273.0 \\
& \\
\hline \hline
\end{tabular}


Table 4.3.2. Core and primary system response - Sequoyah $S_{3} B$.

\begin{tabular}{|c|c|c|c|c|c|c|c|}
\hline $\begin{array}{l}\text { Accident } \\
\text { Event }\end{array}$ & $\begin{array}{l}\text { Time, } \\
\text { minutes }\end{array}$ & $\begin{array}{l}\text { Primary } \\
\text { System } \\
\text { Pressure, } \\
\text { psia }\end{array}$ & $\begin{array}{l}\text { Primary } \\
\text { System } \\
\text { Water } \\
\text { Inventory. } \\
\text { Ib }\end{array}$ & $\begin{array}{l}\text { Average Core } \\
\text { Temperature. } \\
\text { of }\end{array}$ & $\begin{array}{l}\text { Peah Core } \\
\text { Twaporature, } \\
\text { of }\end{array}$ & $\begin{array}{l}\text { Fraction } \\
\text { Core } \\
\text { Helted }\end{array}$ & $\begin{array}{l}\text { Fraction } \\
\text { Clad } \\
\text { Reactod }\end{array}$ \\
\hline Core uncovery & 362.0 & 223 & $1.35 \times 105$ & 494 & 498 & 0.0 & 0.0 \\
\hline Start molt & 434.3 & 639 & $9.62 \times 10^{4}$ & 1609 & 4130 & 0.0 & 0.06 \\
\hline Core slump & 461.3 & 646 & $8.41 \times 104$ & 3683 & 4148 & 0.00 & 0.68 \\
\hline $\begin{array}{l}\text { Lower compartment } \\
\text { Pailure }\end{array}$ & 462.0 & 882 & 8. $23 \times 10^{4}$ & 3672 & $-\infty$ & 0.84 & 0.75 \\
\hline Core collapse & 463.3 & 1140 & $7.60 \times 104$ & 3259 & $\infty$ & 0.90 & 0.76 \\
\hline Dotto head dryout & 471.1 & 2031 & $2.42 \times 1040$ & 2631 & -- & $\cdots$ & 0.76 \\
\hline Botter head failure & 500.3 & 724 & $1.80 \times 104$ & 3515 & $-\cdots$ & $-\infty$ & 0.76 \\
\hline
\end{tabular}

- Water rotainod in low points of the RCS. 


\section{SEQUOYAH S3B}

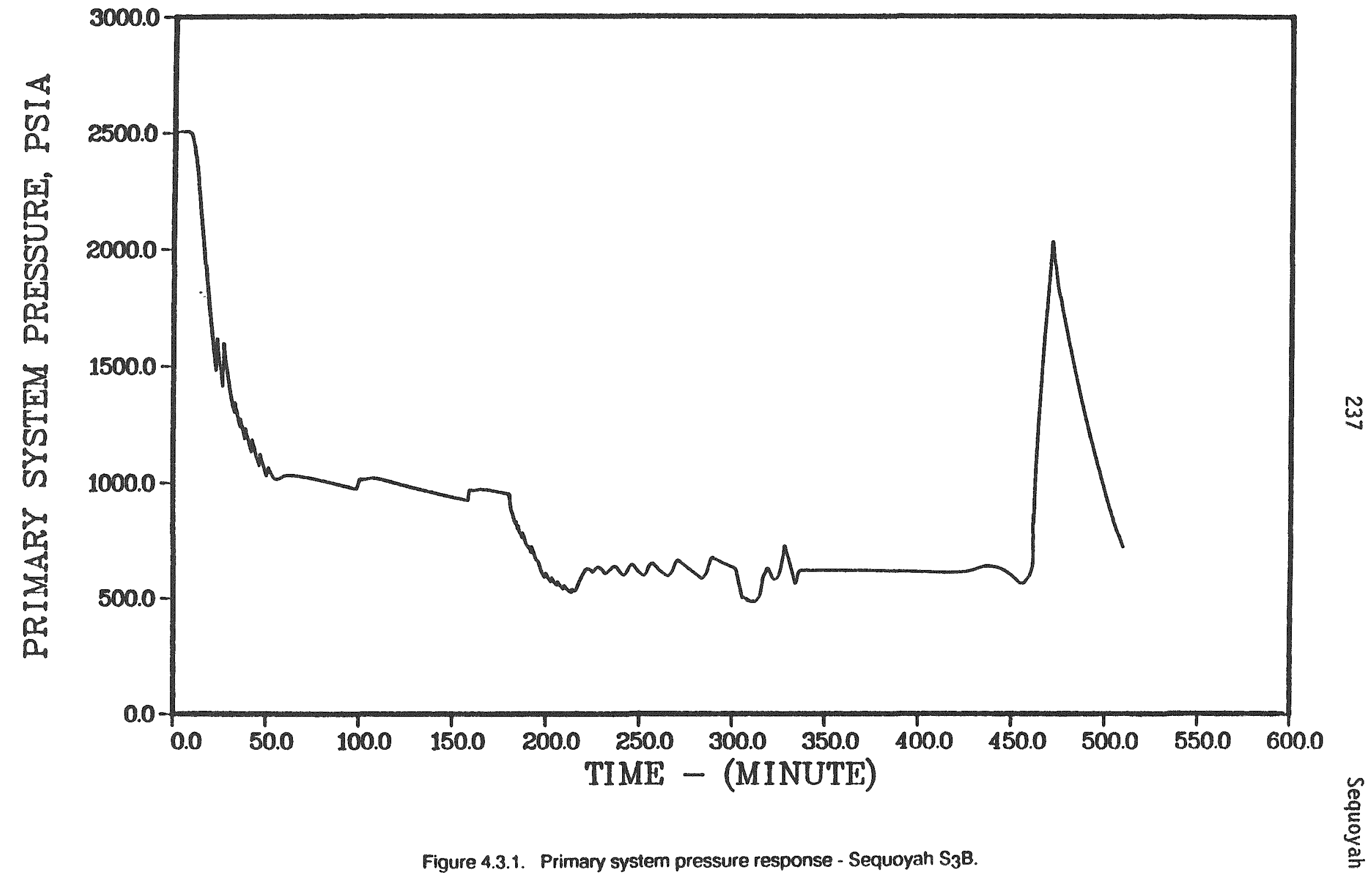




\section{SEQUOYAH S3B}

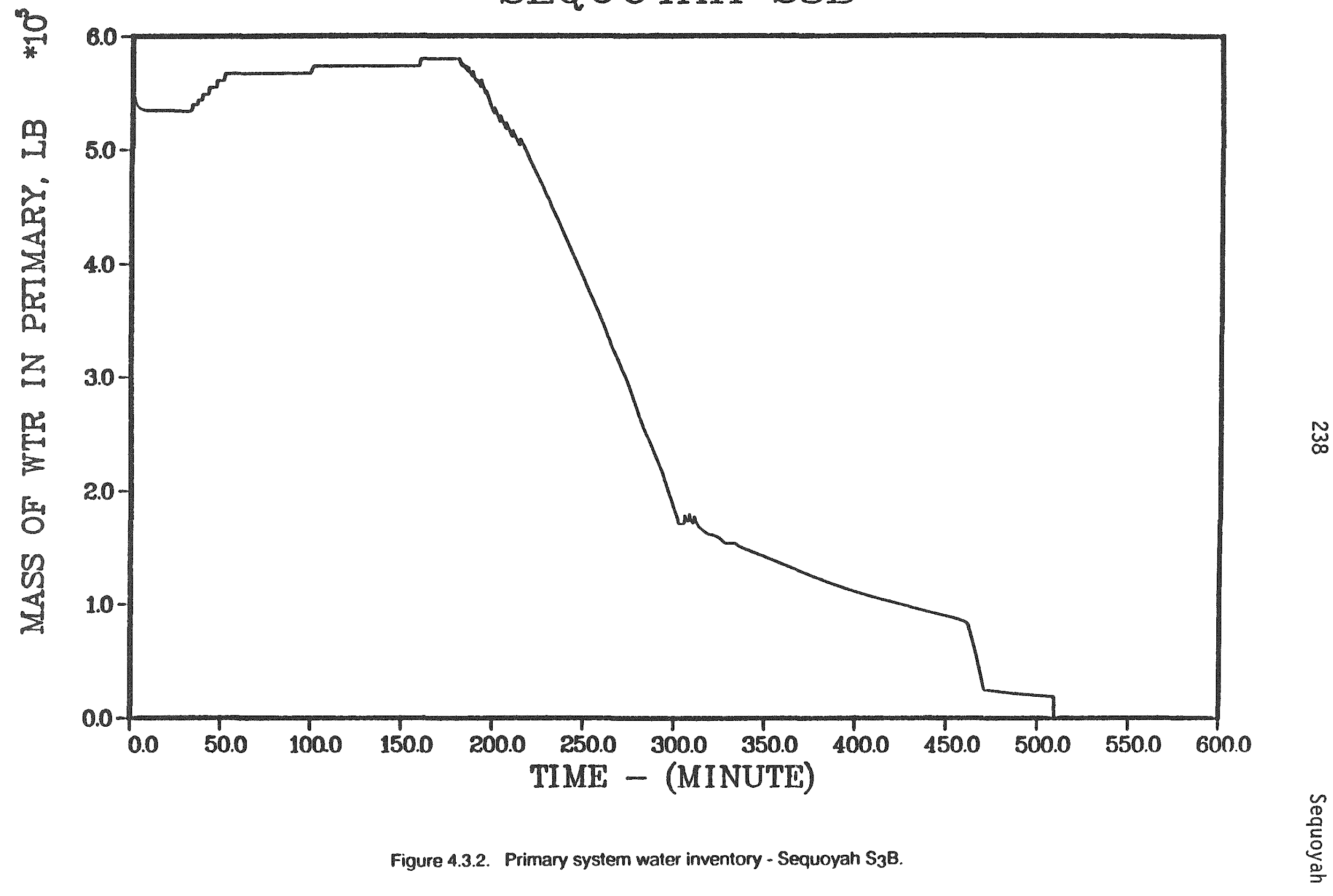




\section{SEQUOYAH S3B}

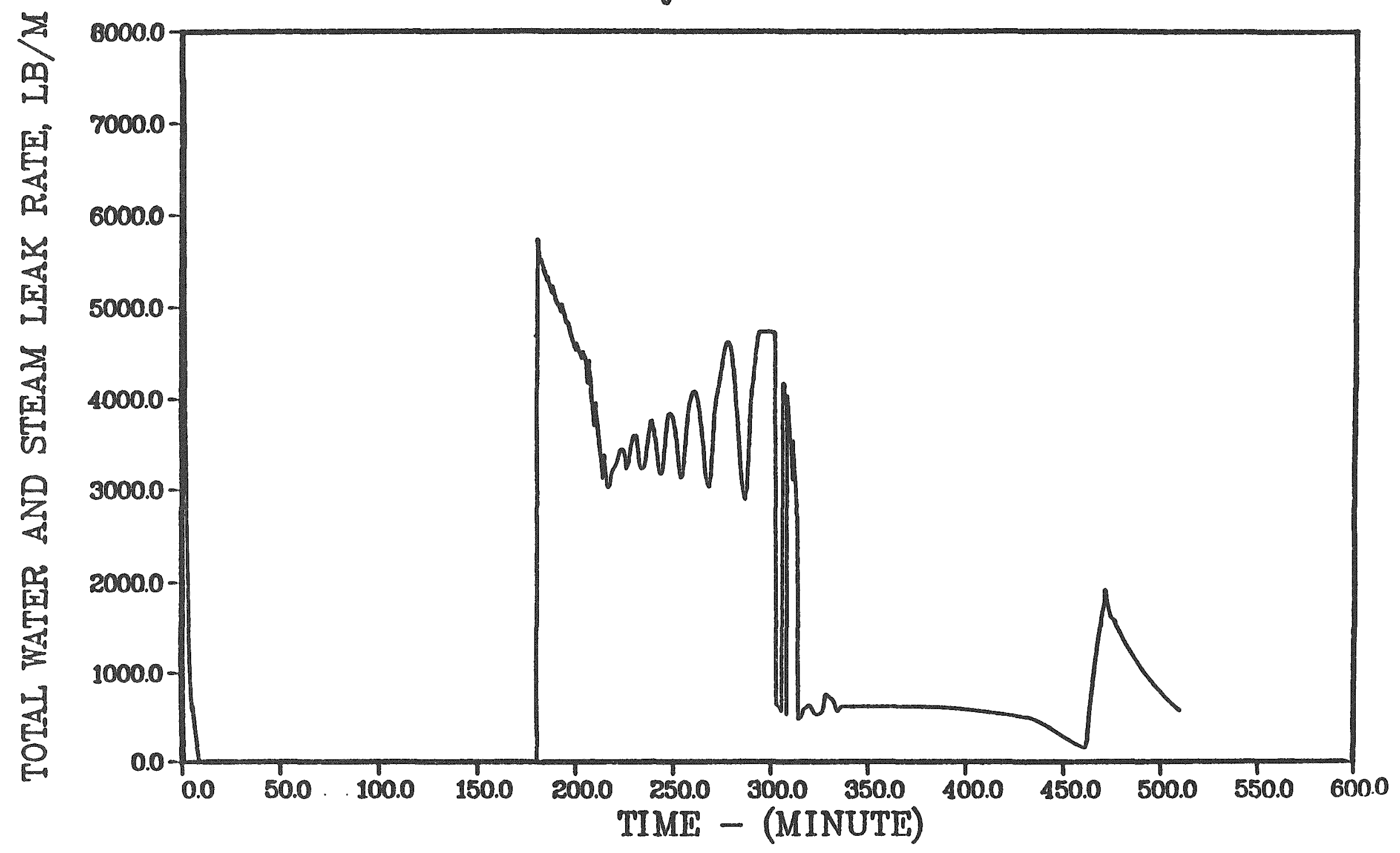

Figure 4.3.3. Primary system total water and steam leak rate - Sequoyah S9B. 
minutes into the accident the break uncovers and the leakage changes from water to steam, with a corresponding change in leak rate. The primary system pressure is observed to level off at about 600 psia, with some accumulator injection taking place. Approximately 73 percent of the accumulator inventory remained until reactor vessel failure at 509.3 minutes.

Figure 4.3.4 illustrates the peak and average core temperatures during this sequence; corresponding fractions of cladding reacted and core melted are illustrated in Figure 4.3.5. The short-term excursions in peak temperature above the assumed liquidus temperature are the result of locally rapid cladding oxidation. The predicted extent of cladding oxidation for this case is somewhat higher than observed for some STCP-modeled accident scenarios ${ }^{(2)}$ for Sequoyah and is believed to be a consequence of continuous steam flow through the core due to the small leak in the system. The rate of hydrogen leakage from the primary system is given in Figure 4.3.6. Temperatures of the gases leaving the core and those exiting the primary system are illustrated in Figure 4.3.7. Consistent with previous MARCH3 calculations, extremely high temperatures are predicted at the top of the core but these are reduced substantially by heat transfer to primary system structures.

\section{CONTAINMENT RESPONSE - Sequoyah $S_{3} B$}

Containment conditions at key times during the accident are summarized in Table 4.3.3 and the calculated leak rates from the containment are given in Table 4.3.4. The predicted containment pressure and temperature histories are given in Figures 4.3 .8 and 4.3 .9 , respectively. As discussed previously, containment failure for this case was assumed to be the "consequence of a localized detonation in the ice condenser; thus the gradual rise and rapid decrease on containment pressure in figure 4.3 .8 does not represent an increase of pressure to an assumed failure level. Similarly, the predicted containment atmosphere temperatures (shown in Figure 4.3.9) remain at relatively low levels. Selected containment structure surface temperatures are illustrated in Figure 4.3.10. 


\section{SEQUOYAH S3B}

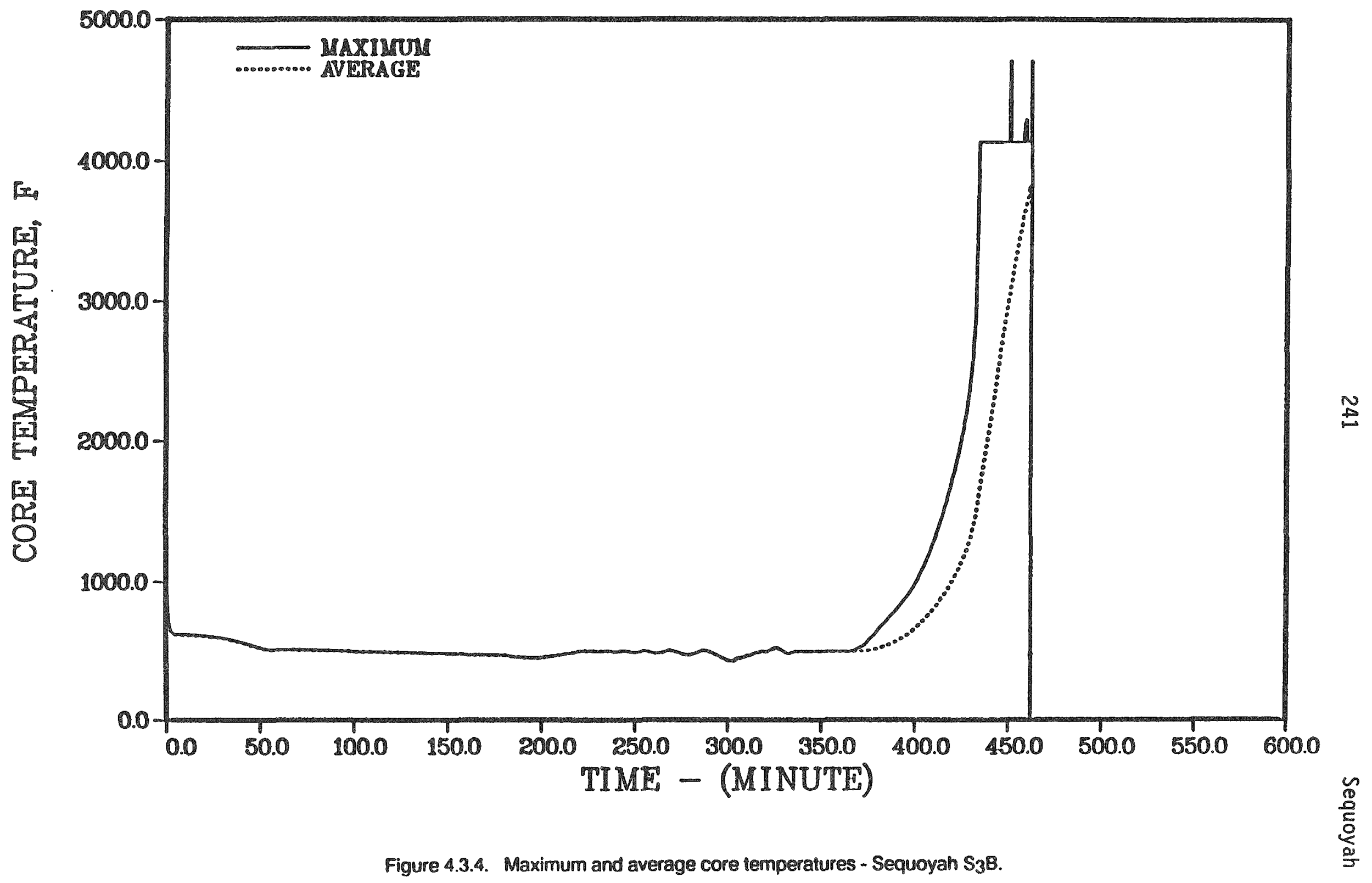




\section{SEQUOYAH S3B}

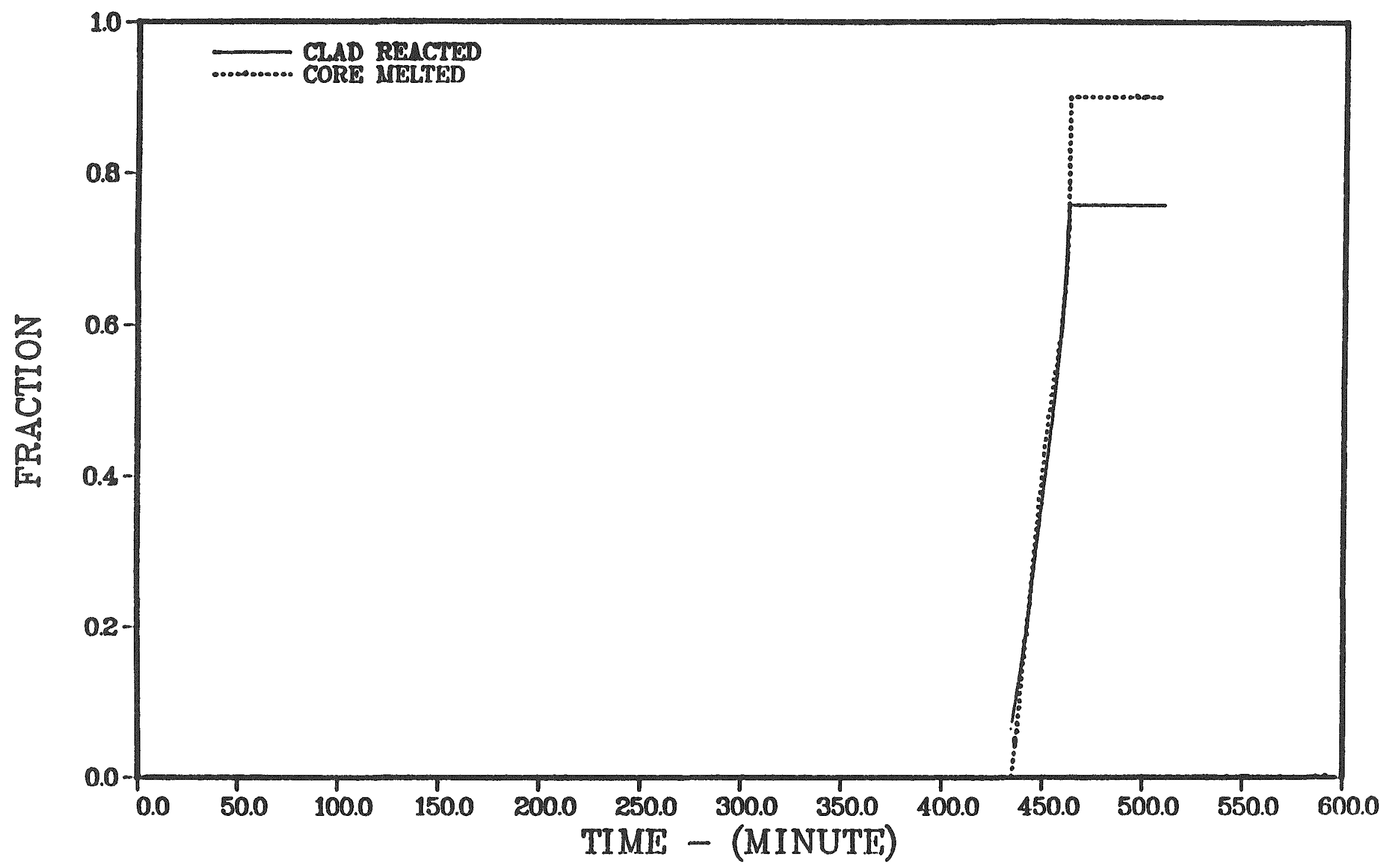

Figure 4.3.5. Fractions of cladding reacted and core melted - Sequoyah $S_{3} B$. 


\section{SEQUOYAH S3B}

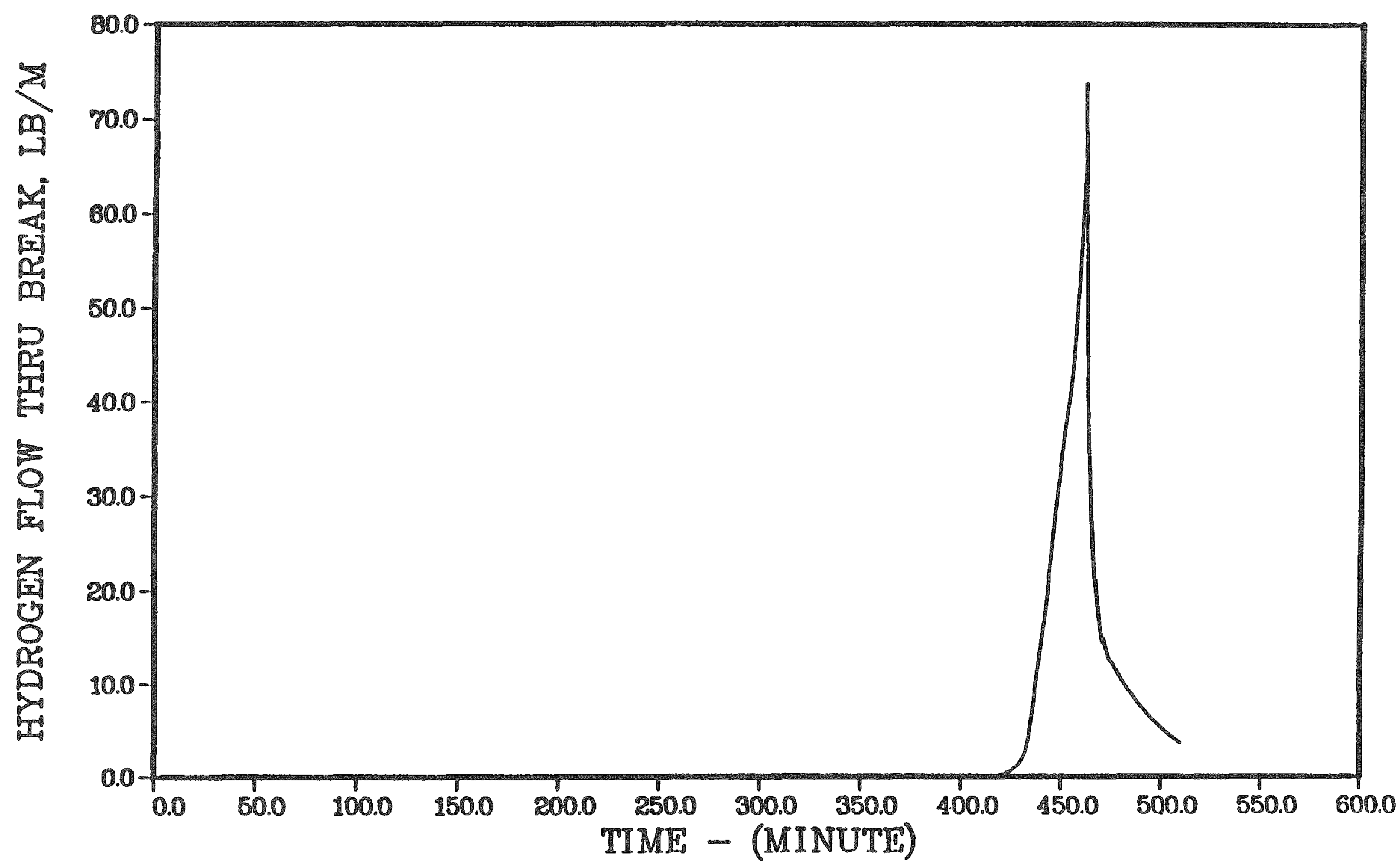

Figure 4.3.6. Primary system hydrogen leak rate - Sequoyah $\mathrm{S}_{3} \mathrm{~B}$. 


\section{SEQUOYAH S3B}

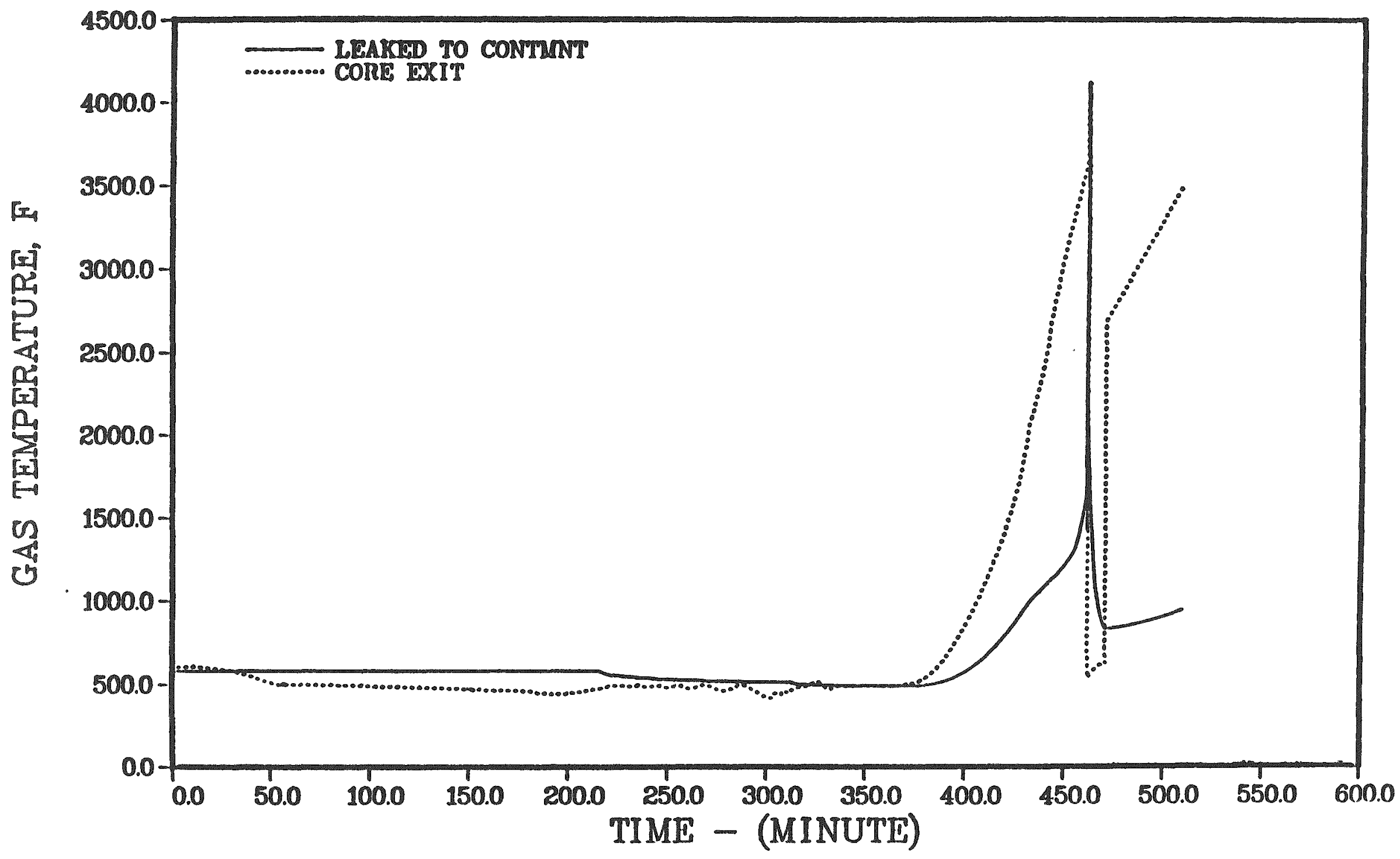

Figure 4.3.7. Temperatures of gases at core exit and leaving the primary systern - Sequoyah $\mathrm{S}_{3} \mathrm{~B}$. 
Table 4.3.3. Containment response - Sequoyah $S_{3} B$.

\begin{tabular}{|c|c|c|c|c|c|c|c|c|c|c|}
\hline \multirow[b]{3}{*}{$\begin{array}{l}\text { Accident } \\
\text { Event }\end{array}$} & \multirow[b]{3}{*}{$\begin{array}{c}\text { Timer, } \\
\text { ninutes }\end{array}$} & \multicolumn{3}{|c|}{ Conta inment } & \multirow{3}{*}{$\begin{array}{l}\text { Ice } \\
\text { Mass, } \\
\text { Ib }\end{array}$} & \multirow{2}{*}{\multicolumn{2}{|c|}{ Sume veter }} & \multirow{2}{*}{\multicolumn{2}{|c|}{ Reactor Cavily Water }} & \multirow{3}{*}{$\begin{array}{c}\text { Compartment Ms II } \\
\text { steam Condensation。 } \\
\text { Ib/m } \\
\text { Lomer/Ice/Upper }\end{array}$} \\
\hline & & \multirow{2}{*}{$\begin{array}{c}\text { Pressure。 } \\
\text { psia }\end{array}$} & \multirow{2}{*}{\multicolumn{2}{|c|}{$\begin{array}{l}\text { Temperature. } \\
\text { of }\end{array}$}} & & & & & & \\
\hline & & & & & & Mass, & $\begin{array}{l}\text { Teap.. } \\
\text { of }\end{array}$ & $\begin{array}{l}\text { Mass, } \\
\text { Ib }\end{array}$ & $\begin{array}{l}\text { Tewp. } \\
\text { of }\end{array}$ & \\
\hline Core uncovery & 302.0 & 21.2 & 233 & 106 & $2.28 \times 106$ & $7.01 \times 10^{8}$ & 190 & 0.0 & $\infty$ & $452 / 153 / 0$ \\
\hline Start melt & 434.3 & 21.4 & 240 & 105 & $2.20 \times 10^{0}$ & . $.30 \times 10^{5}$ & 184 & 0.0 & $\infty$ & $178 / 313 / 1$ \\
\hline Core sur & 461.3 & 22.7 & 291 & 114 & $2.14 \times 10$ & 9.03\%105 & 180 & 0.0 & $-\infty$ & $0 / 524 / 0$ \\
\hline Lower coapartaent & & & & & & & & & & \\
\hline faifure & 462.0 & 28.0 & 2077 & 118 & $2.14 \times 10^{\circ}$ & $9.06 \times 10^{5}$ & 180 & 1.0. & $\infty$ & $0 / 697 / 0$ \\
\hline Core collapso & 463.3 & 18.4 & 248 & 85 & $2.14 \times 10^{8}$ & $0.05 \times 10^{5}$ & 179 & 0.0 & $-\infty$ & $0 / 0 / 0$ \\
\hline Botto: hesd dryouts & 971.1 & 15.3 & 256 & 80 & $2.14 \times 180$ & $.01 \times 105$ & 178 & 0.0 & $-\infty$ & $0 / 0 / 0$ \\
\hline Botbow head failure & 809.3 & 15.0 & 242 & 100 & 2. ออะ1อ & $.0 .44810^{5}$ & 175 & 0.0 & $\infty$ & $0 / 0 / 0$ \\
\hline Accuoulators eapty & 508.8 & 18.1 & 213 & 120 & $2.01 \times 18$ & $1.06 \times 100$ & 170 & $1.60 \times 10^{5}$ & 108 & 0/12098/0 \\
\hline Start conereb otbach & 879.0 & 14.8 & 197 & 130 & $1.30 \times 1000$ & $1.86 \times 108$ & 161 & 1. 1 & 100 & $16 / 0 / 0$ \\
\hline End calculation & 1273.8 & 14.1 & 248 & 104 & $1.35 \times 10$ & $1.84 \times 10^{6}$ & 171 & 10.1 & 100 & $0 / 0 / 0$ \\
\hline
\end{tabular}


Table 4.3.4. Containment leak rates - Sequoyah $S_{3} B$.

\begin{tabular}{|c|c|c|c|c|c|c|c|c|c|c|c|}
\hline \multirow{3}{*}{$\begin{array}{l}\text { Tine } \\
\text { Intorval. } \\
\text { inutes }\end{array}$} & \multicolumn{5}{|c|}{ Lower Compartwent Leakago } & \multicolumn{5}{|c|}{ Upper Compartment Leakage } & \multirow{3}{*}{ Rampres } \\
\hline & \multirow{2}{*}{$\begin{array}{c}\text { Asto( } \\
\text { p/hr }\end{array}$} & \multicolumn{2}{|c|}{ Pressuro } & \multicolumn{2}{|c|}{ Teeperature } & \multirow{2}{*}{$\begin{array}{l}\text { Pate(b) } \\
\text { Whe }\end{array}$} & \multicolumn{2}{|c|}{ Pressure } & \multicolumn{2}{|c|}{ Temperature } & \\
\hline & & $\overline{M P a}$ & $\overline{p s i a}$ & oc & of & & MP & psia & $O C$ & of & \\
\hline $0.0-181.0$ & $0.0 / 0.0$ & 0.10 & 15 & 41 & 107 & 0.0 & 9.10 & 15 & 38 & 100 & Initial coro holup \\
\hline $180.0-362.0$ & $0.0 / 10$ & 0.14 & 20 & 99 & 210 & 0.0 & 0.14 & 20 & 42 & 108 & Initimto LOCA, core hedup \\
\hline $362.1-434.3$ & 0.010 .0 & 0.15 & 22 & 113 & 238 & 0.0 & 9.15 & 22 & 41 & 108 & Core uncovery \\
\hline 439.3 - 461.3 & $1.7 / 0.0$ & 0.15 & 22 & 124 & 256 & 0.0 & 0.15 & 22 & 42 & 108 & Core wits \\
\hline $461.3-462.1$ & $3.0 / 0.0$ & 0.18 & 23 & 148 & 3อบิ & 0.0 & 0.16 & 23 & 96 & 115 & Cor llowps \\
\hline 462.0 & $\ldots$ & 0.16 & 23 & 153 & 307 & $\infty$ & 0.10 & 23 & 46 & 115 & Lower compartaent fillure \\
\hline $462.1-483.3$ & $0.0 / 37.4$ & 0.14 & 20 & 120 & 286 & 6.5 & 0.14 & 20 & 39 & 102 & Coro luaps and collapses \\
\hline $463.3-471.1$ & $0.0 / 13.4$ & 0.11 & 16 & 128 & 259 & 1.3 & ข.11 & 16 & 31 & 87 & Dryout of vassal head \\
\hline $471.1-1000.3$ & $3.1 / 4.4$ & 0.11 & 16 & 120 & 247 & 0.0 & 0.11 & 16 & 39 & 102 & Yesse I heved heatup \\
\hline 509.3 & $-\infty$ & 0.10 & 15 & 117 & 242 & $\ldots$ & 0.10 & 15 & 43 & 109 & Yossel hoad failure \\
\hline $502.3-67.6$ & $3.3 / 0.7$ & 0.10 & 15 & 93 & 2018 & 0.0 & 0.10 & 15 & 53 & 128 & Dryout of pactor cavicy \\
\hline 773.133 .0 & $0.1 / 0.8$ & 0.10 & 15 & 108 & 226 & . 0 & 0.18 & 15 & 59 & 136 & Concreto decomposition \\
\hline 733.0 - 853.0 & $0.0 / 1.2$ & 0.10 & 15 & 123 & 258 & 0.0 & 0.18 & 15 & 62 & 148 & Concreto decomposition \\
\hline $053.0-1033.0$ & $0.0 / 0.0$ & 0.10 & 15 & 123 & 254 & 0.0 & 0.10 & 15 & 68 & 152 & Concrato decoposition \\
\hline 1033. -1273.0 & $0.0 / 0.2$ & 0.10 & 15 & 120 & 246 & .0 & 0.10 & 15 & 71 & 100 & Conereto decomposibien \\
\hline
\end{tabular}

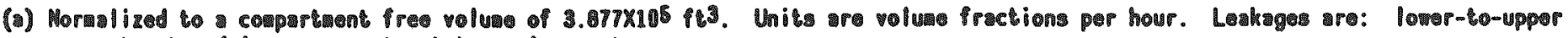
compartment and lower comprataent to envi ronment.

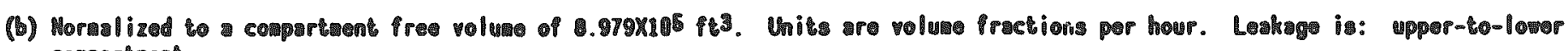
compartment. 


\section{SEQUOYAH S3B}

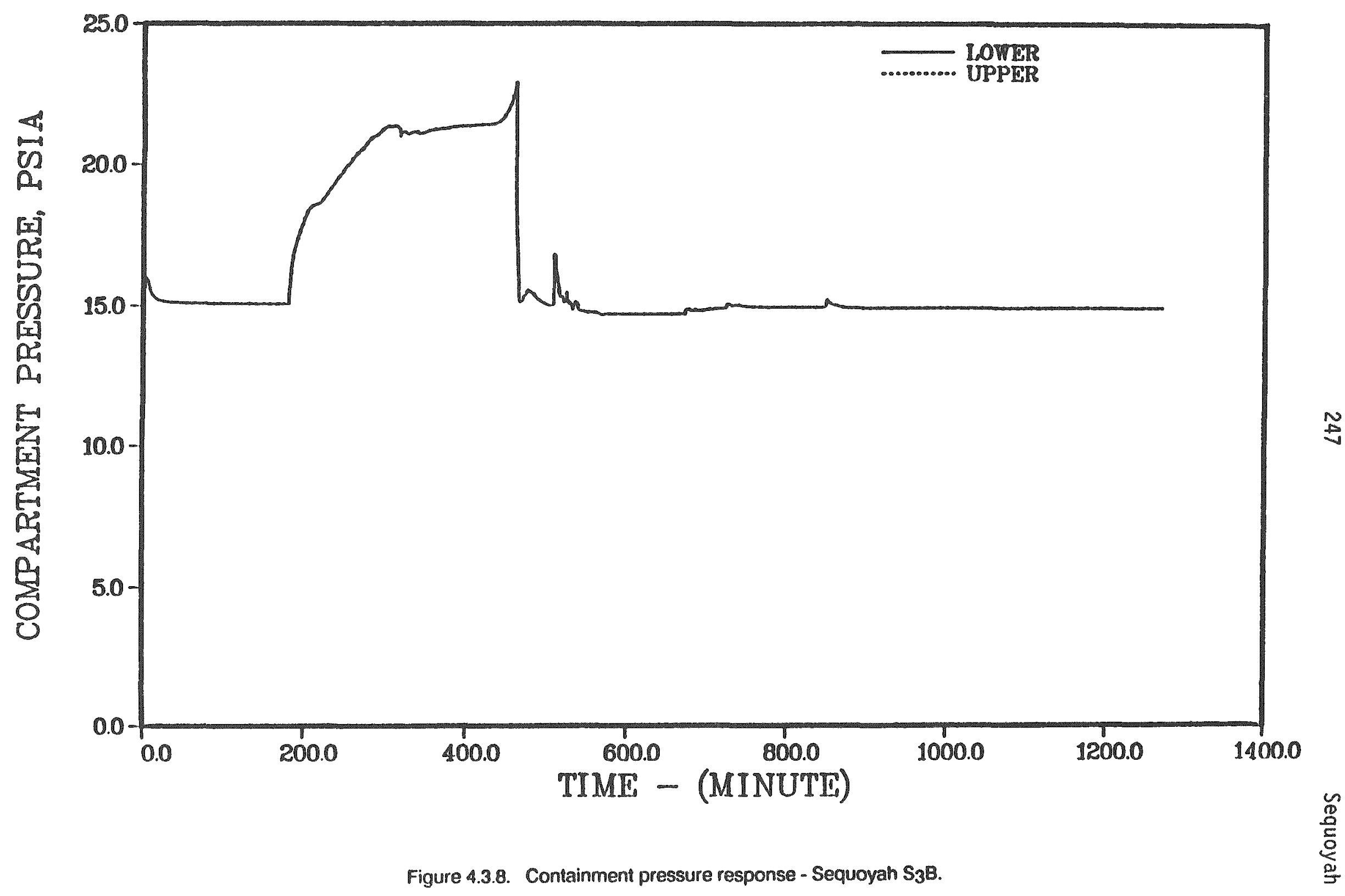




\section{SEQUOYAH S3B}

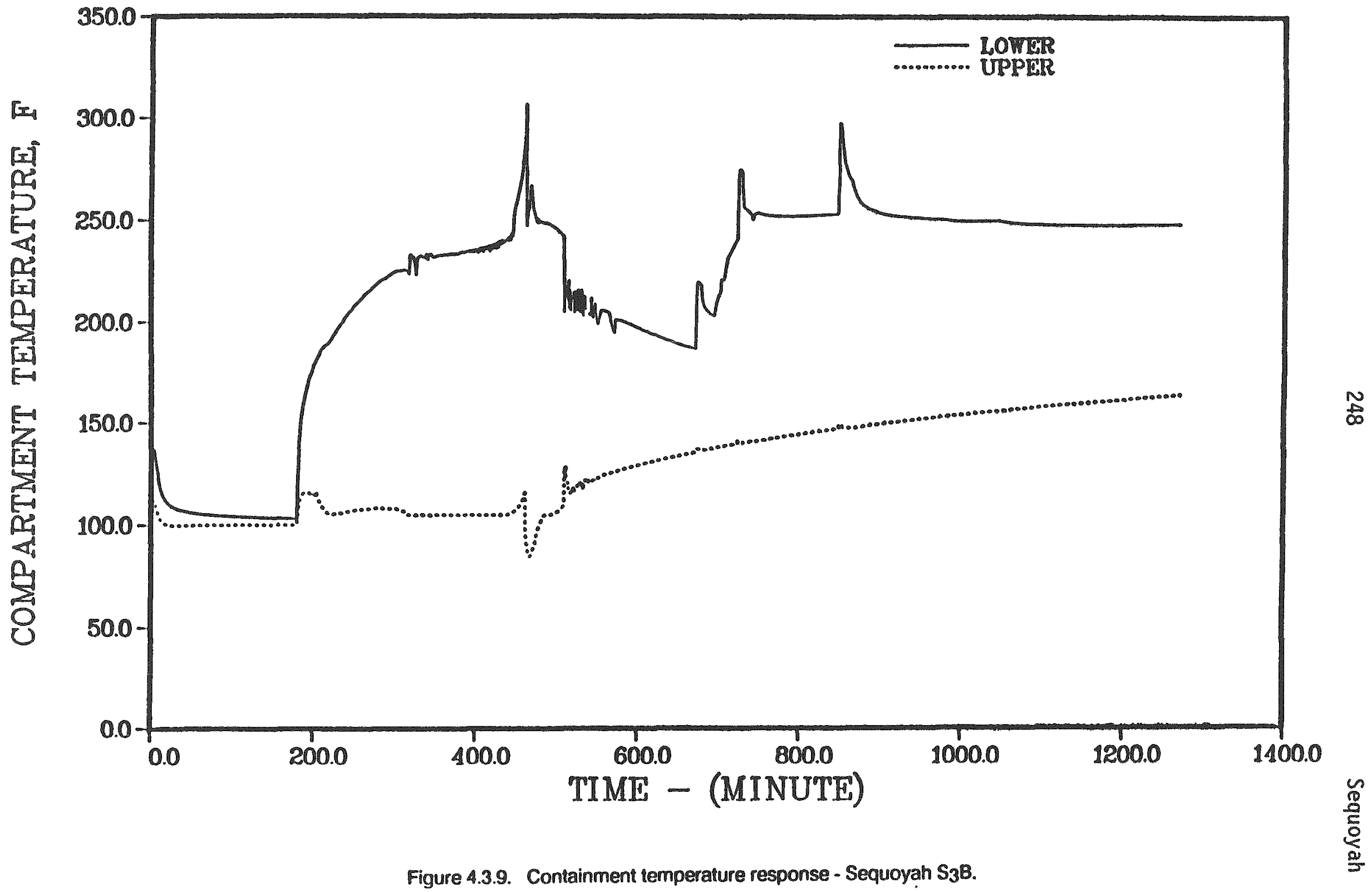




\section{SEQUOYAH S3B}

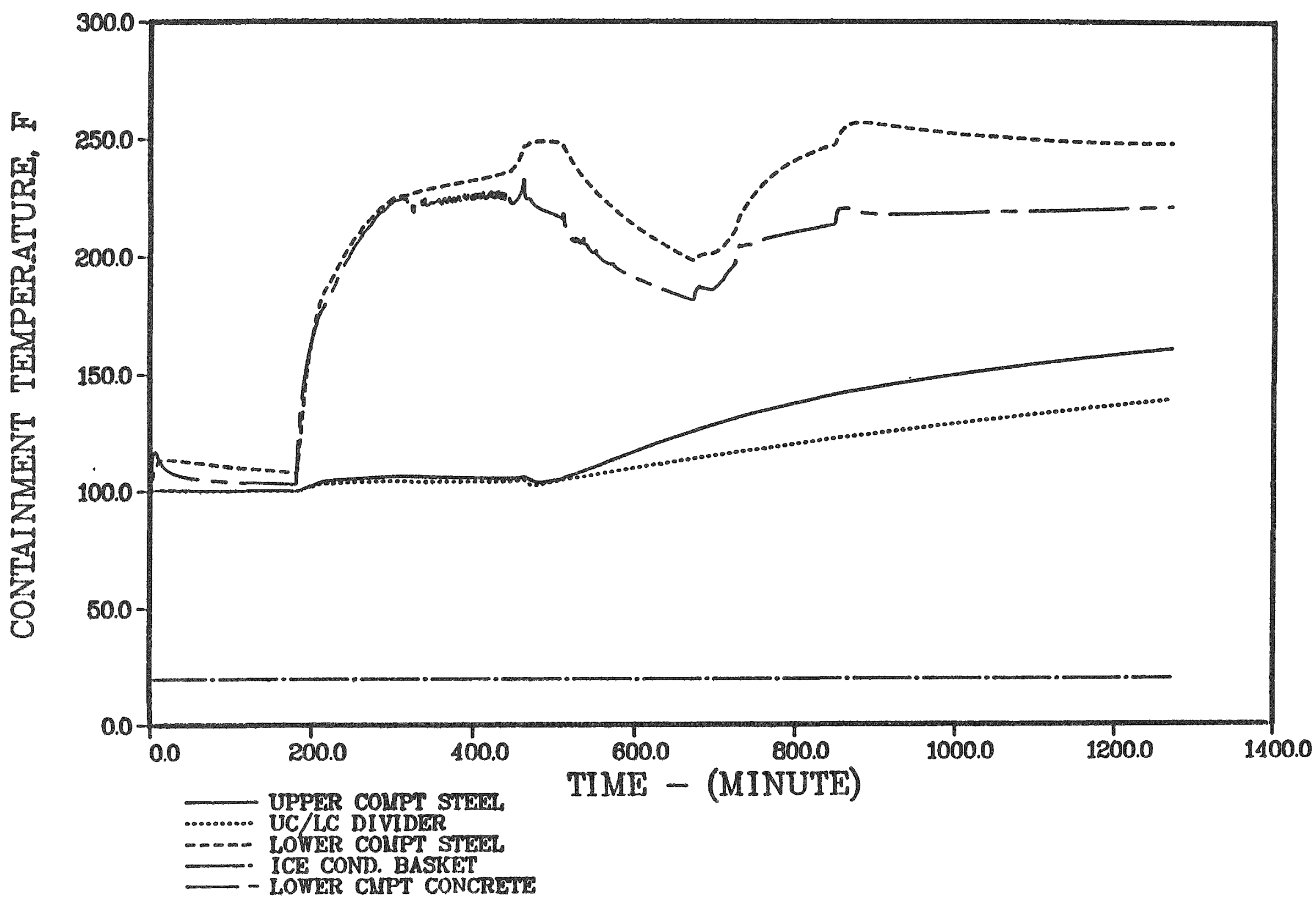


The predicted erosion of concrete resulting from corium-concrete interaction is illustrated in Figure 4.3.11. Because of the relatively high extent of in-vessel cladding oxidation, the progression of concrete attack in this case is somewhat a typical (less rapid) but displays the same trends as generally observed in previous analyses. Initially, the oxide phase is predicted to be under the metallic layer and is in direct contact with the concrete. The early erosion of concrete is predicted to be predominantly radia1. After the metallic and oxide layers invert, the more reactive metal phase comes into contact with the concrete and the radial attack slows down.

Figure 4.3.12 illustrates the history of ice depletion from the ice condenser for this sequence. A rapid decrease in the ice inventory is seen at the time of containment failure (462 minutes), and ice melting essentially ceases after that. This, of course, is a direct consequence of representing the location of containment failure in the lower compartment. The total volume of gases leaked from the containment is shown in Figure 4.3.13. The calculated distribution of released noble gases is illustrated in Figure 4.3.14.

\section{PRIMARY SYSTEM RESPONSE - SEquOyah S3HF $_{3}$}

The predicted timing of important events for this scenario is given in Table 4.3.5; core and primary system conditions at key times in the accident are summarized in Table 4.3.6. The calculated primary system pressure response is illustrated in Figure 4.3.15. As a result of the pump seal failure, the primary system pressure drops rapidly from the normal operating level. Early operation of emergency core cooling systems arrests the primary system depressurization near 1500 psia. Subsequent failure of emergency core cooling upon switchover to recirculation (at approximately 36 minutes), causes the primary system pressure to decrease to approximately saturated conditions. At about 230 minutes, the break (RCP seal failure) becomes uncovered (primary system mixture level falls below the cold leg) and the leakage from the primary system changes from water to steam. The effect of this change can be observed in Figure 4.3.16, which illustrates primary system water inventory, and in Figure 4.3.17, primary system leak rate. Figure 4.3.18 illustrates the peak and average core temperatures during this sequence. The corresponding 


\section{SEQUOYAH S3B}

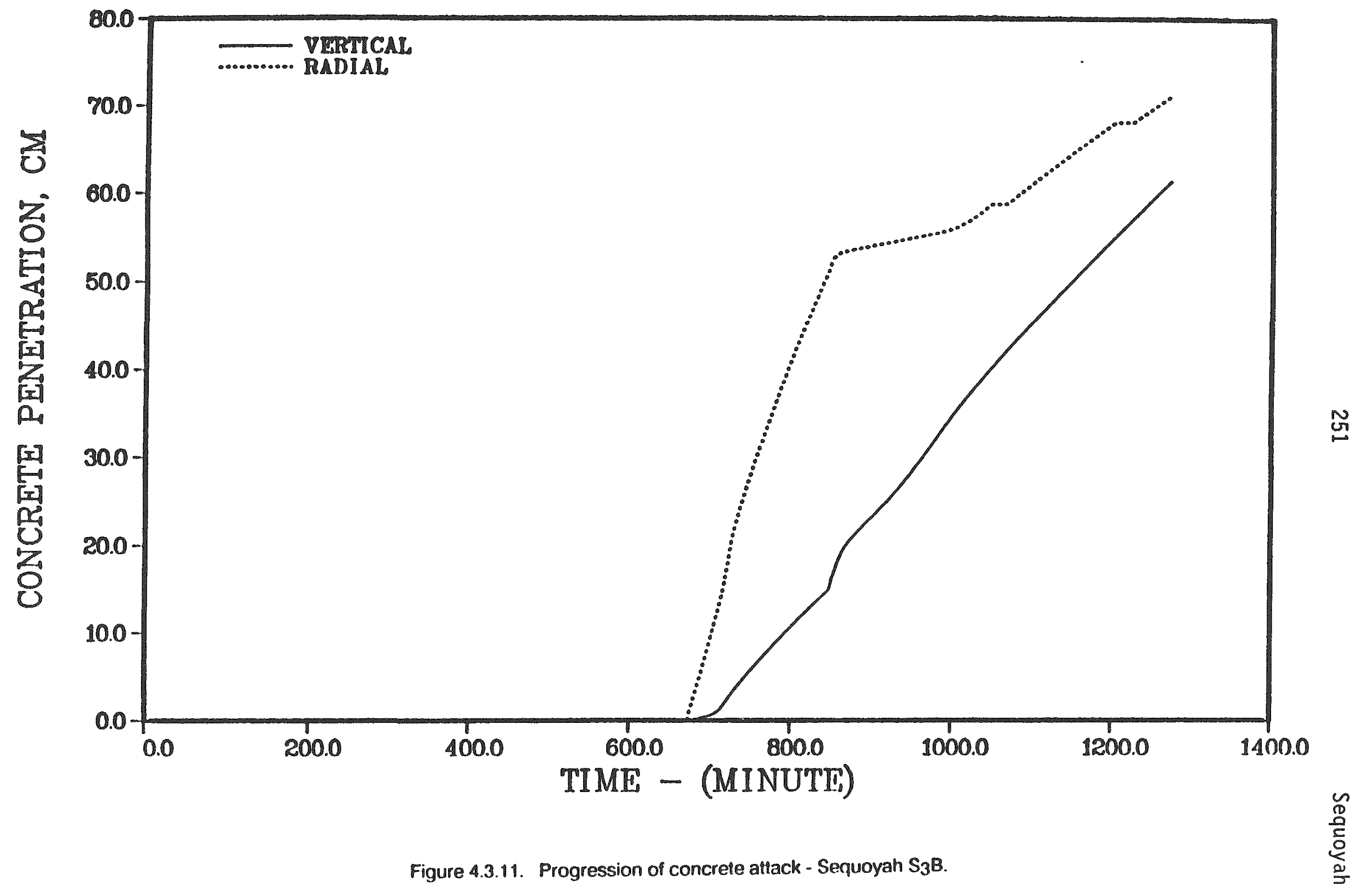




\section{SEQUOYAH S3B}

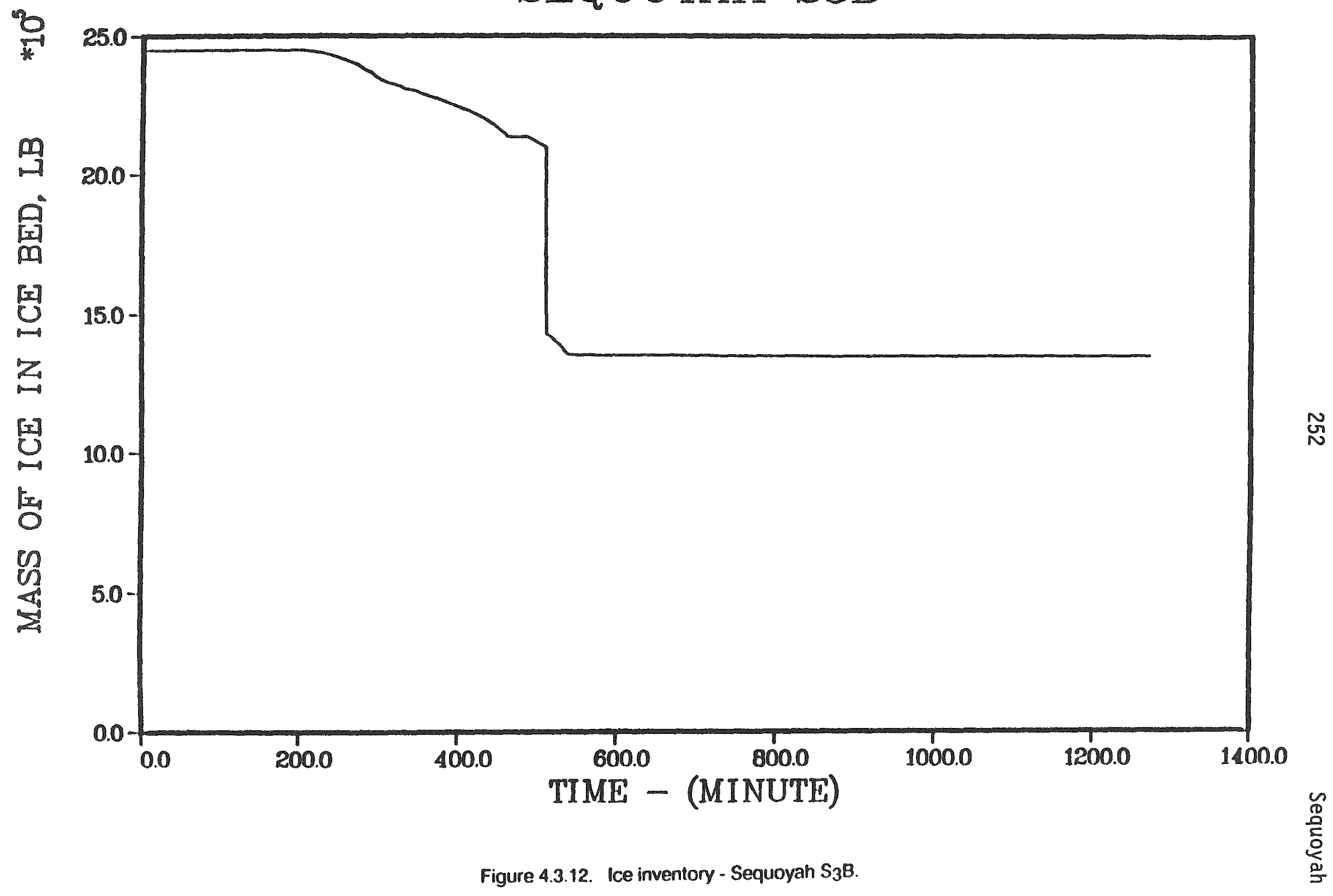




\section{SEQUOYAH S3B}

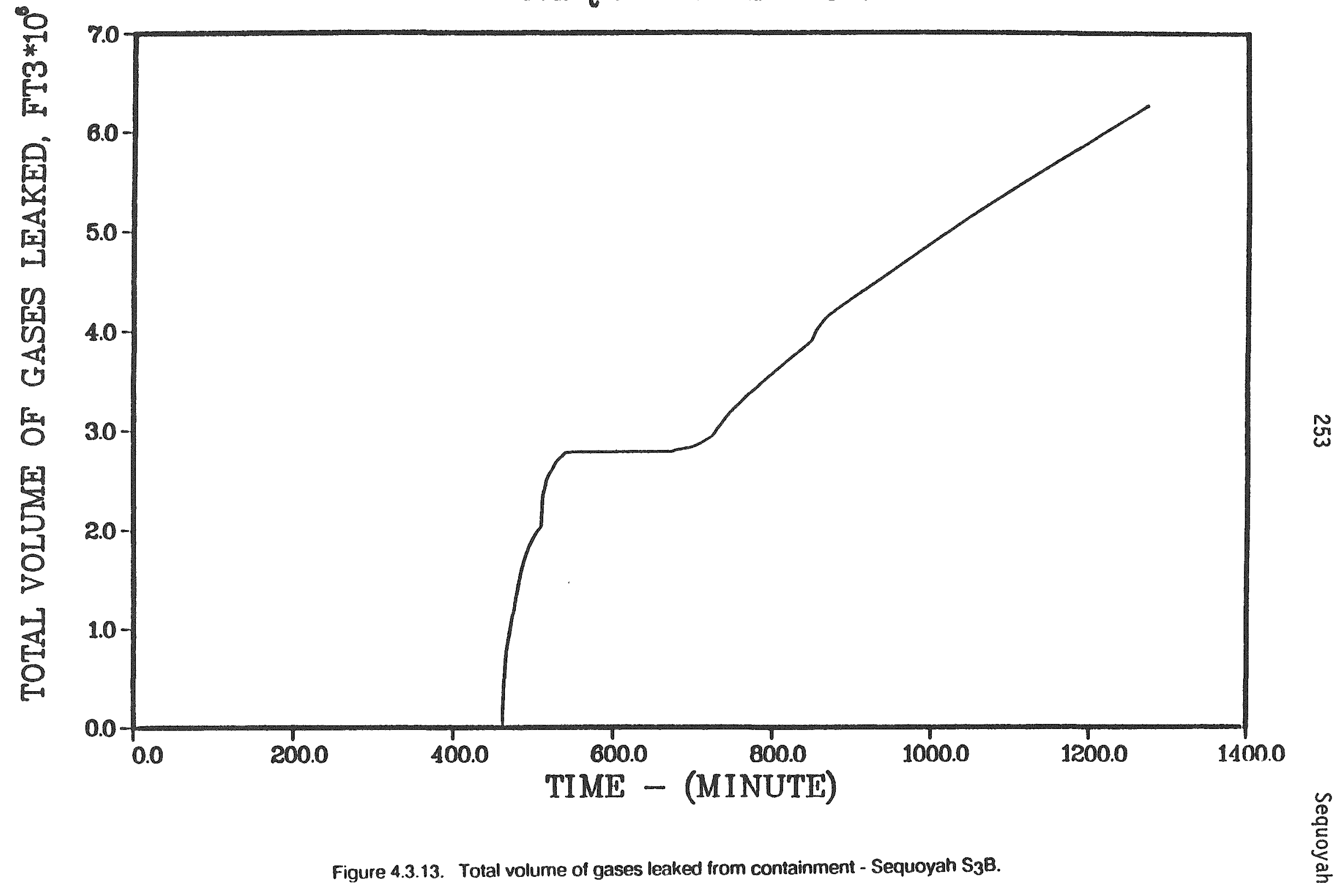




\section{SEQUOYAH S3B}

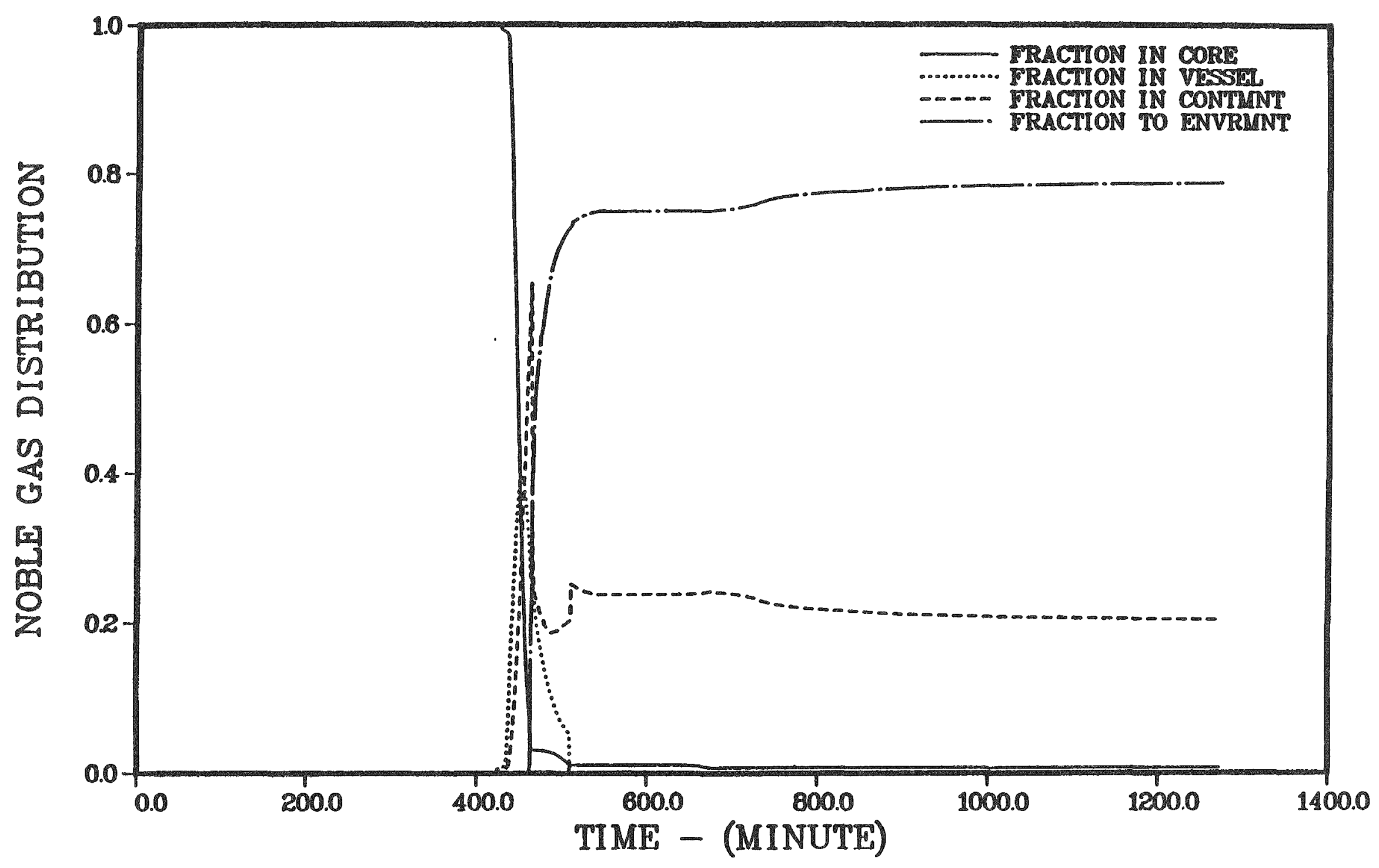

Figure 4.3.14. Noble gas distribution - Sequoyah $\mathrm{S}_{3} \mathrm{~B}$. 
Table 4.3.5. Timing of key events - Sequoyah S3HF.

\begin{tabular}{lc}
\hline \multicolumn{1}{c}{ Event } & Time, \\
& Minutes \\
\hline Eccs on & 1.0 \\
Fans on & 10.8 \\
Sprays on & 11.3 \\
Eccs recirculation failure & 36.0 \\
Spray recirculation failure & 42.5 \\
Core uncovery & 273.7 \\
Start melt & 376.2 \\
Hydrogen burn & 402.4 \\
Core slump & 405.2 \\
Hydrogen burn & 405.4 \\
Core collapse & 406.7 \\
Hydrogen burn & 409.3 \\
Hydrogen burn & 422.7 \\
Bottom head failure & 427.1 \\
Hydrogen burn & 427.2 \\
Hydrogen burn & 427.6 \\
Accumulators empty & 427.8 \\
Hydrogen burn & 428.7 \\
Ice melt complete & 636.4 \\
Containment failure & 1132.7 \\
Reactor cavity dryout & 4400.1 \\
Start concrete attack & 4647.1 \\
Corium layers invert & 4695.4 \\
End calculation & 5247.1 \\
\hline \hline
\end{tabular}


Table 4.3.6. Core and primary system response - Sequoyah $S_{3} H F$.

\begin{tabular}{|c|c|c|c|c|c|c|c|}
\hline $\begin{array}{c}\text { Accidont } \\
\text { Event }\end{array}$ & $\begin{array}{c}\text { Tima } \\
\text { - inutes }\end{array}$ & $\begin{array}{l}\text { Priary } \\
\text { Syster } \\
\text { Prassure. } \\
\text { pisia }\end{array}$ & $\begin{array}{l}\text { Primary } \\
\text { Systea } \\
\text { yater } \\
\text { Inventory. } \\
\text { is }\end{array}$ & $\begin{array}{l}\text { Avmrage Core } \\
\text { Temperature. } \\
\text { of }\end{array}$ & $\begin{array}{c}\text { Peate Core } \\
\text { Tewporature. } \\
\text { of }\end{array}$ & $\begin{array}{c}\text { Fraction } \\
\text { Core } \\
\text { Holted }\end{array}$ & $\begin{array}{c}\text { Fraction } \\
\text { Clad } \\
\text { Racered }\end{array}$ \\
\hline Coro uncovory & 275.7 & 1190 & $1.25 \times 10^{6}$ & 571 & 673 & 0.0 & 0.0 \\
\hline Start 膍 & 376.2 & 1180 & $0.85 \times 104$ & 1588 & 4130 & 0.0 & 1. \\
\hline Coro slump & 405.2 & 1653 & $7.54 \times 104$ & 3887 & 4130 & 0.70 & 0.74 \\
\hline Core collapse & 406.7 & 2007 & 6.5510 & 327 & $-\infty$ & . & 0.74 \\
\hline Dottom head finiluro & 427.1 & 2147 & $2.04 \times 10^{4}$ & 2004 & $\infty$ & $\ldots$ & 0.74 \\
\hline
\end{tabular}




\section{SEQUOYAH S3HF}

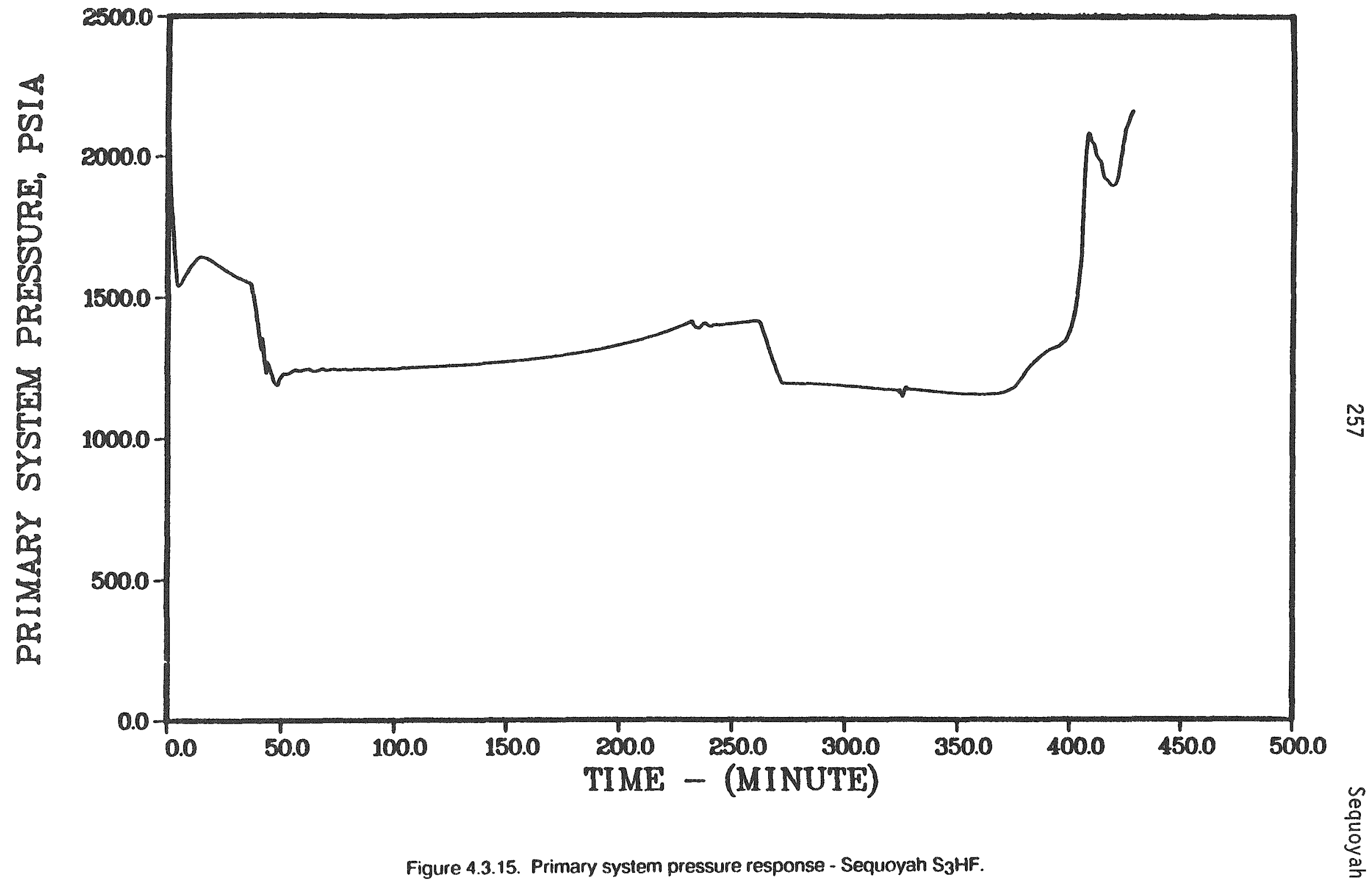




\section{SEQUOYAH S3HF}

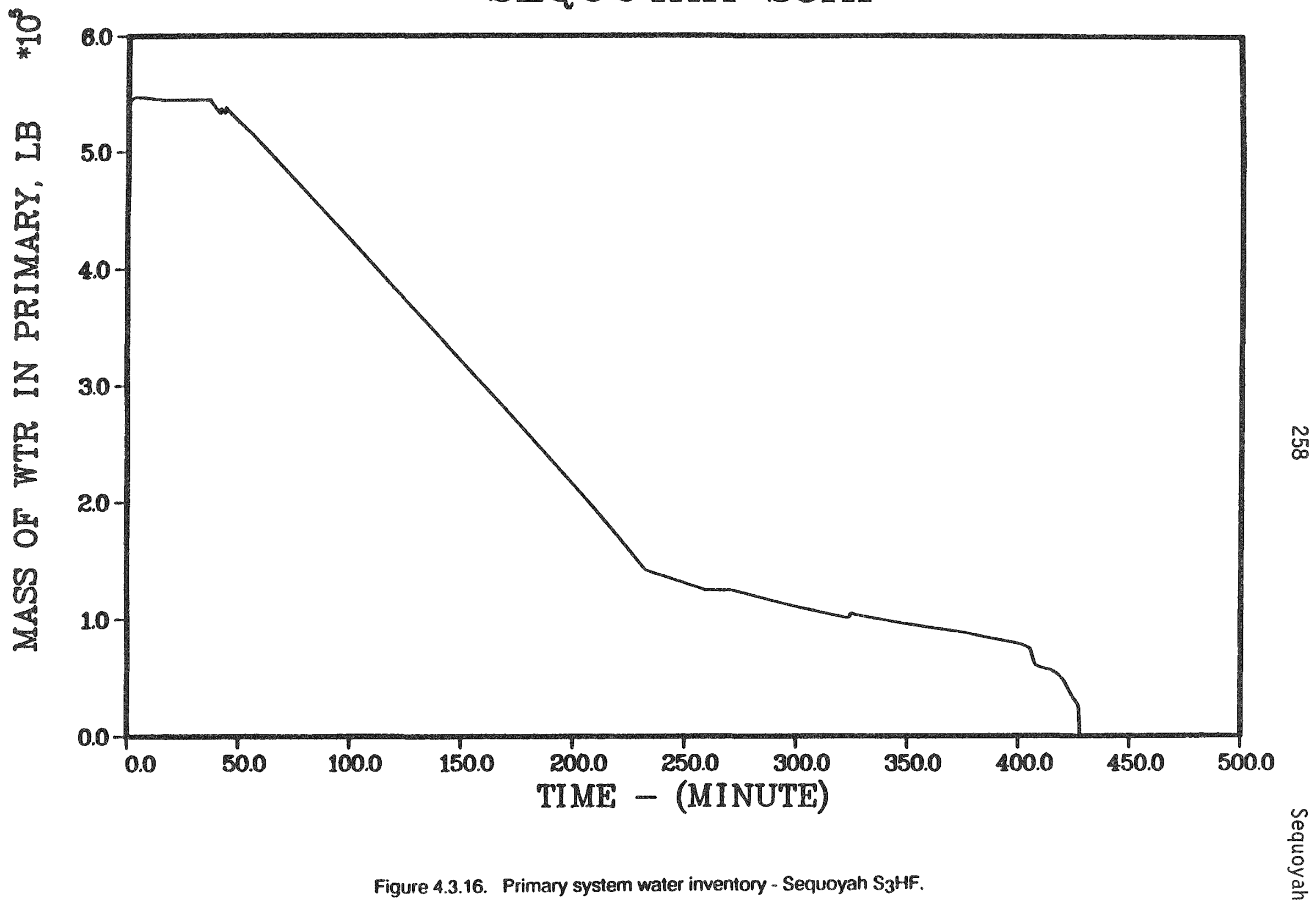




\section{SEQUOYAH S3HF}

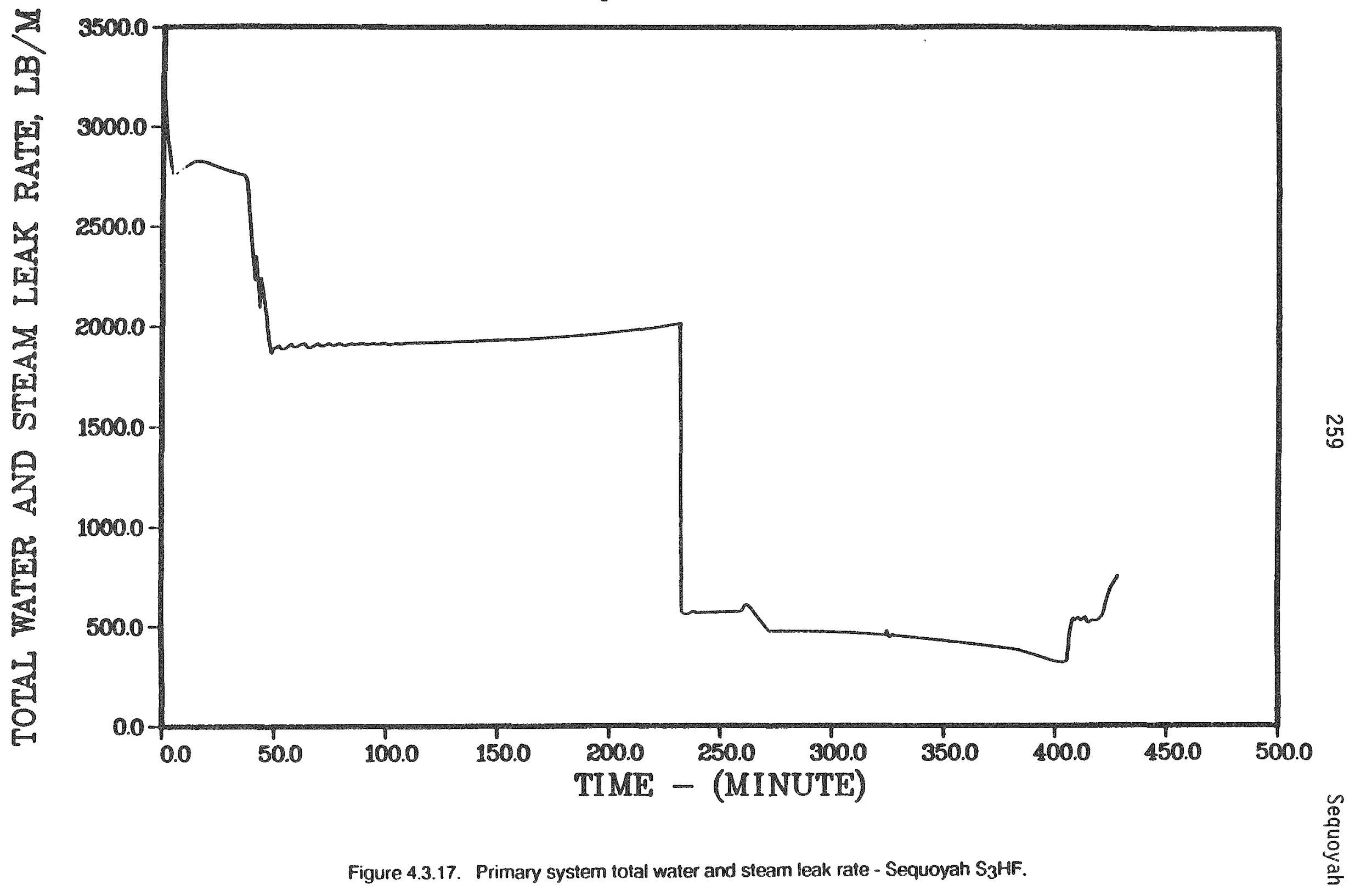




\section{SEQUOYAH S3HF}

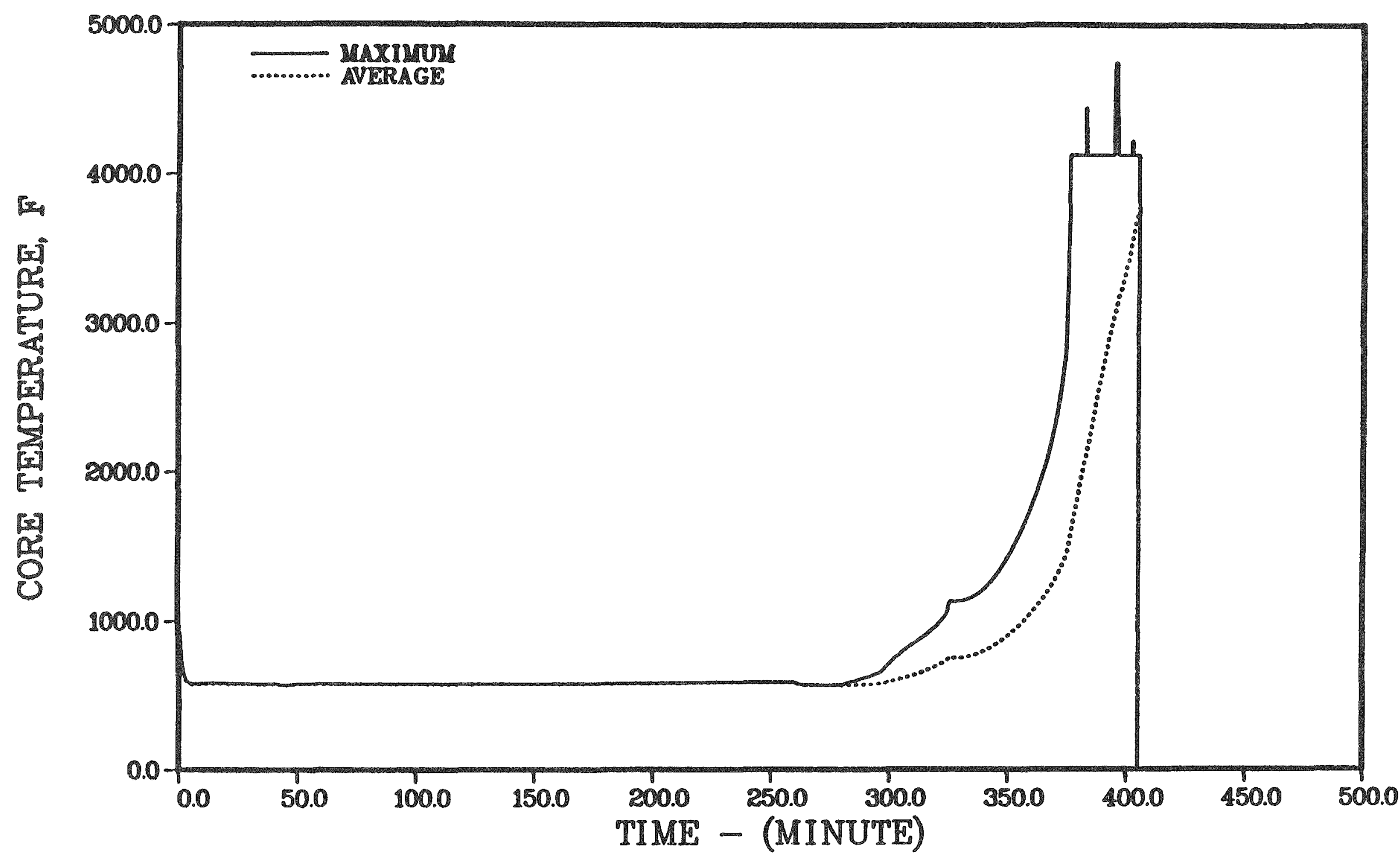

Figure 4.3.18. Maximum and average core temperatures - Sequoyah S3HF. 
fractions of core melted and cladding reacted are shown in Figure 4.3.19. Hydrogen leakage from the primary system is shown in Figure 4.3.20. Temperatures of the gases leaving the core and those entering the containment are shown in Figure 4.3.21.

\section{CONTAINMENT RESPONSE - Sequoyah S SHF}

Containment conditions at key times during this sequence are summarized in Table 4.3.7 and the calculated leak rates from the containment are given in Table 4.3.8. The predicted containment pressure and temperature histories are illustrated in Figures 4.3 .22 and 4.3.23. Surface temperatures of selected containment structures are shown in Figure 4.3.24. At the time of core melting the containment sprays have failed, but the air return fans and igniters are operable. Several hydrogen burns are predicted just prior to and immediately after vessel failure; the resulting peak pressures are below the assumed containment failure level 165 psia). The core debris is quenched by the water in the reactor cavity, but the continuing evaporation of the cavity water leads to depletion of the ice at about 636 minutes into the accident, as illustrated in Figure 4.3.25. Ice depletion is followed by an increased rate of containment pressurization due to the generation of uncondensed steam. Containment overpressure failure is predicted to occur at 1133 minutes. At the time of predicted containment failure the reactor cavity is essentially full of water. Water continues to overflow into the cavity as cavity water boils off. Complete dryout of the reactor cavity is predicted to occur 4400 minutes after the start of the accident.

Dryout of the reactor cavity is followed by core debris reheating and the start of corium-concrete interaction at 4647 minutes. The predicted extent of concrete erosion is illustrated in Figure 4.3.26. As in the previous case, the oxide phase of the debris is initially on the bottom (in contact with concrete) and the initial progression of concrete erosion is primarily radial. After the debris layers flip, and the metal phase comes into contact with the concrete, downward erosion predominates. The total volume of gases leaked during this sequence is illustrated in Figure 4.3.27. It should be noted that the leakage during concrete attack is only a smal1 fraction of the total shown. 


\section{SEQUOYAH S3HF}

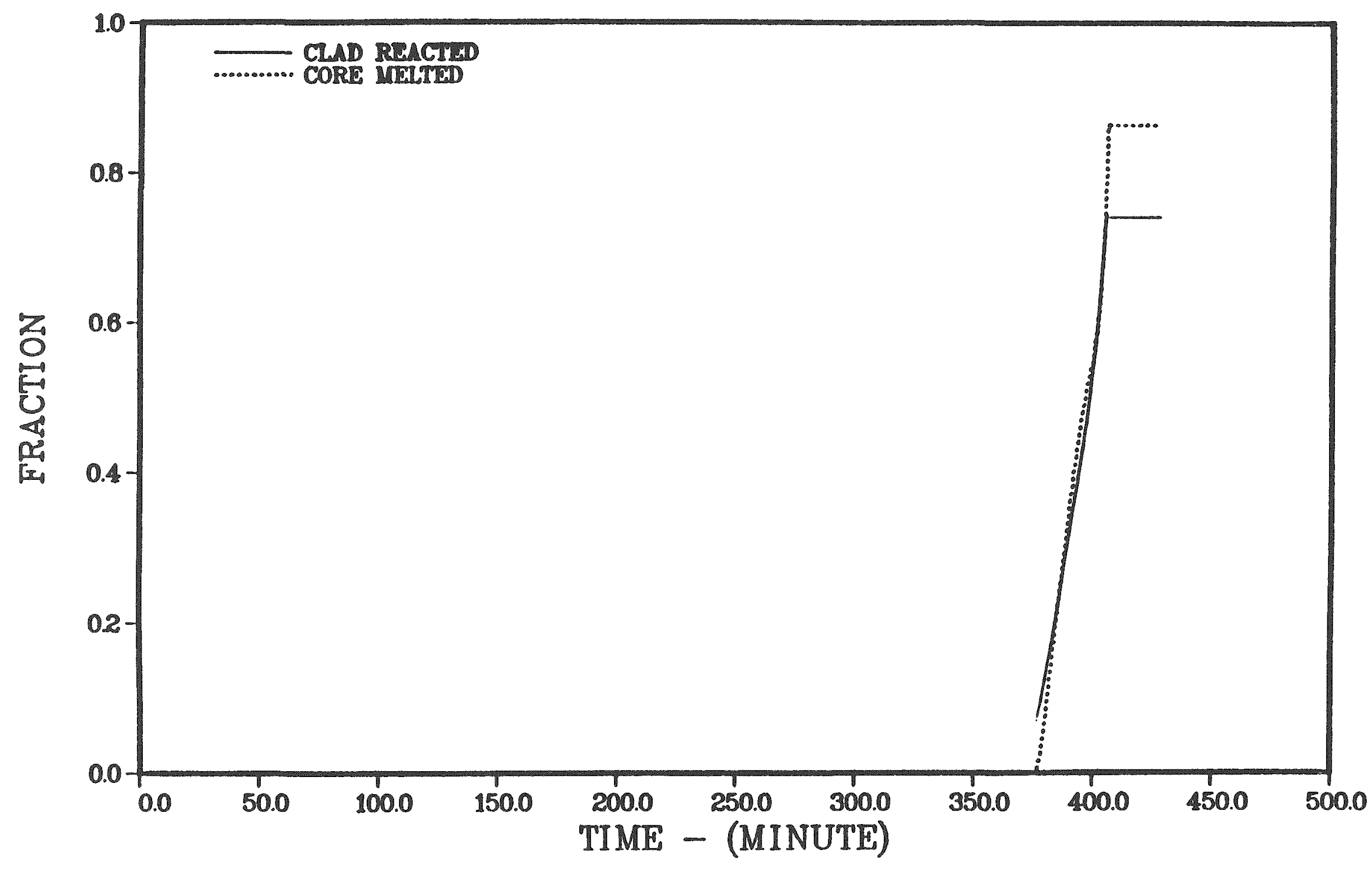

N

Figure 4.3.19. Fractions of cladding reacted and core melted - Sequoyah S3HF. 


\section{SEQUOYAH S3HF}

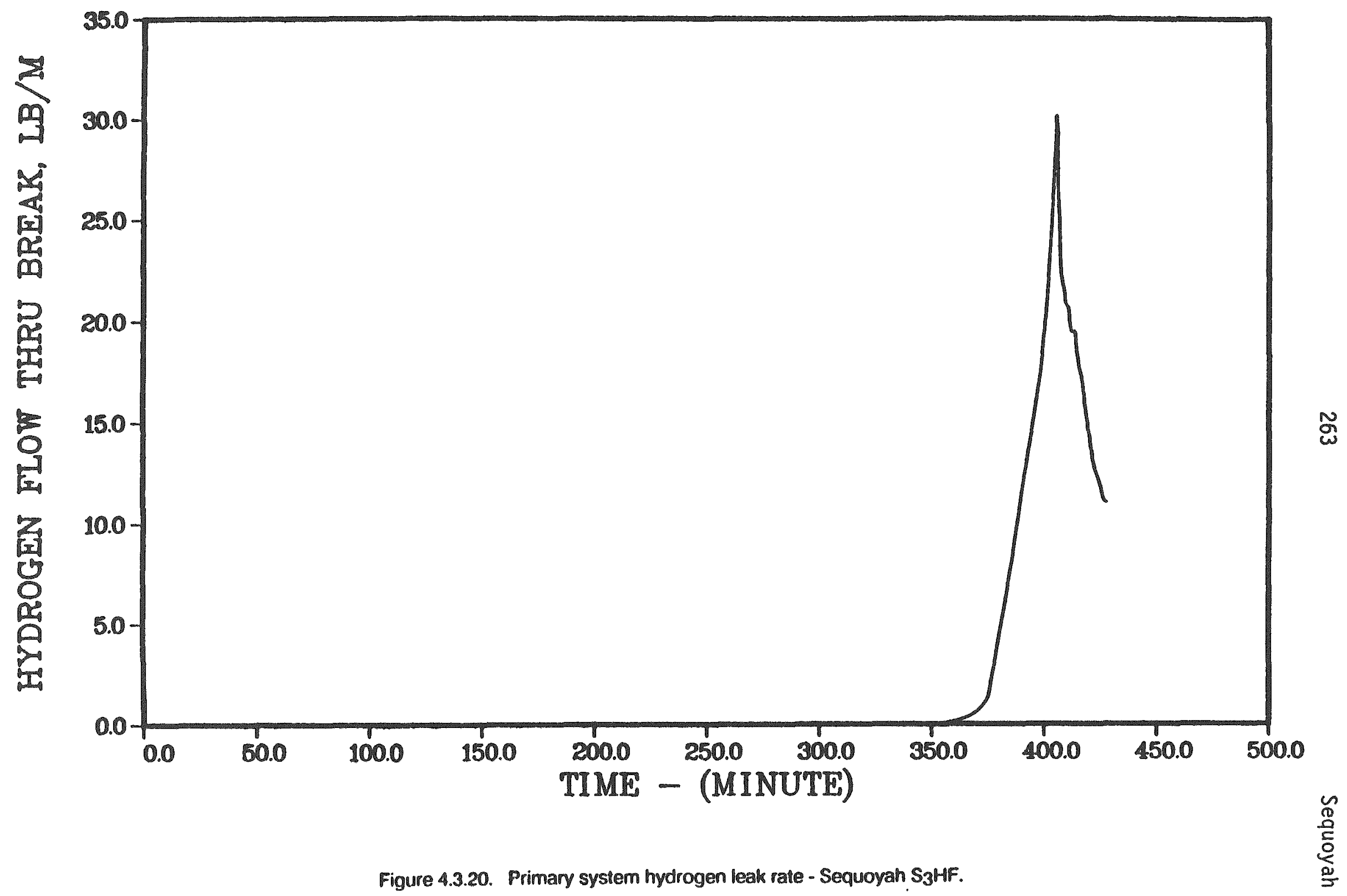




\section{SEQUOYAH S3HF}

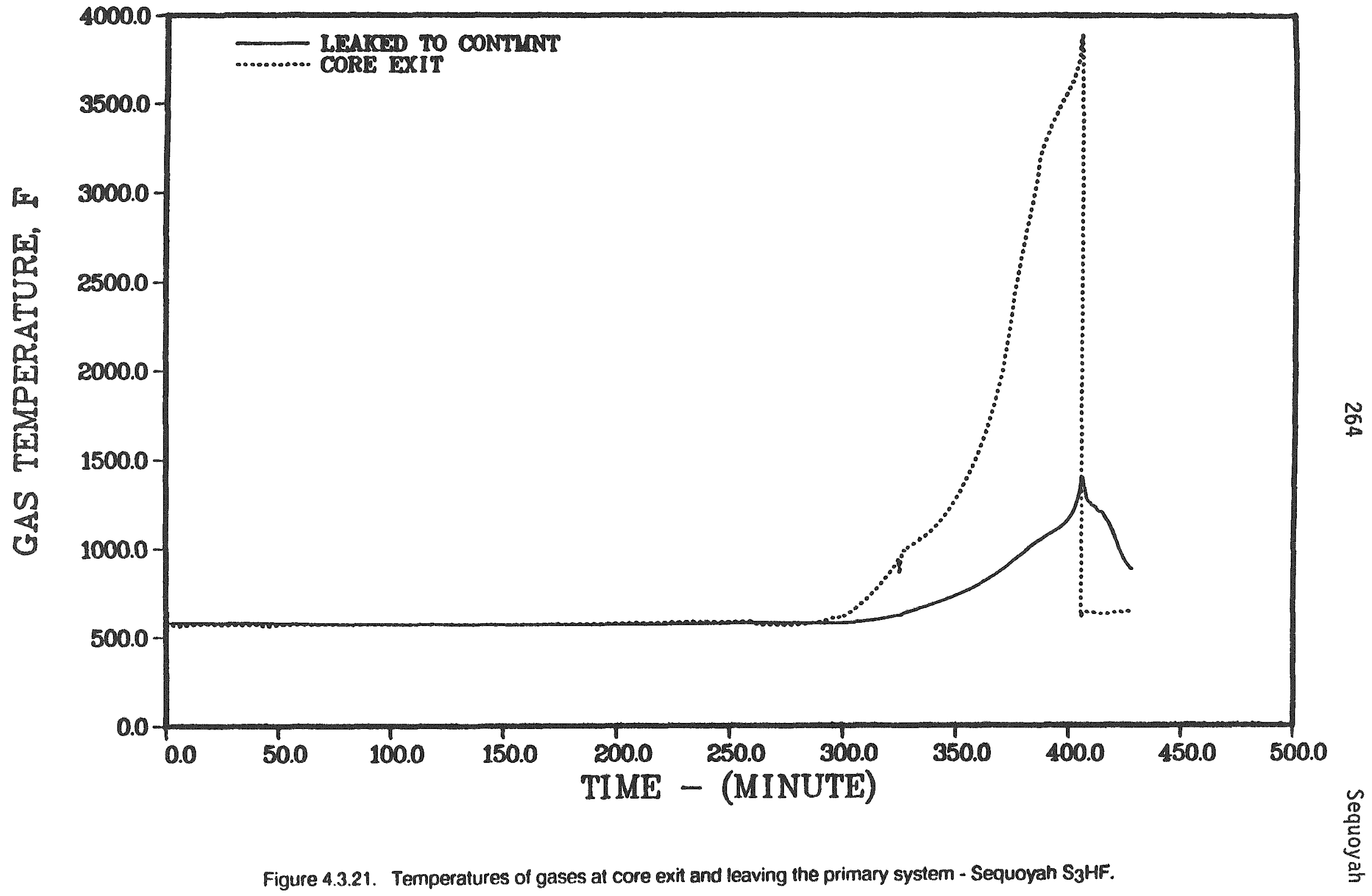


Table 4.3.7. Containment response - Sequoyah $S_{3} H F$.

\begin{tabular}{|c|c|c|c|c|c|c|c|c|c|c|}
\hline \multirow{3}{*}{$\begin{array}{l}\text { Accident } \\
\text { Event }\end{array}$} & \multirow{3}{*}{$\begin{array}{l}\text { Time, } \\
\text { minutes }\end{array}$} & \multicolumn{3}{|c|}{ Conta imment } & \multirow{3}{*}{$\begin{array}{c}\text { Ic } \\
\text { Mass, } \\
\text { Ib }\end{array}$} & \multirow{2}{*}{\multicolumn{2}{|c|}{ Sump water }} & \multirow{2}{*}{\multicolumn{2}{|c|}{ Reactor Cavity Water }} & \multirow{3}{*}{ 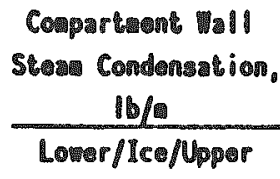 } \\
\hline & & \multirow{2}{*}{$\begin{array}{c}\text { Pressure. } \\
\text { psia }\end{array}$} & \multicolumn{2}{|c|}{$\begin{array}{l}\text { Temperature. } \\
\text { of }\end{array}$} & & & & & & \\
\hline & & & & $\overline{\text { Upper }}$ & & $\begin{array}{c}\text { Mass, } \\
16\end{array}$ & $\begin{array}{l}\text { Teap. } \\
\text { of }\end{array}$ & $\begin{array}{l}\text { Mass, } \\
\text { 1b }\end{array}$ & $\begin{array}{l}\text { Teap. } \\
\text { of }\end{array}$ & \\
\hline Core uncovery & 279.7 & 17 & 137 & 105 & $1.87 \times 10^{6}$ & $1.27 \times 10^{6}$ & 118 & $4.73 \times 10^{5}$ & 110 & $34 / 460 / 0$ \\
\hline Start walt & 376.2 & 17 & 142 & 105 & $1.48 \times 10^{8}$ & $3.27 \times 108$ & 118 & 7.314105 & 117 & 1/380/0 \\
\hline Core luep & 405.2 & 10 & 187 & 100 & $1.39 \times 10^{0}$ & $3.27 \times 108$ & 119 & $0.05 \times 10^{5}$ & 117 & 0/3ะอ/อ \\
\hline Coro collapse & 406.7 & 10 & 228 & 108 & $1.38 \times 106$ & $\$ .27 \times 10^{6}$ & 110 & $8.16 \times 10^{5}$ & 117 & $0 / 0 / 0$ \\
\hline Lotbon head Prilur & 427.1 & 20 & 201 & 234 & 1.30ะ106 & $3.27 \times 10^{\circ}$ & 121 & $0.12 \times 105$ & 117 & $9790 / 0$ \\
\hline Accumulator empty & 427.0 & 4 & 248 & 221 & $1.18 \times 10^{8}$ & $3.75 \times 10^{6}$ & 123 & $1.22 \times 10^{\circ}$ & 138 & อิ10/45240/0 \\
\hline Ice molt comploto & 036.4 & 18 & 162 & 144 & 0.10 & $4.98 \times 106$ & 128 & $.02 \times 105$ & 210 & $02 / 71 / 0$ \\
\hline Uppor coapartuent & & & & & & & & & & \\
\hline failure & 1132.7 & 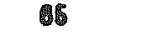 & 270 & 277 & 0.0 & $4.88 \times 10^{6}$ & 172 & $0.01 \times 10^{5}$ & 297 & 469/0/121 \\
\hline Peactor cavity & & & & & & 7sme & & 9 & & \\
\hline Start concrete & & & & & & & & & & \\
\hline attack & 4647.1 & 16 & 224 & 220 & 0.0 & $2.94 \times 10^{6}$ & 213 & 0.0 & $-\infty \infty$ & $0 / 0 / 0$ \\
\hline End calculation & 5247.1 & 16 & 261 & 245 & 0.0 & $2.80 \times 106$ & 196 & 0.0 & $\cdots$ & Dpo/e \\
\hline
\end{tabular}


Table 4.3.8. Containment leak rates - Sequoyah $S_{3} H F$.

\begin{tabular}{|c|c|c|c|c|c|c|c|c|c|c|c|c|}
\hline \multirow{2}{*}{\multicolumn{2}{|c|}{$\begin{array}{c}\text { Time } \\
\text { Interval. } \\
\text { ninutes }\end{array}$}} & \multicolumn{5}{|c|}{ Lower Compartment Leahage } & \multicolumn{5}{|c|}{ Upper Compartment Leakage } & \multirow[b]{2}{*}{ REAMTS } \\
\hline & & $\begin{array}{l}\text { (2) } \\
\text { v/hr }\end{array}$ & \multicolumn{2}{|c|}{ Pressure } & \multicolumn{2}{|c|}{$\frac{\text { Terporatura }}{\text { of of }}$} & $\begin{array}{l}\text { Reto } \\
\text { ofhr }\end{array}$ & \multicolumn{2}{|c|}{ Pressure } & \multicolumn{2}{|c|}{ Teaperature } & \\
\hline 0.0 & 1.0 & 0.0 & 0.10 & 15 & 36 & 97 & 0.010 .0 & 0.10 & 15 & 39 & 102 & Initial core hetup \\
\hline 1.6 & -11.3 & 1.7 & 0.11 & 16 & 62 & 144 & $0.3 / 0.0$ & 0.11 & 16 & 45 & 113 & ECCS on/fans on \\
\hline 11.8 & -42.5 & 14.0 & 0.12 & 10 & 64 & 147 & $5.3 / 0.0$ & 0.12 & 18 & 39 & 102 & Sprays on \\
\hline 42.6 & -273.7 & 13.2 & 0.12 & 18 & 32 & 164 & $5.3 / 10.0$ & 0.12 & 18 & $\$ 10$ & 105 & ECS and sprays of \\
\hline 273.7 & $=370.2$ & 13.6 & 0.12 & 18 & 59 & 137 & $.3 / 0.0$ & 0.12 & 10 & 40 & 105 & $\begin{array}{l}\text { Coro uncovery / accumu lators } \\
\text {-upty }\end{array}$ \\
\hline 378.2 & -402.43 & 13. & B.12 & 16 & 87 & 163 & $5.3 / 0.1$ & 0.12 & 18 & 11 & 100 & Coro walls \\
\hline 402.43 & -402.46 & cos. & 0.13 & 19 & 281 & 501 & $8.3 / 0.0$ & 0.13 & 19 & 49 & 121 & Mydrogen burn (c) \\
\hline 402.46 & -405.2 & 11. & 0.13 & 19 & 116 & 242 & $5.3 / 0.0$ & 0.13 & 19 & 44 & 112 & Core its \\
\hline 405.2 & -405.44 & 15. & 0.12 & 10 & 28 & 107 & $5.3 / 0.0$ & 0.12 & 18 & 43 & 109 & Core slums \\
\hline 405.4 & -405.40 & 724.7 & 0.13 & 18 & 265 & 800 & 5.30. & 1.13 & 19 & 48 & 119 & Hydrogen burns (c) \\
\hline 405.40 & -400.7 & 7. & 0.13 & 19 & 161 & 321 & $5.3 / 0.0$ & 0.13 & 10 & 45 & 113 & Coro s lumps and collapses \\
\hline 406.7 & -409.26 & 14.6 & 0.12 & 10 & 90 & 194 & $8.3 / 0$. & .12 & 18 & 12 & 100 & Vess il head heatup \\
\hline 400.20 & -409.33 & 292. & 0.17 & 24 & 331 & 27 & $0.3 / 0$. & 1.17 & 24 & 193 & 289 & Hydrogen burn (d) \\
\hline 409.33 & -422.73 & 12. & 0.14 & 20 & 103 & 218 & $8 / 10.0$ & 8.14 & 20 & 103 & 210 & Vesso i head heats \\
\hline 422.73 & $-\$ 22.70$ & 277.0 & 0.18 & 26 & 329 & 025 & $5.3 / 0.0$ & 1.10 & 26 & 167 & 333 & Hydrogen burna (d) \\
\hline 422.76 & -427.14 & 11.7 & 0.10 & 23 & 130 & 285 & $5.3 / 0.0$ & 0.16 & 23 & 179 & 358 & Vesso i hoad heats \\
\hline & 427.11 & $-\infty$ & 0.14 & 20 & 94 & 201 & $-\infty$ & 0.14 & 20 & 112 & 234 & Vess il hoad ficilure \\
\hline 427.14 & -427.23 & 182.0 & 0.18 & 20 & 82 & 100 & 5.310 .1 & 1.11 & 20 & 110 & 231 & Dryout of ractor cavity \\
\hline 427.23 & -427.26 & 764.2 & 1. 18 & 23 & 290 & 655 & 5.310. & 1.16 & 23 & 114 & 237 & Hydrogen burns (c) \\
\hline 427.28 & -427.03 & 118.0 & 0.10 & 26 & 156 & 302 & b.3/10. & 0.10 & 26 & 110 & 242 & Dryout of ractor cavity \\
\hline 427.33 & -427.67 & 0.0 & 0.24 & 36 & 110 & 244 & $5.3 / 0.0$ & 1.24 & 36 & 334 & 63 & Hydrogen burns (a) \\
\hline 427.67 & -427.0 & 85. & 0.30 & 44 & 121 & 250 & $5.3 / 0.0$ & 0.30 & 94 & 512 & 953 & Dryout of ractor eaviey \\
\hline 427.8 & -428.68 & 16.1 & 0.26 & 38 & 114 & 237 & $5.3 / 0.1$ & 20 & 30 & 393 & 739 & Dryout of reactor cavity \\
\hline$\$ 28.68$ & -420.72 & 921.4 & 10.29 & 42 & 580 & 1001 & $5.3 / 0.11$ & 1.29 & 42 & 437 & 018 & Mydrogen burn (d) \\
\hline 428.72 & -433.0 & 12. & 0.18 & 20 & 148 & 290 & $5.3 / 6$. & 1.10 & 28 & 251 & 493 & Dryout of resctor cavity \\
\hline 433.8 & -480.0 & 14.3 & 0.13 & 19 & 28 & 107 & $5.3 / 0.0$ & 0.13 & 18 & 28 & 191 & Dryout of pactor cavity \\
\hline 488.0 & -036.4 & 14.2 & 0.12 & 18 & 75 & 168 & 6.310.12 & 0.12 & 10 & 88 & 154 & oryout of peactor cavity \\
\hline 636.4 & -936.4 & 11.0 & 0.21 & 30 & 9 & 207 & $5.3 / 0.0$ & 0.21 & 32 & 93 & 198 & Ice melt completo \\
\hline 930.4 & -1132.7 & 11. & 0.37 & 54 & 120 & 263 & $5.3 / 0.10$ & .37 & 54 & 127 & 201 & Dryout of reactor cavity \\
\hline & 1132.7 & $\ldots$ & 0.45 & 65 & 137 & 270 & $\infty$ & 0.45 & 65 & 136 & 277 & Upper compartment iailur \\
\hline 1132.7 & -1142.7 & 10.3 & 0.24 & 36 & 123 & 254 & $0.0 / 14.0$ & 0.24 & 36 & 122 & 261 & Dryout of pactor cavity \\
\hline 1142.7 & -1192.0 & 4.7 & 0.10 & 15 & 116 & 242 & $0.0 / 2.6$ & 0.10 & 15 & 122 & 251 & Dryout of reactor cavity \\
\hline 1192.8 & -3532. & 3.0 & 0.10 & 15 & 103 & 218 & 0.011 .5 & 0.10 & 15 & 110 & 231 & Dryout of reactor cavily \\
\hline 3592.8 & -9647.1 & 2.7 & 0.10 & 15 & 103 & 218 & $0.0 / 1.1$ & 0.10 & 15 & 110 & 231 & Dryout of reactor cavity \\
\hline 9647.1 & -8707.1 & 6.1 & 0.11 & 16 & 110 & 242 & $10 / 2$. & 0.11 & 16 & 124 & 255 & Concrote decomposicion \\
\hline 4707.1 & -4947.1 & 2. & 0.10 & 15 & 125 & 250 & $0.0 / 0.9$ & 0.10 & 15 & 122 & 251 & Concrate decomposition \\
\hline 4947.1 & -247.1 & 1.3 & 0.10 & 15 & 120 & 262 & $0.0 / 0.0$ & 0.10 & 15 & 119 & 246 & Concret decomposicion \\
\hline
\end{tabular}

(a) Mormalized to compartaent-free voluse of 3.077n105 pts. Units are volume fractions per hour. Loahso is: lower-to-upper

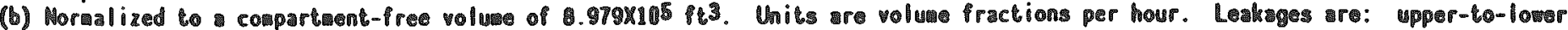
compartment and upper compartment to environaent.

thydrogen burn occurs in the lomer compartwent.

(d) The hydrogen burn occurs in the lower and upper compartaents.

(e) The hydrogen burn occurs in the upper compartigent. 


\section{SEQUOYAH S3HF}

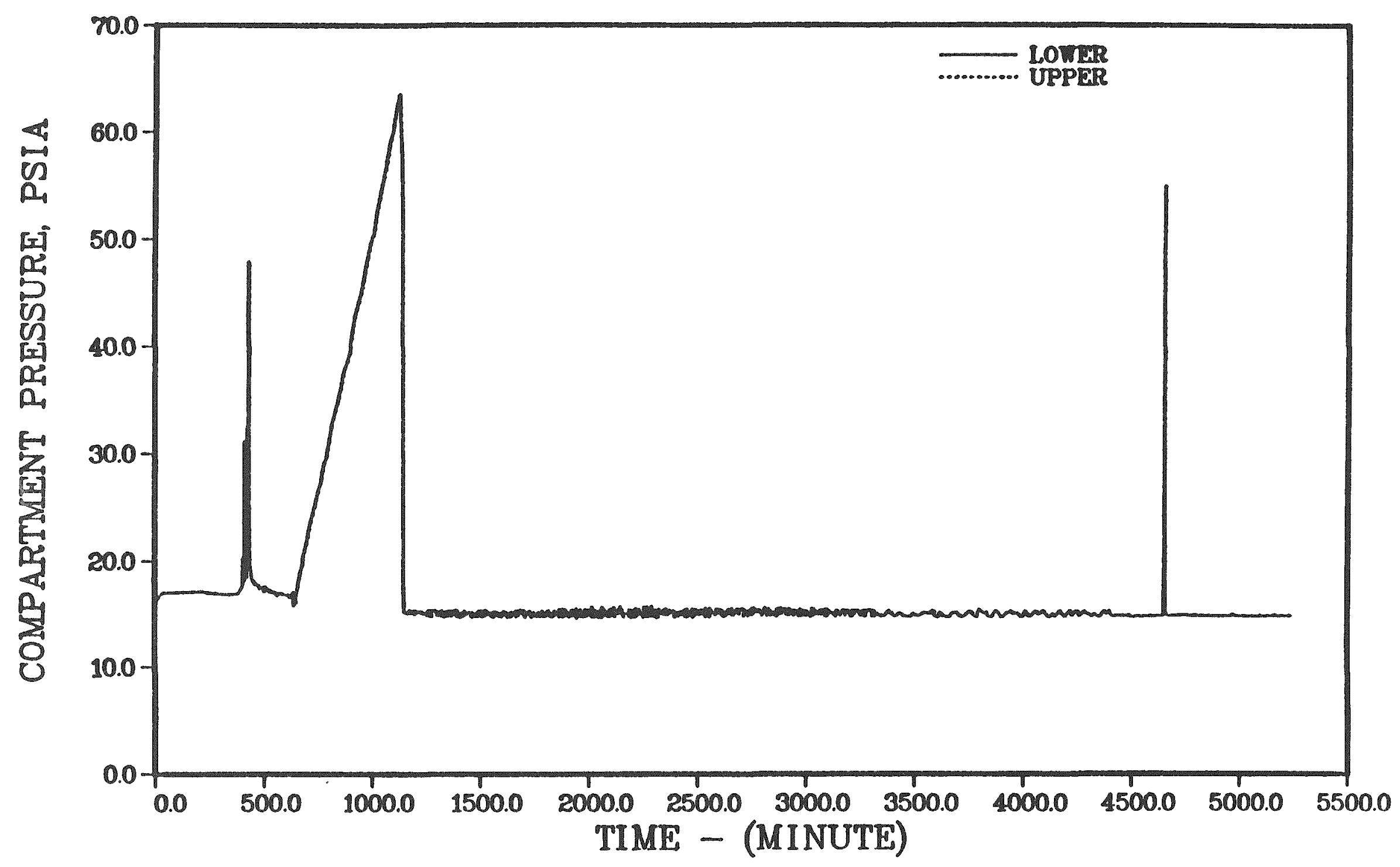

Figure 4.3.22. Containment pressure response - Sequoyah S3HF. 


\section{SEQUOYAH S3HF}

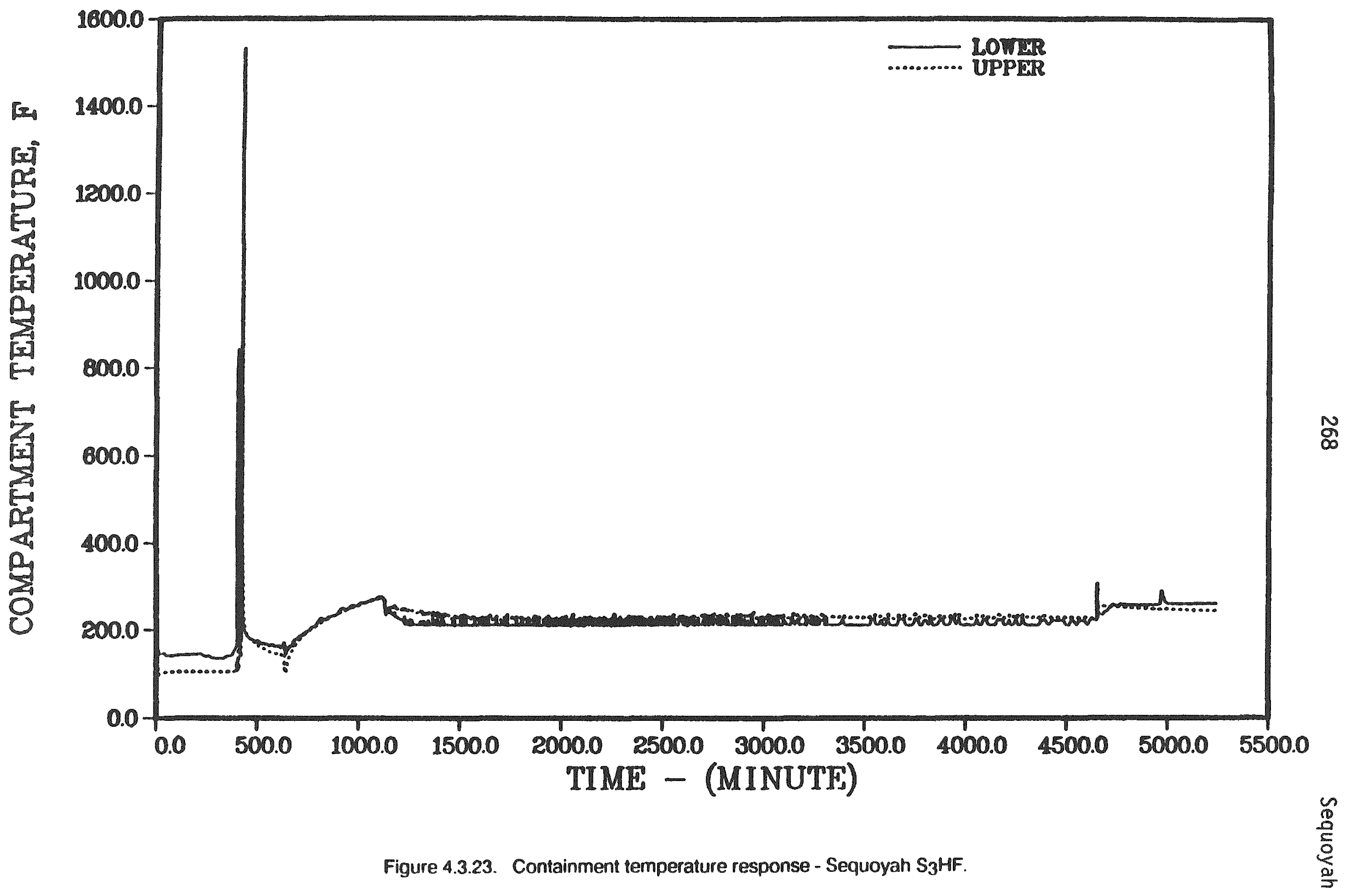




\section{SEQUOYAH S3HF}

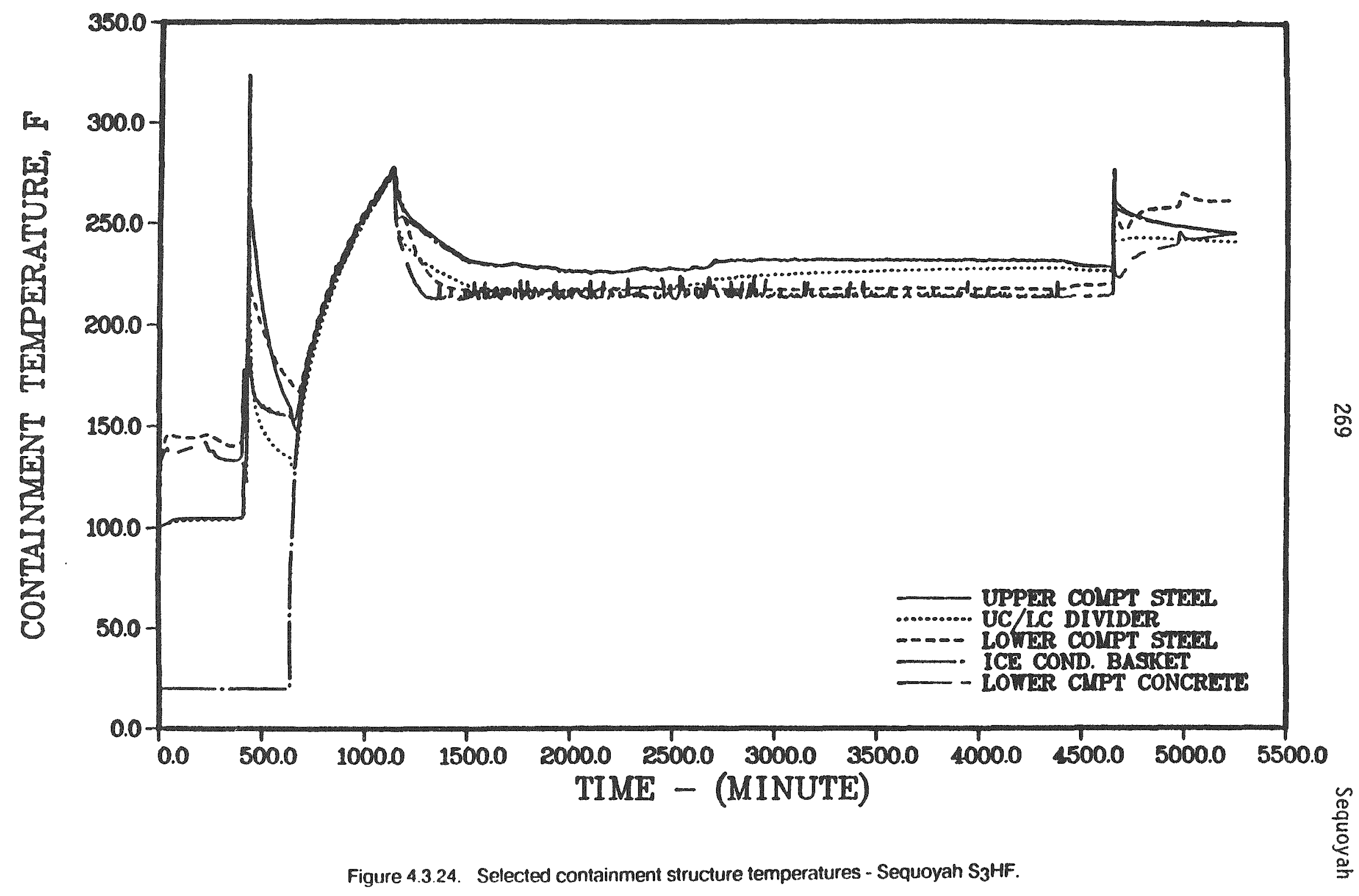




\section{SEQUOYAH S3HF}

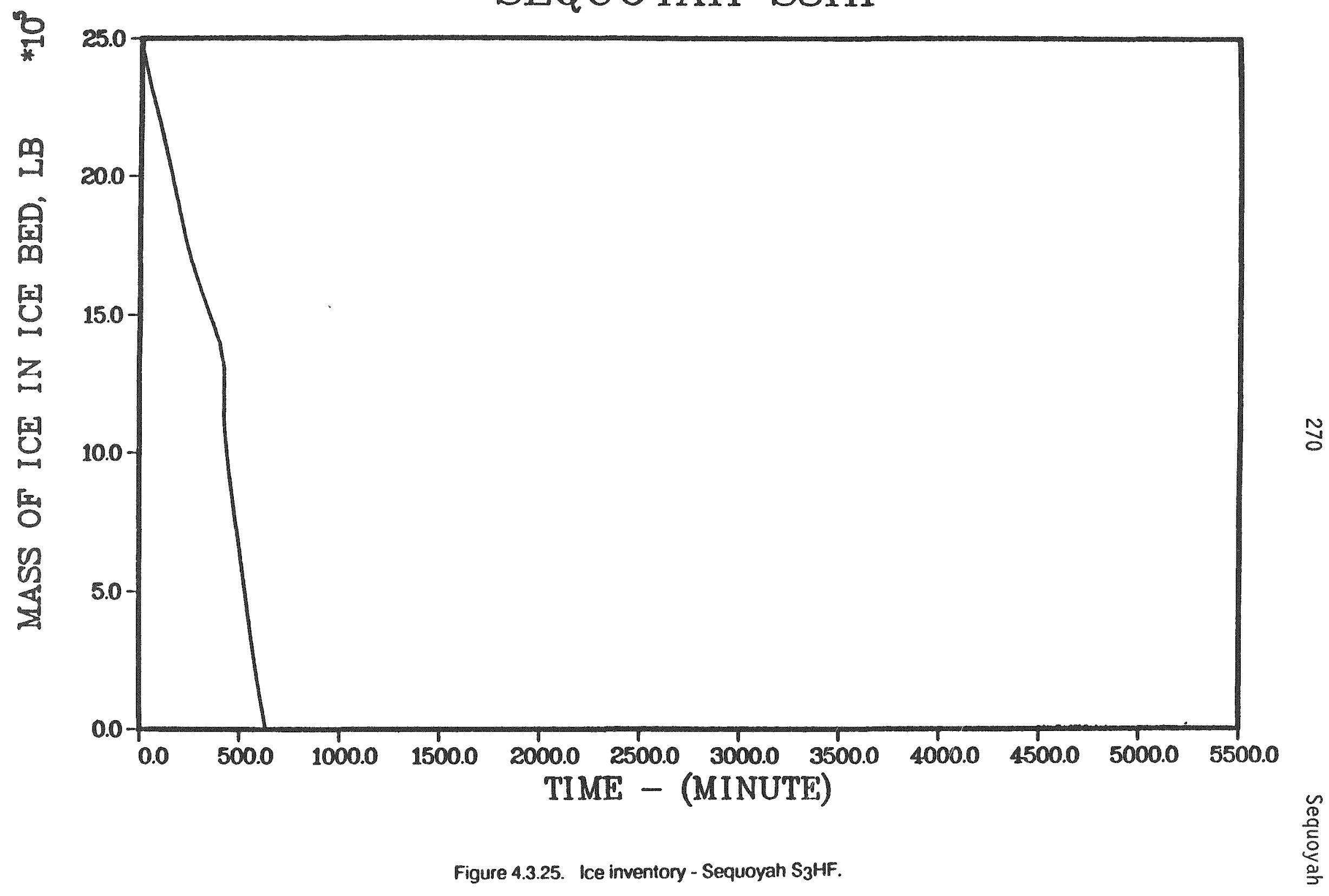




\section{SEQUOYAH S3HF}

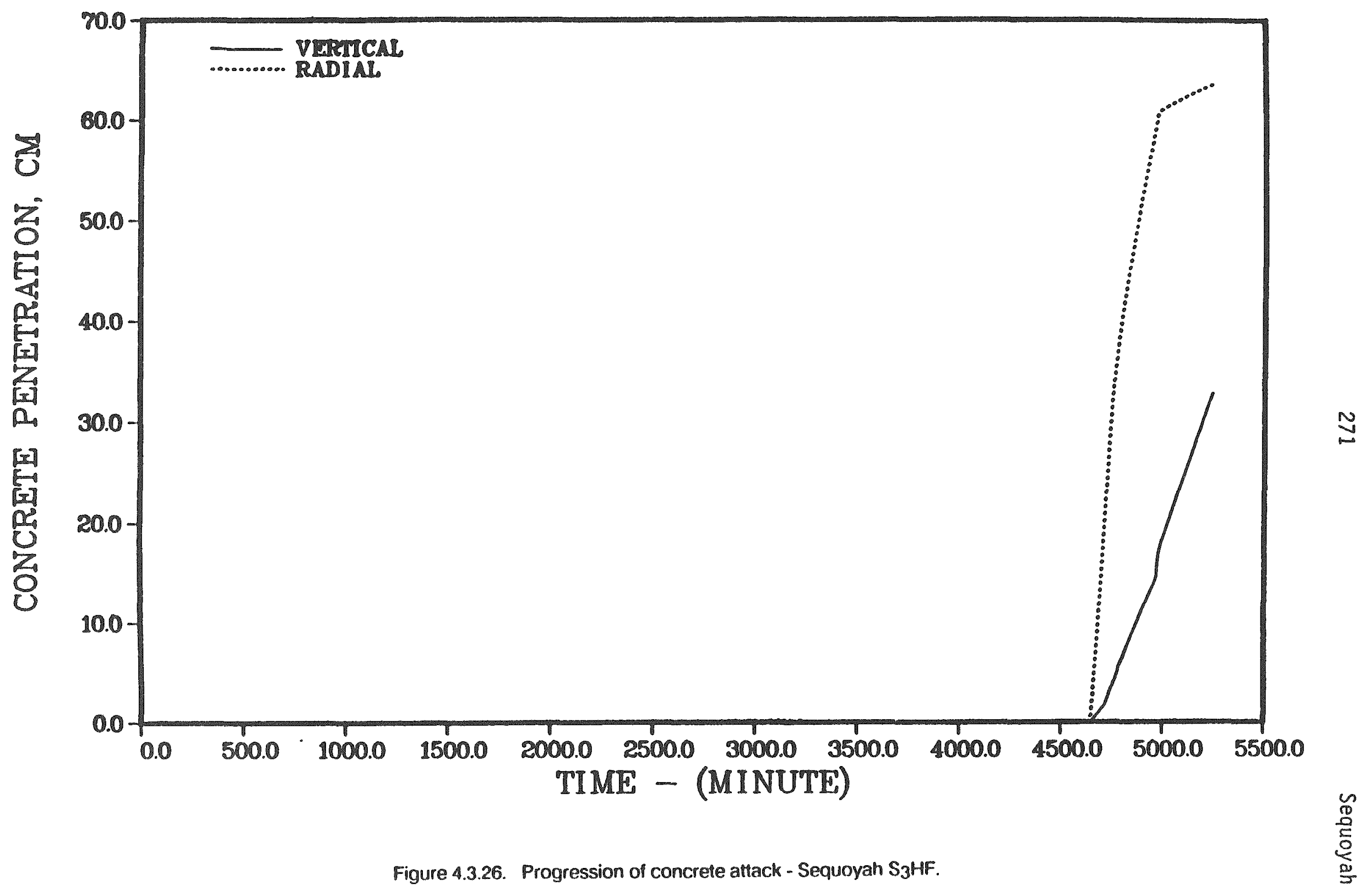




\section{SEQUOYAH S3HF}

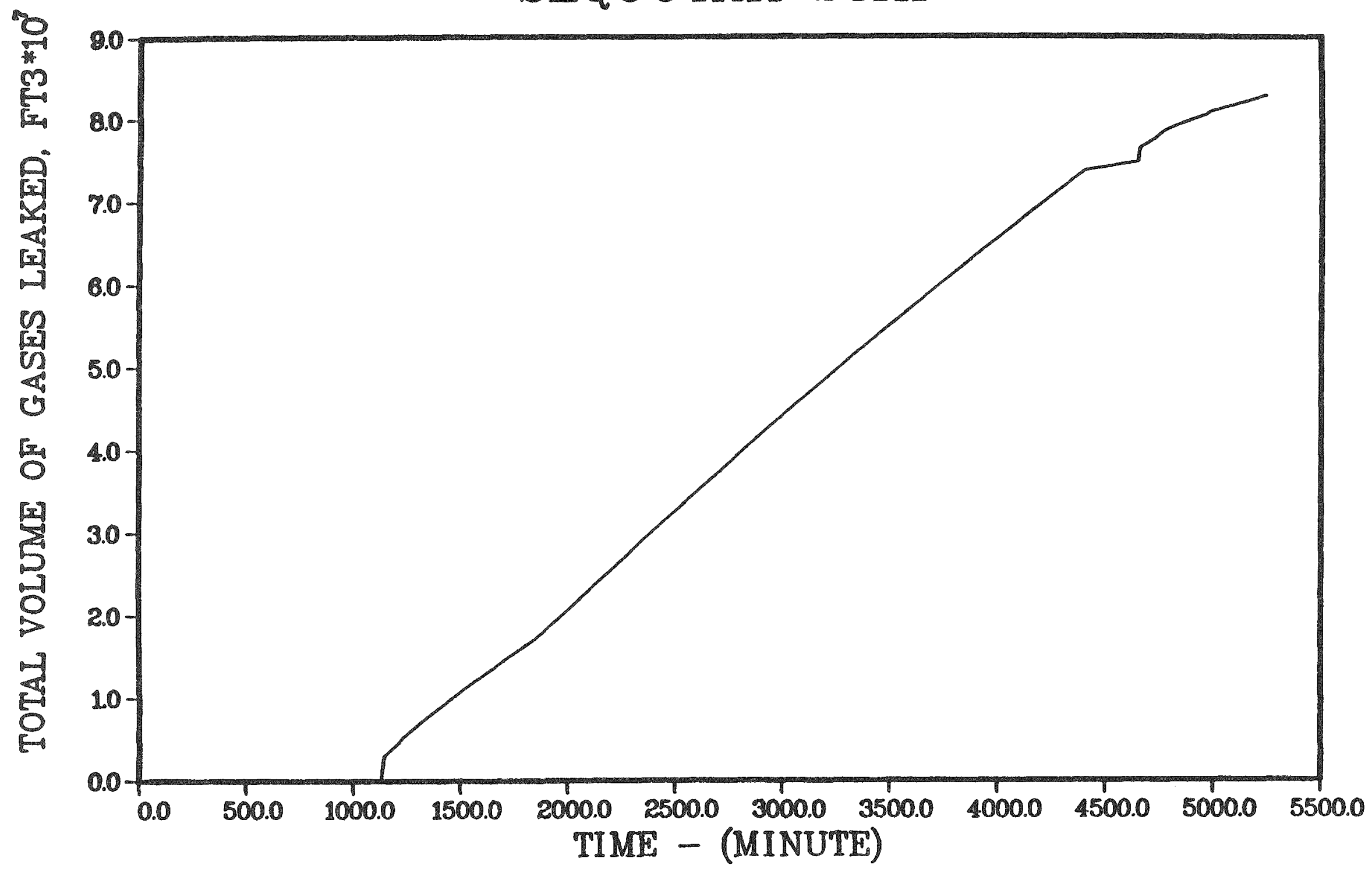

Figure 4.3.27. Total volume of gases leaked from containment - Sequoyah $\mathrm{S}_{3} \mathrm{HF}$. 


\section{PRIMARY SYSTEM RESPONSE - SEquOyah $\mathrm{S}_{3} \mathrm{H}$}

The primary system behavior in the $\mathrm{S} 3 \mathrm{H}$ sequence is identical to that of the S3HF scenario and its discussion will not be repeated here. The predicted timing of accident events for this sequence is given in Table 4.3.5. The core and primary system conditions at key times during the accident progression are summarized in Table 4.3.6.

\section{CONTAINMENT RESPONSE - Sequoyah S3H}

It should be recalled that a primary objective of the analysis for this accident scenario is to determine the likelihood and timing of containment overpressure failure. Figures 4.3 .28 and 4.3 .29 present the predicted containment pressure and temperature responses, respectively. The combination of the ice condenser and the containment sprays maintain the containment pressure at relatively low levels. A number of hydrogen burns, initiated by the igniters, are predicted during the course of this sequence, but the associated peak pressures are substantially below the assumed failure level of 65 psia. The containment atmosphere temperatures reach relatively high levels during these burns, but do not persist.

The calculated progression of concrete erosion during corium concrete interaction is illustrated in Figure 4.3.30. Initially, concrete erosion is seen to proceed both radially and axially, but becomes a predominantly downward attack after the debris layers invert. At the end of the calculation (after 15 hours of concrete attack), essentially all the metals in the debris have been predicted to be consumed. The containment pressure at that time has increased to about the design level, and containment failure by overpressurization does not appear to be imminent.

The extent of ice depletion during this sequence is shown in Figure 4.3.31. The masses of water in the containment sump and the reactor cavity are illustrated in Figure 4.3 .32 ; the corresponding temperatures are shown in Figure 4.3.33. The mass of water in the reactor cavity is essentially constant during most of this sequence since the cavity remains full. The sump water inventory continues to increase due to the melting of the ice and levels 


\section{SEQUOYAH S3H}

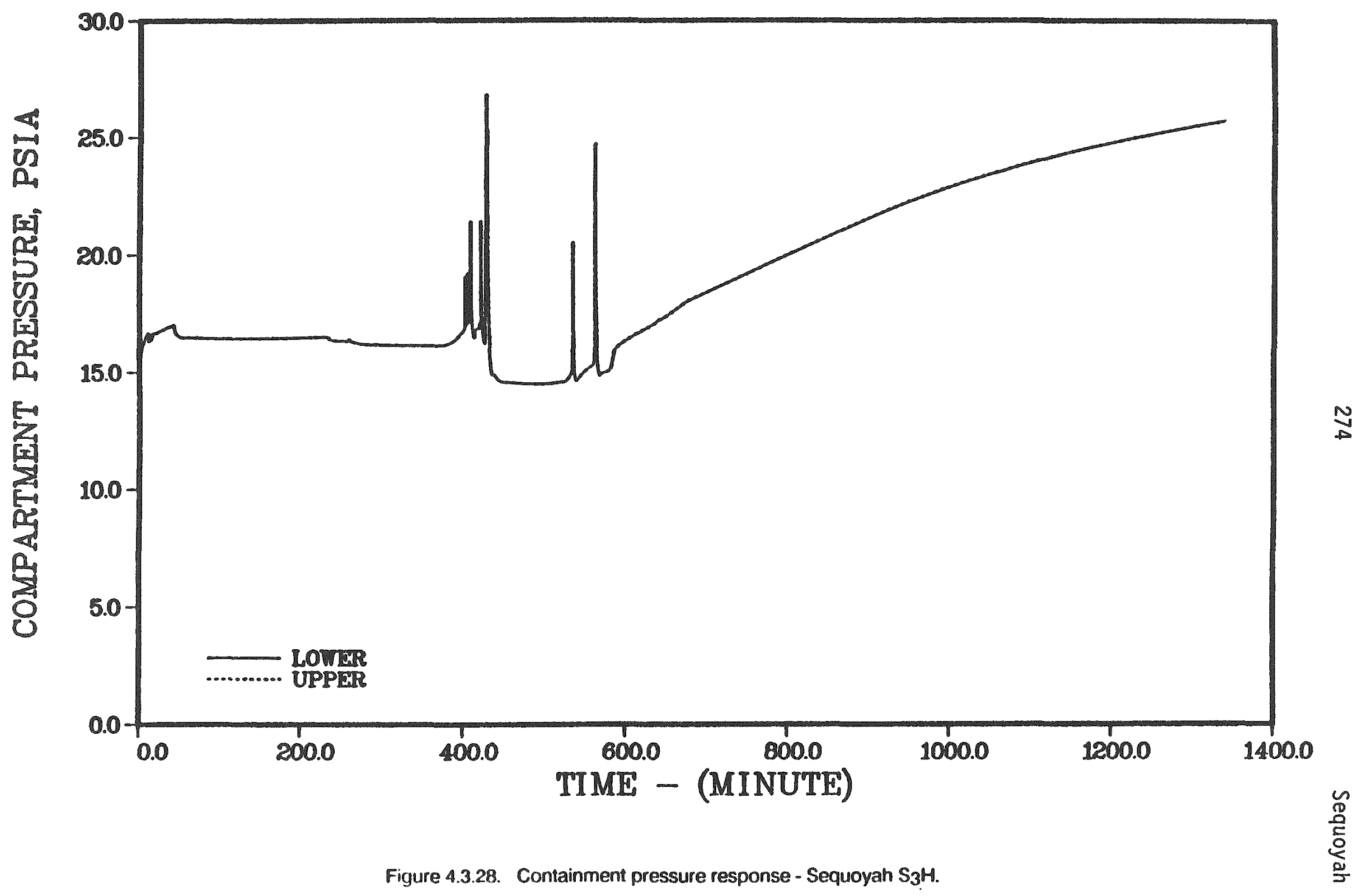




\section{SEQUOYAH S3H}

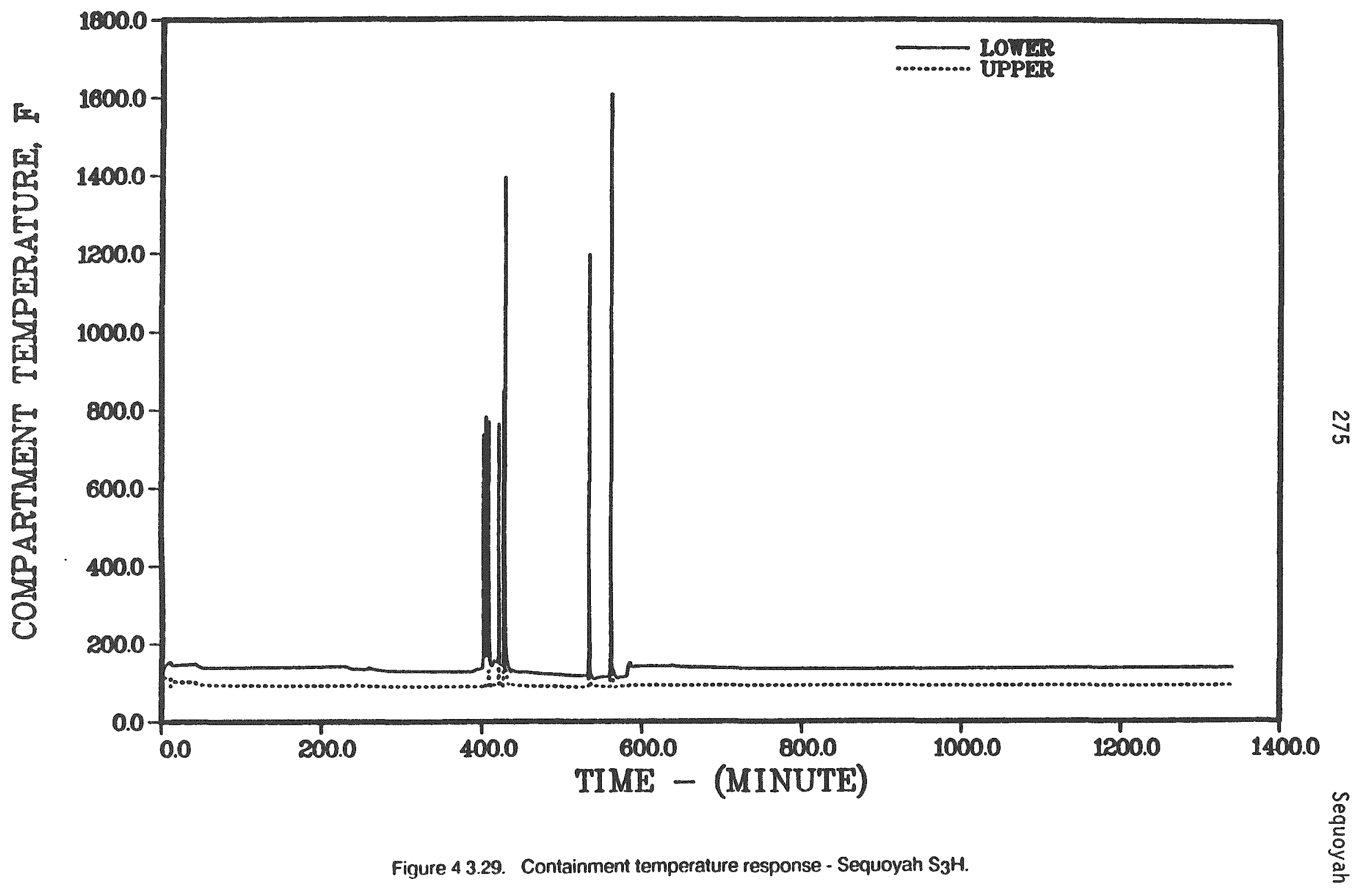




\section{SEQUOYAH S3H}

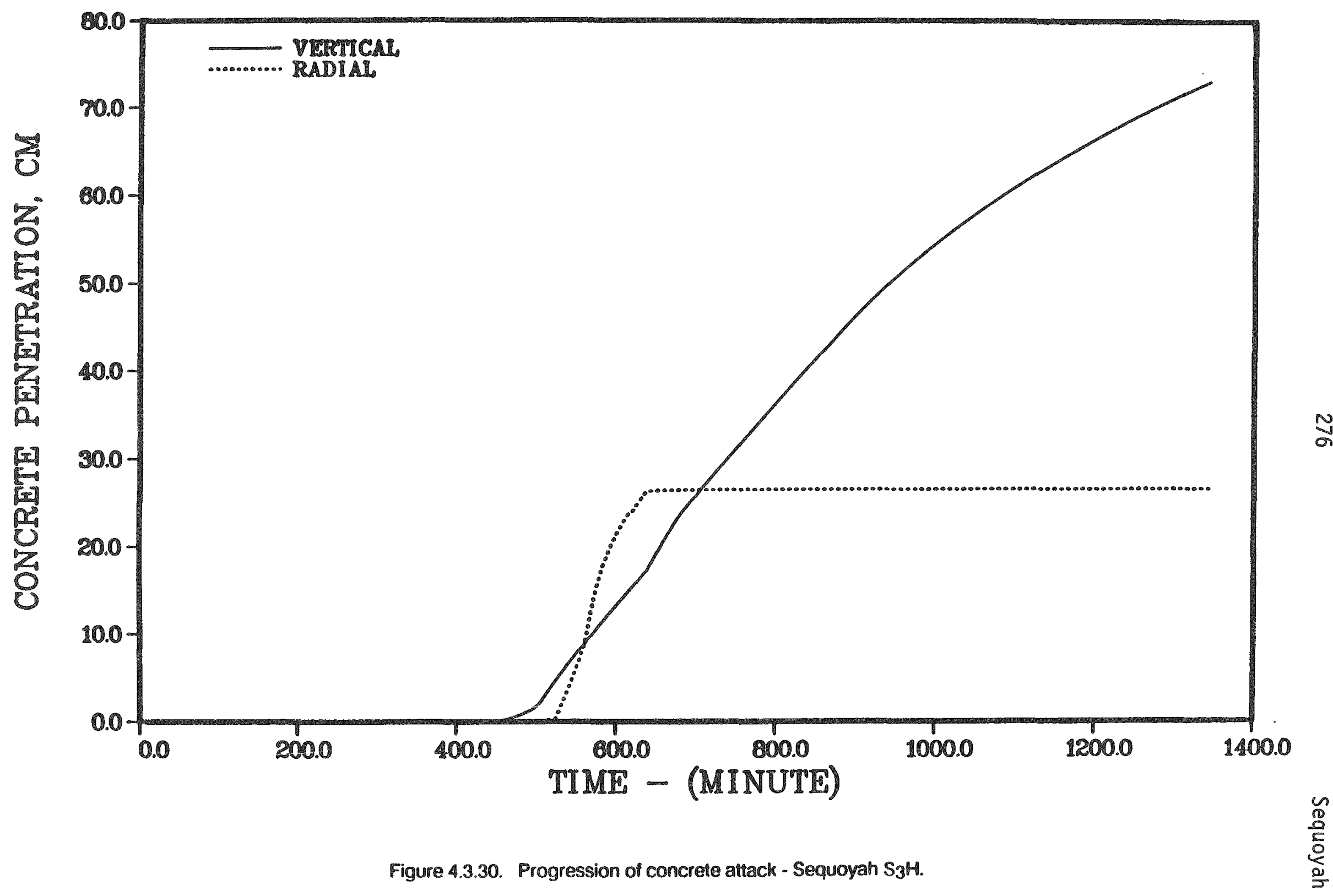




\section{SEQUOYAH S3H}

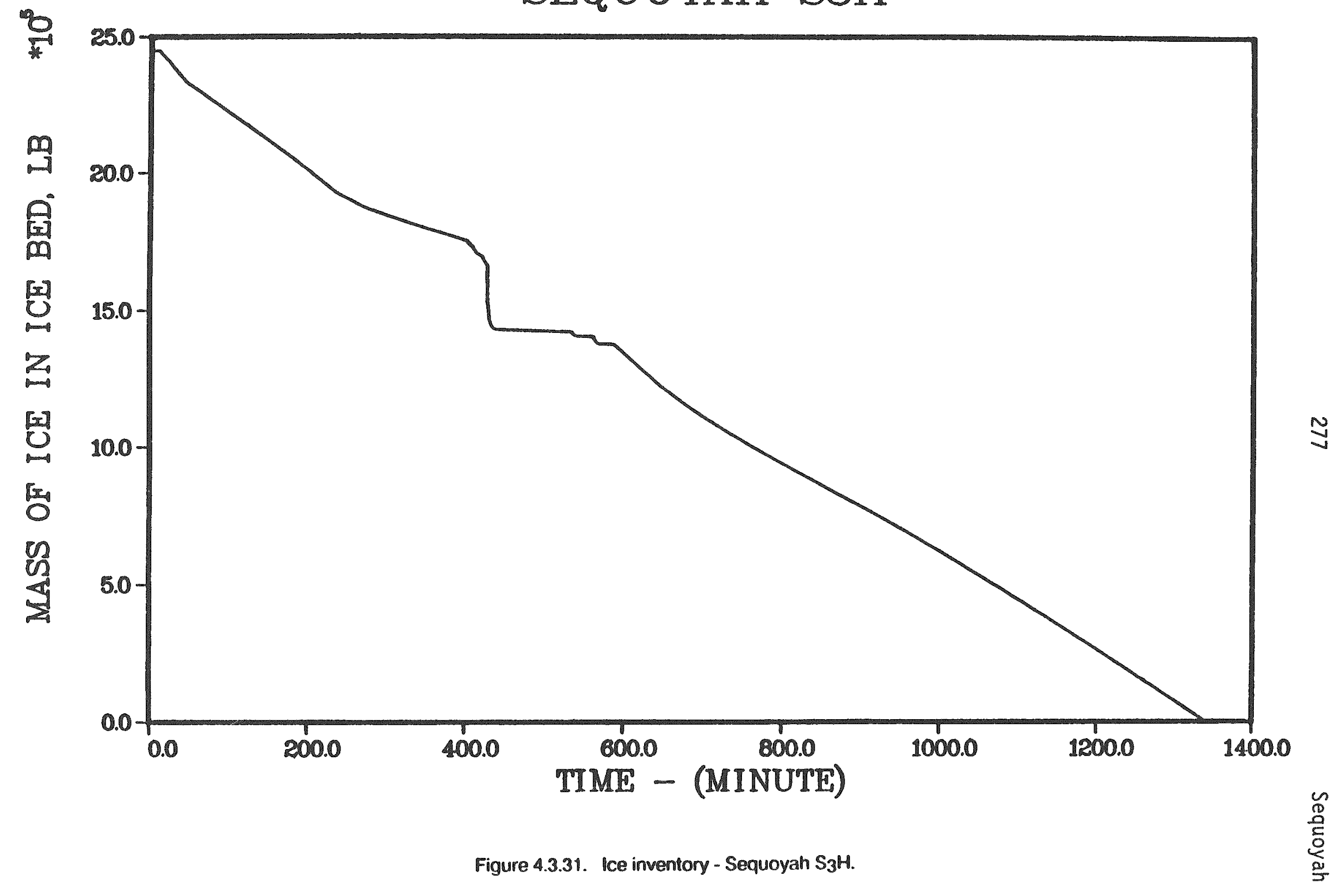




\section{SEQUOYAH S3H}

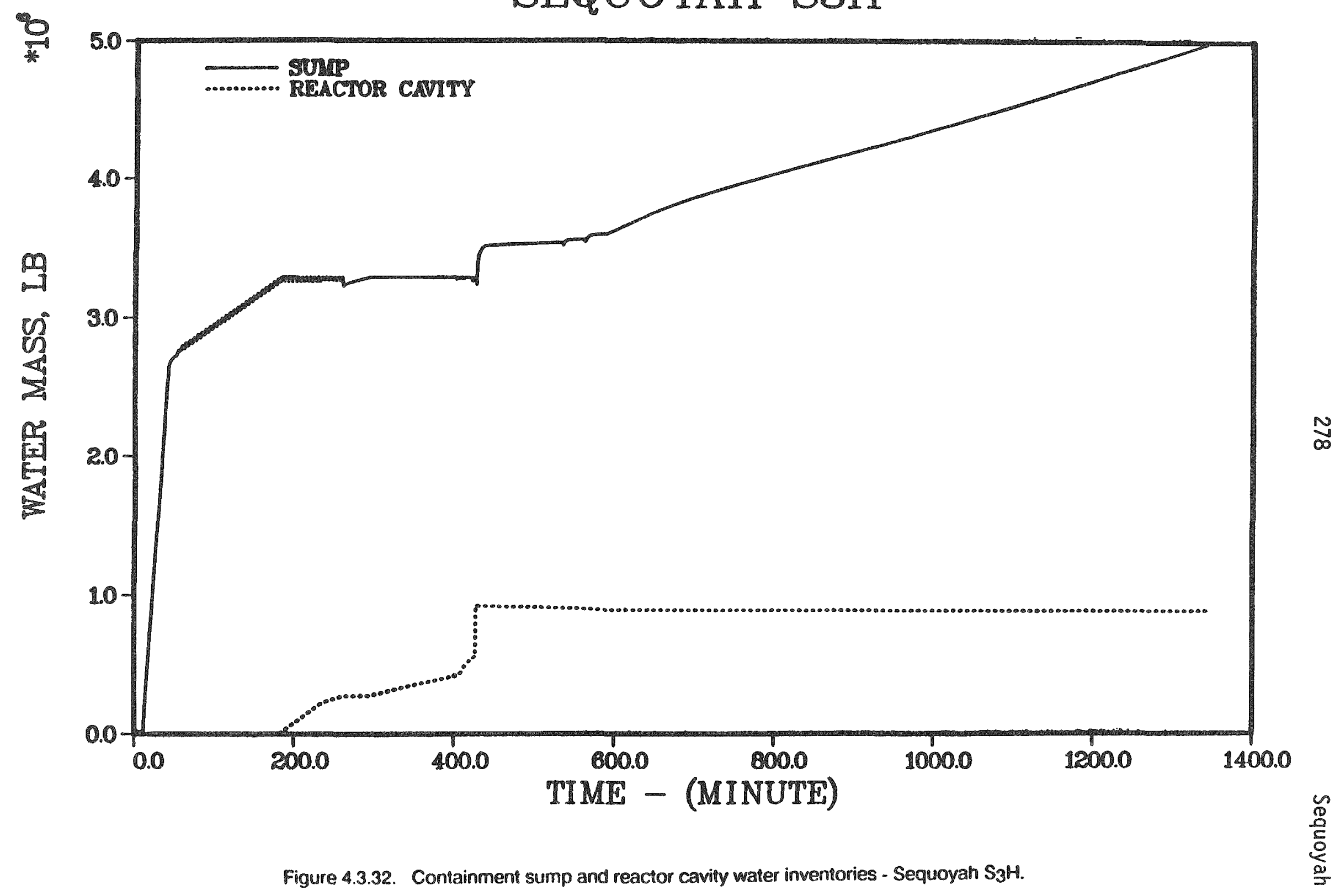




\section{SEQUOYAH S3H}

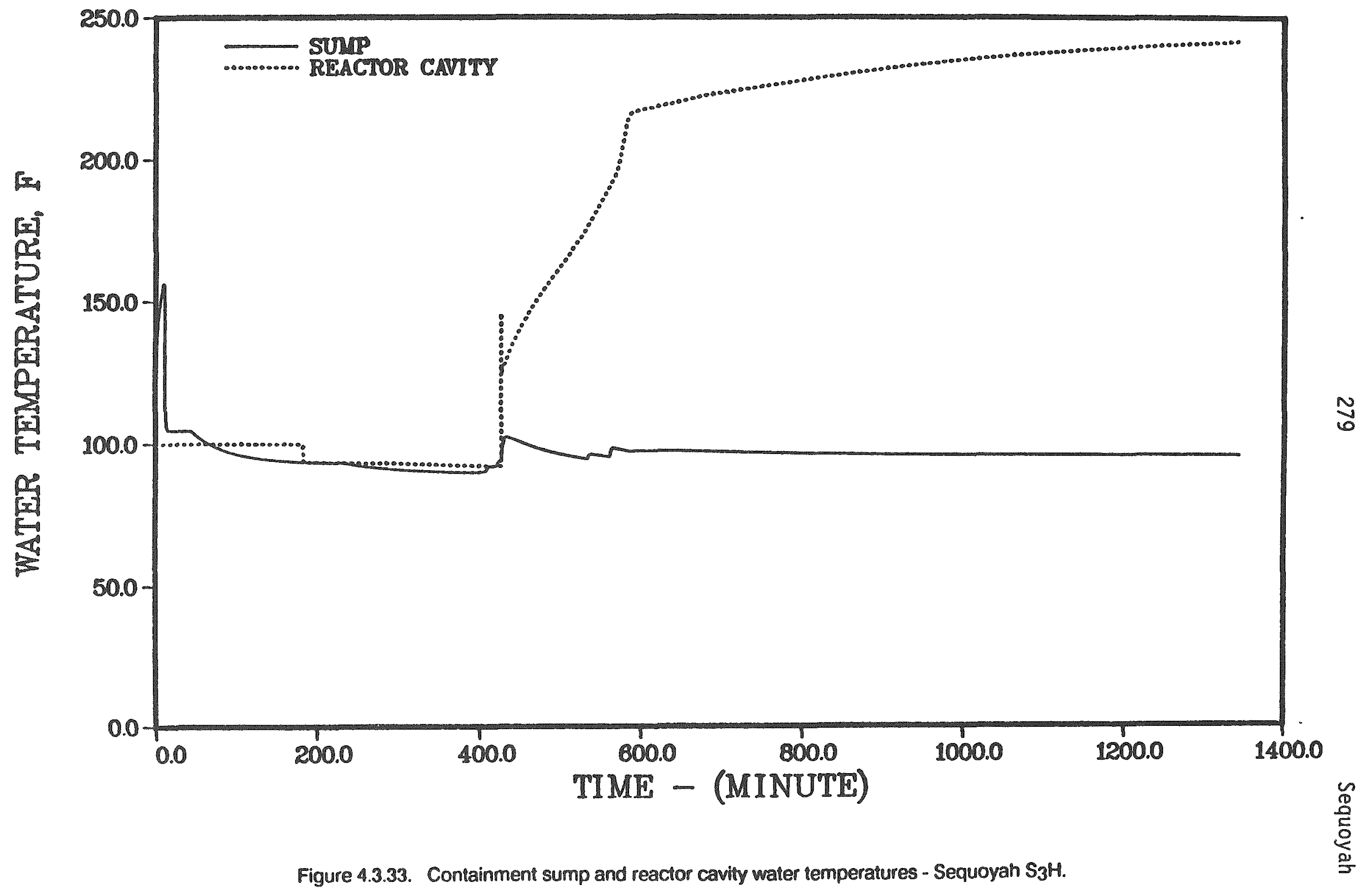


off at the end of the calculation when all the ice is gone. The reactor cavity water is heated to saturation by the core debris, but the sump water is maintained at about $100 \mathrm{~F}$ by the containment spray heat exchanger.

It is concluded, from the results of this calculation, that for the specified $\mathrm{S}_{3} \mathrm{H}$ accident scenario, containment failure is not indicated. Calculations of primary coolant system and containment fission product transport were, therefore, not performed and no description of such analyses is provided in the following discussion.

\section{PRIMARY SYSTEM RESPONSE - SEQUOYAH $S_{3} B$ \\ (with secondary despressurization)}

The predicted progression of accident events is summarized in Table 4.3.9. Core and primary system conditions at key times during the accident are summarized in Table 4.3.10. The operation of the auxiliary feedwater system together with depressurization of the steam generators result in most of the decay heat being accommodated by the steam generators, with relatively little mass and energy release to the containment. The primary system pressure is lowered below the accumulator setpoint with complete discharge of the accumulators into the primary system at about 145 minutes into the accident. The primary system pressure history is given in Figure 4.3.34. After the auxiliary feedwater system is lost, the steam generators dry out (about 478 minutes) and the primary system repressurizes. The latter is due to the fact that the small leak rate associated with the pump seal failure cannot relieve all the steam generated. Primary system leakage is shown in Figure 4.3.35. Thus, core overheating and melting take place with the primary system at an elevated pressure. A further pressure increase is associated with the collapse of the core into the vessel head. Maximum and average core temperatures are illustrated in Figure 4.3.36, fractions of cladding reacted and core melted in Figure 4.3.37, and temperatures of the gases leaving the top of the core and exiting the primary system in Figure 4.3.38. The initial availability of auxiliary feedwater and steam generator depressurization lead to a significant delay in the time of core overheating. 
Table 4.3.9. Timing of key events - Sequoyah $S_{3} B$

\begin{tabular}{lr}
\hline \multicolumn{1}{c}{ Event } & $\begin{array}{c}\text { Time, } \\
\text { minutes }\end{array}$ \\
& \\
RCP seal LoCA initiated & 60.0 \\
Start steam generator depressurization & 70.0 \\
End steam generator depressurization & 100.0 \\
Accumulators discharge & $121-143$ \\
AFW off & 300.0 \\
Steam generator dryout & 478.1 \\
Core uncovery & 506.6 \\
Start melt & 561.6 \\
Core slump & 587.1 \\
Core collapse & 588.8 \\
Bottom head dryout & 596.0 \\
Bottom head failure & 617.1 \\
Start concrete attack & 617.5 \\
Corium layers invert & 813.8 \\
End calculation & 1217.5 \\
\hline
\end{tabular}

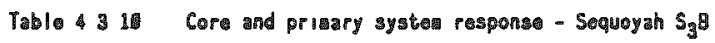

\begin{tabular}{|c|c|c|c|c|c|c|c|}
\hline $\begin{array}{l}\text { Accident } \\
\text { Event }\end{array}$ & $\begin{array}{l}\text { Tirae, } \\
\text { Minubes }\end{array}$ & 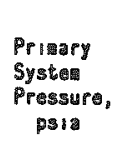 & $\begin{array}{l}\text { Primary } \\
\text { System } \\
\text { water } \\
\text { Inventory, } \\
\text { Ib }\end{array}$ & $\begin{array}{c}\text { Average Coro } \\
\text { Teeperature, } \\
\text { of }\end{array}$ & $\begin{array}{l}\text { Peak Core } \\
\text { Teaperature, } \\
\text { OF }\end{array}$ & $\begin{array}{c}\text { Fraction } \\
\text { Core } \\
\text { Malted }\end{array}$ & $\begin{array}{c}\text { Fraction } \\
\text { Clad } \\
\text { Reacted }\end{array}$ \\
\hline $\begin{array}{l}\text { Ascumulators } \\
\text { apty }\end{array}$ & 1434 & 364 & 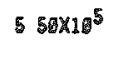 & 428 & 428 & $\infty$ & $\ldots$ \\
\hline Core uncevery & 596 & 673 & $139 \times 16^{5}$ & 502 & 568 & in & 10 \\
\hline Start acle & 561 & 1184 & (251ะ1.4 & 1782 & 4139 & 阐 & 닙 \\
\hline Core slump & 5871 & 384 & $771 \times 10^{4}$ & 3842 & 4151 & 85 & 48 \\
\hline
\end{tabular}




\section{SHQUOYAI SBB}

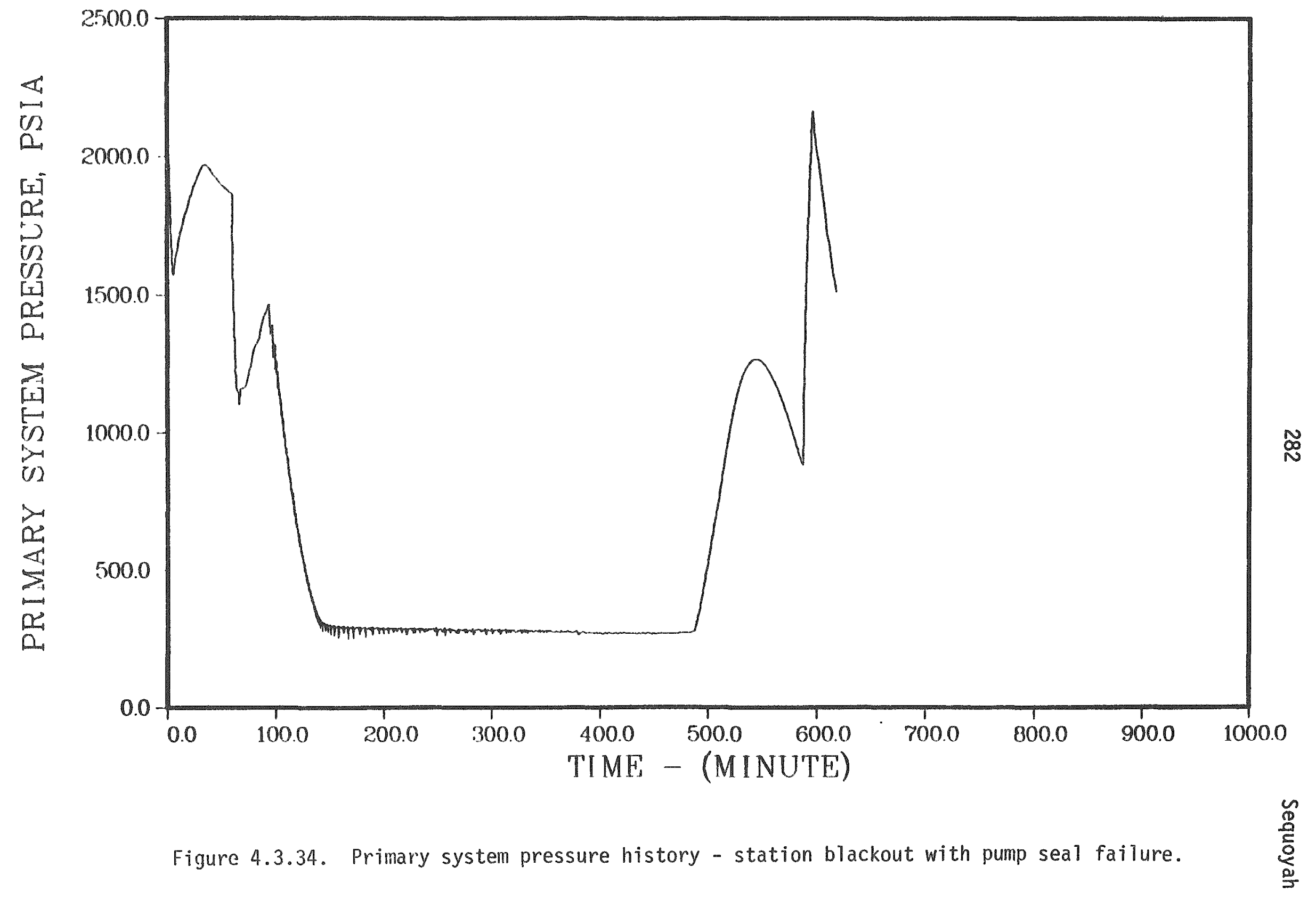


SHQUOYAH SBB

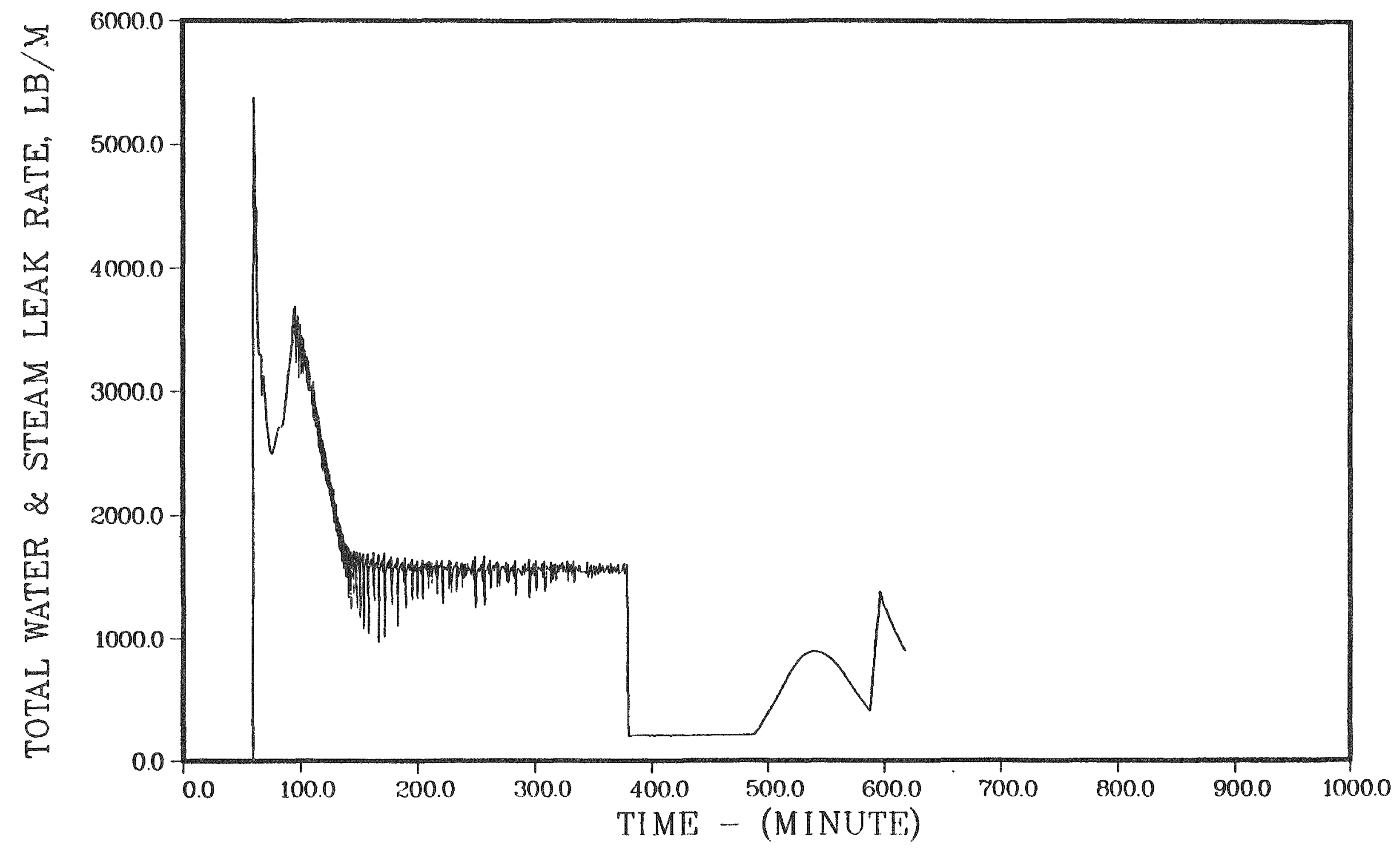

Figure 4.3.35. Primary system leakage - station blackout with pump seal failure. 


\section{SFRUOYAH S3B}

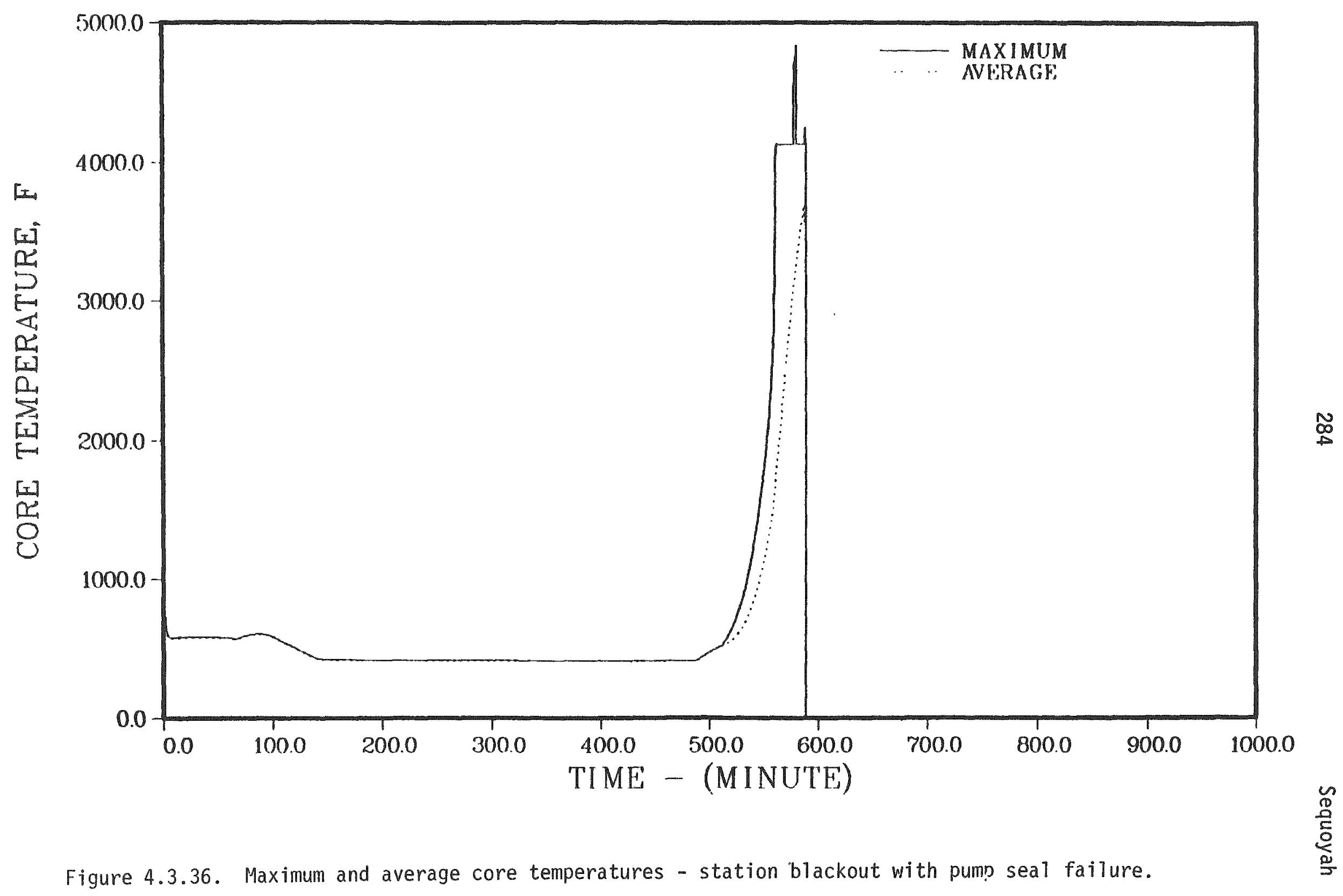




\section{SEQUOYAH SBB}

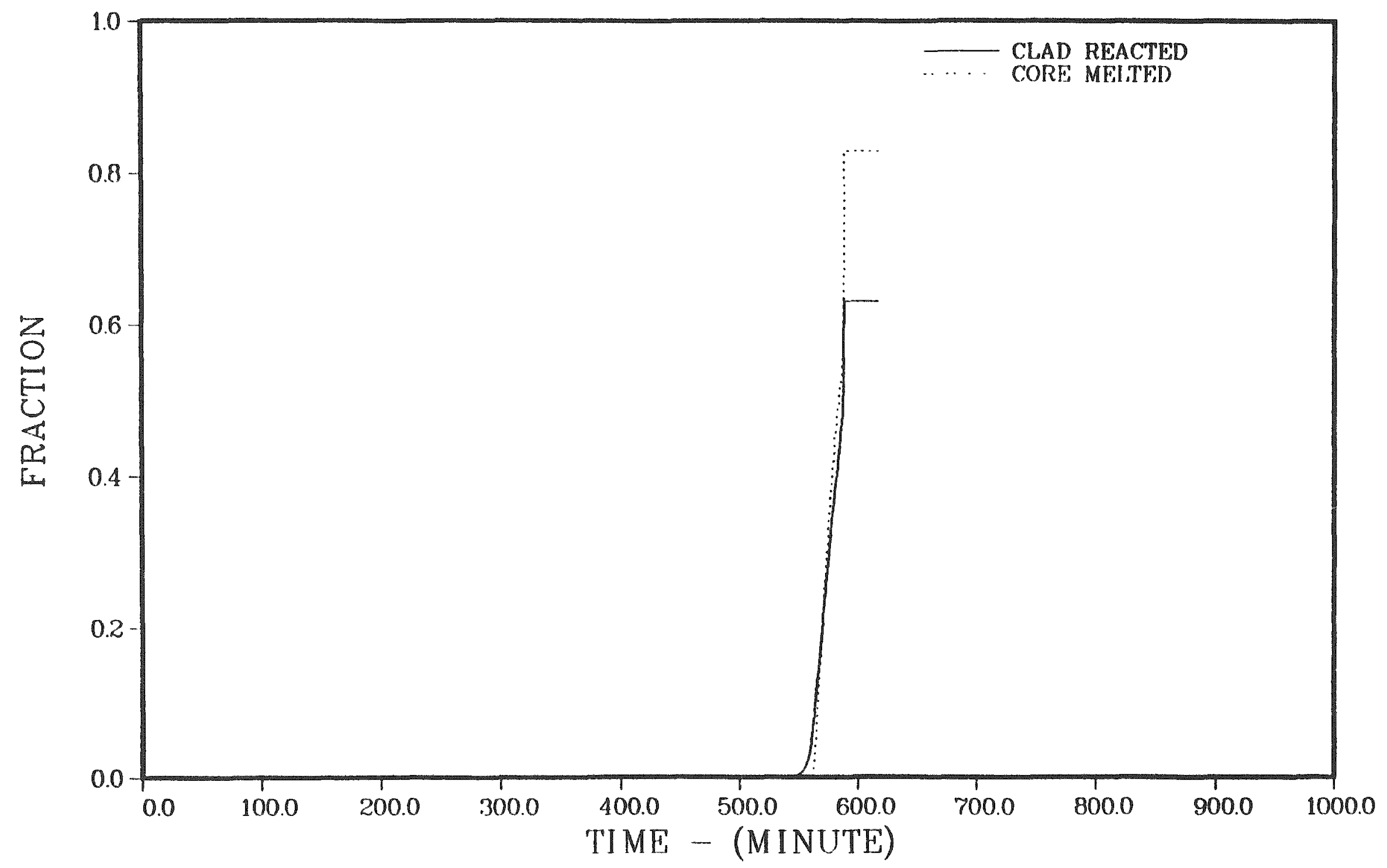

Figure 4.3.37. Fractions of cladding reacted and core melted - station blackout with pump seal failure. 


\section{SUQUOYAH S3B}

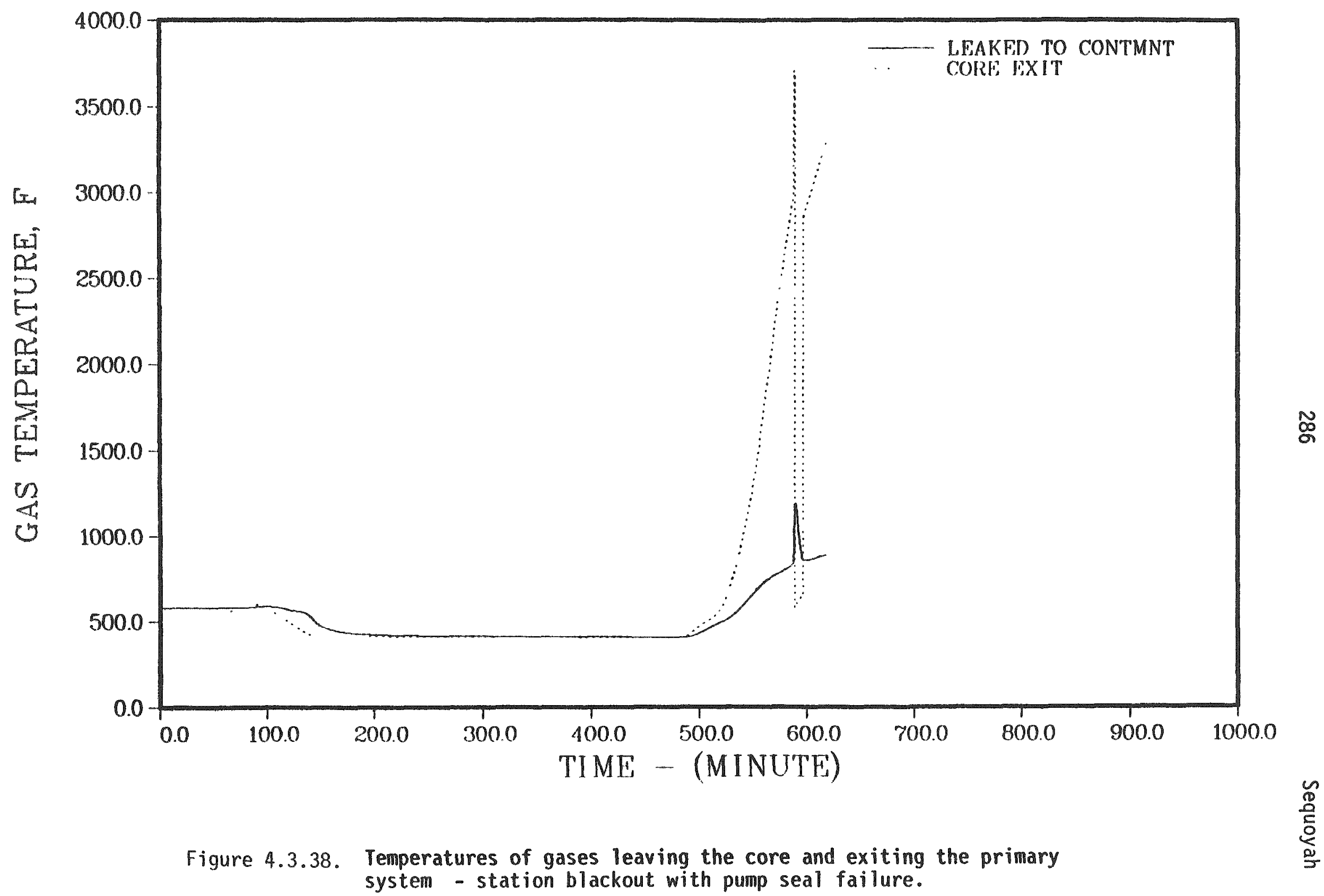


CONTAINMENT RESPONSE - SEQUOYAH $S_{3} B$

(with secondary depressurization)

The conditions in the containment at key times during the accident progression are summarized in Table 4.3.11. Pressure histories for the two compartments of the containment are shown in Figures $4.3 .39 \mathrm{a}$ and $4.3 .39 \mathrm{~b}$; temperature histories are given in Figure 4.3.40. The extent of ice depletion during this sequence is illustrated in Figure 4.3.41. Immediately after reactor vessel failure the lower and upper containment compartments contain 211 and $1034 \mathrm{lbs}$ of hydrogen. The lower compartment's corresponding mole fractions are 0.076 hydrogen, 0.0005 oxygen, and 0.922 steam; those of the upper compartment are 0.137 hydrogen,0.172 oxygen and 0.043 steam. Since the accumulators have discharged prior to reactor vessel breach, the reactor cavity is dry throughout this sequence. At the end of the calculation, after ten hours of concrete attack, the lower and upper compartments contain 441 and 1977 lbs of hydrogen. Corresponding lower compartment mole fractions are 0.079 hydrogen, 0.001 oxygen, and 0.421 steam; corresponding upper compartment mole fractions are 0.156 hydrogen, 0.103 oxygen, and 0.043 steam. Hydrogen buildup in the containment is illustrated in Figure 4.3.42. The mole fractions of the principal components of the containment atmosphere are shown in Figures $4.3 .43 a$ and $4.3 .43 b$.

\section{PRIMARY SYSTEM RESPONSE - SEQUOYAH $S_{3} D$ \\ (with secondary depressurization)}

The calculated timing of the accident events is summarized in Table 4.3.12. Core and primary system conditions at key times during the accident progression are summarized in Table 4.3.13. In this sequence depressurization of the secondary sides of the steam generators was assumed to occur from 30 to 60 minutes after the start of the event. This together with coolant loss through the break led to rapid primary system depressurization, with complete accumulator discharge predicted at about 75 minutes into the accident. The primary system pressure history is given in Figure 4.3 .44 i primary coolant leakage is shown in Figure 4.3.45. Since auxiliary feedwater is available 
Table 4.3.11 Containent Response - Sequoyah $S_{3}{ }^{B}$

\begin{tabular}{|c|c|c|c|c|c|c|c|c|c|}
\hline \multirow[b]{2}{*}{$\begin{array}{l}\text { Accident } \\
\text { Event }\end{array}$} & \multirow[b]{2}{*}{$\begin{array}{l}\text { Tine, } \\
\text { minutes }\end{array}$} & \multicolumn{2}{|c|}{ Containment } & \multirow{2}{*}{$\begin{array}{l}\text { Compartment Wal! } \\
\text { steam Condensation, } \\
\text { Ib/m } \\
\text { Lower/Ice/Upper }\end{array}$} & \multirow{2}{*}{$\begin{array}{l}\text { Ica } \\
\text { Mass, } \\
\text { Ib }\end{array}$} & \multicolumn{2}{|c|}{ Sump Water } & Reactor Cavity & Water \\
\hline & & Psia & $\begin{array}{l}\text { of } \\
\text { Lower70pper }\end{array}$ & & & $\begin{array}{l}\text { Wass, } \\
\text { lb }\end{array}$ & Temp. & Thass, & Temp.: \\
\hline & & & & Soquoy $S_{2}$ & & & & & \\
\hline Accumulators empty & 143.4 & 19.4 & $202 / 105$ & $382 / 0 / 1$ & $2.42 \times 10^{8}$ & $2.44 \times 10^{5}$ & 195 & (1.0 & $-\infty$ \\
\hline AFV off & 300.0 & 19.4 & $292 / 105$ & $279 / 0 / 1$ & $2.41 \times 10^{6}$ & $5.03 \times 10^{5}$ & 202 & 0.0 & $-\infty$ \\
\hline Core uncovery & 506.6 & 19.8 & $214 / 106$ & $262 / 142 / 0$ & $2.39 \times 10^{8}$ & $6.75 \times 10^{5}$ & 292 & 0.0 & $\ldots$ \\
\hline Start melt & 581.6 & 21.5 & $237 / 109$ & $38 / 680 / 6$ & $2.29 \times 10^{6}$ & $8.4 \times 10^{5}$ & 192 & 0.0 & $-\infty$ \\
\hline Core slump & 587.1 & 22.2 & $241 / 112$ & $0 / 763 / 0$ & $2.24 \times 16^{6}$ & $8.77 \times 16^{5}$ & 188 & 0.0 & $\ldots$ \\
\hline Core collapse & 588.8 & 22.3 & $255 / 113$ & $0 / 971 / 0$ & $2.23 \times 10^{6}$ & $8.85 \times 16^{5}$ & 187 & 0.10 & $-\infty$ \\
\hline Botton head dryout & 596.0 & 23.1 & $254 / 119$ & $0 / 1072 / 0$ & $2.20 \times 10^{6}$ & $9.29 \times 10^{5}$ & 188 & 0.0 &.-- \\
\hline Bottom head failur & 617.1 & 25.1 & $249 / 138$ & $210 / 642 / 0$ & $2.11 \times 10^{6}$ & $1.03 \times 10^{6}$ & 182 & 0.0 & $-m \infty$ \\
\hline Start concrete attack & 617.5 & 27.3 & $241 / 151$ & $1032 / 1.4 \times 10^{5} / 0$ & $1.89 \times 10^{6}$ & $1.28 \times 10^{6}$ & 172 & 0.0 & $\cdots$ \\
\hline End calculation & 1217.5 & 57.8 & $256 / 315$ & $0 / 58 / 6$ & $1.56 \times 10^{6}$ & $1.69 \times 10^{8}$ & 238 & 0.6 & $\infty$ \\
\hline
\end{tabular}




\section{SEQUOYAH S3B}

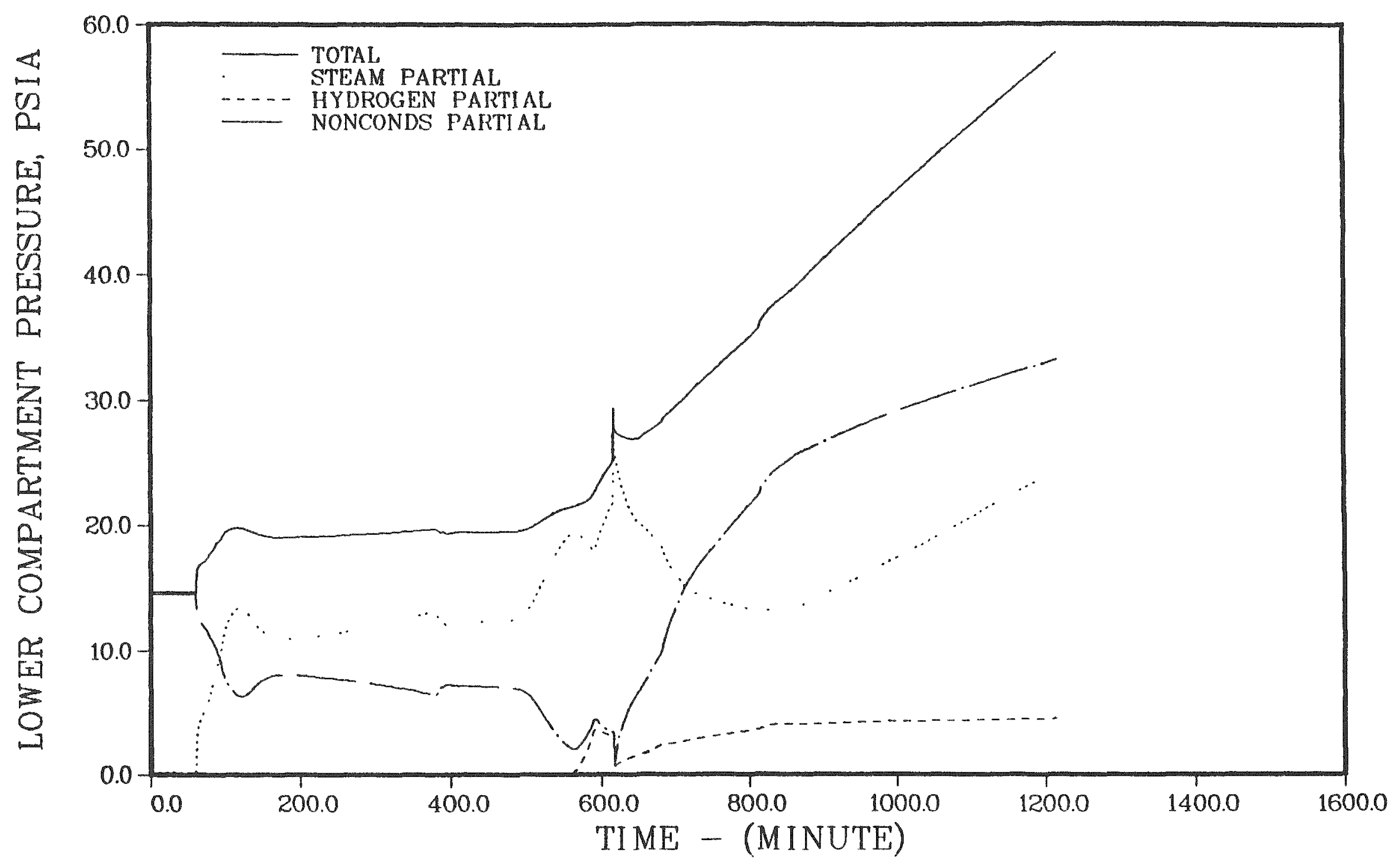

$\tilde{\mathscr{o}}$

Figure 4.3.39a. Lower compartment pressure history - station blackout with pump seal failure. 


\section{SEQUOYAH S3B}

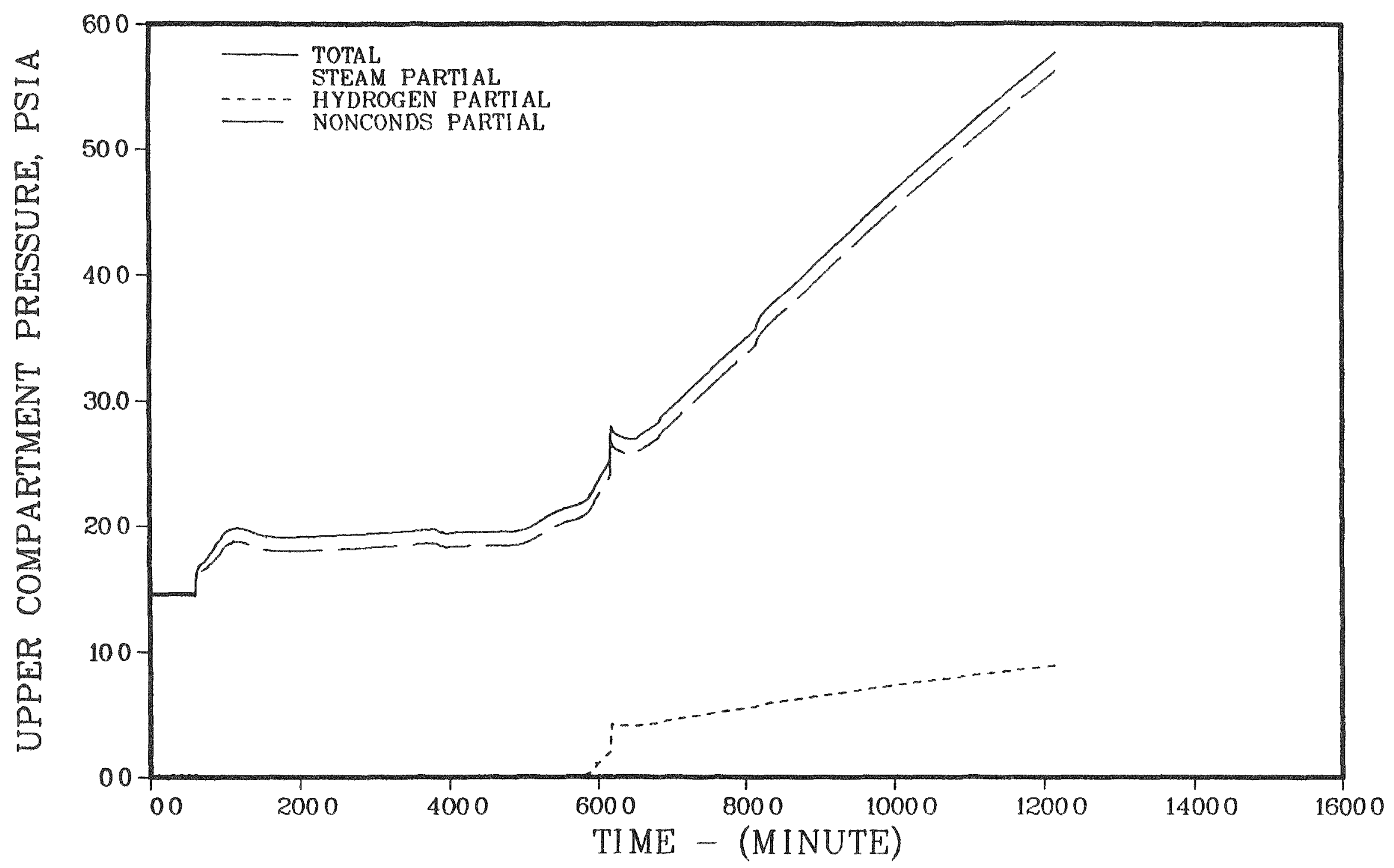

Figure 4.3.39b. Upper compartment pressure history - station blackout with pump seal failure. 


\section{SEQUOYAH SBB}

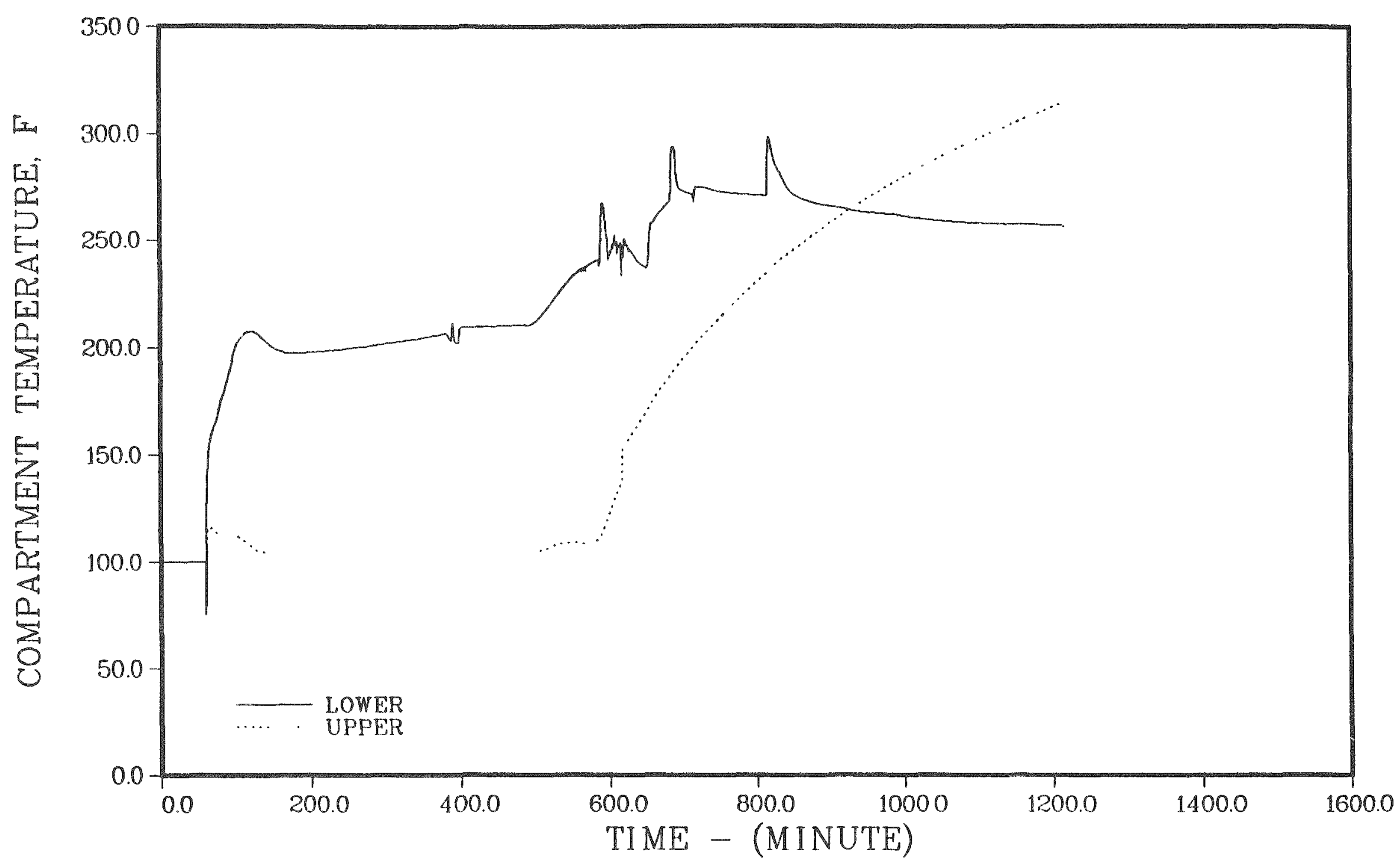

Fiqure 4.3.40. Containment temperature history - station blackout with pump seal failure. 


\section{SEQUOYAH S.BB}

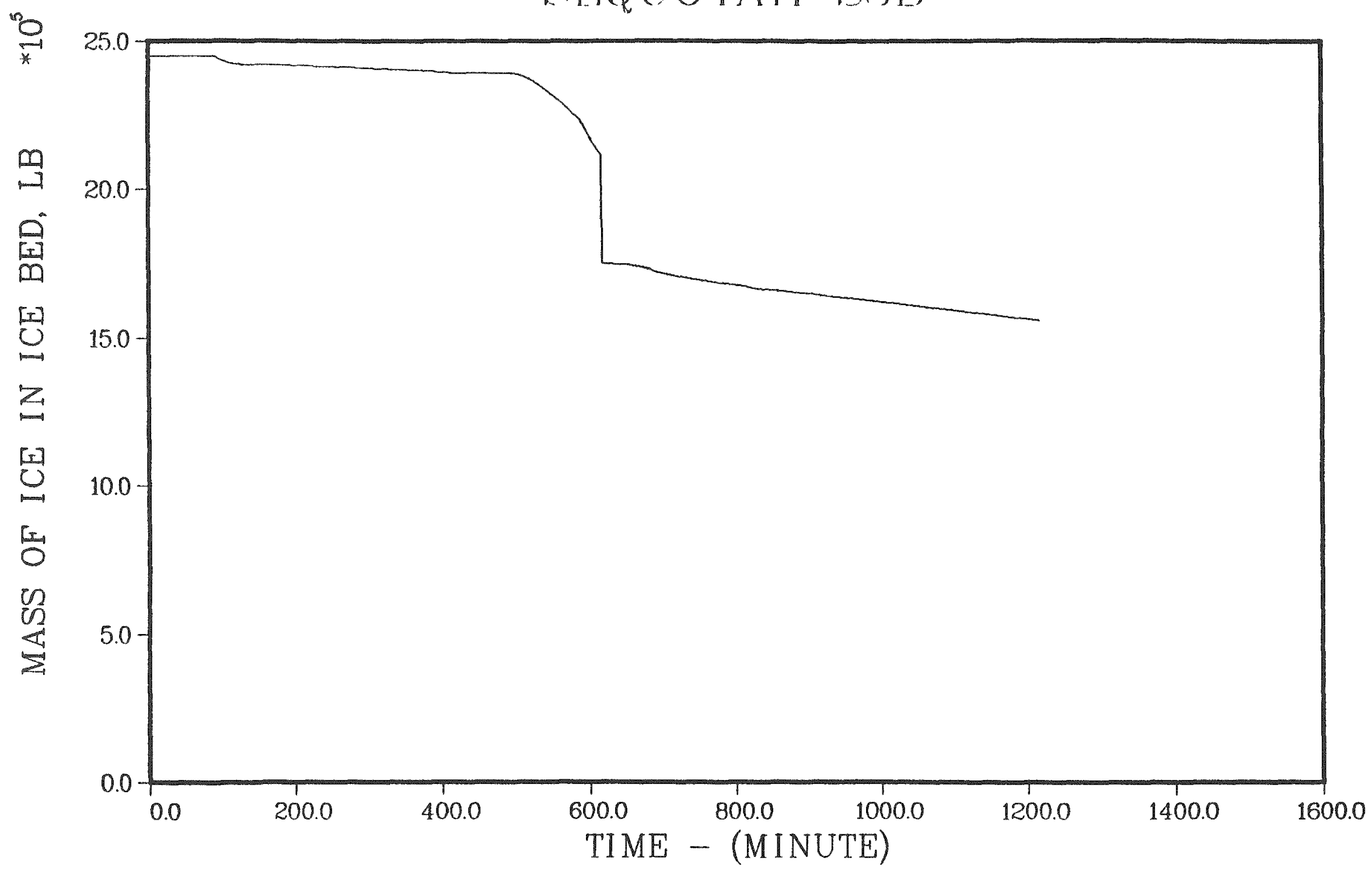

Ficure 4.3.41. Ice inventory - station blackout with pump seal failure. 


\section{SEQUOYAH S3B}

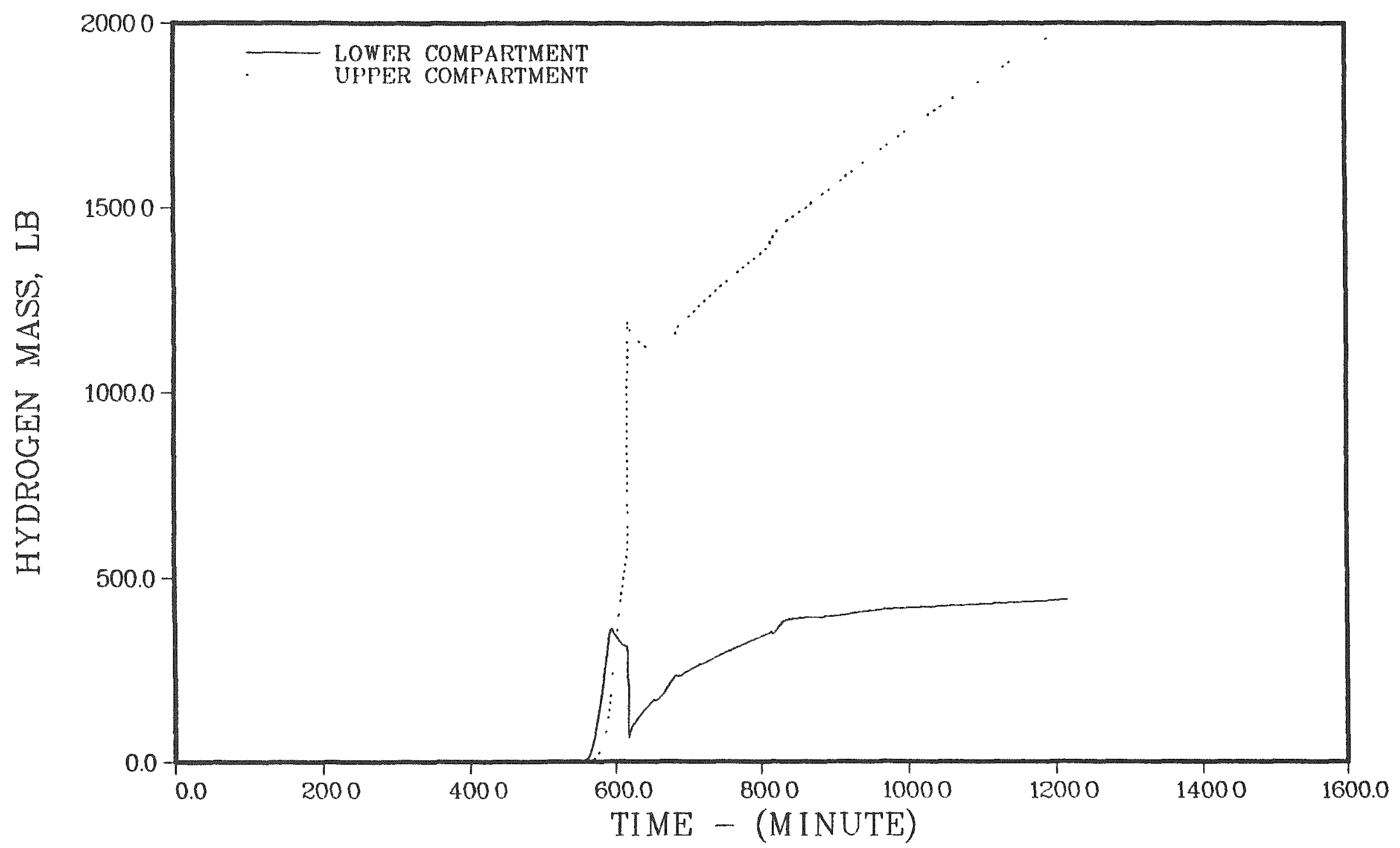

Figure 4.3.42. Hydrogen in the containment - station blackout with pump seal failure. 


\section{SEQUOYAH S3B}

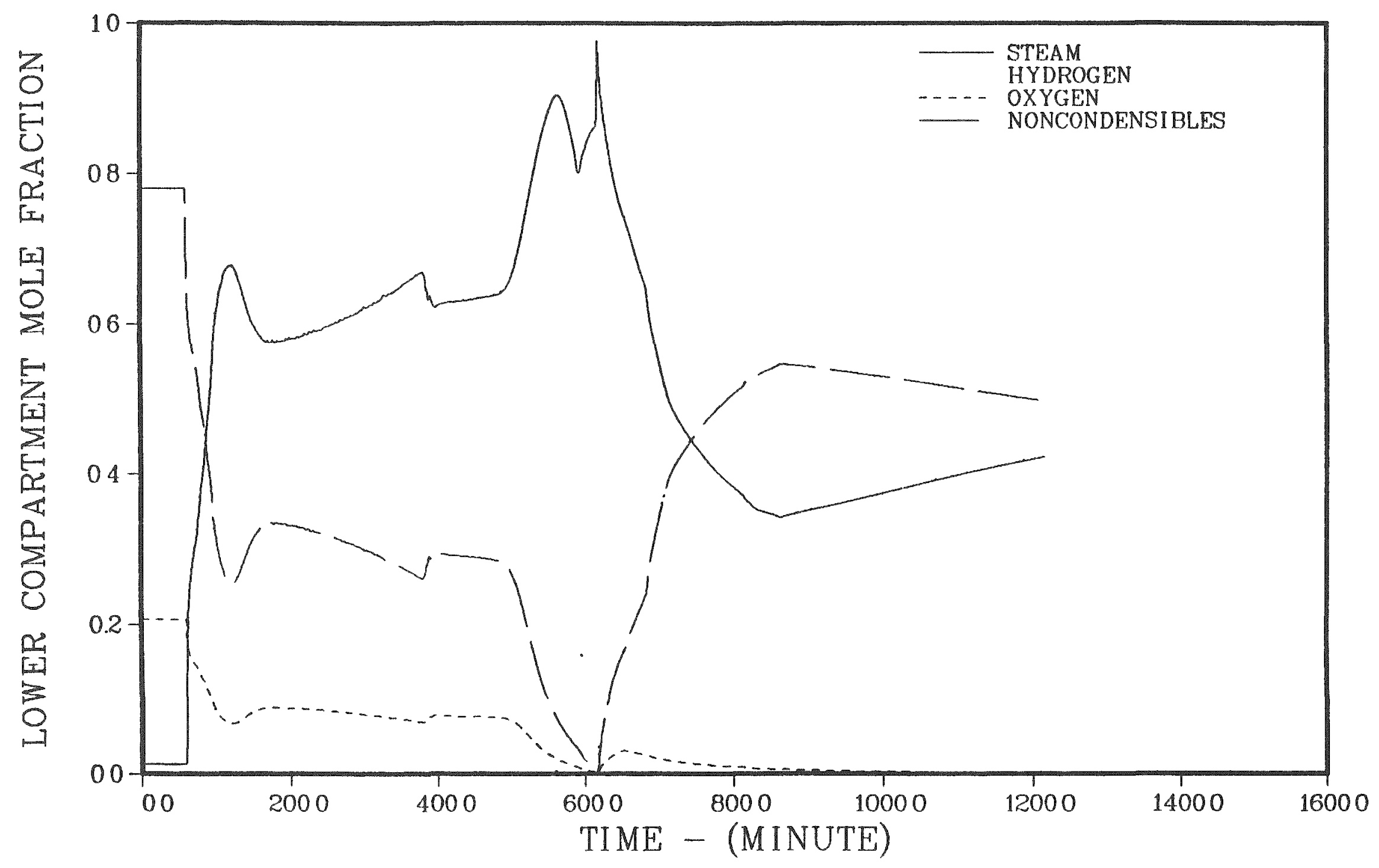

Figure 4.3.43a. Lower compartment atmosphere composition - station blackout with pump seal failure. 


\section{STQQUOYAH S3B}

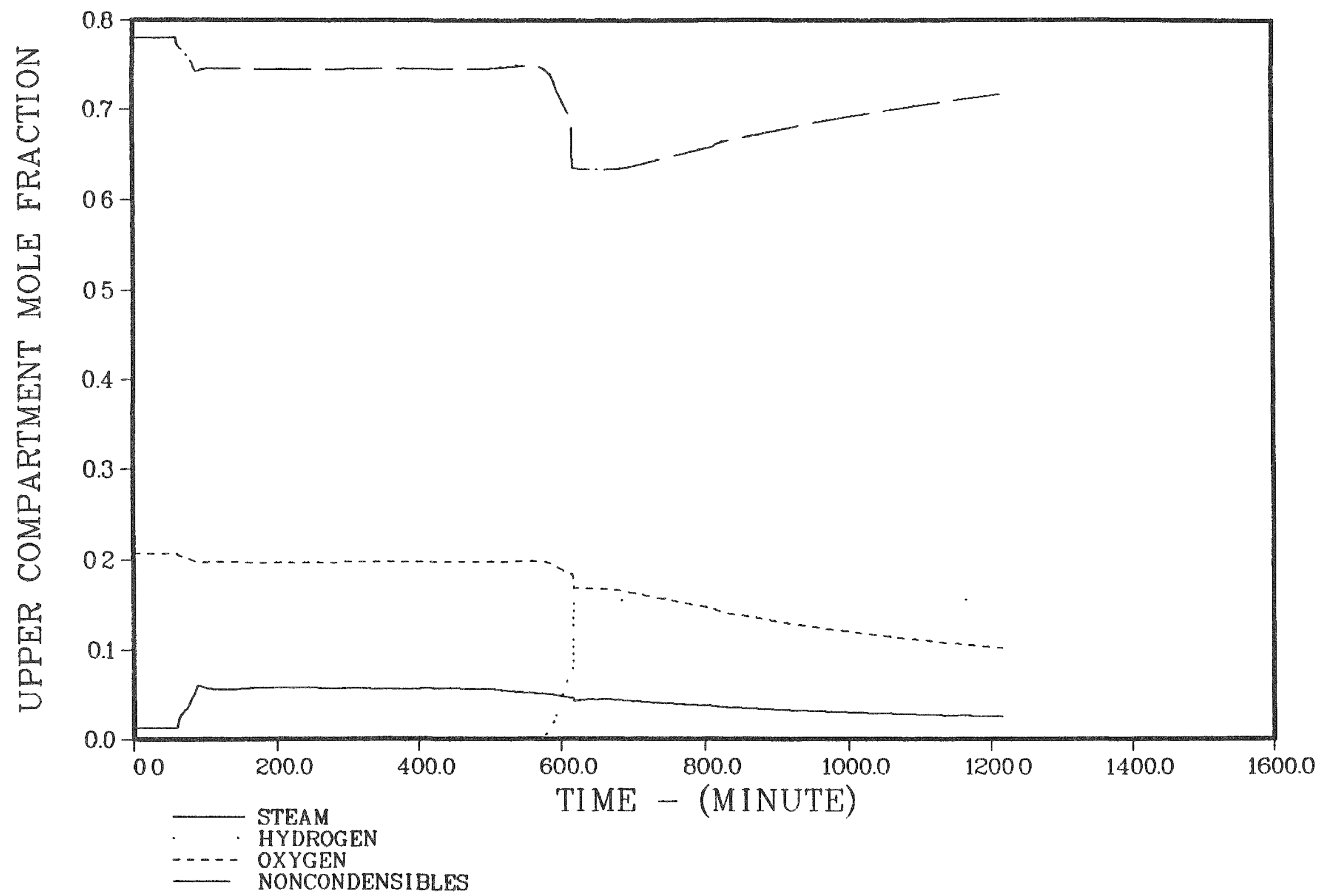

Figure 4.3.43b. Upper compartment atmosphere composition - station blackout with pump seal failure. 
Table 4.3.12. Timing of key events - Sequoyah $S_{3} D$

\begin{tabular}{|c|c|}
\hline Event & $\begin{array}{l}\text { Time. } \\
\text { minutes }\end{array}$ \\
\hline $\begin{array}{l}\text { RCP seal LOCA initiated } \\
\text { Fan on } \\
\text { Containment spray on } \\
\text { Start steam generator depressurization } \\
\text { Containment spray recirculation on } \\
\text { Accumulators discharge } \\
\text { End steam generator depressurization } \\
\text { Core uncovery } \\
\text { Start melt } \\
\text { Hydrogen burn } \\
\text { Hydrogen burn } \\
\text { Hydrogen burn } \\
\text { Core slump } \\
\text { Core collapse } \\
\text { Hydrogen burn } \\
\text { Bottom head dryout } \\
\text { Bottom head failure } \\
\text { Start concrete attack } \\
\text { Hydrogen burn } \\
\text { Hydrogen burn } \\
\text { Ice melt complete } \\
\text { Corium layers invert } \\
\text { End calculation }\end{array}$ & 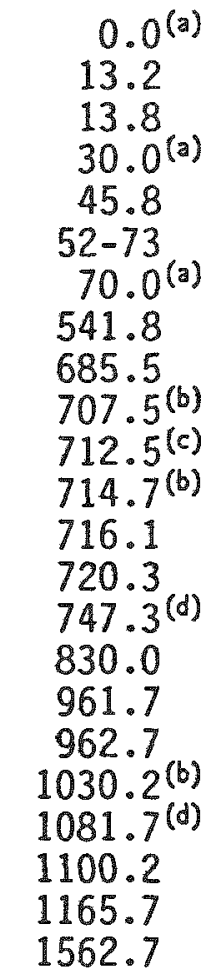 \\
\hline
\end{tabular}
(a) From sequence definition
(b) Hydrogen burns in lower and upper compartments
(c) Hydrogen burns in lower compartment
(d) Hydrogen burns in upper compartment 
Table 4.3.13. Core and primary system response - Sequoyah $S_{3} D$

\begin{tabular}{|c|c|c|c|c|c|c|c|}
\hline $\begin{array}{l}\text { Accident } \\
\text { Event }\end{array}$ & $\begin{array}{l}\text { Time, } \\
\text { minutes }\end{array}$ & $\begin{array}{l}\text { Primary } \\
\text { Systera } \\
\text { Pressure, } \\
\text { psia }\end{array}$ & $\begin{array}{l}\text { Primary } \\
\text { System } \\
\text { Water } \\
\text { Inventory. } \\
\text { Ib }\end{array}$ & $\begin{array}{c}\text { Average Core } \\
\text { Temperature. } \\
\text { of }\end{array}$ & $\begin{array}{l}\text { Peak Core } \\
\text { Temperature, } \\
\text { of }\end{array}$ & $\begin{array}{l}\text { Fraction } \\
\text { Core } \\
\text { Melted }\end{array}$ & $\begin{array}{c}\text { Fraction } \\
\text { clad } \\
\text { Reacted }\end{array}$ \\
\hline $\begin{array}{l}\text { Accumulators } \\
\text { empty }\end{array}$ & 72.6 & 399 & $5.71 \times 10^{5}$ & 428 & 432 & $-\infty$ & $-\infty$ \\
\hline Core uncovery & 541.8 & 271 & $1.32 \times 10^{5}$ & 422 & 424 & 0.0 & 0.10 \\
\hline Stapt melt & 685.5 & 273 & $1.69 \times 10^{5}$ & 1449 & 4130 & 0.0 & 0.05 \\
\hline Core slump & 718.1 & 761 & $9.71 \times 10^{4}$ & 4129 & $-\infty$ & 0.76 & 6.68 \\
\hline Core collapse & 720.3 & 1384 & $7.63 \times 10^{4}$ & 2676 & --- & $-\infty$ & 0.69 \\
\hline Bottom head dryout & 830.0 & 293 & $2.69 \times 10^{4}$ & 1080 & -- & $\cdots$ & 0.69 \\
\hline Bottom head failure & 961.7 & 32 & $2.24 \times 10^{4}$ & 3765 & $-\infty$ & $-\infty$ & 0.69 \\
\hline
\end{tabular}

* Water retained in low points of RCS. 


\section{SEQUOYAH S3D}

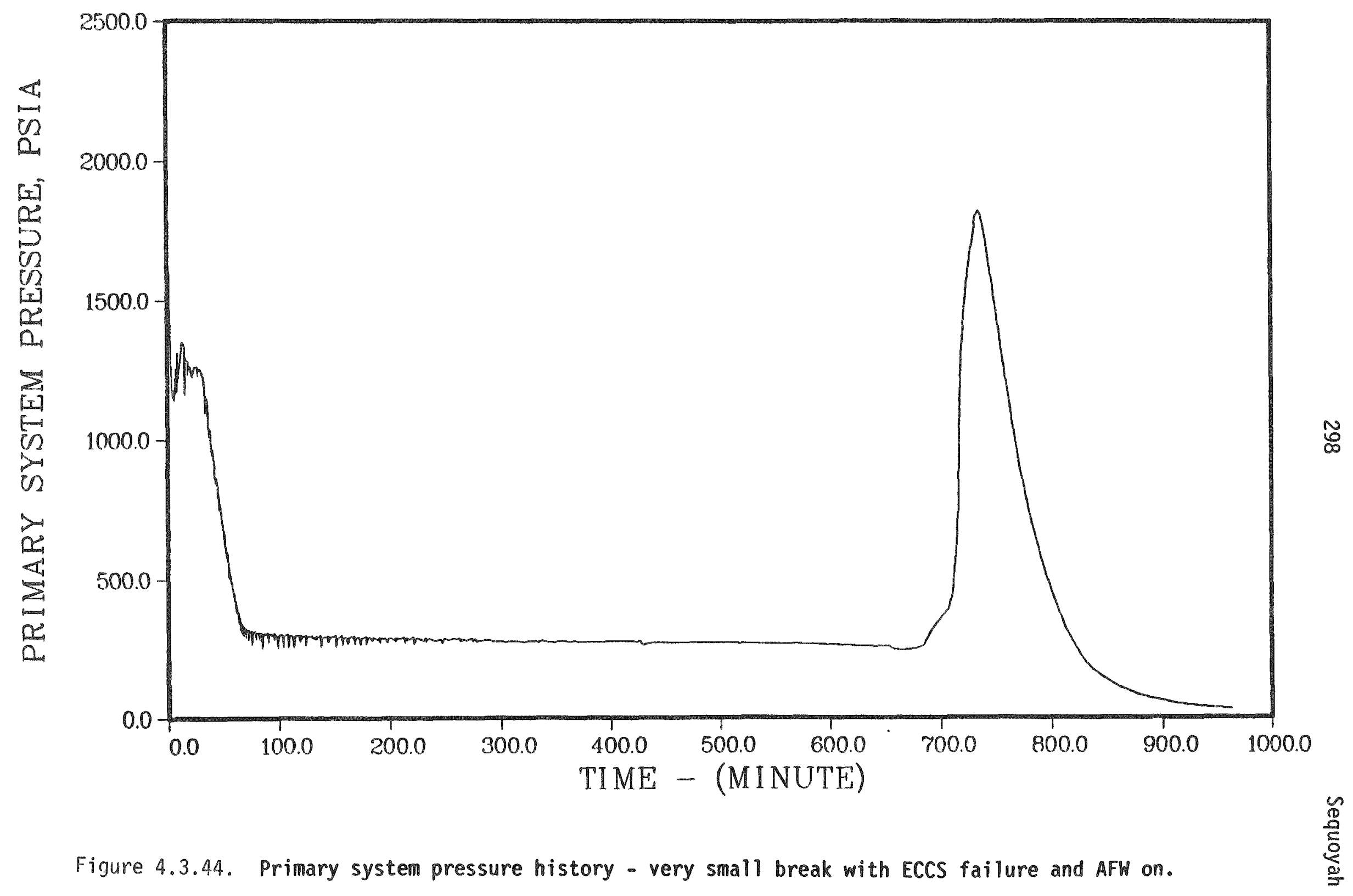




\section{SEQUOYAH S3D}

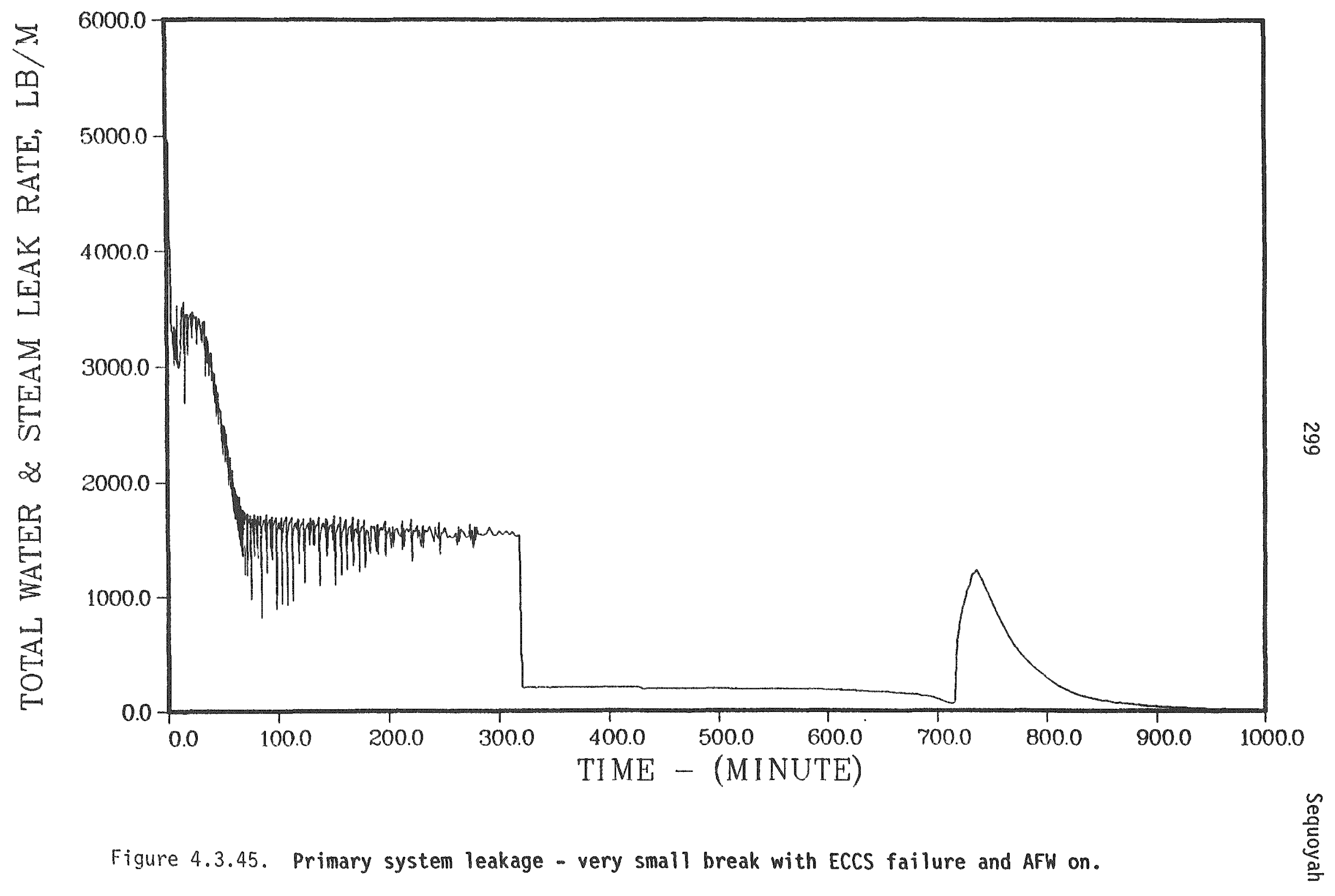


indefinitely, the steam generators do not dry out and continue to remove heat even after core uncovery. Core uncovery and heatup take place due to the loss of coolant through the break in the primary system. The continued refluxing of the steam condensed by the steam generators keeps the lower core nodes cooled and delays core slumping and collapse. The buildup of hydrogen in the primary system eventually decreases the effectiveness of the steam generators. Primary system hydrogen mass is illustrated in Figure 4.3.46. Despite leakage out of the system, hydrogen concentration increases and steam generator heat transfer becomes ineffective. Primary system repressurization occurs as the core slumps and collapse of the core is inevitably predicted. The maximum and average core temperatures are shown in Figure 4.3 .47 ; the fractions cladding reacted and core melted are given in Figure 4.3.48. The interaction between hydrogen generation and steam generator heat transfer, together with the core slumping model utilized, lead to the prediction of very high in-vessel cladding oxidation. The temperatures of the gases leaving the top of the core and those exising the primary system are shown in Figure 4.3.49.

\section{CONTAINMENT RESPONSE - SEQUOYAH $S_{3} D$ \\ (with secondary depressurization)}

The conditions in the containment at key times during the accident progression are summarized in Table 4.3.14. Pressure histories for the two compartments of the containment are given in Figures $4.3 .50 \mathrm{a}$ and $4.3 .50 \mathrm{~b}$; temperature histories are shown in Figure 4.3.51. Containment sprays, air return fans, and igniters are all operable during this sequence. Several hydrogen burns are predicted just prior to and following core slump and collapse. Hydrogen burns also occur during concrete attack. Hydrogen buildup in the containment compartments is illustrated in Figure 4.3.52. The mole fractions of the principal constituents of the containment atmosphere are shown in Figures 4.3 .53 and 4.3.54. The initial burning of hydrogen occurs at 707.5 minutes with the containment's lower and upper compartments containing 125 and $243 \mathrm{Tbs}$ of hydrogen. Corresponding mole fractions in the lower compartment are 0.076 hydrogen, 0.172 oxygen, and 0.096 steam; those in the upper compartment are 0.044 hydrogen, 0.188 oxygen and 0.059 steam. At the 


\section{SEQUOYAH S3D}

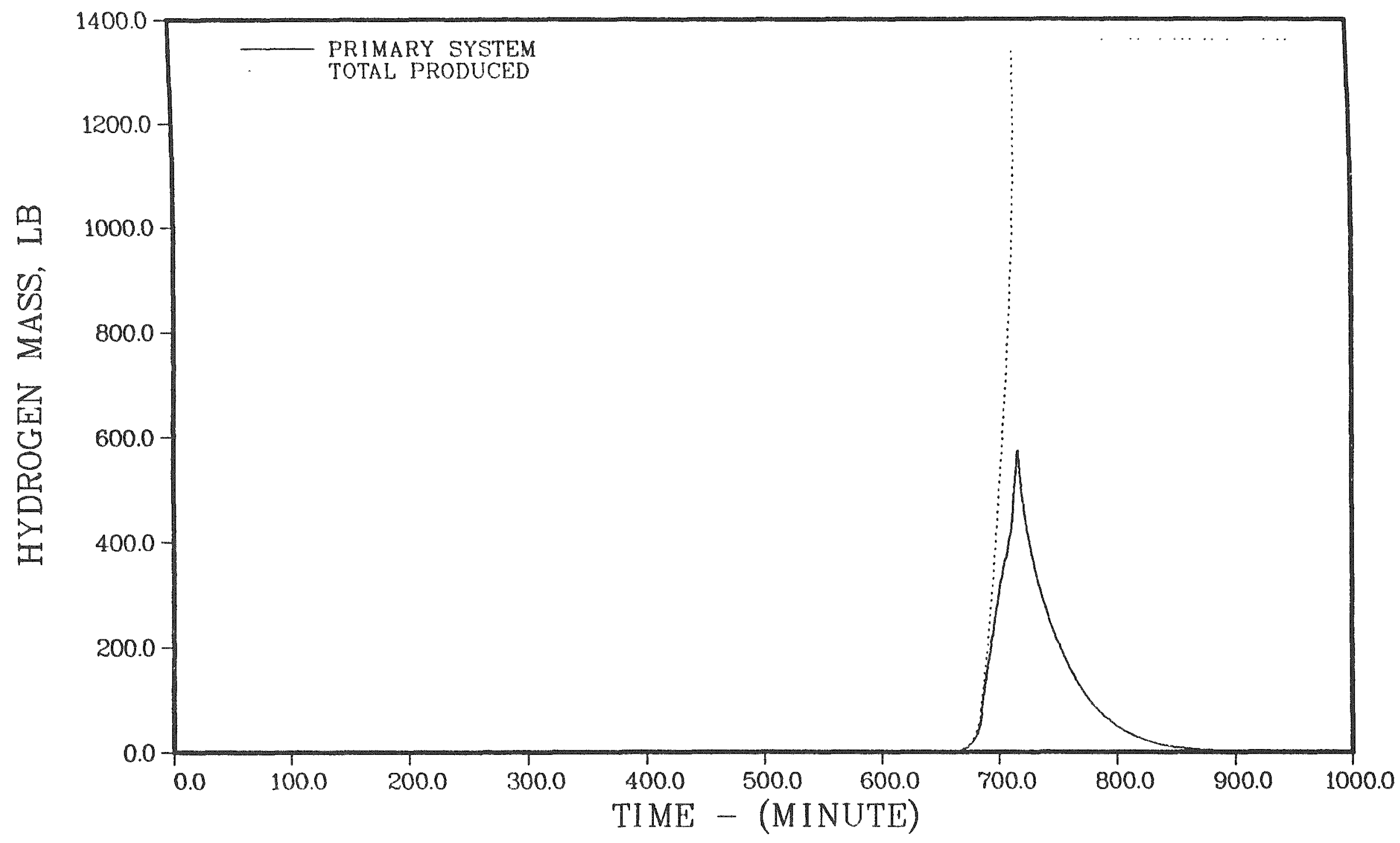

Figure 4.3.46. Hydrogen mass in the primary system - very small break with ECCS failure and AFW on. 


\section{SHEUOYAH S3D}

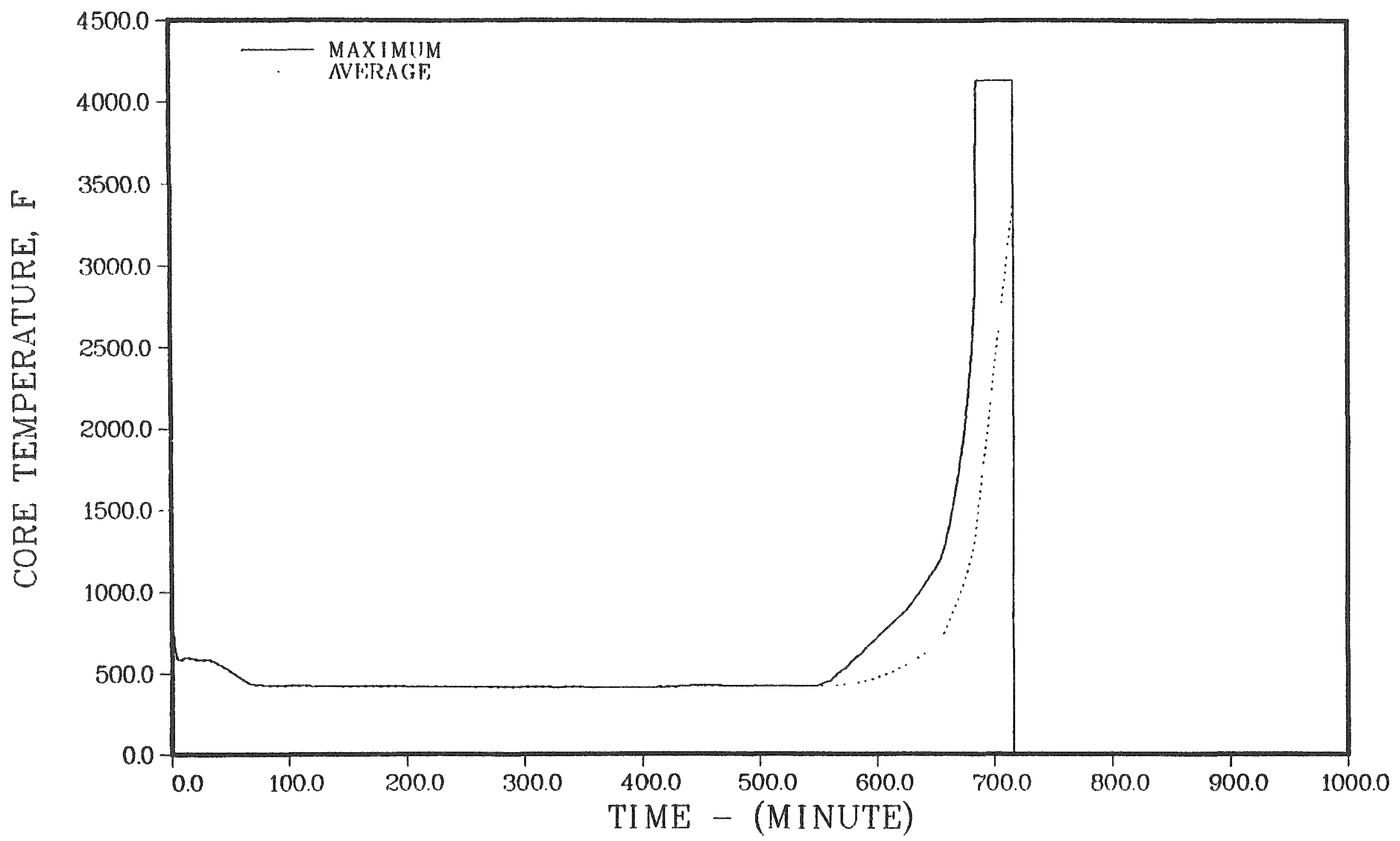

Figure 4.3.47. Maximum and average core temperatures - very small break with ECCS failure and AFW on. 


\section{SEQUOYAH S3D}

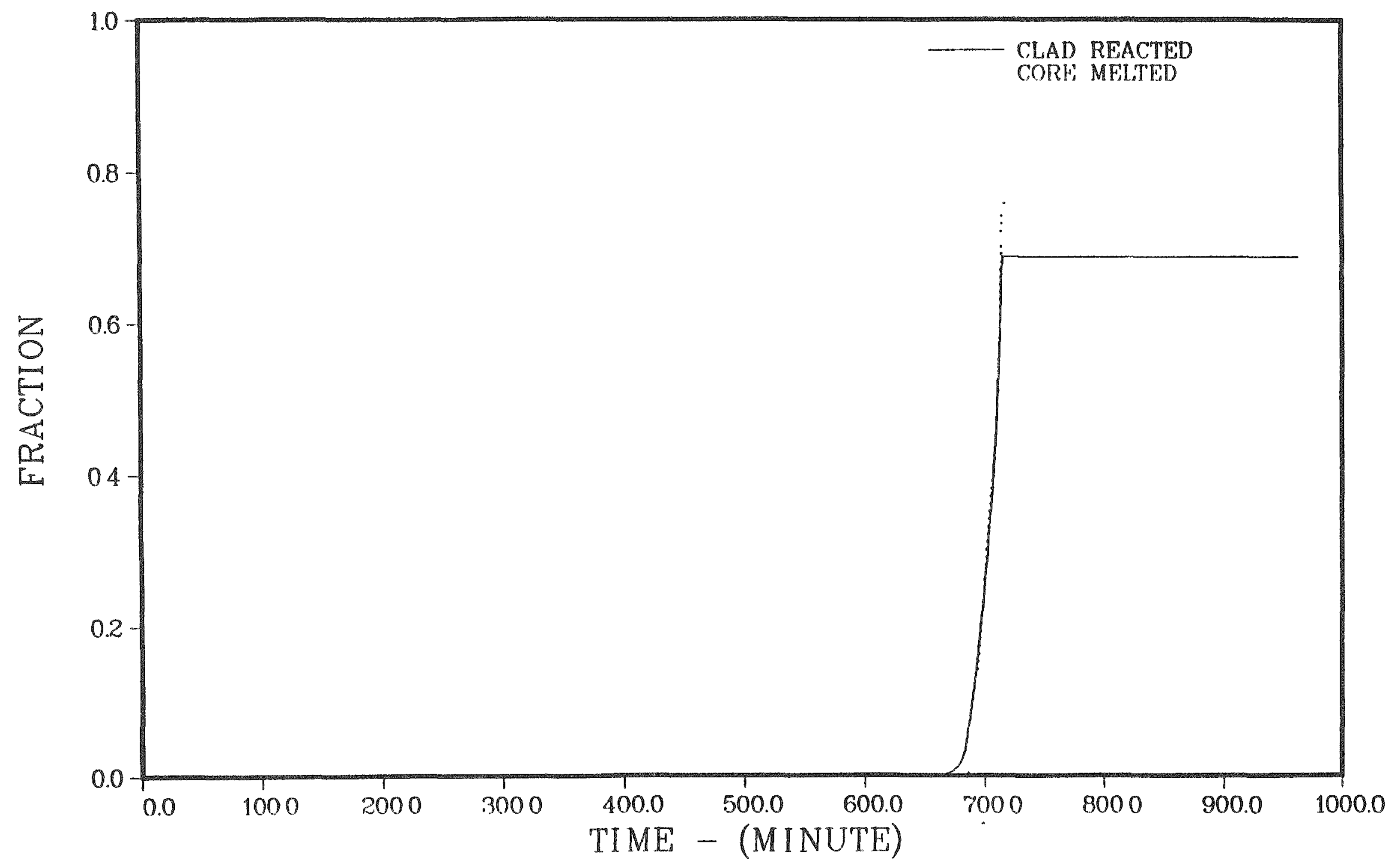

$\ddot{w}$

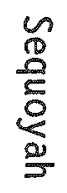

Figure 4.3.48. Fractions of cladding reacted and core melted - very small break with ECCS failure and AFW on. 


\section{SEQUOYAH S3D}

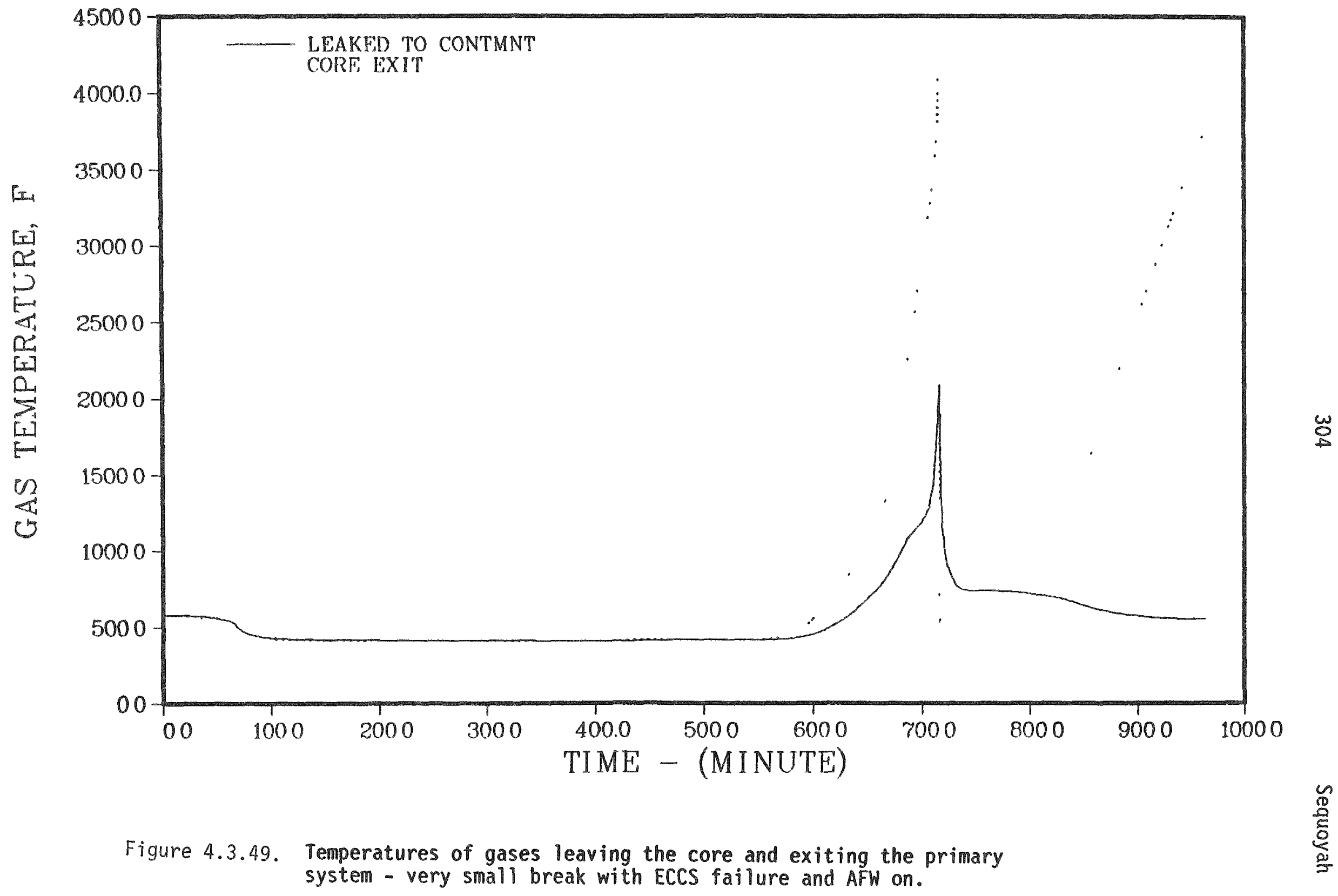


Table 4.3.14 Containment respons - Sequoyah $S_{3} D$

\begin{tabular}{|c|c|c|c|c|c|c|c|c|c|}
\hline \multirow[b]{3}{*}{$\begin{array}{l}\text { Accident } \\
\text { Event }\end{array}$} & \multirow[b]{3}{*}{$\begin{array}{l}\text { Time, } \\
\text { minutes }\end{array}$} & \multicolumn{2}{|c|}{ Containment } & \multirow{3}{*}{$\begin{array}{l}\text { Compartment wal! } \\
\text { steam Condensation, } \\
\frac{1 b / m}{\text { Lomer/Ice/Upper }}\end{array}$} & \multirow{3}{*}{$\begin{array}{l}\text { Ice } \\
\text { Mass, } \\
\text { Ib }\end{array}$} & \multirow{2}{*}{\multicolumn{2}{|c|}{ Sump Water }} & \multirow{3}{*}{$\frac{\text { Reactor }}{\text { Mass, }}$} & \multirow{3}{*}{$\frac{\text { Cavity water }}{\text { Temp. }_{\text {Ten }}}$} \\
\hline & & Pressure, & Temperature, & & & & & & \\
\hline & & Psia & 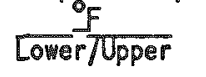 & & & Mass, & ${ }_{{ }_{0}^{\circ} \mathrm{F}}^{\text {Temp. }}$ & & \\
\hline & & & & Sequoyah S & & & & & \\
\hline Fan on & 13.2 & 17.5 & $170 / 116$ & $1008 / 0 / 0$ & $2.45 \times 10^{6}$ & $3.97 \times 10^{4}$ & 170 & 0.0 & $-\infty$ \\
\hline Containment spray on & 13.8 & 17.6 & $167 / 116$ & $833 / 0 / 10$ & $2.45 \times 10^{6}$ & $4.12 \times 10^{4}$ & 168 & 0.0 & $-\infty$ \\
\hline \multicolumn{10}{|l|}{ Containment spray } \\
\hline recirculation on & 45.8 & 17. & $148 / 192$ & $184 / 766 / 6$ & $2.36 \times 10^{6}$ & $2.79 \times 10^{6}$ & 106 & 0.0 & $-\infty$ \\
\hline Accumulators expty & 72.6 & 16.8 & $131 / 106$ & $45 / 468 / 1$ & $2.22 \times 10^{6}$ & $2.93 \times 16^{6}$ & 167 & 9.0 & $-\infty$ \\
\hline Core uncovery & 541.8 & 16.6 & $121 / 105$ & $19 / 165 / 0$ & $1.39 \times 10^{6}$ & $3.26 \times 10^{6}$ & 104 & $9.28 \times 10^{5}$ & 107 \\
\hline Start melt & 685.5 & 16.7 & $128 / 165$ & /143/6 & $1.25 \times 10^{6}$ & $3.43 \times 10^{6}$ & 104 & $9.28 \times 10^{5}$ & 107 \\
\hline Hydrogen burn & 707.5 & 21.9 & $1192 / 132$ & $0 / 25100 / 0$ & $1.21 \times 10^{6}$ & $3.47 \times 10^{6}$ & 104 & $9.28 \times 10^{5}$ & 167 \\
\hline Hydrogen burn & 712.5 & 20.0 & $1196 / 108$ & $0 / 31920 / 0$ & $1.19 \times 10^{6}$ & $3.50 \times 10^{6}$ & 106 & $9.28 \times 10^{5}$ & 107 \\
\hline Hydrogen burn & 714.7 & 21.6 & $1269 / 133$ & $0 / 813 / 194$ & $1.17 \times 16^{6}$ & $3.51 \times 10^{6}$ & 106 & $9.28 \times 10^{5}$ & 107 \\
\hline Core slump & 716.1 & 18.4 & $229 / 124$ & $0 / 782 / 117$ & $1.17 \times 10^{6}$ & $3.51 \times 10^{6}$ & 107 & $9.28 \times 10^{5}$ & 167 \\
\hline Core collapse & 720.3 & 17.3 & $157 / 106$ & $0 / 567 / 6$ & $1.15 \times 10^{5}$ & $3.54 \times 10^{6}$ & 108 & $9.28 \times 10^{5}$ & 107 \\
\hline Hydrogen burn & 747.3 & 23.9 & $185 / 185$ & $757 / 0 / 1733$ & 1. $1 \times 10^{6}$ & $3.69 \times 10^{6}$ & 109 & $9.28 \times 10^{5}$ & 167 \\
\hline Bottom head dryout & 830.0 & 16.7 & $132 / 112$ & $0 / 505 / 6$ & $6.82 \times 10^{5}$ & $4.13 \times 10^{8}$ & 115 & $9.28 \times 10^{5}$ & 107 \\
\hline Botton head failure & 961.7 & 18.6 & $116 / 112$ & $0 / 544 / 0$ & $4.19 \times 10^{5}$ & $4.42 \times 16^{6}$ & 115 & $9.28 \times 10^{5}$ & 107 \\
\hline Start concrete attack & 962.7 & 17.0 & $147 / 112$ & $1937 / 3236 / 0$ & $4.13 \times 10^{5}$ & $4.36 \times 10^{6}$ & 116 & $9.28 \times 10^{5}$ & 107 \\
\hline Hydrogen burn & 1030.2 & 22.8 & $1190 / 157$ & $0 / 28580 / 558$ & $2.82 \times 10^{5}$ & $4.53 \times 10^{6}$ & 116 & $9.06 \times 10^{5}$ & 189 \\
\hline Hydrogen burn & 1081.7 & 37.0 & $285 / 496$ & 01010 & $1.28 \times 10^{5}$ & $4.70 \times 10^{6}$ & 119 & $8.93 \times 10^{5}$ & 222 \\
\hline Ice melt complete & 1100.2 & 17.5 & $152 / 122$ & $122 / 217 / 6$ & 0.0 & $4.84 \times 10^{6}$ & 124 & $8.94 \times 10^{5}$ & 221 \\
\hline End calculation & 1562.7 & 33.1 & $189 / 184$ & $192 / 0 / 58$ & 0.0 & $4.82 \times 10^{6}$ & 179 & $8.79 \times 10^{5}$ & 256 \\
\hline
\end{tabular}




\section{SEQUOYAH SBD}

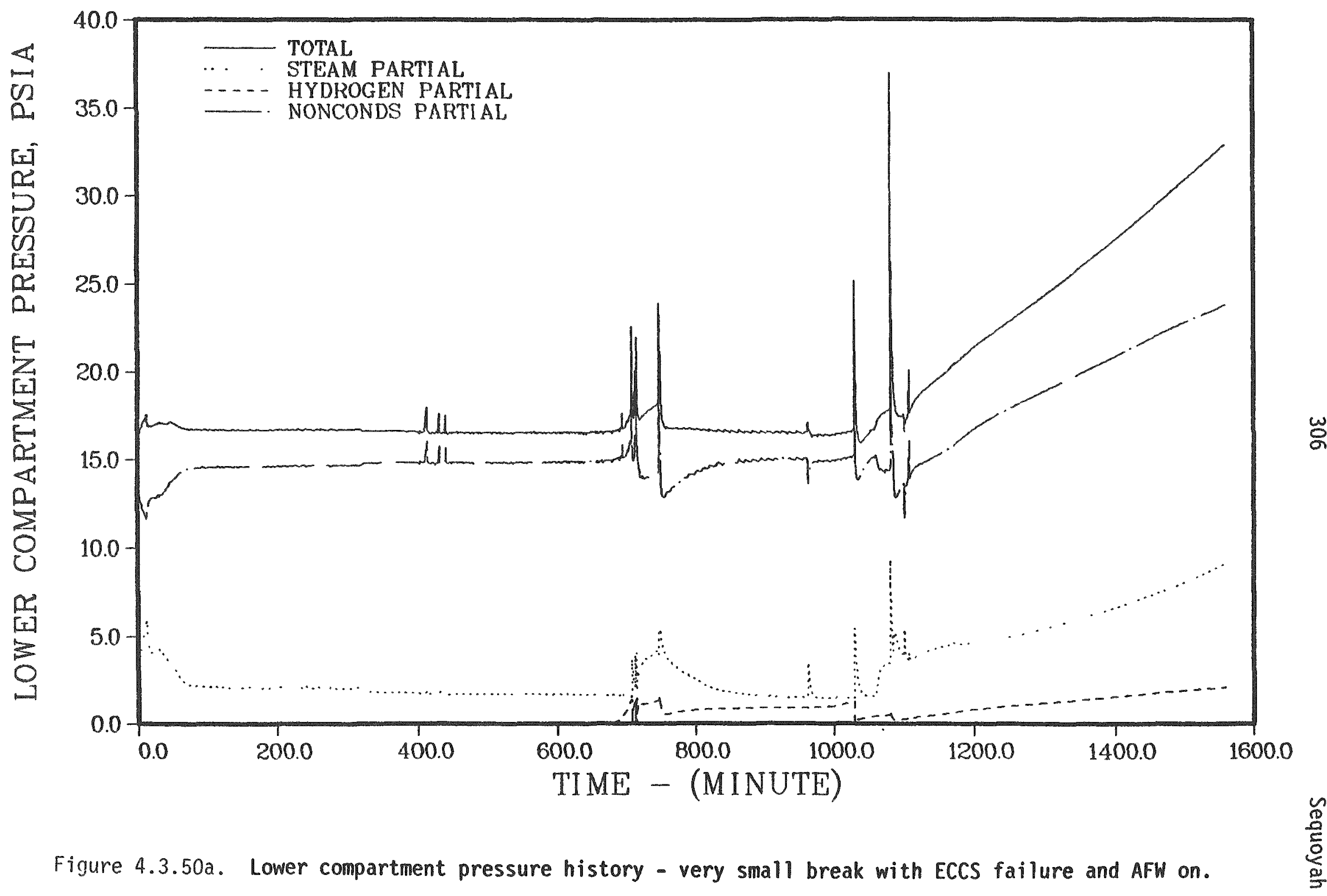




\section{SEQUOYAH S3D}

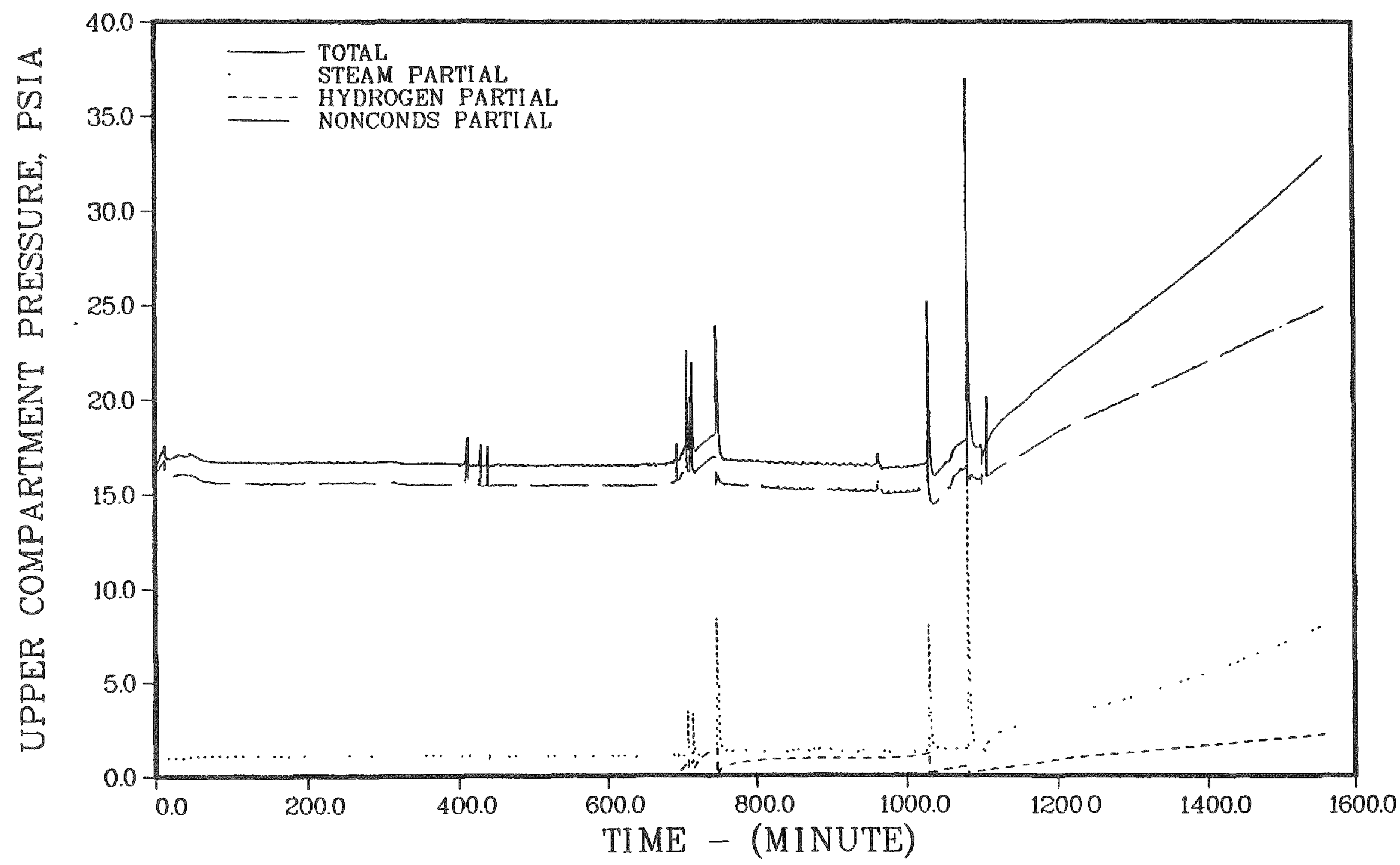

Figure 4.3.50b. Upper compartment pressure history - very small break with ECCS failure and AFW on. 


\section{SEQUOYAH S3D}

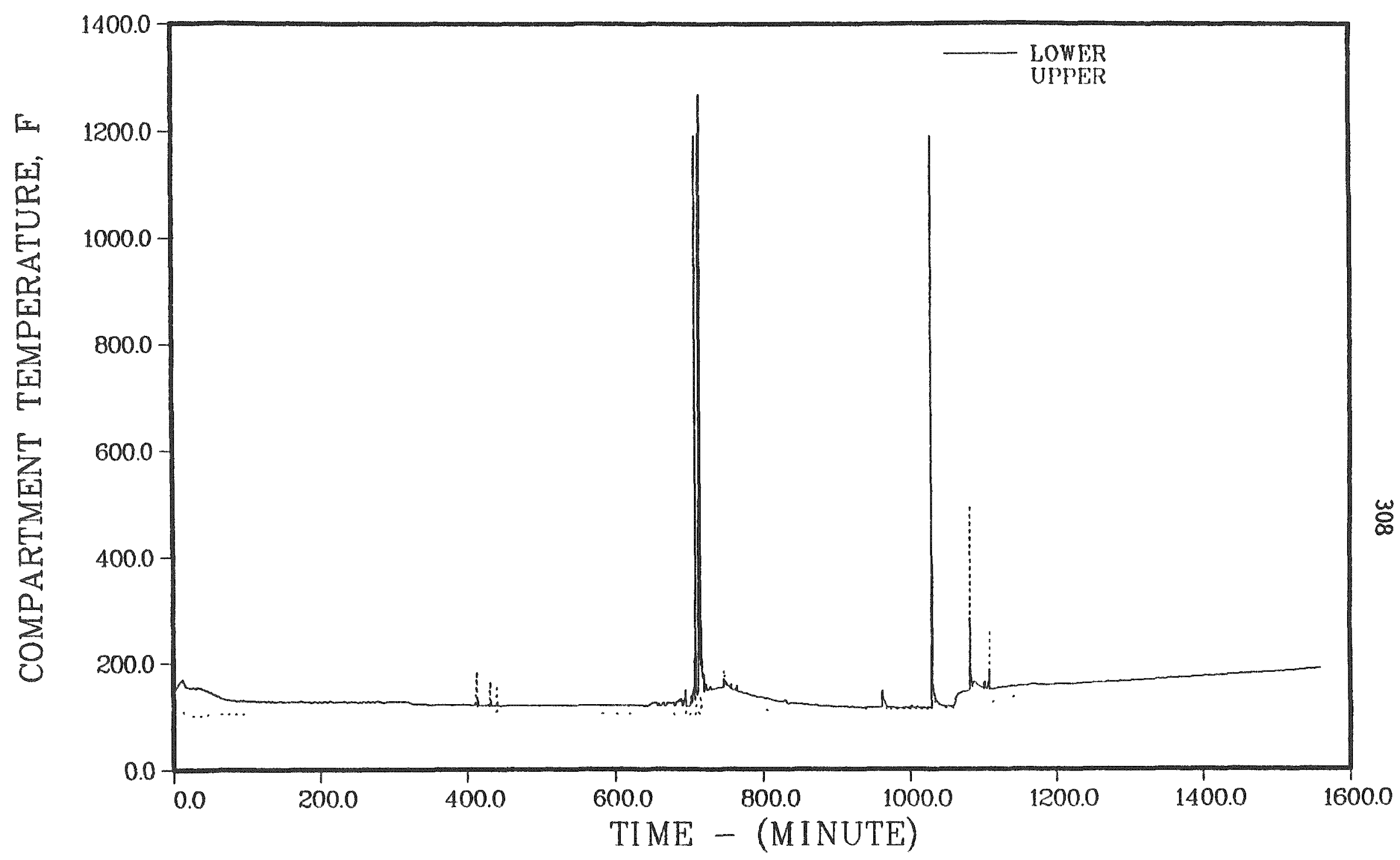

Figure 4.3.51. Containment temperature history - very small break with ECCS failure and AFW on. 


\section{SFQUOYAH S3D}

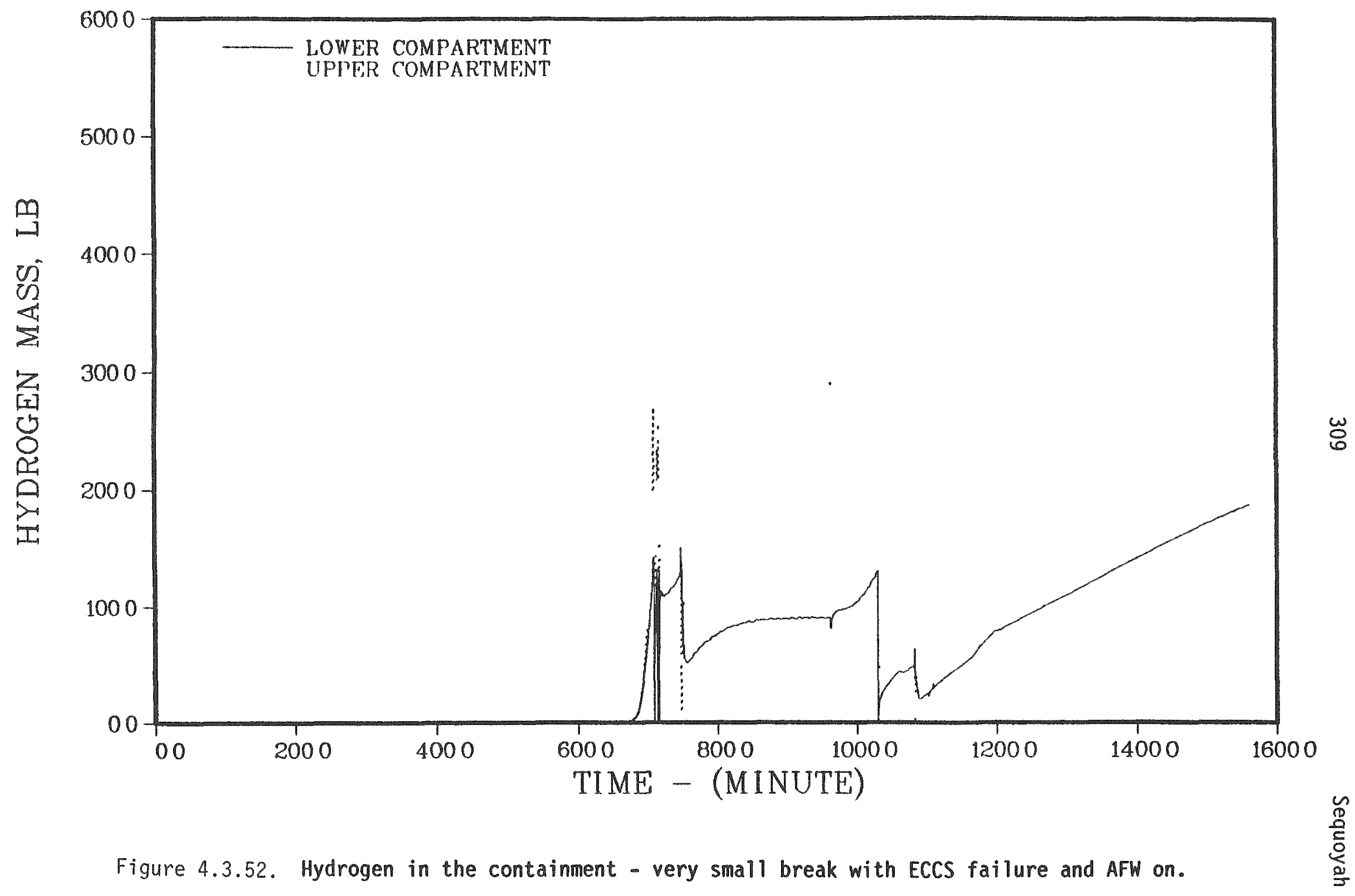




\section{SEQUOYAH S3D}

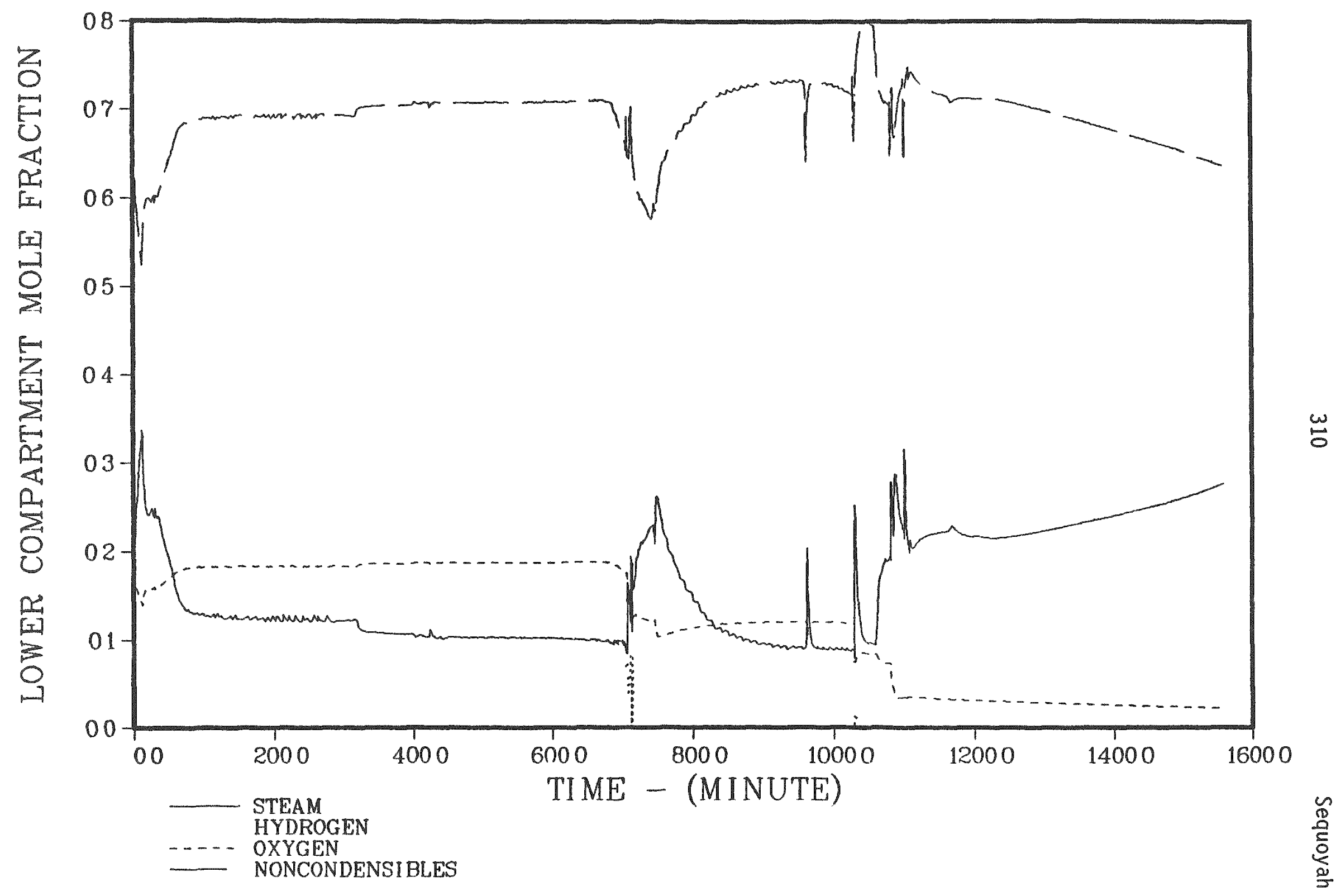

Figure 4.3.53. Lower compartment atmosphere composition - very small break with ECCS failure and AFW on. 


\section{SEQUOYAH S3D}

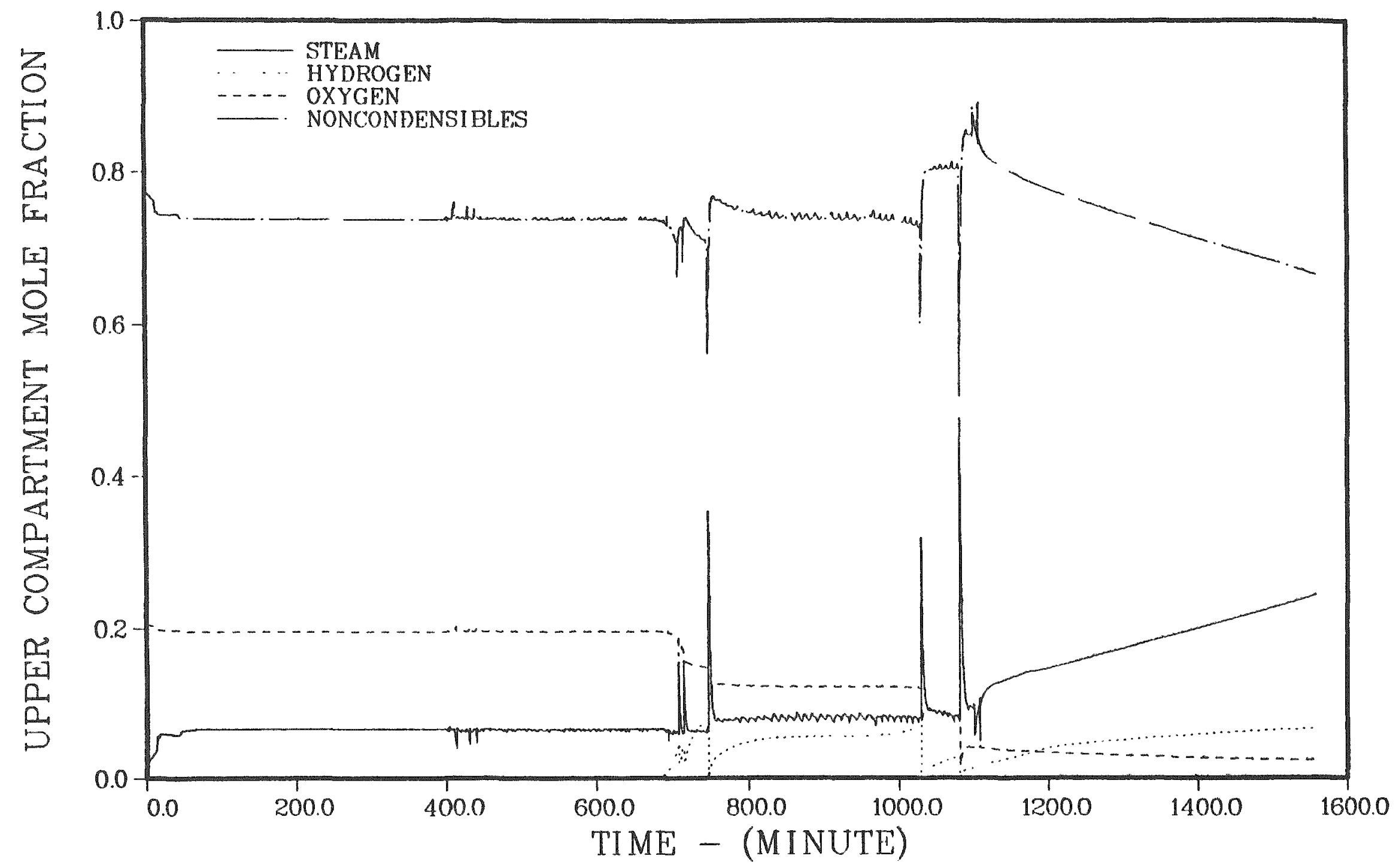

Figure 4.3.54. Upper compartment atmosphere composition - very small break with ECCS failure and AFW on. 
end of the calculation, after ten hours of concrete attack there are 188 and 602 lbs of hydrogen in the lower and upper compartments of the containment. Corresponding mole fractions in the lower compartment are 0.064 hydrogen, 0.022 oxygen and 0.278 steam; corresponding mole fractions in the upper compartment are 0.066 hydrogen, 0.023 oxygen and 0.246 steam failure of the bottom head at 961.7 minutes releases debris to a wet cavity because of water supplied by melting ice and operation of containment sprays. The masses of water in the containment sump and the reactor cavity are illustrated in Figure 4.3.55; the corresponding temperatures are shown in Figure 4.3.56. The mass of water in the reactor cavity is constant from uncovery to start of concrete attack since the cavity remains ful1. The sump water inventory continues to increase due to the melting of the ice. The inventory of ice during accident progression is shown in Figure 4.3 .57 .

\subsubsection{Radionuclide Sources}

\section{SOURCE WITHIN PRESSURE VESSEL}

The inventory of fission products used for these analyses is the same as that used for the BMI-2104(6) and NUREG/CR-4624(2) analyses. Table 4.3.15 provides the inventories for each of the key fission products, actinide, and structural elements. These values are based on the results of analyses performed at ORNL for the Surry plant using the ORIGEN2(17) code. These fission product masses were then scaled up by the ratio of the mass of fuel in the Sequoyah plant to that in the Surry plant to attempt to account for the difference in core size. In Table 4.3.16 these elements are collected into the elemental groups used in this study.

\section{SOURCES WITHIN THE CONTAINMENT}

The VANESA code was used to predict aerosol and gas release rates and compositions that result from corium-concrete interaction as functions of time. The fission product inventory of the core materials contacting the concrete was determined with the CORSOR module in MARCH3. The inventory for the $S_{3} B$ and $S_{3} H F$ sequences are given in Table 4.3 .17 . The concrete was taken to 


\section{SEQUOYAH S3D}

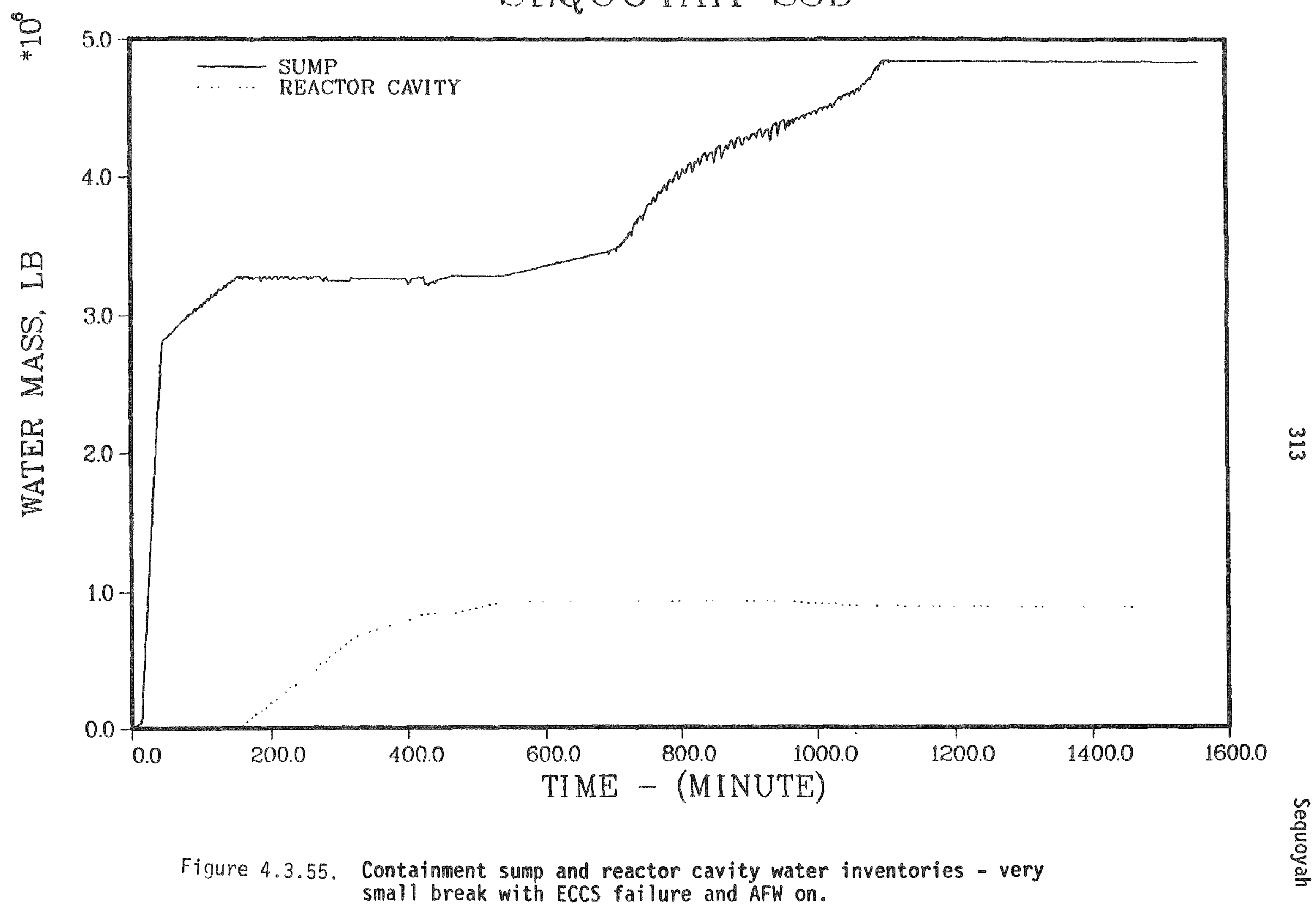




\section{SEQUOYAH S3D}

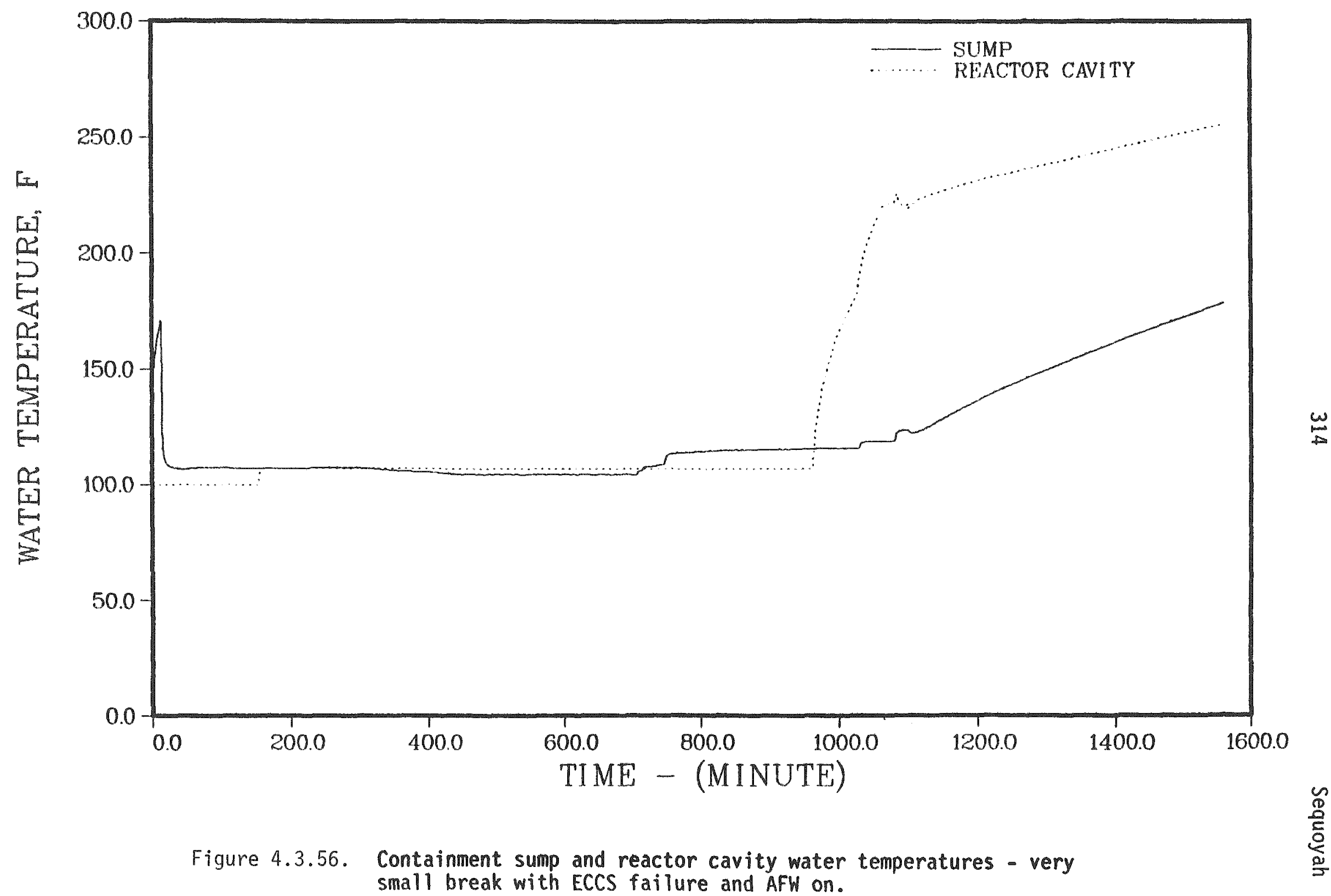




\section{SEQUOYAH S3D}

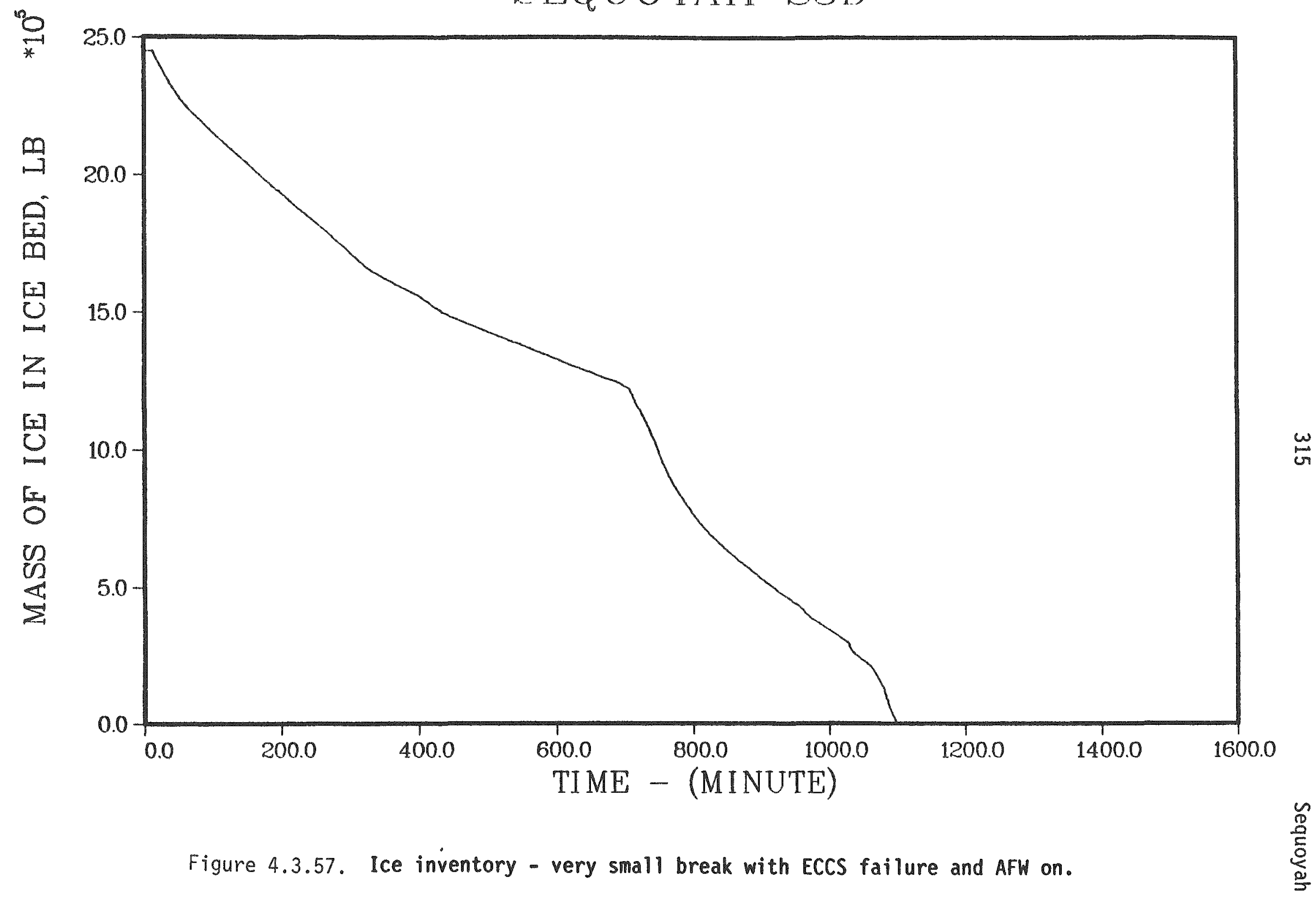


Table 4.3.15. Initial inventories of radionuclides and structural materials for Sequoyah.

\begin{tabular}{|c|c|c|c|}
\hline \multicolumn{2}{|c|}{ Fission Products } & \multicolumn{2}{|c|}{ Actinides/Structural } \\
\hline ETement & Mass (kg) & Element & Mass $(\mathrm{kg})$ \\
\hline $\mathrm{kr}$ & 17. & U & 89,000 \\
\hline RD & 18.7 & Pu & 596 \\
\hline sr & 60.8 & $\mathrm{~Np}$ & 33.0 \\
\hline Y & 29.1 & $\mathrm{Fe}$ & 8690 \\
\hline $\mathrm{Zr}$ & 227. & $\mathrm{Zr}$ & 23,100 \\
\hline $\mathrm{Nb}$ & 3.5 & Sn & 332 \\
\hline Mo & 197. & $\mathrm{Ag}$ & 2290 \\
\hline Tc & 47.2 & Cd & 144 \\
\hline Ru & 132. & In & 421 \\
\hline Rh & 26.6 & & \\
\hline$P d$ & 66.7 & & \\
\hline Te & 31.7 & & \\
\hline I & 15.2 & & \\
\hline $\mathrm{xe}$ & 330. & & \\
\hline Cs & 166. & & \\
\hline $\mathrm{Ba}$ & 77.6 & & \\
\hline La & 79.4 & & \\
\hline $\mathrm{Ce}$ & 167. & & \\
\hline $\mathrm{Pr}$ & 64.4 & & \\
\hline Nd & 217. & & \\
\hline $\mathrm{Pm}$ & 9.2 & & \\
\hline Sm & 43.2 & & \\
\hline Eu & 11.3 & & \\
\hline
\end{tabular}


Table 4.3.16. Inventory by group.

\begin{tabular}{clc}
\hline \hline Group & \multicolumn{1}{c}{ Elements } & Total Mass (kg) \\
\hline 1 & Xe, Kr & 347. \\
2 & I, Br & 15.2 \\
3 & Cs, Rb & 185. \\
4 & Te, Sb, Se & 31.7 \\
5 & Sr & 60.8 \\
6 & Ru, Rh, Pd, Mo, TC & 469. \\
7 & La, Zr, Nd, Eu, Nb, Pm, Pr, Sm, Y & 684. \\
8 & Ce, Pu, Np & 796. \\
9 & Ba & 77.6 \\
\hline
\end{tabular}


Table 4.3.17. Inventory of melt at the time of vessel

failure for Sequoyah $\mathrm{S}_{3} B$ and $\mathrm{S}_{3} \mathrm{HF}$.

\begin{tabular}{|c|c|c|c|c|c|}
\hline \multirow[b]{2}{*}{ Element } & \multicolumn{2}{|c|}{ Inventory $(\mathrm{kg})$} & \multirow[b]{2}{*}{ Element } & \multicolumn{2}{|c|}{ Inventory $(\mathrm{kg})$} \\
\hline & $S_{3} B$ & $S_{3} H F$ & & $S_{38}$ & $\mathrm{~S}_{3 \mathrm{HF}}$ \\
\hline $\mathrm{Cs}$ & 1.2 & 2.5 & $R h$ & 26.6 & 26.6 \\
\hline I & 0.11 & 0.24 & $P d$ & 66.7 & 66.7 \\
\hline Xe & 2.4 & 5.1 & Nd & 217 & 217 \\
\hline $\mathrm{Kr}$ & 0.12 & 0.26 & Eu & 11.3 & 11.3 \\
\hline $\mathrm{Te}$ & 3.0 & 2.5 & $\mathrm{Gd}$ & 0. & 0 \\
\hline $\mathrm{Ag}(\mathrm{FP})$ & 0. & 0 & $\mathrm{Nb}$ & 3.5 & 3.5 \\
\hline$S b$ & 0. & 0. & $P_{m}$ & 9.2 & 9.2 \\
\hline $8 a$ & 76.4 & 76.6 & $\operatorname{Pr}$ & 64.4 & 64.4 \\
\hline Sn & 305 & 307 & Sm & 43.2 & 43.2 \\
\hline TC & 47.2 & 47.2 & $Y$ & 29.1 & 29.1 \\
\hline $\mathrm{UO}_{2}$ & 101,000 & 101,000 & Np & 33.0 & 33.0 \\
\hline $\operatorname{Zr}$ (struct) & 5500 & 5910 & $\mathrm{Pu}$ & 596 & 596 \\
\hline $\operatorname{Zr}(F P)$ & 54.0 & 58.0 & $\mathrm{Se}$ & 0. & 0. \\
\hline $\mathrm{Fe}$ & 46600 & 47400 & $\mathrm{FeO}$ & 1150 & 128. \\
\hline Mo & 197 & 197 & $\mathrm{ZrO}_{2}$ & 23700 & 23100 \\
\hline$s r$ & 60.7 & 60.7 & & & \\
\hline $\mathrm{Cr}$ & 9320 & 9320 & & & \\
\hline $\mathrm{Ni}$ & 5180 & 5180 & & & \\
\hline Mn & 0. & 0. & & & \\
\hline La & 79.4 & 79.4 & & & \\
\hline $\mathrm{Ag}$ (struct) & 2140 & 2170 & & & \\
\hline $\mathrm{Cd}$ & 58.0 & 63.7 & & & \\
\hline In & 405. & 414. & & & \\
\hline $\mathrm{Ce}$ & 167 & 167 & & & \\
\hline $\mathrm{Rb}$ & 0.14 & 0.30 & & & \\
\hline $\mathrm{Br}$ & 0. & 0. & & & \\
\hline Ru & 132 & 132 & & & \\
\hline
\end{tabular}


be a high-limestone concrete and the initial temperature of the molten material was as calculated with by MARCH3. The total release rates and composition of the release for the $S_{3} B$ and $S_{3} H F$ sequences are given in Tables 4.3 .18 and 4.3 .19 , respectively.

\section{A Sensitivity Study of the Effects of Scrubbing by Accumulator Water}

In the base case S3B scenario for Sequoyah, the accumulator water remaining at the time of vessel failure was assumed to interact with the core debris in the reactor cavity and be evaporated. This led to the temporary quenching of the core debris and a delay in the onset of concrete attack. The ex-vessel fission product releases took place in a dry cavity. There was also interest in considering the possible effect of the accumulator water on scrubbing of the ex-vessel release if the debris did not quench and concrete attack started immediately after vessel failure. Thus, the MARCH3 and VANESA analyses were repeated for this latter case. It must be noted that straightforward application of the STCP(4) will predict fission product removal by water overlying corium-concrete interactions; as presently configured, however, the STCP(4) does not account for the possibility of the reevolution of

the scrubbed species when the water is evaporated, as it is in the case in question.

The predicted timing of accident progression for this scenario can be found in Table 4.3.1. In the base case, cavity water is predicted to be evaporated in about 30 minutes; in the sensitivity calculation without debris fragmentation (non-coolable debris bed), complete water boiloff is calculated to take about 3 hours.

While the nature of concrete attack and fission product release in the two cases is quite similar, calculated releases are somewhat different. The calculated results for the two cases prior to and during corium-concrete interactions are summarized in Tables 4.3 .20 and 4.3 .21 , respectively. The most obvious reason for differences is, of course, the presence of the water in the second (sensitivity calculation) case. The fission product inventories at the start of concrete attack in the two cases are somewhat different because some releases are predicted in the base case while the debris is 
Table 4.3.18. Aerosol release rate during corium-concrete interaction for Sequoyah $S_{3} B$.

\begin{tabular}{|c|c|c|c|c|c|c|c|c|}
\hline Time (minutes) & 0.0 & 20.0 & 40.0 & 60.0 & 20.0 & 100.0 & 120.1 & 140.0 \\
\hline \multicolumn{9}{|c|}{ Percent of tobal arosol source rate } \\
\hline FEO & 35.58 & 14.87 & 11.58 & 15.13 & 20.08 & 2.368 & 2.332 & 2.188 \\
\hline CR2O3 & $.0926 \mathrm{E}-16$ & $.2611 E-14$ & $.7734 E-13$ & $.6313 E-13$ & $.0238 E-12$ & 2.040 & 1.976 & 1.676 \\
\hline mI & .1078 & .7778 & 2.268 & .8732 & .5104 & 1.186 & .9588 & .0123 \\
\hline Mo & $.1175 E-07$ & $.5244 E-06$ & $.3578 E-05$ & $.6324 E-16$ & $.2123 E-06$ & $.2043 E-03$ & $.1586 \mathrm{E}-03$ & $.1408 E-03$ \\
\hline 的 & $.8585 E-07$ & .3687E-05 & $.2471 E-04$ & $.4439 E-05$ & $.1503 E-05$ & $.2310 E-05$ & $.1384 E-05$ & $.9005 E-08$ \\
\hline SH & .1310 & .4081 & .8409 & .4402 & .3228 & 2.895 & 2.798 & 2.781 \\
\hline SB & 0. & 0. & p. & 0. & 0. & 0. & 1. & 0. \\
\hline TE & $.9944 E-01$ & $.9657 E-11$ & .1082 & $.0013 E-01$ & $.8717 E-11$ & .2918 & .3264 & .3684 \\
\hline$A G$ & 12.40 & 22.51 & 17.46 & 22.91 & 27.60 & 78.97 & 73.87 & 71.51 \\
\hline$M N$ & 0. & 0. & 0. & 0. & 0. & 0. & 0 & t. \\
\hline CAO & 0. & 6.415 & 0.042 & 11.84 & 16.43 & .2716 & .2921 & .3127 \\
\hline M203 & 0. & .7238 & 2.681 & 1.477 & .2383 & $.9960 \mathrm{E}-03$ & $.1226 \mathrm{E}-02$ & $.1510 E-02$ \\
\hline MAZO & 0. & 2.530 & 3.181 & 2.242 & 1.103 & .4685 & .7046 & .0853 \\
\hline$\$ 102$ & 1. & 12.11 & 11.85 & 14.32 & 17.64 & .7760 & .0435 & .5227 \\
\hline 102 & .1847 & .6110 & 1.906 & .6122 & .3254 & 3.207 & 3.254 & 2.820 \\
\hline 2ณ02 & $.2577 E-01$ & $.1064 E-01$ & $.4109 E-01$ & $.1846 \mathrm{E}-01$ & .1832E-11 & $.6799 E-01$ & $.0482 E-01$ & .1000 \\
\hline $\operatorname{cs} 20$ & .9361 & .3504 & .2586 & .3014 & 0. & 0. & D. & 0. \\
\hline BAO & 3.146 & 2.215 & 1.994 & 1.537 & .5785 & . OA43E-01 & . 213E-D1 & $.172 E-01$ \\
\hline SAO & 3.229 & 3.378 & 3.809 & 2,242 & .6785 & $.9407 E-02$ & $.0440 E-02$ & $.7713 E-02$ \\
\hline LA203 & $.4388 E-01$ & .6027 & 2.343 & .5873 & .1557 & $.1179 E-01$ & $.728 \pm E-02$ &. .587E-02 \\
\hline $\mathrm{CEO} 2$ & .1047 & 1.454 & 4.251 & 1.158 & .2038 & $.2482 E-02$ & $.2741 E-02$ & $.3000 E-02$ \\
\hline Mอ205 & 1.288 & 3.285 & 8.557 & 0. & 0. & 0. & 0. & 0. \\
\hline $\operatorname{csI}$ & .5832 & .6845 & .3271 & $.3011 E-12$ & $.3866 E-12$ & $.1415 E_{-11}$ & $.1787 E-11$ & $.2100 E-11$ \\
\hline $\mathrm{co}$ & 42.08 & 15.77 & 11.66 & 13.56 & 0. & 0. & b. & 0. \\
\hline SOURCE RATE(GM/S) & 0.046 & 22.53 & 182.5 & 270.3 & 170.6 & 29.83 & 21.28 & 16.32 \\
\hline AEROSOL DENSIT (CM/CMS) & 5. 005 & 3.857 & 3..61 & 3.739 & 3.708 & 6.558 & 6.035 & 6.600 \\
\hline AEROSOL SIZE(MICRON) & .6763 & .9871 & 1.07 & .9916 & .0929 & .4547 & .4237 & .4006 \\
\hline DXIDE MET TEMP(K) & 2005. & 2387. & 2560. & 2400. & 2298. & 2229. & 2176. & 2136. \\
\hline
\end{tabular}


Table 4.3.18. (Continued)

\begin{tabular}{|c|c|c|c|c|c|c|c|c|}
\hline 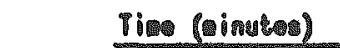 & 15. & 101. & 290. & 221. & 246.0 & 200.1 & 200.6 & 2อบ. \\
\hline \multicolumn{9}{|c|}{ Percone of cotal acrosol source pate } \\
\hline Fel & 2.91 & 1.320 & .0648 & .7202 & .0304 & .0437 & 1.031 & 1.121 \\
\hline ch20 & 1.398 & .659 &.$\$ 210$ & .2110 & .181 & .1014 & .1263 & .179 \\
\hline MI & .712 & .3960 & .3020 & .2801 & .2656 & .2330 & .2141 & .12008 \\
\hline 4 & .1437 - -93 & $.0414 E-04$ & .\$011E-13 & $.2236-14$ & $.2504 E-12$ & $.2068 \mathrm{E}-02$ & .2007E-12 & $.2712 \mathrm{E}-12$ \\
\hline W & $.0232 E-06$ & . HBS7E-06 & . O143E-OT & . OSATE-OT & . E\$บะE-D7 & . AS3EE-0T & $.3567 E-17$ & $.2010 E-07$ \\
\hline se & 0. & . & (7) & 1. & i. & a. & ก. & i. \\
\hline TE & .928 & .807 & .8770 & .6168 & .63งิ & .6473 & .0003 & .0726 \\
\hline$M$ & 63.11 & 89. & เม. & 18.20 & 16.68 & [5. & 81.40 & 50. 01 \\
\hline 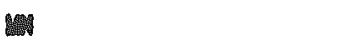 & 6. & . & 0. & . & ข. & 2. & 0. & 0. \\
\hline CAO & .3580 & .3757 & .5220 & .712 & .7481 & .7737 & .7037 & .110 \\
\hline R203 & . 1AEE-I2 & . $613 E-92$ & . & . B311E-02 & $.002 C-02$ & .760 E-02 & $.4426-2$ & . O20KE-12 \\
\hline ma20 & 1.010 & 1.308 & 1.311 & 1.146 & 1.183 & 1.111 & 1.216 & 1.296 \\
\hline 120 & 10.77 & 8. & 3.76 & 30.2 & 32.44 & $\$ 4.21$ & $\$ 7.07$ & 37.4 \\
\hline 402 & 2.68 & 1.94 & 2.34 & 3.268 & . .127 & 2.028 & 2.750 & 2. 51 \\
\hline IMO2 & $.11 \mathrm{Et}$ & .2067 & .2013 & .2030 & .2247 & .3046 & . 1126 & .3100 \\
\hline $\operatorname{cs} 2$ & . & 0. & 0. & 1. & 1. & i. & ขิ. & 0. \\
\hline BAO & . 101E-01 & . BS1 & .1128 & .1502 & .1001 & .1570 & .1528 & .1461 \\
\hline 500 & $.7195 \mathrm{E}-02$ & . 19อบ-02 & $.7167 E-02$ & . DOด E-12 & $.8775 E-02$ & $.0304 \mathrm{E}-\mathrm{O}$ & $.7910 E-22$ & $.7514 E-02$ \\
\hline La205 & $.470 \mathrm{E}-02$ & . A3945-02 & . A83TE-02 & $.6091 E-02$ &. . 114E-02 & $.5132 E-02$ & $.271 \mathrm{E}-122$ & . B57FE-12 \\
\hline CEO2 & $.3460 E-02$ & .0000E-02 & $.7605 E-02$ & . จ22ธE-02 & . EBEE-02 & $.883 E-12$ & . จดควE-02 & $.9272 E_{-102}$ \\
\hline 2อ206 & t. & o. & 0. & . & 0. & 0. & 0. & . \\
\hline CSI & .241E-11 & . МงองE-11 & . EAMOE-II &. . C002E-11 & . 196E-11 & $.6341 E-11$ & $.6812 E-11$ & $.6041 E-11$ \\
\hline$C$ & 0. & 0. & (3. & 0. & . & 0. & . & . \\
\hline SOURCE RATE(Ca/s) & 16.63 & 10.94 & 6.344 & 3.443 & 3.165 & $\$ .100$ & 3.260 & 3.277 \\
\hline AEDSTL DENIT/(Ca/cas) & 5.286 & 4.203 & 4.02 & 4.233 & 4.127 & 4.013 & $\$ .006$ & $\$ .000$ \\
\hline AEROSOL SILE(MICRON) & .2810 & .3258 & .2258 & .2790 & .2739 & .2800 & .2680 & .2827 \\
\hline ONIOE MAT TEP(K) & 2101. & 1987. & 1936. & 1916. & 1003. & 1888. & 1078. & 1063. \\
\hline
\end{tabular}


Table 4.3.18. (Continued)

\begin{tabular}{|c|c|c|c|c|c|c|c|c|}
\hline Iim (cinutes) & 920.1 & 340.0 & 290.0 & 29อง. & \$01. & 421.0 & 440.0 & 40. \\
\hline \multicolumn{9}{|c|}{ Porcenc of botal aerosol source race } \\
\hline 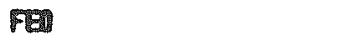 & 1.1. & 1.271 & 1.393 & 1.397 & 1.497 & 1.4018 & 1.516 & 1.647 \\
\hline CN20s & .1746 & .1626 & .1020 & .1570 & .16100 & .1440 & .1396 & .1234 \\
\hline MI & .1035 & .1747 & .1008 & .1030 & .1600 & .1611 & .1001 & .1606 \\
\hline 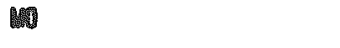 & $.274 E-02$ & $.2770 \mathrm{E}-02$ & $.2020 E-12$ & $.2860 \mathrm{c}-12$ & $.2023 E-02$ & $.2201 \mathrm{E}-02$ & $.30436-02$ & $.3110 E-02$ \\
\hline m & $.21125-07$ & $.2247 \mathrm{E}-07$ & $.2040 E-07$ & $.1002 E-17$ & $.1220 \mathrm{E}-17$ & $.1793 E-07$ & $.1774 E-17$ & .1763E-07 \\
\hline 5ิ & 0. & 0. & . & 0. & 0. & 0. & c. & t. \\
\hline TE & . & .048 & . & .0002 & .6001 & .686 & .6016 & .64 \\
\hline Mo & 40.3 & 40.11 & 17.67 & 47.22 & 47.21 & 47.30 & 47.02 & 47.2 \\
\hline 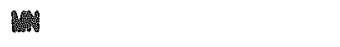 & 0. & 0. & (c). & 0. & 0. & 0. & 0. & 1. \\
\hline Cal & .0384 & .44 & . CEA6 & .0660 & . & . & .73 & .646 \\
\hline 1203 & .92 & . $1040 \mathrm{E}-1$ & . $1008 E-01$ & $.1123 E-11$ & $.1146 E-01$ & . 1152E-11 & $.1101 \mathrm{E}-1$ & .1186E- \\
\hline พมะ20 & 1.262 & 1.25 & 1.281 & 1.280 & 1.254 & 1.246 & 1.237 & 1.226 \\
\hline ณ2ข & 59.97 & 89. 11 & 41.46 & 10.09 & 40.97 & 40.8 & 40.65 & 40.37 \\
\hline $4 a 2$ & 2. .91 & 2.240 & 2.123 & 2. & 1.200 & 1.13 & 1.720 & 1.65 \\
\hline 2ne2 & .3204 & .3164 & .8108 & . 2034 & .2035 & .2826 & .2717 & .2812 \\
\hline cs20 & . & . & ข. & B. & 0. & 0. & 0. & 0. \\
\hline 200 & .1424 & .1360 & .1208 & .1235 & .1174 & .1116 & .1096 & .1018 \\
\hline 520 &. T102E-12 & $.6702 E-02$ & . & . $982 E-12$ & . CEA3E-12 & .5872E-12 & $.51 \mathrm{cec}-12$ & $.4011 E-02$ \\
\hline LA203 & . OOE-02 & . B331E-12 & . I34E-12 &. .112E-02 & . 4046E-D2 & $.4702 E-02$ & $.4570 E-02$ & . A402E-12 \\
\hline CED2 & . 931 AE-02 & $.9197 E-02$ & . ของดE-02 & . เอ20E-12 2 & . BSIE-02 & . $215 E-12$ & $.72908-02$ & $.7504 E-02$ \\
\hline 19206 & o. & . & 0. & 0. & 0. & a. & . & 0. \\
\hline CSI & . & . .677E-11 & . C468E-11 & $.0317 E-11$ & $.6110 E_{-11}$ & $.604 E-11$ & . 68EEE-11 &. . $4395-11$ \\
\hline$C$ & 0. & (i. & 0. & 0. & ๑. & 0. & . & 0. \\
\hline SOURE RATE(CA/S) & 3.227 & 3.170 & 3.141 & 3.052 & 2.860 & 2.022 & 2.917 & 2.02 \\
\hline AEROSQL DESITV(CH/OMS) & 3.730 & 3.001 & 9.87 & 3.635 & 8.83 & 3.638 & 3.647 & $\$ .602$ \\
\hline AEROSAL SIZE(MICAOM) & .2802 & .2586 & .2577 & .2570 & .2570 & .2673 & .2570 & .2583 \\
\hline OUIDE MRT TEP(N) & 198. & 164. & 1840. & 1135. & 1832. & 1830. & 1020. & 1228. \\
\hline
\end{tabular}


Table 4.3.18. (Continued)

\begin{tabular}{|c|c|c|c|c|c|c|c|}
\hline Time (minutes) & 480.0 & 500.0 & 520.0 & 540.0 & 560.0 & 580.0 & 600.0 \\
\hline Species & \multicolumn{7}{|c|}{ Percent of total aerosol source rate } \\
\hline FEO & 1.571 & 1.591 & 1.606 & 1.616 & 1.622 & 1.625 & 1.624 \\
\hline CR203 & .1281 & .1230 & .1182 & .1137 & .1093 & .1051 & .1011 \\
\hline NI & .1611 & .1618 & .1627 & .1637 & .1648 & .1661 & .1674 \\
\hline MO & $.3181 E-02$ & $.3258 E-02$ & $.3341 E-02$ & $.3429 E-02$ & $.3525 E-02$ & $.3628 E-02$ & $.3739 \mathrm{E}-02$ \\
\hline RU & $.1757 E-07$ & $.1753 E-07$ & $.1751 E-07$ & $.1752 E-07$ & $.1754 \mathrm{E}-07$ & $.1759 E-07$ & $.1764 E-07$ \\
\hline SN & 5.063 & 5.125 & 5.190 & 5.261 & 5.336 & 5.416 & 5.500 \\
\hline SB & 0. & 0. & 0. & 0. & 0. & 0. & 0. \\
\hline TE & .6820 & .8797 & .6774 & .6751 & .8727 & .6702 & .6676 \\
\hline$A G$ & 48.27 & 48.64 & 49.05 & 49.48 & 49.95 & 50.44 & 50.95 \\
\hline$M N$ & 0. & 0. & 0. & 0. & 0. & 0. & 0. \\
\hline CAO & .8617 & .8577 & .8530 & .8476 & .8415 & .8348 & .8275 \\
\hline AL203 & .1168E-01 & $.1171 E-01$ & $.1170 \mathrm{E}-01$ & $.1169 E-01$ & $.1165 E-01$ & $.1160 E-01$ & $.1154 E-01$ \\
\hline MA20 & 1.214 & 1.201 & 1.188 & 1.173 & 1.158 & 1.142 & 1.125 \\
\hline 120 & 40.06 & 39.71 & 39.32 & 38.91 & 38.46 & 37.98 & 37.48 \\
\hline $\mathrm{SI02}$ & $.3833 E-01$ & $.3811 E-01$ & $.3784 \mathrm{E}-01$ & $.3755 E-01$ & $.3721 E-01$ & $.3685 E-01$ & $.3645 E-01$ \\
\hline vo2 & 1.577 & 1.509 & 1.445 & 1.385 & 1.328 & 1.275 & 1.224 \\
\hline ZRO2 & .2512 & .2416 & .2324 & .2237 & .2153 & .2072 & .1994 \\
\hline $\operatorname{cs} 20$ & 0. & 0. & 0. & 0. & 0. & 0. & 0. \\
\hline$B A O$ & $.9668 \mathrm{E}-01$ & $.9236 E-01$ & $.8833 E-01$ & $.8455 E-01$ & $.8098 \mathrm{E}-01$ & $.7762 \mathrm{E}-01$ & $.7444 E-01$ \\
\hline SRO & $.4634 E-02$ & $.4423 E-02$ & $.4225 E-02$ & $.4040 E-02$ & $.3866 E-02$ & $.3702 \mathrm{E}-02$ & $.3547 E-02$ \\
\hline LA203 & $.4232 E-02$ & $.4071 E-02$ & $.3916 \mathrm{E}-02$ & $.3769 E-02$ & $.3627 E-02$ & $.3491 E-02$ & $.3361 E-02$ \\
\hline $\mathrm{CEO} 2$ & $.7301 E-02$ & $.7022 E-02$ & $.6756 \mathrm{E}-02$ & $.6502 \mathrm{E}-02$ & $.6257 \mathrm{E}-02$ & $.6022 \mathrm{E}-02$ & $.5797 E-02$ \\
\hline NB205 & 0. & 0 & 0. & 0. & 0. & 0. & 0. \\
\hline CSI & $.5229 E-11$ & $.5030 \mathrm{E}-11$ & $.4839 E-11$ & $.4657 \mathrm{E}-11$ & $.4482 \mathrm{E}-11$ & $.4314 E-11$ & $.4152 E-11$ \\
\hline$C D$ & 0. & 0. & 0. & 0. & 0. & 0. & 0. \\
\hline SOURCE RATE $(\mathrm{CM} / \mathrm{S})$ & 2.944 & 2.964 & 2.986 & 3.011 & 3.040 & 3.073 & 3.113 \\
\hline AERDSOL DENSITY (GM/CM3) & 3.678 & 3.697 & 3.718 & 3.741 & 3.765 & 3.792 & 3.821 \\
\hline AEROSOL SIZE(MICRON) & .2588 & .2594 & .2600 & .2605 & .2611 & .2617 & .2623 \\
\hline OXIDE MELT TEMP(K) & 1827. & 1826. & 1825. & 1825. & 1824. & 1823. & 1823. \\
\hline
\end{tabular}


Table 4.3.19. Aerosol release rate during corium-concrete interaction for Sequoyah $S_{3} H F$.

\begin{tabular}{|c|c|c|c|c|c|c|c|c|}
\hline Time (minutes) & 1.0 & 20.0 & 40.0 & 00.0 & 80.0 & 100.0 & 120.0 & 14010.0 \\
\hline \multicolumn{9}{|c|}{ Percent of total arosol source rato } \\
\hline FED & 31.54 & 10.02 & 14.05 & 13.06 & 12.77 & 15.07 & 19.42 & .7112 \\
\hline $\mathrm{CR203}$ & $.6072 E-10$ & $.3502 E-15$ & $.1550 E-14$ & $.5437 E-14$ & $.3934 E-13$ & $.6319 E-13$ & $.2320 E-12$ & 1.005 \\
\hline MI & $.9540 E-01$ & .2426 & .5731 & 1.141 & 1.369 & .9557 & .7001 & 1.448 \\
\hline 唂 & $.9916 \mathrm{E}-08$ & $.0937 E-07$ & $.3333 E-06$ & . $1004 E-05$ & $.1497 E-05$ & $.7412 \mathrm{E}-08$ & $.3820 E-10$ & .3239E-03 \\
\hline 婊 & $.7235 E-07$ & $.4982 E-06$ & $.2351 E-05$ & $.7588 E-05$ & $.1036 E-04$ & $.519 \$ E-05$ & $.2693 E-05$ & .4117E-05 \\
\hline SM & .1148 & .1820 & .3173 & .5168 & .5870 & .4880 & .3990 & 3.134 \\
\hline$\$ 8$ & 0. & 0. & 0. & 0. & 0. & 0. & 1. & 0. \\
\hline TE & TSISE-MI & $.6341 E-01$ & $.6837 E-01$ & $.7885 E-01$ & $.7918 E-11$ & $.7483 E-01$ & $.7540 E-01$ & .2034 \\
\hline AC & 11.45 & 17.00 & 21.30 & 19.77 & 19.35 & 22.64 & 29.65 & 79.50 \\
\hline M & I. & 0. & 0. & 0. & ॥. & 0. & 0. & 0. \\
\hline CAO & 0. & 3.014 & 10.99 & 10.23 & 10.01 & 11.80 & 16.26 & .2766 \\
\hline A203 & 0. & .2815 & .8389 & 1.817 & 2.400 & 1.672 & .6002 & $.0510 E-03$ \\
\hline M120 & 0. & 2.090 & 3.140 & 3.527 & 3.052 & 1.384 & .2884 & .2968 \\
\hline 120 & 0. & 12.01 & 0.455 & 8.043 & 0.042 & 10.77 & 13.35 & 6.010 \\
\hline$\$ 102$ & 0. & 16.23 & 12.41 & 12.84 & 13.47 & 14.55 & 16.73 & .9722 \\
\hline บ12 & .1580 & .2167 & .4614 & .9285 & 1.094 & .6901 & .4644 & 5.306 \\
\hline 2RO2 & $.2484 E-01$ & $.1496 E-11$ & $.1571 E-01$ & $.2250 E-01$ & $.2522 E-01$ & $.1952 E-01$ & $.1879 E-01$ & $.5163 E-01$ \\
\hline $\operatorname{cs} 20$ & 1.236 & .0840 & .0523 & .5780 & .5458 & .8725 & 0. & 0. \\
\hline AMIII & 3.124 & 2. 334 & 2.084 & 2.047 & 1.906 & 1.851 & .0127 & $.9430 E_{-01}$ \\
\hline SRO & 3.246 & 2.788 & 3.011 & 3.401 & $\$ .289$ & 2.316 & 1.038 & $.1046 E-01$ \\
\hline L203 & $.4002 E-01$ & .1410 & .4337 & 1.012 & 1.231 & .6703 & .2800 & . 1000E-01 \\
\hline CEO2 & .1701 & .4636 & 1.108 & 2.173 & 2.464 & 1.297 & .4165 & $.2437 E-02$ \\
\hline PQ205 & 1.254 & 1.239 & 3.105 & 4.326 & 3.666 & 0. & 0. & $\mathbb{0}$. \\
\hline CSI & 1.206 & 1.022 & .8312 & .4523 & .1030 & $.6771 E-12$ & .6BME-12 & $.2039 E-11$ \\
\hline$c 0$ & 42.60 & 20.55 & 15.17 & 13.45 & 12.80 & 13.31 & 0. & 0. \\
\hline SOURCE RATE(CA/S) & 5.941 & 13.41 & 21.87 & 31.09 & 163.4 & 234.5 & 132.4 & 26.22 \\
\hline AEROSOL DEISITY(CM/CMB) & 4.936 & 3.843 & 3.746 & 3.753 & 3.717 & 3.762 & 3.790 & 7.185 \\
\hline AEROSOL SIZE(UICROM) & .6802 & .0433 & 1.015 & 1.040 & 1.051 & .0906 & .0080 & .4964 \\
\hline OXIDE MลT TEM(K) & 2078. & 2236. & 2359. & 2454. & 2481. & 2414. & 2346. & 2282. \\
\hline
\end{tabular}


Table 4.3.19. (Continued)

\begin{tabular}{|c|c|c|c|c|c|c|c|c|}
\hline Tin (ninutes) & 100.0 & 100.0 & 200.0 & 220.11 & 240.0 & 260.0 & 280.0 & 300.0 \\
\hline \multicolumn{9}{|c|}{ Porcent of total aerosol source rata } \\
\hline FEd & 1.032 & 1.240 & 1.366 & 1.433 & 1.454 & 1.440 & 1.395 & 1.325 \\
\hline CR2O3 & 2.296 & 2.258 & 2.089 & 1.867 & 1.628 & 1.389 & 1.158 & .8404 \\
\hline MI & 1.253 & 1.100 & .9933 & .8992 & .210 & .7552 & .6990 & .6522 \\
\hline MO & $.2557 \mathrm{E}-03$ & $.2168 E-03$ & $.1943 E-03$ & $.1638 \mathrm{E}-03$ & $.1033 E-03$ & $.1944 E-03$ & $.2216 \mathrm{E}-03$ & $.2711 \mathrm{E}-03$ \\
\hline 戚 & $.2806 E-05$ & $.2024 E-05$ & $.1517 E-05$ & $.1171 E-05$ & $.2281 \mathrm{E}-08$ & $.7472 E-06$ & $.0137 E-06$ & $.5122 E-08$ \\
\hline SN & 3.023 & 2.958 & 2.925 & 2.920 & 2.959 & 3.037 & 3.173 & 3.392 \\
\hline so & 0. & 0. & . & 0. & 0 & 0. & t. & ก. \\
\hline TE & .2222 & .2381 & .2543 & .2682 & .2000 & .2920 & .3041 & .3150 \\
\hline$A C$ & 77.64 & 76.168 & 74.50 & 73.21 & 71.03 & 70.76 & 69.72 & 68.2 \\
\hline M & 0. & 0. & 0. & อ. & 0. & 0. & 0. & 1. \\
\hline CAO & .2916 & .3050 & .3178 & .3310 & .3756 & .3628 & .36สి & .4100 \\
\hline AL203 & $.1026 E-112$ & $.1100-02$ & $.1285 E-02$ & $.1443 E-02$ & $.1641 \mathrm{E}-02$ & $.1859 E-02$ & $.2096 \varepsilon-02$ & $.2351 E-02$ \\
\hline NA2O & .4708 & .0218 & .7425 & .8440 & .8298 & .9969 & 1.046 & 1.073 \\
\hline 120 & 0.233 & 10.34 & 12.34 & 14.20 & 18.80 & 17.41 & 16.67 & 10.65 \\
\hline 5102 & .8700 & .7814 & .6915 & .6069 & .827 & .4539 & .3849 & .3204 \\
\hline U02 & 4.471 & 3.006 & 3.504 & 3.210 & 3.022 & 2.901 & 2.852 & 2.880 \\
\hline ZRO2 & . O144E-O1 & .T097E-01 & $.0012 E-01$ & . $2888 \mathrm{E}-01$ & $.9730 E-01$ & .1054 & .1132 & .1207 \\
\hline $\operatorname{cs} 20$ & 0. & 0. & 0. & 0. & 0. & 0 & ข. & 0. \\
\hline BAO & . D005E-11 & . 2021E-01 & $.9461 E-01$ & .0307E-01 & . Q230E-01 & $.8243 E-01$ & $.8356 \mathrm{E}-01$ & $.0614 E-11$ \\
\hline SRO & $.9644 E-12$ & . O9A5E-02 & $.837 E-02$ & $.7970 E-02$ & $.7606 E-12$ & $.7316 E-02$ & $.7113 \mathrm{C}_{-02}$ & $.0990 E-02$ \\
\hline LA203 & $.1383 E-01$ & .1033E-01 & . $193 E-02$ & $.0742 E-12$ & $.6731 E-12$ & $.6012 E-02$ & $.4495 E-02$ & $.4120 E-12$ \\
\hline CEO2 & $.2394 E-12$ & $.2176 \mathrm{E}-02$ & $.2620 E-02$ & .2793E-02 & $.2902 E-12$ & $.3177 E-02$ & $.3378 E-02$ & $.3519 E-02$ \\
\hline MB205 & 0. & 0. & 0. & 0. & 2. & 0. & 1. & 0. \\
\hline CSI & $.2433 E-11$ & $.2012 E-11$ & $.3175 E-11$ & $.3523 E-11$ & $.3857 E-11$ & $.4177 E-11$ & $.4486 \mathrm{E}-11$ & . A7O4E-11 \\
\hline$C O$ & 0. & 0. & 1. & o. & 0. & 1. & 0. & 0. \\
\hline SQURCE RATE(CA/S) & 21.65 & 17.28 & 14.32 & 12.22 & 10.64 & 2.394 & 0.395 & 8.689 \\
\hline AEROSOL DENSITY (CM/CMB) & 0.741 & . 311 & 6.070 & 5.82 & 6.811 & 5.438 & 6.290 & 5.100 \\
\hline AEROSOL SIZE(MICROH) & .4690 & .4474 & .4290 & .4158 & .4021 & .3905 & .3790 & .3690 \\
\hline OXIDE MELT TEF (K) & 2250. & 2215. & 2186. & 2100. & 2138. & 2117 & 2090. & 2083. \\
\hline
\end{tabular}


Table 4.3.19. (Continued)

\begin{tabular}{|c|c|c|c|c|c|c|c|c|}
\hline Tive (rinutes) & 320.0 & 340.0 & 360.0 & 300.0 & 400.0 & 420.0 & 440.0 & 460.1 \\
\hline \multicolumn{9}{|c|}{ Percent of total aerosol source rato } \\
\hline FED & .9349 & .6892 & .6521 & .7265 & .0035 & .0744 & .9376 & .9938 \\
\hline C8203 & .4544 & .2772 & .2149 & .2047 & .1987 & .1940 & .1901 & .1868 \\
\hline HI & .3563 & .2946 & .2809 & .2643 & .2494 & .2387 & .2254 & .2164 \\
\hline & $.1641 E-03$ & $.5649 E-03$ & $.2145 E-02$ & $.2493 E-02$ & $.2587 E-02$ & $.2625 E-02$ & $.2847 E-02$ & $.2863 \mathrm{C}_{-02}$ \\
\hline M & $.1207 E-06$ & $.7599 E-07$ & $.6827 \mathrm{E}-07$ & $.5762 E_{-07}$ & $.6054 E-07$ & $.4489 E-07$ & $.4020-07$ & $.3627 E-17$ \\
\hline $\mathrm{SH}$ & 2.828 & 3.742 & 5.233 & 5.350 & 6.312 & 5.251 & 5.187 & 0.124 \\
\hline \$8 & 0. & tึ. & 0. & 0 & 0. & 0. & 0. & 0. \\
\hline TE & .4300 & .4728 & .4911 & .8002 & .5081 & .5148 & .5200 & .8283 \\
\hline AC & 59.05 & 56.17 & 56.40 & 56.34 & 64.31 & 53.37 & 82.51 & 51.71 \\
\hline m & (8). & t. & 0. & อี. & 0. & 0. & 0. & 0. \\
\hline CAO & .4502 & .8946 & .7251 & .7540 & .7712 & .7849 & .7970 & .0001 \\
\hline M203 & $.4110 E-62$ & $.5842 E-02$ & $.0403 E-02$ & $.005 a E-02$ & $.7290 E-02$ & $.7713 E-02$ & .0115E-02 & $.0504 E-02$ \\
\hline MA20 & 1. 100 & 1.333 & 1.171 & 1.175 & 1.190 & 1.205 & 1.210 & 1.231 \\
\hline 120 & 31.44 & 33.03 & 31.02 & 31.92 & 33.02 & 34.04 & 36.01 & 35.91 \\
\hline$\$ 102$ & .1330 & $.7584 E-01$ & $.5328 E-01$ & . $9804 E-01$ & $.4668 E-01$ & $.4600 E-01$ & .4370 -01 & . 4260E-01 \\
\hline 402 & 2.166 & 2.603 & 3.285 & 3.230 & 3.107 & 2.983 & 2.869 & 2.784 \\
\hline 2702 & .2286 & .2713 & .2835 & .2910 & .2980 & .3046 & .3491 &.$\$ 130$ \\
\hline $\operatorname{cs} 20$ & 0. & 1. & 0. & 0. & 0. & 0. & 0. & 0. \\
\hline Bato & $.9770 \mathrm{E}-01$ & .1272 & .1582 & .1610 & .1589 & .1679 & .1557 & .1533 \\
\hline S170 & $.6726 E-12$ & $.7716 \mathrm{E}-02$ & $.9010 E-02$ & $.0951 E-12$ & $.0746 E-02$ & $.0517 E-02$ & $.0184 E-02$ & .7970 E-12 \\
\hline LA203 & $.4501 E-02$ & $.4980 E-02$ & $.5126 \mathrm{E}-02$ & .5092E-12 & $.5054 E-02$ & $.5149 E-12$ & $.5229 E-02$ & $.8296 E-12$ \\
\hline CEO2 & $.6666 \mathrm{E}-02$ & $.7911 E-02$ & $.0287 E-02$ & $.0507 E-02$ & $.0713 E-02$ & $.0877 E-02$ & $.9014 E-02$ & $.120 E-02$ \\
\hline MB205 & a. & 0. & 0. & 0. & 0. & 0. & . & 0. \\
\hline $\operatorname{cs} 1$ & . 9083E-11 & $.1075 E-10$ & $.1124 E-10$ & $.1187 E-10$ & . 1185E-10 & $.1207 \mathrm{E}-10$ & $.1228 E-10$ & $.1241 E-10$ \\
\hline 60 & i. & 0. & 0. & 0. & 0. & 0. & 0. & 0. \\
\hline SOURCE RATE $(G / S)$ & 5.960 & 4.097 & 2.230 & 2.022 & 1.808 & 1.815 & 1.737 & 1.670 \\
\hline AEROSEL DENSITY(CH/CM3) & 4.207 & 4.090 & 4.227 & 4.163 & 4.090 & 4.024 & 3.984 & 3.910 \\
\hline AEPOSQL SIZE(MICRON) & .3100 & .2897 & .2793 & .2756 & .2728 & .2703 & .2882 & .2803 \\
\hline OXIDE WET TEMP(K) & 1968. & 1930. & 1912. & 1900. & 1900. & 1892. & 1884. & 1978. \\
\hline
\end{tabular}


Table 4.3.19. (Continued)

\begin{tabular}{|c|c|c|c|c|c|c|c|}
\hline Tino (rinutes) & 480.1 & 500.0 & 520.0 & 540.0 & 560.0 & 580.0 & 600.0 \\
\hline \multicolumn{8}{|c|}{ Percent of tobal aerosol source rate } \\
\hline FED & 1.043 & 1.080 & 1.128 & 1.184 & 1.196 & 1.226 & 1.252 \\
\hline CR203 & .1838 & .1811 & .1786 & .1783 & .1742 & .1721 & .1702 \\
\hline NI & .2083 & .1982 & .1909 & .1843 & .1783 & .1720 & .1679 \\
\hline 40 & $.2676 \mathrm{E}-02$ & $.2690 E-02$ & $.2703 E-02$ & $.2717 \mathrm{E}-02$ & $.2731 E-02$ & $.2747 E-12$ & $.2783 E-02$ \\
\hline RU & $.3294 E-07$ & $.3010 E-07$ & $.2766 E-07$ & $.2554 E-07$ & $.2389 \mathrm{E}-07$ & $.2208 E-07$ & $.2089 E-07$ \\
\hline SN & 5.065 & 5.011 & 4.960 & 4.914 & 4.871 & 4.833 & 1.799 \\
\hline SB & 0. & 0. & 0. & 0. & D. & te. & 0. \\
\hline TE & .5312 & .5367 & .5398 & .5436 & .5471 & .6504 & .5533 \\
\hline$A G$ & 50.87 & 50.20 & 10.65 & 49.06 & 48.52 & 48.03 & 47.58 \\
\hline$M$ & 0. & 0. & 0. & 0. & t. & 0. & 0. \\
\hline CAO & .8104 & .6278 & .367 & .8450 & .0528 & .0590 & .0665 \\
\hline A1203 & $.0879 E-02$ & $.8242 E-02$ & $.9591 E-02$ & $.9928 \mathrm{E}-02$ & $.1025 E-01$ & $.1058 E-01$ & $.1086 E-01$ \\
\hline NA2O & 1.241 & 1.250 & 1.258 & 1.264 & 1.260 & 1.273 & 1.276 \\
\hline ๓20 & 36.73 & 37.50 & 30.22 & 38.08 & 39.40 & 40.05 & 40.58 \\
\hline$\$ 102$ & $.4102 \mathrm{E}-01$ & $.9116 \mathrm{E}-\mathrm{DI}$ & $.4063 E-11$ & $.4022 E-01$ & $.3980 E-01$ & $.3985 E-01$ & $.3947 E-D 1$ \\
\hline 402 & 2.608 & 2.581 & 2.601 & 2.427 & 2.350 & 2.285 & 2.238 \\
\hline $2 \% 02$ & .3162 &.$\$ 180$ & .3206 & .3222 & .3232 & .3239 & .3240 \\
\hline $\operatorname{Cs} 20$ & to. & 10. & D. & 0. & 0. & 0. & 0. \\
\hline BAD & .1506 & .1483 & .1458 & .1433 & .1400 & .1384 & .1360 \\
\hline SRO & $.7769 \mathrm{E}-02$ & $.7567 E-02$ & $.7373 E-02$ & $.7185 E-02$ & $.7006 E-02$ & $.6834 E-02$ & $.6669 E-02$ \\
\hline LA203 &. .5349E-02 & $.3392 E-02$ & $.6425 E-02$ & $.5450 E-02$ & $.5487 E-02$ & $.5470 E-02$ & $.5400 \varepsilon-02$ \\
\hline CEO2 & $.0221 E-02$ & $.9295 E-02$ & $.9353 E-02$ & $.9395 E-02$ & $.0425 C-02$ & $.8443 E-02$ & $.0447 E-02$ \\
\hline MB20S & 0. & . & 0. & . & 0. & 0. & 0. \\
\hline CSI & $.1254 E-10$ & $.1264 E-10$ & $.1271 E-10$ & $.1277 E-10$ & $.1281 E-10$ & $.1284 E-10$ & $.1264 E-10$ \\
\hline $\mathrm{CD}$ & 0. & 0. & 0. & 11. & 0. & 0. & 0. \\
\hline SOUNCE RATE(ON/S) & 1.610 & 1.557 & 1.609 & 1.467 & 1.421 & 1.378 & 1.347 \\
\hline AEROSOL DEASITY(CM/CM3) & 3.681 & 8.817 & 3.777 & 3.741 & 3.708 & 3.678 & 3.652 \\
\hline AEROSOL SIZE(MICROW) & .2646 & .2830 & .2615 & .2802 & .2590 & .2570 & .2560 \\
\hline OXIDE ME.T TEMP(K) & 1871. & 1868. & 1860. & 1855. & 1850. & 1845. & 1041. \\
\hline
\end{tabular}


Table 4.3.20. Fraction of initial core inventory released from fuel prior to corium-concrete interactions Sequoyah $S_{3} B$.

\begin{tabular}{lcc}
\hline \hline Species & $\begin{array}{c}\text { Base Case } \\
S_{3^{*}}\end{array}$ & $\begin{array}{c}\text { Wet Cavity } \\
\text { Sensitivity } \\
\text { Study** }\end{array}$ \\
\hline$I$ & .99 & .99 \\
$\mathrm{CS}$ & .99 & .99 \\
$\mathrm{Te}$ & .90 & .85 \\
$\mathrm{Sr}$ & $8.1 E-04$ & $8.1 E-04$ \\
$\mathrm{Ru}$ & $1.8 E-06$ & $1.8 E-06$ \\
$\mathrm{La}$ & $3.2 E-03$ & $3.2 E-03$ \\
$\mathrm{Ce}$ & $9.4 E-15$ & $9.4 E-15$ \\
$\mathrm{Ba}$ & $1.4 E-02$ & $1.4 E-02$ \\
\hline \hline
\end{tabular}

* Corium-concrete releases do not take place until cavity water is boiled off.

* Corium-concrete releases begin under water. 
Table 4.3.21. Fraction of initial core inventory released to containment during corium-concrete interactions Sequoyah $\mathrm{S}_{3} \mathrm{~B}$.

\begin{tabular}{lccc}
\hline \hline Species & $\begin{array}{c}\text { Base } \\
\text { Case } \\
S_{38^{*}}\end{array}$ & \begin{tabular}{c} 
Wet Cavity Sensitivity Study* \\
\cline { 3 - 4 }
\end{tabular} & $\begin{array}{c}\text { Retained } \\
\text { In Water }\end{array}$ \\
\hline $\mathrm{I}$ & .00734 & .00680 & .00394 \\
$\mathrm{CS}$ & .00716 & .00605 & .00441 \\
$\mathrm{Te}$ & .0513 & .0172 & .0559 \\
$\mathrm{Sr}$ & .184 & .0946 & .0704 \\
$\mathrm{Ru}$ & $6.0 \mathrm{E}-06$ & $2.0 \mathrm{E}-07$ & $5.0 \mathrm{E}-06$ \\
$\mathrm{La}$ & .0133 & .00589 & .00393 \\
$\mathrm{Ce}$ & .0122 & .00455 & .00323 \\
$\mathrm{Ba}$ & .0878 & .0522 & .0414 \\
\hline \hline
\end{tabular}

* Corium-concrete releases do not take place until cavity water is boiled off.

* Corium-concrete releases begin under water. 
heating up prior to concrete attack. In the wet cavity case there is no delay in time between vessel failure and the start of concrete attack.

The differences in the predicted releases of iodine and cesium during corium-concrete interactions do not appear to be significant since the ex-vessel contribution to the total environmental releases for these species are small. The predicted releases of tellurium during corium-concrete interactions in the two cases are quite comparable, apparently because in the wet cavity case a significant portion of the total tellurium release takes place after the water is evaporated. The releases of the nonvolatile species during corium-concrete interactions in the wet cavity case are lower than in the base case due to the predicted water scrubbing. The differences are only of the order of a factor of 2 or 3 , however. As has been previously noted, these calculated results do not take into account the possible reevolution of the scrubbed species as the water is evaporated.

\subsubsection{Radionuclide Release and Transport}

Transport in and release from the RCS of radionuclide and structural materials was calculated with the TRAPMELT3 code described in Section 2.1. The release from the RCS (and corium-concrete interaction) define the aerosol source term to the containment.

\subsubsection{Results: Transport in the Reactor Coolant System}

\section{Sequoyah $S_{3} B$}

In the $S_{3} B$ sequence (sma11 LOCA) the reactor coolant system is at intermediate pressure (640 psi) during most of the sequence. Pressure plays a role in mass transfer principally in its effect on boundary layer transport and on linear velocities through the system. It is important to keep in mind, in interpreting the calculated results, that pressure can vary over two orders of magnitude. At $640 \mathrm{psi}$ it is likely that the chemical kinetics of $\mathrm{CsOH}$ reaction with stainless steel surfaces is the limiting rate, while mass transport through the boundard layer is the limiting rate for Te adsorption. 
Table 4.3.22 provides the time-dependent release from fuel and deposition within the RCS of the three volatile fission product species (CSI, $\mathrm{CsOH}$, and $\mathrm{Te}$ ) and for control rod and structural material aerosol. At the time of vessel failure (i.e., completion of the in-vessel period) 46 percent of $\mathrm{CsI}, 53$ percent of $\mathrm{CsOH}_{2} 90$ percent of $\mathrm{Te}$, and 54 percent of the aerosol material released from the fuel have been retained on RCS surfaces. Note the evidence of slight revolatilization at the time of bottom head heatup (464.3 minutes) (RET for CSI and CSOH decreases slightly) and at the end of the invessel period. Te does not show this phenomenon because it is retained largely by irreversible chemical bonding to the stainless steel surfaces of the RCS. Aerosol particles are assumed to be irreversibly deposited on surfaces.

Table 4.3 .23 indicates the total quantities of material released from fuel and retained on RCS surfaces at the end of the in-vessel period for each of the elemental release groups.

Figures 4.3 .58 through 4.3 .61 provide a more detailed view of the transport behavior of the volatile fission products and refractory materials ("aerosol") as a function of time. (Note that the volatile materials transport to a large degree as condensate on aerosol particles.) Several characteristics deserve special attention. One is, of course, the decrease of the source to essentially zero release with slump of the core into the residual water of the lower head. Another is the importance of the steam generators in retaining transported material and to a lesser degree, the upper plenum for CSI, CsOH, and aerosol. The upper plenum plays a greater role for $\mathrm{CsOH}$ because, unlike CSI, it can chemisorb irreversibly to surfaces there. Te chemisorbs to a much greater degree and hence is captured largely at its first encounter with large surface areas -- the upper plenum. Figure 4.3 .60 thus shows the upper plenum to be the dominant retainer for $\mathrm{Te}$.

Table 4.3 .24 gives the relative particle size distribution of material released from the RCS to the containment. Twenty-six equi-spaced time edits are given. That resolution is sufficient to clearly show the growth of particles to the time of core slump and the sudden reversal to primary size as the mass concentration in the RCS decreases due to reduction of source from fuel and increase inflow rates (reduction in residence times). At the end of the in-vessel period, the residual airborne material in the RCS is assumed to 
Table 4.3.22. Masses of dominant species released from fuel and retained on RCS structures as functions of time for the Sequoyah $S_{3} B$ sequence.

(Time $=0.0$ corresponds to start of accident)

\begin{tabular}{|c|c|c|c|c|c|c|c|c|}
\hline \multirow[b]{2}{*}{$\begin{array}{c}\text { Time } \\
(M)\end{array}$} & \multicolumn{2}{|c|}{ CsI } & \multicolumn{2}{|c|}{$\mathrm{CsOH}$} & \multicolumn{2}{|c|}{$\mathrm{Te}$} & \multicolumn{2}{|c|}{ Aerosol } \\
\hline & $\begin{array}{l}\text { Ret } \\
(\mathrm{Kg})\end{array}$ & $\begin{array}{l}\text { Total } \\
(\mathrm{Kg})\end{array}$ & $\begin{array}{l}\text { Ret } \\
(\mathrm{Kg})\end{array}$ & $\begin{array}{c}\text { Tota } \\
(\mathrm{Kg})\end{array}$ & $\begin{array}{l}\operatorname{Ret} \\
(\mathrm{Kg})\end{array}$ & $\begin{array}{c}\text { Total } \\
(\mathrm{kg})\end{array}$ & $\begin{array}{l}\text { Ret } \\
(\mathrm{kg})\end{array}$ & $\begin{array}{c}\text { Total } \\
(\mathrm{kg})\end{array}$ \\
\hline $\begin{array}{l}429.5 \\
433.8 \\
438.0 \\
442.2 \\
446.4 \\
450.7 \\
454.9 \\
459.1 \\
463.3 \\
467.6 \\
471.8 \\
476.0 \\
480.2 \\
484.5 \\
488.7 \\
492.9 \\
497.1 \\
501.4 \\
505.6 \\
509.8\end{array}$ & $\begin{array}{r}.1 \\
.1 \\
.9 \\
3.9 \\
8.2 \\
11.6 \\
13.8 \\
12.7 \\
14.3 \\
14.1 \\
14.1 \\
14.1 \\
14.1 \\
14.1 \\
14.1 \\
14.2 \\
14.2 \\
14.2 \\
14.2 \\
14.1\end{array}$ & $\begin{array}{r}.2 \\
.3 \\
4.0 \\
9.6 \\
15.5 \\
20.7 \\
24.8 \\
27.7 \\
30.1 \\
30.1 \\
30.2 \\
30.2 \\
30.2 \\
30.2 \\
30.3 \\
30.3 \\
30.4 \\
30.5 \\
30.7 \\
30.8\end{array}$ & $\begin{array}{r}1.0 \\
1.6 \\
6.7 \\
25.3 \\
50.9 \\
76.5 \\
91.1 \\
91.6 \\
100.2 \\
99.2 \\
99.0 \\
99.0 \\
99.1 \\
99.2 \\
99.3 \\
99.5 \\
99.7 \\
99.9 \\
100.0 \\
99.9\end{array}$ & $\begin{array}{r}2.7 \\
4.2 \\
26.4 \\
60.1 \\
95.5 \\
127.6 \\
151.9 \\
169.6 \\
184.2 \\
184.7 \\
184.7 \\
184.8 \\
184.9 \\
185.1 \\
185.4 \\
185.7 \\
186.3 \\
186.9 \\
187.7 \\
188.4\end{array}$ & $\begin{array}{r}.0 \\
.0 \\
.3 \\
2.5 \\
7.1 \\
12.8 \\
17.5 \\
21.0 \\
24.0 \\
24.1 \\
24.1 \\
24.2 \\
24.2 \\
24.2 \\
24.2 \\
24.2 \\
24.3 \\
24.3 \\
24.4 \\
24.5\end{array}$ & $\begin{array}{r}.0 \\
.0 \\
.7 \\
3.6 \\
9.3 \\
15.5 \\
20.1 \\
23.7 \\
26.7 \\
26.7 \\
26.7 \\
26.7 \\
26.7 \\
26.8 \\
26.8 \\
26.8 \\
26.9 \\
26.9 \\
27.0 \\
27.1\end{array}$ & $\begin{array}{r}.0 \\
.5 \\
12.8 \\
34.4 \\
65.4 \\
95.6 \\
127.5 \\
157.0 \\
227.1 \\
229.7 \\
229.7 \\
229.7 \\
229.7 \\
229.7 \\
229.7 \\
229.7 \\
229.8 \\
229.8 \\
230.0 \\
230.3\end{array}$ & $\begin{array}{r}.0 \\
17.0 \\
50.0 \\
87.9 \\
135.5 \\
185.4 \\
236.9 \\
288.7 \\
419.9 \\
420.3 \\
420.3 \\
420.4 \\
420.4 \\
420.6 \\
420.8 \\
421.2 \\
421.9 \\
423.1 \\
425.0 \\
427.6\end{array}$ \\
\hline
\end{tabular}


Table 4.3.23. Masses of radionuclides released from fuel and retained by RCS (by group) for the Sequoyah $S_{3} B$ sequence at the time of reactor vessel failure ( 509.8 minutes).

\begin{tabular}{lrr}
\hline Group & $\begin{array}{c}\text { Released } \\
(\mathrm{Kg})\end{array}$ & $\begin{array}{r}\text { Retained } \\
(\mathrm{Kg})\end{array}$ \\
\hline $\mathrm{I}$ & 15.0 & 6.9 \\
$\mathrm{Cs}$ & 182.8 & 95.9 \\
$\mathrm{Te}$ & 27.1 & 24.5 \\
$\mathrm{Sr}$ & .0 & .0 \\
$\mathrm{Ru}$ & .0 & .0 \\
$\mathrm{La}$ & .0 & .0 \\
$\mathrm{Ng}$ & 343.5 & .0 \\
$\mathrm{Ce}$ & .0 & .0 \\
$\mathrm{Ba}$ & 1.1 & .6 \\
\hline \hline
\end{tabular}




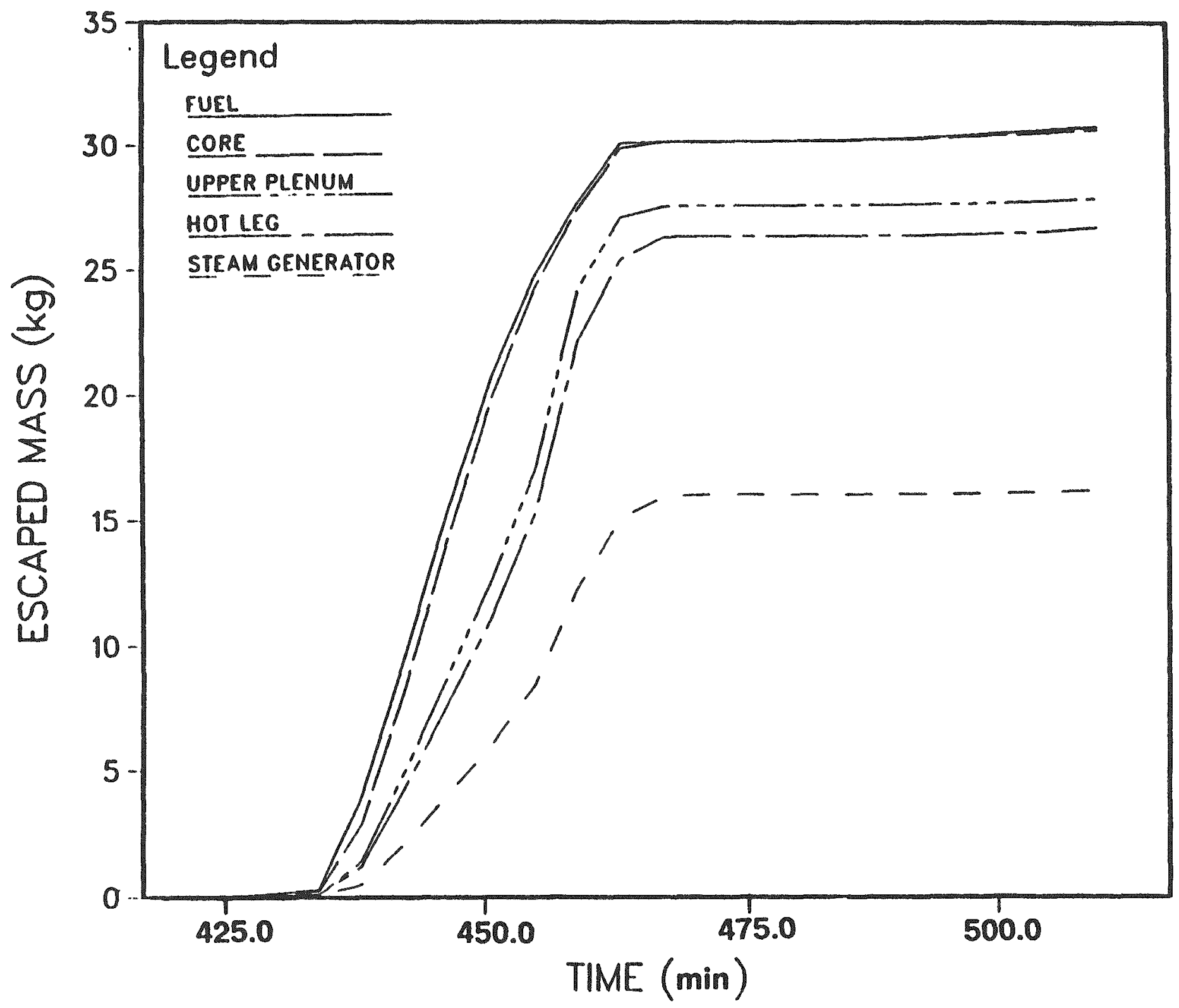

Figure 4.3.58. Mass of CSI released from indicated RCS components as a function of time - Sequoyah $S_{3} B$. 


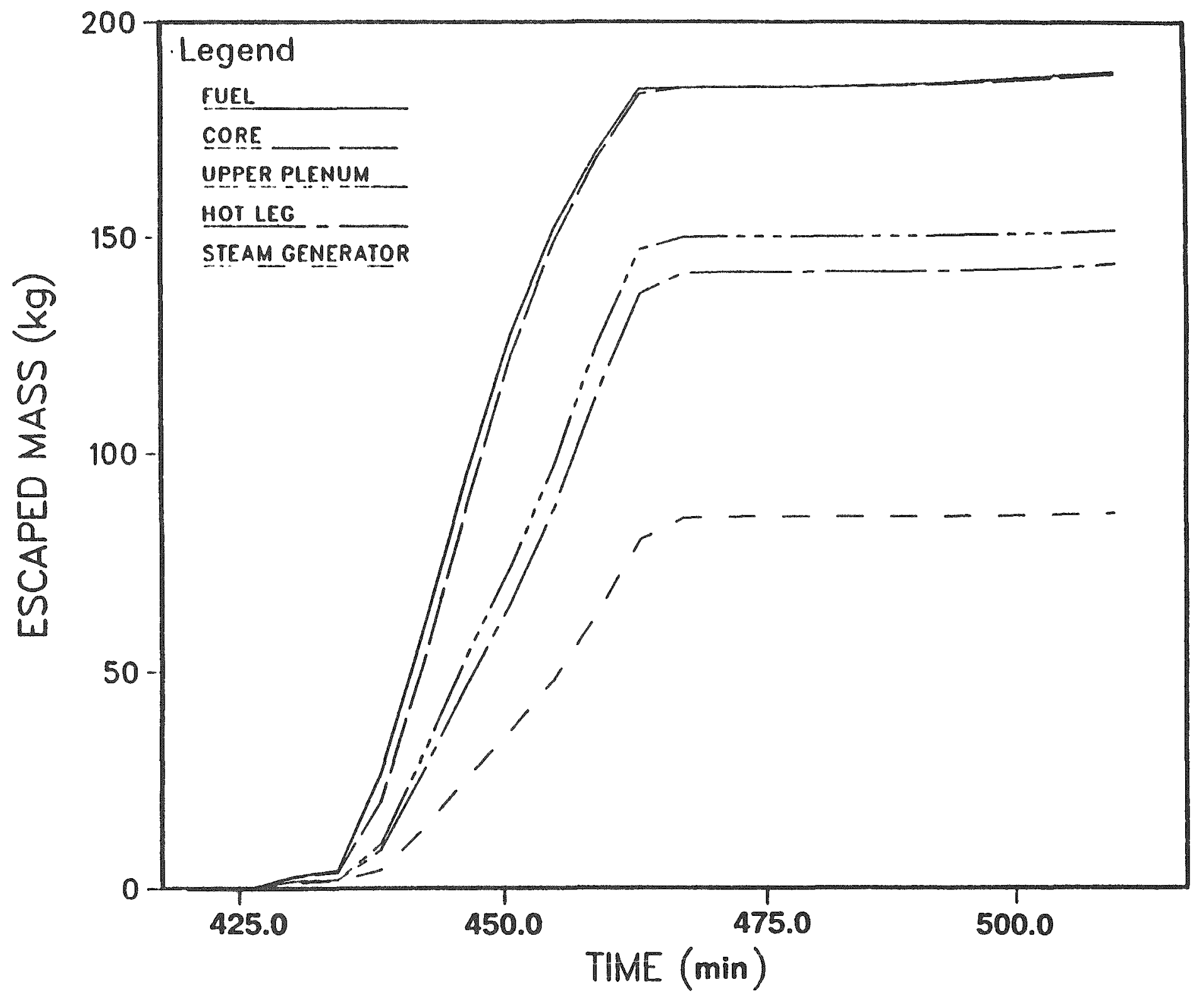

Fiqure 4.3.59. Mass of $\mathrm{CSOH}$ released from indicated RCS components as a function of time - Sequoyah $S_{3} B$. 


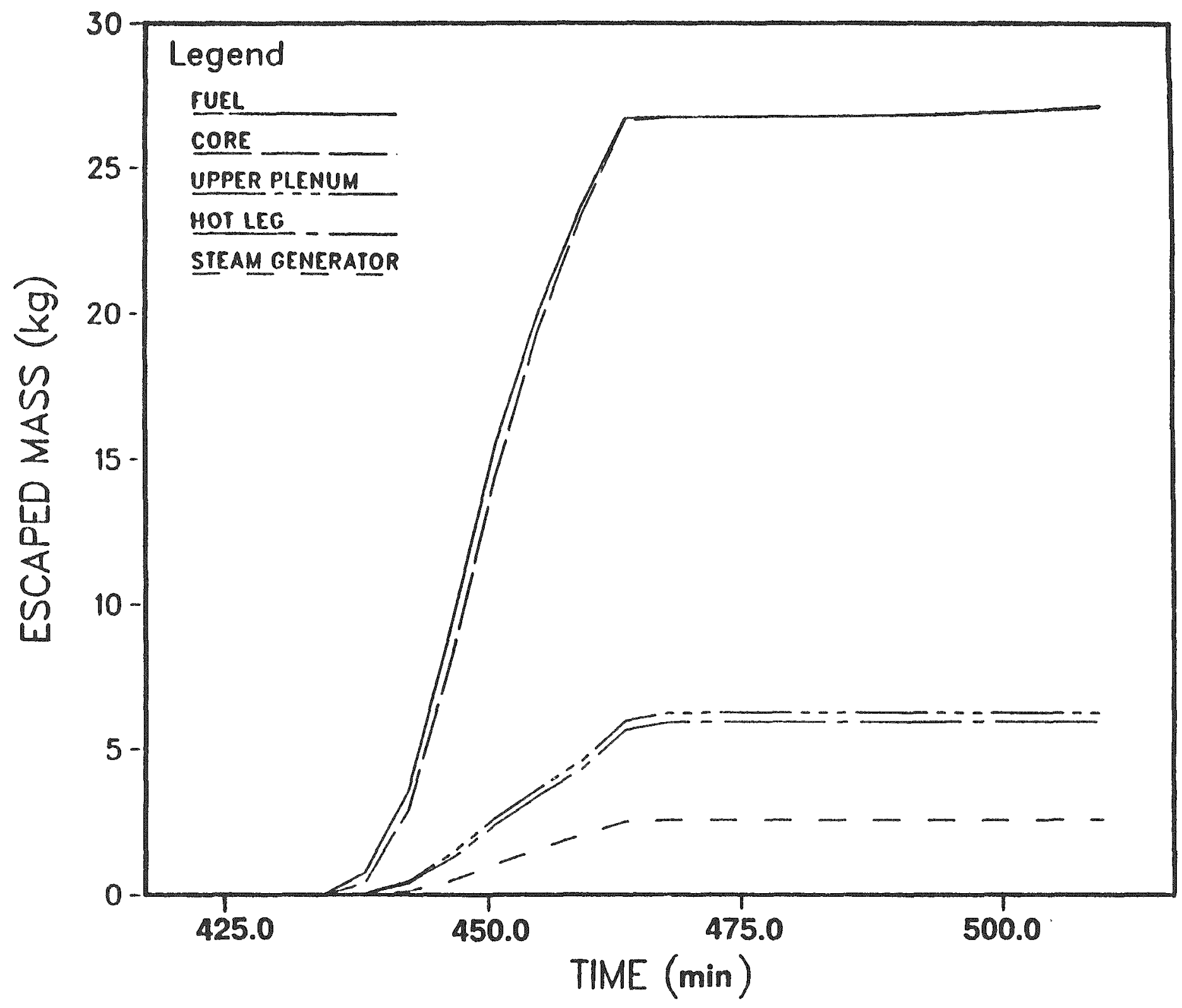

Figure 4.3.60. Mass of Te released from indicated RCS components as a function of time - Sequoyah $S_{3} B$. 


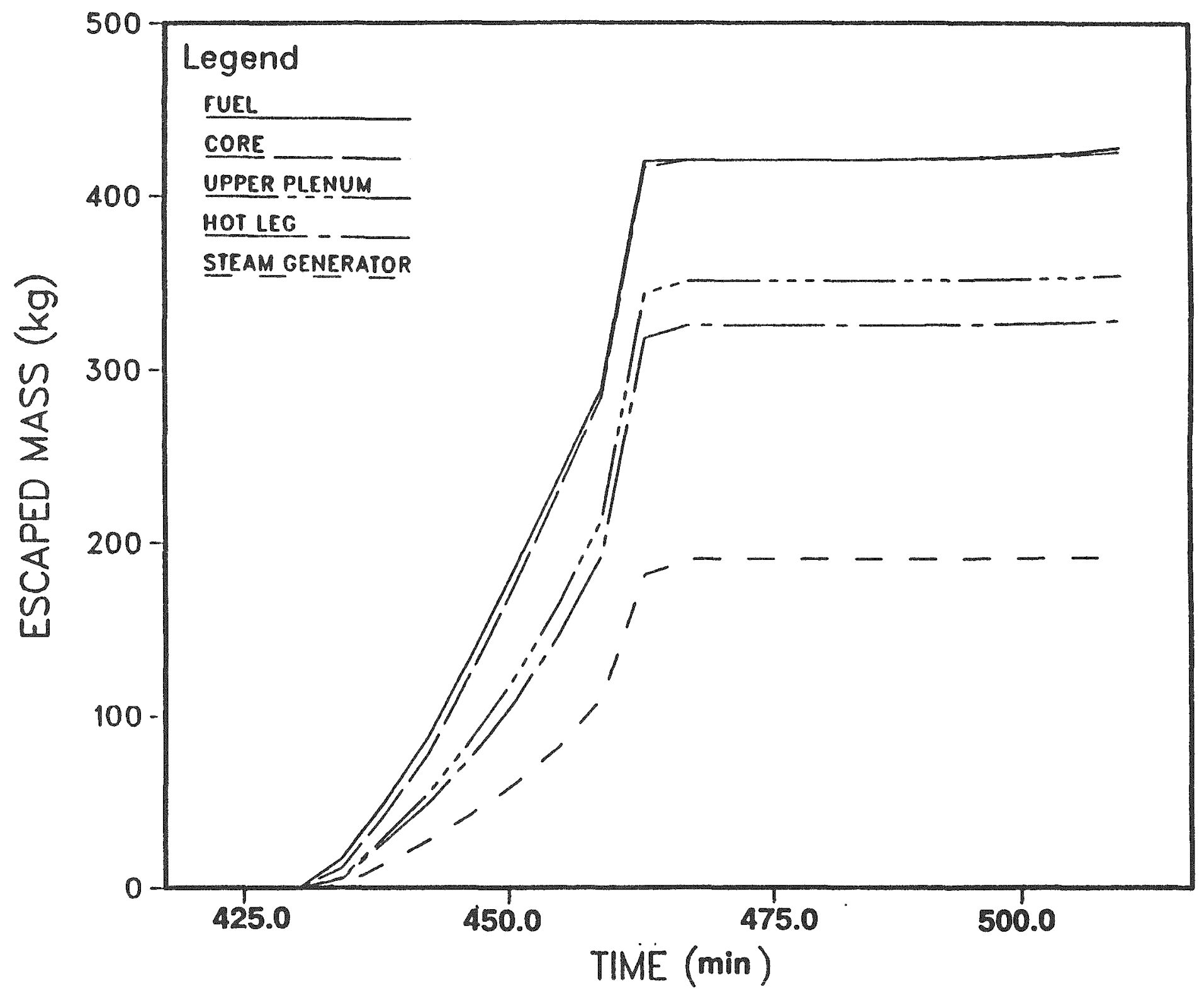

Figure 4.3.61. Mass of aerosol released from indicated RCS components as a function of time - Sequoyah $S_{3} B$. 
Table 0.3 .24 . Particle size distributions (relative number by diameter) of material released to the containment from the RCS at 26 oqui-spaced times throughout the in-vessel period - Sequoyah S3B.

\begin{tabular}{|c|c|c|c|c|c|c|c|c|c|c|c|c|c|}
\hline in) & 428.3 & 431.7 & 435.0 & 438.3 & 441.7 & 445.0 & 448.3 & 451.7 & 455.0 & 458.3 & 461.7 & 465.0 & 466.7 \\
\hline 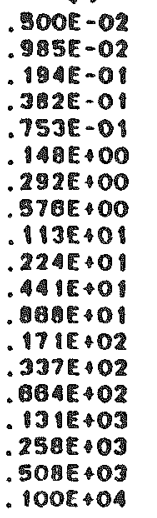 & 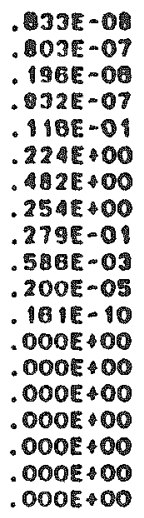 & $\begin{array}{l}.158 E-07 \\
.236 E-05 \\
.328 E-04 \\
.555 E-03 \\
.772 E-01 \\
.302 E+00 \\
.390 E+00 \\
.203 E+00 \\
.284 E-01 \\
.723 E-09 \\
.354 E-05 \\
.179 E-10 \\
.220 E-14 \\
.320 E-11 \\
.868 E-23 \\
.170 E-27 \\
.175 E-33 \\
.000 E+00 \\
.000 E+00\end{array}$ & 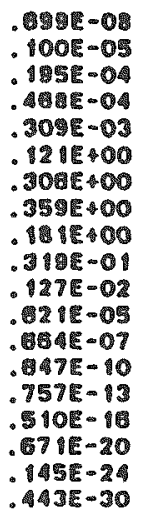 & 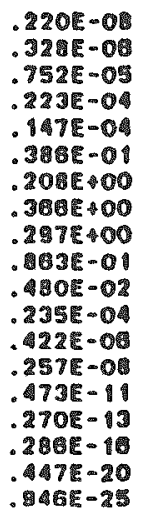 & 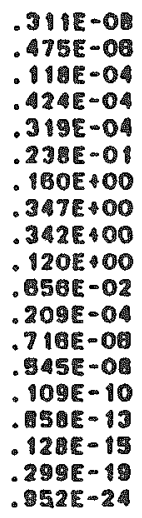 & 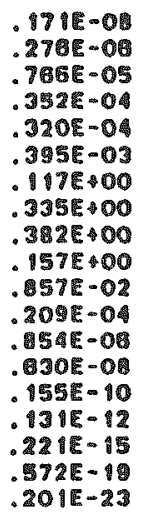 & 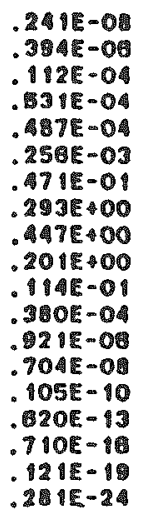 & $\begin{array}{l}.242 E-0 E \\
.397 E-08 \\
.114 E-01 \\
.520 E-04 \\
.100 E-03 \\
.200 E-03 \\
.335 E-01 \\
.24 B E+00 \\
.489 E+00 \\
.218 E+00 \\
.113 E-01 \\
.2218-04 \\
.775 E-00 \\
.710 E-08 \\
.730 E-11 \\
.359 E-13 \\
.311 E-16 \\
.393 E-20 \\
.397 E-25\end{array}$ & $\begin{array}{r}.359 E-00 \\
.592 E-00 \\
.171 E-04 \\
.142 E-04 \\
.150 E-03 \\
.141 E-02 \\
.322 E-01 \\
.197 E+00 \\
.509 E+00 \\
.258 E+00 \\
.121 E-08 \\
.303 E-04 \\
.172 E-00 \\
.947 E-08 \\
.763 E-11 \\
.337 E-13 \\
.255 E-10 \\
.279 E-20 \\
.408 E-25\end{array}$ & 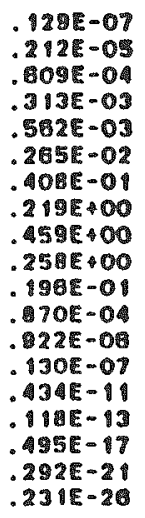 & 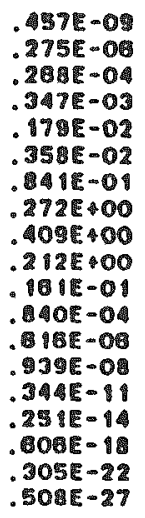 & 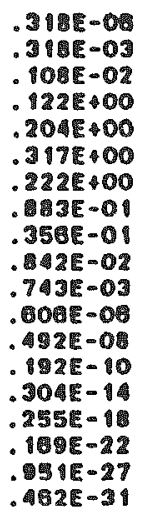 & $\begin{array}{l}.394 E-03 \\
.277 E-02 \\
.580 E-01 \\
.144 E+00 \\
.279 E+00 \\
.309 E+00 \\
.189 E-00 \\
.350 E-01 \\
.239 E-02 \\
.967 E-04 \\
.122 E-03 \\
.139 E-09 \\
.104 E-12 \\
.25 A E-17 \\
.238 E-23 \\
.059 E-30 \\
.176 E-30 \\
.000 E-00 \\
.000 E+00\end{array}$ \\
\hline & 470.0 & 473.3 & 476.8 & 480.0 & 483.3 & 86.7 & 90.0 & 493.3 & 496.7 & 500.0 & 503.3 & 506.7 & 510.0 \\
\hline 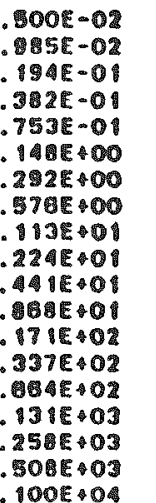 & 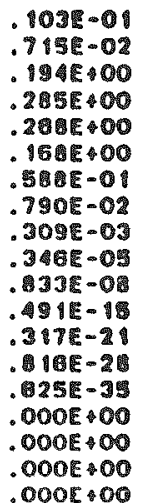 & 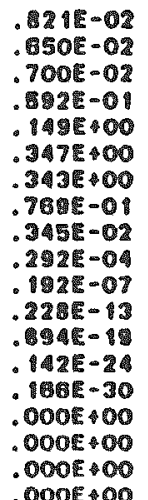 & 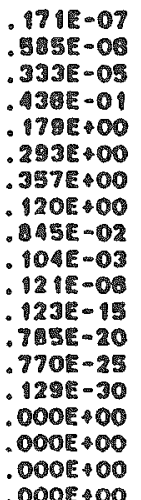 & 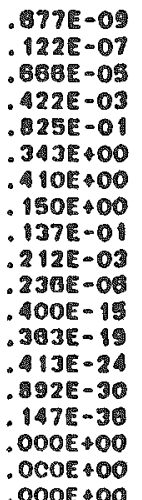 & 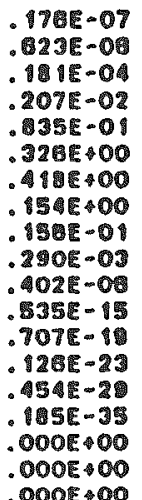 & 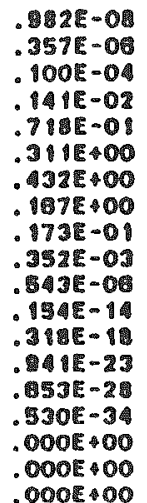 & 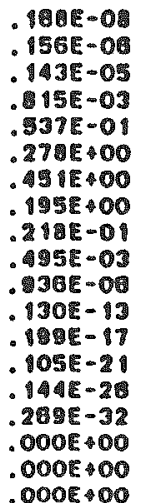 & 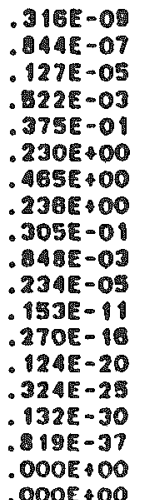 & 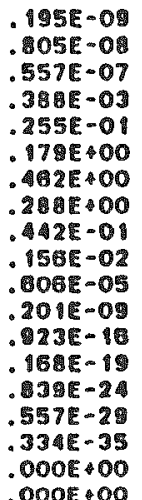 & 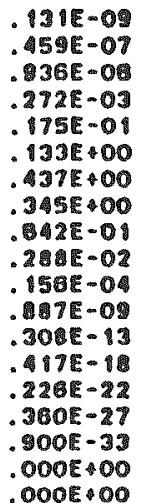 & 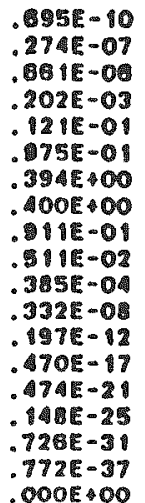 & 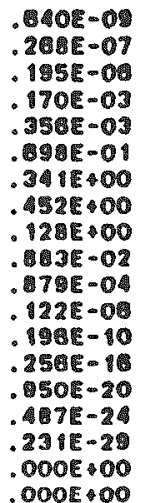 & 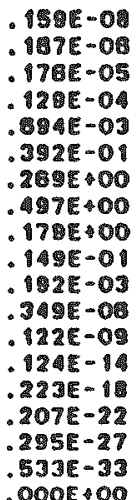 \\
\hline
\end{tabular}


be transported directly to the containment. An arbitrary period of 2 minutes and a constant flow rate of $63.5 \mathrm{~g} / \mathrm{sec}$ are assumed.

\section{Sequoyah $\mathrm{S}_{3} \mathrm{HF}$}

The general thermal hydraulic behavior of RCS, and likewise the invessel transport and release of radionuclides, for this scenario is similar to that for the $S_{3} B$, and the TRAPMELT3 results from the $S_{3} B$ analys is were utilized to represent the $S_{3} H F$ RCS transport and release. The way in which this was accomplished is discussed below.

The in-vessel period of the $S_{3} B$ sequence occurs from 362 minutes to 509 minutes and that for the $S_{3} H F$ from 274 minutes to 427 minutes. The in-vesse time period is therefore roughly the same, 2-1/2 hours, for both sequences. They differ basically in that the decay heat for the $S_{3} H F$ sequence is higher and the system pressure is roughly double that of the S3B sequence. These two factors will affect fission product transport, but because of the minor role of RCS fission product behavior in the activity release from containment for the $S_{3} H F$ sequence (containment failure is predicted 12 hours after the in-vessel release period), it was considered a justifiable expedient to utilize the calculated in-vessel events of the $S_{3} B$ sequence.

To do so, the source rate to containment file generated by TRAPMELT3 for each TRAPMELT3 time step was modified to reflect the new times from initiation of accident and the time period at that rate. The latter change required a small proportional change in rates of release in order to conserve total releases. These changes are reflected in Table 4.3 .25 which corresponds to Table 4.3.24 for the $S_{3} B$ sequence. $A 11$ other figures and tables exhibited for the $S_{3} B$ sequence, therefore, carry over for the $S_{3} H F$ sequence with appropriate changes in the indicated times. 
Tab le 4.3.25. Particle size distributions (relative number by diameter) of material released to the containment from the RCS at 26 equi-spaced times throughout the in-vessel period - Sequoyah S3HF.

\begin{tabular}{|c|c|c|c|c|c|c|c|c|c|c|c|c|c|}
\hline $\begin{array}{c}\text { Timo(Min) } \\
\mathrm{D}(\mathrm{s})\end{array}$ & 365.0 & 68.7 & 370.0 & 373.3 & 375.0 & 78.3 & 80.0 & 383.3 & 385.0 & 388.3 & 390.0 & 393.3 & 95.0 \\
\hline & & 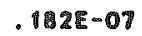 & 83 & 248 & .3 & & $\infty$ & - & 80 & 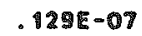 & 4 & . & \\
\hline & & & อฮ & & & & & & & & & & \\
\hline 194 & .198 & $.323 E-04$ & .79E-05 & .784 & .11 & .75 & .110 & 11 & OA & & & & \\
\hline & .844 & $.621 \mathrm{E}-03$ & $.333 E-04$ & .22 & .42 & .34 & $.523 E$ & .92 & 04 & .31 & 34 & 12 & 100 \\
\hline & & 76 & .23 & .148 & .318 & .31 & .482 & & 3 & .58 & & & \\
\hline & .223 & 300 & .12 & .30 & .241 & .4 & .277 & & .14 & & & & \\
\hline & .482 & $.391 E+00$ & $.306 \mathrm{E}$ & .208 & .18 & .118 & .47 & .33 & .32 & .40 & 04 & & 00 \\
\hline 78 & .25 & .2005 & .358 & .36 & .34 & $.33 !$ & & .24 & & & 27 & & \\
\hline & & & & & & & & & & & & & \\
\hline & .5916 & $.732 \mathrm{E}-03$ & $.320 E-01$ & .86 & .120 & .15 & .20 & .21 & .25 & .25 & .2 & 2 & 04 \\
\hline & .203 & .359 & .128 & .478 & .09 & .5 & .11 & .112 & & & & & \\
\hline 800 & & .2 & .38 & & & .20 & .33 & .213 & .30 & & & . 60 & \\
\hline .171 & .000 & .259 & .688 & & & & & & & & & & 0 \\
\hline 3 & .00 & .37 & .86 & .23 & .523 & .01 & .87 & .80 & .9 & .13 & .93 & .19 & \\
\hline 604 & .000 & .107 & .986 & .402 & .1095 & .1558 & .1008 & .72 & .762 & .43 & .34 & .30 & .23 \\
\hline & & $.219 E$ & $.6818-18$ & $.261 E-13$ & $.8978-13$ & $.130 E$ & .8016 & .358 & .337 & & & .25 & .658 \\
\hline & $.000 E+00$ & $.63 A E-33$ & .121 & $.271 E-18$ & & & & & & & & & \\
\hline & .000 & .00 & $.586 \mathrm{E}$ & .4 & .30 & .50 & & & & & & & \\
\hline 10OE 404 & $.000 E+00$ & $.000 \mathrm{E} \leftrightarrow 00$ & $.1045-28$ & .8035 & $.051 E$ & $.190 \mathrm{E}-23$ & $.313 E-24$ & $.660 \mathrm{E}-25$ & .408 & 26 & $.508 E-27$ & $2 E-3 i$ & 0 \\
\hline
\end{tabular}

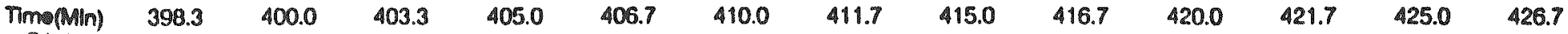

$.500 \mathrm{E}-02$

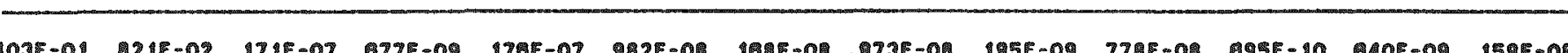

TISE-01

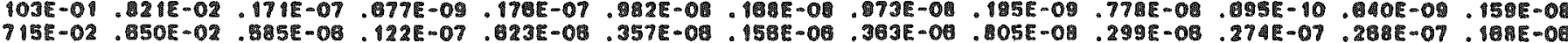

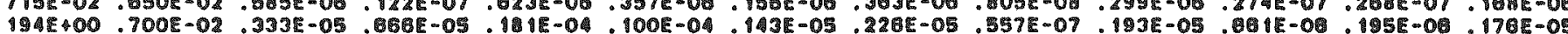

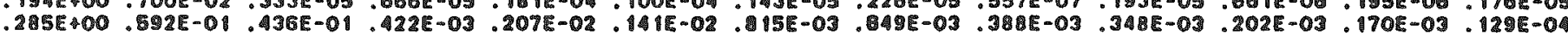

$.7535-01$

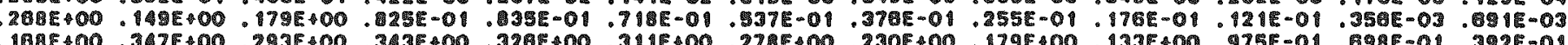

14 月

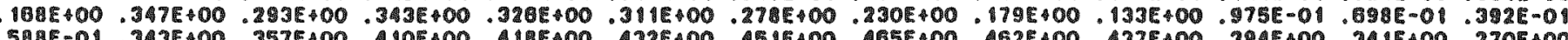

292400

(1)

1)

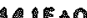

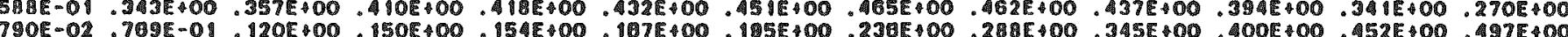

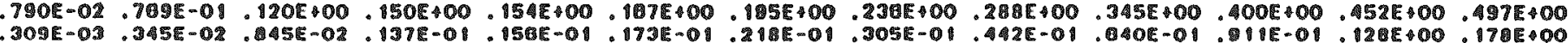

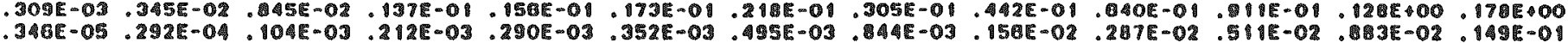

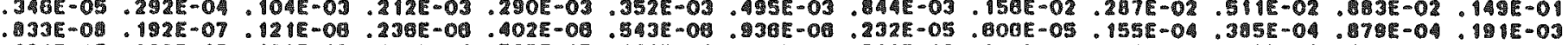

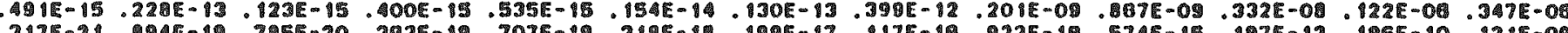

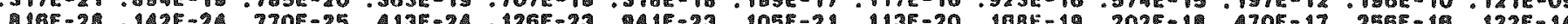
$.025 \mathrm{E}-35000$

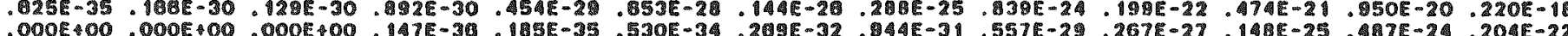

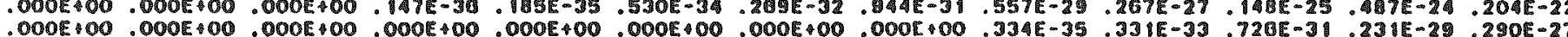

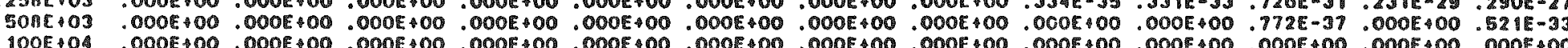




\subsubsection{Results: Transport in the Containment}

\section{Sequoyah $S_{3} B$}

In the S3B scenario, fission products are released from the RCS and corium-concrete interactions into the lower compartment. Containment failure occurs before reactor vessel failure. As discussed previously, containment failure is assumed to occur in the ice condenser upper plenum, and it was further assumed that when the containment fails, no ice is available for scrubbing the fission products (i.e., the detonation events causes extensive damage to the ice condenser).

Table 4.3.26 summarizes the various sources of radionuclides to the containment. The fraction of the core inventory released from the lower compartment to the environment is shown in Table 4.3.27 for each of the fission product groups. Table 4.3 .28 provides the time-dependent size distribution for aerosols released from containment. Table 4.3 .29 presents the locational distribution of each fission product group after the scenario is completed. As can be seen in Table 4.3.29, a substantial amount of volatile fission products such as I and Cs are released into the environment reflecting the effects of early containment failure and the diminished role of the ice condenser in scrubbing fission products in this scenario.

\section{Sequoyah $\mathrm{S}_{3} \mathrm{HF}$}

In the $S_{3} H F$ accident scenario, fission products are released into the environment from the upper compartment. Unlike the $S_{3} B$ sequence, the containment fails after reactor vessel failure but substantially before all reactor cavity water is boiled off. Table 4.3 .30 summarizes the various sources of radionuclides to the containment. The fraction of the initial core inventory transported from the lower-to-upper compartment is given in Table 4.3.31 and the aerosol size distribution for this material is given in Table 4.3.32. The fraction of the core inventory released to the environment from the upper compartment is listed in Table 4.3 .33 and the aerosol size distribution for this material is given in Table 4.3.34. Table 4.3.35 
Table 4.3.26. Fraction of initial core inventory released to containment - Sequoyah $S_{3} B$.

\begin{tabular}{clll}
\hline \hline Group & $\begin{array}{c}\text { During } \\
\text { In-Vesse } \\
\text { Release }\end{array}$ & \multicolumn{1}{c}{$\begin{array}{c}\text { During } \\
\text { Puff } \\
\text { Release }\end{array}$} & $\begin{array}{c}\text { During } \\
\text { Core-Concrete } \\
\text { Attack }\end{array}$ \\
\hline $\mathrm{I}$ & 0.5218 & $1.3327 \mathrm{E}-02$ & $7.3445 \mathrm{E}-03$ \\
$\mathrm{Cs}$ & 0.4602 & $1.0371 \mathrm{E}-02$ & $7.1574 \mathrm{E}-03$ \\
$\mathrm{Pi}$ & $1.4120 \mathrm{E}-03$ & $3.8483 \mathrm{E}-05$ & 0.0 \\
$\mathrm{Te}$ & $8.1535 \mathrm{E}-02$ & $1.0824 \mathrm{E}-03$ & $5.1347 \mathrm{E}-02$ \\
$\mathrm{Sr}$ & $3.6825 \mathrm{E}-04$ & $6.1094 \mathrm{E}-06$ & $1.8443 \mathrm{E}-01$ \\
$\mathrm{Ru}$ & $8.2671 \mathrm{E}-07$ & $3.1245 \mathrm{E}-09$ & $5.8072 \mathrm{E}-06$ \\
$\mathrm{La}$ & $1.0577 \mathrm{E}-07$ & $7.8948 \mathrm{E}-11$ & $1.3329 \mathrm{E}-02$ \\
$\mathrm{Ng}$ & 0.9770 & $1.2421 \mathrm{E}-02$ & 0.0 \\
$\mathrm{Ce}$ & 0.0 & 0.0 & $1.2210 \mathrm{E}-02$ \\
$\mathrm{Ba}$ & $6.4050 \mathrm{E}-03$ & $2.0507 \mathrm{E}-04$ & $9.7829 \mathrm{E}-02$ \\
\hline
\end{tabular}


Table 4.3.27. Fraction of core inventory released from the lower compartment to environment - Sequoyah $S_{3} B$.

\begin{tabular}{|c|c|c|c|c|c|c|c|c|c|c|c|}
\hline \multirow{2}{*}{$\begin{array}{l}\text { Timo } \\
\text { (M) }\end{array}$} & \multirow[b]{2}{*}{ 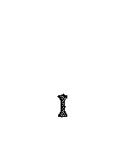 } & \multirow[b]{2}{*}{ cs } & \multirow[b]{2}{*}{ PI } & \multirow[b]{2}{*}{ TE } & \multicolumn{3}{|c|}{ Fission Product Group } & \multirow[b]{2}{*}{ CE } & \multirow[b]{2}{*}{ Ba } & \multirow[b]{2}{*}{$P E$} & \multirow[b]{2}{*}{ TR } \\
\hline & & & & & $\$ R$ & Re & LA & & & & \\
\hline 488.0 & $3.15 E-01$ & 2.73E-01 & $0.18 E-04$ & 4. $99 E-02$ & 2.60E-04 & 6.04E-07 & 0.04E-08 & 0.0 & $4.46 E-03$ & 0.0 & 0.0 \\
\hline 488.0 & 3.57E-01 & $3.10 E-01$ & 1.04E-03 & $5.01 E-02$ & $2.84 E-04$ & 6.85E-07 & 8.17E-08 & 0.0 & $6.03 E-03$ & 0.0 & 0.0 \\
\hline 610.0 & 3. $62 \mathrm{E}-01$ & $3.14 E-01$ & 1.05E-03 & 6.68E-02 & $2.86 E-04$ & $6.21 \mathrm{E}-07$ & $0.26 \mathrm{E}-08$ & 0.0 & $6.08 E-03$ & 0.0 & 1. $18 \mathrm{E}-103$ \\
\hline 500.0 & 3. $87 \mathrm{E}-01$ & $3.18 \mathrm{E}-111$ & 1.08E-03 & B. $22 E-02$ & $2.09 E-04$ & $6.22 E-07$ & $0.26 \mathrm{E}-108$ & 0.0 & $5.16 \mathrm{E}-03$ & 0.0 & 8.60E-01 \\
\hline 800.0 & 3.67E-01 & $3.18 E-01$ & 1.06E-03 & 6.06E-02 & $2.99 E-04$ & $6.82 E-07$ & $9.28 \mathrm{E}-08$ & 0.0 & $5.16 \mathrm{E}-03$ & 0.0 & 8.70E-01 \\
\hline 260.0 & $3.67 E-01$ & $3.18 E-11$ & 1.06E-03 & 5. $85 E-02$ & $2.90 E-14$ & 6.22E-07 & 0.28E-18 & 0.0 & $5.16 \mathrm{E}-0$. & 0.0 & 3.70E-01 \\
\hline 700.0 & 3.73E-01 & $3.23 E-111$ & 1.07E-103 & 1.37E-02 & 1.01E-01 & $8.01 E-07$ & $7.78 E-03$ & $6.68 E-03$ & $5.00 E-02$ & 2900.0 & 8.7बE-01 \\
\hline 200.0 & $3.73 E-01$ & 3.24E-11 & $1.07 E_{-03}$ & $9.63 E-82$ & $1.25 E-01$ & $1.37 E-06$ & $0.19 E-03$ & $8.30 E-03$ & $7.01 E-02$ & 4860.1 & 8.00E-01 \\
\hline 1000.0 & $3.73 E-01$ & $3.24 E-01$ & $1.07 E-03$ & 1. DIE-01 & 1.26E-D1 & $2.75 \varepsilon-16$ & $0.25 E-03$ & (6.37E-13 & $7.12 E-02$ & 48800.0 & 3.86E-01 \\
\hline 1501.1 & $3.78 E-01$ & $3.24 E-01$ & 1.07E-03 & $1.12 E-01$ & $1.26 \mathrm{E}-111$ & $8.42 E-106$ & $0.4 \mathrm{DE}-03$ & $8.50 E-03$ & 7.17E-02 & 8380.0 & 8.10E-01 \\
\hline
\end{tabular}


Table 4.3.28. Size distribution of aerosols in the lower compartment - Sequoyah $\mathbf{S}_{3} \mathrm{~B}$.

\begin{tabular}{|c|c|c|c|c|c|c|c|c|c|c|}
\hline $\begin{array}{l}\text { Time (Minutes) } \\
\text { Density (GM/CM }\end{array}$ & $\begin{array}{l}468.0 \\
5.008+00\end{array}$ & $\begin{array}{c}486.0 \\
5.00 \%+00\end{array}$ & $\begin{array}{l}510.0 \\
5.00 E+00\end{array}$ & $\begin{array}{c}540.0 \\
5.00 E+00\end{array}$ & $\begin{array}{c}600.0 \\
.00 E+00\end{array}$ & $\begin{array}{c}660.0 \\
5.00 E 400\end{array}$ & $\begin{array}{c}780.0 \\
.05 E+00\end{array}$ & $\begin{array}{c}\$ 00.0 \\
\text {. A5E } 400\end{array}$ & $\begin{array}{l}1080.0 \\
3.77 E+00\end{array}$ & $\begin{array}{c}1501.1 \\
3.756+00\end{array}$ \\
\hline \multicolumn{11}{|l|}{$\begin{array}{l}\text { PARTICLE } \\
\text { OARAE IER } \\
\text { (MICRONS) }\end{array}$} \\
\hline 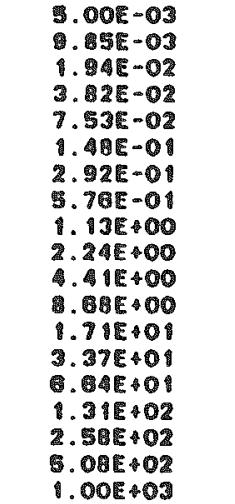 & $\begin{array}{r}5.30 E-13 \\
2.73 E-10 \\
1.03 E-07 \\
5.08 E-06 \\
1.34 E-04 \\
1.87 E-03 \\
9.90 E-03 \\
3.27 E-02 \\
1.00 E-01 \\
1.49 E-01 \\
3.33 E-01 \\
3.18 E-02 \\
1.00 E-03 \\
.04 E-05 \\
7.51 E-07 \\
.76 E-10 \\
.00 E+00 \\
.00 E+00 \\
.00 E+00\end{array}$ & 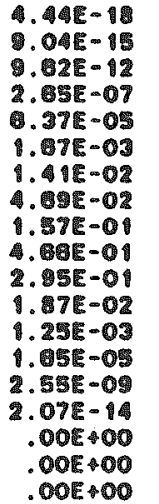 & 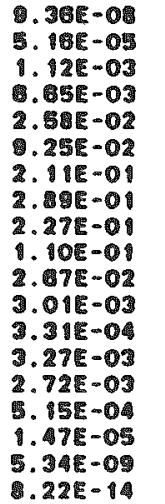 & $\begin{array}{r}.00 E+00 \\
1.98 E-05 \\
.09 E-01 \\
1.15 E-02 \\
5.86 E-02 \\
1.42 E-01 \\
2.22 E-01 \\
2.05 E-01 \\
2.02 E-01 \\
.39 E-02 \\
1.00 E-02 \\
1.05 E-04 \\
5.80 E-07 \\
1.29 E-11 \\
.00 E+00 \\
.00 E+00 \\
.00 E+00 \\
.00 E+00 \\
.00 E+00\end{array}$ & 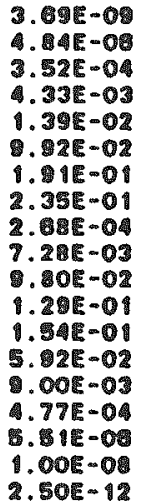 & 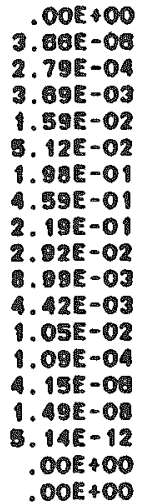 & $\begin{array}{r}3.52 E-29 \\
1.08 E-11 \\
.58 E-09 \\
1.17 E-08 \\
8.48 E-05 \\
1.88 E-03 \\
.58 E-03 \\
3.00 E-02 \\
.011 E-02 \\
3.37 E-01 \\
3.78 E-01 \\
1.25 E-01 \\
1.09 E-02 \\
.35 E-04 \\
.21 E-00 \\
.55 E-09 \\
.21 E-13 \\
.00 E+00 \\
.00 E+00\end{array}$ & $\begin{array}{r}1.10 E-28 \\
1.07 E-09 \\
3.23 E-07 \\
2.73 E-05 \\
7.27 E-04 \\
7.13 E-03 \\
3.28 E-02 \\
1.04 E-08 \\
2.04 E-01 \\
3.915-01 \\
1.07 E-01 \\
1.25 E-02 \\
1.01 E-04 \\
1.30 E-07 \\
1.30 E-10 \\
5.00 E-15 \\
.00 E 400 \\
.005400 \\
.00 E+00\end{array}$ & 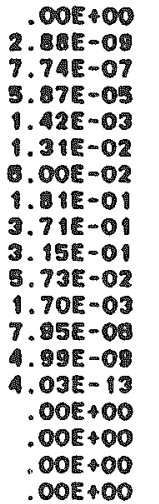 & $\begin{array}{r}.00 E+00 \\
.00 E+00 \\
.00 E+00 \\
3.01 E-17 \\
.76 E-10 \\
8.00 E-05 \\
2.97 E-03 \\
6.96 E-02 \\
4.34 E-01 \\
4.01 E-01 \\
3.23 E-02 \\
1.09 E-04 \\
1.34 E-07 \\
.96 E-12 \\
.00 E+00 \\
.00 E+00 \\
.00 E+00 \\
.00 E+00 \\
.00 E+00\end{array}$ \\
\hline
\end{tabular}


Table 4.3.29. Final distribution of fission product inventory by group - Sequoyah $\mathrm{S}_{3} \mathrm{~B}$.

\begin{tabular}{|c|c|c|c|c|c|c|}
\hline Species & RCS & Melt & $\begin{array}{c}\text { Lower } \\
\text { Compartment }\end{array}$ & $\begin{array}{l}\text { Ice } \\
\text { Bed }\end{array}$ & $\begin{array}{c}\text { Upper } \\
\text { Compartment }\end{array}$ & Environment \\
\hline 1 & $4.5 E-01$ & 0.0 & $4.4 E-02$ & $9.7 E-02$ & $2.6 \mathrm{E}-02$ & $3.8 \mathrm{E}-01$ \\
\hline$C_{S}$ & $5.2 E-01$ & 0.0 & $4.0 E-02$ & $9.0 \mathrm{E}-02$ & 2.2E-02 & $3.2 E-01$ \\
\hline Te & $7.7 E-01$ & 4. $4 E-02$ & $4.5 E-02$ & $1.6 E-02$ & $8.2 E-03$ & 1.1E-01 \\
\hline$S r$ & $4.3 E=04$ & $8.1 E-01$ & $5.6 \mathrm{E}-02$ & 4.1E-05 & $1.9 E-03$ & $1.2 E-01$ \\
\hline Ru & $9.6[-07$ & 1.0 & $1.1 E-06$ & 7. $4 E-08$ & $2.7 E-08$ & $5.4 E-06$ \\
\hline La & $1.2 \mathbb{E}-07$ & $9.8 E-01$ & $3.8 \mathrm{E}-03$ & $6.4 E-09$ & $1.9 E-04$ & $9.4 E-03$ \\
\hline Ce & 0.0 & $9.9 E-01$ & $3.6[-03$ & 0.0 & $1.3 E-04$ & $8.5 E-03$ \\
\hline $\mathrm{Ba}$ & $7.5 E-03$ & $8.9 E-01$ & 3.0E-02 & $7.4 E-04$ & $1.2 E-03$ & $7.2 \mathrm{E}-02$ \\
\hline $\operatorname{Tr}$ & 0.0 & 0.0 & $1.1 E-01$ & 0.0 & $3.9 E-01$ & $5.1 \mathrm{E}-01$ \\
\hline
\end{tabular}


Table 4.3.30. Fraction of initial core inventory released to containment - Sequoyah S3HF.

\begin{tabular}{llll}
\hline \hline Group & $\begin{array}{c}\text { During } \\
\text { In-Vessel } \\
\text { Release }\end{array}$ & \multicolumn{1}{c}{$\begin{array}{c}\text { During } \\
\text { Puff } \\
\text { Release }\end{array}$} & $\begin{array}{c}\text { During } \\
\text { Core-Concrete } \\
\text { Attack }\end{array}$ \\
\hline $\mathrm{I}$ & 0.5218 & $1.3327 \mathrm{E}-02$ & $1.5650 \mathrm{E}-02$ \\
$\mathrm{CS}$ & 0.4602 & $1.0371 \mathrm{E}-02$ & $1.5230 \mathrm{E}-02$ \\
$\mathrm{Pi}$ & $1.4120 \mathrm{E}-03$ & $3.8483 \mathrm{E}-05$ & 0.0 \\
$\mathrm{Te}$ & $8.1535 \mathrm{E}-02$ & $1.0824 \mathrm{E}-03$ & $3.4757 \mathrm{E}-02$ \\
$\mathrm{Sr}$ & $3.6825 \mathrm{E}-04$ & $6.1094 \mathrm{E}-06$ & $1.8673 \mathrm{E}-01$ \\
$\mathrm{Ru}$ & $8.2671 \mathrm{E}-07$ & $3.1245 \mathrm{E}-09$ & $2.9400 \mathrm{E}-06$ \\
$\mathrm{La}$ & $1.0577 \mathrm{E}-07$ & $7.8948 \mathrm{E}-11$ & $1.0876 \mathrm{E}-02$ \\
$\mathrm{Ng}$ & 0.9770 & $1.2421 \mathrm{E}-02$ & 0.0 \\
$\mathrm{Ce}$ & 0.0 & 0.0 & $9.1650 \mathrm{E}-03$ \\
$\mathrm{Ba}$ & $6.4050 \mathrm{E}-03$ & $2.0507 \mathrm{E}-04$ & $1.0403 \mathrm{E}-01$ \\
\hline \hline
\end{tabular}


Table 4.3.37. Fraction of core inventory released from the lower-to-upper compartment - Sequoyah $\mathrm{S}_{3} H F$.

\begin{tabular}{|c|c|c|c|c|c|c|c|c|c|c|c|}
\hline \multirow{2}{*}{$\begin{array}{l}\text { Ti: } \\
\text { (M) }\end{array}$} & \multicolumn{8}{|c|}{ Fission Product Group } & \multirow[b]{2}{*}{ MA } & \multirow[b]{2}{*}{$\mathrm{P}$} & \multirow[b]{2}{*}{$T R$} \\
\hline & 1 & CS & PI & TE & SR & RU & LA & CE & & & \\
\hline 420.0 & $1.07 \%$ & $9.84 E-01$ & 2.85E-03 & $1.70 E-01$ & $7.20 \varepsilon-04$ & 1. $59 \mathrm{E}-00$ & $2.00 E-07$ & 0.0 & $1.25 E-02$ & 0.0 & 0.0 \\
\hline 540.0 & 1.36. & $1.20 \%$ & $3.66 E-03$ & 3.05E-11 & - $.32 E-04$ & 2.06E-16 & 2.60E-07 & 0.0 & 1. $65 E-02$ & 0.0 & $1.70 \%$ \\
\hline 1080.8 & 1.36 & 1.20 & 3.0OE-03 & 3. BL- -1 & 1.34E-04 & $2.06 \mathrm{E}-16$ & 2.00E-07 & 0.1 & 1. $25 E-02$ & 0.0 & 1.700 \\
\hline 1881.5 & 1.36 & $1.29 \%$ & -6BE-03 & $3.01 E-01$ & $0.34 E-04$ & 2.06E-10 & 2.60E-07 & 0.0 & 1.6EE-02 & 0.0 & 1.78 \\
\hline 2200.0 & 1.36 & $1.20 \mathrm{a}$ & 3.68E-03 & 3.1E-11 & -.3ิE-04 & 2. $16 \mathrm{E}-00$ & 2.00E-17 & 0. & 1.65E-12 & 0.0 & 1.76ิ \\
\hline $2 \times 0.0$ & 1.36 & 1.210 & 3.68E-03 & 3. $18-111$ & 3.3AE-04 & 2. $46 E-06$ & 2.60E-07 & 0.0 & 1.65E-12 & 0.1 & 1.76 \\
\hline 3480.0 & $1.38 \%$ & 1.20 & 3.6อE-03 & 3.1E-11 & -34E-04 & 2. $06 \mathrm{E}-00$ & 2.60E-07 & 0.0 & 1. 65E-02 & 0.0 & $1.70 \%$ \\
\hline 4647.1 & 1.36. & 1.20 & 3. $2 \mathrm{E}-03$ & $3.15-11$ & 1.3AC-04 & 2. 16E-10 & $2.01 E-07$ & 2. $46 E-10$ & 1. $35 \mathrm{E}-02$ & 1. 1 EE- & 1.76 \\
\hline 4680.1 & $1.36 \%$ & 1. 2อิ & $3.68 E-03$ & 3.81E-01 & 4. .9E-03 & 2. $08 \mathrm{E}-06$ & 1. $42 E-14$ & 2.04E-05 & 1.91E-02 & 100.0 & 1.76 \\
\hline 8400.0 & 1.37 & $1.21 \mathrm{e}$ & 3. องE-03ิ & 4.10E-U1 & $1.62 E-01$ & 4. 4.E-08 & $0.00 \mathrm{E}-13$ & $7.81 E-03$ & 1. DEE-11 & 6830.0 & 1.78 운 \\
\hline
\end{tabular}

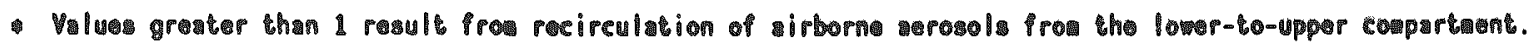


Table 4.3.32. Size distribution of aerosols in the lower compartment - Sequoyah $S_{\mathrm{a}}$ HF.

\begin{tabular}{|c|c|c|c|c|c|c|c|c|c|c|}
\hline $\begin{array}{l}\text { Tima } \\
\text { (Minuter }\end{array}$ & 42.10 & 540.10 & 1080. & 1001.5 & 2280.1 & 2880.0 & 3900. & 4647.1 & 1609. & 5400.0 \\
\hline Dons ity (a)/can) & $5.00 \pi+00$ & 5.00600 & $\$ .00 E+00$ & $5.00 E+00$ & $5.00 E+00$ & $5.00 E+00$ & $5.00 \% 400$ & 4,40400 & $9.728+00$ & $3.74 \frac{-}{400}$ \\
\hline $\begin{array}{l}\text { PARTICLE } \\
\text { DIAMETER } \\
\text { (MICRONS) }\end{array}$ & & & & & & & & & & \\
\hline 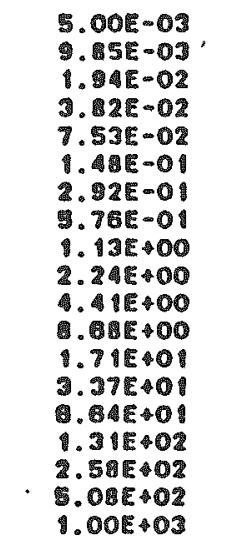 & $\begin{array}{l}1.80 E-20 \\
7.45 E-17 \\
3.55 E-14 \\
3.76 E-10 \\
5.39 E-07 \\
0.28 E-05 \\
2.54 E-03 \\
2.21 E-02 \\
1.49 E-01 \\
9.34 E-01 \\
2.78 E-01 \\
1.03 E-02 \\
4.18 E-04 \\
1.79 E-00 \\
.32 E-10 \\
5.72 E-14 \\
1.20 E-19 \\
3.59 E-25 \\
2.73 E-32\end{array}$ & 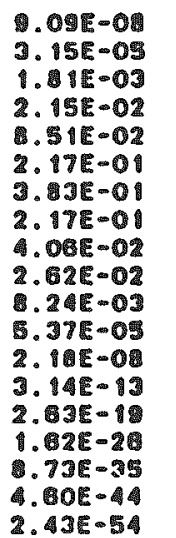 & $\begin{array}{l}1.7 A E-58 \\
7.32 E-26 \\
1.57 E-10 \\
7.01 E-05 \\
2.00 E-02 \\
2.03 E-01 \\
5.3 A E-01 \\
1.56 E-01 \\
7.01 E-01 \\
.77 E-05 \\
2.05 E-07 \\
2.111 E-12 \\
1.08 E-20 \\
1.34 E-49 \\
.00 E+00 \\
.00 E 400 \\
.00 E+00 \\
.00 E+00 \\
.00 E+00\end{array}$ & 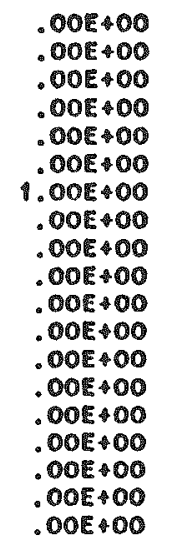 & $\begin{array}{l}.00 E+00 \\
.00 E+00 \\
.00 E+00 \\
.00 E+00 \\
.00 E+00 \\
.00 E+00 \\
.00 E+00 \\
.00 E+00 \\
.00 E+00 \\
.00 E+00 \\
.00 E+00 \\
.00 \%+00 \\
.00 E+00 \\
.00 E+00 \\
.00 E+00 \\
.00 E+00 \\
.00 E+00 \\
.00 E \$ 00 \\
.00 E+00\end{array}$ & $\begin{array}{l}.00 E+00 \\
.00 E+00 \\
.00 E+00 \\
.00 E \$ 00 \\
.00 E \$ 00 \\
.00 E+00 \\
.00 E+00 \\
.00 E+00 \\
.00 E+00 \\
.00 E+00 \\
.00 E+00 \\
.00 E+00 \\
.00 E+00 \\
.00 E+00 \\
.00 E+00 \\
.00 E+00 \\
.00 E+00 \\
.00 E+00 \\
.00 E+00\end{array}$ & $\begin{array}{l}.00 E+00 \\
.0 O E+00 \\
.00 E+00 \\
.00 E+00 \\
.00 E+00 \\
.00 E+00 \\
.00 E+00 \\
.00 E+00 \\
.00 E+00 \\
.0 O E+00 \\
.00 E+00 \\
.0 O E+00 \\
.0 O E+00 \\
.00 E+00 \\
.0 O E+00 \\
.00 E+00 \\
.00 E+00 \\
.00 E+00 \\
.00 E+00\end{array}$ & 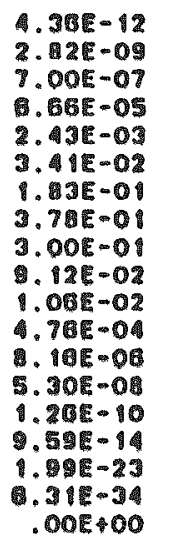 & 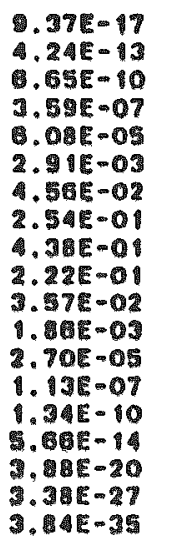 & $\begin{array}{r}.00 E+00 \\
.00 E+00 \\
5.94 E-40 \\
4.32 E-15 \\
3.68 E-07 \\
1.92 E-01 \\
2.20 E-07 \\
2.29 E-01 \\
5.52 E-01 \\
1.93 E-01 \\
1.20 E-03 \\
3.26 E-00 \\
1.26 E-10 \\
5.22 E-18 \\
2.47 E-22 \\
1.415-29 \\
1.07 E-97 \\
1.00 E-18 \\
.00 E+00\end{array}$ \\
\hline
\end{tabular}


Table 4.3.33. Fraction of core inventory released from the upper compartment to environment - Sequoyah $S_{3} H F$.

\begin{tabular}{|c|c|c|c|c|c|c|c|c|c|c|c|}
\hline \multirow[b]{2}{*}{$\begin{array}{l}\text { Time } \\
\text { (M) }\end{array}$} & \multicolumn{11}{|c|}{ Fission Product Group } \\
\hline & 1 & cs & PI & TE & $S R$ & 的 & LA & CE & $B A$ & PE & $T R$ \\
\hline 1141.2 & 3. 6 E-22 & 3. เอนE-22 & $.13 E-26$ & $7.76 E-21$ & 1.04E-96 & $4.68 E-28$ & 6.19E-31 & 0.1 & $7.16 E-24$ & . & 0.86E-25 \\
\hline 1448.2 & 4.1BE-22 & $4.00 E-22$ & 2. 62E-26 & 6. 40E-21 & $1.70 E-26$ & 5. $37 E-20$ & $0.1 E-31$ & 0.0 & $7.7 B E-24$ & e.c. & 9.80E-26 \\
\hline 4008.2 & 4.1EE-22 & 4.00E-22 & $0.2 E-25$ & - ADE-21 & $1.76 E-28$ & 6.97E-29 & C. DIE-\$1 & 0.0 & $7.76 E-24$ & 1.0 & 1.0E-26 \\
\hline 4200.2 & $4.118 E-22$ & $4.00 \varepsilon-22$ & -.2 & . 1DE-21 & $1.76 \mathrm{E}-2 \mathrm{E}$ & S.MRE-\% & . . A1E-\$1 & 0.0 & $7.76 E-24$ & 0.0 & 9.00E-25 \\
\hline 4320.2 & 4.15E-22 & 4. $.005-2$ & 9.62E-25 & . 4NE-21 & $1.76 E-2 E$ & B. $37 E-29$ & -OIE-II & 0.0 & $7.75 E-24$ & 1.1 & 0.00E-25 \\
\hline 4440.2 & 4.1EE-22 & 4. 10E-22 & . $8 E-26$ & 6. คดอ 21 & $1.72 E-25$ & B. $37 E-20$ & $0.11 E-31$ & 0.0 & $7.75 E-24$ & 1.0 & 7. $60 E-28$ \\
\hline 4080.1 & 1.81E-14 & 2.74E-MA & $0.02 E-25$ & 5. B2E-015 & 1.0EE-OS & 0.00E-12 & S.OBE-OR & . ISE-06 & 8.20E-04 & 28.6 & 1.60E-25 \\
\hline 4020. & $1.25 E-02$ & 1. OSE-112 & 1. $12 \mathrm{E}-28$ & 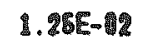 & 1.28E-01 & 4. 2RE-17 & 7. DAE-0S & 1. \$EE-13 & 6.71E-02 & 4011.0 & 0. 60 E-2E \\
\hline 5160.0 & 1. 2.2E-19\% & 1.12E-01 & - $12 E-96$ & 1. .อE-12 & 1. $32 E-01$ & 1.10E-06 & D. DIE-03 & 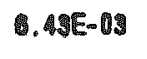 & $7.29 E-02$ & 5084. & D. .ME-26 \\
\hline 5400.0 & 1.20E-02 & 1.13E-02 & $0.62 E-28$ & 2.28E-02 & 1.33E-01 & 1. 625-06 & 3. OAE-03 & 6. 46E-03 & 7. & B260.1 & 1.00E-25 \\
\hline
\end{tabular}


Table 4.3.34. Size distribution of aerosols in the upper compartment - Sequoyah SgMF.

\begin{tabular}{|c|c|c|c|c|c|c|c|c|c|c|}
\hline $\begin{array}{l}\text { Time (Minutes) } \\
\text { Density (GM/CM3) }\end{array}$ & $\begin{array}{c}1140.2 \\
1.00 E+00\end{array}$ & $\begin{array}{c}1440.2 \\
5.006+00\end{array}$ & $\begin{array}{c}4000.2 \\
5.00 \%+00\end{array}$ & $\begin{array}{c}4200.2 \\
5.00 E * 00\end{array}$ & $\begin{array}{c}4320.2 \\
5.008400\end{array}$ & $\begin{array}{c}4440.2 \\
.008400\end{array}$ & $\begin{array}{c}4680.0 \\
3.908400\end{array}$ & 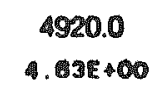 & $\begin{array}{c}5160.0 \\
.476+00\end{array}$ & $\begin{array}{r}5400.0 \\
.058+00\end{array}$ \\
\hline \multicolumn{11}{|l|}{ 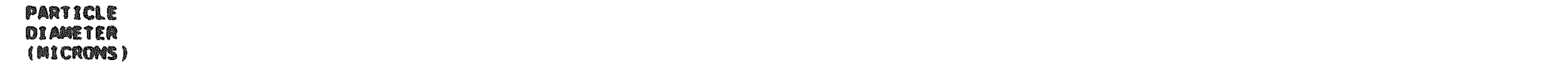 } \\
\hline 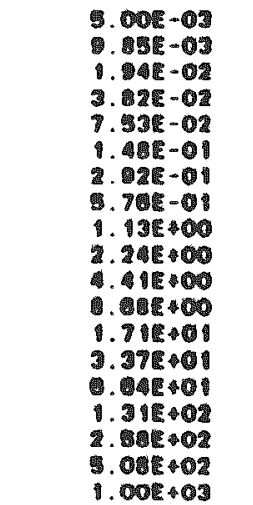 & 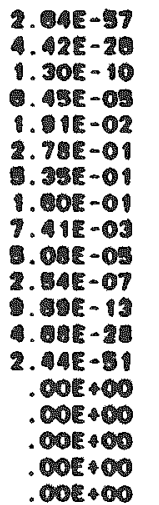 & 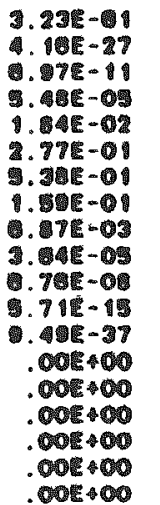 & 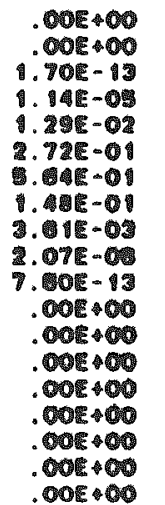 & 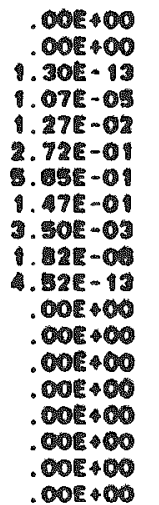 & 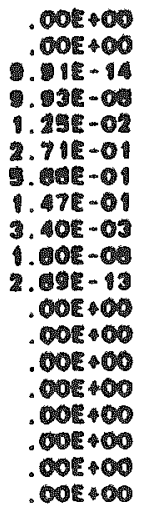 & 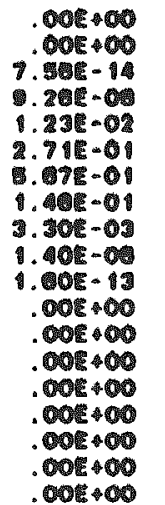 & 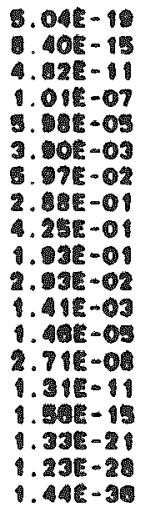 & 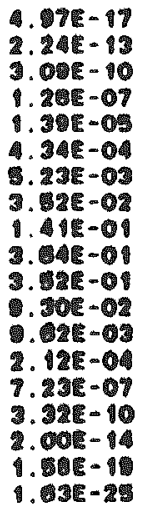 & 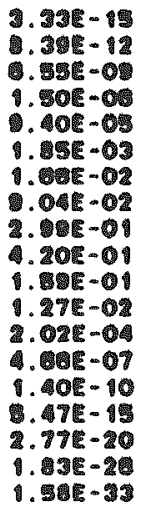 & 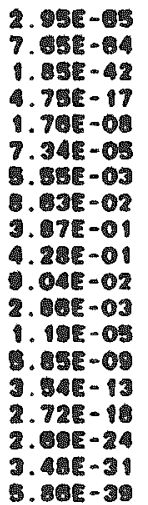 \\
\hline
\end{tabular}


Table 4.3.35. Final distribution of fission product inventory by group - Sequoyah $\mathrm{S}_{3} \mathrm{HF}$.

\begin{tabular}{|c|c|c|c|c|c|c|}
\hline Species & RCS & Melt & $\begin{array}{l}\text { Lower } \\
\text { Compartment }\end{array}$ & $\begin{array}{l}\text { Ice } \\
\text { Bed }\end{array}$ & $\begin{array}{c}\text { Upper } \\
\text { Compartment }\end{array}$ & Environment \\
\hline 1 & $4.5 E-01$ & 0.0 & $7.5 E-02$ & $4.4 E-01$ & $2.8 \mathrm{E}-02$ & $1.3 E-02$ \\
\hline Cs & $5.2 E-01$ & 0.0 & $6.7 \mathrm{E}-02$ & $3.9 E-01$ & $2.6 \mathrm{E}-02$ & $1.1 E-02$ \\
\hline Te & $7.7 \mathrm{E}-01$ & 4. $3 E-02$ & $3.1 \mathrm{E}-02$ & $1.2 E-01$ & 1. $3 E-02$ & $2.3 E-02$ \\
\hline $\mathrm{Sr}$ & $4.3 E-04$ & 8.1E-01 & $2.6 E-02$ & $3.1 E-04$ & 2. $9 \mathrm{E}-02$ & $1.3 E-01$ \\
\hline Ru & $9.6 E-07$ & 1.0 & $5.3 E-07$ & $6.8 E-07$ & 4. $6 \mathrm{E}-07$ & $1.9 E-06$ \\
\hline La & $1.2 E-07$ & $9.8 E-01$ & $1.3 E-03$ & $8.7 E-08$ & $1.5 E-03$ & $8.0 \mathrm{E}-03$ \\
\hline $\mathrm{Ce}$ & 0.0 & $9.9 E-01$ & $1.3 E-03$ & 0.0 & $1.4 E-03$ & $6.5 E-03$ \\
\hline $\mathrm{Ba}$ & $7.5 E-03$ & $8.8 E-01$ & $1.5 E-02$ & $5.5 E-03$ & $1.6 \mathrm{E}-02$ & $7.4 E-02$ \\
\hline $\operatorname{Tr}$ & 0.0 & 0.0 & 1. $3 E-01$ & $8.5 E-01$ & $2.1 E-02$ & $9.8 E-25$ \\
\hline
\end{tabular}


presents the locational distribution of each fission product group after the scenario is completed. In comparison to the $S_{3} B$ scenario results, the environmental release in this scenario is relatively low. 


\section{SUMMARY AND CONCLUSIONS}

Analyses for a total of fourteen severe accident scenarios have been presented in this report: one for the Peach Bottom Atomic Power Station, Unit 2, eight for the Surry Nuclear Power Plant, Unit 1, and five for the Sequoyah Nuclear Power Plant, Unit 1. Complete source term calculations were performed for four of these scenarios. For each of these scenarios, the final distribution of modeled radionuclide species are presented below. One scenario, Sequoyah $-\mathrm{S}_{3} \mathrm{H}$ (reactor coolant pump seal LOCA with failure of ECC recirculation), was concluded to not result in containment overpressure failure and, therefore, would yield a very small environmental fission product release.

Three steam generator tube rupture scenarios were performed for the Surry plant. Only the MARCH3 and TRAP-MELT3 calculations were performed for these scenarios, corresponding to the in-vessel release phase of the accident. The environmental release fractions for the volatile radionuclides are potentially quite large.

Peach Bottom - TBUX (Early station blackout with failure of ADS)

\begin{tabular}{|c|c|c|c|c|c|c|c|c|}
\hline Species & RCS & Helt & Drywell & $\begin{array}{c}\text { Suppression } \\
\text { Pool }\end{array}$ & 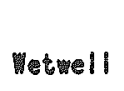 & $\begin{array}{l}\text { Reactor } \\
\text { Building }\end{array}$ & $\begin{array}{c}\text { Refuel ing } \\
\text { lay }\end{array}$ & Environment \\
\hline$I$ & 2. 4E-01 & 0.0 & 5.4E-12 & (3.8E-01 & $1.2 E-02$ & $1.8 E-03$ & 1.2E-04 & 2. $8 \mathrm{E}-03$ \\
\hline $\mathrm{Cs}$ & $5.8 E-1$ & 0.0 & $4.5 E-02$ & $3.6 E-01$ & $7.9 E-03$ & $1.2 \mathrm{E}-03$ & $7.6 E-05$ & $1.7 E-03$ \\
\hline To & $3.1 E-01$ & 2.7E-01 & 1.2E-01 & $2.8 E-01$ & $7.8 E-04$ & 1.8E-02 & 2. $0 E-0.4$ & $4.3 E-03$ \\
\hline$S t$ & $6.9 E-04$ & 2. 4E-01 & $3.2 E-11$ & 4.3E-11 & 2. DE- 14 & $4.2 \mathrm{E}-03$ & $1.1 E-04$ & $1.7 E-03$ \\
\hline Rus & 1.2E-06 & 1.0 & $1.5 E-07$ & 1. BE-06 & 8.0E-04 & $3.5 E-07$ & 2.0E-09 & 1.1E-07 \\
\hline La & 9. $.0 \mathrm{E}-08$ & 8.7E-01 & 1.3E-12 & $1.9 E-02$ & 1.5E-05 & 1.8E-04 & $5.2 \mathrm{E}-06$ & 8.0E-05 \\
\hline $\mathrm{Ce}$ & 0.10 & $9.4 E-01$ & 2.5E-02 & $3.7 E-02$ & $1.8 E-105$ & $3.7 E-14$ & 1.0E-05 & $1.5 E-04$ \\
\hline Ba열 & 1.3E-02 & $4.6 E-01$ & 2.0E-01 & $3.2 E-01$ & $2.2 E-04$ & 3. EE-03 & $8.4 E-15$ & 1.2E-103 \\
\hline$T R$ & 0.0 & 0.0 & $5.3 E-01$ & $4.8 \mathrm{E}-01$ & $7.0 \mathrm{E}-13$ & 2.5E-103 & 1.4E-05 & $3.2 E-03$ \\
\hline
\end{tabular}


Surry - S, B (Station blackout with induced RCP seal LOCA)

\begin{tabular}{|c|c|c|c|c|c|}
\hline Species & RCS & Melt & $\begin{array}{l}\text { Cavity } \\
\text { Water }\end{array}$ & Containment & Environment \\
\hline I & $7.08 \mathrm{E}-0 \mathrm{~s}$ & $2.23 E-04$ & $1.30 E-02$ & $1.105-01$ & $1.85 E-01$ \\
\hline Cs & 7. A2E-01 & $1.90 \varepsilon .05$ & $5.54 E-03$ & $1.09 \mathrm{E}-02$ & $1.60 E-01$ \\
\hline Te & $2.29 E-01$ & $5.96 \mathrm{E}-0 \mathrm{Z}$ & $1.35 E-02$ & $1.04 E-01$ & $6.14 E-02$ \\
\hline sp & $3.76 E-04$ & $9.09 \mathrm{E}-01$ & $2.09 E-02$ & $5.40 E-02$ & $1.58 E-02$ \\
\hline$R u$ & $6.77 \mathrm{E}-07$ & 1.0 & $8.12 E-10$ & $4.63 E .07$ & $1.24 E-07$ \\
\hline La & $5.88 E-08$ & $9.92 E-01$ & $1.27 \mathrm{E} .03$ & $2.08 E-03$ & $8.15 E .04$ \\
\hline $\mathrm{Ce}$ & 0.0 & $9.99 E-01$ & $2.66 \varepsilon-04$ & $4.92 E-04$ & $1.79 E-04$ \\
\hline $\mathrm{Ba}$ & $6.97 E-03$ & $9.29 E-01$ & $1.49 E-02$ & $3.67 \mathrm{E}-02$ & $1.24 E .02$ \\
\hline $\operatorname{Tr}$ & $\ldots$ & $\ldots$ & $\ldots$ & 2.115 .01 & $7.82 E-0:$ \\
\hline
\end{tabular}

\section{Sequoyah - $\$ 33$ (Station blackout with induced RCP seal LOCA)}

\begin{tabular}{|c|c|c|c|c|c|c|}
\hline Species & RCS & Melt & $\begin{array}{l}\text { Lower } \\
\text { Compartment }\end{array}$ & $\begin{array}{l}\text { Ice } \\
\text { Bed }\end{array}$ & $\begin{array}{c}\text { Upper } \\
\text { Compartment }\end{array}$ & Environment \\
\hline 1 & $4.5 E-01$ & 0.0 & $4.4 E-02$ & $9.7 E-02$ & $2.6 E-02$ & $3.8 E-01$ \\
\hline $\mathrm{cs}$ & $5.2 E-01$ & 0.0 & $4.0 E-02$ & $9.0 E-02$ & $2.2 \mathrm{E}-02$ & $3.2 E=01$ \\
\hline Te & $7.7 E-01$ & 4.4E-02 & $4.5 E-02$ & $1.6 E-02$ & $8.2 E-03$ & $1.1 E-01$ \\
\hline$S r$ & $4.3 E-04$ & $8.1 E-01$ & $5.6 E-02$ & 4.1E-05 & $1.9 E-03$ & $1.2 E-01$ \\
\hline Ru & $9.6 E-07$ & 1.0 & $1.1 E-06$ & $7.4 \varepsilon-08$ & $2.7 E-08$ & $5.4 E-06$ \\
\hline La & $1.2 E-07$ & $9.8 E-01$ & $3.8 \mathrm{E}-03$ & $6.4 E-09$ & $1.95-04$ & $9.4 E=03$ \\
\hline $\mathrm{Ce}$ & 0.0 & $9.9 E-01$ & $3.6 \mathrm{E}-03$ & 0.0 & $1.3 E-04$ & $8.5 E-03$ \\
\hline$B$ & $7.5 E-03$ & $8.9 E-01$ & $3.0 E-02$ & $7.4 E-04$ & $1.2 E-03$ & $7.2 E-02$ \\
\hline $\operatorname{Tr}$ & 0.0 & 0.0 & $1.1 E-01$ & 0.0 & $3.9 E-0]$ & $5.1 E-01$ \\
\hline
\end{tabular}

Sequoyah - S. HF (RCP Seal LOCA with failure of ECC and containment spray recirculation)

\begin{tabular}{|c|c|c|c|c|c|c|}
\hline Species & RCS & Melt & $\begin{array}{c}\text { Lower } \\
\text { Compartment }\end{array}$ & $\begin{array}{l}\text { lee } \\
\text { Bed }\end{array}$ & $\begin{array}{c}\text { Upper } \\
\text { Compartment }\end{array}$ & Environment \\
\hline I & $4.5[-0]$ & 0.0 & $7.5 E-02$ & $4.48-01$ & $2.8 E-02$ & $1.3 E-02$ \\
\hline$c s$ & $5.2 E-01$ & 0.0 & $6.7 E-02$ & $3.9 \mathrm{E}-01$ & $2.6 \mathrm{E}-02$ & $1.15-02$ \\
\hline Te & $7.7 E-01$ & $4.3 E-02$ & $3.1 E-02$ & $1.2 E-01$ & $1.3 E-02$ & $2.3 E-02$ \\
\hline Sr & $4.3 E-04$ & $8.1 E-01$ & $2.6 \varepsilon-02$ & $3.1 E-04$ & $2.9 E-02$ & $1.3 E-01$ \\
\hline Ru & $9.6 E-07$ & 1.0 & $5.3 E-07$ & $6.8 E-07$ & $4.6 E-07$ & $1.9 E-06$ \\
\hline La & $1.2 E-07$ & $9.8 E-01$ & 1. $3 E-03$ & $8.7 E-08$ & $1.5 E-03$ & $8.0 E-03$ \\
\hline $\mathrm{Ce}$ & 0.0 & $9.9 E-01$ & $1.3 E-03$ & 0.0 & $1.4 E-03$ & $6.5 E-03$ \\
\hline$B a$ & $7.5 E-03$ & $8.8 E-01$ & $1.5 E-02$ & $5.5 E-03$ & $1.6 E-02$ & $7.4 E-02$ \\
\hline $\operatorname{Tr}$ & 0.0 & 0.0 & $1.3 E-01$ & $8.5 E=01$ & $2.1 E-02$ & $9.8 E-25$ \\
\hline
\end{tabular}


The effect of secondary side depressurization was examined for sequences in both the Sequoyah and Surry plants. In the case of station blackout with accompanying pump seal failure at Sequoyah, heat removal by the steam generators in combination with leakage reduce primary system pressure to the point where complete accumulator discharge takes place prior to core uncovery. Some of the accumulator water is subsequently lost by leakage through the failed pump seals. After the auxiliary feedwater is lost, the primary system heats up and repressurizes. Thus eventual core overheating is predicted to take place at a substantial primary system pressure. The initial availability of auxiliary feedwater and steam generator depressurization lead to a significant delay in the time of core overheating.

In the case of the very small break with ECCS injection failure, auxiliary feedwater continues to be available indefinitely allowing the steam generators to act as effective heat sinks for about 9 hours into the accident. Accumulator discharge is predicted to take place relatively early in the scenario, in response to the depressurization of the secondary side of the steam generators. Core uncovery takes place eventually due to loss of inventory through the primary system break. For this case there is significant primary system repressurization associated with core collapse.

In the Surry plant, for the long term station blackout scenario the initial availability of auxiliary feedwater together with depressurization of the steam generators lead to significant depressurization of the primary system. Only partial discharge of the accumulators is predicted, however, since the primary system is essentially full at that time. After the loss of auxiliary feedwater, the primary system heats up and repressurizes to the safety valve level. Core overheating and melting thus take place at very high primary system pressure. The initial availability of auxiliary feedwater led to a substantial delay in the time of core overheating.

In the case of station blackout with accompanying pump seal failure, heat removal by the steam generators in combination with leakage reduce primary system pressure to the point where complete accumulator discharge takes place prior to core uncovery. Some of the accumulator water is subsequently lost by leakage through the failed pump seals. After the auxiliary feedwater is lost, the primary system heats up and repressurizes. 
Thus eventual core overheating is predicted to take place at a substantial primary system pressure.

For the very small break with ECCS injection failure, auxiliary feedwater continues to be available indefinitely; thus the steam generators continue to act as heat sinks throughout the in-vessel portion of the accident. Accumulator discharge is predicted to take place relatively early in the scenario, in response to the depressurization of the secondary side of the steam generators. Core uncovery takes places eventually due to loss of inventory through the primary system break. The steam generators continue to condense steam during the core overheating phases and, under the modeling assumptions utilized, prevent core collapse by keeping the lower core nodes cooled. An unusually high in-vessel hydrogen generation is predicted for this sequence. For this case there is significant primary system repressurization associated with core collapse, immediately prior to the time of vessel failure.

In the sequence with a very small break and ECCS injection failure, but with the opening of the PORVs, there is some primary system repressurization due to the buildup of hydrogen during core melting; at the time of predicted vessel failure the system is essentially depressurized.

In the case of the small break with ECCS failure the primary system response is dominated by the leakage out of the break. The availability of auxiliary feedwater and steam generator depressurization do contribute to primary system pressure reduction. In this case accumulator discharge was predicted prior to appreciable core overheating; earlier analyses without these actions had indicated accumulator discharge after the onset of melting. At the predicted time of vessel failure the primary system is completely depressurized in this scenario. 


\section{REFERENCES}

1. Benjamin, A. S., et al., "Evaluation of Severe Accident Risks and the Potential for Risk Reduction", NUREG/CR-4551, Volumes 1-4, Draft, February 1987.

2. Denning, R. S., et al., "Radionuclide Release Calculations for Selected Severe Accident Scenarios", NUREG/CR-4624, BMI-2139, Volumes 1-5, Draft, July 1986.

3. U. S. Nuclear Regulatory Commission, "Severe Accident Risks: An Assessment for Five U.S. Nuclear Power Plants", NUREG-1150, Volumes 1 and 2, Draft, June 1989.

4. Gieseke, J. A., et al., "Source Term Code Package: A User's Guide (Mod 1)", NUREG/CR-4587, BMI-2138, July 1986.

5. Silberberg, M., et a1., "Reassessment of the Technical Bases for Estimating Source Terms", NUREG-0956, July 1986.

6. Gieseke, J. A., et a1., "Radionuclide Release Under Specific LWR Accident Conditions", BMI-2104, Draft, July 1984.

7. Wooton, R. 0., Cybulskis, P., and Quayle, S. F., "MARCH2 (Meltdown Accident Response Characteristics) Code Description and User's Manual". Battelle's Columbus Laboratories, NUREG/CR-3988, BMI-2115, September 1984.

8. Kuhlman, M. R., Lehmicke, D. J., and Meyer, R. 0., "CORSOR User's Manual", Battelle's Columbus Laboratories, NUREG/CR-4173, BMI-2122, March 1985.

9. Cole, R. K., Kelly, D. P., and Ellis, M. A., "CORCON MOD2: A Computer Program for Analysis of Molten Core Concrete Interactions", NUREG/CR-3920, August 1984.

10. Powers, D. A., Brockmann, J. E., and Shiver, A. W., "VANESA, A Mechanistic Model of Radionuclide Release and Aerosol Generation During Core Debris Interactions with Concrete (Draft)", Sandia National Laboratories, NUREG/CR-4308, SAND85-1370, July 1986.

11. Muir, J. F., et al., "CORCON-Mod 1: An Improved Model for MoltenCore/Concrete Interactions", Sandia National Laboratories, NUREG/CR-2142, SAND80-2415, July 1981.

12. Freeman-Kelly, R., and Jung, R. G.. "A User's Guide for MERGE", Battelle's Columbus Laboratories, NUREG/CR-4172, BMI-2121, March 1985.

13. Jordan, H., and Kuhlman, M. R., "TRAPMELT2 User's Manual", Battelle's Columbus Laboratories, NUREG/CR-4205, BMI-2124, May 1985. 
14. U. S. Nuclear Regulatory Commission, "Reactor Safety Study - An Assessment of Accident Risks in U. S. Commercial Nuclear Power Plants". WASH-1400 (NUREG 75-104), October 1975.

15. Bergeron, K. D., et a1. "User's Manual for CONTAIN 1.0, A Computer Code for Severe Nuclear Reactor Accident Containment Analys is", Sandia National Laboratories, NUREG/CR-4085, SAND84-1204, July 1985.

16. Wichner, R. P., et al. "Station Blackout at Browns Ferry Unit One--Iodine and Noble Gas Distribution and Release", NUREG/CR-2181, August 1982.

17. Groff, A. G. "ORIGEN2: A Versatile Computer code for Calculating the Radionuclide Compositions and Characteristics of Nuclear Materials", Nuclear Technology, Vo1.62, pg 335, September 1983. 